ANDERSON LUIZ FÉLIX DE SÁ

\title{
Preservação do patrimônio arquitetônico no Instituto Butantan
}

Dissertação apresentada à Faculdade de Arquitetura e Urbanismo da Universidade de São Paulo para obtenção do título de Mestre em Ciências.

Área de concentração: História e Fundamentos da Arquitetura e do Urbanismo.

Orientadora: Profa. Dra. Maria Lucia Bressan Pinheiro 
Autorizo a reprodução e divulgação total ou parcial deste trabalho, por qualquer meio convencional ou eletrônico, para fins de estudo e pesquisa, desde que citada a fonte.

EXEMPLAR REVISADO EM RELAÇÃO À VERSÃO ORIGINAL SOB RESPONSABILIDADE DO AUTOR E ANUÊNCIA DA ORIENTADORA.

E-mail do autor: anderson-felix@hotmail.com

Catalogação na Publicação Serviço Técnico de Biblioteca

Faculdade de Arquitetura e Urbanismo da Universidade de São Paulo

Sá, Anderson Luiz Félix de

Preservação do patrimônio arquitetônico no Instituto Butantan / Anderson Luiz Félix de Sá; orientadora Maria Lucia Bressan Pinheiro. - São Paulo, 2019.

$321 \mathrm{p}$.

Dissertação (Mestrado) - Faculdade de Arquitetura e Urbanismo da Universidade de São Paulo. Área de

concentração: História e Fundamentos da Arquitetura e do Urbanismo.

1. Instituto Butantan. 2. Patrimônio Arquitetônico. 3. História da Arquitetura. 4. Restauro. I. Pinheiro, Maria Lucia Bressan, orient. II. Título.

Elaborada eletronicamente através do formulário disponível em: <http://www.fau.usp.br/fichacatalografica/> 
Nome: SÁ, Anderson Luiz Félix de

Título: Preservação do patrimônio arquitetônico no Instituto Butantan

Dissertação apresentada à Faculdade de Arquitetura e Urbanismo da Universidade de São Paulo para obtenção do título de Mestre em Ciências.

Aprovado em:

Banca Examinadora

Prof. Dr.

Instituição:

Julgamento:

Prof. Dr.

Instituição:

Julgamento:

Prof. Dr.

Instituição:

Julgamento: 

Aos profissionais da saúde. 


\section{Agradecimentos}

A todos os professores e colegas que me ajudaram com sugestões, críticas e trocas de experiência em minha recente vida acadêmica. Na impossibilidade de mencionar todos, agradeço em especial à professora Beatriz e ao professor Renato pelas observações valiosas em meu exame de qualificação e em outras ocasiões.

Aos bibliotecários, museólogos, historiadores e coordenadores de acervos que abriram caminhos sem os quais essa pesquisa não seria possível. Não posso deixar de citar Eny e Luiz, do Núcleo de Documentação, Adriana e Osvaldo, do Museu Histórico do Instituto Butantan, e demais colaboradores.

Aos que gentilmente deram seus depoimentos, compartilhando informações e vivências preciosas. Em especial a Maria Brazil, Osmar Mammini e José Siqueira, testemunhas da história cuja longevidade não diminuiu o entusiasmo.

Aos amigos, pelo apoio, paciência e contribuição nessa trajetória. Meu agradecimento especial à Denise, pelo encorajamento, Silvia e Tadeu pelo apoio constante. Ao José, pelo incentivo. Emily, Sabina, Dadu... são muitos.

À minha orientadora, Maria Lucia, de quem tive a sorte de absorver um pouco do conhecimento e amor ao patrimônio cultural, mas sobretudo por sua generosidade, confiança e amizade que retribuirei sempre.

À minha família: Lilian, Rogério e André, sempre tornando tudo mais feliz, e meus pais, Luis e Silma, minha base. 
"Cada face, cada pedra do venerável monumento não é somente uma página da história do país, mas também da história da ciência e da arte."

HUGO, Victor (2011, p.150) 



\title{
Resumo
}

A presente dissertação tem por objetivo estudar o patrimônio arquitetônico do Instituto Butantan, localizado na cidade de São Paulo. Esse Instituto, fundado em 1901 para produção de imunobiológicos, e que se notabilizou mundialmente pela pesquisa em ofidismo, instalou-se em um campus de pesquisa no qual cientistas e arquitetos criaram, durante o último século, um conjunto de elementos arquitetônicos, urbanísticos e paisagísticos relevantes do ponto de vista não só científico, mas também histórico e patrimonial, dentro do contexto recente de valorização do patrimônio arquitetônico da saúde. Mais especificamente, pretende-se analisar também como tem se dado a preservação deste importante acervo arquitetônico, já reconhecido e tombado pelo órgão estadual (Condephaat) e municipal (Conpresp) de proteção do patrimônio cultural. A partir de levantamentos da história, do espaço construído e das normativas dessa instituição, analisou-se em que medida as ações preservacionistas que incidiram sobre esse patrimônio seguiram as recomendações da Carta de Veneza (1964), documento internacional em vigor que estabelece os princípios básicos que devem fundamentar quaisquer intervenções no patrimônio cultural, e da Teoria da Restauração, de Cesare Brandi (1963), um dos textos-base nesse campo. Para tanto, foram consultadas principalmente fontes primárias do acervo documental e iconográfico do Instituto, fontes secundárias pertinentes e depoimentos de frequentadores desse campus.

Palavras-chave: Instituto Butantan-arquitetura. Instituto Butantan-história. Arquitetura da saúde. Preservação do patrimônio cultural.

\begin{abstract}
This research intends to study the architectural heritage of the Instituto Butantan, in the city of São Paulo. This institute, founded in 1901 for the production of immunobiologicals, has garnered world-recognition for its research on ophidism and is located in a research campus where scientists and architects created a set of architectonic, urban and landscape elements during the last century. This set is relevant not only for its scientific importance, but also due to its historical and heritage significance, given the recent context of valuation of healthcare architecture. Furthermore, this research analyses how this architectural heritage has been preserved, since it has already been recognized and listed by the state and municipal departments of protection of cultural heritage. Based on surveys on the institution's history, its built space and its regulations, it was analyzed the extent to which actions toward such heritage have followed the recommendations from the Venice Charter (1964), an international document that establishes the basic principles to support interventions on cultural heritage, and the Theory of Restoration, by Cesare Brandi (1963), a reference text in this field. For such, primary sources from the Institute's document and image collection were consulted, as well as pertinent secondary sources, and statements from users of the campus.
\end{abstract}

Keywords: Instituto Butantan-architecture. Instituto Butantan-history. Healthcare architecture. Preservation of cultural heritage. 


\section{Lista de abreviaturas e siglas}

Anvisa: Agência Nacional de Vigilância Sanitária

BPF: Boas Práticas de Fabricação

CIAM: Congresso Internacional da Arquitetura Moderna

CNPq: Conselho Nacional de Desenvolvimento Científico e Tecnológico

COC: Casa de Oswaldo Cruz (Fiocruz)

COESF: Coordenadoria do Espaço Físico (USP)

Cogic: Coordenação Geral de Infraestrutura dos Campi (Fiocruz)

Condephaat: Conselho de Defesa do Patrimônio Histórico, Arqueológico, Artístico e Turístico (SP)

Conpresp: Conselho Municipal de Preservação do Patrimônio Histórico, Cultural e Ambiental (PMSP)

CPOS: Companhia Paulista de Obras e Serviços

CUASO: Cidade Universitária Armando de Salles Oliveira (USP)

DAD: Departamento de Arquivo e Documentação (Fiocruz)

DEA: Divisão de Engenharia e Arquitetura (IBu)

Dirac: Diretoria de Administração do Campus (Fiocruz)

Docomomo: International Committee for Documentation and Conservation of Buildings, Sites and Neighbourhoods of the Modern Movement

DOE: Diário Oficial do Estado (SP)

DOP: Departamento de Obras Públicas (SP)

DPH: Departamento do Patrimônio Histórico (COC ou PMSP)

Fapesp: Fundação de Amparo à Pesquisa do Estado de São Paulo

FCCUASO: Fundo para Construção da Cidade Universitária Armando de Salles Oliveira

Finep: Financiadora de Estudos e Projetos

Fiocruz: Fundação Oswaldo Cruz

Fundusp: Fundo de Construção da Universidade de São Paulo

IBAM: Instituto Brasileiro de Administração Municipal

IBu: Instituto Butantan

ICOMOS: International Council of Monuments and Sites

ICR: Istituto Centrale di Restauro (atual ISCR)

Inepac: Instituto Estadual do Patrimônio Cultural (RJ)

Iphan: Instituto do Patrimônio Histórico e Artístico Nacional

IPT: Instituto de Pesquisas Tecnológicas (SP)

ISCR: Istituto Superiore per la Conservazione ed il Restauro (Itália)

MHIB: Museu Histórico do Instituto Butantan

NAHM: Núcleo Arquitetônico Histórico de Manguinhos

NDoc: Núcleo de Documentação (IBu)

OEA: Organização dos Estados Americanos

Page: Plano de Ação do Estado (governo Carvalho Pinto-SP)

Pladi: Plano de Desenvolvimento Integrado (governo Ademar de Barros-SP)

PMSP: Prefeitura do Município de São Paulo

Poap: Plano de Ocupação da Área de Preservação (Fiocruz)

RA: Relatório Anual ( $\mathrm{IBu})$

RDC: Resolução da Diretoria Colegiada (Anvisa)

RIAP: Relatório de Impacto sobre Área de Preservação (Fiocruz)

Sagmacs: Sociedade para Análise Gráfica e Mecanográfica Aplicada aos Complexos Sociais

SEF: Superintendência do Espaço Físico (USP)

STCR: Serviço Técnico de Conservação e Restauro (Condephaat)

UPPH: Unidade de Preservação do Patrimônio Histórico (Condephaat)

USP: Universidade de São Paulo 


\section{Sumário}

Introdução

1 - O patrimônio cultural da saúde .....................................................................................19

1.1. Instituições precursoras: Instituto Pasteur e Fundação Oswaldo Cruz .............. 22

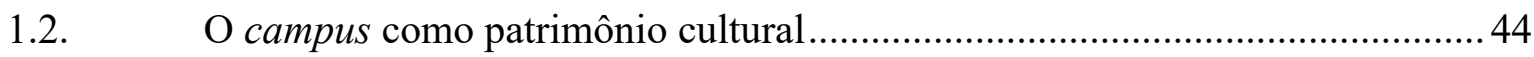

2 - Levantamento do patrimônio do Instituto Butantan ..........................................................47

2.1. Histórico e descrição do campus atual .............................................................. 50

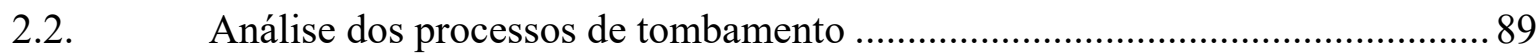

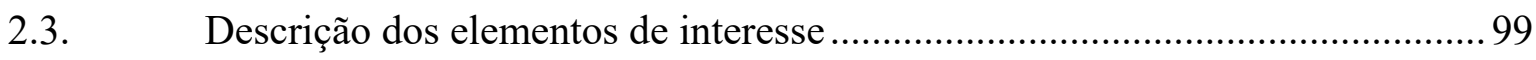

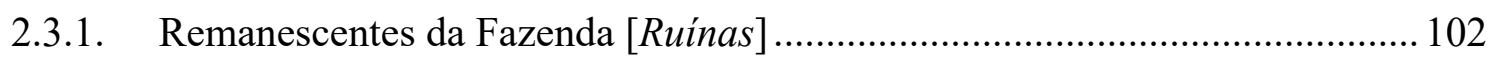

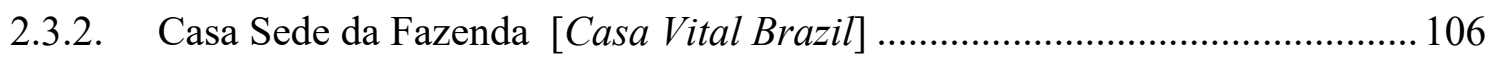

2.3.3. Cocheira-enfermaria [Laboratórios diversos] ............................................. 113

2.3.4. Edifício Principal [Edificio Vital Brazil] ..................................................... 122

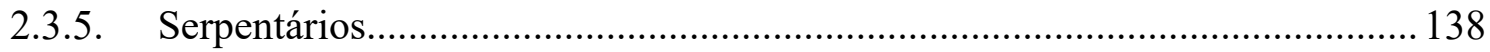

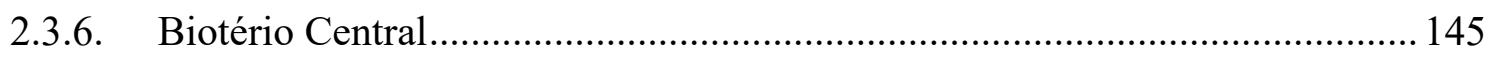

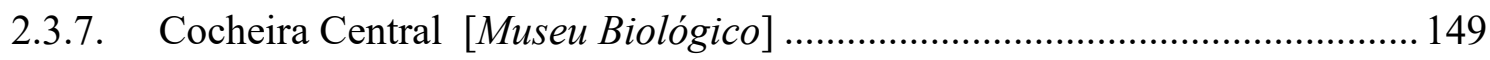

2.3.8. Escola de Veterinária [Pavilhão Lemos Monteiro] ......................................... 160

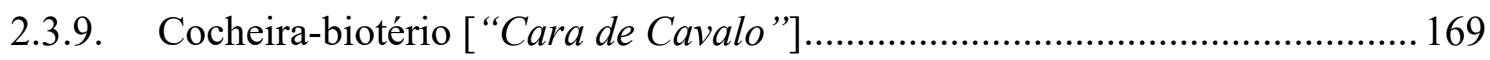

2.3.10. Paiol e Oficinas [Centro de Difusão Científica] .............................................. 174

2.3.11. Mostruário de Cobras [Bilheteria ] ................................................................. 179

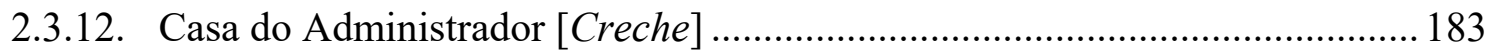

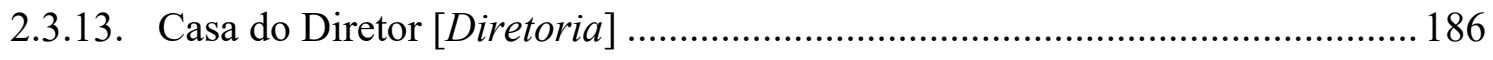

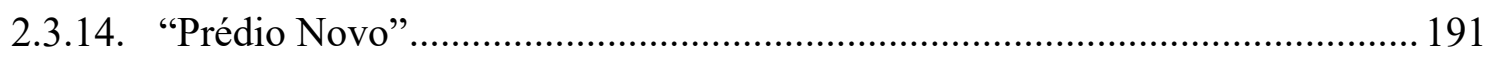

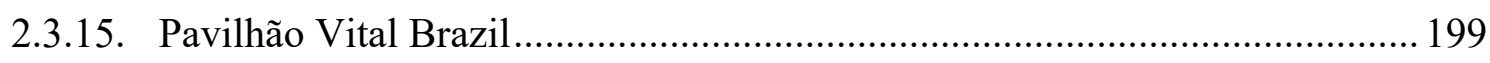

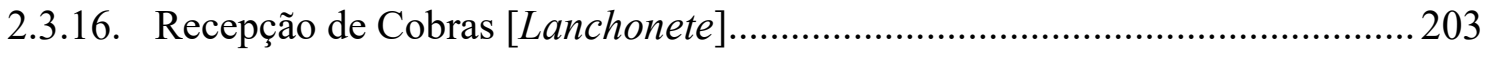

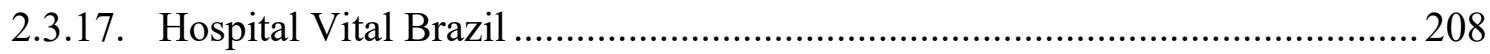

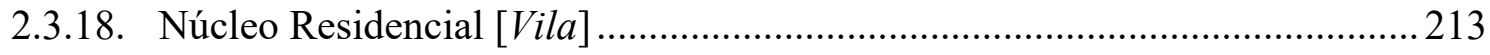

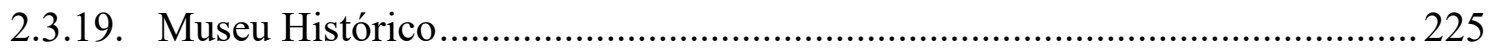

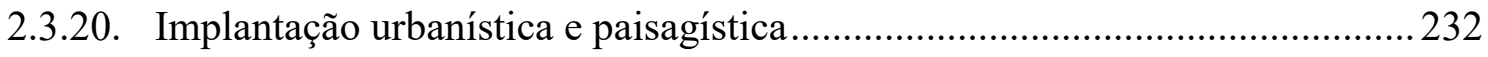

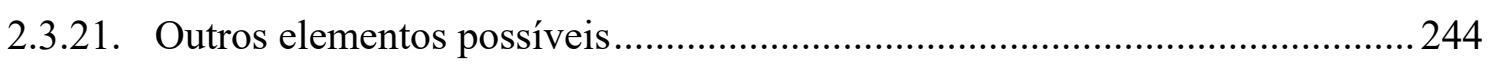

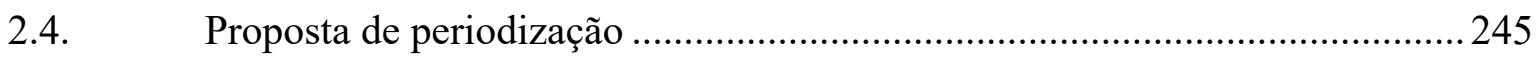




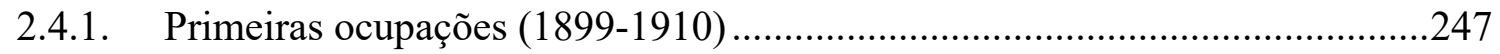

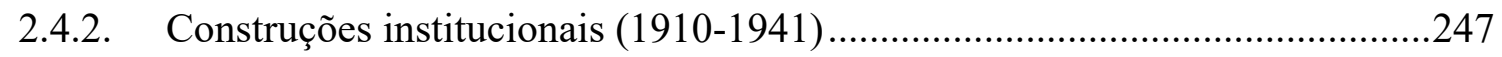

2.4.3. Reconfiguração territorial (1941-1961)........................................................248

2.4.4. Convênio com a Cidade Universitária (1961-1981)........................................248

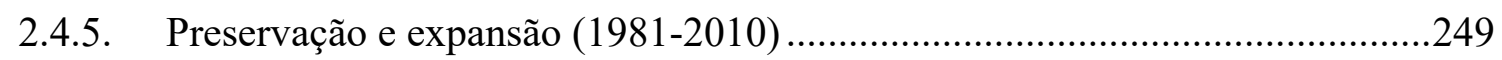

2.4.6. Gestão integrada $(2010$ - atualmente $)$.......................................................250

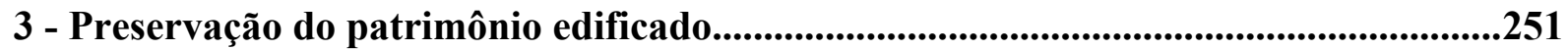

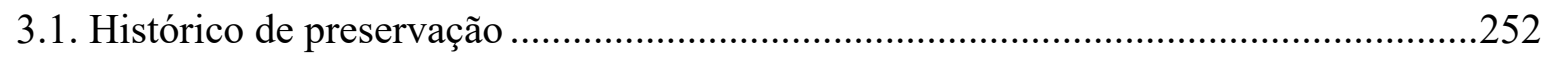

3.2. Estudos de caso por linhas de preservação...............................................263

3.2.1. Edifício Principal [Edificio Vital Brazil] - análise .........................................269

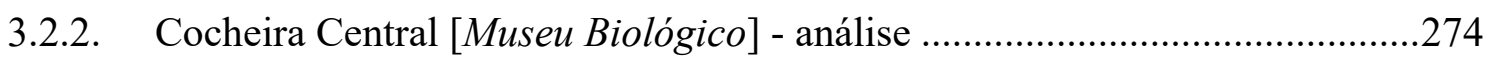

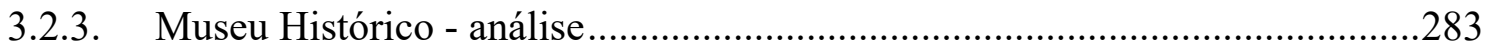

3.2.4. Remanescentes da Fazenda [Ruínas] - análise .............................................228

3.2.5. Implantação urbanística e paisagística - análise ...........................................290

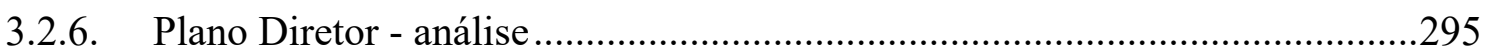

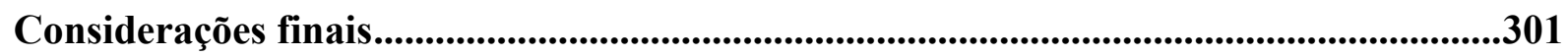

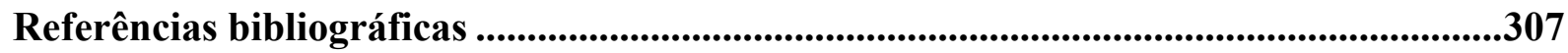

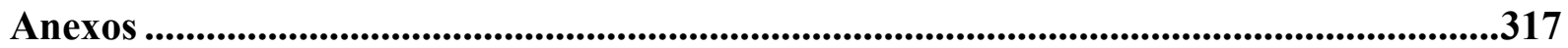


Introdução 
Dentro da tendência de reconhecimento do patrimônio cultural edificado ligado à ciência, têm sido produzidos na última década diversos trabalhos relevantes na área da historiografia e do restauro, na esteira da formação de grupos e instituições dedicados a essa temática. Graças a eles, publicações, linhas de pesquisas e ações de preservação têm levado cada vez mais a um público amplo a importância de conhecer e proteger os registros da trajetória de nossos cientistas, médicos, biólogos, veterinários e demais profissionais dedicados à saúde humana e ao estudos da fauna e flora, dentro de um espectro da arquitetura da ciência.

Entre as instituições que têm sido objeto de estudos com mais frequência estão os hospitais, por terem uma história mais longeva ${ }^{1}$, influenciando arquitetonicamente outros estabelecimentos na área da saúde, entre eles, os institutos de medicina experimental, responsáveis pela pesquisa, desenvolvimento e produção de medicamentos, soros e vacinas desde o final do século XIX. Entre esses institutos, no caso do Brasil, dois se destacam por sua importância no cenário científico brasileiro e pela semelhança de suas trajetórias: a Fundação Oswaldo Cruz (Manguinhos), no Rio de Janeiro, e o Instituto Butantan, em São Paulo, objeto dessa dissertação. Enquanto há diversos trabalhos acadêmicos sobre o patrimônio arquitetônico da primeira, ainda é incipiente a produção sobre o instituto paulista nesse campo $^{2}$, em geral realizada pelas próprias equipes de sua divisão cultural, uma das razões pelas quais se decidiu estudar o Instituto Butantan sob o ponto de vista da valorização e preservação de sua arquitetura, aliada ao crescente reconhecimento do patrimônio cultural da saúde 3 .

Tombado em 1981 pelo Condephaat e em 1991 pelo Conpresp, o Instituto Butantan, fundado em 1901 para debelar a epidemia de peste bubônica no Estado de São Paulo, tornouse em poucos anos uma referência como instituição científica na área da imunobiologia e do

\footnotetext{
${ }^{1}$ No Brasil, a história dos hospitais remonta ao século XVI, quando foi fundada a Santa Casa de Misericórdia de Todos os Santos em $1^{\circ}$ de novembro de 1543, em Santos-SP, inspirada nas Misericórdias de Portugal.

${ }^{2} \mathrm{Na}$ bibliografia consultada foram identificados apenas três publicações que abordam a arquitetura desse campus: BITTENCOURT (2009), MOTT e SANGLARD (2011) e MONTEIRO (2017). A publicação do número dos Cadernos de História da Ciência (pelo Laboratório de História da Ciência do IBu) dedicado à arquitetura da saúde, uma importante iniciativa na área, ainda estava em preparação ao término da presente pesquisa. Também não foram identificadas dissertações de mestrado ou teses de doutorado na área de arquitetura e urbanismo tratando do Instituto Butantan, e nenhuma publicação sobre a preservação e restauro de seus monumentos.

${ }^{3}$ Também influenciou na escolha do tema a minha participação profissional em alguma reformas de edifícios do Instituto entre 2005 e 2007.
} 
ofidismo, tendo hoje renome internacional pelo seu trinômio "pesquisa/produção/formação". Essa notoriedade foi constituída ao longo de uma história rica em conquistas, mas também em controvérsias, tendo como pano de fundo material seu conjunto arquitetônico, urbanístico e paisagístico que, além de registrar os avanços e mudanças dessas atividades científicas, também constitui um registro de diversas expressões técnicas, construtivas e estéticas de projetistas e construtores do século XIX até hoje. Como um palimpsesto, esse espaço, com seus edifícios, vias e praças se tornou, inevitavelmente, um repositório de memórias de diversos matizes (histórico, político, científico, biográfico, social e arquitetônico) e de diversas épocas. Memórias a serem preservadas, e das quais a própria comunidade de funcionários e visitantes do Instituto foi se dando conta por meio de acontecimentos chave que são levantados aqui. Com base em tais levantamentos, o objetivo central dessa pesquisa é estudar como o patrimônio arquitetônico do Instituto Butantan tem sido preservado ao longo de sua história.

Para esse estudo, considerando a mencionada escassez de trabalhos acadêmicos sobre a instituição no campo da arquitetura, constatou-se primeiramente que grande parte da pesquisa se daria sobre fontes primárias. Em segundo lugar, verificou-se a necessidade de elaborar um histórico da instituição, com ênfase em sua ocupação física, para embasar as análises da preservação de seu patrimônio arquitetônico, objetivo final do trabalho.

Seguindo essas premissas, a estrutura da dissertação se divide conceitualmente em três partes: a primeira parte, introdutória, dá uma visão geral do patrimônio edificado na área de saúde; a segunda, descritiva, apresenta a história do Instituto Butantan concentrando-se nos aspectos da sua ocupação física e seu patrimônio cultural; na terceira parte, analítica, utilizamse os levantamentos acumulados para estudar como o Instituto preserva esse patrimônio. Essa estruturação baseou a metodologia de pesquisa, que necessariamente combina levantamento de fontes primárias, consulta a bibliografia de referência e análise dos levantamentos com base nas teorias do campo de restauro.

Assim, o primeiro capítulo se concentra na pesquisa bibliográfica que faz referência às iniciativas e instituições voltadas ao estudo e à preservação do patrimônio da saúde, tomando o Instituto Pasteur e a Fundação Oswaldo Cruz como exemplos fundamentais. 
No segundo capítulo, foi possível utilizar as fontes primárias pesquisadas, aliadas à bibliografia de referência, para recompor um histórico do Instituto com foco em sua ocupação física. Essas fontes compõe-se principalmente por materiais do Núcleo de Documentação do Instituto Butantan, entre os quais se encontram peças de iconografia de arquitetura, acervo fotográfico e documentos textuais. Entre os documentos textuais, a base norteadora foi o conjunto de relatórios anuais elaborados pelo Instituto (geralmente em nome de seus diretores) para o governo estadual, nos quais se descreviam as principais atividades realizadas a cada ano, bem como as necessidades da instituição. A partir de todas essas fontes, procurou-se reconstituir a história do Instituto pelo viés de seu espaço físico ${ }^{4}$. Há trabalhos muito relevantes no campo da história da ciência, história cultural, pedagogia e museologia que tratam de diversos aspectos do Instituto relacionados a sua fundação, desenvolvimento e atualidade, mas que se fixam em aspectos socioculturais que não se aprofundam no papel do espaço construído da instituição, compreensivelmente, pois tal abordagem fugiria do escopo dessas pesquisas.

Nesse sentido, faz-se pertinente apresentar o Instituto sob o ponto de vista de seu espaço construído, para situá-lo na história da arquitetura de São Paulo e do Brasil, bem como, a partir desse histórico, demonstrar a importância de seu patrimônio cultural edificado como representante da ciência e da arquitetura brasileiras, além de toda importância científica já reconhecida dessa instituição ${ }^{5}$. Tal apresentação não se pretende exaustiva, uma vez que os aspectos envolvidos na formação do espaço físico são inúmeros, e podem ser explorados futuramente. Mas opta-se por elencar os principais eventos históricos e administrativos que tiveram influência e expressão direta no espaço edificado desse conjunto. Como modelo metodológico, adotam-se trabalhos sobre esse Instituto, como os já mencionados, de MOTT e SANGLARD (2011) e MONTEIRO (2017), além de estudos sobre outras instituições coetâneas,

\footnotetext{
${ }^{4} \mathrm{Na}$ época da pesquisa, grande parte do acervo (sobretudo o de desenhos técnicos), ainda não havia sido catalogado nem digitalizado, trabalho que vem sendo realizado gradativamente pelo Núcleo de Documentação desde sua criação em 2010. Por isso, algumas peças ainda não possuíam classificações precisas, numeração de páginas ou título. Procura-se nas citações fornecer o maior número de informações possível para identificação dessas peças. As citações literais mantiveram a ortografia e acentuação original dos documentos consultados, ainda que diferente das normas linguísticas atuais, salvo em casos de flagrante erro de grafia involuntário de seus autores.

${ }^{5}$ A utilização de fontes não textuais, como obras arquitetura, fotografias e informação oral também tem sido valorizada no campo da História desde a década de 1960. Sobre isso, ver BURKE (2011).
} 
como os de OLIVEIRA, COSTA e PESSOA (2003), e CYTRYNOWICZ e STÜCKER (2010), entre outros listados nas referências bibliográficas. Sobre a importância da história nos estudos e ações de preservação do patrimônio cultural, conforme defende KÜHL,

[...] a historiografia pode prescindir da conservação e da restauração; já as ações de preservação não deveriam prescindir, jamais, da história e historiografia, e os profissionais atuantes na preservação, mesmo não sendo todos historiadores, deveriam possuir uma "visão histórica" e sólida formação no campo - para entender e respeitar aquilo que é relevante do ponto de vista histórico-documental -, pois a ausência de uma consciência histórica pode trazer, e na maioria dos casos traz, consequências da maior gravidade nas ações sobre os bens culturais. (KÜHL, 2006, p. 17)

Segue-se, ao final desse capítulo, uma proposta de periodização, que sintetiza as informações levantadas durante a pesquisa, aglutinando-as em forma de uma linha do tempo que resume a história do Instituto do ponto de vista do espaço construído e de sua preservação.

No terceiro e último capítulo desse trabalho, é feita uma análise de alguns elementos representativos de ações de preservação e restauro empreendidas no Instituto. Para evitar interpretações meramente subjetivas sobre a pertinência dessas ações, foram escolhidos dois textos base: a Teoria da Restauração, de Cesare Brandi (BRANDI, 2004), e a Carta de Veneza (CURY, 2004), resultante do Segundo Congresso Internacional de Arquitetos e Técnicos dos Monumentos Históricos, promovido pelo Conselho Internacional de Monumentos e Sítios (ICOMOS), em 1964. Desse modo, procedeu-se o estudo dos edifícios, espaços e normativas do Instituto que receberam ou influenciaram ações de preservação e restauro, e avaliou-se em que medida essas ações atendiam às recomendações dos dois textos base mencionados.

Procura-se apresentar em todo trabalho, de forma contextualizada e analítica, as informações e imagens obtidas nos acervos de diversas bases, sendo especialmente relevantes aquelas do Núcleo de Documentação (NDoc) e do Museu Histórico do Instituto Butantan (MHIB). Por fim, foram fundamentais para a pesquisa os levantamentos in loco e as entrevistas semiestruturadas realizadas com funcionários, ex-funcionários, visitantes e estudiosos do Instituto, levando a informações que nem sempre estariam disponíveis nos documentos textuais e iconográficos. 
1 - O patrimônio cultural da saúde 
No campo da arquitetura, aqui estudado, o patrimônio cultural da saúde está relacionado aos edifícios e conjuntos paisagísticos e urbanísticos ligados à história das atividades de atendimento, cuidado, pesquisa e produção científica na área da saúde humana. Se forem incluídas as atividades de veterinária, biologia e botânica, esse universo pode ser ampliado, mas em geral elas se situam em um conjunto mais amplo que é o da arquitetura da ciência.

O patrimônio cultural da saúde tem sido objeto de crescente valorização e iniciativas de proteção nas últimas três décadas. Embora já houvesse ações anteriores, como o tombamento de hospitais, asilos e sanatórios pelo Iphan e pelos órgãos estaduais, essas iniciativas eram mais ligadas à excepcionalidade arquitetônica de tais monumentos ${ }^{6}$. É a partir da década de 1980 que pesquisas, grupos de estudo e ações de preservação passaram a considerar tais espaços como integrantes de um contexto da história da ciência e da saúde no Brasil, em um diálogo com as expressões arquitetônicas, sendo que todos os aspectos eram relevantes como documentos dessa história a serem estudados e preservados. Essa mudança se insere em um contexto de alargamento do campo patrimonial, com a crescente valorização de programas anteriormente incomuns ou inexistentes nas listas de patrimônio cultural, caso das indústrias, conjuntos residenciais e tecidos urbanos.

O início de ações mais sistemáticas de preservação do patrimônio da saúde internacionalmente se deu na França (SERRES, 2015), onde foi fundada em 1958 a Sociedade Francesa de História dos Hospitais (Société Française d'Histoire des Hôpitaux), que tem entre seus objetivos promover a defesa do patrimônio cultural edificado ligado aos hospitais.

Um marco dessa nova orientação foi a fundação do Docomomo (International Comitte for Documentation and Conservation of Sites, Buildings and Neighbourhood of Modern Mouvement) em 1988, motivada pela iminente destruição do sanatório de Zonnestraal, na Holanda (PORTO, 2008).

\footnotetext{
${ }^{6}$ Os primeiros edifícios ligados à saúde tombados pelo IPHAN foram o Hospital da Ordem Terceira de Nossa Senhora do Monte do Carmo (Rio de Janeiro) e a Santa Casa de Misericórdia da Bahia (Salvador), ambos em 1938. Sobre os tombamentos do patrimônio da saúde, ver MONTEIRO e RIBEIRO (2013) e SERRES (2015).
} 
No Brasil, a criação da Casa de Oswaldo Cruz (COC) em 1985 foi um marco na área de história e preservação do patrimônio da saúde 7 . A partir da década de 1990, a COC passou a realizar o levantamento do patrimônio cultural da saúde, incluindo o arquitetônico, relacionando-se com iniciativas similares da América Latina com apoio da UNESCO (como a Unidad de Patrimonio Cultural de la Salud, fundada em 2002 no Chile pelo Ministério da Saúde), culminando na criação da Rede Latino-americana de História e Patrimônio Cultural da Saúde. Tais pesquisas se integram à Biblioteca Virtual de Saúde (BVS), uma base de dados online voltada à pesquisa desse tipo de patrimônio. O documento apresentado pelo grupo de trabalho História e Patrimônio Cultural da Saúde, durante a $4^{\text {a }}$. Reunião de Coordenação Regional da Biblioteca virtual de Saúde, no $7^{\circ}$. Congresso Regional de Informação em Ciências da Saúde (Crics), em 2005 em Salvador, pode ser entendido como um marco na discussão sobre história, memória e patrimônio da saúde no Brasil, ao considerar o patrimônio cultural da saúde como um conjunto de bens materiais e simbólicos socialmente construídos, que expressam o processo da saúde individual e coletiva nas suas dimensões científica, histórica e cultural.

Simultaneamente a esses grupos de estudo, as iniciativas de tombamento passaram a considerar os monumentos relacionados à história da saúde de forma mais contextualizada. Em 1981 foi tombado pelo Iphan (processo 1037-T-80), o conjunto do Edifício Central (Pavilhão Mourisco), o Pavilhão da Peste e a Cavalariça do campus da Fiocruz, em Manguinhos. No mesmo ano foi tombado pelo Condephaat o Instituto Butantan, objeto deste trabalho, envolvendo todo conjunto do campus (item 2.2). O processo de tombamento do chamado “quadrilátero da saúde” em curso no Condephaat (processo 52.290/2005) ${ }^{8}$, também mostra essa valorização de conjuntos arquitetônicos da saúde, e não apenas de monumentos isolados.

Alguns institutos semelhantes no mundo já se conscientizaram da necessidade de estabelecer critérios combinando uso e preservação de seu patrimônio cultural (tanto da

\footnotetext{
${ }^{7}$ A COC foi fundada “tendo como finalidade a recuperação e a preservação da memória da ciência biomédica e da saúde no Brasil, o desenvolvimento de pesquisas históricas e de atividades museológicas, bem como a restauração e a conservação do patrimônio arquitetônico histórico da Fiocruz". (OLIVEIRA, COSTA e PESSOA, 2003, p.182) ${ }^{8} \mathrm{O}$ chamado "quadrilátero da saúde" é formado por um conjunto de edificações vinculadas à saúde pública (Faculdade de Medicina, Hospital das Clínicas, Instituto Adolfo Lutz, entre outros) delimitado pelas avenidas Doutor Arnaldo e Rebouças, e pelas ruas Teodoro Sampaio e Oscar Freire, em São Paulo. (MIURA, 2012)
} 
história da ciência, quanto do espaço edificado), preocupação que se insere em um dos pilares da maioria dessas instituições: a difusão cultural. Como exemplo, pode-se citar o Instituto Pasteur, que teve seu conjunto arquitetônico em Paris tombado pelo Ministério da Cultura francês em 1981, e também preserva suas unidades em diversos países (Tunísia, Senegal, Irã).

\subsection{Instituições precursoras: Instituto Pasteur e Fundação Oswaldo Cruz}

Para contextualizar o surgimento do Instituto Butantan, é importante estudar outras instituições semelhantes, e ter um panorama da virada do século XIX para o XX na área científica. Esse momento foi marcado pelas fundamentais descobertas na área da microbiologia. Desde 1887, as pesquisas de Louis Pasteur e Robert Koch, especialmente no combate à raiva e à tuberculose, desvendaram os mecanismos de transmissão de doenças causadas por microrganismos, bem como os métodos de diagnóstico e de cura que na prática transferiam grande parte dos exames médicos do leito do consultório para a bancada do laboratório. Essa transição, embora relativamente rápida ${ }^{9}$, manteve por alguns anos as práticas tradicionais, calcadas na prevalência do exame clínico dos pacientes em campanhas sanitárias, convivendo com as novas práticas microbiológicas, baseadas nos exames laboratoriais de sangue, menos passíveis de erros de interpretação, pois seguiam protocolos objetivos de análise de reagentes químicos e identificação de microrganismos.

Rapidamente o combate às epidemias através da microbiologia pasteuriana se tornou não apenas uma questão científica ou humanitária, mas estratégica do ponto de vista econômico, uma vez que as trocas comerciais entre a Europa, suas colônias, e os países recém independentes envolviam também o inevitável contato com doenças infecciosas autóctones das Américas, África e Ásia. No final do século XIX foram identificadas epidemias no Rio de Janeiro e em Santos que implicavam no fechamento de portos e quarentena de viajantes, a ponto de se recomendar que os navios de comércio se dirigissem a Buenos Aires, evitando passar por tais cidades (BERTUCCI, 2004; SEVCENKO, 2010). A microbiologia pasteuriana veio como

\footnotetext{
${ }^{9}$ Entre a criação da primeira vacina antirrábica, por Pasteur, em 1885, a fundação do Instituto com seu nome, em 1887 e a fundação do Instituto Soroterápico Federal no Rio de Janeiro, em 1900, transcorreram 15 anos.
} 
solução auspiciosa a esses entraves, e o lugar por excelência dessa atividade passou a ser o instituto de pesquisa e produção de vacinas e soros, implicando também em um novo programa arquitetônico para abrigar trabalhos de investigação básica, testes e produção de fármacos. Anteriormente, já existiam instituições com tais atividades. Porém, eram ligadas aos hospitais, administrados pela Igreja, com configurações físicas advindas dos mosteiros e claustros ${ }^{10}$. Inicialmente, esses hospitais eram centrados na medicina empírica, ou seja, que desenvolvia suas pesquisas a partir dos próprios doentes. Gradativamente foram desenvolvendo a medicina experimental, em que os estudos são realizados in vitro com os vírus e microorganismos isolados, exigindo outros tipos de espaço, como o laboratório, o abrigo de animais para inoculação, a fábrica de fármacos, as estufas, entre outros. Para isso, construíram-se pavilhões com ambientes amplos, em geral utilizando linguagens arquitetônicas da época, formando conjuntos paisagísticos também utilizados como parques. Segundo COSTA(2009), a implantação dos primeiros institutos de pesquisa em saúde seguiram o sistema Tollet:

O chamado sistema Tollet foi desenvolvido pelo engenheiro militar francês Casimir Tollet (1828-1892) em 1872 e estabelecia novas bases sanitárias para a construção de edifícios hospitalares. Esse sistema propugnava que tais construções deveriam ser afastadas das aglomerações urbanas e localizadas em terrenos ensolarados. A superfície do terreno seria crescente em relação ao número de alojamentos coletivos. Os edifícios seriam dispostos por toda a superfície do terreno e respeitariam um paralelismo entre os diversos prédios; entre outros itens de segurança. O sistema Tollet, assim concebido, foi amplamente difundido por toda a Europa e ficou conhecido como "modelo pavilhonar" e foi marcado pelo medo do contágio pelos germes - seguindo as descobertas de Louis Pasteur. Era caracterizado por edifícios de, no máximo, dois andares. Neles imperavam o princípio de isolamento, onde cada doença e cada doente eram isolados no interior do pavilhão. (COSTA, Renato da Gama-Rosa. A arquitetura do IVB, um patrimônio moderno. In: BITTENCOURT, 2009, p.82)

Foi o caso do Instituto Pasteur em Paris ${ }^{11}$, considerado berço da microbiologia, fundado em 1887, com suas instalações inauguradas em 1888. Seguindo o sucesso da vacina contra a raiva elaborada por Pasteur, e com a doação de fundos por vários colaboradores, o plano do

\footnotetext{
${ }^{10} \mathrm{O}$ modelo da Santa Casa da Misericórdia portuguesa (Lisboa, 1498), foi transladado ao Brasil e constituiu o principal centro de cuidados dos doentes pobres nas primeiras cidades coloniais. SEGRE, Roberto. Hospitais. Arquitetura da linha da sombra - Reflexão acerca do papel da arquitetura hospitalar na história mundial. http://www.vitruvius.com.br/revistas/read/resenhasonline/12.134/4607, acessado em 05/09/2017.

${ }^{11} \mathrm{O}$ imperador D. Pedro II, entusiasta dos avanços científicos e movido pela necessidade de combate a epidemias, convidou Louis Pasteur (com quem mantinha amizade) para testar suas pesquisas no Brasil pouco antes da fundação desse Instituto em Paris, mas o cientista declinou. (ASSUMPÇÃO, 2014)
} 
Instituto Pasteur previa, já em seu surgimento, as atividades de fornecimento de soros e vacinas, de centro de pesquisa de doenças infecciosas, e de centro de ensino, configurando o tripé “produção, pesquisa e formação" que seria modelo para institutos semelhantes no mundo, incluindo os do Brasil (DIAS, 2010). Em março de 1887 foi adquirido um terreno de $11.000 \mathrm{~m}^{2}$ na Rue Dutot (atual Rue Docteur Roux), com fundos para a Rue des Fourneaux (atual Rue Falguière), no distrito parisiense de Vaugirard, então ocupado por usinas de gás, abatedouros, linha férrea e indústrias incipientes (ROULEAU, 1985). O projeto do arquiteto Félicien Brebant ${ }^{12}$ começou a ser executado em junho do mesmo ano e foi inaugurado em 14 de novembro de $1888^{13}$. Segundo descrição da instituição, foram utilizados arenitos, pedras lavradas e tijolos para construir dois grandes blocos paralelos unidos por uma circulação central, com uma fachada em linguagem denominada Louis XIII.

No primeiro bloco do edifício principal, junto à Rue Dutot, estavam instalados os apartamentos de Louis Pasteur e esposa, e seu laboratório. No segundo bloco se encontravam os serviços gerais de raiva dirigidos pelo Dr. Grancher, quatro laboratórios para o estudo de doenças infecciosas, dirigidos por Émile Duclaux, Émile Roux, Elie Metchnikoff e Charles Chamberland, e salas de cursos. Em 1900 o Instituto se ampliou quando foi adquirido um terreno do outro lado da Rue Dutot, graças a doações de Madame Lebaudy, para construir um hospital e um Instituto de Bioquímica, financiado pela Baroneza de Hirsch. Hoje o Instituto Pasteur é um campus com cerca de 6 hectares e mais de 20 edifícios, em que os primeiros, típicos do Ecletismo, foram convertidos em museus e convivem com edificações contemporâneas.

Pelas descrições da época e análise das plantas (figuras 01 e 02), verifica-se que o Instituto Pasteur de Paris, implantado em um terreno em forma de paralelogramo, possuía o mencionado edifício principal com planta " $\mathrm{H}$ " de dois blocos interligados concentrando a maior parte das atividades, e construções secundárias destinadas ao abrigo de animais para os experimentos, galpões para depósito (paióis), residências de funcionários e apoios. Esses dois blocos, de acordo com as plantas estudadas, diferenciavam as atividades laboratoriais de atividades mais privadas

\footnotetext{
${ }^{12} \mathrm{O}$ Ministério da Cultura também cita os arquitetos Charles Girault; Luc-Olivier Merson e Martin M.F., responsáveis por alterações posteriores (como a cripta de Pasteur) e outros edifícios do conjunto.

${ }^{13}$ Portanto, o edifício foi concluído após a fundação formal do próprio Instituto.
} 
do seu diretor, incluindo seu laboratório e residência ${ }^{14}$. Do ponto de vista estético, o edifício seguia as correntes classicizantes valorizadas por franceses, espanhóis e flamencos, mostrando um certo tradicionalismo mesmo nos edifícios vinculados à ciência de ponta (figuras 03 e 04). Porém, a planta interna diverge bastante dos ordenamentos simétricos e proporcionais classicistas, adaptando essa estética tradicional a um uso totalmente novo.

Também é possível notar em diversas publicações e divulgações desse Instituto o papel que o edifício principal teve na formação de sua identidade institucional, constituindo metonimicamente sua imagem, um conhecido mecanismo de significação da arquitetura: para o senso comum, o edifício é o próprio Instituto Pasteur. Especialmente a fachada de Brébant se tornou uma marca da instituição (figura 05).

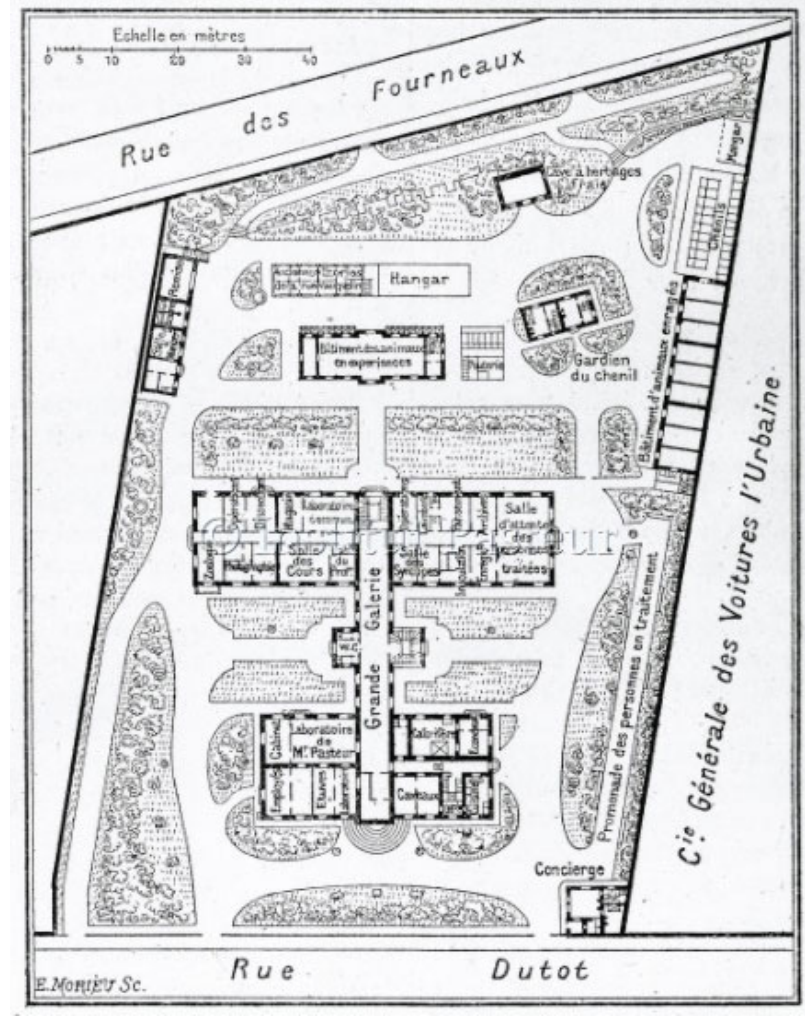

Fig. 01

Implantação original do Instituto Pasteur em Paris, 1888. Vê-se o edifício principal com dois blocos conectados por uma Grande Galerie, além de edificações de apoio (estábulos, depósitos) e jardins. (Fonte: http://www.pasteur.fr, acessado em 05/08/2018)

\footnotetext{
${ }^{14}$ Com o falecimento de Pasteur em 1895, seu corpo foi sepultado em uma cripta nesse edifício.
} 

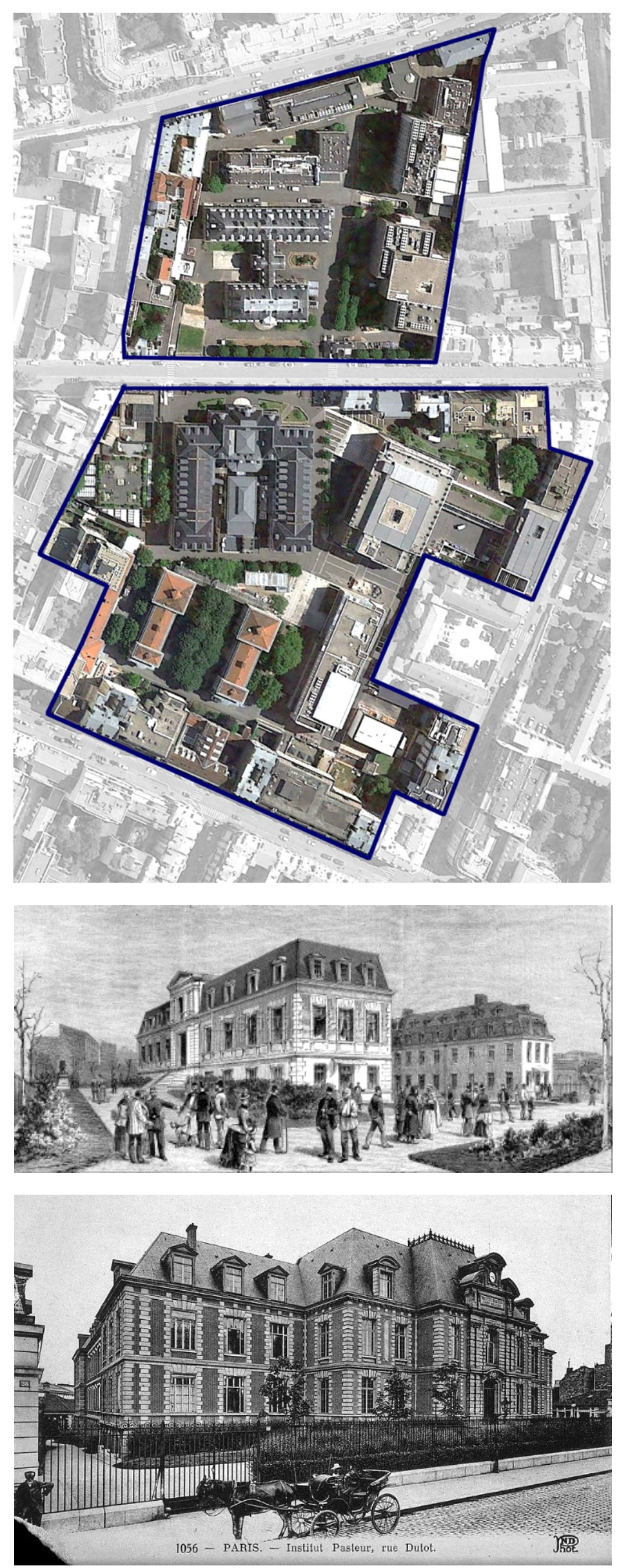

Fig. 02

Implantação do Instituto Pasteur em Paris em 2018: o perímetro original se expandiu lateralmente e para o novo terreno do outro lado da antiga Rue Dutot, adquirido em 1900. Hoje o conjunto soma cerca de 60 mil $\mathrm{m}^{2}$ (Fonte: plataforma Google Earth, acessada em $05 / 08 / 2018$, cor alterada)

Fig. 03

Ilustração do edifício principal do Instituto Pasteur no início do século XX, projeto de Félicien Brebant: é possível ver os dois blocos conectados e a utilização do espaço público (Fonte: http://www.pasteur.fr, acessado em 05/08/2017)

Fig. 04

Fachada frontal do hospital do Instituto Pasteur no início do século XX, projeto de M.F. Martin, com elementos classicizantes próprios do Ecletismo (Fonte: Welcome Library, Iconographic Collection cod. 569063i) 


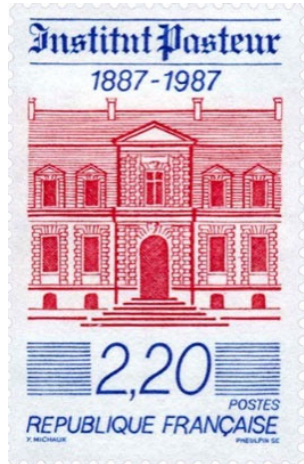

Fig. 05

Selo comemorativo do centenário do Instituto Pasteur: a arquitetura utilizada como identidade da instituição (Fonte: http://www.laposte.fr, 05/08/2018)

Fig. 06

Instituto Pasteur de Dakar, Senegal: as diversas filiais da instituição hoje têm seu valor cultural e científico reconhecidos (Fonte: http://www.pasteur.sn, 06/08/2018)

A partir de seu surgimento, o Instituto Pasteur se tornou um modelo para esse novo programa, inspirando a fundação de instituições semelhantes na Europa (como a London School of Hygiene \& Tropical Medicine) e em outros continentes. Estas últimas são de especial interesse pois se assemelham, em sua origem e desenvolvimento, aos institutos criados no Brasil. A razão principal da abertura desses institutos na Ásia, África e América era a necessidade de controlar epidemias de doenças autóctones, garantindo a estabilidade do comércio com essas regiões. As filiais do próprio Instituto Pasteur em outros continentes são um exemplo ${ }^{15}$. Chamam atenção as linguagens arquitetônicas utilizadas nesses conjuntos, com elementos então considerados exóticos (orientalistas), próprios dos locais em que eram implantados, combinados com as correntes modernizantes da época, principalmente o Art

\footnotetext{
${ }^{15}$ O Instituto Pasteur possui filiais na Grécia, Itália, Rússia, Uruguai, Camarões, República Central Africana, Costa do Marfim, Madagascar, Senegal, Argélia, Irã, Marrocos, Tunísia, Cambodja, China, Laos e Vietnã.
} 
Nouveau e Art Déco. Essa opção estética possivelmente fazia parte da construção simbólica da identidade desses institutos, na qual o uso das linguagens mais avançadas da época (as citadas correntes modernizantes) se coadunava com soluções técnicas inovadoras: critérios de ventilação, insolação e acabamentos que facilitavam a assepsia, sobretudo cerâmicos, evitando superfícies porosas, frestas e cantos acumuladores de sujeira. Alguns exemplos desses casos são: filial do Instituto Pasteur da Tunísia (1902), do Irã (1920), do Senegal (1924) (figura 06) e do Vietnã (1936). Essas unidades são mantidas em condições de conservação ou restauradas pelas próprias instituições.

Ainda assim, o Instituto Pasteur de Paris sofreu diversas alterações, tanto na conformação de seu terreno quanto nos edifícios, além das modificações urbanas do entorno, sendo tombado, parcialmente, apenas em novembro de 1981 pelo departamento de Monumentos Históricos do Ministério da Cultura francês ${ }^{16}$. O tombamento compreende o edifício principal, o hospital, a estufa e blocos administrativos menores, como é descrito pela ficha desse processo:

Estabelecimento de saúde construído em 1888 pelo arquiteto Félicien Brébant, financiado por uma petição pública aberta em 1886 após a descoberta da vacina por Louis Pasteur. O cientista, morto em 1895, está sepultado na cripta de uma capela funerária realizada em 1896 pelo arquiteto Charles Girault e decorada com mosaicos por Luc-Olivier Merson. Em 1900, graças às doações da Baronesa Hirsch e da madame Lebaudy, novos edifícios foram construídos: os escritórios administrativos, uma estufa e um hospital, do arquiteto M.F.Martin, com 90 leitos. Desde 1936, o apartamento e o laboratório de Pasteur abrigam um museu histórico-científico. (http://www2.culture.gouv.fr/culture/inventai/patrimoine, 15/10/2018, trad. nossa)

Muitos desses edifícios continuam sendo utilizados até hoje como centros de pesquisas laboratoriais, com todas as adaptações necessárias para abrigar desde sequenciadores de DNA, salas limpas ${ }^{17}$ e exaustores, até despejos de material radioativo, entre outras especificidades. Essa longevidade parece se dar por dois motivos: economia e simbologia. A primeira se refere ao reaproveitamento de estruturas, e a segunda à representação da longevidade das instituições,

\footnotetext{
${ }^{16}$ Código Mérimee PA00086655 de 13/11/1981.

17 "Sala limpa" é o termo utilizado para laboratórios concebidos com elementos para evitar contaminação, entre os quais estão revestimentos resistentes a sujeira e umidade, com mínimo de juntas nos revestimentos, com execução de cantos arredondados, controle de ventilação e de entrada/saída de pessoas (com antecâmaras) e, conforme as atividades, eliminação de janelas. Esses procedimentos são tratados pela área de conhecimento da Biossegurança, que estabelece vários níveis de proteção dos ambientes científicos. (BLUCHER, 2010)
} 
algo sempre respeitado no meio científico. Assim, o Instituto Pasteur de Paris influenciou, cientificamente e espacialmente, outros institutos semelhantes pelo mundo.

No caso do Brasil do final do século XIX, vivia-se a transição do Império para a República, marcada, no campo do urbanismo, pelo investimento em obras de infraestrutura em capitais como São Paulo e Rio de Janeiro ${ }^{18}$. Ao mesmo tempo, essas cidades cresciam com a chegada de imigrantes europeus e a libertação dos escravos. A ocupação acelerada e sem planejamento em bairros insalubres, aliada a doenças tropicais e importadas, levou a epidemias de peste bubônica, febre amarela e varíola, matando milhares de pessoas entre 1890 e 1904 . Essa foi uma das causas da reurbanização liderada pelos prefeitos Pereira Passos, no Rio de Janeiro, e Antônio Prado, em São Paulo ${ }^{19}$, que implicou na reforma de vastas áreas, seguindo as novas recomendações da Higiene, campo de conhecimento que ganhava cada vez mais adeptos sobretudo entre os engenheiros e arquitetos, mas que também levava ao que hoje se conhece como "gentrificação" e "higienismo", ou seja, a retirada (muitas vezes violenta) de populações de baixa renda de determinados espaços no intuito de torná-los supostamente mais "limpos" e valorizados. ${ }^{20}$

Paralelamente às reformas urbanas, as descobertas científicas evidenciaram a importância da pesquisa e desenvolvimento para o controle de doenças. As ex-colônias que, em princípio, importaram os fármacos do Instituto Pasteur, perceberam a necessidade de fundar institutos semelhantes para atender suas demandas. Nesse contexto, médicos como Oswaldo Cruz, Vital Brazil, Emilio Ribas, Adolpho Lutz e Carlos Chagas aliaram o conhecimento adquirido na Europa às necessidades locais para fundar tais instituições de pesquisa e produção em saúde no Brasil. Embora haja um caráter humanitário nessas iniciativas, a urgência em controlar as epidemias se devia também aos prejuízos comerciais que começavam a acarretar.

\footnotetext{
${ }^{18}$ Para mais informações sobre o crescimento urbano do período, ver TOLEDO, 2004.

19 "De que adiantaria reformar o porto e replanejar a cidade, se ninguém quisesse atracar no primeiro nem adentrar na segunda? Para que se pudesse consagrar efetivamente a campanha de atração de capitais, imigrantes, técnicos e equipamentos estrangeiros, seria igualmente indispensável proceder ao saneamento da cidade. Eis aí delineadas as três diretrizes básicas da administração de Rodrigues Alves, e o modo como ele procurava, por meio delas, articular os interesses paulistas e as finanças internacionais." (SEVCENKO, 2010, p.65)

${ }^{20}$ No caso do Rio, o artigo na Revista dos Constructores mostrava (inclusive em seu título) a intenção de "limpar" áreas da orla voltadas às transações comerciais: "Nosso ideal é reduzir toda a cidade baixa a um belíssimo parque, só tendo na linha do litoral os estabelecimentos necessários ao movimento de importação e de exportação." Demolir-demolir-e demolir. Revista dos Constructores. Rio de Janeiro, Ano III, núm. 9, setembro de 1889.
} 
Duas dessas instituições chamam atenção pelas semelhanças em sua origem: a Fundação Oswaldo Cruz (Manguinhos) ${ }^{21}$ no Rio de Janeiro e o Instituto Butantan, em São Paulo, objeto desse trabalho. Ambas foram criadas como centros de pesquisa e produção biomédica em conjuntos paisagísticos e arquitetônicos localizados em áreas então periféricas e semi-rurais, lideradas por pesquisadores ilustres no contexto científico do momento, e se tornaram referências mundiais em pesquisa e produção de soroterápicos ao longo do último século. Pelo menos a partir de 1985, Manguinhos tem desenvolvido trabalhos de conservação, pesquisa e divulgação de seu patrimônio científico e arquitetônico, através da Casa de Oswaldo Cruz, que é sua divisão cultural. Por essas semelhanças, cabe levantar alguns pontos do desenvolvimento de Manguinhos como base de comparação em relação à trajetória do Instituto Butantan, inclusive porque ambos estabeleceram relações e influências múltiplas em sua história.

Manguinhos também surgiu devido à epidemia de peste bubônica em 1899, que levou o prefeito do Rio de Janeiro, Cesário Alvim, a autorizar o sanitarista Barão de Pedro Affonso, chefe do Instituto Vacínico Municipal, a montar um centro de pesquisa e produção de soros. O local escolhido foi uma fazenda em Inhaúma, desapropriada para atividades de queima de lixo, entre a Baía da Guanabara e o Rio Faria, próximo à atual Ilha do Governador. O terreno, já conhecido como Fazenda Manguinhos, era afastado do centro e próximo às recentes ferrovias D. Pedro II e ao cais de Inhaúma, facilitando o recebimento e transporte de fármacos. Em 1900, a Prefeitura recuou em seu plano de investimento no centro de pesquisa, e o governo federal assumiu a direção, fundando o Instituto Soroterápico Federal. Em 1902 o até então assistente, Oswaldo Cruz, assumiu a direção do Instituto, que passaria a levar seu nome em 1914. Em 1903, o médico foi nomeado Diretor Geral de Saúde Pública pelo presidente Rodrigues Alves. Vieram então campanhas sanitaristas que ajudaram a controlar epidemias, mas com fundo higienizador

\footnotetext{
${ }^{21}$ Ao longo de sua história, essa instituição foi chamada de Instituto Soroterápico Federal, Instituto Oswaldo Cruz, Fundação Instituto Oswaldo Cruz, Fundação Oswaldo Cruz, além de nomes de setores ou funções específicos (como BioManguinhos) e de unidades em outras partes do país. Nesse trabalho, opta-se por adotar o nome "Manguinhos", por ser o mais vinculado à noção de espaço físico (o campus do bairro de Manguinhos no Rio de Janeiro). O nome Manguinhos se referia à menor quantidade de mangues, prevenindo o terreno de inundações. Para mais detalhes sobre a origem da instituição, ver OLIVEIRA, COSTA e PESSOA, 2003 e BENCHIMOL, 1990.
} 
frente à população mais pobre das áreas centrais, fato que gerou a Revolta da Vacina em 1904 (SEVCENKO, 2010).

A fazenda de Manguinhos ocupava área de aproximadamente $793.000 \mathrm{~m}^{2}$ (figura 07). Algumas construções nela remanescentes, como cocheiras e barracões, foram improvisadas para a urgente tarefa de produção de soros. Os antigos fornos e chaminés de queima de lixo permaneceram até a década de 1920, quando foram demolidos. Sobre as primeiras instalações daquele Instituto, Oswaldo Cruz descrevia em 1902:

Os laboratórios do Instituto estão instalados em dois edifícios existentes sobre outras tantas colinas distantes entre si e separadas por um planície. Nesta existem, além dos fornos de incineração de lixo, a enfermaria especial onde são inoculados os cavalos com culturas vivas de peste; um barracão transformado em depósito de forragens; capinzal que fornece alimento para os cavalos do Instituto, dependências essas que têm sido ocupadas efetivamente e têm sido imprescindíveis para o preparo exclusivo de soro anti-pestoso. A cocheira-enfermaria, sobretudo, constitui por si a maior garantia contra a infecção possível pela peste, não só do pessoal do Instituto, como as pessoas que habitam as imediações do local [...]. As instalações do laboratório superior são acanhadas e insuficientes para a extensão do serviço. Muitos aparelhos não estão instalados por falta de espaço; não existe o quarto-estufa para culturas em grande escala de bacilos da difteria para o preparo do soro anti-diftérico, nem da tuberculose, para o preparo da tuberculina, que vai ser também iniciado". (Carta de Oswaldo Cruz ao Diretor Geral de Saúde Pública, 31 de dezembro de 1902, Rio de Janeiro, Arquivo Geral da Cidade do Rio de Janeiro)

A partir de então, foram construídos edifícios para a finalidade de laboratórios, biotérios e depósitos, para os quais Oswaldo convidou o arquiteto português Luiz Moraes Júnior, radicado no Brasil, que iniciou os projetos e a construção daqueles edifícios necessários, combinando técnicas avançadas para a época (como o uso de elevador, revestimentos cerâmicos com cantos arredondados, ambientes com farta ventilação), combinadas com as linguagens de época, vinculadas ao Ecletismo. A dicotomia entre atividades científicas de ponta e aspectos estéticos acadêmicos pitorescos é visível no principal edifício construído então, e até hoje ponto de referência do campus, o chamado Pavilhão Mourisco ou Castelo, construído entre 1905 e 1914, situado no alto da maior colina do terreno, de frente para a Baía de Guanabara (figuras 08 a 10). Nele, podem ser vistos traços inspirados no palácio de Alhambra, com materiais provenientes de diversos países europeus, além do elevador mais antigo em funcionamento no Rio de Janeiro, feito de mogno com cúpula de espelhos e cristal. Luiz Moraes Jr. vinha de Faro, Portugal, região de intensa influência mourisca, o que, somado à crescente presença do 
orientalismo no Rio de Janeiro do início do século $\mathrm{XX}^{22}$, pode explicar as opções do engenheiroarquiteto para Manguinhos. De qualquer forma, as linguagens orientalizantes faziam parte de uma tendência que se formara no final do século XVIII na Europa, no sentido de se afastar do rigor das fórmulas neoclássicas francesas, que, segundo seus críticos, eram demasiadamente acadêmicas, rígidas e vinculadas a uma nobreza decadente. Essas mudanças se deram com idas e vindas, caracterizadas pelas misturas de linguagens do Ecletismo, das quais o alhambrismo, o medievalismo islâmico, a arquitetura neoumourisca, neoegípcia, entre tantos outros "neos", também chamados de revivalismos ${ }^{23}$, são exemplos (figura 11).

Apesar das transformações nos edifícios individuais, permaneceu razoavelmente preservada a conformação paisagística do núcleo histórico, formada por caminhos entre os edifícios e a mata. Entre eles, é implantada uma praça central, em uma das duas colina, da qual saem os caminhos pelo campus, em uma conformação de parque. Pode-se classificar essa configuração como mais próxima ao paisagismo inglês, já que as escalas não são monumentais, evitando-se grandes perspectivas ou eixos retilíneos.

Desde então, foram construídos e destruídos diversos edifícios, conforme as necessidades das pesquisas. A partir de 1930, com o governo de Getúlio Vargas, diminuiu-se drasticamente a autonomia de Manguinhos, e se iniciou uma fase de queda nas pesquisas e deterioração do espaço físico, ao mesmo tempo em que se criou o aterro para um clube aeronáutico, tirando do campus a margem da baía da Guanabara.

A revolução de 1930 é um marco muito importante na história não só do Instituto Oswaldo Cruz como de todas as instituições ligadas à saúde, ao ensino e à pesquisa. Para Manguinhos redundou, principalmente, na supressão de parte substancial dos elementos de autonomia que Oswaldo Cruz conquistara em 1908 e Chagas preservara na reforma de 1920. (BENCHIMOL e TEIXEIRA, 1993, p.203)

Houve uma pequena retomada de novas construções a partir 1940, agora já com influência do Movimento Moderno, em especial com sua vertente carioca, aliando os princípios

\footnotetext{
${ }^{22}$ Embora ainda não fosse tão presente na arquitetura do Brasil, o orientalismo estava em voga em diversas frentes, como a moda, a literatura e as artes gráficas (FEIJÃO, 2011). Sobre outros exemplares da arquitetura mourisca no Rio de Janeiro e em São Paulo, ver COSTA, 2003.

${ }^{23}$ Aqui se opta pelo termo "neos" em vez de "revivalismos", uma vez que esse último pode passar a noção de que se buscava com tais obras retornar a um modo de vida e a um comportamento do passado, hipótese que ao nosso ver extrapola o campo formal e estético de modo exageradamente especulativo.
} 
defendidos por Le Corbusier com uma expressividade nacional notada nos desenhos mais livres, na utilização de elementos caraterísticos de nossa arquitetura colonial, como os elementos de proteção solar, a azulejaria e as varandas, reinterpretados. Nessa linguagem, esse campus contou com projetos do arquiteto Jorge Ferreira, da equipe de obras do Ministério de Educação e Saúde, Roberto Nadalutti, do Serviço Especial de Saúde Pública (SESP) e murais de Burle Marx e Paulo Rossi Osir, entre outros profissionais (figura 12).

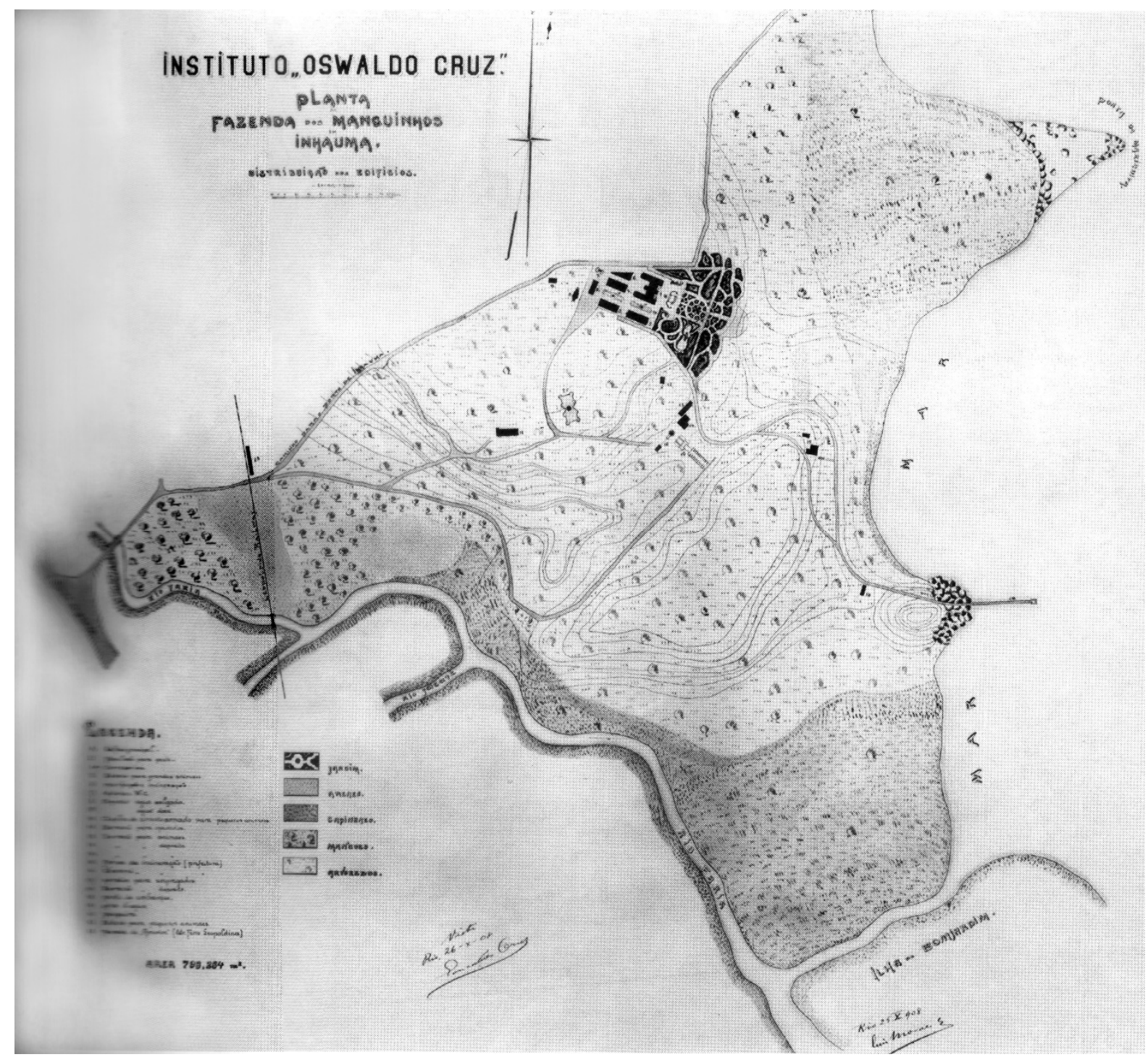

Fig. 07

Implantação do conjunto de Manguinhos elaborada por Luiz Moraes Jr. em 1908: a leste está a baía da Guanabara. É possível notar a preocupação do arquiteto em ambientar a ocupação com jardins e vias internas, e não apenas construções utilitárias isoladas. (Fonte: Departamento Arquivo e Documentação (DAD) / Fiocruz) 

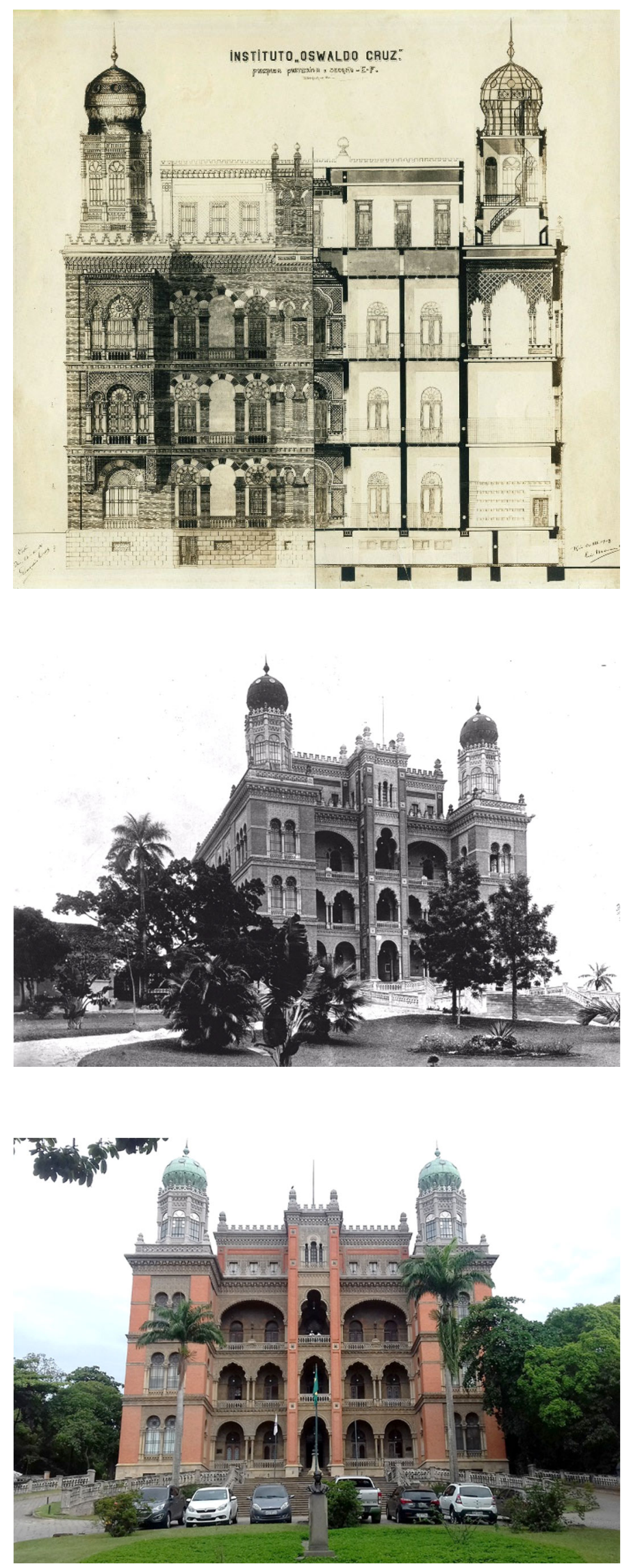

Fig. 08

Fachada do Pavilhão Mourisco projetada por Luiz Moraes Jr.: inicialmente com 2 pavimentos, o projeto foi modificado para ter 4 pavimentos (Fonte: DAD/Fiocruz)

Fig. 09

Pavilhão Mourisco na década de 1920: nota-se a preocupação com o paisagismo do entorno. (Fonte: $\mathrm{DAD} /$ Fiocruz)

Fig. 10

Pavilhão Mourisco em 2016: como resultado de planos de preservação e restauro, o edifício mantém suas principais características arquitetônicas conservadas. (Fonte: autor) 

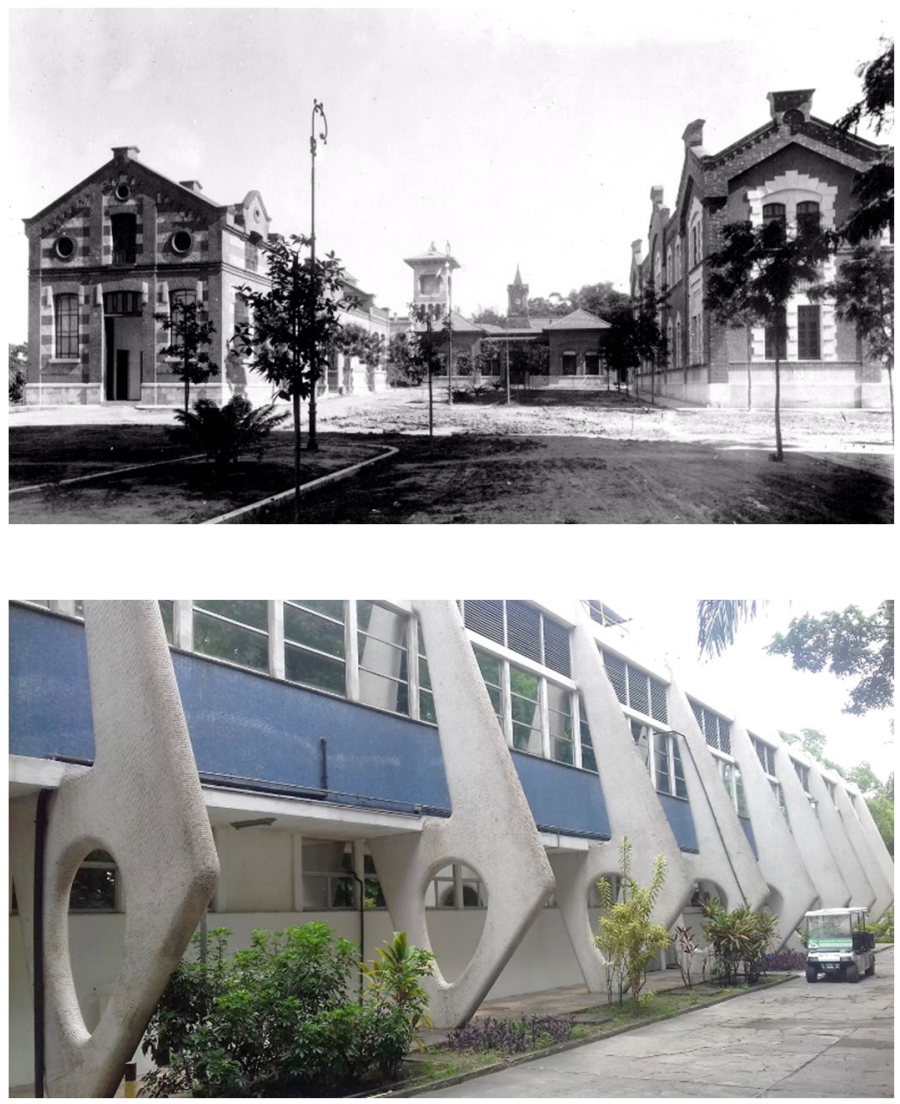

Fig. 11

Conjunto da Praça Pasteur, localizado ao fundo do Pavilhão Mourisco, década de 1910. As linguagens "neos" eram comuns na época e foram adotadas amplamente nos novos edifícios do Instituto Soroterápico Federal (Fonte: DAD/Fiocruz)

Fig. 12

Pavilhão da Febre Amarela (atual Pavilhão Henrique Aragão), construído na década de 1950, com projeto de Roberto Nadalutti: a estrutura independente, com certa expressão fugindo da ortogonalidade racionalista, mostra a presença marcante do modernismo carioca nesse campus. (Fonte: autor, 2016)

Especialmente a obra de Nadalutti mostra a preocupação em aliar a linguagem expressiva à técnica necessária para o uso científico ${ }^{24}$.

Após essas obras realizadas a partir da década de 1940, Manguinhos passou a sofrer novamente com falta de recursos e de planejamento, somados a ingerências externas de cunho político. O momento de maior deterioração na gestão e conservação do espaço físico se deu nas décadas de 1960 e 1970, quando diversos edifícios menores, vinculados ao Ministério da Saúde, mas alheios às atividades da instituição, foram construídos no campus. Os monumentos se encontravam em estado de má conservação, assim como o espaço urbanístico e paisagístico.

\footnotetext{
${ }^{24}$ No campo do patrimônio arquitetônico, OLIVEIRA, COSTA e PESSOA (2003) fazem um histórico aprofundado da ocupação do campus de Manguinhos. Sobre o Pavilhão da Febre Amarela, o trabalho transcreve o depoimento de Nadalutti: "A intenção naquele tempo era mostrar a estrutura do edifício, então foi feito com aquela estrutura saliente, tem aquele pilar com uma forma vazada no meio, e a intenção foi liberar o espaço interno, porque uma obra dessas tem sempre que sofrer modificações, é como um hospital, é uma função que muda muito, os equipamentos, ainda mais num laboratório daquele tipo, eu imaginava isso; bom, isso aqui vai ser mudado, evidentemente naquele tempo ainda não tinha divisórias, a gente pensava mesmo em alvenaria, mas enfim, a alvenaria você quebra e muda. Mas a intenção era essa, você poder arrasar tudo aquilo e refazer sem criar problema para o conjunto." (OLIVEIRA, COSTA e PESSOA, 2003, p.140)
} 
Institucionalmente, o auge (ou fundo) dessa crise foi o decreto de cassação de dez cientistas de Manguinhos pelo governo militar ${ }^{25}$.

Finalmente, com a abertura política, a partir de 1985, e sob a direção do médico sanitarista Sérgio Arouca, implantaram-se meios democráticos de escolha de dirigentes e tomadas de decisões estratégicas, devolvendo a autonomia que havia sido tolhida desde o Estado Novo. Em 1985 foi criada a Casa de Oswaldo Cruz, setor responsável pela recuperação e manutenção da memória científica do instituto, da qual faz parte o Departamento de Patrimônio Histórico $(\mathrm{DPH})$, primeiro setor especificamente destinado à conservação do patrimônio edificado e elaboração de diretrizes para os novos projetos. Foi de suma importância para essas iniciativas a atuação do Iphan, que em 1981 definiu o tombamento do núcleo histórico (primeiros edifícios) e seu entorno. O processo $n^{\circ}$. 1.037-T/80, aberto no Iphan em 1980, resultou no tombamento em nível federal de três exemplares do conjunto eclético localizados em torno da Praça Pasteur: o Pavilhão Mourisco, o Pavilhão do Relógio e a Cavalariça. ${ }^{26}$

Em 1986 foi iniciado, no Iphan, o Processo nº. 40099.060054/86-41, ainda não efetivado, com proposta de extensão de tombamento federal incluindo outras edificações do período eclético: Hospital Evandro Chagas, Pavilhão Figueiredo de Vasconcelos (Quinino), Pombal e Casa Amarela. Já o Inepac, em 1999, determinou o tombamento dos dois principais exemplares modernistas implantados no Campus Fiocruz Manguinhos: o Pavilhão Arthur Neiva e o Pavilhão Carlos Augusto da Silva ${ }^{27}$.

A Casa de Oswaldo Cruz, através de seu DPH, tem atuado na pesquisa, formação, publicações e planejamento relacionados à história da ciência, em especial na área do patrimônio cultural edificado. ${ }^{28}$ Para implementar diretrizes de conservação e restauro, o DPH

\footnotetext{
${ }^{25} \mathrm{O}$ episódio ficou conhecido como "massacre de Manguinhos", sendo inclusive registrado em livro com capa desenhada por Oscar Niemeyer (LENT, Herman. O Massacre de Manguinhos. Rio de Janeiro: Avenir, 1968.)

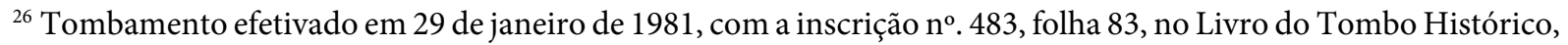
além da Inscrição no ${ }^{\circ}$ 546, folha 3, no vol. II do Livro do Tombo das Belas Artes.

${ }^{27}$ Processo E-18/001-538/98 no Inepac. Prospecções realizadas desde a década de 1960 também atestam que o terreno possui vestígios arqueológicos pré-históricos, o que motivou a inscrição de Manguinhos na Ficha de Cadastro Nacional de Sítios em 1966.

${ }^{28}$ Entre as ações da Casa de Oswaldo Cruz, podem-se citar os cursos de restauro oferecidos às comunidades do entorno, e as publicações relacionadas ao patrimônio, bem como o material que guarda em seu acervo, hoje o maior de história da ciência e da saúde na América Latina.
} 
dividiu o campus em dois conjuntos. O conjunto eclético é composto pelas antigas instalações da Fazenda Manguinhos e pelas erigidas entre 1904 e 1919, formando o Núcleo Arquitetônico Histórico de Manguinhos (NAHM). Esse núcleo é composto pelas edificações projetadas pelo engenheiro-arquiteto Luiz Moraes Jr. Já o conjunto modernista é composto por prédios construídos a partir da década de 1940. Com base nessas listagens dos órgãos de patrimônio, e nos trabalhos do DPH da Casa de Oswaldo Cruz, podem-se elencar como principais edificações e espaços do seu campus:

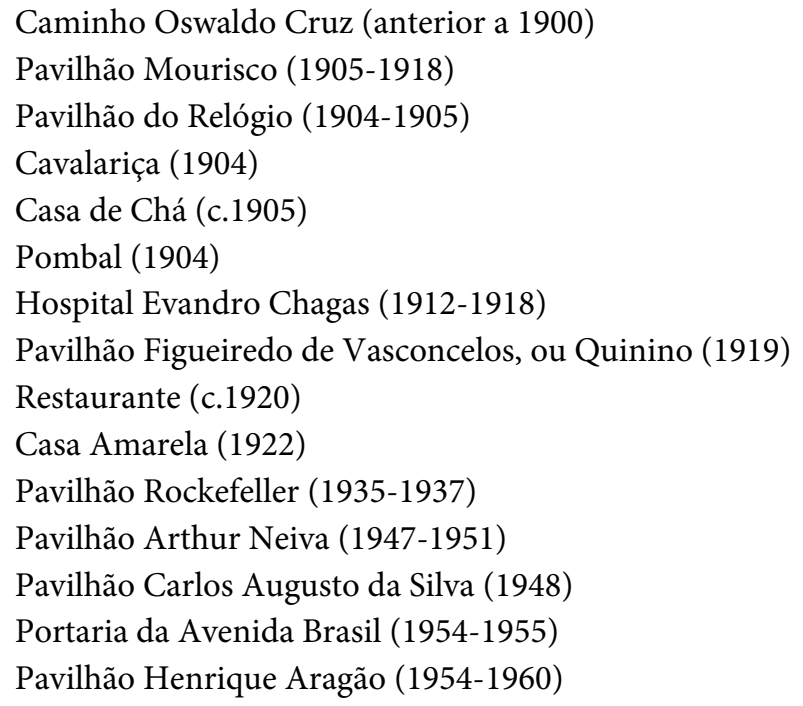

Entre as publicações da Casa de Oswaldo Cruz diretamente ligadas ao tema da preservação de seu patrimônio arquitetônico, pode-se citar PINHEIRO (2009), que descreve a metodologia e os trabalhos realizados no levantamento e na regulação de práticas de preservação e restauro dos edifícios do NAHM.

Em 2011 foi concluído o Plano de Ocupação da Área de Preservação (Poap) do Campus Fiocruz Manguinhos, resultado de contrato firmado entre a Fiocruz e o Instituto Brasileiro de Administração Municipal (IBAM) em trabalho que reuniu uma equipe multidisciplinar, com membros de diversos setores da instituição (inclusive da área científica), além do acompanhamento de representantes do Iphan-Rio e do Inepac. O documento resultante deixa claro quais são suas intenções e suas premissas conceituais:

O Poap deverá ser adotado como referência por todas as unidades e toda a comunidade Fiocruz no que diz respeito a proposições de intervenções físico-espaciais na Área de Preservação, bem como intervenções nos bens de interesse para preservação, mesmo que apenas na parte interna do edifício. 
O Poap orienta a gestão do conjunto arquitetônico e paisagístico de relevância histórica e cultural do Campus Fiocruz Manguinhos tendo como referências fundamentais os seguintes documentos:

- O Decreto Lei Federal no. 25, de 30 de novembro de 1937, que organiza a proteção do patrimônio histórico e artístico nacional e cria o instituto do tombamento;

- A Lei Estadual no. 509, de 3 de dezembro de 1931, que dispõe sobre o Conselho Estadual de Tombamento;

- O tombamento pelo Iphan do Pavilhão Mourisco, do Pavilhão do Relógio e da Cavalariça;

- O tombamento pelo Inepac do Pavilhão Arthur Neiva e do Pavilhão Carlos Augusto da Silva;

- Carta de Veneza. Carta internacional sobre a conservação e o restauro de monumentos e sítios. ICOMOS, 1964;

- Convenção para a Proteção do Patrimônio Mundial, Cultural e Natural. UNESCO, 1972.

- Carta de Florença. Carta dos jardins históricos. ICOMOS, 1981;

- Convenção Europeia da Paisagem. Florença, 2000;

- World Heritage Cultural Landscape. ICOMOS Documentation Centre, 2007;

- Relatório Final do VI Congresso Interno da Fiocruz, 2010. [...]

A preservação do bem cultural implica na salvaguarda das várias modalidades possíveis de percepção e reconhecimento dos valores nele implícitos, tais como: sua forma aparente; seu valor histórico e artístico; a relação estabelecida pelo bem cultural com seu entorno imediato; a espacialidade dos objetos arquitetônicos; a autenticidade do bem como testemunho da técnica construtiva e dos modos de vida de épocas passadas que, todavia, se insere e se presentifica no cotidiano vivido e se atualiza permanentemente pelo acesso e pela fruição do observador.

(FIOCRUZ, 2011, p.11-15)

Isso significa que não são propostas ações concebidas previamente, mas sim oferecidas diretrizes que orientam quaisquer ações que interfiram no patrimônio cultural edificado. Para isso, o plano ressalta a importância de que todas as unidades da instituição venham a aderir às recomendações. Também introduz o conceito de “campus-parque”, procurando abordar o conjunto como um todo, sem se restringir aos monumento históricos isolados, e valorizar aspectos como o paisagismo, a mobilidade, o desenho urbano, a comunicação visual, a fruição dos visitantes e a integração das atividades atuais com os espaços de memória. Do ponto de vista especificamente relacionado à preservação e restauro arquitetônico, o plano preconiza:

- a adequação de usos nos edifícios históricos, eliminando gradativamente as atividades incompatíveis (laboratórios, depósitos, oficinas);

- a otimização da infraestrutura, readequando quantidade e localização de abrigos, subestações, reservatórios, geradores, bem como adotando instalações subterrâneas quando possível, melhorando a ambiência do núcleo histórico; 
- o respeito à estratificação de intervenções que contribuem para a imagem dos edifícios históricos, sem a intenção de recompor artificialmente um estado original idealizado;

- a remoção criteriosa de elementos que prejudicam a legibilidade de tais monumentos, incluindo mobiliário urbano e paisagismo;

- a recomposição de elementos faltantes, desde que tal ação seja importante para a recuperação da unidade estética e técnica dos monumentos, e mantendo a diferenciação entre tais elementos e os originais através de recursos cromáticos, táteis e de informação. O plano estabelece alguns cenários propostos, organizados em setores de acordo com seu estado de conservação, usos, características arquitetônicas, infraestrutura e possíveis usos futuros. Nesses cenários, são detalhadas sugestões de ações pontuais para cada edifício de interesse, para grupos de edifícios e para áreas externas, dentro de conceitos de conservação preventiva, visando principalmente à recuperação da legibilidade dos espaços, adequação dos usos, valorização da autenticidade dos elementos quando possível, qualidade dos percursos, estabilidade e durabilidade dos elementos construtivos. Na prática, essas ações podem significar desde a sugestão de repintura mais adequada a determinada fachada, até à demolição de algum acréscimo que interfira na volumetria de um monumento, sempre considerando as necessidades técnicas e funcionais envolvidas.

Outro ponto importante do Poap é a proposta de uma sistematização da gestão do patrimônio cultural edificado, definindo as atribuições de cada setor e os procedimentos administrativos envolvendo intervenções no espaço físico, que devem seguir trâmites bem definidos a fim de que se registre e se fiscalize adequadamente como as intervenções físicas serão implementadas e quais serão seus impactos no existente. Para isso, é definida uma instância técnica, responsável pela condução dos trabalhos de implementação do plano, denominada Coordenação Técnica (CT-Poap) e uma instância consultiva, responsável pelo acompanhamento e monitoramento das ações que interferem direta ou indiretamente na Área de Preservação, denominada Comitê de Acompanhamento (CA-Poap). O trecho a seguir esclarece esses trâmites:

Todos os projetos arquitetônicos, urbanísticos, paisagísticos, de infraestrutura, de sinalização e de acessibilidade na Área de Preservação do Campus Fiocruz Manguinhos deverão ser informados ao DPH/COC, que acompanhará o 
desenvolvimento dos mesmos desde a concepção inicial e orientará tecnicamente as equipes responsáveis.

Todas as intervenções nos bens de interesse para preservação deverão ser coordenadas pelo DPH/COC com apoio técnico da Dirac e dos setores de infraestrutura das unidades, quando for o caso.

Novas construções, ou ampliação de área construída das existentes dentro da Área de Preservação do Campus Fiocruz Manguinhos dependerão da apresentação de Relatório de Impacto sobre a Área de Preservação, que será objeto de análise e manifestação do CA-Poap.

Considerando que intervenções fora da Área de Preservação poderão também produzir impactos sobre o conjunto de interesse histórico e cultural, o CA-Poap deverá analisar e se manifestar sobre intervenções potencialmente impactantes.

Para fins de implementação do Poap, são consideradas como intervenções potencialmente impactantes sobre a Área de Preservação e, por isso, sujeitas à análise pelo CA-Poap, as que se enquadrarem em pelo menos uma das situações a seguir:

Proximidade com a Área de Preservação do Campus Fiocruz Manguinhos menor ou igual a 30 (trinta) metros;

Altura da edificação igual ou maior que 12 (doze) metros de altura;

Área construída total igual ou maior que $2.000 \mathrm{~m}^{2}$ (dois mil metros quadrados).

A manifestação do CA-Poap sobre projetos de intervenção que se enquadrarem nos critérios acima terá como referência o respectivo Relatório de Impacto sobre a Área de Preservação.

O CA-Poap poderá ainda, quando verificar potencial impacto sobre a Área de Preservação de determinados projetos não enquadrados nos critérios indicados, solicitar a apresentação de relatório de Impacto sobre a Área de Preservação à unidade responsável pelo mesmo. (FIOCRUZ, 2011, p. 64)

Em seguida, o plano também propõe a elaboração de um Relatório de Impacto sobre a Área de Preservação (Riap) para todas a construções e reformas que interfiram no patrimônio. Finalmente, o Poap recomenda a permanente interlocução da Fiocruz, por meio da COC, com os órgãos de preservação:

A Fiocruz, ou mesmo o Iphan ou o Inepac, deverá propor, quando for oportuno, a publicação de Notas Técnicas a serem estabelecidas em comum acordo pelas três instituições, esclarecendo sobre procedimentos específicos a serem adotados para aprovação de projetos no Campus Fiocruz Manguinhos, visando à maior agilidade e eficiência nas análises. (FIOCRUZ, 2011, p.67)

Embora a abrangência de escopo seja extensa, chegando a abordar questões de manejo ambiental, sustentabilidade, urbanização e regularização fundiária de bairros vizinhos, o plano apresenta clareza como orientador de uma política de preservação do patrimônio cultural edificado baseada em levantamentos consistentes e em trabalho multidisciplinar com participação da comunidade do campus. 
O Poap está em fase de implantação, e novos edifícios dentro desses núcleos têm sido construídos já sob estratégias gerais de implantação, gabarito e acabamentos. Em visita feita a Manguinhos em 2016, verificou-se que diversos setores continuam fora desses conjuntos de preservação. Entre eles se encontra a sede da Coordenação-Geral de Infraestrutura dos Campi (Cogic), antiga Diretoria de Administração do Campus (Dirac), projetada por João Figueiras Lima (Lelé), que na época da visita estava em plano de ser demolida para que fosse executada outra sede "mais funcional", nas palavras de alguns funcionários.

Em 2010 foi encomendado a Oscar Niemeyer o projeto para implantação de um Complexo de Difusão Científica junto à Avenida Brasil, sem previsão de execução. Nesse momento a unificação de práticas de normatização de projetos no campus através do Poap e o enfrentamento da saturação de construções têm sido o foco dos setores responsáveis.

Das instituições inspiradas pelo Instituto Pasteur de Paris, a Fiocruz-Manguinhos é a de maior área (hoje cerca de $765.000 \mathrm{~m}^{2}$ ) e complexidade espacial, seguida pelo Instituto Butantan (cerca de $709.000 \mathrm{~m}^{2}$ ). Esses institutos, somados àqueles citados de outros continentes, mostram que a partir do final do século XIX, na esteira da segunda Revolução Industrial ${ }^{29}$, ao lado de diversos novos programas que exigiram novas soluções espaciais (hospitais, ferrovias, aeroportos etc.), surgiu também o instituto de pesquisa em saúde. Guardadas as especificidades de cada instituição, é possível identificar as características desse programa da seguinte forma:

- Organização de usos fundamentada no trinômio produção-pesquisa-formação;

- Estrutura espacial com vários edifícios especializados em um mesmo terreno com unidade paisagístico-urbanística, formando um campus (ver item 1.2);

- Necessidade permanente de alterações do espaço físico para adequação às atividades científicas;

- Existência de um núcleo histórico formado pelas primeiras edificações;

- Existência de uma frente de crescimento, formada por edifícios de tipo industrial mais flexíveis;

\footnotetext{
${ }^{29}$ A segunda Revolução Industrial ocorreu na segunda metade do século XIX e abrangeu o rápido desenvolvimento nas áreas de eletricidade, petróleo, aço, química, biologia e medicina (BARRACLOUGH, 1964).
} 
- Predominância de baixa taxa de ocupação (de 10 a 12\%), baixos gabaritos e alta proporção de áreas verdes ${ }^{30}$.

Considera-se pertinente a descrição sucinta aqui realizada sobre Manguinhos, uma vez que apresenta muitas semelhanças com o Instituto Butantan, objeto dessa pesquisa. Primeiramente, ambas foram fundadas no mesmo período, respectivamente em 1900 e 1901, devido à epidemia de peste bubônica, dentro de um contexto de modernização nacional ${ }^{31}$. A ocupação de áreas semelhantes (cerca de 70ha) em regiões afastadas dos centros urbanos, lideradas por cientistas de renome para a produção de soros e vacinas também as aproxima. Embora tenha havido momentos de disputas entre os dois institutos (que podem continuar no campo científico), estas rivalidades eram em grande parte pessoais de seus diretores, como a polêmica entre Carlos Chagas e Arthur Neiva:

A defasagem de temporalidade e magnitude na evolução das instalações físicas dos dois institutos resulta, em parte, de suas diferentes inserções políticoadministrativas em suas respectivas esferas do aparelho de Estado. A história de Manguinhos foi, em larga medida, condicionada pelo fato de ser uma agência do poder central, e de haver galgado vários degraus nesse âmbito: de instituto municipal passou a federal; de repartição da Saúde Pública ascendeu ao mesmo status da diretoria, com conexão direta com o ministro da Justiça. O Instituto Butantan lucrou ao se desprender do Bacteriológico, mas teve de disputar com outras repartições do Serviço Sanitário as verbas escassas que o governo estadual destinava à Secretaria do Interior, e que esta rateava entre vários outros serviços.

A questão não é só de ordem burocrática, nem se mede só pelo grau de riqueza. $\mathrm{O}$ arco de alianças e adversidades políticas com que tiveram de lidar os dirigentes destes institutos, assim como o espectro de clientes e usuários dos bens e serviços que tinham a oferecer variou consideravelmente em função das diversidades peculiares à economia, à vida política e à formação social do Distrito Federal e do estado de São Paulo, com suas respectivas áreas de influência." (BENCHIMOL, TEIXEIRA, 1993, p.16)

\footnotetext{
${ }^{30}$ Segundo seus planos diretores, o Instituto Butantan possui taxa de ocupação de 12\% e Manguinhos 11\%.

31 "Médicos brasileiros, em institutos como o de Manguinhos ou Oswaldo Cruz, em laboratórios como os das Faculdades de Medicina da Bahia e do Rio de Janeiro, à frente de repartições públicas, de Saúde ou Higiene, juntaram-se na época aqui considerada, a engenheiros e a uns poucos agricultores e industriais arrojados [...] concorrendo para que a República de 89, desde os seus primeiros decênios, se avantajasse ao Império um tanto moroso de Pedro II na demonstração do fato de ser possível, no Brasil, o desenvolvimento de uma civilização agrária e industrial que, por ser situada no trópico, não tinha fatalmente de conservar-se nem apenas sub-européia em suas técnicas nem inferior nas suas realizações, às civilizações situadas em regiões temperadas." (FREYRE, 2000, p.809)
} 
Sobre a relação histórica entre Manguinhos e o Instituto Butantan (bem retratada por BENCHIMOL e TEIXEIRA, 1993), cabe reproduzir a carta de Vital Brazil a Oswaldo Cruz pouco antes da fundação dos dois institutos:

São Paulo, 20 de novembro de 1899.

Caro amigo Oswaldo,

Desejo-te toda saúde e todo o bem estar de que é merecedor. Dirijo-te estas linhas para, de acordo com o que te prometi, dar-te notícias nossas e pedir-te que nos pagues na mesma moeda.

Regressei, como deves ter sabido, para S. Paulo, no dia 4 do corrente, trazendo algumas das minhas culturas, que pareceram-me em melhores condições. Aqui chegando meti-me logo em um trabalho insano e cruel, mui pouco apropriado ao meu estado de fraqueza. Foi uma imprudência de que me arrependo, porquanto o resultado foi ter de enfermar-me de novo por alguns dias. Hoje, felizmente, já estou melhor e desde ontem estive trabalhando.

Ainda não acabei o meu relatório, por ter sido interrompido por trabalhos de outra natureza.

Fiz experiências, em pequenos animais, ratos e cobaias, com as culturas que trouxe de Santos. Resultados magníficos. Ainda não concluí, entretanto, o estudo das culturas.

Como já deves saber, o Governo adquiriu a fazenda do Butantan, destinandoa para o Instituto Serumtherapico do Estado. Soube pelo Ribas, que vistes e apreciastes muito aquele local para instalação do Instituto, o que muito agradou-me pela autoridade de tua opinião.

Sou encarregado do preparo do soro e quiçá da instalação do Instituto. Não sei se poderei com tamanha responsabilidade. Comecei a imunização de 4 cavalos pela injeção endovenosa de culturas mortas, até conseguirmos uma cocheira-enfermaria para os cavalos pestosos. Empregaremos então culturas virulentas.

A $1^{\text {a }}$. injeção nos 4 cavalos correu bem. Apresentaram alguma reação que não durou muito tempo. Hoje, porém, ao fazermos a $2^{\mathrm{a}}$. injeção perdemos subitamente um dos animais, ao que parece de uma embolia.

Como vae o teu Instituto? Conta-me as tuas esperanças e auxilia-me com os teus sábios conselhos. Peço-te, com o maior empenho, que com a possível brevidade, me mandes a relação completa dos aparelhos, pequenos objetos e todo o material necessário para a instalação de um Instituto soroterápico.

Logo que tenhas o teu instituto montado irei até o Rio, pedir o auxílio de tuas luzes.

Abraça-te cordialmente o teu colega e amigo muito agradecido

V. Brazil

(Dossiê Vital Brazil - 1899/1914 - Acervo da Biblioteca Virtual Oswaldo Cruz - COC)

Atualmente, ambas as instituições têm estabelecido parcerias nas quais o campo de preservação do patrimônio arquitetônico tem se beneficiado, especialmente nas atividades de formação em que o setor de Difusão Cultural do Instituto Butantan e a Casa de Oswaldo Cruz trocam experiências através de encontros, cursos e publicações. 


\subsection{O campus como patrimônio cultural}

Como se sabe, à época de seu surgimento, a nova medicina experimental envolvia a necessidade de combinar diversos tipos de atividades próprias: as laboratoriais, semelhantes às de hospitais; as rurais (criação de animais para inoculação de soros e outras pesquisas); as industriais (produção em larga escala de fármacos) e as educacionais (tanto a formação de cientistas quanto a difusão para o público em geral). $\mathrm{Na}$ arquitetura, isso levou a uma combinação do tipo de implantação pavilhonar (diversos blocos de uso específico) com a de monobloco (concentração de usos no mesmo edifício). Também levou à necessidade de glebas relativamente grandes para abrigar tais instituições. Por fim, essas glebas teriam que ser afastadas dos grandes centros, seja pela necessidade de criação de animais, seja pelo receio da população da época quanto à ainda desconhecida investigação de doenças, vírus e bactérias.

Em sua maioria, os institutos de medicina experimental construídos no Ocidente na virada do século XIX para o XX seguiram essas premissas, sendo implantados em conjuntos conformando campi de pesquisa. A noção de campus, um conjunto urbanístico com diversos edifícios da mesma instituição para fins de educação ou pesquisa, remonta ao período colonial norte-americano. Segundo TURNER (1984), as universidades naquelas colônias se baseavam nos colleges puritanos, para os quais interessava que os alunos e docentes morassem no local de estudo, construindo-se para isso minicidades acadêmicas. Essas instituições, geralmente em terrenos afastados dos centros urbanos, se desenvolveram nesses campi, com especificidades em cada uma $^{32}$. No século XIX, os projetos dos arquitetos Joseph Jacques Ramée para a Union College de Nova Iorque, em 1813, e de Thomas Jefferson para a Universidade de Virgínia em 1819, passaram a inspirar novas instituições em outros países, como o Brasil, onde essa noção

\footnotetext{
32 “A romântica noção de uma escola na natureza, separada das forças corruptoras da cidade, tornou-se um ideal americano. Nesse processo, o college transformou-se em uma espécie de cidade em miniatura, e o seu desenho constituiu um experimento de urbanismo. Outro traço específico que tipifica o planejamento do college americano é sua espacialidade e abertura para o mundo. Desde o início, em Harvard, no século XVII, o college americano rejeitou a tradição europeia de estruturas de claustros em favor de edifícios separados, construídos em espaço verde aberto. Esse ideal é tão forte na América que, mesmo as escolas localizadas nas cidades, onde a terra é mais escassa, procuram áreas que simulem, de alguma forma, com muito verde, um rio ou um lago, uma espacialidade rural." (BUFFA, PINTO, 2016, p.815)
} 
de campus foi utilizada principalmente na construção de novas universidades a partir dos anos de 1940 (Universidade do Brasil e Universidade de São Paulo). Mas o termo também foi adotado para os institutos de pesquisa, iniciando-se por Manguinhos:

O termo campus, adotado para Manguinhos, foi primeiramente utilizado por Vinícius
da Fonseca, ao assumir a presidência da Fundação Oswaldo Cruz, em 1975. Baseia-se
na experiência norte-americana da Universidade de Virgínia, projetada ainda no
início do século XIX, segundo a qual as instituições deveriam ser organizadas em um
espaço unificado. [...] Em todo o mundo esse termo passou a ser mais empregado,
principalmente após a Segunda Guerra Mundial, quando a universidade passa por um
período de expansão. No caso brasileiro, a aplicação do termo estaria relacionada com
a reforma universitária de 1968. Anteriormente, o termo mais difundido era "Cidade
Universitária". No caso de Manguinhos, o campus se destaca por ser não
propriamente uma universidade, mas um campus científico de uma Instituição
dedicada sobretudo à pesquisa biomédica. (OLIVEIRA, COSTA, PESSOA, 2003, p.11)

No Instituto Butantan, o termo "campus" para designar seu espaço edificado tem sido usado diversas vezes nos relatórios após a década de 2000 e no Plano Diretor de 2016. Opta-se por utilizá-lo aqui para enfatizar as características de conjunto urbanístico coeso voltado à pesquisa, produção e formação científica. Também é uma opção que estabelece um contraste com o termo "Cidade Universitária", utilizado pela USP, comum a partir dos anos 1940 nas universidades e tendo como matriz conceitos da Arquitetura Moderna, como a separação de circulações, a transgressão da quadra urbana tradicional, as grandes escalas privilegiando os automóveis, entre outras características expressas sobretudo nos Congressos Internacionais de Arquitetura Moderna (CIAM) a partir de 1928 (embora também haja Cidades Universitárias não modernas).

Para além da questão etimológica, o aspecto mais importante do ponto de vista do patrimônio cultural é que esses espaços, após atravessarem mais de um século dedicados às atividades da pesquisa científica, acabam tendo em sua estrutura física registros das diferentes fases da ciência, da história e da arquitetura, coexistindo no mesmo local. Esse museu vivo se diferencia de tecidos da cidade ou da universidade, que na maioria das vezes são formados por unidades com funções isoladas com poucas conexões entre si, ao passo que o campus biomédico é uma fábrica em que cada elemento tinha sua função ligada às demais (a cocheira, o serpentário, os laboratórios, as casas etc.). Essas funções mudaram com a evolução da ciência. Como exemplo, a diminuição da necessidade de animais de porte e as novas técnicas 
moleculares, assim como a intensificação de atividades culturais, permitiu a conversão de cocheiras em laboratório ou museus.

Diversos campi universitários já possuem departamentos voltados à pesquisa, acervo, divulgação e proteção de seu patrimônio cultural edificado. A Universidade de São Paulo, por meio de seu Centro de Preservação Cultural, criado em 2002, tem como atribuições formular políticas de preservação do patrimônio cultural universitário, elaborar inventários dos bens culturais da USP, promover atividades relacionadas à preservação e assessorar ações de restauro e conservação desse patrimônio (LANNA, 2005).

No caso dos campi de institutos de medicina experimental, a referência na área de preservação é a já mencionada Casa de Oswaldo Cruz, que desenvolve diversos estudos e atividades relacionadas ao seu patrimônio arquitetônico (e também à história da Ciência e do patrimônio cultural da saúde em geral).

Com base nos trabalhos desenvolvidos pelos órgãos aqui citados, verifica-se que os campi dos institutos de pesquisa em saúde podem ser valorizados pelos seguintes aspectos:

a) sua localização em áreas originalmente pouco urbanizadas, constituindo frentes de urbanização a partir das quais se desenvolveu o entorno;

b) seu caráter de "minicidades", abrigando diversos usos complementares aos principais: residências, lavanderias, hospitais, transporte, lazer e educação;

c) formação e consolidação de um núcleo original, do qual se irradiou a ocupação do restante do terreno, constituindo, assim, um núcleo histórico;

d) permanência de vastas áreas verdes que, relacionadas à criação de animais ou à pesquisa em botânica, também passaram a ser utilizadas como parques;

e) caráter público dos espaços, abertos à população para atividades de lazer, informação e serviços ligados à saúde;

f) caráter de "museu urbano", ao manter elementos históricos, arquitetônicos, urbanísticos e paisagísticos que documentam os usos dessas instituições em seu patrimônio edificado. Todos esses elementos são encontrados no Instituto Butantan, conforme será descrito no levantamento de seu patrimônio arquitetônico, a seguir. 
2 - Levantamento do patrimônio do Instituto Butantan 
O Instituto Butantan é hoje o maior produtor de imunobiológicos do Brasil, sendo administrativamente formado pelo "Instituto Butantan", órgão público vinculado à Secretaria de Saúde do Estado de São Paulo, e pela "Fundação Butantan", órgão de direito privado que auxilia na administração e obtenção de recursos para aplicação no Instituto.

Fisicamente, o campus principal ocupa hoje um terreno de $709.140 \mathrm{~m}^{2}$ no distrito do Butantan $^{33}$ (figura 13), zona oeste do município de São Paulo, fazendo divisa ao norte com a Cidade Universitária Armando de Salles Oliveira (CUASO) da Universidade de São Paulo, a leste pelo córrego Pirajuçara Mirim, o Centro de Saúde Samuel Barnsley Pessoa, a Escola Estadual Alberto Torres, a Paróquia Nossa Senhora dos Pobres e o Foro Regional de Justiça do Butantan, e ao sul por lotes residenciais. Pela proximidade com o córrego mencionado e com o Rio Pinheiros, o terreno se encontra em região historicamente inundável ${ }^{34}$, com lençol freático alto e solo de baixa capacidade de suporte, dificultando a execução de edificações verticalizadas. Outra característica do terreno era, originalmente a predominância de vegetação rasteira característica de várzeas, o que foi modificado com aterros e plantio de espécies. Também é relatada por funcionários a presença de cupins, que dificulta a manutenção de edificações em madeira. Por outro lado, a presença de solo mole propiciou durante os primeiros anos do Instituto a facilidade na retirada de barro para confecção de tijolos e telhas, razão pela qual ali se instalou uma olaria desde o final do século XIX até meados do século XX. Já a drenagem do Instituto se dá a partir de sua porção noroeste em direção a leste, para o córrego Pirajuçara Mirim, sendo que no vértice noroeste do Instituto há uma nascente, formando um curso d'água e lagoas na porção desocupada do terreno, correndo para o córrego mencionado. A adutora de Cotia determinou a divisa de desmembramento do terreno da Cidade Universitária em 1941.

Pelos levantamentos recentes da Divisão de Engenharia e Arquitetura (DEA) ${ }^{35}$, o terreno é hoje ocupado por cerca de 40 edifícios, além de estruturas menores, como abrigos, reservatórios, guaritas etc. Destes, cerca de 20 foram construídos há mais de 60 anos e, além do

\footnotetext{
${ }^{33}$ Além do campus principal, o Instituto administra a Fazenda São Joaquim, na região de São Roque/Araçariguama, adquirida em 1945 e o Museu Emílio Ribas, no bairro do Bom Retiro, incorporado em 2010.

${ }^{34}$ Com as obras de retificação do Rio Pinheiros, a partir de 1940, a região deixou de ser naturalmente inundável.

${ }^{35}$ A partir de 2018 passou a ser denominada Divisão de Infraestrutura, que engloba o Núcleo de Engenharia e o Núcleo de Arquitetura e Urbanismo.
} 
aspecto cronológico, possuem valor cultural como testemunhos da história do Instituto e da ciência, de acordo com seus usuários, estudiosos e órgãos de proteção do patrimônio, sendo alguns pré-existentes à própria fundação do Instituto.

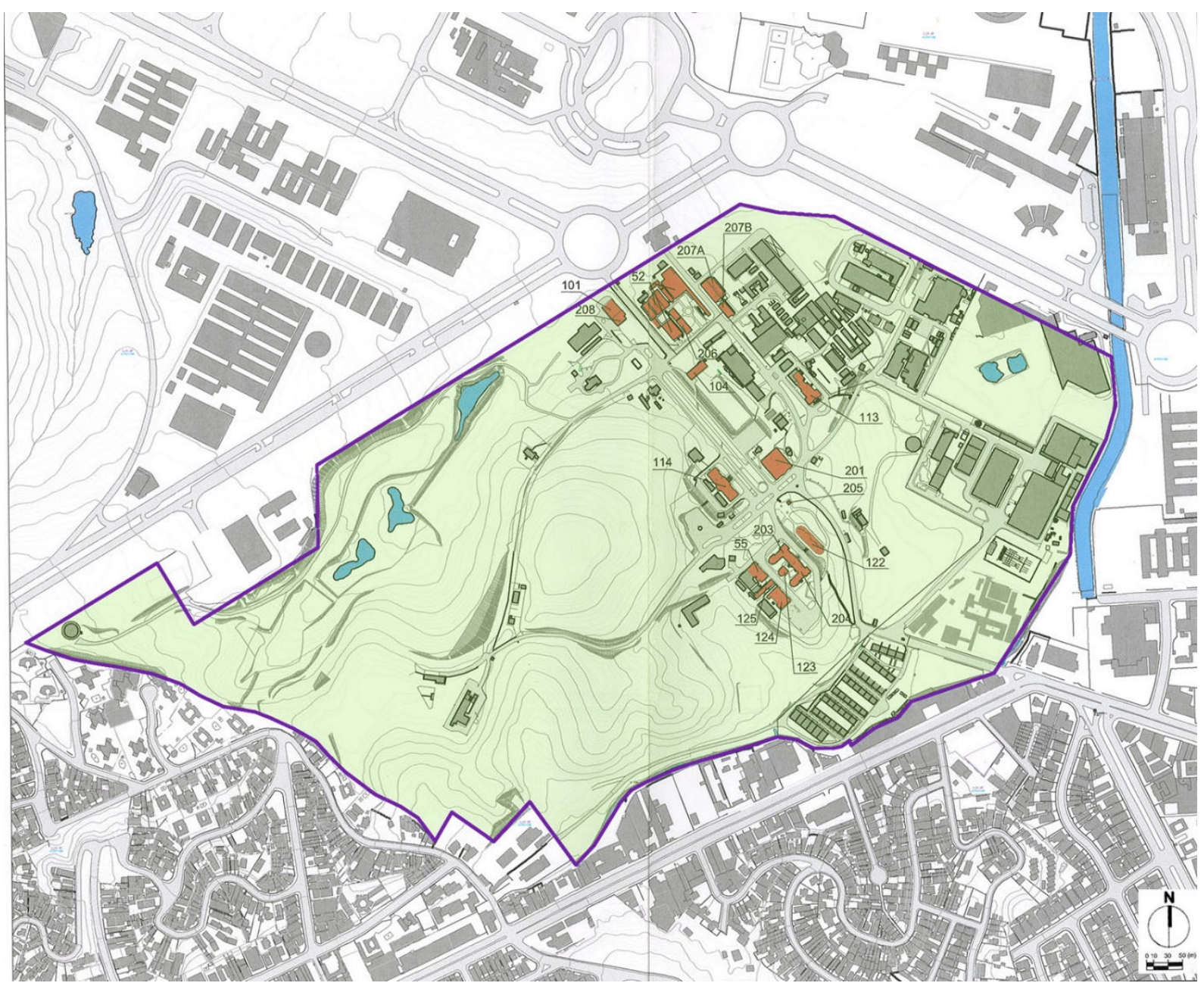

Fig. 13: Implantação geral do Instituto Butantan em 2017, com perímetro em roxo. Ao norte está a Cidade Universitária. A leste o córrego Pirajuçara Mirim e ao sul lotes particulares do bairro do Butantan. Os elementos avermelhados são os edifícios listados no processo de tombamento do Condephaat (ver item 2.2), com os códigos de identificação adotados pelo Departamento de Engenharia e Arquitetura do Instituto:

\begin{tabular}{|c|c|}
\hline 101/208: & Casa Sede da Fazenda (atual Casa Vital Brazil) \\
\hline$\underline{55 / 125 / 124:}$ & Cocheira-enfermaria (atuais laboratórios) \\
\hline 203/204/123: & Edifício Principal (atual Edifício Vital Brazil) \\
\hline 122: & Serpentário \\
\hline 52: & Biotério Central \\
\hline 201: & Cocheira Central (atual Museu Biológico) \\
\hline 113: & e Veterinária (atual Pavilhão Lemos Monteiro) \\
\hline 207A/207B: & Paiol e Oficinas (atual Centro de Difusão) \\
\hline 205: & Mostruário de cobras (atual Bilheteria) \\
\hline 114: & "Prédio Novo" \\
\hline 104: & Hospital Vital Brazil \\
\hline 06: & Museu Histórico \\
\hline
\end{tabular}




\title{
2.1. Histórico e descrição do campus atual
}

Em 1899, rumores de que uma epidemia de peste bubônica se espalhava pela cidade de Santos, com vítimas fatais, levaram o Governo do Estado de São Paulo a mobilizar o Serviço Sanitário para identificá-la e combatê-la. Sendo essa cidade já um dos principais entrepostos de trocas comerciais do país, tal epidemia colocava em risco as atividades econômicas, a exemplo do que ocorrera com o Rio de Janeiro:

\begin{abstract}
Sua fama era internacional, e tornava o Rio de Janeiro conhecido no exterior como "o túmulo dos estrangeiros". Por isso as tripulações e passageiros nem se atreviam a descer dos navios quando estes chegavam ao porto: permaneciam a uma distância prudente, para evitar qualquer contágio. (SEVCENKO, 2010, p.63)
\end{abstract}

Dirigido então por Emilio Ribas, o Serviço Sanitário do Estado de São Paulo acumulava, desde o início da República, as atividades de fiscalização, campanhas sanitárias e pesquisas biomédicas, através de seu Instituto Bacteriológico, então dirigido pelo médico Adolfo Lutz, e localizado na atual Avenida Doutor Arnaldo ${ }^{36}$, sendo pioneiro no uso dos novos métodos pausterianos da medicina experimental no Brasil (CYTRYNOWICZ; STÜCKER, 2010). Lutz indicou seu jovem assistente, o médico Vital Brazil Mineiro da Campanha ${ }^{37}$, para ir a Santos verificar a existência e tipo de epidemia utilizando-se das técnicas da microbiologia pasteuriana.

Vital Brazil chegou a Santos e conseguiu finalmente identificar a presença da bactéria Pasteurella pestis no organismo dos vitimados. Como alguns médicos da cidade ainda negavam a existência da epidemia, as amostras colhidas também foram verificadas por Oswaldo Cruz, de Manguinhos, e pelo Instituto Pasteur, de Paris, confirmando o diagnóstico do jovem médico. Como o domínio de técnicas científicas e a política sanitária autônoma já eram uma questão estratégica para a República ${ }^{38}$, e tendo médicos capacitados para a produção dos soros e vacinas

\footnotetext{
${ }^{36}$ O Instituto Bacteriológico, hoje chamado Instituto Adolfo Lutz, se localiza no chamado "Quadrilátero da Saúde", atualmente em processo de tombamento pelo Condephaat (MIURA, 2012).

${ }^{37}$ Segundo o próprio Vital Brazil, ele foi o assistente escolhido por Lutz porque já havia contraído e superado uma peste bubônica, estando portanto imune para poder investigar a epidemia. Vital se dizia o mais "novo e obscuro ajudante" do Instituto Bacteriológico. (Revista Médica de São Paulo, II, 12, p.343-355)

38 "Com a proclamação da República (1889) e a adoção do sistema federativo, as questões de saúde pública no Brasil se tornaram competência dos governos estaduais. Para enfrentar essa nova conjuntura, o estado de São Paulo criou uma forte estrutura de saúde pública que visava reunir e ampliar os poucos serviços então existentes. O Serviço Sanitário do Estado de São Paulo começou a ser implantado em 1892, tendo como seu principal sustentáculo uma
} 
necessários ${ }^{39}$, foi decidido produzir tais fármacos na capital. Assim, seria necessário encontrar um local para tal produção, que deveria ter como características a capacidade de abrigar animais para inoculação (sobretudo cavalos), edifícios de laboratórios, e localização preferencialmente periférica, distante do centro urbano, uma vez que ainda existia certo receio e desconhecimento em relação à manipulação de microrganismos. Em clima de urgência, o governo identificou na capital que a chamada Fazenda Butantan atendia a esses requisitos.

Os primeiros registros históricos da fazenda datam do século XVII (PACCE, 1980) e, tendo passado por diversos proprietários, foi finalmente adquirida de Arnaldo de Oliveira Barreto pelo governo paulista em 08 de novembro de 1899, conforme noticiário da época:

Os drs. José Pereira de Queiroz, Alfredo Guedes, secretários de Interior da Agricultura, Emilio Ribas, director do Serviço Sanitário e Vital Brasil, ajudante do Instituto Bacteriologico, visitaram hontem a chácara de Butantan, que o governo adquiriu afim de ali estabelecer o instituto serumtherapico. As instalações de aparelhos, reparação e adaptação do edifício, construcção de estrebaria, etc., em breve serão iniciadas, devendo, daqui a pouco tempo, ser terminadas. O dr. Vital Brasil já começou a preparação dos cavalos, que escolheu no regimento da cavalaria, afim de os inocular com culturas mortas para a preparação do sérum antipestoso. (A peste bubônica. O Estado de São Paulo. 10/11/1899, p.1)

Os trabalhos da equipe de Vital Brazil foram iniciados naquele ano, ainda como seção subordinada ao Instituto Bacteriológico. A Fazenda Butantan, com cerca de 4 milhões de metros quadrados, tinha até então como principal atividade a produção de leite, além de lavouras de diversas culturas. Portanto, a presença de gado era comum, necessitando de telheiros, estábulos e cercados. Antigos trabalhadores da fazenda permaneceram morando no local, em casas de pau-a-pique, enquanto as casas em alvenaria dos antigos proprietários foram utilizadas para trabalhos laboratoriais e administrativos. A existência desses elementos construtivos pode ser verificada em mapas e escrituras ${ }^{40}$, mas sem precisão de quantidades e localização. As diversas solicitações de cercamento e delimitação das divisas, verificadas nos

rede de laboratórios de saúde pública voltados prioritariamente para o diagnóstico de doenças epidêmicas, elaboração de imunobiológicos e produção de insumos para as desinfecções." (TEIXEIRA, 2006, pp.106-107)

${ }^{39}$ Adolfo Lutz se formou em Berna e fez especializações em outras partes da Europa, estudando inclusive com Louis Pasteur. Vital Brazil e Emílio Ribas, formados na Faculdade de Medicina do Rio de Janeiro, também fizeram cursos de especialização na Europa.

${ }^{40}$ O trabalho de PACCE (1980) sobre a Casa Bandeirista recupera o histórico de proprietários e escrituras do terreno. As fotos do Núcleo de Documentação do Instituto Butantan, os mapas disponibilizados pela PMSP e pelo Arquivo do Estado de São Paulo indicam a presença de algumas construções remanescentes da fazenda. 
relatórios até a década de 1930, indicam uma paisagem aberta e indefinida, delimitada predominantemente pelos rios Pinheiros e Pirajuçara Mirim, caracterizada por pastos e áreas inundáveis, elevando-se em direção a oeste em região ainda rural (figuras 14 a 16).

Com equipe relativamente pequena, de 12 pessoas, as primeiras tarefas foram adaptar, $\mathrm{o}$ quanto fosse possível, as construções da fazenda para a produção do soro de combate à peste bubônica. Vital Brazil descreveria esse início posteriormente:

Foi aí, nesse ambiente paupérrimo, onde o desconforto corria parelho com a impropriedade das instalações, que tiveram início os primeiros trabalhos técnicos do Instituto Butantan. (BRAZIL, 1941, p.12)

Embora tenha sido criado como solução ad hoc para debelar a epidemia de peste bubônica em Santos, esse laboratório seguia a tendência estratégica, entre os estados da República, de buscar autonomia na área sanitária, reafirmando sua vinculação às novas linhas científicas pausteurianas. O Instituto Bacteriológico ainda acumulava funções de fiscalização e realização de campanhas de saneamento de caráter policial. Nesse sentido, a fundação de um instituto voltado às práticas mais avançadas na época, de diagnóstico e produção de fármacos, tinha também um aspecto simbólico e progressista. Assim, em 23 de fevereiro de 1901, pelo decreto 878-A, foi criado o Instituto Soroterápico do Estado de São Paulo, sendo portanto desmembrado do Instituto Bacteriológico, e tendo Vital Brazil como seu primeiro diretor ${ }^{41}$. Em junho desse ano eram entregues ao Serviço Sanitário os primeiros tubos de soro antipestoso e em 1902 a epidemia era considerada debelada, o que deu extrema notoriedade ao novo instituto, ao seu jovem diretor e à própria microbiologia pasteuriana no Brasil.

Conquistado esse reconhecimento inicial, o Instituto passa os primeiros anos construindo sua imagem e seus edifícios, sempre sob reivindicações de Vital ao governo do Estado, em que ressalta a importância da instituição para a sociedade, e lista as necessidades de verbas para melhoria de suas instalações.

\footnotetext{
${ }^{41}$ Embora o mérito da criação do Instituto seja atribuído a Vital Brazil, formalmente essa ordem coube ao diretor do Serviço Sanitário, dr. Emílio Ribas. Nas palavras do próprio Vital: "Foi na administração de Emilio Ribas que teve início o Instituto de Butantan. A ele se deve a escolha do local, a indicação do pessoal, a orientação dos primeiros trabalhos para instalação." (BRAZIL, 1941, p.21) Oficialmente, a instituição teve primeiro o nome de Instituto Serumtherapico e depois (1918) Instituto Butantan. A palavra, que já era usada para a fazenda, deriva de Ibytatá, que significa terra dura em tupi-guarani. Embora não seja utilizada pela instituição, a grafia Butantã também pode ser encontrada, sobretudo em referência ao bairro. (IBu, 2001)
} 


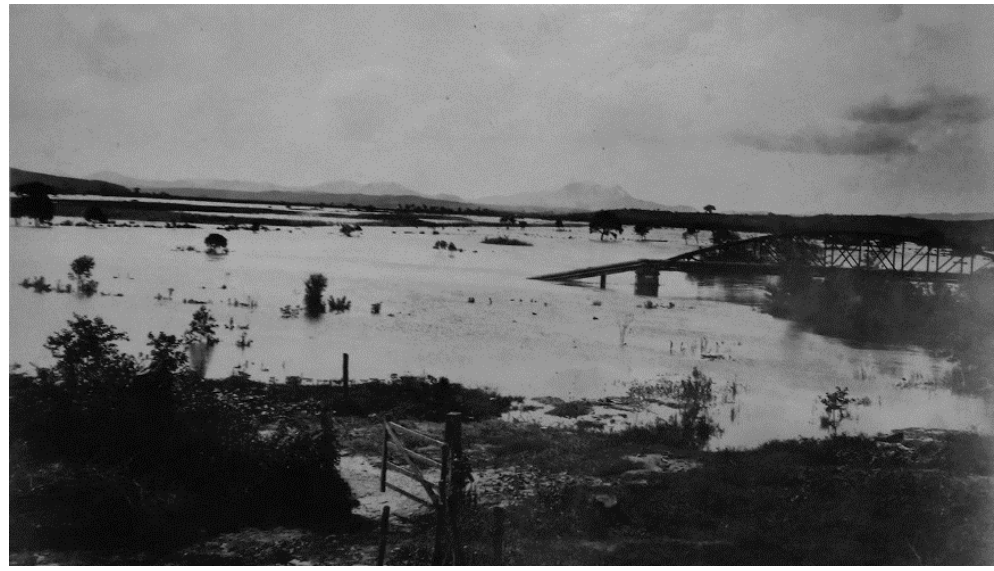

Fig. 14

Inundação na várzea do Rio Pinheiros em 1929, com Pico do Jaraguá ao fundo: na década de 1920 o Instituto ainda mantinha algumas características da antiga fazenda (Fonte: Relatório Anual IBu (RA) 1929, np)

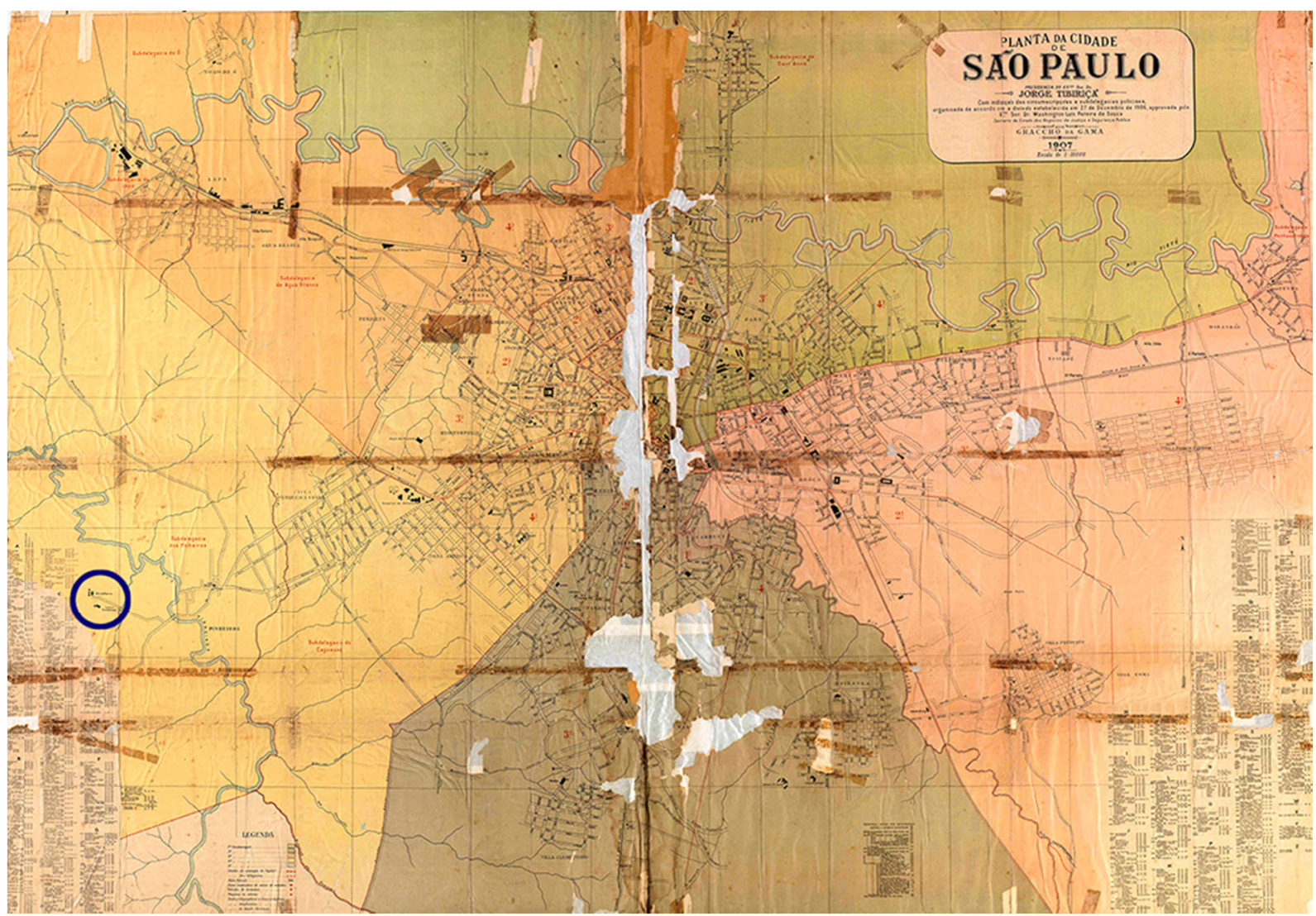

Fig. 15 - Mapa da cidade de São Paulo de 1907 - Graccho da Gama: o círculo mostra a localização do recém criado Instituto Soroterápico do Butantan, afastado da zona urbanizada da cidade e além do rio Pinheiros. S/ escala (Arquivo PMSP)

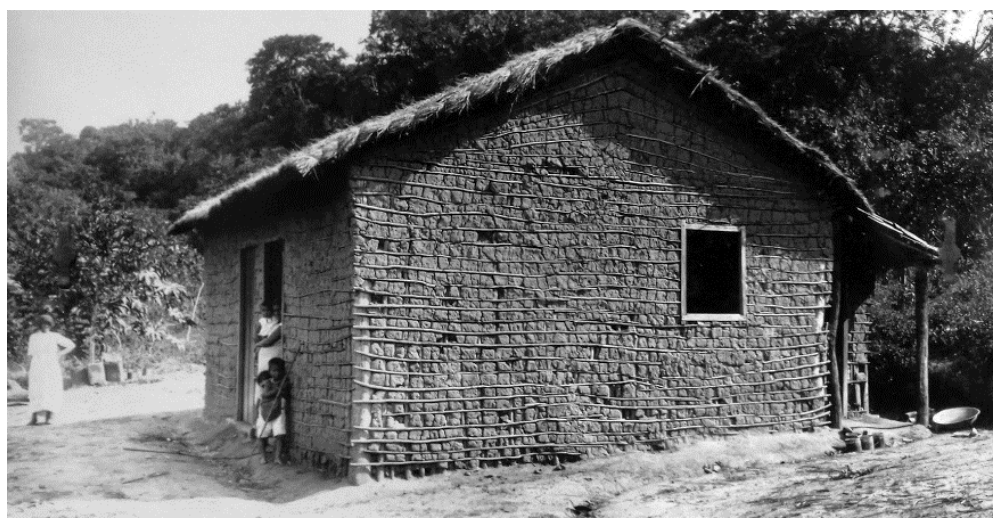

Fig. 16

Casa da fazenda: até a década de 1920 restavam casas de funcionários da fazenda, em sua maioria de pau-a-pique ou taipa de mão, que foram gradativamente eliminadas, restando poucas ruínas. (RA 1929, np) 
Após as adaptações emergenciais de construções da fazenda, o primeiro edifício construído especificamente para os serviços soroterápicos, ainda submetidos ao Instituto Bacteriológico, foi o conjunto da Cocheira-enfermaria, destinado a inocular os cavalos para produção de soro e tratar os animais doentes, com projeto de 1899, do arquiteto Victore Andrigo, do qual não se têm registros de outras atuações no Instituto.

BENCHIMOL e TEIXEIRA (1993) defendem que no Instituto Butantan, assim como em outras instituições semelhantes, várias historiografias ressaltaram o mito de origem, com o líder heroico, o ambiente hostil e a superação das dificuldades para a aclamada vitória e reconhecimento. Nessa narrativa, o espaço construído desempenha um papel importante ao constituir sua materialização. Enquanto no Rio era Oswaldo Cruz o líder fundador, sendo a Fazenda de Manguinhos o locus, e o engenheiro-arquiteto Luiz Moraes Jr. o projetista dessa epopeia através de obras como o Pavilhão Mourisco e a Cavalariça, entre outros, em São Paulo foi Vital Brazil, na Fazenda Butantan, o personagem heroico. Aqui, quanto à arquitetura, parece ter havido diversos profissionais atuantes, seja do Departamento de Obras do Estado, seja com particulares contratados, como é o caso de Andrigo. Mas, pelo número de obras projetadas nesses primeiros anos, pode-se dizer que o arquiteto que desempenhou aqui um papel como o de Moraes no Rio foi o engenheiro-arquiteto Mauro Álvaro de Souza Camargo.

Segundo a se formar pela Escola Politécnica de São Paulo (FICHER, 2005), Mauro se tornou reconhecido principalmente como sanitarista, e pelos projetos para hospitais e escolas. Fundada em 1894, a Politécnica passou a se destacar pela introdução de uma arquitetura que seus próprios graduados chamavam de "racionalista", ou seja, privilegiando a funcionalidade e a pesquisa tecnológica na construção, deixando em segundo plano o estudo de ordens e ornamentos próprios do Ecletismo (apesar de Ramos de Azevedo, expoente desse tipo de arquitetura, ter sido diretor dessa escola).

Mauro Álvaro foi convidado em 1910 para projetar e acompanhar a construção dos primeiros edifícios no Instituto Butantan (então ainda chamado Instituto Serumtherapico) por ser especialista em engenharia sanitária. Além disso, era necessário construir uma imagem institucional em seus novos espaços. Em 1901, ele ocupava o cargo de Engenheiro Sanitário, responsável pela direção das comissões do Serviço Sanitário da Secretaria do Estado do Interior, 
criado em 1891. Por esse órgão publicou dois textos que esclarecem mais seu entendimento do que considerava racionalismo: "Projectos de grupos, escolas reunidas e ruraes", no qual sugere tanto procedimentos técnico-construtivos e funcionais quanto estéticos, e, mais tarde, o livro “Hospitaes", com toda sua experiência tratando desde assuntos como implantação, orientação solar, ventilação, acabamentos, até da influência do espaço construído sobre os doentes, assuntos que seriam constantes nas falas dos modernos ao longo do século XX.

Por esses escritos de Mauro Álvaro, por seus trabalhos profissionais e por sua linha de pensamento ligada à Politécnica, pode-se notar que, para ele e seus pares, sua arquitetura era mais racional, funcional e moderna (termos bastante repetidos nas publicações de então). Tentando enxergá-lo com olhos da época, sua arquitetura não era exótica ou fantasiosa, mas plenamente congruente com o espírito científico positivista de então (guiado pela técnica e pela ciência). Essa escolha, como foi dito, estava vinculada à formação de uma imagem institucional que também era buscada por outras instituições semelhantes no Brasil e no mundo (como Manguinhos, no Rio de Janeiro, e filiais do Instituto Pasteur, de Paris).

Um dos grandes expoentes dessa linha funcional ${ }^{42}$ foi Victor Dubugras, professor da Politécnica que passou por diversas correntes de arquitetura, mas sempre com a tendência a novas pesquisas que se contrapunham ao academicismo tradicional e buscavam a aplicação de novas técnicas construtivas e novos arranjos funcionais. Esse movimento lento, partindo do Ecletismo do século XIX para o Modernismo do século XX, que hoje é claro, era na época ainda pouco nítido para seus contemporâneos. Desse modo, correntes como o Art Nouveau, o Art Déco e mesmo o Neocolonial, que hoje podem ser identificados como linguagens estéticas circunscritos à época ${ }^{43}$, foram naquele momento reações ao academicismo, e tentativas de criar novas expressões, na esteira das mudanças trazidas pela segunda Revolução Industrial, época

\footnotetext{
${ }^{42}$ Ressalte-se que os termos "funcional", "racional", "econômico", eram utilizados pelos próprios engenheirosarquitetos da Politécnica para se referir às novas linguagens que passavam a suceder o Ecletismo, o que não significa que essas qualidades não estivessem presentes nas expressões arquitetônicas anteriores.

${ }^{43}$ As novas linguagens (Art Nouveau e Art Déco) são classificadas por alguns autores (WATKIN, 1977 e REIS FILHO, 2005) como "protomodernas", uma visão teleológica que privilegia o Movimento Moderno como destino final daquelas tendências, com o que não concordamos. Essa visão foi especialmente estimulada pela historiografia de autores como Giedion e Pevsner, defensores do Movimento Moderno. Segundo CRIPPA, Pevsner via "todo período de 1760 a 1914 como uma batalha entre o protomodernismo e o 'historicismo', considerado a imitação de um período" (CRIPPA, 1994, p.39, tradução nossa).
} 
de aceleração, de descobertas científicas e de necessidade de eficiência. Esse momento do positivismo, dos números e das pesquisas quantitativas exigia também novas materialidades, que se afastavam paulatinamente da tradição historicista e clássica do século XIX.

Esses conceitos se traduzem na obra de Dubugras. Segundo REIS FILHO, “entre 1906 e 1918, Dubugras se tornou conhecido pelo uso de soluções construtivas e plásticas que mais tarde se tornariam comuns da arquitetura do Movimento Moderno" (REIS FILHO, 2005). Nas publicações da época, como na Revista Politécnica, seus discípulos se referiam a suas obras, explicitamente, como "modernas" e "racionais". Um desses discípulos era Mauro Álvaro, em cujas obras no Instituto Butantã se podem notar muitas semelhanças com as produzidas por Dubugras, sobretudo na primeira década do século XX, nas quais se adotava

uma versão austera, de caráter mais construtivo, correspondente à chamada Secessão Vienense, lembrando também a corrente italianizante denominada Floreale, ambas de sentido racionalista. (REIS FILHO, 2005, p.54).

Nessa arquitetura, elementos como pináculos, ornamentos com formas geométricas simplificadas, janelas mais verticais para aproveitamento do sol, eram considerados mais racionais que os predecessores. O próprio Edifício Principal do Instituto é citado na Revista de Engenharia como exemplo de racionalismo.

Em 1911, juntamente com a equipe de Manguinhos, o Instituto Butantan foi representado na Feira Internacional de Higiene em Dresden, na Alemanha, tornando-se instituição de renome mundial, na esteira de seu bem sucedido combate à peste. A apresentação foi organizada por Mauro Álvaro, incluindo a exposição do projeto para o Edifício Principal do Instituto, que havia iniciado as obras no ano anterior e viria a se tornar seu principal símbolo arquitetônico. No mesmo ano, o projeto também foi publicado na Revista de Engenharia e, na sua inauguração em 1914, recebeu ampla cobertura da imprensa, com reportagem especial em O Estado de São Paulo ${ }^{44}$ e na Revista Médica de São Paulo de 15 de maio de 1914.

Como visto, o objetivo oficial de criação do Instituto foi a produção de soro antipestoso para combate à peste bubônica e, posteriormente, de outros fármacos de acordo com as

\footnotetext{
44 "O Instituto de Butantan - Ligeiro historico do bello estabelecimento scientifico. - A obra do Dr. Vital Brasil. A nova installação, a inaugurar-se hoje”; O Estado de São Paulo; 4/4/1914, p.3.
} 
necessidades que surgissem. Mas juntamente com esse objetivo bem direcionado, e graças a uma atuação bastante pessoal de seu diretor, o Instituto agregou outras atividades que o destacariam na comunidade científica e em geral: a pesquisa básica em microbiologia pasteuriana e a pesquisa na área do ofidismo, que era desde a última década do século XIX tema das investigações pessoais de Vital Brazil ${ }^{45}$. Nesse sentido, foi por iniciativa do médico que o Instituto Butantan, já em seus primeiros anos, não se restringiu à mera produção de soros e vacinas para doenças infecciosas, mas expandiu sua atuação para a pesquisa e o ofidismo. Essa extrapolação de suas atribuições não foi oficialmente aceita por seus superiores do Serviço Sanitário nos primeiros anos. Mas foi finalmente reconhecida pelo decreto $\mathrm{n}^{\circ} 2.918$ de 09/04/1918, no qual o Instituto Serumtherapico passou a se chamar Instituto Butantan, incluindo entre suas atribuições a pesquisa e formação de novos cientistas, passando a seguir o trinômio do Instituto Pasteur de Paris: produção/pesquisa/formação. Os primeiros edifícios construídos no Instituto Butantan, nas décadas de 1900 e 1910, trazem essas características, com espaços voltados à elaboração dos fármacos, exigindo grandes áreas e também a criação de animais; espaços laboratoriais e administrativos menores, próprios da pesquisa científica básica, e, por fim, espaços para formação e ensino, como salas de conferência, museu e biblioteca. Foi também importante desde o início o aspecto urbanístico-paisagístico, visto na ambientação das vias e na criação, em 1918, do Horto Oswaldo Cruz.

A partir de 1916, sob influência do novo diretor do Serviço Sanitário, Arthur Neiva, o Instituto vinha passando por mudanças significativas em suas atribuições, e o foco se voltou para a produção de soros e vacinas, e menos para a pesquisa, no intuito de transformá-lo em uma verdadeira indústria de fármacos, atividade já identificada como estratégica e extremamente rentável. Além disso, acrescentava outras atividades alheias aos primeiros objetivos do Instituto, como a inclusão de uma escola de veterinária. Finalmente, um contrato firmado com a Casa Armbrust \& Cia., por decisão do Serviço Sanitário, para que esta tivesse

\footnotetext{
${ }^{45}$ Vital Brazil já realizava pesquisas sobre soros antiofídicos desde o início de sua carreira, sendo célebre no meio científico sua vitória na polêmica com Albert Calmette, bacteriologista do Instituto Pasteur de Paris, na qual o brasileiro provou que não havia soro antiofídico de eficácia geral, como Calmette pensava, mas que, na verdade, era necessário o desenvolvimento de soros específicos de acordo com o gênero da serpente agressora (BENCHIMOL; TEIXEIRA, 1993)
} 
exclusividade na revenda de soros, gerou um conflito entre Vital e seus superiores. Essas novas atribuições iam de encontro ao que idealizara o médico, e precipitaram sua saída do Instituto Butantan em 1919 para fundar em Niterói outra instituição, privada, para a pesquisa, produção e ensino em microbiologia: o Instituto Vital Brazil, que viria a se tornar um dos três grandes institutos semelhantes, juntamente com o Butantan e o de Manguinhos ${ }^{46}$. Brazil retornou ao instituto paulista em 1924, permanecendo até 1927, procurando dar mais ênfase à pesquisa/formação e menos à produção/vendas, dicotomia que permaneceria em toda a trajetória do Instituto ${ }^{47}$.

Na década seguinte, com o fim da República Velha, e o início do governo de Getúlio Vargas, implantado no Golpe de 1930, a principal repercussão nos institutos de saúde foi o enfraquecimento da relativa autonomia com a qual foram criados, passando-se a um controle centralizador do governo federal, inclusive com a indicação de diretores e de políticas administrativas. Do ponto de vista de ocupação espacial, pode-se dizer, grosso modo, que as décadas de 1930 e 1940 foram caracterizadas por um arrefecimento no crescimento das instalações físicas do Instituto, o que estaria relacionado também às crises econômicas após 1929 e à Segunda Guerra, o que exigiu a contenção de recursos. Ao mesmo tempo, no final desse período já estava caracterizado um núcleo de origem, que viria a ser o que hoje se chama núcleo histórico do Instituto (figuras 17 e 18).

Esse núcleo era caracterizado por um eixo que ia da antiga Casa Sede da Fazenda até o Edifício Principal. Segundo informações dos projetos consultados no acervo do Instituto Butantan, estes eram contratados através do Departamento de Obras Públicas (DOP), responsável por diversos tipos de programas do Estado, incluindo aqueles na área da saúde. ${ }^{48}$

\footnotetext{
${ }^{46}$ O prédio do Instituto Vital Brazil, em Niterói, inaugurado em 1942 viria a se tornar uma das renomadas obras do arquiteto Álvaro Vital Brazil (filho do fundador), ao lado do Edifício Ester, em São Paulo, representantes do modernismo. Para mais informações sobre o Instituto Vital Brazil de Niterói, ver BITENCOURT (2009).

${ }^{47}$ Para mais informações sobre esse caso Armbrust, ver ACOSTA (2014).

${ }^{48}$ As linguagens arquitetônicas adotadas nos projetos do DOP em todo estado transitavam entre o Ecletismo e o Neocolonial (no caso do Instituto Butantan também o Art Nouveau e o Art Déco), o que levou a um menosprezo da historiografia que privilegiava o modernismo. "Em geral, as linguagens exploradas pelo DOP foram sumariamente desclassificadas pela historiografia da arquitetura brasileira, que a partir de 1930, apenas valorizou a produção moderna e considerou qualquer outra linguagem como alheia ao universo da modernidade." (BUZZAR; JUNQUEIRA; CORDIDO, 2016, p.8)
} 


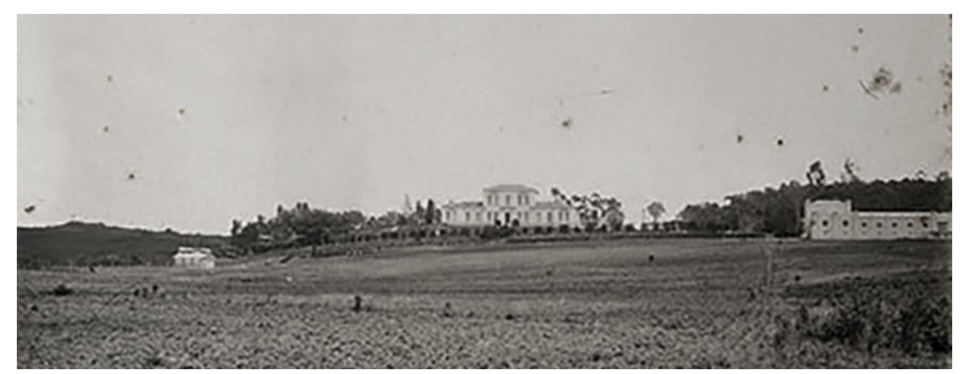

Fig. 17 - Instituto em 1917: na segunda década de existência, os novos edifícios em linguagens mais elaboradas conviviam com o aspecto ainda rural (Fonte: IB_ICO_011498) ${ }^{49}$

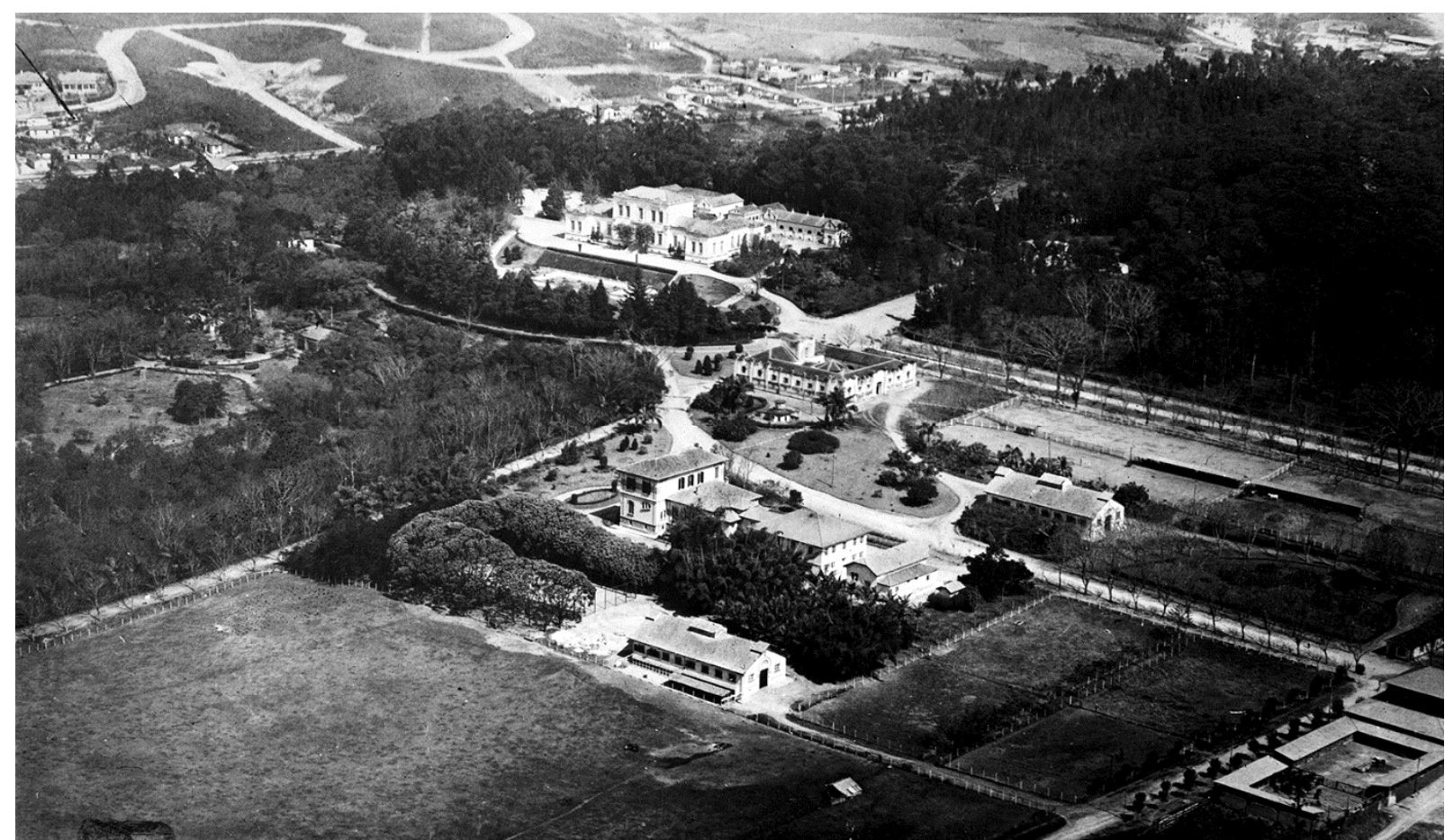

Fig. 18 - Vista aérea do núcleo histórico, c.1930: as linhas urbanísticas já estavam definidas, com o Edifício Principal, a alameda principal, a Cocheira Central, o Pavilhão Lemos Monteiro e as Cocheiras-biotério (Fonte: IB_ICO_009358)

A mudança física mais importante ocorrida nesse período foi a criação, na década de 1940, da Cidade Universitária Armando de Salles Oliveira para abrigar as novas instalações da Universidade de São Paulo ${ }^{50}$, desmembrando $80 \%$ da área do Instituto Butantan (figura 19). Originalmente, a área destinada à USP era constituída de pastos e pequenas construções esparsas, sobretudo casebres isolados remanescentes da fazenda. Com o decreto de desmembramento, os cavalos que aí eram criados foram transferidos para a Fazenda São Joaquim, na região de São Roque, adquirida para esse fim em 1945. Mas devido às dificuldades orçamentárias, essa área desmembrada permaneceria subutilizada até meados dos anos 1950,

\footnotetext{
${ }^{49}$ Quando mencionados códigos iniciados com "IB_ICO", estes se referem à identificação utilizada pelo Núcleo de Documentação do Instituto Butantan para as imagens de seu acervo iconográfico.

${ }^{50} \mathrm{O}$ decreto 6283, de 25 de janeiro de 1934 criou a Universidade de São Paulo e o decreto 12.401, de 16 de dezembro de 1941 determinou o desmembramento de parte do Instituto Butantan para a construção da Cidade Universitária.
} 
mantendo a atividade agrícola, até que no final da década se intensificaram os trabalhos de construção das primeiras estruturas da Cidade Universitária ${ }^{51}$ (figura 23).

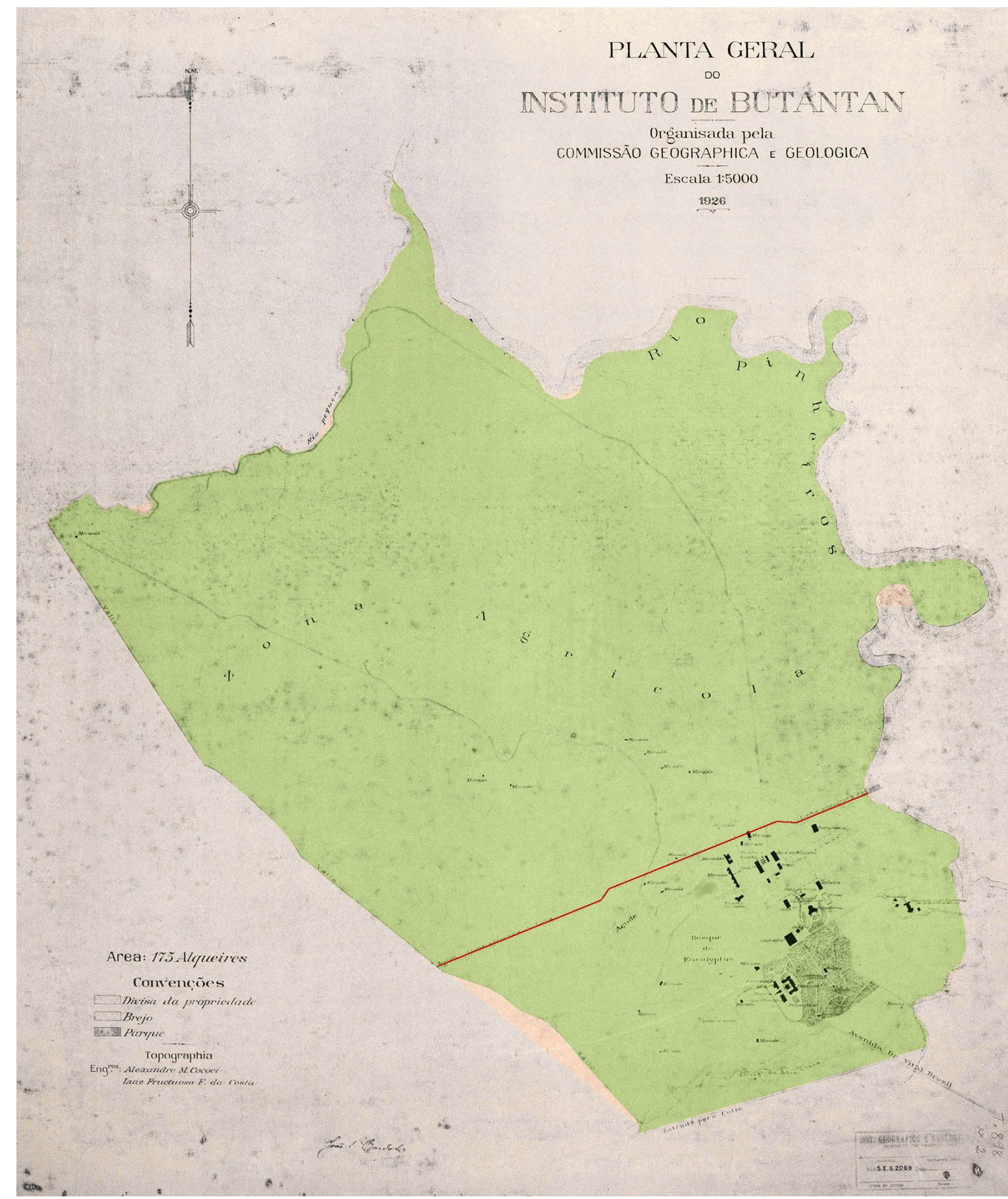

Fig. 19 - Planta geral do Instituto, 1926: novos edifícios se concentraram a sudeste e construções da fazenda permaneceram pelo terreno. A linha vermelha mostra a adutora de Cotia, ao norte da qual o terreno seria desmembrado em 1941 para construção da CUASO. (Fonte: Arquivo do Estado, cor alterada, sem escala)

\footnotetext{
${ }^{51}$ No final da década de 1940 já começam as primeiras movimentações de terra para construção da infraestrutura da USP. Mas apenas no final da década de 1950 se intensificou a ocupação com edifícios do conjunto de Química, da reitoria e do chamado Corredor de Humanas. (LANNA, 2005)
} 


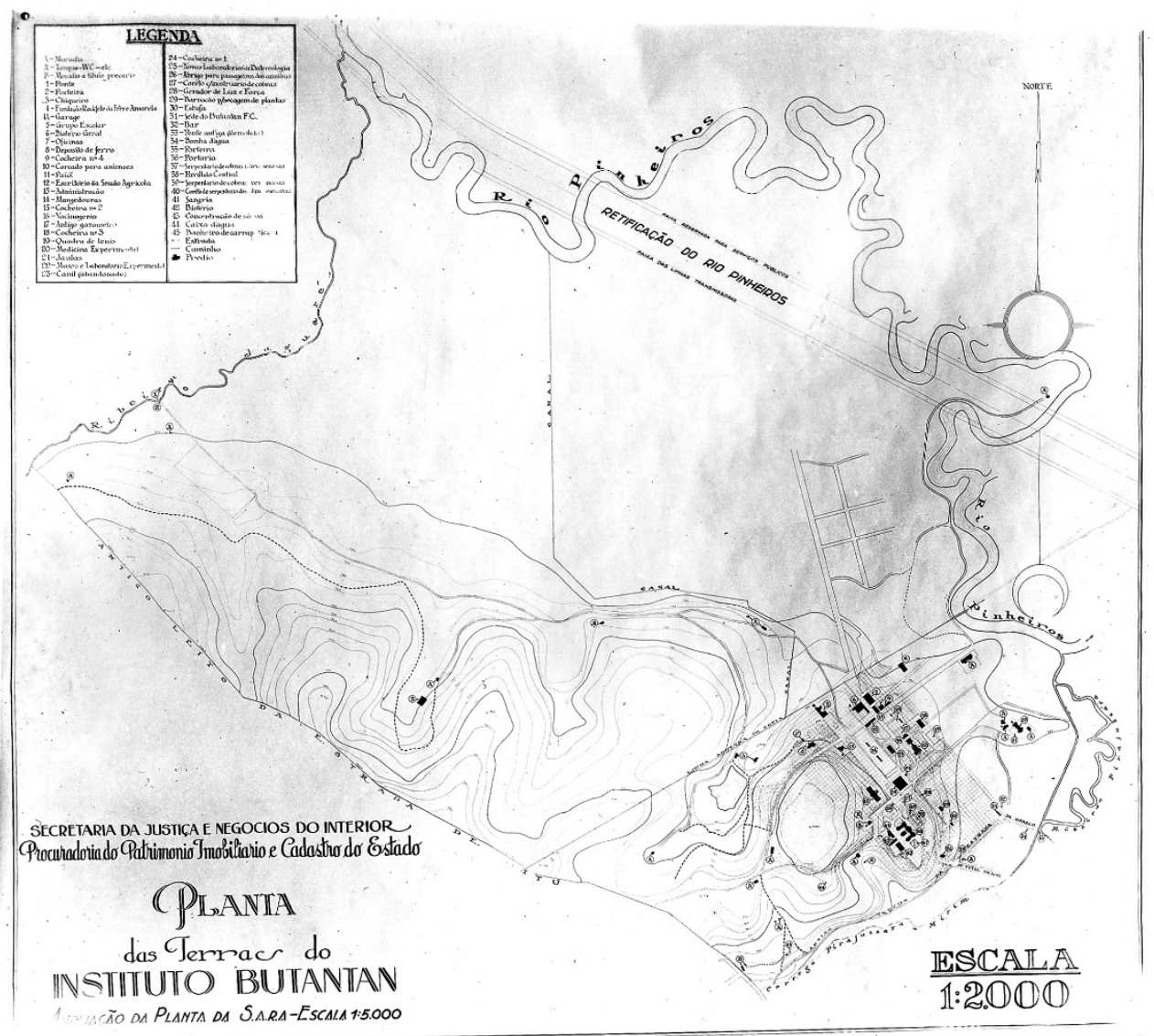

Fig. 20 - Planta cadastral baseada no mapa Sara (1930), sem escala. (Fonte: Arquivo do Estado)

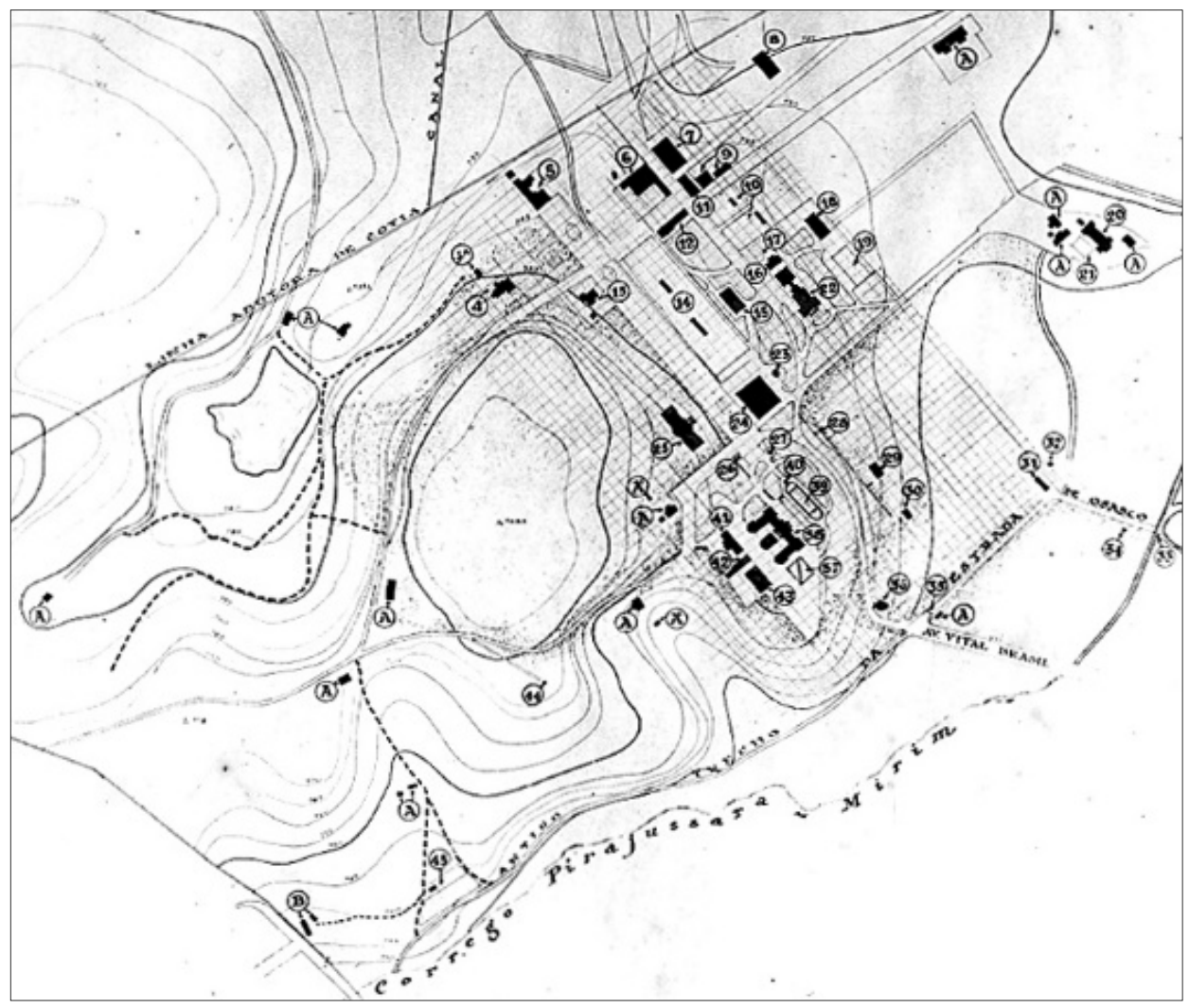

Fig. 21 - Detalhe da planta anterior: a implantação dos primeiros edifícios se deu seguindo uma malha ortogonal em torno da alameda principal, sem escala. (Fonte: Arquivo do Estado) 


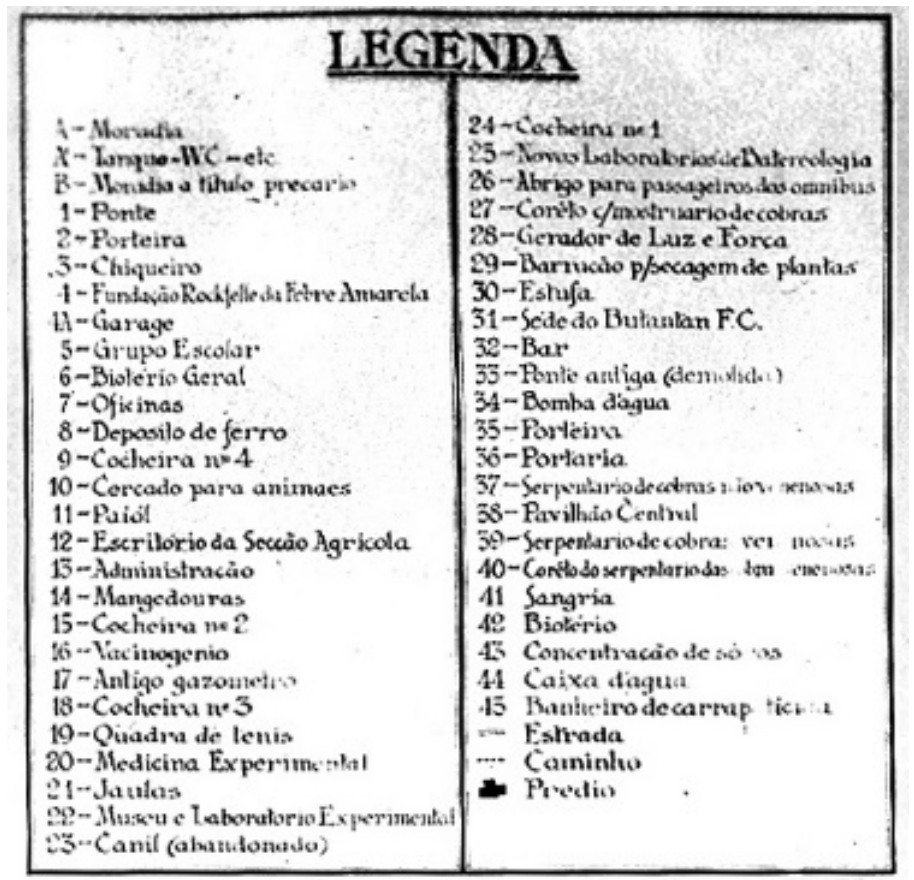

Fig. 22 - Legenda da planta anterior: nota-se a multiplicidade de funções no terreno na época: científicas, agrícolas, residenciais e até de lazer (como quadra de tênis e bar) (Fonte: Arquivo do Estado)

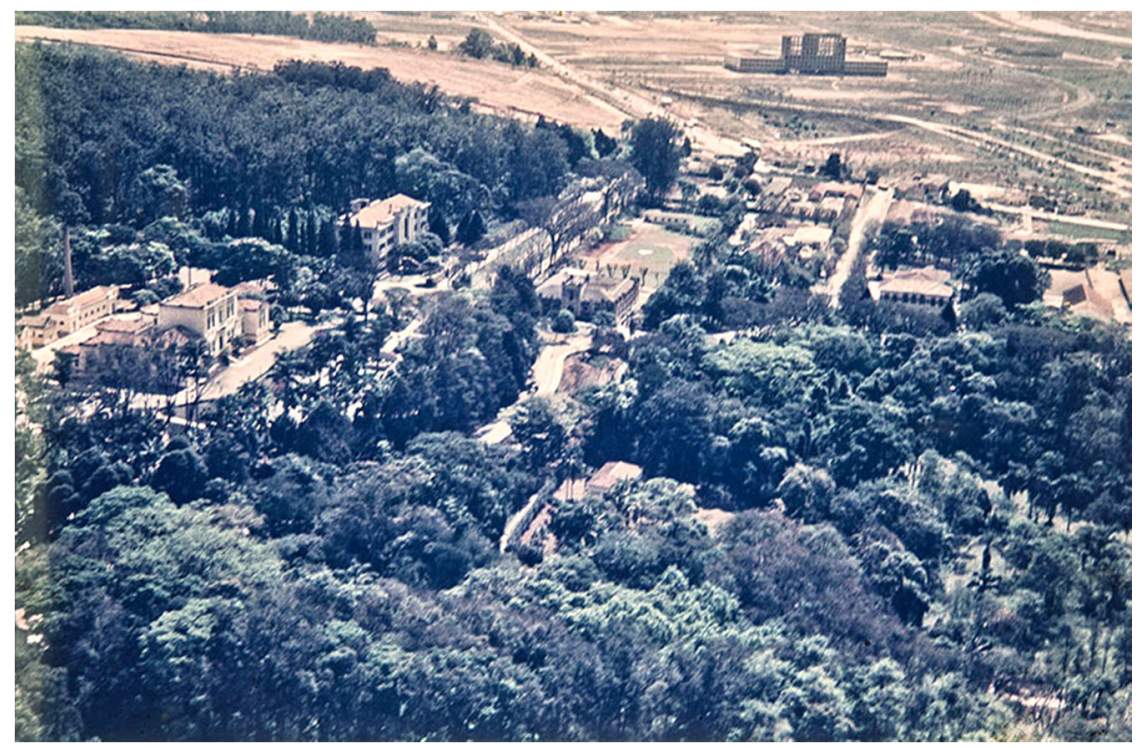

Fig. 23 - Instituto Butantan no final da década de 1950: em segundo plano, a já desmembrada Cidade Universitária da USP, com o edifício da reitoria em construção (Fonte: IB_ICO_000672)

A partir de 1953 foram feitos diversos estudos e levantamentos urbanísticos que procuravam pensar o Instituto como um todo, desenvolvidos pelo arquiteto Carlos Alberto Cerqueira Lemos. No relatório daquele ano, o diretor Afrânio do Amaral demonstrou pela 
primeira vez uma atenção clara dada ao conjunto arquitetônico do Instituto ao criticá-lo, mostrando interesse pelas soluções da Cidade Universitária:

Tem-se a impressão, quando se procura friamente alcançar o objetivo dessas obras [no Instituto Butantan], cada qual no seu estilo mais disparatado, que, no fundo, tais iniciativas, ou são produto do devaneio ou desorientação de espíritos superficiais incapazes de ter uma visão panorâmica do conjunto de construções que o Instituto deve possuir, ou são o resultado de algum plano de sabotagem que vise a lançar êste tradicional estabelecimento no ridículo perante o juízo das pessoas de bom senso. [...] ninguém que tenha passado pela administração do Instituto pode alegar desconhecimento da circunstância, que se acha fixada em lei, de ser o Instituto um dos órgãos complementares da Universidade de São Paulo, tornando-se, por motivos óbvios inclusive os de contiguidade topográfica, imprescindível a progressiva adaptação do estilo arquitetônico de nossas futuras construções ao estilo arquitetônico que vem adotando em suas construções a Cidade Universitária. Se, como está, o conjunto de prédios do Butantan já representa verdadeira colcha de retalhos, imaginese a impressão que deixariam futuramente os seus numerosos edifícios, caso continuassem a desorientação que neste particular aqui lavrou nos últimos tempos. (RA1953, pp.5-6)

Mas foi a partir da década de 1960 que esses planos ganharam força, com o início da urbanização efetiva da CUASO, motivada pelo Plano de Ação (Page) do governador Carvalho Pinto $^{52}$. Esse plano essencialmente desenvolvimentista implicou a contratação de técnicos de diversas áreas para realizar projetos de infraestrutura do Estado, incluindo escolas, fóruns etc. Além disso, alguns órgãos foram criados para implementação do plano, entre eles o Fundo para Construção da Cidade Universitária Armando de Salles Oliveira (FCCUASO), posteriormente chamado Fundusp ${ }^{53}$, órgão responsável pela implantação física do novo campus da USP, e que se tornou em 1961 responsável também pelo planejamento físico do Instituto Butantan.

O relatório de 1961 traz diversos esclarecimentos sobre a relação entre o Instituto Butantan e a nascente Cidade Universitária, além do papel de diversos arquitetos em seu planejamento. Por isso grande parte desse relatório é reproduzido no ANEXO A. Nele, é descrita a mencionada participação do arquiteto Carlos Alberto Cerqueira Lemos nos levantamentos de necessidades em 1953, trabalho assumido pelo arquiteto Rubens Gouveia

\footnotetext{
${ }^{52}$ O Page (Plano de Ação do Governo do Estado) foi implantado pelo governador Carvalho Pinto em 1959-1963, e era baseado nas metodologias da Sociedade de Análises Gráficas e Mecanográficas Aplicadas aos Complexos Sociais (Sagmacs), criada pelo padre francês Louis Joseph Lebret. Para mais detalhes sobre o Page, ver BUZZAR, CORDIDO E SIMONI (2015); BUZZAR, CAMARGO e CORDIDO (2016) e CAMARGO (2016).

${ }^{53}$ O FCCUASO passou a ser denominado FUNDUSP (Fundo de Construção da Universidade de São Paulo) em 1969, COESF (Coordenadoria do Espaço Físico) em 2002, e SEF (Superintendência do Espaço Físico) em 2012.
} 
Carneiro Vianna em 1958, que resultou em um Plano Piloto (como programa de necessidades), objeto de concurso público em 1961, do qual participaram arquitetos autônomos ${ }^{54}$. O relatório de 1963 faz um resumo do plano de obras resultante do convênio do Instituto com o FCCUASO (já havia três anos). Como premissas fundamentais para essa ação, foram listadas:

1) Dar ao Instituto Butantã uma individualização que o diferencie da Cidade Universitária, sem colisão com a conceituação geral da mesma.

2) Construção dos setores básicos, sem interferência com edificações existentes, fundamentais ao funcionamento atual do Instituto.

3) Conservação da flora.

4) Redução do movimento de terra nas construções futuras e na abertura das diversas ruas.

5) Localização dos setores de maneira a permitir ampliações futuras sem quebra do funcionamento orgânico.

6) Dar ao sistema viário um caráter semelhante ao da Cidade Universitária.

7) Permitir, através do sistema viário, fácil escoamento dos esgotos e das águas pluviais. (RA 1963, np)

Esses trabalhos foram consolidados no primeiro Plano Diretor do Instituto em 1966, elaborado pela equipe do FCCUASO. O papel dos arquitetos no Page foi importante pois se inseria na visão desenvolvimentista contemporânea à construção de Brasília e que, em certo sentido, era reproduzida em outra escala no Estado de São Paulo. A atuação desses profissionais se deu em duas configurações: aqueles que faziam parte de equipes permanentes (servidores públicos), e aqueles que eram contratados para projetos específicos (autônomos):

Apesar da declarada valorização do conhecimento técnico do funcionalismo público, o Page foi responsável pela contratação de centenas de arquitetos autônomos, um número até então nunca verificado em administrações anteriores por meio de um inédito e polêmico acordo com o Instituto dos Arquitetos do Brasil (IAB-SP). Contemporâneo às obras da nova capital do país, que selou com grande ênfase a associação da arquitetura com a imagem de progresso e modernidade, o Page também se propôs promover o desenvolvimento do Estado, valorizando a arquitetura paulista. Tal relação - deflagrada com muito sucesso com o projeto do Ministério da Educação e Saúde Pública, de 1936, e reiteradamente afirmada pelas obras que marcaram a trajetória política de Juscelino Kubitschek, culminando com a construção de Brasília - revela a afinidade de Carvalho Pinto com as estratégias políticas em curso e esclarece a distinção dada à arquitetura no seu plano. A incorporação de arquitetos que tinham trabalhado na Sagmacs, ativos no IAB-SP e próximos aos professores, especialmente a Vilanova Artigas, fortaleceu a relação entre a arquitetura e o Plano. Tal proximidade, frente às ambições do Plano e à confiança na representatividade da arquitetura, favoreceu essa contratação de profissionais externos ao serviço público para o desenvolvimento de cerca de mil projetos. (CAMARGO, 2016)

\footnotetext{
${ }^{54} \mathrm{O}$ termo "autônomo" é aqui utilizado no sentido de "prestadores de serviço da iniciativa privada", atuando individualmente ou em grupo, ou seja, que não eram profissionais do funcionalismo público.
} 
Para a implantação célere, foi proposto pelo governador Carvalho Pinto um convênio entre o Instituto Butantan e o recém criado FCCUASO, conforme descrito no ANEXO A. Nessa nova organização administrativa, em que o espaço físico da USP e do Instituto Butantan eram pensados em conjunto, houve a atuação de arquitetos nas duas configurações: alguns da equipe permanente do FCCUASO, e outros contratados externamente para determinados projetos. Porém, analisando os relatórios e principalmente o acervo iconográfico, com projetos de arquitetura e engenharia da época, pode-se notar que, em termos de execução de obras, a equipe permanente de arquitetos (servidores) foi mais efetiva, enquanto os contratados externos realizaram diversos projetos e planos que não foram executados.

Além da preocupação com o planejamento integrado do campus, foi nos anos de 1960 que os relatórios passaram a fazer menções claras à necessidade de conservação do patrimônio cultural edificado. No relatório de 1960 foi definido que seriam criados os Serviços Culturais de Documentação e Setor Turístico que tratariam da parte histórica do Instituto (RA 1960, np).

O relatório de 1961, previa, dentro do convênio com o FCCUASO,

[...] uma série de obras que redundariam na transformação total do Instituto Butantan, ao mesmo tempo que se aproveitariam os edifícios com valor técnico ou histórico indiscutível. (RA 1961, np)

No concurso então lançado pelo Instituto, exigiram-se, entre outras coisas, "obras destinadas à conservação do patrimônio do Instituto" (ver Anexo A).

Apesar dessas preocupações apresentadas nos relatórios, os projetos aprovados no concurso previam a demolição de diversos edifícios históricos, para a construção de prédios modernistas (típicos da arquitetura paulista do Page), entre eles uma torre de pesquisa de 21 andares $^{55}$ (figura 24$)$.

\footnotetext{
${ }^{55}$ A torre teve projeto do engenheiro-arquiteto Rubens Carneiro Vianna, formado em 1939 pela Escola Politécnica e conhecido por diversos projetos em parceria com Ricardo Sievers (como as torres Cetenco Plaza, na Avenida Paulista). Além dele, uma equipe também foi contratada para outros projetos (não executados) de arquitetura e paisagismo para o Instituto Butantan no âmbito do Page, formada pelos arquitetos Abelardo de Souza, João Carlos Bross, Jacob Goldenberg, Leo Quanji Nishikawa e Luiz Construcci, e pela paisagista Miranda Magnoli.
} 


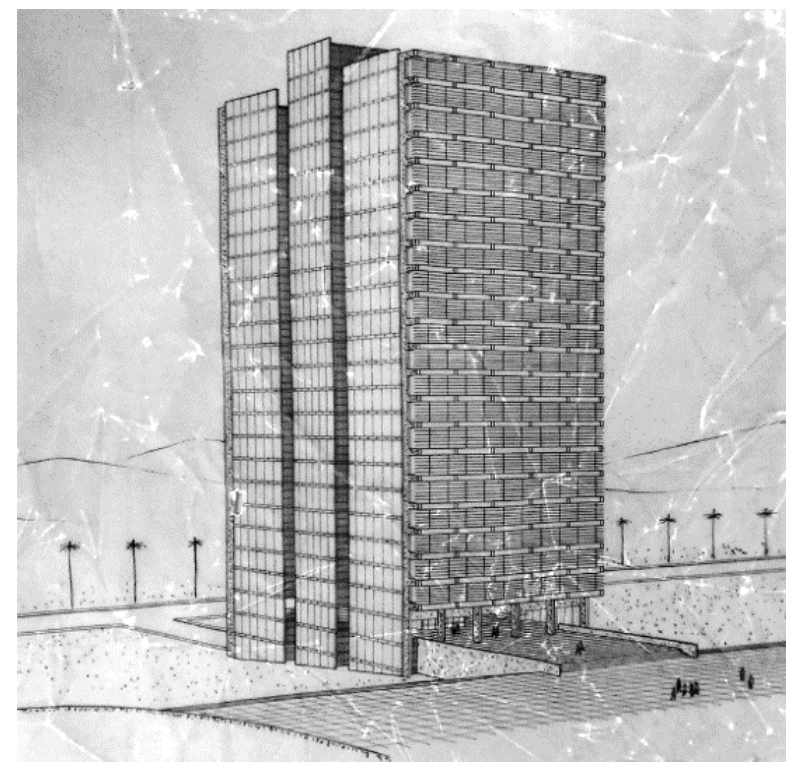

Fig. 24

Projeto de torre de pesquisa (arquiteto Rubens Carneiro Vianna, 1961): projetos não executados pelo Page, como esse, previam a demolição de grande parte dos edifícios históricos (Fonte: Acervo IBu)

Diversos projetos não executados no Instituto Butantan foram desenvolvidos na década de 1960 por alguns dos arquitetos que se tornariam importantes na historiografia da arquitetura. Entre eles estavam Jorge Wilheim, Abelardo de Souza, João Carlos Bross, Miranda Magnoli e Lina Bo Bardi, que desenvolveu estudo para a Cocheira, convertendo-a em Museu de Biologia. Apesar de não ter progredido, este estudo de Lina ${ }^{56}$ trazia aspectos interessantes de preservação do edifício existente com adição de novos elementos (assunto que será aprofundado no item 2.3.7). Pesquisas sobre o Page dão conta de que a questão da contratação de arquitetos autônomos estava ligada tanto à insuficiência das equipes de servidores para tantas demandas, quanto ao desejo de dar à arquitetura um papel mais proeminente como símbolo da atuação governamental (a exemplo dos monumentos de Getúlio e Juscelino) convidando arquitetos de renome. Vilanova Artigas, que foi um dos autônomos contratados pelo Page, escreveu em seu artigo "Sobre Escolas" acerca dessa questão:

Um plano de emergência, como se vê. Para a emergência, os órgãos de projeção do estado não estavam aparelhados. Para ajudá-los, resolveu-se atribuir projetos a arquitetos de fora da estrutura do funcionalismo público. Já tinham uma experiência técnica, acumulada a duras penas, realizando obras particulares. Assim foi projetado, em tempo relativamente curto, um conjunto apreciável de escolas, e a sociedade tomou conhecimento da existência dessa reserva técnica que são os quadros da arquitetura paulista. Trabalham por honorários mediante os quais 'arquitetos de outros países não moveriam um dedo' - como disse revista estrangeira que a eles se referiu. (ARTIGAS, 1970, pp.10-13)

\footnotetext{
${ }^{56}$ Não foram encontradas evidências de que ela tenha sido contratada dentro do Plano de Ação através do FCCUASO, ou se o estudo foi encomendado pela própria diretoria do Instituto Butantan.
} 
Embora não seja objetivo desse trabalho analisar os edifícios não executados, cabe citar o plano de zoneamento da equipe de João Carlos Bross (ver nota 55) pelo fato de evidenciar qual a visão de correntes menos conservativas em relação ao patrimônio cultural. O plano propunha a implantação de grandes edifícios novos, prevendo a demolição de quase todo núcleo histórico, incluindo o Edifício Principal. Esses edifícios projetados por arquitetos autônomos não foram construídos, sendo que alguns projetos chegaram ao nível de detalhamento executivo, incluindo estrutura e instalações (como a citada torre de 21 andares) (figura 24). O fato de tais projetos terem sido abortados, mesmo em estágio avançado (possível assunto a se pesquisar), foi fundamental para a preservação do núcleo histórico do Instituto.

Durante o Page, o projeto mais significativo executado no Instituto, do ponto de vista de área e de pesquisa projetual, foi o Núcleo Residencial, que não foi dos citados autônomos, mas do arquiteto, servidor do FCCUASO, Mário Rosa Soares, que também foi corresponsável por alguns edifícios da Cidade Universitária (tema a ser retomado no item 2.3.18).

Em 1963 o governador Carvalho Pinto foi sucedido por Ademar de Barros, e o Page foi substituído pelo Pladi (Plano de Desenvolvimento Integrado). Embora pudesse parecer uma nova roupagem para a mesma ideia, o Pladi significou a redução no número de contratações de arquitetos autônomos e privilegiou a atuação de equipes de servidores, inclusive com acumulação de tarefas. No caso do Instituto Butantan, o plano levou ao cancelamento de projetos daqueles arquitetos contratados, sendo tais obras assumidas pela equipe de servidores do FCCUASO, de modo que os projetos que saíram do papel foram predominantemente gerados por esses funcionários, que foram alocados no Instituto Butantan para diversos serviços ligados ao espaço físico. Essa equipe, que permaneceu no Instituto pelo menos até 1981, variou em tamanho, mas foi sempre reduzida, sendo formada por dois a três arquitetos, e em média três desenhistas, que por vezes dividiam-se entre projetos da Cidade Universitária e do Instituto Butantan, e também acompanhavam o andamento das obras de reforma e de construções novas.

Para o presente trabalho, foram realizadas entrevistas com Osmar Mammini, arquiteto do FCCUASO responsável pelo maior número de obras do Instituto Butantan entre o período 
de 1965 e 1981, quando atuou dirigindo obras e projetos nesse campus ${ }^{57}$. Osmar, que ficava alocado no subsolo do Edifício Principal e se reportava diretamente ao diretor do Instituto (na época Aristides Vallejo-Freire), projetou e dirigiu as obras de reforma da Cocheira Central, convertendo-a em Museu de Biologia (descartando-se, portanto, o projeto de Lina Bo Bardi), do almoxarifado, lavanderia, oficinas, depósito de combustíveis e explosíveis, a reforma do restaurante, que posteriormente se tornaria Museu de Microbiologia (com projeto de Márcio Kogan), a construção de uma réplica do primeiro laboratório do Instituto Butantan (será abordado no item 2.3.19), além de edifício novos de pesquisa, que seguiam a linha do Brutalismo Paulista. Segundo Osmar:

"Lá tinha o Fundo de Construção da Cidade Universitária Armando de Salles Oliveira. Eles estavam abrindo uma vaga e eu fui lá. E felizmente depois de trinta dias me contrataram. Aí pediram pra eu trabalhar num convênio que eles tinham com o Instituto Butantan. [...] eu fui trabalhar sozinho no Instituto. Aí depois entrou um outro arquiteto, que era o Carlos Henrique Heck. Ele inclusive casou com uma moça e teve que fugir pra França por causa da Revolução. Porque eles não eram muito queridos. Até quando eu publiquei esses projetos na Revista Acrópole, em um deles eu pus o meu nome primeiro e no outro eu propus o nome do Carlos Henrique primeiro, pra poder, digamos assim, empatar." (Depoimento Osmar Mammini)

Bem aceita de início, a atuação do FCCUASO no Instituto Butantan passou a ser vista por sua diretoria e pela comunidade como uma ingerência, e trouxe alguns conflitos. Na prática, nota-se que as maiores realizações foram feitas pela equipe permanente do FCCUASO e, em geral, limitadas a reformas, reconstruções ou pequenas obras novas, enquanto as propostas modernizadoras e mais drásticas dos arquitetos externos não foram executadas. No relatório de 1966 foi feita uma listagem das obras realizadas, em que se podem ver diversas melhorias urbanísticas (jardins, iluminação, estacionamentos, terraplenagens, redes hidráulicas e elétricas) e reformas de edifícios (Cocheira Central, restaurante, biotério, Edifício Principal, entre outros). O documento é assinado por Osmar Mammini, pelo arquiteto Carlos Henrique Heck e pelo engenheiro Francisco Mariano de Souza Costa. Assim, nas ações de arquitetos no âmbito do Page (governo Carvalho Pinto) e do Pladi (governo Ademar de Barros) parece ter

\footnotetext{
${ }^{57}$ Osmar Mammini, arquiteto formado pela Universidade Mackenzie em 1959, também foi responsável pelo projeto do Hospital Universitário, pelo edifício da Faculdade de Farmácia, entre outros na USP. As informações sobre as equipes do FCCUASO foram colhidas em entrevista com o arquiteto, estando portanto sujeitas a imprecisões de memória.
} 
havido uma divisão, ficando as propostas mais arrojadas e de arquitetura "de autoria" na Cidade Universitária, e as mais moderadas e conservativas no Instituto Butantan, talvez pelo fato de serem situações diametralmente opostas de pré-existência: este Instituto já era consolidado, enquanto a Cidade Universitária estava por ser feita. Mas, além disso, houve a participação ativa da comunidade do Instituto para preservar seu território e seus edifícios, como se verá adiante, e ressalta-se novamente que o primeiro ímpeto das autoridades e dos planos apresentados pelos arquitetos convidados pelo Page foi do tipo “arrasa quarteirão" para com o Instituto Butantan. É difícil mensurar o quanto esse movimento de resistência à desfiguração do território e do patrimônio edificado do Instituto foi encampado por seus funcionários e usuários, uma vez que a documentação mostra unicamente a voz de sua diretoria. Mas é plausível que essas ações expressadas individualmente pelos diretores possam ter sido provocadas por uma conscientização de toda a comunidade do Instituto frente à sucessivas perdas de terreno e alterações de edifícios que ocorreram.

Nesse sentido, pode-se dizer que o período do início dos anos 1960, com a atuação do FCCUASO no Instituto Butantan, o nascimento da Cidade Universitária no terreno desmembrado do Instituto, e a atuação de arquitetos de vertente moderna pelos planos Page e Pladi despertaram pela primeira vez na comunidade do Instituto a noção de pertencimento ao espaço edificado, e da necessidade de que este campus fosse protegido e defendido, não só por questões práticas, mas também por uma identidade e uma memória ligada ao seu território. Quanto aos edifícios e espaços projetados pelos arquitetos autônomos (Wilheim, Souza, Bross, Bo Bardi etc.) e não executados, é assunto que pode dar ensejo a novas pesquisas de interesse sobre o período ${ }^{58}$. Posteriormente, esse conflito de atribuições seria um dos motivos da iniciativa de pedido de tombamento do Instituto junto ao Condephaat.

Os anos de 1960 também marcaram o conflito entre o crescimento vertiginoso das atividades de produção de fármacos versus a falta de espaços voltados para ela. Segundo o relatório de 1963:

\footnotetext{
${ }^{58}$ Durante a finalização deste trabalho, estava em elaboração a dissertação de mestrado de Luiz de Lucca Netto, para a FAU-USP, abordando os edifícios projetados (e em sua maioria não construídos) sob o Plano de Ação do governo Carvalho Pinto para o Instituto Butantan.
} 
[...] O que se verificou nos últimos anos foi a progressiva intromissão de atividades de produção em reduzidos e acanhados laboratórios de pesquisa, inadequados para obedecer às exigências e aos rigores das modernas técnicas e seguir processos de trabalho altamente qualificados em condição de boa produtividade. (RA 1963, np)

Isso levou ao planejamento de edifícios voltados à produção fabril, portanto de escala e conformação bastante diferentes dos que vinham sendo feitos até a década de 1950, caracterizados por plantas compartimentadas para os laboratórios específicos. Os novos complexos previstos no plano diretor do FCCUASO propunham inicialmente a substituição dos edifícios existentes. Mas estes complexos, como se viu, não foram construídos. Posteriormente, houve um deslocamento da ocupação do campus em direção ao setor hoje chamado de "Produção", mais próximo ao córrego Pirajuçara Mirim, no qual grandes pavilhões e redes de infraestrutura passaram a ser implantados de acordo com as necessidades técnicas próprias da indústria farmacêutica (figura 25). Segundo o relatório de 1965, os novos laboratórios Centrais de Tecnologia em construção somariam cerca de $30.000 \mathrm{~m}^{2}$, portanto deveriam ser implantados em novas áreas do campus. Consequentemente, e por contraste, surgiu a noção de "núcleo histórico" para o eixo antigo, que foi mantido.

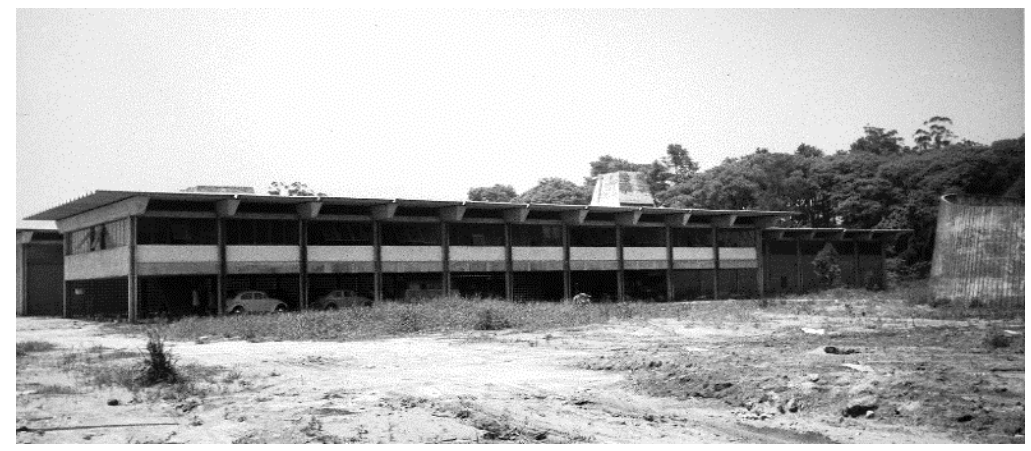

Fig. 25

Edifícios novos do setor de produção e almoxarifados: os projetos da equipe do FCCUASO (Mammini e Heck) seguiram princípios do brutalismo e técnicas préfabricação (Fonte: IB_ICO_008573)

Do ponto de vista administrativo, surgiu na década de 1960 entre alguns diretores a ideia de transformar o Instituto em uma Fundação, o que daria mais liberdade na captação e utilização de recursos financeiros, ideia inicialmente rechaçada por grande parte da comunidade da instituição, mas que viria a ser retomada nos anos de 1980.

A época dos planos Page e Pladi, que se estenderam de 1959 a 1966, marcaram, portanto, o amadurecimento da noção de conjunto urbanístico; a implantação de edifícios em escala industrial com características fabris (grandes galpões e unidades pré-fabricadas) e a utilização 
de métodos de planejamento mais objetivos (cronogramas, controles de orçamento). Esses encaminhamentos foram influenciados pela implantação da Cidade Universitária e pela ação administrativa centralizadora do governo estadual, fato que, se por um lado gerou a sensação de inovação e ruptura notada em suas novas instalações, também trouxe certa reação de defesa do núcleo original do Instituto e, consequentemente, de seu patrimônio cultural edificado.

A década de 1970 foi marcada por um arrefecimento na velocidade dessas reformas, concentrando os recursos na construção de novos edifícios de produção, enquanto os mais antigos passavam apenas por reparos emergenciais. Uma reforma administrativa que vinha ocorrendo gradativamente desde 1968 descentralizava as responsabilidades do Instituto, deixando a cargo de diretores de cada setor as decisões sobre obras de reforma e construção necessárias. Isto gerou, no final dos anos 1970, um enfraquecimento no conceito de gestão unificada do espaço físico buscada no início dos planos de Carvalho Pinto e Ademar de Barros.

Em 1977, por conta de uma controvérsia em que o Instituto Butantan perdeu mais um trecho de seu terreno ${ }^{59}$ para a Cidade Universitária, destinado à instalação da Fundação Faria Lima, ficou evidente o descontentamento do Instituto em relação à integridade de seu perímetro. Em suas considerações, o diretor Fauze Carlos acatava a cessão da área pelo Instituto, determinada pelo Governo, mas fazendo as seguintes ressalvas:

[...] na salvaguarda dos inúmeros planos de expansão do Instituto Butantan, ininterruptamente solicitado para atendimento das necessidades da Saúde Pública [...], apelamos, em nome do progresso da ciência e da pesquisa biomédica, para que na mensagem a ser enviada à Assembléia Legislativa, para a cessão da área ora convencionada que seja consignado um dispositivo proibindo terminantemente qualquer cessão de novas áreas a qualquer órgão público ou não, preservando-se assim a integridade do patrimônio que representa a renomada instituição científica de reconhecida projeção internacional. (RA 1978, p. 6)

Concomitantemente, nessa década se intensificaram no Instituto os investimentos de diversas instituições externas, com objetivo de complementar os recursos advindos da Secretaria de Saúde, considerados insuficientes. Assim, recursos oriundos de convênios com Finep, Fapesp, CNPq, e mesmo órgãos internacionais, complementavam as necessidades de

\footnotetext{
${ }^{59}$ Inicialmente, haviam sido cedidos $54.000 \mathrm{~m}^{2}$ para a Secretaria de Obras e Meio Ambiente através do Decreto $6869 / 75$ e $6.000 \mathrm{~m}^{2}$ pela Lei $208 / 74$ totalizando $60.000 \mathrm{~m}^{2}$. Através de várias representações da diretoria do Instituto junto ao Governo Estadual, foram recuperados $44.000 \mathrm{~m}^{2}$ (RA 1978, pg.4)
} 
verbas. Com isso, algumas melhorias foram realizadas no final dos anos de 1970, agora não só nas instalações científicas, mas também visando à preservação de seus edifícios históricos, além de melhorias em nível urbanístico e paisagístico.

Outra forma de evitar essa desfiguração de seu território foi através de uma ocupação mais efetiva, já que até então a implantação de seus edifícios estava concentrada no núcleo histórico e no de produção. Essa ocupação privilegiou as áreas de recreação com tratamento paisagístico, plantio de espécies vegetais, abertura de trilhas e lagos.

Todas essas iniciativas de apropriação (simbólica e de fato) do território culminaram com o pedido de tombamento do Instituto Butantan pelo Condephaat em 1980, com o intuito principal de defender o terreno de novas cessões, mas tendo como argumento principal a relevância de seu patrimônio arquitetônico (assunto a ser aprofundado no item 2.2).

Em 11 de junho de 1981, durante as comemorações do centenário do Instituto, foi entregue o que foi então chamada "Restauração do $1^{\circ}$. Laboratório do Instituto Butantan" (item 2.3.19). Em 14 de setembro do mesmo ano foi decretado o tombamento do Instituto pelo Condephaat, atendendo aos mencionados objetivos de proteger o campus contra novos desmembramentos. Mas além desse objetivo prático, a consciência de sua importância como patrimônio cultural edificado e como equipamento urbano e paisagístico passou a um outro nível de reconhecimento, conforme palavras do diretor Bruno Soerensen:

\footnotetext{
"Pretende-se integrar o Instituto à coletividade de São Paulo que se ressente com a falta de verde. A esta transformação será dada ainda aspectos culturais no campo da Saúde Pública de utilidade à formação de todos os visitantes. O nosso Museu foi visitado no presente ano por aproximadamente 300.000 pessoas. O Tombamento do Instituto Butantan como patrimônio Histórico e Cultural no dia 14 de setembro garantiu a preservação do Instituto Butantan e pode-se considerar um reconhecimento do Governo do Estado ao desempenho internacional do Instituto Butantan." (RA 1981, np)
}

Com o tombamento e a definição de um núcleo histórico, as novas construções, a partir dos anos 1980, mostraram a prioridade dada às atividades de produção de fármacos. Do ponto de vista do espaço físico, essa opção também foi evidenciada no crescimento do setor nordeste do campus, dedicado às atividades fabris. Isso também mostra a decisão (não implementada) de ocupar os edifícios históricos (na época considerados aqueles até a década de 1940), com usos de pesquisa científica, administração, educação e cultura, já que atividades industriais 
seriam incompatíveis com tais estruturas (originalmente laboratórios). Ainda assim, os usos que os edifícios históricos passaram a receber não foram livres de problemas.

Mesmo com a prioridade dada à produção de fármacos, a atividade de pesquisa continuou aumentando sua relevância na década de 1980, agora incluindo as áreas de História, Museologia e Arquitetura. O papel da conservação documental relacionada à História da Ciência ganhou espaço, conforme o relatório de 1982, descrevendo a reestruturação

[...] da Divisão de Extensão Cultural segundo projeto já apresentado em 1977, do qual constam pelo menos três serviços: Serviço de Documentação, Serviço de Educação e Serviço de Relações Públicas. Neste projeto é estudada a inclusão das atividades de Desenho e Fotografia em Setor ou Seção. (RA 1982, np)

A criação da carreira de pesquisador científico em 1983 estimulou tais atividades no Instituto, ampliando-as para as áreas de ciências humanas mencionadas.

Em meados da década de 1980, devido a crises econômicas e mudanças de prioridade, passaram a ser constantes as reclamações da diretoria junto à Secretaria da Saúde e ao Governo do Estado em relação à insuficiência de quadros de recursos humanos, com especial ênfase na Divisão Cultural. Essas dificuldades ensejaram uma busca maior de fontes alternativas junto a entidades de fomento nacionais e internacionais. No plano da pesquisa científica biomédica strictu sensu, essas entidades eram as já ligadas à pesquisa na área farmacêutica (CNPq, Fapesp, Finep). Já em relação às atividades culturais, houve a busca de novas fontes de recursos ainda não exploradas. Assim, segundo o relatório de 1984:

Num plano mais amplo, envolvendo não apenas o Museu, mas também o Horto e demais instalações do Instituto Butantan tombados pelo patrimônio histórico, contatou-se a Fundação Roberto Marinho. Foram realizadas várias reuniões com seu representante em São Paulo, que encaminhou nossa solicitação à Sede no Rio de Janeiro; a Fundação já se manifestou favorável à assinatura de convênio ou acordo prevendo a concessão de auxílio ao Instituto Butantan. Cabe registrar que há grande dificuldade para viabilização desse tipo de entrada de recursos externos no Instituto e no encontro de um patrocinador adequado por parte da Fundação. [...] Foram iniciados os entendimentos com o Condephaat/DOP e Fundação Roberto Marinho, para colaboração nos projetos de reforma arquitetônica e museológica do Museu. [...] Haverá andamento dos projetos de reforma do Museu em sua área física, com proposta de colaboração ao Condephaat/DOP, e de reforma arquitetônica e museológica do interior do Museu, com estudo de apresentação do mesmo ao público, com proposta de colaboração da Fundação Roberto Marinho (RA 1984, np) 
Curiosamente, o Condephaat participou dos entendimentos de reforma para o edifício que era uma réplica, inaugurado apenas três anos antes (como será visto nos itens 2.2 e 2.3.19). No Plano Quinquenal 1984-1989 era descrito:

O Museu do Instituto Butantan é constituído de duas unidades: uma, recentemente criada e instalada, para exposição de documentos e objetos históricos da Instituição e outra, mais antiga, que se destina à transmissão de conhecimentos sobre animais peçonhentos, sobre a prevenção de acidentes por eles causados e sobre o tratamento de acidentados, bem como, à divulgação das demais atividades da Instituição. Para cumprir satisfatoriamente essas finalidades, o Museu requer a adoção de técnicas adequadas que deverão ser definidas por especialistas em museologia. Nesse sentido, tentar-se-á obter a colaboração da Faculdade de Arquitetura e Urbanismo da USP para elaboração de um anteprojeto de reforma a ser submetido ao Condephaat, considerando o recente tombamento do Instituto por esse órgão. Recursos financeiros para a concretização do mesmo deverão ser solicitados principalmente à Secretaria de Turismo, já que o Instituto Butantan constitui um dos principais pontos de atração turística do Brasil, conforme comprova o número de aproximadamente 250.000 visitantes por ano, recebidos pela Instituição nos últimos três anos. (Plano Quinquenal do IBu - 1984-1989)

A nova postura em relação ao aspecto urbanístico e paisagístico do Instituto, notada a partir da década de 1960, e intensificada com a construção dos lagos e arborização dos terrenos remanescentes do campus, é aqui vista claramente em relação ao Horto:

O Horto Oswaldo Cruz, inaugurado a 20.02.1918 pelo Dr. Arthur Neiva, e que concretizava uma idéia do botânico Frederico Hoehne de reservar uma área para cultivo de plantas medicinais junto ao Instituto de pesquisa, com o passar dos anos, foi sendo gradativamente descaracterizado e necessita ser recuperado. Para tal fim, já foi estabelecido contato inicial com a Secretaria das Administrações Regionais da Prefeitura de São Paulo, da qual se espera também a manutenção da área verde do Instituto Butantan. (Plano Quinquenal IBu 1984-1989)

No final da década de 1980 se acentuou a crise de investimentos no Instituto, e a própria diretoria usou a comparação com Manguinhos para evidenciar a gravidade da situação:

Espera-se que o governo paulista, não venha a permitir que o Instituto Butantan continue sendo mantido em condições de perniciosa defasagem com relação ao Instituto Manguinhos, órgão federal do qual é congênere e equivalente por suas origens e tradições, e que, hoje, já se encontra plenamente revitalizado e ampliado graças ao decisivo apoio ainda recentemente concedido pelo governo federal. (RA 1985, p. 26) 
A crise orçamentária passou a ser assunto na imprensa ${ }^{60}$, que relatava as reivindicações da administração do Instituto e de seus funcionários quanto a investimentos em pesquisa, políticas salariais e planos de carreira, além das necessidades de melhorias nas instalações físicas $^{61}$. As reformas, construções e trabalhos de conservação necessários à manutenção dos edifícios e ao trabalho adequado dos funcionários exigiam vultosos recursos, e por isso passaram a ser paliativas. Entre as obras necessárias, os setores de pesquisa e a Divisão Cultural eram preteridos em relação ao de produção. Nesse cenário, as obras de conservação e restauro se tornaram algumas das últimas prioridades, já que as urgências relativas à produção de fármacos e ao andamento das pesquisas se sobrepunham.

A crise levou o Instituto a buscar alternativas além do pedido de verbas ao governo estadual e a agências de fomento. Assim, em 1986 foi lançada uma campanha publicitária solicitando doações da população. Foram feitos leilões de itens do acervo histórico ${ }^{62}$ e foi organizada uma exposição no MASP (Museu de Arte de São Paulo) revertendo recursos para o Instituto. A ação foi noticiada em periódicos da época mostrando a iniciativa de Pietro Maria Bardi para ajudar o Instituto (duas décadas após Lina Bardi ter sido preterida no projeto para o Museu Histórico):

\begin{abstract}
A idéia é do diretor do Masp, Pietro Maria Bardi, que acredita 'ser o Museu um dos melhores pontos para a arrecadação de donativos, pois oferece à população a possibilidade de conhecer o processo de produção de soro e poderá dar a todos condições de avaliar a importância do Instituto Butantã para a saúde pública'. Todo o dinheiro arrecadado com a venda de ingressos será depositado no Fundo Especial de Pesquisas do Butantã, no Banco Nacional. Segundo Bardi, a idéia surgiu assim que leu a reportagem sobre o lançamento da campanha, publicada por O Estado de São Paulo. 'Pensei - diz ele - e concluí: por que não uma exposição dedicada à cobra numa cidade de cobras?' (Masp prepara exposição para ajudar o Butantan. O Estado de São Paulo. 10/05/1986, p.11)
\end{abstract}

\footnotetext{
60 "Crise atinge o Butantã", O Globo, 15/10/1983; "Em greve, o Instituto Butantã pede apoio urgente ao ministro", Jornal da Tarde, 15/06/1985; "Confirmado o abandono do Butantã", O Estado de São Paulo,15/06/1985; "Greve e falta de verba: a pior crise do Butantã”, O Estado de São Paulo, 13/06/1985; "Butantã: agora só resta esperar o pior", O Estado de São Paulo, 01/05/1986. “O esvaziamento do Butantã”, O Estado de São Paulo, 14/05/1986.

${ }^{61}$ Essa situação se agravou tendo como marco a chamada "crise do soro" em 1984, quando verificou-se que a produção de soro pelo Instituto era insuficiente e seguia procedimentos obsoletos, precipitando uma reforma administrativa que trouxe de volta cientistas já aposentados para debelar a crise.

62 "Cartas de Vital Brazil no leilão. Pelo Butantã”, O Estado de São Paulo, 09/05/1986, p.9.
} 
Apesar do citado convênio em que o setor de obras da USP atuou na gestão do espaço físico do Instituto Butantan desde 1961, e que durou até 1985, foi apenas em 1990 que foi firmado entre as duas instituições um convênio de cooperação técnico-científica para desenvolver conjuntamente pesquisas, produtos e cursos de formação.

Do ponto de vista administrativo, a ideia, que vinha desde a década de 1960, de instituir uma fundação para auxiliar na captação e administração de recursos, foi posta em prática com a criação da Fundação Butantan em 31 de maio de 1989, um órgão de caráter privado ligado ao Instituto Butantan (que permanecia público e subordinado à Secretaria da Saúde). A Fundação Butantan passou a auxiliar o Instituto para captar recursos, implementar linhas de pesquisa e desenvolver diversas atividades valendo-se da agilidade proporcionada por sua natureza privada, dispensando trâmites burocráticos da administração estatal. A descrição das funções da Fundação diz:

A Fundação Butantan é uma entidade civil fundacional, com personalidade de direito privado, sem fins lucrativos, com autonomia administrativa, financeira e patrimonial. A Fundação tem por finalidade principal apoiar a todas as atividades do Instituto Butantan.

Fundada em 1989, tem entre suas atividades de apoio:

a) A operacionalização da produção de imunobiológicos, biofármacos e outros produtos afins, tendo em vista $\mathrm{o}$ atendimento às políticas de saúde pública;

b) A colaboração com o Instituto Butantan, por intermédio de cooperação técnica e financeira, no cumprimento de suas atribuições legais, relativas ao desenvolvimento científico, tecnológico e cultural, bem como a prestação de serviços à comunidade;

c) A possibilidade para Instituto Butantan oferecer melhores condições para recrutamento e seleção de pessoas, sua fixação, formação e atendimento assistencial, contribui para a profissionalização e modernização da gestão das atividades de pesquisa, ensino e cultura do Instituto Butantan. (RA 2012, p.10)

A partir de então, foi sensível o aumento de recursos no campus, permitindo o desenvolvimento de novas pesquisas e crescimento da produção, que viria a tornar o Instituto Butantan o maior produtor de imunobiológicos do país e um dos mais importantes do mundo. Isso teve reflexo na sua ocupação física, com ampliação significativa de sua área fabril, junto ao córrego Pirajuçara Mirim e à divisa com a CUASO. Essa nova configuração binária da instituição (Instituto + Fundação) não deixou de receber críticas, como a do diretor do Instituto Willy Beçak, o próprio criador da fundação: 
A proposta original [...] era de que a fundação apoiasse financeiramente todas as atividades do instituto, incluindo a pesquisa básica, a produção de vacinas e as atividades culturais. Mas não foi o que aconteceu. Após sua saída da presidência, em 1997, diz ele, "os estatutos foram alterados, de modo a priorizar a produção de vacinas e aumentar o poder da fundação, que passou a ditar financeiramente e politicamente os rumos do instituto. ("Não fiz a Fundação Butantã para ser fábrica de vacinas", $O$ Estado de São Paulo, 20/06/2010, p.A24) ${ }^{63}$

A partir dos anos 1990, a situação orçamentária do Instituto melhorou com a atuação da Fundação e a participação de convênios com a iniciativa privada ${ }^{64}$. Na área cultural, foram desenvolvidos projetos de pesquisa, publicações e reformas com apoio de empresas como Banespa, Itautec, Camargo Correa, JHS e Unibanco. Já em 1991, foi incluído entre os objetivos planejados para o Instituto, sob a rubrica "Atividades Culturais":
a. recuperar o patrimônio histórico
b. atualizar o Museu didático
c. ampliar a exposição no Museu histórico
d. recuperar a área ajardinada
e. reflorestar a área dos lagos
f. instalar ponto de atendimento de estudantes e turistas
g. ampliar o Centro de Convivência Infantil (RA1991)

Relativamente recuperado da crise financeira, o Instituto passou a direcionar os novos recursos principalmente à produção, para atender às necessidades de imunobiológicos no país. $\mathrm{Na}$ ocupação física, o uso de tais recursos privilegiou a construção de novos edifícios, como o de produção de vacina contra o sarampo. Mas já no final dos anos 1990, perto de completar 10 anos de tombamento, o núcleo histórico passou a atrair cada vez mais a atenção da comunidade do Instituto e seus visitantes, seja pela situação de degradação que apresentava, seja pela maior conscientização desses grupos quanto ao patrimônio cultural.

Essa nova preocupação em relação ao patrimônio cultural edificado era diferente da que surgiu na década de 1960, quando se relacionava à proteção do território, enquanto agora o interesse era preservar e restaurar seus elementos de memória. O início da década de 2000 se caracterizou pela consolidação das colaborações entre o Instituto e a iniciativa privada. Essa tendência já havia se iniciado no final dos anos 1980, com a redemocratização. A partir de então,

\footnotetext{
${ }^{63}$ Sobre a controvérsia envolvendo a Fundação, ver "Instituto Butantan, público, subordina-se a fundação privada", Revista Adusp, setembro de 2010, pp 41-48)

${ }^{64}$ Para mais detalhes sobre as condições financeiras e administrativas do Instituto a partir dos anos 1990, ver MELLO (2000)
} 
a presença de fundos provenientes de agências de fomento brasileiras e internacionais, bem como de indústrias farmacêuticas, possibilitaram a manutenção da pesquisa científica de alto nível, do patrimônio cultural e da produção de imunobiológicos.

$\mathrm{Na}$ área de divulgação e cultura, o Instituto se tornou um centro de formação de novos cientistas. Mas além da área científica, houve nos anos 2000 um incremento no número de pesquisas e programas relacionados à documentação histórica da instituição, dando continuidade às iniciativas do começo da década de 1980 (publicações, cursos e atividades educativas). O Instituto Butantan foi um dos pioneiros a utilizar os meios digitais, tanto nas suas pesquisas científicas em saúde (uma exigência na área), quanto em seus programas culturais. Em 1998 já havia endereços eletrônicos do Museu Biológico, com lista de espécies de animais que abrigava, e apresentações em multimídia, tecnologias incipientes na época.

$\mathrm{Na}$ área de pesquisa, nos primeiros anos da década de 2000, foi registrado um aumento do número de patentes registradas pelo Instituto. Novamente, a presença de recursos privados não ocorreu sem controvérsias. Conforme os relatórios e notícias estudados, esse momento foi marcado por disparidades entre ilhas de excelência e áreas com poucos recursos e estrutura inadequada. Essas disparidades eram complexas, pois envolviam pesquisa científica, produção e venda de fármacos, setor cultural e o espaço físico. Em geral, todos os profissionais envolvidos eram de grande capacidade e boa formação. Portanto, o que determinava a disparidade de condições entre os diferentes setores do Instituto era a diferença de recursos financeiros, o que é comum em qualquer organização pública desse porte. Mas aqui a complexidade (que perdura até hoje) advém não só da disparidade recursos, mas também da multiplicidade de suas fontes.

Como exemplo, pode-se citar o caso do Centro de Toxinologia Aplicada (CAT), que a partir de 2007 passou a dividir o Pavilhão Vital Brazil com o setor de Vacina contra Raiva. A diferença de recursos de cada um desses setores acabou gerando, além de disputas internas, disparidades visíveis no espaço físico, ficando os ambientes mais amplos e renovados para o CAT, enquanto os menos privilegiados ficaram com a Raiva.

Portanto, convivendo com áreas de excelência (material e espacial), havia setores improvisados e mal estruturados. Estes eram em geral aqueles que não possuíam verbas das indústrias farmacêuticas e da Fundação Butantan, e não estavam diretamente ligados à 
atividade de produção (a mais rentável). Assim, os museus, a biblioteca, os setores de documentação histórica, não obstante o trabalho dedicado de seus servidores, careciam de investimentos no espaço físico. Enquanto novos edifícios eram construídos e outros reformados para instalação de laboratórios com recursos da Fapesp, Finep, Merck, Roche etc., outros permaneciam praticamente nas condições originais, mas sem um plano de conservação preventiva. O ex-diretor do Instituto e criador da Fundação Butantan Willy Béçak se manifestou novamente em 2010 sobre o desvirtuamento dos recursos privados dentro do campus, e seu impacto no espaço físico:

Beçak chama ainda atenção para a separação entre laboratórios de pesquisa básica e
área fabril. Para um desavisado, a separação é imperceptível, mas há muro e portões
separando as fábricas do restante do instituto, tanto nas fábricas sob administração
direta da fundação, que funcionam junto da entrada do instituto, de acesso restrito.
[...] A própria presença de fábricas na área do Instituto Butantan, que é cercada por
zonas residenciais e comerciais, e próxima a um córrego, é questão delicada. No
entorno das plantas estão um posto de saúde e uma escola, sem falar nas matas da
USP. (“Instituto Butantan, público, subordina-se a fundação privada”. Revista Adusp,
Setembro 2010, p.47)

Um dos casos de investimento de recursos privados na área de preservação, sendo o primeiro caso de restauro de um edifício de fato no campus, foi o convênio da Fundação Butantan com a Fundação Armando Álvares Penteado (FAAP) para restauro dos antigos galpões de serralheria, marcenaria e paiol em 2004 (tema a ser retomado no item 2.3.10).

Em 2009, uma crise relacionada a desvios de recursos provocou o afastamento do diretor da Fundação Butantan, Isaias Raw, levando a vários problemas administrativos e, consequentemente, de investimento em instalações. Segundo os relatórios seguintes, a intenção inicial da criação da Fundação Butantan, de complementar as ações do Instituto, havia se perdido, concentrando-se a primeira na produção fabril, e o segundo em pesquisa e cultura. No entanto, a crise de governança na Fundação, que foi de 2009 a 2012, causou problemas nas próprias atividades produtivas. Em 2011, segundo o então diretor do Instituto, Jorge Kalil:

A produção industrial estava completamente estagnada. De 2001 a 2010, a Anvisa publicou três normativas técnicas (RDC 123 de 2001, RDC 210 de 2003 e RDC 17 de 2010) relacionadas às práticas de fabricação, que exigiam que todos os fornecedores de medicamentos, incluindo soros e vacinas, para o Ministério da Saúde, atendessem às regras de Boas Práticas de Fabricação (BPF). No entanto, o Instituto Butantan, 
assim como outros produtores, não havia se adequado às normas e seu parque fabril se tornara obsoleto. (RA 2011, np)

Um dos resultados deletérios dessa situação, e talvez o mais emblemático, ocorreu em 15 de maio de 2010, quando um incêndio destruiu o edifício da coleção de serpentes, perdendo-se o maior acervo mundial de serpentes para pesquisa, coletadas desde a fundação do Instituto.

Diante dessa crise, em 2012, com apoio da Secretaria da Saúde e da Curadoria de Fundações de São Paulo, decidiu-se pela unificação da gestão do Instituto Butantan e da Fundação Butantan, passando ambos à direção do médico Jorge Kalil ${ }^{65}$, e foram implantados controles administrativos mais rígidos, com auditoria de procedimentos contábeis, fiscais, trabalhistas e previdenciários. Profissionais com experiência na gestão da indústria farmacêutica foram contratados e, a partir de então, a administração do Instituto, integrada à da Fundação, assemelha-se cada vez mais à da iniciativa privada, em termos de planejamento, metas de produção e setores de gerência.

Todas essas transformações estruturais envolvendo o tipo de gestão, a administração de recursos públicos e privados combinados, levou a mudanças sensíveis também na área física, em princípio com reformas e construções no setor de produção para atender às normas da Anvisa e, posteriormente, no aprimoramento dos sistemas de telefonia, cabeamento, instalações elétricas, hidráulicas e de segurança. Finalmente, o aumento das receitas proporcionado pela reorganização administrativa permitiu investimentos na recuperação dos edifícios históricos. A título de comparação, o faturamento do Instituto passou de $\mathrm{R} \$ 348$ milhões em 2011 para cerca de R\$1,1 bilhão em 2014.

O setor de produção continua sendo, nos últimos anos, muito maior e mais bem equipado que o de pesquisa e cultura. Reformas foram realizadas para modernizar laboratórios adequando-os às exigências de biossegurança e normas biomédicas, como a obtenção da

\footnotetext{
${ }^{65}$ A unificação da direção do Instituto e da Fundação foi desfeita em 2015. Segundo o relatório desse ano: "o Secretário da Saúde e o Curador de Fundações, em conjunto com os Conselhos do Instituto Butantan e da Fundação Butantan, observando os resultados positivos atingidos pela gestão unificada, definiram que era chegado o momento de segregar novamente as instituições, que haviam amadurecido suas gestões e estavam agora prontas para voltar a ter dirigentes independentes, inaugurando um novo modelo de cooperação entre as entidades." (RA2015, p. 5)
} 
Certificação das Boas Práticas de Fabricação, da Anvisa, seguindo o RDC No. $17^{66}$. Hoje a gestão do espaço físico do Instituto Butantan cabe à Divisão de Infraestrutura (até 2018, Divisão de Engenharia e Arquitetura-DEA), que procura gerenciar o espaço físico do campus de forma multidisciplinar e integrada, mesmo com as dificuldades de atuar com equipes muitas vezes insuficientes para a complexidade das atividades. Para isso, foram realizados levantamentos que resultaram em bases digitais do campus, incluindo topografia, sistema viário, implantação dos edifícios organizados por números de identificação, plantas de instalações, entre outras bases que têm sido continuamente atualizadas, entre elas os levantamentos dos edifícios do núcleo histórico. O Relatório de 2016 dá um panorama sobre as atividades da DEA:

A Divisão de Engenharia e Arquitetura - DEA tem como finalidade dar suporte às atividades fabris, de pesquisa e culturais desenvolvidas no Complexo Butantan, relacionadas às Engenharias de Segurança do Trabalho, de Projetos, de Manutenção, de Utilidades e de Meio Ambiente. (RA 2016, p.17)

Na área cultural, em 2010 ocorreu uma reforma administrativa da Divisão Cultural que estimulou a pesquisa em museologia, comunicação e educação não formal da ciência. No mesmo ano foi incorporado à administração do Instituto o Museu de Saúde Pública Emílio Ribas, localizado no bairro do Bom Retiro.

Hoje o Instituto é visto não apenas como espaço de excelência na produção de imunobiológicos, mas também como lugar de memória de seus frequentadores, sejam visitantes ou funcionários, aspecto que acaba tendo relação intrínseca com a patrimonialização de seu espaço material. O valor de memória do Instituto vem basicamente de duas vertentes: por um lado, sua importância como instituição científica (com todas as expectativas e simbologias que o progresso científico representou no século XX), por outro lado, como equipamento público de destaque no tecido urbano, desempenhando também papel de parque, ponto de encontro e de lazer. Dessa forma, o Instituto entra no imaginário de diversas formas, e foi possível identificar algumas através de observação e depoimentos de frequentadores para a presente pesquisa. Basicamente, existe a relação mais afetiva de quem visita o Instituto com frequência,

\footnotetext{
${ }^{66}$ A resolução RDC $n^{\circ} .17$ da Anvisa estabelece requisitos mínimos a serem seguidos na fabricação de medicamentos para cumprimento das chamadas Boas Práticas de Fabricação de Medicamentos (BPF) de uso humano, incluindo os requisitos de ambientes e edifícios.
} 
como morador do bairro, usuário frequente ou funcionário, e existem os visitantes esporádicos, geralmente turistas, atraídos pelo renome da instituição, ou estudantes que participam de visitas guiadas ao campus (especialmente aos museus). Essas duas vertentes de valorização como memória foram construídas ao longo da história, como é possível verificar nos relatórios e em periódicos abordando especificamente o valor do Instituto como memória.

O aspecto da memória científica é notado desde os primeiros anos, quando uma das salas do Edifício Principal era utilizada como museu. Além disso, cada sala era nomeada para homenagear um grande cientista. A área museográfica do Instituto é por si só significativa, pois sempre houve preocupação com o registro de sua história, ainda que as estruturas físicas não fossem as mais adequadas para exposição e armazenamento de acervo.

No caso da memória científica sobre o Instituto, desenvolvida pelo público externo, corroboram três aspectos: o já mencionado mito de origem, a pesquisa em ofiologia e a produção científica. O primeiro se refere ao que BENCHIMOL e TEIXEIRA (1993) descrevem como uma construção historiográfica de um início cheio de obstáculos, capitaneado por um líder (Vital Brazil) em um meio hostil (a fazenda), conseguindo heroicamente seu objetivo (debelar a epidemia de peste bubônica), narrativa também reproduzida, guardadas as especificidades, em Manguinhos. Esse aspecto rende até hoje objetos de estudos, atividades e publicações, sendo portanto uma memória relevante.

O segundo formador de memória, o desenvolvimento de pesquisa ofiológica, trouxe desde o início muita curiosidade do público em geral. Ainda que não tenha sido o objetivo principal de fundação do Instituto, esse campo trazido pessoalmente por Vital Brazil era, em grande parte, uma novidade para a época. Aliada a um certo fascínio quase circense das demonstrações ao público ${ }^{67}$, essa atividade construiu uma memória até internacional ${ }^{68}$ do Instituto, a ponto de fazê-lo integrar o imaginário popular como "local das cobras".

Esse trecho de 1931 mostra a importância da instituição como atração turística:

\footnotetext{
${ }^{67}$ As apresentações de extração de veneno foram abolidas na década de 2000, seguindo um movimento de conscientização da comunidade científica quanto à manipulação e exposição desnecessária de animais. Sobre a ética nos experimentos com animais pela ciência, ver ANDRADE, PINTO e OLIVIERA (2002).

${ }^{68}$ Cure for snake bite given away by Brazil. New York Times, 6 jun. 1926.
} 
A não ser o Instituto de Butantan, sério e sábio, com suas cobrinhas envergonhadas reduzidas à inoffensiva condição de bichinhos acariciantes, há pouca coisa característica em S. Paulo que a um exigente 'touriste' de binóculo e 'kodak', sedento do 'peculiar' nativo, a gente possa mostrar com absoluta certeza de o 'épater' sufficientemente. [...] É uma fatalidade: hão de ser sempre esses macios e flexuosos bichos que nos farão conhecidos, admirados e temidos pelos srs. forasteiros. (Página do Baedecker Paulistano. O Estado de São Paulo, 24 abr. 1931)

O terceiro aspecto formador de memória no campo científico, a sua produção, está vinculado à excelência do Instituto na fabricação e fornecimento de imunobiológicos, aspecto que pode ser notado sobretudo em periódicos relatando sua atuação no combate a surtos epidêmicos. Era comum encontrar anúncios publicitários, no início do século XX, utilizando o nome do Instituto para dar credibilidade aos produtos anunciados.

Por toda essa memória construída sobre sua importância científica, são comuns nos relatórios e periódicos as menções às visitas de personalidades ilustres ao Instituto, mostrando que era considerado cartão de visitas do governo estadual e federal para impressionar autoridades nacionais e internacionais.

$\mathrm{O}$ aspecto espacial na formação da memória do Instituto, ou seja, a sua presença urbanística, como parque, campus e mesmo bairro, não pode ser desvinculado das memórias mencionadas acima, uma vez que faz parte de tais acontecimentos. Sua própria vocação turística se dá pelo fato de atrair um público que deseja conhecer seus aspectos científicos, ao mesmo tempo em que procura um espaço de lazer, sendo difícil separar as duas dimensões. Mas ao longo de sua história, alguns relatos mostram o crescente interesse especificamente por seus elementos edificados e seu paisagismo, já a partir de 1910:

Butantan tem um pouco de tudo: museu de serpentes, instituto serumtherapico contra o veneno das serpentes, repartição de ophidiogia, e sobretudo um tranquillo recanto, onde entre os eucaliptus e as araucarias o estudioso se queda admirado e commovido. (Entre as serpentes do Butantan. O Estado de São Paulo. 10 out. 1910, p.6)

Nessa mesma linha, em 1954 o Instituto era tratado como parque e local de retiro:

O ambiente bucólico do Butantã, parque tropical isolado do bulício trepidante da metrópole, é propício ao fim a que foi destinado pelos seus fundadores, meditação e pesquisa. Possa perseverar sempre nessa trilha. (FONSECA in INSTITUTO HISTÓRICO E GEOGRÁFICO DE SÃO PAULO, 1954, p.317) 
O caráter turístico se intensifica a partir dos anos de 1940, sendo que a partir da década de 1950 o Instituto Butantan foi diversas vezes mencionado como uma das atrações turísticas mais visitadas da cidade, informação repetida pelo New York Times em 2000:

Exibições nas quais é extraído veneno das serpentes não são mais oferecidas ao público, mas o Instituto Butantan, Avenida Vital Brazil 1500 no bairro do Butantã, continua a ser provavelmente a atração turística mais popular da cidade. Um dos principais centros mundiais de pesquisa em répteis, tem uma coleção de mais de 60.000 animais, e seu pequeno museu apresenta aranhas e escorpiões vivos, assim como cobras venenosas com nomes exóticos como jararaca e mussurana. (What's doing in São Paulo. New York Times, 25/06/2000, tradução nossa). [Lembrando que o incêndio de 2010 destruiria a quase totalidade da citada coleção]

Nas visitas turísticas, registradas nos relatórios e em noticiário, passou a ser crescente o interesse pelo patrimônio cultural edificado após o tombamento do Instituto pelo Condephaat em 1981. A memória do patrimônio edificado, demonstrada pelo público e pela comunidade científica, pode ser notada na reação à deficiência na conservação dos edifícios nos anos de 1990, exemplificada nessa carta de leitor ao jornal O Estado de São Paulo:

Carta No. 10.354

Butantã está abandonado

"No domingo dia 10/1, como costumo, levei amigos para visitar o Instituto Butantã e ficamos impressionados com o estado de abandono em que se encontra a instituição, tão querida pelas pessoas. Durante a visita, o revestimento de madeira de uma das paredes, carcomida pelo cupim, desabou. De quem é a responsabilidade de zelar por esse patrimônio? A quem cabe a recuperação de um bem comum, que tanto contribuiu para a formação de várias gerações?” Everardo de Carvalho, médico sanitarista do Ministério da Saúde e ex-estagiário do Butantã - Capital.

O Instituto Butantã responde:

"Compartilhamos com o leitor a perplexidade com relação à exposição do Museu do Instituto Butantã, uma instituição centenária, responsável pelo pioneirismo da ciência experimental no Brasil, juntamente com o Instituto de Manguinhos do Rio de Janeiro. É preciso alçar voz sobre esse estado de coisas. Estamos cansados de tentar sensibilizar as autoridades sobre a necessidade de verbas para, pelo menos, manter o patrimônio histórico tombado. Temos tentado alternativas, como conseguir recursos na Fapesp e patrocínio com empresas privadas que, diante do quadro econômico, não se arriscam a investir. Encaminhamos, ainda, um projeto para o Ministério da Cultura para aprovação pela Lei Rouanet. Enquanto isso, o governo estadual não responde aos pedidos de verba para restauração da viga central do auditório do museu, interditado desde agosto, deixando de oferecer mais de 200 vagas em nossos cursos para toda a comunidade. Muito menos fornecem verbas para a restauração do museu, que a Fundação Butantã, dentro dos seus poucos recursos, tem tentado ajudar, para resolver a falta de pessoal, o ataque dos cupins (tivemos de retirar uma parte do revestimento, que está condenado), os vazamentos d'água pelo telhado e, inclusive, a falta de verba para atividades mínimas de infraestrutura. Para tentar resolver a situação, fizemos plano de demissão voluntária, recolhimento de verbas e cortes orçamentários. Concordamos com a austeridade, mas com discernimento. Por que não fazemos 
cortes na máquina tecno-burocrática? Pedimos à sociedade e à mídia que se manifestem antes que o museu desabe sobre as nossas cabeças. Nossos pedidos foram engavetados pela burocracia. Quem sabe o público eleitor possa interferir? O que o leitor relata é apenas a ponta do iceberg de um problema muito maior, relacionado à Saúde Pública. Para quem não sabe, o Instituto Butantã é responsável por cerca de $80 \%$ da produção nacional de soros e vacinas, com qualidade reconhecida pela Organização Mundial de Saúde (OMS). Sem demagogia, todos os empenhados funcionários que aqui permaneceram, pesquisadores e diretoria, quando o instituto completar o centenário, em 2001, gostariam de oferecer algo melhor no internacionalmente reconhecido Instituto. O futuro agradecerá.” Prof. Dr. Marcos Ferreira Santos, diretor-substituto da Divisão Cultural do Instituto Butantã. (Sessão de cartas. O Estado de São Paulo, 01/02/1999, p C2)

No final do mesmo ano, foi publicada a seguinte correspondência, que teve repercussão direta na administração:

Carta No. 11.202

Ajudem o Butantã

"Após a leitura de um artigo no Estadinho sobre o Instituto Butantã, eu e minha mulher resolvemos conferir o programa com nossa filha de 3 anos. É uma pena, mas o instituto tornou-se uma atração cultural decadente. No domingo, 14/11, os únicos atrativos abertos à visitação eram o Museu Histórico (quase abandonado) e o Biológico, que não tem informações suficientes. O terminal multimídia estava desligado e a loja de artigos fechada. Essa é a triste realidade da nossa administração pública. O mais impressionante era a quantidade de turistas estrangeiros, insatisfeitos. De um alemão ouvi o seguinte comentário: 'Em todo lugar as coisas melhoram, mas aqui ficam piores...' Fiquei aborrecido com a imagem do Brasil que esse turista levará para casa, pois, infelizmente, ele tem razão.” Alexandre Kröner - Granja Julieta

O Butantã responde:

"O Instituto Butantã, órgão da Secretaria da Saúde, produz 70 milhões de doses de vacinas/ano e 200 mil ampolas de soro contra os venenos mais conhecidos, com orçamento e funcionários voltados para essa produção, alimentada pela pesquisa de 130 cientistas. O Butantã tem grande importância histórica, pois mantém os Museus Históricos, de Rua e Biológico, além do serpentário. $\mathrm{O}$ orçamento que recebemos infelizmente não é suficiente, pois há necessidade de investimento e funcionários especializados. Para a área cultural temos só dois funcionários de nível superior: não temos monitores, assessores de imprensa ou bibliotecária. Os cupins estão destruindo as instalações de madeira do Museu Biológico. Por isso, pedimos aos cidadãos (como é comum nos Estados Unidos) que contribuam, para ajudar o governo a manter o instituto. No dia 23/2/2000, inauguraremos o novo serpentário, inteiramente doado por uma empresa particular e por um famoso arquiteto. Sr. Alexandre, volte ao instituto para visitá-lo ou quando sua filha completar 10 anos. Tenho a certeza de que o encontrará mais bonito." Walter Colli, diretor. (Sessão de cartas. O Estado de São Paulo, 28/11/1999, p.C2)

Dois dias após essa publicação, o diretor Walter Colli foi afastado de suas funções, causando revolta entre os servidores do Instituto. Segundo o governador, que tomou a decisão:

"Não é nada pessoal, mas eu não gostei do que ele escreveu. [...] Dizer que os cupins estão deteriorando o Museu Biológico quando tem o IPT lá do seu lado para resolver 
esse problema, não dá!" ("Covas reitera determinação de afastar diretor”. O Estado de São Paulo. 09 dez. 1999, p.C4)

Com a proximidade do centenário do Instituto, grande parte das reivindicações de frequentadores e funcionários se concentrou na questão das condições do espaço físico, em especial à conservação de seu patrimônio arquitetônico, já tombado também pelo Conpresp.

Após o incêndio de 2010, a constatação de diversas deficiências na gestão do espaço edificado, e de problemas administrativos, levaram à mencionada unificação das direções do Instituto e da Fundação Butantan, procurando-se compatibilizar as decisões em uma visão de conjunto. Dentro dessa perspectiva, também se decidiu contratar através da Fundação Butantan uma equipe de arquitetos oriunda da FAU-USP, liderada por Alessandro Ventura, para elaborar um novo Plano Diretor para o campus, plano que se estendeu por alguns anos, sendo implantado em partes até o momento ${ }^{69}$.

Esta proposta inovadora prevê a construção de mais $30 \mathrm{mil} \mathrm{m}^{2}$ de novos edifícios para a pesquisa científica, um novo eixo cultural com $85 \mathrm{mil} \mathrm{m}^{2}$ para museus, bibliotecas, auditórios e outros serviços, além de $135 \mathrm{mil} \mathrm{m}^{2}$ destinados à área de produção e plantas-piloto. Fazem parte ainda do Plano Diretor a ocupação do prédio que fica ao lado do Paço das Artes para um moderno complexo de pesquisa e desenvolvimento, a recuperação dos prédios históricos e a destinação de $240 \mathrm{mil} \mathrm{m}^{2}$ de área de lazer para a população. (Informe do IBu, no $.185,2012$, pg. 2)

No relatório anual de 2011-2014, o diretor Kalil faz um resumo das intenções e de como foi a elaborado desse plano:

A elaboração de um novo Plano Diretor, em 2012, partiu da constatação de que o Instituto, para se consolidar como o principal produtor de vacinas da América Latina, deveria ser equipado com instalações adequadas, aprimorando o uso do espaço para a comunidade. Para alcançar este objetivo, era essencial organizar o espaço físico de toda a área ocupada, prevendo sua adequação e crescimento para os próximos vinte anos.

O novo Plano Diretor contempla a totalidade do terreno de $709.140 \mathrm{~m}^{2}$ do Butantan, incluindo seus edifícios históricos, museus, laboratórios, fábricas de vacinas, Paço das Artes e as extensas áreas de vegetação, compostas por plantas exóticas e nativas. Foram considerados os aspectos históricos do Instituto e suas atuais atividades de difusão, pesquisa e produção, que o caracterizam como o Centro de Pesquisas Biomédicas.

Inicialmente, foram estudados a localização, topografia, características naturais e vegetação do Butantan, além do perfil socioeconômico da região, que

\footnotetext{
${ }^{69}$ O Plano, já em implantação, tem sido revisado e ampliado continuamente. A versão aqui estudada é a de 2016, com a conceituação principal, doada por Alessandro Ventura para a Biblioteca da FAU-USP, e que em linhas gerais é o texto básico ainda válido em seus objetivos e diretrizes.
} 
revelaram aspectos interessantes, como por exemplo o fato de que as encostas são bastante íngremes, com altas colinas, equiparadas às da Avenida Paulista, e que a região carece de um equipamento de lazer com dimensões significativas, que o Instituto poderá oferecer por meio do manejo da extensa área, atualmente coberta por vegetação exótica e conservação das plantas nativas. Também foi avaliado o entorno do Instituto, o sistema viário estrutural, o sistema de transporte coletivo, o uso e a ocupação do solo à luz do Plano Diretor Estratégico do Município de São Paulo.

Em seguida, foram abordados os temas próprios à área do planejamento urbano, determinando-se as características físicas do Instituto por meio da tipologia do solo, dos padrões de vegetação, do potencial paisagístico, dos padrões de drenagem, da geomorfologia do terreno e de sua topografia. Buscou-se também a caracterização de outros aspectos do Instituto por meio do detalhamento do uso e da ocupação atual do solo, das áreas de circulação (públicas e institucionais), do sistema viário, dos espaços livres, dos museus, dos estacionamentos e do fluxo administrativo e de trabalho.

Os estudos iniciais da arquitetura trataram do estado atual de cada edifício por levantamentos fotográficos e de ocupação, da atualização dos programas necessários às várias unidades de pesquisa e de produção, da diferenciação entre o atendimento ao público e institucional, do levantamento dos edifícios a serem preservados e adequados, da setorização das funções, do funcionamento dos museus, e da consolidação do programa de necessidades para os edifícios existentes e futuros.

Somente então teve início a elaboração do Plano Diretor propriamente dito, com a definição de uma clara proposta de zoneamento composta por cinco grandes áreas: Laboratórios, Produção, Administração, Museus e Parque (destinada ao lazer do público visitante). Também foram definidos novos sistemas de circulação e drenagem, e analisados os terrenos do entorno, visando a possibilidade de desapropriação e criação de acessos alternativos para o público e para a área de Produção.

Foram feitos também estudos nas áreas de paisagismo, laboratórios e de restauro dos edifícios tombados e daqueles cuja manutenção foi considerada importante. (RA2011-2014, np)

Esses estudos originaram, em 2016, um trabalho de mais de mil páginas em oito volumes, abrangendo extenso levantamento da história do Instituto, de suas características físicas e institucionais, conforme descreve o resumo citado. A cada seção do plano foi designado um coordenador, sendo o responsável pela área de restauro o arquiteto Carlos Augusto Mattei Faggin $^{70}$, com participação de vários outros arquitetos.

Os levantamentos realizados são descritivos, apresentando detalhadamente as características do Instituto. Em seguida, são feitas propostas projetuais em nível de master plan, definindo zonas de ocupação, que são as seguintes:

\footnotetext{
${ }^{70}$ A equipe liderada por Alessandro Ventura e Carlos Faggin foi contratada pela Fundação Butantan para elaboração do Plano em 2012, até sua finalização em 2016. Após isso, a equipe fixa do Departamento de Engenharia e Arquitetura do Instituto assumiu a implantação do plano. Em 2018, Carlos Faggin foi contratado novamente para revisar todo o plano, sendo também, desde março 2017, presidente do Condephaat.
} 
- Pesquisa científica: $30.000 \mathrm{~m}^{2}$ junto à entrada da Av. Vital Brazil;

- Eixo cultural: $85.000 \mathrm{~m}^{2}$ no núcleo histórico;

- Administração: Edifício Principal e Cocheira-enfermaria;

- Produção: $135.000 \mathrm{~m}^{2}$ na porção nordeste;

- Área verde de lazer: $240.000 \mathrm{~m}^{2}$ na porção noroeste desocupada;

- Centro de pesquisa biotecnológica no antigo Paço das Artes da USP.

O conceito desse zoneamento é basicamente agrupar funções correlatas, evitando a pulverização ou redundância de usos, para otimizar a ocupação do campus. Assim, salas de laboratórios que exercem atividades parecidas podem ser unificadas e compartilhadas por setores diferentes. Do ponto de vista urbanístico, essa proposta adensa algumas áreas, liberando outras partes do terreno, o que leva a uma conformação paisagística que privilegia a fruição do Instituto como parque público, concepção fomentada também pela proposta de aumentar o uso das áreas livres do terreno na porção oeste. Essas ideias gerais do plano, em nível urbanístico, finalmente se desdobram em proposições de construção de novos elementos, demolição de alguns existentes, e reconfiguração de vias e da vegetação.

O primeiro mérito desse novo Plano Diretor foi finalmente unificar, sob um planejamento técnico, as ações sobre o espaço físico do campus, que haviam sido até então ditadas apenas pelas necessidades individuais de cada setor, sem uma visão de conjunto. Embora houvesse a atuação dos departamentos de engenharia e manutenção, antes os regimentos não eram claros quanto a diversos aspectos, e não havia um planejamento a longo prazo para essas transformações. Em segundo lugar, o Plano faz pela primeira vez um levantamento aprofundado das características geográficas do campus (hidrografia, topografia, solo, acessos, ocupação), seu histórico e sua inserção na malha urbana de São Paulo.

Do ponto de vista de preservação e restauro do patrimônio, foco da presente pesquisa, o Plano Diretor propõe inicialmente uma reconfiguração urbanística, alterando algumas vias e a implantação de quadras internas, como é o caso da principal via de acesso, que seria deslocada avançando sobre o Horto Oswaldo Cruz. Em seguida, pode-se notar uma maior apropriação da parte leste do Instituto, hoje ocupada por vegetação. O intuito é se apropriar do território e com 
áreas verdes à população. Ainda na questão do território, o Plano trata da recuperação da área do Paço da Artes, que havia sido cedida à USP em 1970, e onde havia sido construído edifício museológico com projeto de Jorge Wilheim, nunca concluído. Em 2010, sob solicitação do Instituto, essa parte do terreno foi oficialmente devolvida ao seu $\operatorname{campus}^{71}$.

Após essas definições gerais, o Plano chega ao nível de projeto de construção e reforma de edifícios. Os edifícios novos propostos têm linguagem contemporânea, procurando adensar os usos correlatos de laboratórios e administração. Dessa forma, os edifícios mais antigos, especialmente aqueles da primeira metade século XX e citados no processo de tombamento do Condephaat, devem ser convertidos a funções administrativas ou culturais, retirando-se os usos de pesquisa científica, que devem ser transferidos para novos edifícios. Além disso, o Plano adiciona outros elementos à listagem de edifícios históricos (Casa do Diretor, Recepção de cobras, Pavilhão Vital Brazil, entre outros), que devem ser objeto de restauro.

O resultado do plano consolidado muda substancialmente os aspectos urbanísticos, paisagísticos e arquitetônicos do campus, o que tem dividido as opiniões de sua comunidade. Como o foco do presente trabalho é a política de preservação e restauro efetivamente em execução, optou-se por não inserir exaustivamente os projetos do novo Plano, uma vez que em sua maioria ainda estão em desenvolvimento e podem, futuramente, sofrer revisões. Esses projetos são citados ao final das respectivas descrições dos elementos estudados nos itens 2.3 e 3.2, com foco nas atividades do Plano que já estão sendo implantadas.

\subsection{Análise dos processos de tombamento}

Conforme mencionado no item 2.1, em 1980 foi solicitado junto ao Condephaat o tombamento do Instituto Butantan. A iniciativa partiu do então Secretário de Saúde do Estado, Adib Jatene. Embora no ofício, de 3 de junho, Jatene citasse a necessidade de que "preservemos o seu patrimônio não só histórico mas também físico", bem como toda "área que o circunda”,

\footnotetext{
${ }^{71}$ Em 2018, o edifício passou a abrigar equipes de engenharia e arquitetura do Núcleo de Infraestrutura, após reforma em que os espaços foram convertidos em escritórios, procurando-se não alterar as fachadas e a visibilidade das estruturas de concreto armado.
} 
foi consenso entre diversos funcionários da época e na imprensa o fato de que o objetivo principal do pedido foi a defesa do uso do terreno pelo Instituto, até então frequentemente ocupado por outros órgãos públicos, como se pode ver na seguinte notícia:

O secretário da Saúde, Adib Jatene, acaba de pedir o tombamento do Instituto Butantã, segundo ele, para defendê-lo do apetite de vários organismos públicos que, ao longo dos anos, foram ocupando áreas da velha fazenda onde Vital Brasil trabalhou, reduzindo-os dos seus 100 alqueires originais, para apenas 27 . Embora, no ofício que encaminhou à Secretaria da Cultura pedindo o tombamento, Jatene fale na necessidade de tombar todos os imóveis e a área circunjacente para preservar a 'instituição internacionalmente conhecida pelo que representa no campo médico e científico', os funcionários do Instituto garantem que a preocupação principal é evitar que os incessantes pedidos de cessão de novas áreas tenham de ser atendidos. (Pedido tombamento do Instituto Butantã. O Estado de São Paulo. 12 jun. 1980)

Para instruir o processo de tombamento, foi anexado ao pedido citado a planta geral primitiva, fotos do primeiro laboratório (que seria reconstruído no ano seguinte como réplica) e planta de um trecho do Instituto. A autorização de abertura do processo pelo então Secretário da Cultura, Antônio Henrique Cunha Bueno, foi concedida no mesmo dia do pedido. No dia seguinte, 4 de junho de 1980, este enviou ofício a Jatene informando a autorização, e reforçando:

Cumpre-me ainda informar a Vossa Excelência, que na conformidade da legislação aplicável à espécie, especificamente as disposições contidas nos artigos 142 parágrafo único, e 146 do Decreto nº. 13.426, de 16 de março de 1979, a simples abertura do processo assegura a preservação do bem até decisão final da autoridade, sendo proibida, como consequência, qualquer intervenção em termos de destruição, demolição, mutilação ou alteração do bem em referência, devendo os eventuais projetos de restauração ser previamente submetidos à aprovação do Conselho de Defesa do Patrimônio Histórico, Arqueológico, Artístico e Turístico do Estado Condephaat, desta pasta. (Processo 21306-CONDEPHAAT, 1981, pg. 9)

No mesmo dia, o Diretor da Secretaria Executiva do Condephaat, Aldo Nilo Losso, enviou ofício com o mesmo teor ao diretor do Instituto Butantan, Bruno Soerensen Cardoso.

Em 10 de junho, foi publicada nota no Jornal da Tarde ${ }^{72}$ informando sobre o tombamento. Essa nota foi anexada ao processo a pedido de Aldo Losso.

No dia 11 de junho, o presidente do Condephaat, arquiteto Ruy Ohtake, solicitou o encaminhamento do processo ao Serviço Técnico de Conservação de Restauro (STCR) ${ }^{73}$ para

\footnotetext{
${ }^{72} \mathrm{O}$ Butantã, para as gerações futuras. Jornal da Tarde, 10 jun. 80, p.16.

${ }^{73}$ O Serviço Técnico de Conservação e Restauro foi o departamento de análises e suporte técnico do Condephaat até 2006, quando foi substituído pela Unidade de Preservação do Patrimônio Histórico (UPPH).
} 
levantamento dos edifícios, pedindo celeridade à responsável, a arquiteta Mariângela da Silva Castro, que foi ao Instituto e ao Fundusp, entrando em contato com o Diretor Soerensen e com o arquiteto Osmar Mammini, que desenvolvia então o primeiro Plano Diretor. Sobre a visita, a arquiteta citou em relatório a intenção de registrar fotograficamente os edifícios, a área envoltória (paisagismo) e objetos de mobiliário e de pesquisa científica de interesse histórico.

A arquiteta também citou a intenção do diretor em construir o Museu Histórico:

[...] um museu que este diretor gostaria de construir nas dependências do Instituto, precisamente uma réplica do antigo laboratório, onde Vital Brasil, fundador do Instituto Butantan, realizou as primeiras experiências. Há, além de fotos da fachada, fotos do seu interior, assim como grande parte do piso original em tijolo cozido em estado razoável de conservação, que tive oportunidade de ver. Mesmo que tal política de construção não seja adotada por este Condephaat, a solicitação deste diretor deverá ser estudada, pois a solução para tal problemática pode vir a ser facilmente encontrada, realizando-se desta forma nossa contribuição maior, isto é, aliar as reivindicações das comunidades às normas técnicas de restauração. (CONDEPHAAT, 1981, p. 17)

Em abril de 1981 foi concluída resenha histórica do Instituto pela historiógrafa Jandira Lopes de Oliveira, que traçou um resumo da trajetória do Instituto, com foco nas atividades de pesquisa, produção e educação em saúde, seguido de uma cronologia de fatos importantes. A menção ao espaço físico se limitou a informações sobre anos de fundação e usos do terreno.

Ao final, seguindo todos os trâmites do processo de tombamento na época, a documentação incluía: autorização do processo de tombamento; autorização de abertura do processo no Condephaat; autorização de encaminhamento do processo ao STCR; informação sobre o Instituto ao STCR; resenha histórica; resenha do valor turístico; planta geral do novo Instituto Butantan; planta geral dos terrenos; 32 fotos; esboço gráfico de 12 edifícios e cronologia do Instituto.

Nos dados básicos do estudo de tombamento, foi feita a seguinte observação:

Foram selecionadas, neste trabalho, doze edificações, dentre as outras, tendo como critério de escolha: $1^{\circ}$. Representatividade Histórica (da própria instituição); $2^{\circ}$. Representatividade arquitetônica. (CONDEPHAAT, 1981, p. 41)

Os elementos selecionados para tal estudo no processo (figura 26) foram:

1. Pavilhão Lemos Monteiro

2. Museu Histórico

3. Serpentário

4. Hospital Vital Brazil

5. Museu e Auditório 


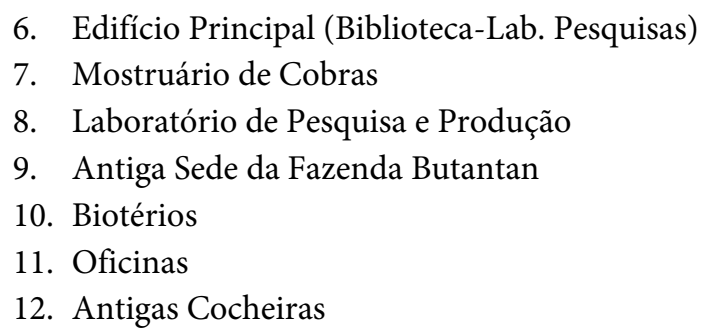

Essa seleção, também chamada no processo de "edifícios pesquisados" não deixou claro se apenas a fração selecionada nessa pesquisa era objeto de tombamento, ou se constituía uma espécie de amostragem do objeto, questão que traria dúvidas anos depois, durante a elaboração do Plano Diretor de 2016. Também não se percebe qual o critério para números e nomes.

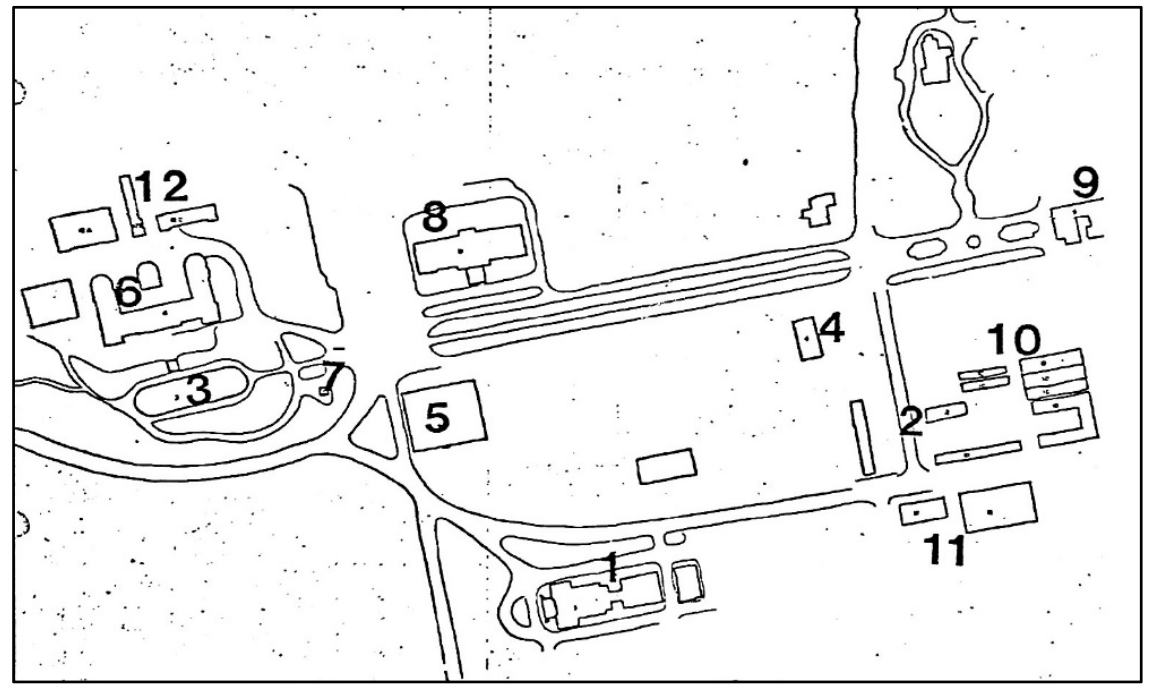

Fig. 26 - Mapa do processo mostrando os 12 elementos do campus pesquisados pela equipe de tombamento (Fonte: CONDEPHAAT, 1981, p.42)

Em seguida, foi feita uma análise de cada um desses 12 elementos, em forma de ficha, primeiramente com informações básicas sobre:

Grau de alteração
Dados históricos / arquitetônicos
Documentação existente
Observações
Planta de situação

As descrições eram resumidas e geralmente indicavam a linguagem estética de época à qual pertencia o edifício. Em seguida, foi feita uma verificação de uma lista de itens construtivos, para os quais foi dada uma pontuação avaliando características como estabilidade, dimensões, grau de alteração, localização no edifício etc. A figura 27 reproduz a ficha do Pavilhão Lemos Monteiro. 
Em 13 de agosto de 1981, o STCR emitiu seu parecer final sobre o tombamento, assinado pela diretora Giselda Visconti:

O STCR é de parecer que o tombamento formalize o reconhecimento do Condephaat à importância do Instituto Butantã, pelas seguintes razões:

a) O grande significado científico que essa Instituição representa, não só para o Estado, bem como a nível nacional e internacional.

b) Apesar de o conjunto das edificações não ser arquitetônicamente muito representativo, o STCR é de opinião que esse mesmo deva ser considerado num todo edifícios e áreas verdes. O conjunto assim formado, ganha, então um significado urbano dentro de nossa metrópole.

c) A área objeto do presente estudo, internamente cercada, [...] ocupando 27 alqueires, sendo integralmente propriedade da Fazenda do Estado de São Paulo, sob a direção da Secretaria da Saúde. (CONDEPHAAT,1981, pp.144-145)

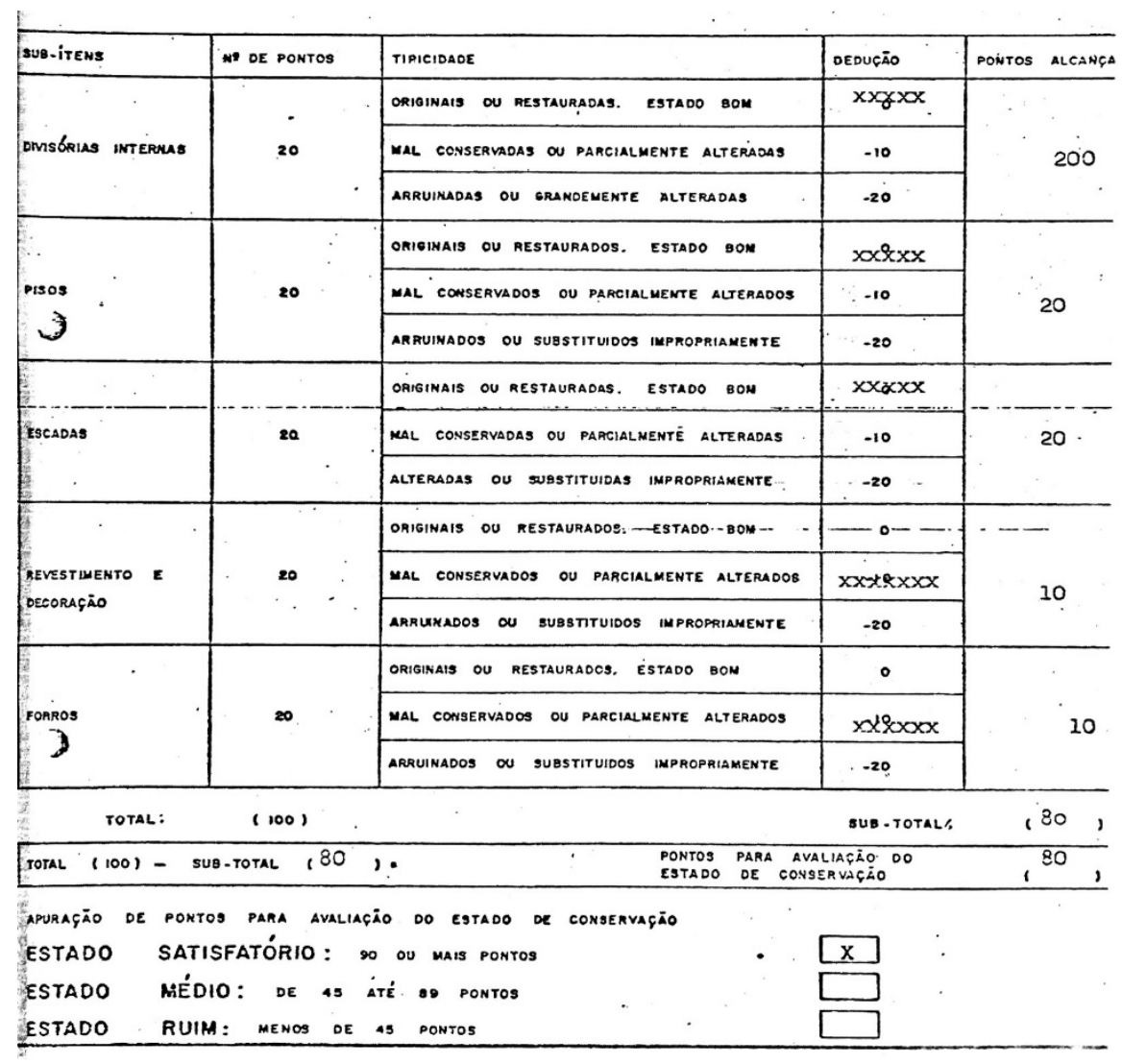

Fig. 27 - Exemplo de ficha do processo do tombamento (Fonte: CONDEPHAAT, 1981, p.47)

Em 27 de agosto, o presidente do Condephaat Ruy Ohtake autorizou a elaboração da Resolução de Tombamento. Antes de sua publicação, em 31 de agosto, o diretor do Instituto, Soerensen, recebeu ofício do diretor do Condephaat, Aldo Losso, informando sobre a decisão do Conselho, e em 3 de setembro o Secretário de Saúde, Adib Jatene, demandante do tombamento, recebeu a mesma informação em carta do Secretário da Cultura, Cunha Bueno. 
Em 14 de setembro de 1981, foi assinado o decreto de tombamento ${ }^{74}$, com cerimônia organizada no Instituto Butantan, da qual participaram Cunha Bueno, Jatene e Soerensen, protagonistas de todo processo. ${ }^{75} \mathrm{~A}$ imprensa foi convidada para o ato e foi distribuído folheto ilustrativo com informações sobre o Instituto. No dia seguinte, a notícia foi publicada em diversos órgãos de imprensa.

Em 24 de setembro, Losso, diretor do Condephaat, enviou novo ofício ao diretor do Instituto, Soerensen, ressaltando novamente que o monumento não poderia ser destruído, mutilado ou alterado sem prévia autorização do Condephaat. O processo se encerrou com o ofício do Secretário da Saúde, Adib Jatene, agradecendo ao Secretário da Cultura, Cunha Bueno:

Nesta oportunidade desejo manifestar a Vossa Excelência o mais vivo agradecimento pelo empenho e providências adotadas que culminaram com o reconhecimento daquele patrimônio estadual como de interesse histórico e paisagístico (CONDEPHAAT,1981, p. 158)

Analisando o processo de tombamento do Condephaat, o primeiro aspecto que se destaca é a sua dimensão política, que particulariza esse caso em relação a outros processos de tombamento de monumentos públicos na mesma época. $\mathrm{O}$ andamento célere do processo em seu início e no final, o contato quase instantâneo entre os agentes públicos, mostrado nas correspondências e nas declarações à imprensa, são pontos que sugerem o alinhamento desses vários agentes visando a um mesmo objetivo final. Esse objetivo, conforme relatado, não era exatamente a conservação dos monumentos históricos, mas, antes, a manutenção da integridade do terreno. As queixas quanto às cessões de partes do campus do Instituto para a USP e para outros órgãos públicos, como se viu no item 2.1, já ocorriam desde os anos de 1960. No próprio ano do tombamento, o diretor do Instituto declarou:

\footnotetext{
Com toda essa folha de serviços prestados ao País e a diversas outras nações, o Instituto Butantã não está livre de ser envolvido por ato de política rasteira, que de alguns anos a esta parte tem retalhado a área onde ele se situa, numa verdadeira ação de loteamento para atender a interesses políticos. (Os 80 anos do Butantã. O Estado de São Paulo, 25/02/1981, p.13)
}

\footnotetext{
${ }^{74}$ Resolução 35 de 14/09/1981, inscrição no. 98 no Livro do Tombo Histórico.

${ }^{75}$ A cerimônia ocorreu como abertura do $3^{\circ}$. Congresso Brasileiro de Bioteristas no auditório do Museu Biológico e foi organizada pelo Gabinete do Secretário da Cultura.
} 
A intenção de preservar o perímetro do terreno foi bem sucedida, uma vez que a área do campus deixou de ser ocupada posteriormente e, inclusive, conseguiu recuperar alguns trechos da Cidade Universitária. O fato de ter havido um objetivo político no tombamento, acima do objetivo da preservação em si, não necessariamente invalidou este último. Alguns corolários do tombamento na questão da preservação foram a maior conscientização da comunidade em relação ao seu núcleo histórico, o desenvolvimento de setores culturais do Instituto voltados ao levantamento e documentação de sua história, e o início de ações diretamente voltadas à preservação, restauro e fiscalização de alterações em seu espaço edificado.

Porém, há questões que podem ser levantadas quanto à influência negativa da questão política no tombamento. A primeira delas se refere à instrução do processo. Há uma resenha histórica e uma análise arquitetônica separadas, que não apresentam um diálogo claro entre si, sendo a primeira mais completa e aprofundada, dentro dos limites de tempo que teve. A resenha é focada em fatos do campo científico, social e administrativo do Instituto, contextualizandoos na história de São Paulo. O papel de diversas personalidades nessa trajetória também é apresentado. A citação dos edifícios, paisagismo e urbanismo do Instituto nessa resenha histórica é vinculada a avanços da ciência e a aspectos políticos da instituição.

Separadamente, a análise arquitetônica apresenta dados bastante resumidos dos edifícios, com uma abordagem quantitativa, ao atribuir notas a aspectos construtivos dos monumentos. Tais elementos construtivos colocam lado a lado aspectos estritamente técnicos (como posição dos sanitários) e aspectos de julgamento crítico (como o grau de autenticidade de ornamentos). Esse tipo de análise seguiu, segundo o processo, recomendações da UNESCO.

Quanto ao método de levantamento, chama atenção positivamente o papel da resenha histórica no processo, pois avaliou não apenas os aspectos estéticos excepcionais, mas também memoriais, biográficos e políticos como valores a serem considerados. Antes da década de 1960, a seleção de bens patrimoniais era baseada na excepcionalidade e na construção de narrativas históricas. Segundo NASCIMENTO:

Grosso modo, pode-se afirmar que, até a década de 1960, os bens culturais calcados na excepcionalidade e monumentalidade ditadas pelo Decreto-lei 25/37 foram, de certa forma, "suficientes" como fontes da história que se escrevia.

Do ponto de vista da preservação, o cenário começa a mudar a partir da década de 1960, quando novos parâmetros sobre o que valeria preservar às gerações futuras 
entram em cena. A escrita da história da arquitetura se verá numa encruzilhada da ampliação das fontes e mudanças no conceito de patrimônio. [...]

Os "historiadores do patrimônio" buscavam ultrapassar a noção de excepcionalidade para a valorização da história processual, numa perspectiva historiográfica bastante renovada para o campo da preservação no Brasil. A argumentação do documento histórico, em contrapartida à tradicional noção de monumento isolado (tal como tratado pelo Iphan desde sua fundação), foi cada vez mais utilizada para justificar a seleção de bens fora do escopo da ancianidade ou das belas-artes." (NASCIMENTO, 2016, p.124)

A autora descreve o tombamento do centro histórico de Laguna-SC pelo Iphan em 1984 como um exemplo de mudança nos conceitos aos quais se recorreu desde que foi publicado o Decreto 25/1937, baseados na excepcionalidade, monumentalidade, estética e antiguidade das obras, ao mesmo tempo em que se buscavam valores nacionais, construídos através de uma narrativa calcada nas produções coloniais e modernistas. A partir dos anos 1970, essa visão se alarga, sendo deslocada do âmbito apenas arquitetônico para incluir visões historiográficas mais amplas, considerando que valor patrimonial também pode prescindir daquelas características excepcionais, desde que possua aspectos documentais relevantes, o que torna passíveis de proteção diversos objetos antes considerados menores: traçados viários, elementos paisagísticos, mobiliário, entre outros que documentam processos históricos e não apenas expressões artísticas estanques. Nesse sentido, a noção de que era necessária a expressão de uma identidade nacional por uma obra para que fosse considerada bem cultural também se ampliou, permitindo a valorização de identidades regionais, daí a multiplicação de órgãos de proteção ao patrimônio estaduais e municipais a partir dos anos de 1970, ramificando a ação do Iphan.

Esses desdobramentos podem ser verificados no caso do tombamento do Instituto Butantan, por ter sido acionado junto a um órgão estadual, que em seu parecer destaca o papel do Instituto na história da ciência paulista. Além disso, o parecer do STCR deixa claro que o motivo primordial do tombamento é o valor documental histórico e não arquitetônico:

Apesar de o conjunto das edificações não ser arquitetônicamente muito representativo, o STCR é de opinião que esse mesmo deva ser considerado num todo, edifícios e áreas verdes. O conjunto assim formado, ganha, então, um significado urbano dentro de nossa Metrópole. (CONDEPHAAT,1981, p. 145)

É interessante notar a semelhança dessa justificativa à que foi dada pelo Iphan para o tombamento de Laguna, três anos depois: 
Em sua dimensão estritamente arquitetônica, o patrimônio construído do centro histórico de Laguna não apresenta as características de excepcionalidade normalmente adotadas como critério para decidir sobre a oportunidade do tombamento. [...] Cremos, não obstante, tratar-se de documento precioso da história urbana do país [...]. (NASCIMENTO, 2016, pp.135-136)

Embora fique clara a mudança de paradigma, saindo da valorização estrita do chamado "belo e antigo" para incluir também o valor de documento histórico, essa questão ganha complexidade ao se perceber que a própria noção de "belo" e de "antigo" foi se modificando na área da preservação, e o caso da reconsideração das obras do Ecletismo do século XIX e de outras expressões arquitetônicas do início do século XX, presentes nesse Instituto, atestam que não se trata apenas de alargar a visão do que é bem cultural para além dos elementos arquitetônicos, mas também de mudanças do que é relevante dentro da própria historiografia da arquitetura, assunto que será tratado no capítulo 3. Por ora, percebe-se que influência da dimensão política na iniciativa do tombamento (para manutenção do perímetro do terreno), o alargamento nos critérios de valoração do patrimônio para além dos aspectos meramente arquitetônicos, e o curto espaço de tempo disponível (devido a pressões externas), foram condicionantes que levaram a uma relativa insuficiência de instrução desse processo. Pela magnitude da área física, pela quantidade de edificações, e pela relativa longevidade do Instituto, percebe-se que as informações foram superficiais, principalmente na análise da arquitetura, limitando-se a valorações quantitativas, sem descrições mais pormenorizadas dos sistemas construtivos e linguagens utilizadas, e sem menção sequer aos autores dos projetos ${ }^{76}$.

Além dessa primeira questão problemática, que é a relativa superficialidade na instrução do processo, influenciada pela "pressa" política, houve um problema decorrente no campo técnico: não fica claro quais elementos efetivamente são protegidos e qual o nível de tal proteção. O que em um primeiro momento poderia parecer óbvio (todo o conjunto arquitetônico estaria tombado), gerou dúvidas ao longo dos anos. O processo de tombamento (21306/80) utilizou termos ambíguos em diversas passagens, ao procurar definir a área de tombamento como sendo:

[...] dos prédios pertencentes àquela instituição, bem como de toda área que a envolve.

[...] dos prédios e áreas circunvizinhas ao Instituto Butantan.

\footnotetext{
${ }^{76} \mathrm{Na}$ análise arquitetônica do processo de tombamento, não é mencionada nem mesmo a autoria de Mauro Álvaro.
} 
[...] dos prédios e áreas que circundam o Instituto Butantan.

[...] dos edifícios e da vegetação.

[...] do conjunto de edificações e de áreas verdes que compõem o Instituto Butantan.

[...] do conjunto de edifícios que compõem o Instituto Butantan, bem como o entorno no qual estão inseridos os diversos setores que compõem essa instituição.

(CONDEPHAAT-1981, passim)

Soma-se a essa multiplicidade de definições a seleção de apenas 12 edifícios para o levantamento e resenha arquitetônica no processo. Isso poderia ser justificado pela insuficiência de fontes disponíveis e de tempo para um levantamento mais aprofundado, o que levou à exclusão do estudo de exemplares relevantes e/ou contemporâneos aos outros, como a antiga Casa do Diretor e a Recepção de Cobras, por exemplo. Além disso, não ficou claro qual o nível de proteção dos edifícios, se externo, volumétrico ou total.

A consequência prática foi a constante alteração de elementos construídos, havendo acréscimos, demolições e substituições de partes dos edifícios, chegando-se ao caso da réplica autorizada e recomendada pelo Condephaat.

Passando ao caso do Conpresp, este incluiu o Instituto Butantan na lista de tombamento ex-officio decretada em 1991, com 89 monumentos. Não foi identificado processo específico para cada monumento da lista, sendo citado o processo do Condephaat como base. Porém, em outubro de 2017, por meio da Resolução 32, o órgão municipal reduziu a área envoltória de $300 \mathrm{~m}$ em torno de todo o Instituto para apenas uma quadra (Setor 082, 401), flexibilizando a ocupação desse entorno e dispensando qualquer empreendimento de análise prévia pelo Departamento do Patrimônio Histórico, conforme reproduzido a seguir:

“Artigo $3^{\circ}$ - Nas intervenções nos lotes enquadrados como Área Envoltória dos bens tombados [...] devem ser seguidas as seguintes diretrizes:

1. Mínimo de $30 \%$ da área do lote deverá ser permeável, para efeito do computo da permeabilidade, não serão admitidos jardins sobre lajes;

2. Apresentar Laudo Técnico, elaborado por profissional habilitado, atestando que a obra não atingirá o nível dos lençóis freáticos ou nascentes;

3. A altura máxima da edificação, contando todos os elementos construídos, deverá observar o limite máximo de $25,00 \mathrm{~m}$, a partir do ponto médio do perfil natural do terreno na testada do lote.

Artigo $4^{\circ}$ - Em razão dos parâmetros fixados no artigo anterior a serem observados pelos órgãos de licenciamento edilício (Prefeitura Regional do Butantã ou Secretaria Municipal de Urbanismo e Licenciamento - SMUL), ficam dispensados da prévia análise do DPH e da prévia aprovação do CONPRESP as intervenções realizadas nos imóveis definidos como área envoltória pelo quadro do artigo $2^{\circ}$ desta resolução. 
Artigo 5 - O CONPRESP e/ou o Departamento do Patrimônio Histórico $\mathrm{DPH}$ poderão, a qualquer tempo e desde que julgado necessário, requerer os processos referentes aos imóveis inseridos no perímetro descrito no Artigo $2^{\circ}$ para fins de análise técnica e eventual despacho decisório, visando à verificação do correto atendimento das disposições da presente Resolução.

Artigo $6^{\circ}$ - Ficam expressamente excluídos da área envoltória municipal os demais imóveis não listados no quadro do artigo $2^{\circ}$ desta resolução e que estavam inseridos na anterior área envoltória compreendida num raio de 300 (trezentos), em torno do Instituto Butantã.

$\S$ Único - Os imóveis excluídos da área envoltória na forma do caput também estão dispensados da anuência prévia e decisão do DPH/CONPRESP.” (Resolução No. 32 / CONPRESP / 2017, grifo do próprio decreto)

Nesse caso do Conpresp, são os desdobramentos de 2017 que trazem maior impacto à proteção do conjunto, uma vez que a resolução mencionada se concentra em flexibilizar a ocupação do entorno, liberando os empreendimentos da necessidade de análise dessas ocupações pelo DPH, o que pode levar a interferências visuais, de insolação e ventilação, com efeitos principalmente para a vegetação do campus. Essa alteração deverá trazer maiores consequências na divisa da porção sudoeste, uma vez que as divisas com a Cidade Universitária e córrego Pirajuçara Mirim não devem, em princípio, sofrer novas ocupações significativas.

Mesmo com as contradições apresentadas, os tombamentos foram importantes: para garantir a preservação da maioria dos edifícios com suas conformações gerais (mesmo com diversas alterações); para conscientizar a comunidade de funcionários e frequentadores do Instituto sobre sua importância histórica, estimulando pesquisas e atividades correlatas; e, finalmente, como se intencionava a princípio, para resguardar o perímetro do terreno do Instituto contra novas ocupações.

\subsection{Descrição dos elementos de interesse}

Com base no histórico do Instituto e nos processos de tombamento, e tendo em vista que a área do campus possui $709.140 \mathrm{~m}^{2}$ e mais de 400 elementos construídos com várias idades e funções, torna-se necessária uma seleção de elementos principais como patrimônio cultural edificado, com objetivo de estudar a importância histórica desses elementos e analisar as intervenções que receberam do ponto de vista da conservação e restauro. 
Viu-se no item 2.2 que a listagem do Condephaat no processo de tombamento de 1981 não aborda todos os monumentos relevantes, sendo considerada um conjunto de exemplos. $\mathrm{O}$ próprio Instituto possui suas seleções de elementos relevantes ${ }^{77}$, nas quais se baseia este trabalho, procurando analisar criticamente essas seleções e tecer considerações sobre os critérios utilizados. Tais critérios se baseiam nas características dos próprios edifícios, grupos paisagísticos e urbanísticos, que podem ter valores históricos, arquitetônicos e de memória da comunidade. Nesse ponto, é importante a base teórica desenvolvida por autores como RIEGL(2014) e BRANDI(2004), que discutem as diferentes camadas de valores adquiridas pelos monumentos ao longo do tempo, e como essas diferentes camadas se sobrepõem de forma não óbvia, exigindo uma análise apurada e multidisciplinar a orientar eventuais intervenções de restauro. WAISMAN(2013) também defende essa multiplicidade de valores interagindo nos monumentos, acrescentando a necessidade de pensar sobre a condição latino-americana de tais produções, e o que essa condição suscita como valores específicos.

Com base nesses critérios, o presente trabalho propõe 20 elementos para análise. $\mathrm{O}$ quadro 1, a seguir, mostra essa lista em ordem cronológica, bem como a presença de tais elementos (em verde) nas seleções anteriores do Condephaat e do Instituto Butantan, já mencionadas. Os elementos marcados com asterisco (remanescentes da fazenda, núcleo residencial, implantação urbanística e paisagística) não constam explicitamente nas listas de patrimônio arquitetônico do Condephaat e do Instituto Butantan consultadas, mas considerase, nesse trabalho, que também são elementos importantes a serem estudados e preservados.

Como toda lista patrimonial, essa é uma proposta que pode ser acrescida e subtraída conforme outros critérios de seleção. Ratifica-se que os critérios aqui adotados são baseados nas listagens já elaboradas por órgãos de preservação e pelo próprio Instituto, pelos elementos já valorizados em bibliografia pertinente, pelos conceitos presentes em bibliografia de história da arquitetura e também de patrimônio cultural. Em relação às fontes primárias, a listagem se valeu

\footnotetext{
${ }^{77}$ Não existe uma seleção oficial de edifícios históricos do próprio Instituto, mas percebe-se em suas publicações, atividades e no recente Plano Diretor quais são os elementos mais frequentemente valorizados pela instituição como patrimônio arquitetônico, e que variam em cada apresentação.
} 
dos levantamentos de iconografia, documentação, entrevistas e visitas que revelaram a importância de alguns espaços ausentes das listagens citadas.

Quadro 1: Lista de patrimônio arquitetônico para análise $\mathrm{e}^{78}$

\begin{tabular}{|l|l|l|}
\hline \multicolumn{1}{|c|}{ Elementos propostos } & Condephaat & IBu \\
\hline Remanescentes da Fazenda [Ruínas] & & \\
\hline Casa Sede da Fazenda [Casa Vital Brazil] & & \\
\hline Cocheira-enfermaria [Laboratórios] & & \\
\hline Edifício Principal [Edifício Vital Brazil] & & \\
\hline Serpentários & & \\
\hline Biotério Central & & \\
\hline Cocheira Central [Museu Biológico] & & \\
\hline Escola de Veterinária [Pavilhão Lemos Monteiro] & & \\
\hline Cocheira-biotério [“Cara de Cavalo”] & & \\
\hline Paiol e Oficinas [Centro de Difusão] & & \\
\hline Mostruário de Cobras [Bilheteria] & & \\
\hline Casa do Administrador [Creche] & & \\
\hline Casa do Diretor [Diretoria] & & \\
\hline “Prédio Novo” & & \\
\hline Pavilhão Vital Brazil & & \\
\hline Recepção de Cobras [Lanchonete] & & \\
\hline Hospital Vital Brazil & & \\
\hline Núcleo Residencial & & \\
\hline Museu Histórico & & \\
\hline Implantação urbanística e paisagística* & & \\
\hline
\end{tabular}

Sistematizando esses critérios, essa seleção optou por considerar:

a) apenas os elementos existentes (descartando os já demolidos ou não executados) ${ }^{79}$;

b) a importância de seu papel na história do Instituto e da Ciência ${ }^{80}$;

\footnotetext{
78 Optou-se por adotar a denominação mais usada dos elementos quando foram construídos, seguida da denominação mais usada atualmente (quando houver mudado) entre colchetes.

${ }^{79}$ Em relação aos remanescentes da fazenda, não se teve acesso por estarem em área de segurança restrita ou mata fechada, muitos deles podendo já estar demolidos ou totalmente alterados.

${ }^{80} \mathrm{~A}$ importância na história do Instituto e da ciência se refere ao valor do elemento como documento de técnicas ou acontecimentos que não estariam registrados da mesma forma em outros exemplares. Como exemplo, podemse citar a Cocheira e o Paiol, que registram determinadas funções necessárias nos trabalhos científicos, não verificadas em outras tipologias, ou mesmo a Recepção de cobras, que registra, isoladamente, a prática de coleta de cobras e a passagem de determinada linguagem arquitetônica pelo Instituto.
} 
c) a disponibilidade de informações escritas e de iconografia obtida por fontes primárias;

d) as características verificadas nos levantamento realizados in loco;

e) a relevância desses elementos na memória da comunidade frequentadora do local, observada nos depoimentos de usuários entrevistados.

Para cada um desses elementos da lista, são apresentados um histórico e um resumo com informações sobre sua autoria, idade, técnicas construtivas, uso original, uso atual, mudanças significativas ao longo do tempo e estado de conservação atual. O objetivo dessas descrições não é uma apresentação exaustiva dos elementos relevantes, mas principalmente dar uma visão de conjunto da importância patrimonial do campus através de suas partes constitutivas, fornecendo subsídios para a análise da política de preservação da instituição.

Para manter uma visão da linha do tempo do conjunto, optou-se pela apresentação cronológica dos elementos (iniciando-se com os remanescentes da Fazenda Butantan). Além do histórico sucinto de cada um, soma-se uma descrição das principais intervenções por que passou e de suas características construtivas. Ao final, incluem-se os aspectos urbanísticos e paisagísticos, fundamentais na leitura do campus como elemento relevante em si.

\subsubsection{Remanescentes da Fazenda [Ruínas]}

Quando foi adquirida pelo governo paulista para início dos trabalhos em soroterapia, a Fazenda Butantan já possuía diversas construções, como os citados telheiros, casas e uma olaria, conforme listagens em documentos de venda da época:

Ainda em 1899, Arnaldo de Oliveira Barreto vendeu sua propriedade à Fazenda do Estado de São Paulo através do seu $1^{\circ}$. Procurador Fiscal Dr. Luis Arthur Varella. O objeto de venda se constitui por casas de moradia, olaria, estábulos, cocheiras, plantações, caixa d'água, pastos, cercados e outras benfeitorias pela quantia de cem contos de reis. (PACCE, 1980, p.13)

Na correspondência de Vital Brazil com o Serviço Sanitário em 1905, o diretor cita a presença da olaria, queixando-se de transtornos e solicitando o fim da atividade no Instituto e a saída de seu operador, Paschoal Gravini: 


\begin{abstract}
"Remeto-vos o incluso documento pelo qual se vê que Paschoal Gravini requereu e obteve manutenção de posse da olaria que tem exemplar em virtude de um contrato de mão com a ex-proprietária D. Gertrudes Jordão Avelina de Camargo da Chácara do Butantan cumpre-me informar-vos do seguinte: Em dezembro de 1899 quando o Governo adquiriu a chácara do Butantan para nela instalar o Instituto Serumtherapico encontramos estabelecida na entrada da propriedade uma pequena olaria explorada por Paschoal Gravini que nos mostrou um contrato de mão feito com D. Gertrudes Jordão Avelino de Camargo antiga proprietária da Chácara, pelo qual Gravini ficava autorizado a instalar-se por olaria por um certo numero de anos obrigando-se a pagar cem mil réis mensais de aluguel até terminação do prazo do referido contrato. Em virtude desse documento e de acordo com essa Diretoria toleramos Gravini embora este tivesse perdido os direitos que lhe davam o dito contrato pelo fato de não haver pago o arrendamento estipulado. Não sendo possível cobrar a Gravini os aluguéis em dinheiro fomos recebendo materiais fabricados na olaria, na intenção de respeitar a moralidade do contrato, embora a permanência em terras do Butantan de Gravini fosse incômoda e até prejudicial por mais de uma razão. Gravini que sempre mostrava respeitoso e submisso fornecendo o material que se lhe pedia até fins do ano passado recusou-se d'ora em diante fornecer material. Tendo nós exigido a exibição do contrato a fim de verificar como supúnhamos estar terminado o prazo estipulado para a exploração da olaria, Gravini a isso se recusou sobre pretexto de achar-se ele em poder do seu advogado. É o que me cumpre informar-vos pedindo-vos emergência providenciais no sentido de ser expulso desta propriedade semelhante intruso." (Transcrição do Ofício n ${ }^{\circ} 714$ de 06/07/1905 para o Diretor Geral do Serviço Sanitário em ALMEIDA et al., 2014, p.99).
\end{abstract}

A carta confirma, em primeiro lugar, a permanência de estruturas da fazenda e de seus usuários durante os primeiros anos (senão décadas) do Instituto. Em segundo lugar, sugere a utilização de materiais produzidos na olaria para as novas construções, o que pode explicar a alvenaria em tijolo cozido presente em todos os primeiros edifícios dessa fase, técnica que era considerada avançada para a época, quando se passava da taipa de pilão para a alvenaria (LEMOS, 1985). Apesar das atividades científicas, a olaria continuaria funcionando durante pelo menos três décadas, já que notícia de 1938 relata acidente com oleiro morador do Instituto Butantan (Accidente no trabalho. O Estado de São Paulo, 16/12/1938, p.8) e fotos do acervo mostram-na em funcionamento no mesmo ano.

Pelas fotos da década de 1930, pode-se ver que a olaria, devido à sua própria atividade, tinha um aspecto rural e utilitário, assim como outras estruturas funcionais da fazenda (figura 28). As imagens da década de 1980 mostram a construção já em estado de ruína, mas com possibilidade de identificação de alguns elementos, como aberturas, fornos e a técnica construtiva (figura 29). 


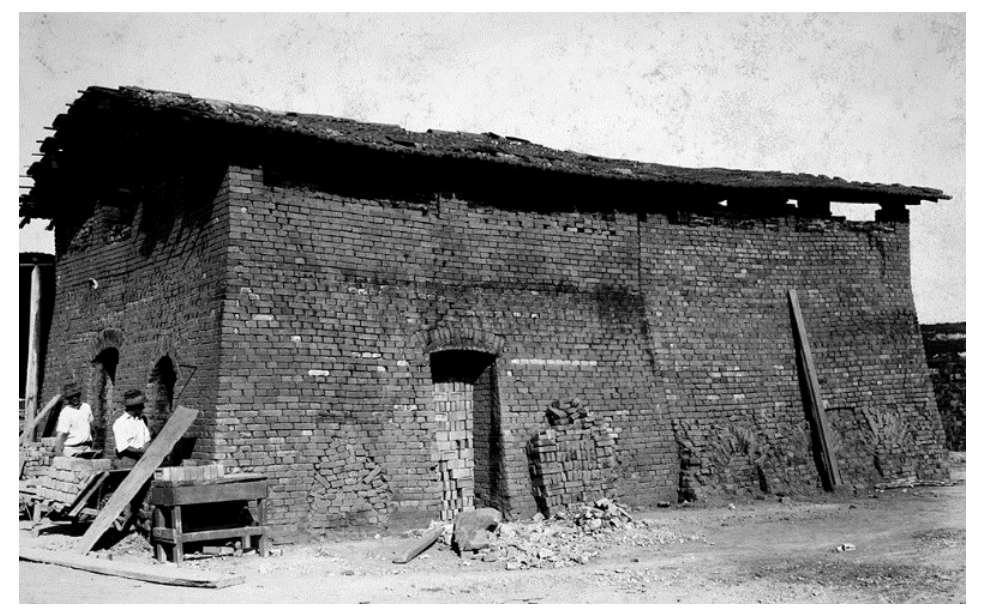

Fig. 28 - Olaria em 1938: parte do material nela produzido foi utilizado nos edifícios do Instituto, reforçando seu valor simbólico. (Fonte: IB_ICO_008897)

Fig. 29 - Olaria em 1981: a ruína mantém algumas características reconhecíveis da edificação original (Fonte: IB_ICO_003348)

As casas foram mencionadas nos relatórios durante as primeiras quatro décadas do Instituto, atestando que em algumas continuaram morando antigos funcionários da fazenda (alguns readmitidos) e outras foram adaptadas para a residência de novos ocupantes. A maior descrição dessas estruturas se dá no relatório de Afrânio do Amaral em 1928:

Por não oferecerem segurança nem condições hygienicas, foram derrubados: o grupo de casas de empregados conhecido pelo significativo nome de "cortiço" e a "cocheira velha", em cujo fundo, por um desses caphichos do destino, funcionava a antiga escola, tendo-se iniciado a reforma de algumas das casas de que apresentei fotografia em meu referido memorial. Quanto ás choupanas existentes, é pensamento desta directoria substitui-las por casas hygienicas, mas com certo vagar, para evitar que se agrave o problema da retenção dos empregados subalternos. (RA 1928, pp 7-8)

Como se vê, havia ocupações em estado precário, principalmente casas, tanto isoladas (figura 30), como em conjunto. Um exemplo de conjunto de casas era o chamado "cortiço" (figura 31). Muitas dessas construções rurais se tornaram simplesmente subutilizadas, várias delas tendo sido demolidas e algumas mantidas com outros usos. 

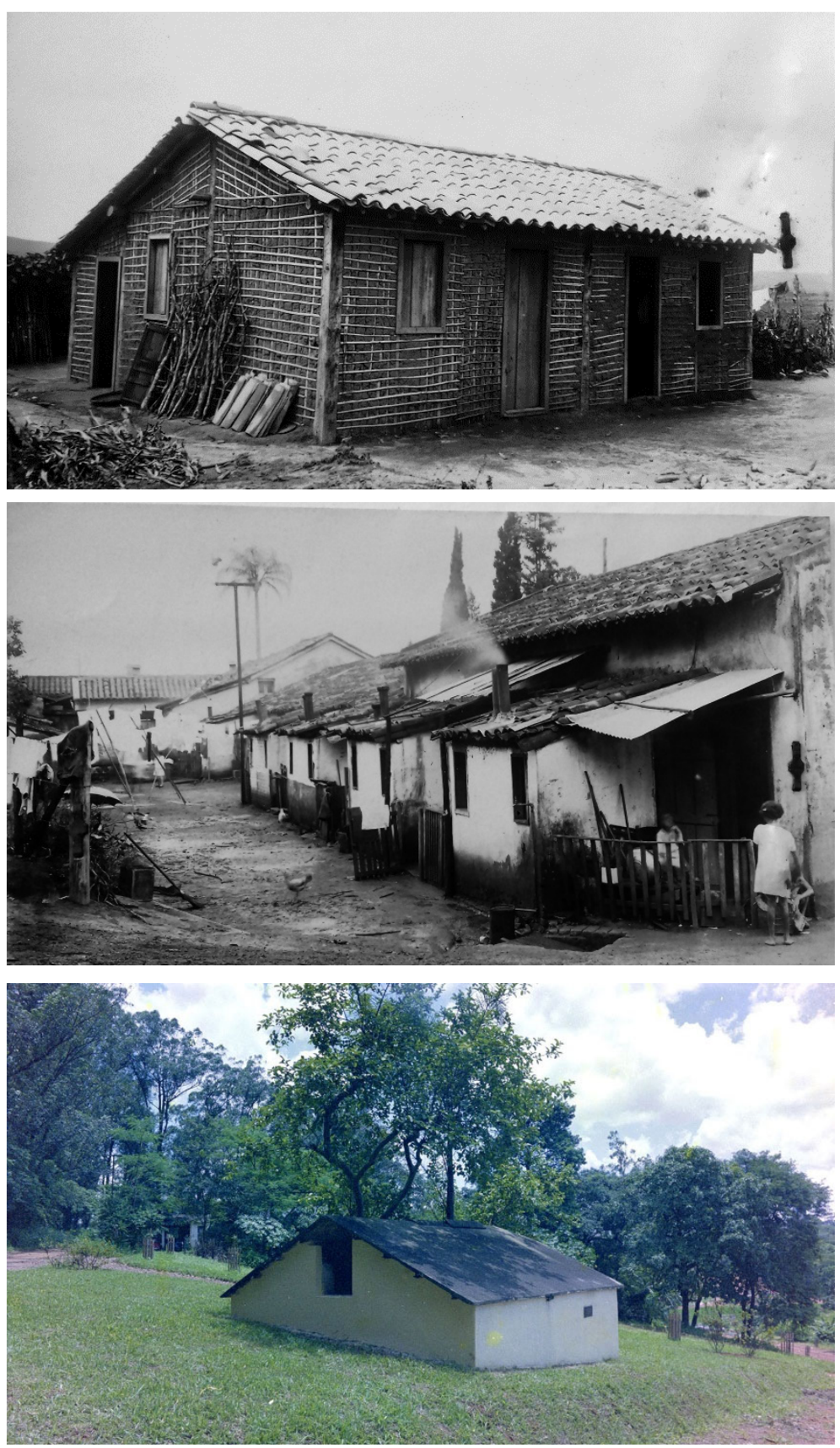

Fig. 30 - Casa de pau-a-pique da fazenda em 1928 (Fonte: RA 1928, p.77)

Fig. 31 - O chamado "cortiço", demolido em 1928: não há notícias de que os moradores tenham permanecido no terreno após a demolição (Fonte: RA 1928, p.78)

Fig. 32: Casa remanescente da fazenda utilizada como depósito em 1980 (Fonte: IB_ICO_003305)

Partes de estruturas demolidas permaneceriam visíveis posteriormente. A alvenaria dessas demolições foi aproveitada na construção de novas edificações. Ainda assim, fotos da década de 1980 mostravam ruínas de casas antigas (figura 32). Segundo depoimentos de funcionários, algumas se encontram hoje abandonadas no meio da mata na porção oeste do campus, enquanto outras foram completamente alteradas para serem adaptadas como depósitos. No levantamento in loco identificaram-se algumas dessas estruturas remanescentes, mas não foi possível ter acesso a todas, por se encontrarem em área restrita do Instituto. 
Não foram encontradas propostas no Plano Diretor de 2016 sobre conservação e estabilização de ruínas. Mesmo pela simplicidade das características construtivas, meramente utilitárias, diversas estruturas remanescentes, além de abrigar os primeiros ocupantes do terreno, forneceram o material para construção da maioria dos elementos utilizados pelas primeiras equipes do Instituto, o que dá a elas uma significância histórica, mais do que o interesse arquitetônico.

\section{RESUMO:}

Categoria: conjunto de edificações

Denominação original: Casas/telheiros/olaria

Denominação atual: Ruínas

Autoria: desconhecida

Área original: c. $900 \mathrm{~m}^{2}$

Área atual: desconhecida

Número de pavimentos original: 1 a 2

Número de pavimentos atual: desconhecido

Início-término da construção: séc. XIX

\section{Itens arquitetônicos originais:}

Estrutura: alvenaria portante, pau-a-pique ou taipa de mão

Vedação: alvenaria (tijolo de barro cozido), pau-a-pique ou taipa de mão

Revestimentos paredes externas: não revestido ou argamassa de areia e cal

Revestimentos paredes internas: não revestido ou argamassa de areia e cal

Revestimentos pisos internos: alvenaria (tijolo de barro cozido) ou terra batida

Revestimentos pisos externos: não revestido

Caixilharia: sem caixilho ou madeira

Uso original: casas/telheiros/olaria

Itens arquitetônicos atuais:

Originais em ruínas

\subsubsection{Casa Sede da Fazenda [Casa Vital Brazil]}

Remanescente da Fazenda Butantan, essa casa da antiga fazenda serviu de diretoria, residência do diretor (até 1932) e grupo escolar (até 1952). Após isso, passou a abrigar trabalhos laboratoriais e hoje abriga a administração do Museu Histórico, Núcleo de Documentação e laboratórios de herpetologia. 
Trata-se de uma construção para residência térrea do final do século XIX, que foi implantada em um promontório do terreno da fazenda (hoje junto à divisa com a CUASO). Sua implantação veio a demarcar um ponto focal da principal via interna no núcleo histórico do Instituto, situação que permanece, mantendo certa monumentalidade do pequeno edifício.

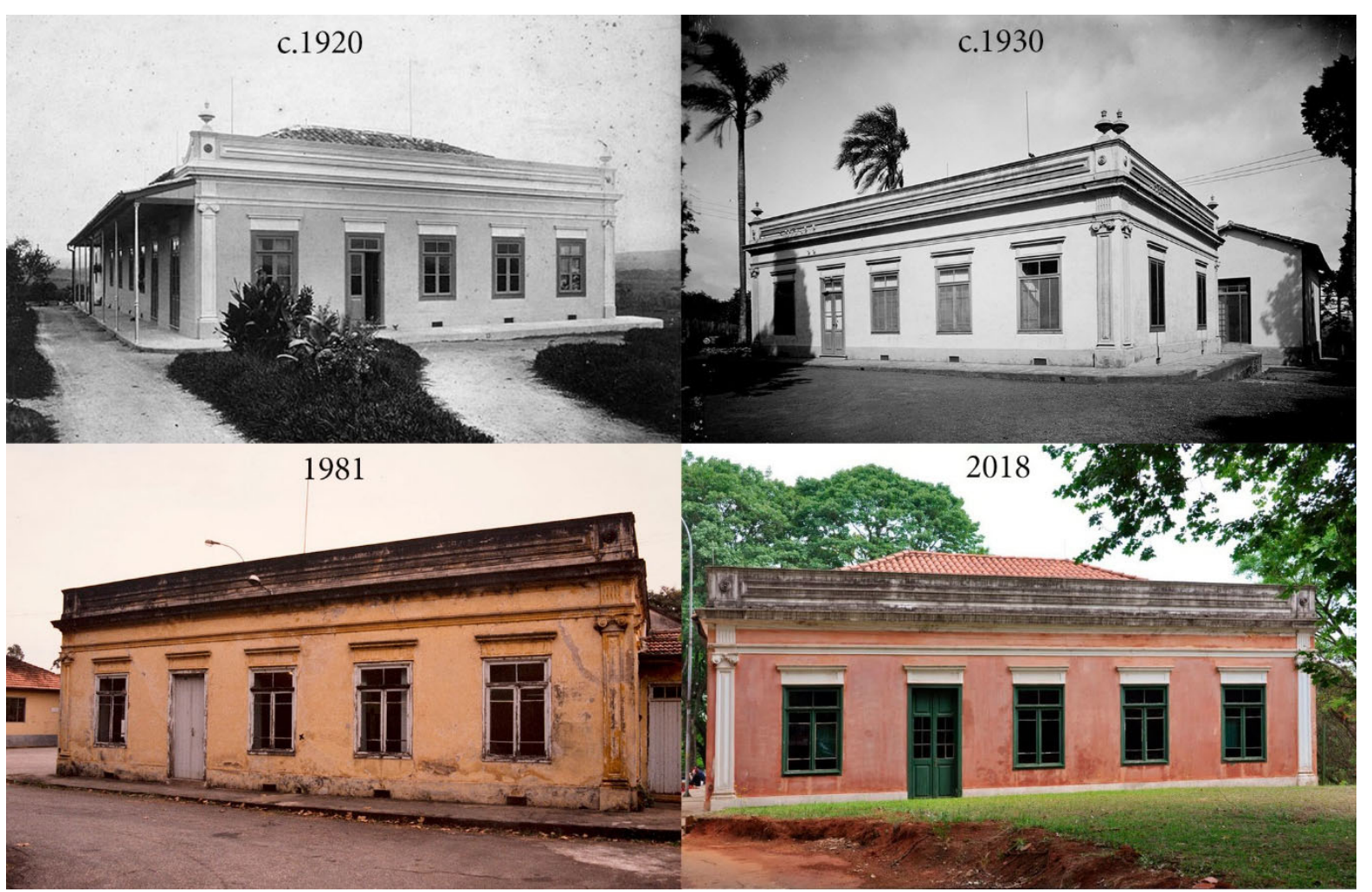

Fig. 33 - Diferentes fases da Casa sede da fazenda: ocorreram diversas alterações, supressões e acréscimos em acabamentos, coberturas e caixilhos. Na primeira foto vê-se o alpendre lateral. Já em 1930 é possível identificar um anexo no fundo da casa. $\mathrm{Na}$ década de 1980 não são mais vistas as compoteiras na platibanda, e o revestimento apresenta patologias e pátina. Na imagem mais atual a casa se encontra em melhor estado, mas vê-se que as telhas não são mais as originais (Fonte: Acervo IBu).

Apesar de diversas transformações por que passou, alguns elementos mais marcantes de sua arquitetura ainda permanecem, e em sua composição chama atenção a convivência de elementos ornamentais classicizantes, comuns em casas urbanas da mesma época em São Paulo. O assunto foi meticulosamente tratado por LEMOS (1985), ao analisar a substituição da arquitetura residencial colonial, em taipa, pela de tijolos com influências europeias do Ecletismo, durante o rápido crescimento da cidade na era do café. Segundo o autor, no final do século XIX aumentava a frequência de:

[...] edifícios soltos, isolados em suas quatro faces, onde o arquiteto esmerou-se em demonstrar toda a potencialidade da alvenaria, abrindo grandes vãos, aproximando janelas, fazendo coisas que a taipa tradicional não poderia permitir. (LEMOS, 1985, p.94). 
O arquiteto a que se refere Lemos nesse caso era Ramos de Azevedo, responsável pelos grandes edifícios públicos e palácios das abastadas famílias cafeeiras. Mas essas soluções eram reproduzidas nas classes média e baixa de forma diluída e simplificada, e esse parece ser o caso dessa casa que, embora pudesse ser de família abastada (proprietária da fazenda), tinha dimensões modestas, talvez utilizada como casa do administrador. Mas elementos como o tijolo, as grandes aberturas iluminando todos os ambientes, o telhado e a ornamentação neoclássica estão presentes como sinal de modernidade.

Os caixilhos em madeira subdivididos em módulos com vidro também são características do período. O século XIX marca a substituição das treliças nas janela pelo vidro. Especialmente os ornamentos, simplificados e em proporções pouco acadêmicas, denotavam esse desejo de aderir às linguagens europeias: pilastras com capitéis jônicos que simulam entablamentos, cimalhas sobre os caixilhos, platibanda com frisos e rosáceas, e compoteiras sobre a platibanda. Muitos desses elementos eram comprados pré-moldados em argamassa e montados na obra, e essa tendência às linguagens classicizantes e pouco rigorosas nas casas menos sofisticadas demorou a ser valorizada pela historiografia da arquitetura no século XX. Sobre isso, FABRIS(1993) cita opinião de Francisco Acquarone,

\begin{abstract}
Que percebe a arquitetura do século XIX alicerçada no abandono do "colonial verdadeiro" em prol de "uma infinidade de casas horríveis", caracterizadas por platibandas ornadas com compoteiras e bolas. Ao lado delas, destacavam-se 'fortalezas medievais', cheias de pedras e outros atentados, exibindo fachadas de ladrilhos ou pintadas de "mármore fingindo". Sobre os telhados começaram a aparecer em certa época, cúpulas arredondadas, casas que lembravam caricaturas da igreja de São Pedro em Roma...". Nem mesmo a oportunidade representada pela abertura da Avenida Central conseguiu melhorar a situação: o mestre-de-obras continuava a ser o "senhor absoluto" da arte de edificar, repelindo os arquitetos do campo de ação e impondo seus critérios de gosto (ACQUARONE, Francisco. História das artes plásticas no Brasil. Rio de Janeiro: Ed. Americana, 1980 apud FABRIS, 1993)
\end{abstract}

Esse trecho é emblemático do preconceito da historiografia e dos órgãos de proteção do patrimônio em meados do século $\mathrm{XX}$, (que valorizavam quase exclusivamente $\mathrm{o}$ colonial/barroco) e se aplica a essa casa e ao próprio Instituto, representante da arquitetura da virada do século XIX para o XX, que vem sendo reabilitada nas últimas décadas.

A citação acima se refere à situação no Rio, mas se aplica também a outras cidades. Essa tendência classicizante chegaria mais tarde a São Paulo, segundo Carlos Lemos, que também 
menciona uma casa, fotografada em 1860 por Militão de Azevedo, como a mais antiga localizada nessa linguagem:

Desde os anos finais do século XVIII até 1850, São Paulo praticamente não conheceu nenhuma novidade arquitetônica. Tão perto do Rio de Janeiro, praticamente não conheceu o Neoclássico trazido pela Missão Francesa. A mais antiga construção neoclássica paulistana, à moda do novo Império, que conseguimos localizar, foi um sobrado da chácara afastada do centro histórico que está registrada no álbum de fotografias de Militão de Azevedo [...]. Parece ser ela uma construção de alvenaria de tijolos, como sugerem as manchas de umidade na platibanda da parte assobradada. (LEMOS in FABRIS, 1997)

O sobrado mencionado trazia algumas semelhanças de elementos decorativos vistos nesta casa do Instituto, mas certamente em outra escala. Há menções em notícias e em alguns relatórios de que a Casa Sede seria de 1850, mas são bastante posteriores e sem indícios claros sobre a data. De qualquer forma, ela já existia quando a fazenda foi adquirida pelo Estado.

Nas imagens mais antigas, datando da década de 1920, já se identificam elementos prémoldados em argamassa sobrepostos à fachada principal. A cobertura principal, nas imagens até os anos de 1930, era constituída de telhas cerâmicas do tipo capa-canal grandes e com tonalidades variadas, típicas dos telhados coloniais. Também é possível identificar, em imagem do início do século XX, a existência de uma segunda cobertura formando um alpendre de entrada lateral, aparentemente em estrutura metálica. Esse alpendre não aparece mais nas imagens posteriores aos anos de 1920.

Quanto ao revestimento externo, não se pode identificar sem levantamentos estratigráficos o tipo de pintura originalmente utilizado. Mas os relatórios da década de 1910 descrevem o uso generalizado de argamassa de cimento e cal no instituto, o que pode indicar os primeiros revestimentos.

Pelas imagens do acervo e pela observação das alvenarias no local, verifica-se que a planta original era em "L", mas hoje se encontra bastante alterada em virtude dos acréscimos que recebeu para abrigar laboratórios de herpetologia e sanitários. Tais acréscimos e remoções ao longo do tempo resultaram em uma planta que atualmente possui um pátio interno descoberto e um volume saliente na fachada leste, abrigando sanitários. Em 1928 foi mencionada reforma para adaptá-la como casa e escola do Instituto. Logo foram sendo introduzidas atividades laboratoriais, e em 1953 a casa foi mencionada como seção de ofiologia: 
[...] os Laboratórios de Ofiologia com suas ricas coleções de répteis conservados em álcool, foram instalados no prédio centenário, sede da primitiva Fazenda, e cuja situação de quase ruína, com o soalho e o vigamento já podres, a instalação elétrica defeituosa e as portas mal vedadas, representa verdadeiro perigo à integridade do precioso material ali conservado e para a vida dos funcionários que lá trabalham. (RA 1953, p.1)

Nota-se no trecho que ainda não havia preocupação com a preservação do edifício em si, mas apenas de seu conteúdo. Essa abordagem mudaria na década seguinte, diante da crescente conscientização pela comunidade do Instituto a respeito de seu patrimônio edificado, como se vê no relatório de 1968, em que pese uma certa confusão quanto ao significado de "relíquia" e ao real estado de conservação:

Outro prédio que já deveria estar tombado como relíquia histórica é o local onde fica situada a Seção de Herpetologia. Foi antigamente residência de Dr. Vital Brazil e depois o $1^{\circ}$. Grupo escolar do Butantan. Muito bem conservado, agradável em seu sabor histórico, torna-se até perigoso para alojar uma seção de responsabilidade, com arquivos e mapas de sistemática. (RA 1968, p.3)

Como se vê nesses trechos, a deficiência no acondicionamento das serpentes já era notada, fato que posteriormente desembocaria no fatídico incêndio de 2010.

Quanto ao aspecto externo, algumas janelas foram fechadas com alvenaria ou substituídas por portas, e portas novas foram abertas, prejudicando a unidade estética, sendo que na fachada noroeste e nordeste, a construção de acréscimos incluiu o uso de janelas e portas metálicas e de madeira contemporâneas.

Já a partir da década de 1980 é possível ver telhas menores e mais uniformes que as originais, formando um telhado de 10 águas, com drenagem através de condutores metálicos que adentram as paredes. Pela falta de documentação, é difícil identificar se esses condutores eram originais. No entanto, com a retirada do alpendre, é possível que sejam posteriores. As imagens das décadas de 1980 mostram patologias nos revestimentos, com descascamentos de pintura e desprendimento de revestimentos, provavelmente causados por umidade, tanto ascendente quanto de intempéries, resultante em parte da retirada do alpendre. Fissuras na alvenaria também são identificadas. Isso levou a diversos reparos do revestimento externo ao longo do tempo, sendo que as cores também foram modificadas. Nos anos 1970 a cor predominante era amarelada. Hoje, o edifício (também conhecido como "Casa Rosa” devido à 
cor da fachada, feita com cal e pó xadrez) é exemplo de alguns conflitos entre o patrimônio arquitetônico e os usos muito diversos dos originais, já que na parte ocupada pela administração do MHIB e o Núcleo de Documentação as características originais são mais conservadas do que na parte das pesquisas biológicas, onde a própria natureza do uso exige adaptações radicais que, como em geral nesse tipo de intervenção, acabam atendendo mal tanto às necessidades do laboratório quanto à preservação patrimônio tombado (figura 34).

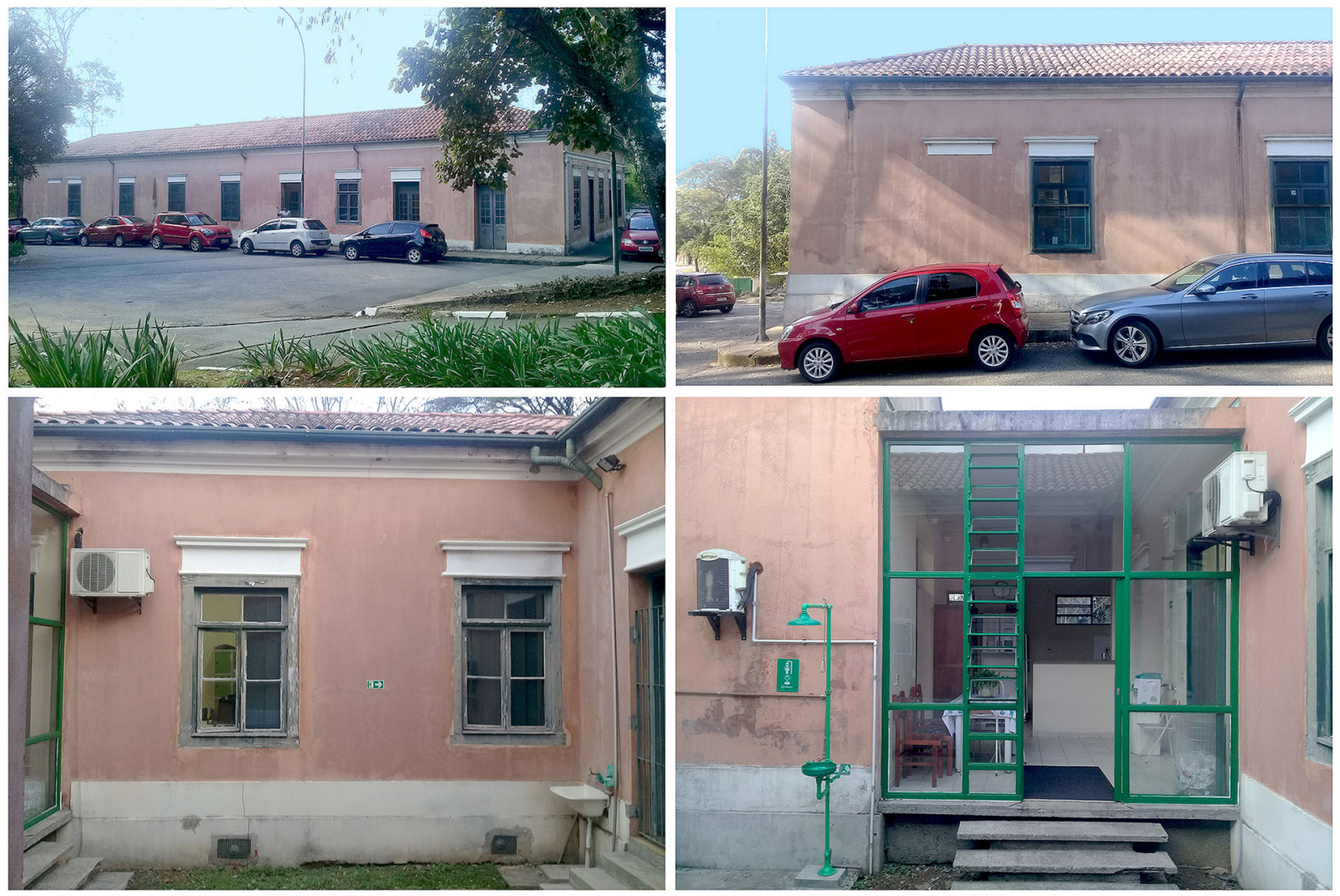

Fig. 34 - Casa Sede da Fazenda (hoje chamada Casa Vital Brazil ou “Casa Rosa”) em 2018: a interferência de instalações, anexos, gradis e caixilhos novos, fechamentos de janelas e mesmo a presença excessiva de veículos, leva ao conflito entre preservação do patrimônio e usos atuais (quando não planejados conjuntamente). Ainda assim, a manutenção de características que ainda resistem e as propostas do novo Plano Diretor indicam a possibilidade de melhor destinação do monumento (Fonte: autor)

A intenção do novo Plano Diretor é converter a casa em novo museu (com programa a definir). Para isso, divisórias internas, acréscimos ditos espúrios, revestimentos internos, instalações elétricas e hidráulicas serão, pelo projeto, substituídas por novos elementos adequados ao uso museológico, sem intenção de restituir a casa à sua condição original (até porque não há documentação suficiente a respeito), mas melhorando a legibilidade de seus elementos autênticos. Assim, é prevista a recuperação do padrão de aberturas das fachadas, do madeiramento dos caixilhos e telhado, descupinização geral, solução dos pontos de umidade e 
revisão das pinturas, mantendo cores e tintas atuais. Os revestimentos internos propostos são basicamente cimento queimado novo no piso, no lugar de cerâmicas, manutenção de assoalhos e pisos cimentícios atuais.

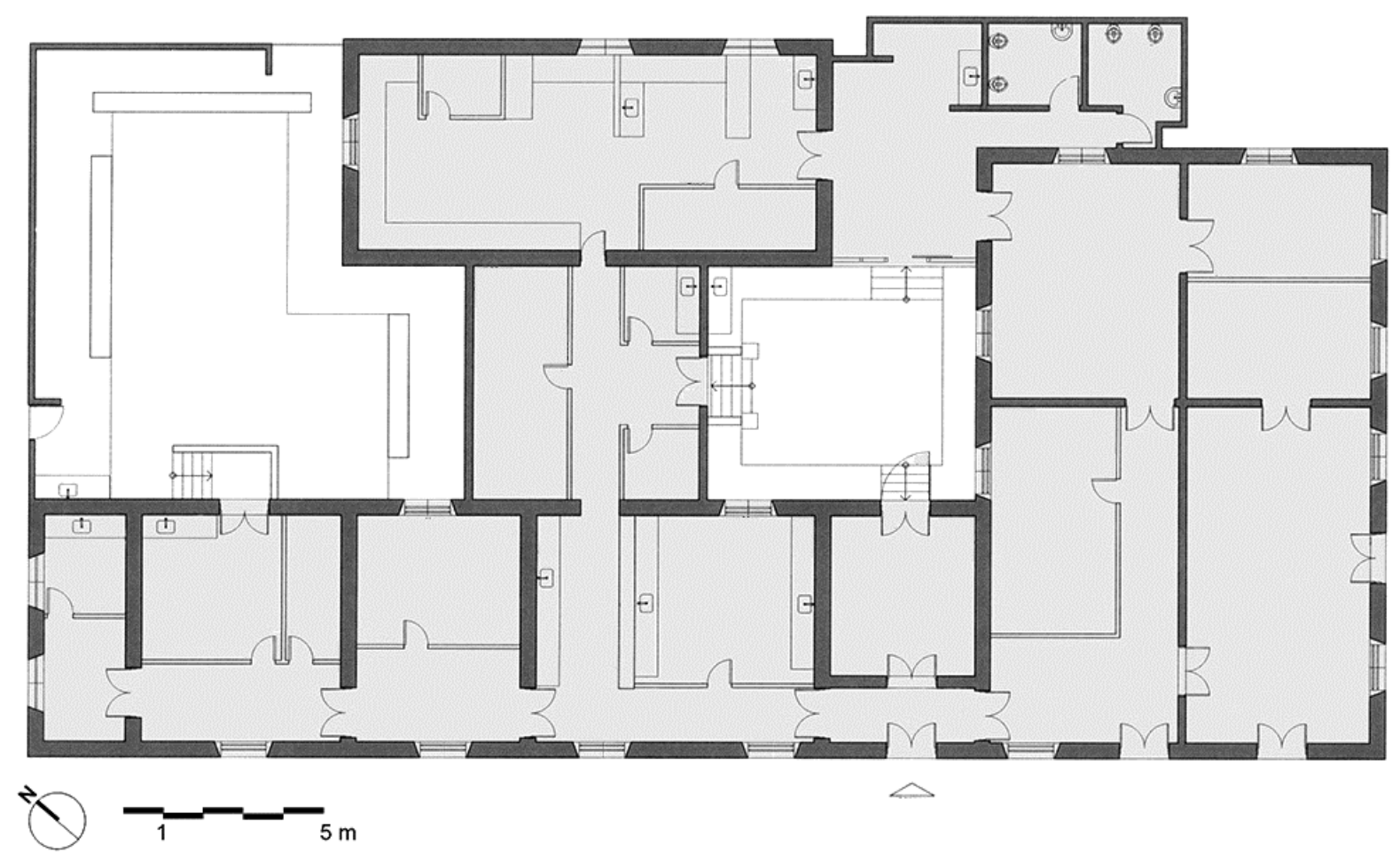

Fig. 35 - Planta da atual Casa Vital Brazil: o perímetro original era o "L" na parte sudeste e sudoeste (Fonte: IBu, 2016, alterada)

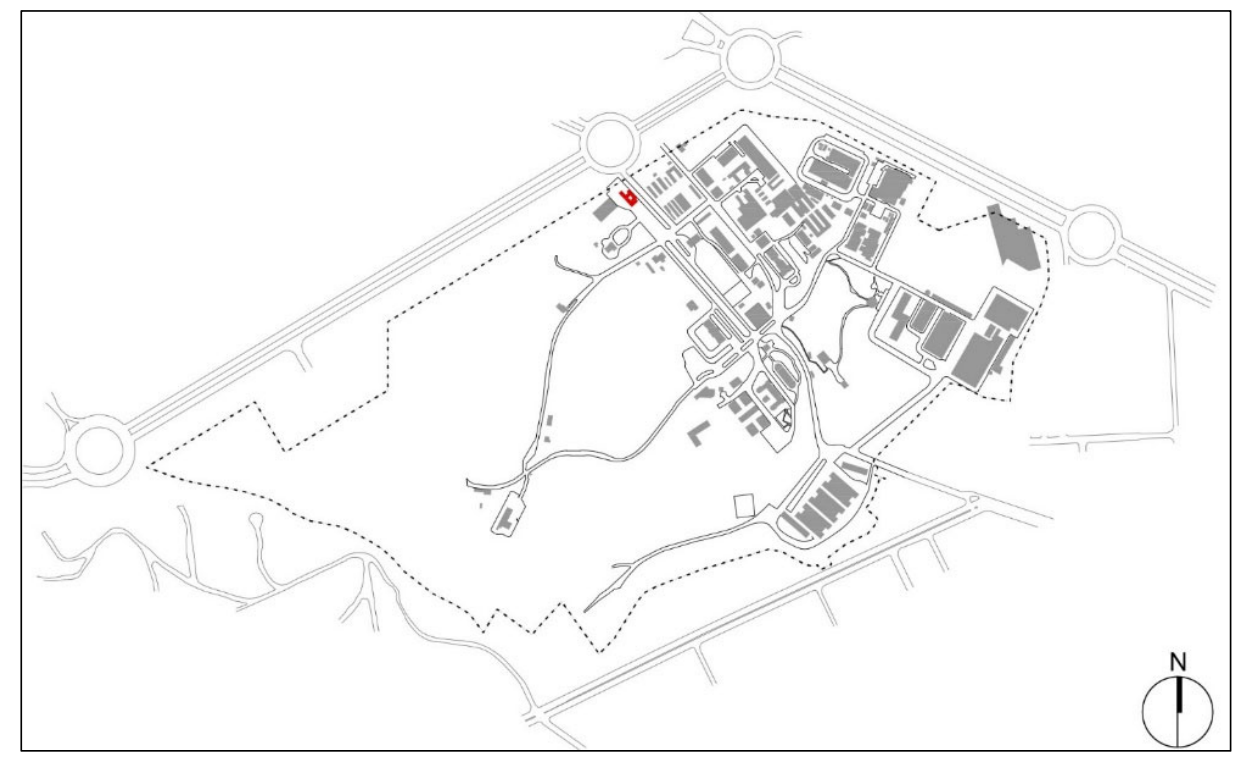

Figura 36 - Localização da Casa Sede da Fazenda (atual Casa Vital Brazil) em 2018 (autor) 


\section{RESUMO:}

Categoria: edifício

Denominação original: Casa Sede da Fazenda

Denominação atual: Casa Vital Brazil

Autoria: desconhecida

Área original: c. $300 \mathrm{~m}^{2}$

Área atual: $627 \mathrm{~m}^{2}$

Número de pavimentos original: 1

Número de pavimentos atual: 1

Início-término da construção: desconhecido (meados do século XIX)

Itens arquitetônicos originais:

Estrutura: alvenaria portante

Vedação: alvenaria (tijolo maciço)

Revestimentos paredes externas: argamassa de cimento e cal

Revestimentos paredes internas: argamassa de cimento e cal

Revestimentos pisos internos: assoalho

Revestimentos pisos externos: cimento desempenado

Caixilharia: madeira

Uso original: residência

Itens arquitetônicos atuais:

Estrutura: original + concreto armado

Vedação: original + divisórias leves

Revestimentos paredes externas atual: original + pintura cal e pó xadrez

Revestimentos paredes internas atual: original + massa corrida e tinta acrílica

Revestimentos pisos internos atual: originais + cerâmicos e cimentícios

Revestimentos pisos externos: cimento desempenado

Uso atual: laboratórios, arquivo e administração

\subsubsection{Cocheira-enfermaria [Laboratórios diversos]}

O conjunto de 3 edifícios construídos como cocheira-enfermaria a partir de 1900 hoje abriga laboratórios de diversos setores. Os dois primeiros blocos (a cocheira-enfermaria à esquerda e o pavilhão de sangria no centro) foram concluídos em 1901, e o terceiro bloco, espelhando a cocheira à direita daquele pavilhão, seria construído em 1917, assim como um acréscimo na parte posterior, para transferência do gerador que causava trepidações indesejadas no Edifício Principal, onde estava instalado até então (item 2.3.4).

Como se sabe, as primeiras atividades da equipe de Vital Brazil foram iniciadas em 1899, ainda sob administração do Instituto Bacteriológico, adaptando construções da fazenda. Logo foi necessário prever instalações próprias para os trabalhos laboratoriais. Assim, foi construído 
em 1900-1901 o primeiro edifício desse conjunto, que veio a ser também o primeiro criado para o Instituto Butantan (meses antes de sua fundação, ainda como Instituto Soroterápico). O projeto foi assinado pelo arquiteto Victore Andrigo e data de 1899 (figura 37).

$\mathrm{Na}$ listagem das instalações do Instituto apresentada no primeiro relatório anual, de 1901, Vital Brazil descreve:

"Tivemos logo de faser as seguintes obras: [...]

$6^{\text {a }}$. Construção de uma cocheira enfermaria onde deveriam ser recolhidos os animaes depois de inoculados com peste virulenta" (RA 1901, p.3)

O diretor afirma que as primeiras obras foram realizadas por um dos três órgãos: a Superintendência de Obras Públicas, a Repartição de Água e Esgoto, ou o próprio Instituto Butantan. Vital Brazil prossegue:

\begin{abstract}
A cocheira enfermaria, destinada a receber os animaes inoculados de peste mereceu nossa especial attenção, visto a importância do fim a que éra destinada. A sua construcção confiada ao hábil engenheiro Dr. Augusto Fomm só ficou terminada em princípios de março de 1901. (RA 1901, p.3)
\end{abstract}

Portanto, houve um intervalo de cerca de dois anos entre o projeto identificado e a conclusão da obra. Não foram encontrados mais detalhes sobre o arquiteto Victore Andrigo, ou sobre outros projetos que tenha desenvolvido para o Instituto. Já sobre o engenheiro Fomm, há diversas menções do próprio Vital Brazil em ofícios enviados ao Serviço Sanitário até 1905 (ALMEIDA et al, 2014). O engenheiro sanitarista Augusto Fomm já havia sido responsável pelas primeiras obras, ainda antes da fundação do Instituto, seja adaptando os estábulos e o casario da fazenda para as novas atividades, seja dirigindo obras novas, como esta Cocheiraenfermaria. O engenheiro foi citado diversas vezes no Diário Oficial como credor do então Instituto Serumteraphico por serviços de construção ${ }^{81}$. Nesse sentido, verifica-se que sua atuação era mais ligada à atividade de execução de obras e não de projeto, embora Fomm tenha feito o primeiro estudo para o Edifício Principal (item 2.3.4)

\footnotetext{
${ }^{81}$ O Diário Oficial do Estado de São Paulo mencionava o pagamento a Augusto Fomm em 4/6/1900 e 16/4/1901 por serviços de terraplenagem e alvenarias para abastecimento de água no Instituto.
} 


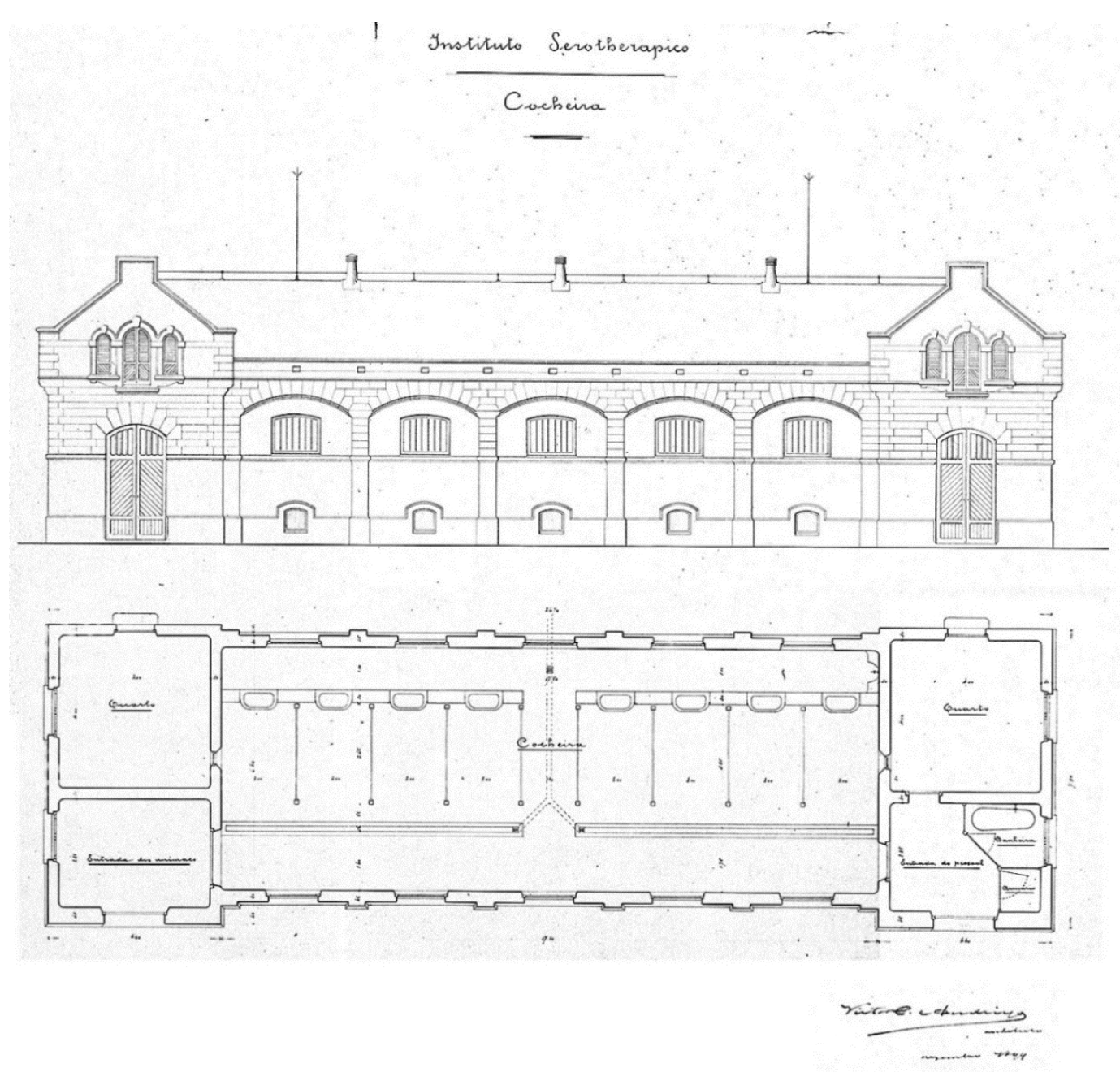

Fig. 37 - Elevação frontal e planta da Cocheira-enfermaria, assinadas pelo arquiteto Victore Andrigo em dezembro de 1899: as extremidades eram ocupadas por funcionários e a parte central pelas baias dos animais (Fonte: Arquivo do Estado)

De acordo com as listagens de materiais da época, o conjunto foi construído em alvenaria revestida com argamassa de cal e areia, com cobertura em telhas de barro. Segundo o Diário Oficial de 1901:

Solicitaram-se da Secretaria da Fazenda pagamentos:

De $416 \$ 000$ a Paschoal Gravino, pelo fornecimento de materiaes para as obras da cocheira-enfermaria do Instituto Serumtherapico do Butantan. (Diário Oficial do Estado de São Paulo, 16 abr. 1901, p.1104)

Sabe-se, pelo ofício de Vital Brazil já mencionado, que Paschoal Gravino foi proprietário da olaria (item 2.3.1), da qual, portanto, vieram esses materiais (tijolos e telhas).

Quanto à linguagem arquitetônica, aqui aparece a preocupação em diferenciar essa nova construção daquelas rurais improvisadas da fazenda, mostrando que essa obra era destinada aos trabalhos inovadores da microbiologia. Desse modo, vê-se a opção por projetar edifícios mais 
modernos que os da fazenda. Assim como as fábricas, armazéns e outro edifícios utilitários do final do século XIX e início do XX, este conjunto possui uma fachada principal seguindo características do Neoclássico, frisos horizontais, janelas em arco abatido, simetria, cornijas, juntamente com cobertura e frontão simplificado (figura 38). Tais características eram comuns em antigas construções rurais inglesas e encontrado em edificações semelhantes no Brasil, como por exemplo nos antigos estábulos da Avenida Celso Garcia, em São Paulo e de Manguinhos. $\mathrm{Na}$ configuração original, podia-se notar a diferença entre alturas e dimensões das janelas no corpo central (destinado aos cavalos) e nos corpos laterais (destinados a funcionários). As janelas dos recintos de animais eram do tipo basculante, e as laterais com folhas de abrir. Internamente, os poucos registros mostram uma construção utilitária, com pisos em pedra, baias em madeira, comedouros, drenagem, ventilações superiores, entre outros detalhes próprios para o trabalho com animais. Conforme descrito no Guia de Arquitetura do Instituto:

Eram galpões simples, com interior subdividido em baias individuais para acondicionar os animais no processo de inoculação do veneno e posterior extração do sangue para produção do soro. Continha espaço específico para enfermaria, desinfecção e necropsia dos animais, além de um cômodo para forno crematório e uma grande estufa de esterilização. (MONTEIRO, 2017)

Ainda assim, a assepsia necessária ao edifício não dispensava a preocupação com certos detalhes ornamentais, como nas traves em arco abatido entre as baias (figura 39).

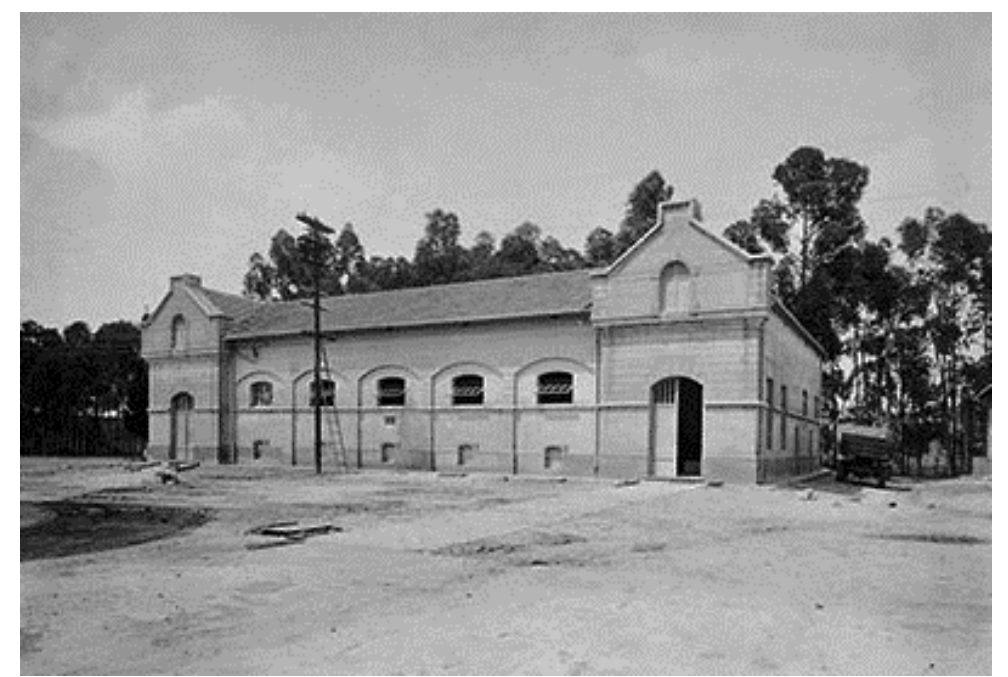

Fig. 38 - Bloco do lado esquerdo, antes da construção dos outros dois blocos do conjunto (Fonte: IB_ICO_010255) 


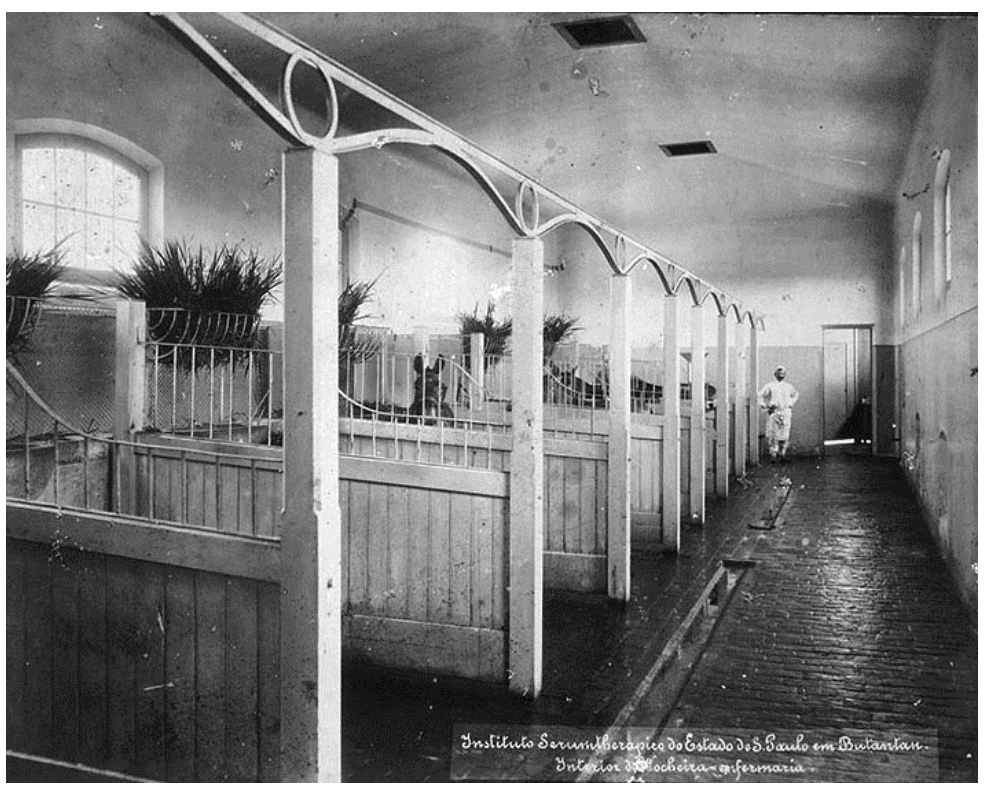

Fig. 39 - Interior da Cocheira-enfermaria: o projeto funcional com piso de pedra, canaleta de escoamento, comedouros e baias, convivia com as volutas ornamentais nos arcos de travamento (Fonte: IB_ICO_010832)

Ao longo do tempo o edifício foi sendo modificado tanto em seus usos quanto em sua arquitetura. Já em 1924, quando Vital retornou de Niterói para reassumir a diretoria do Instituto, sua descrição do estado de conservação dos edifícios atestava:

O edifício da cocheira enfermaria, o primeiro que se construiu em Butantan que fora estudado para o fim que se destinava, isto é, para albergar animaes que fosse inoculados de peste virulenta, e que durante 20 annos se prestara perfeitamente, sem o minimo accidente, para os seus fins, foi modificado sem o minimo criterio, com a construcção dentro do quarto do enfermeiro dos animaes, de dois cubiculos, verdadeiras solitarias de cavallos, onde estes, se não morressem de péste, morreriam certamente asphyxiados

A autoclava installada na parte posterior da cocheira enfermaria e que se destinava a estirillisação das roupas do enfermeiro, bem como de todos os objectos que tivessem servido na enfermaria, acha-se arrancada do seu logar e atirada a um canto não tendo sido utilisada desde a minha retirada do Instituto. (RA 1924, np)

Em 1943 é citada reforma da "velha cocheira-enfermaria" para instalação de biotério de animais inoculados (RA 1943, p.44). A aquisição da fazenda de São Joaquim em 1945 eliminou os trabalhos com animais de grande porte no campus do Instituto em São Paulo, levando à adaptação desse conjunto para usos apenas laboratoriais.

Segundo levantamento da equipe do Museu Histórico, esse conjunto da Cocheiraenfermaria já abrigou uma gráfica, o setor de Patrimônio, Compras e Finanças, uma parte da Secretaria da Fazenda e o Laboratório de vacina BCG. Atualmente, nele funciona o Laboratório Especial de Dor e Sinalização (bloco central), Bioquímica (bloco à esquerda) e um Centro de 
Descobertas de Alvos Moleculares (bloco à direita), vinculado à FAPESP e à GlaxoSmithKline Brasil (GSK) em parceria público-privada. Para isso, no caso de laboratórios que precisavam de controle de luminosidade, temperatura e condições do ar, muitas janelas foram fechadas com alvenaria, e sistemas de condicionamento de ar instalados. Internamente, a profusão de novos ambientes e revestimentos é totalmente destoante da original, devido às necessidades laboratoriais, podendo-se encontrar divisórias em alvenaria, laminado melamínico, gesso acartonado, pisos cerâmicos, vinílicos, em granilite, forros em gesso, em PVC e em madeira, e diversos outros elementos que não convém listar exaustivamente, mas que é possível notar na compartimentação das plantas atuais. Além disso, foram acrescentados pisos superiores em partes dos edifícios (aproveitando o pé-direito original) e acréscimos na planta. Também foram aplicadas diferentes pinturas sobre o revestimento original.

Apesar de se manterem preservados os relevos das fachadas e a volumetria geral, o fato de abrigar hoje usos bastante diversos dos originais e entre si, bem como administrações diferentes em cada bloco, faz com que o conjunto não apresente mais em seu aspecto geral a mesma unidade arquitetônica. Pode-se dizer que, por ser o primeiro conjunto construído para o Instituto, esse foi o elemento menos preservado em sua unidade arquitetônica. Ainda assim, sua parte externa mantém características originais que podem ser conservadas em sua legibilidade. A intenção do novo Plano Diretor é substituir os usos laboratoriais desse conjunto por setores administrativos do Instituto (juntamente com o Edifício Principal). 


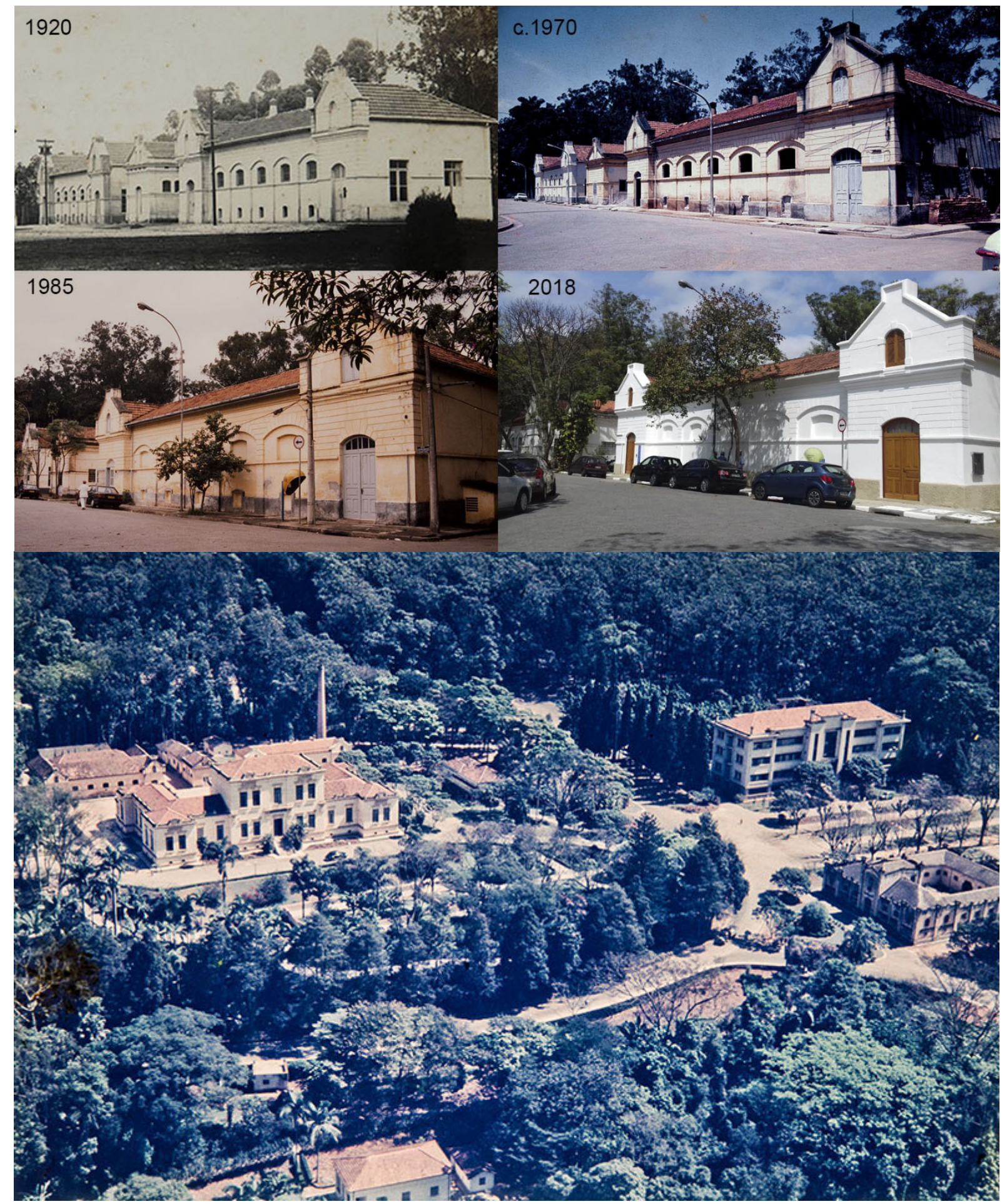

Fig. 40 - Fachada principal em diversas épocas e vista aérea da década de 1940: vê-se que as fachadas da Cocheira-enfermaria passaram por diversas modificações em seus fechamentos e pinturas. Também se nota que o conjunto, atrás do Edifício Principal, possuiu uma chaminé, provavelmente para a área de máquinas (Fonte: Acervo IBu) 


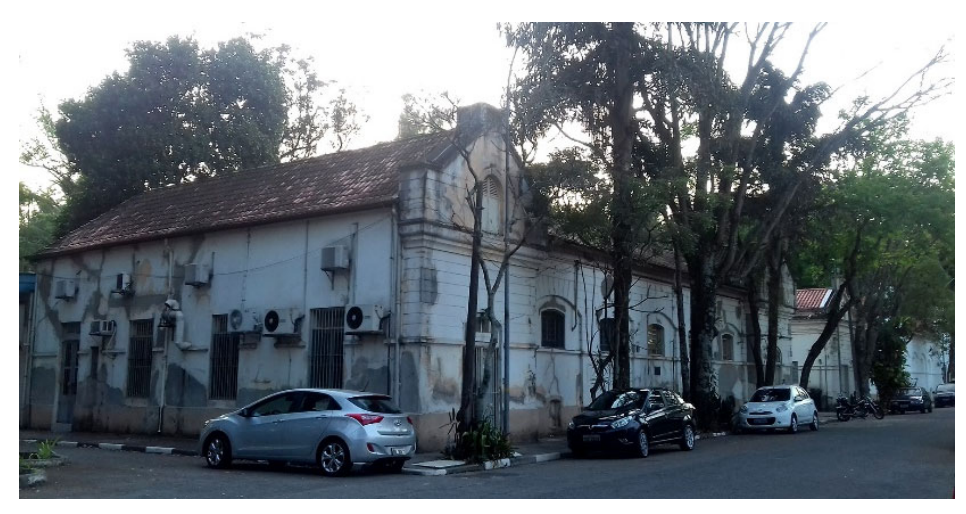

Fig. 41 - Bloco do lado esquerdo em 2018: hoje o conjunto não recebe tratamento uniforme, há interferências de instalações e patologias em revestimentos, contrastando com pinturas renovadoras (Fonte: autor)

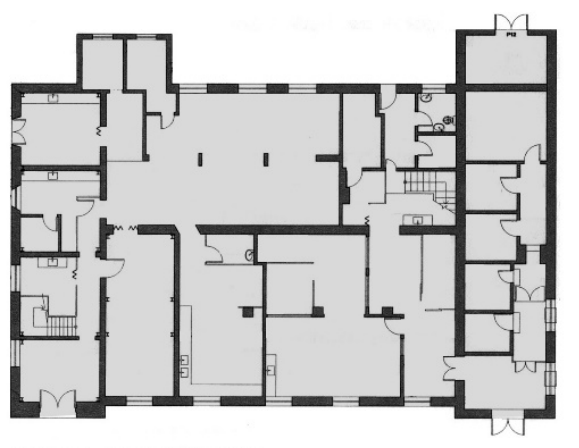

PAVIMENTO TÉRREO
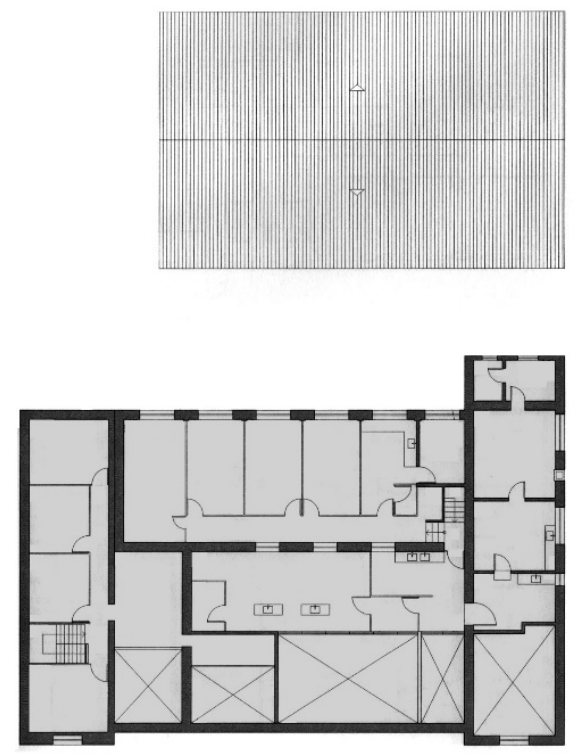

PAVIMENTO SUPERIOR
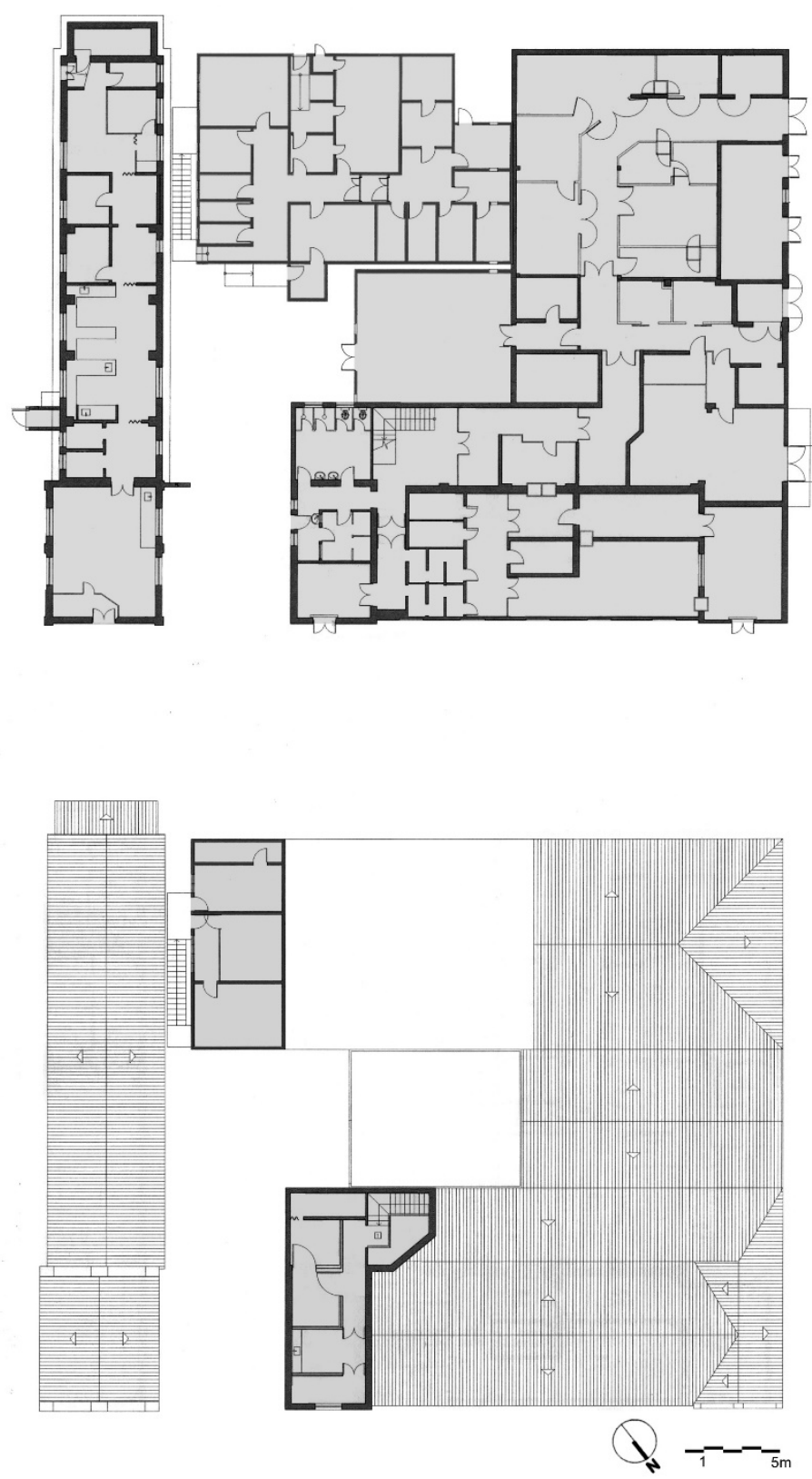

Fig. 42 - Planta recente: os acréscimos dificultam a identificação da planta original. Também foram construídos pavimentos superiores em alguns trechos (Fonte: IBu, 2016, alterada) 


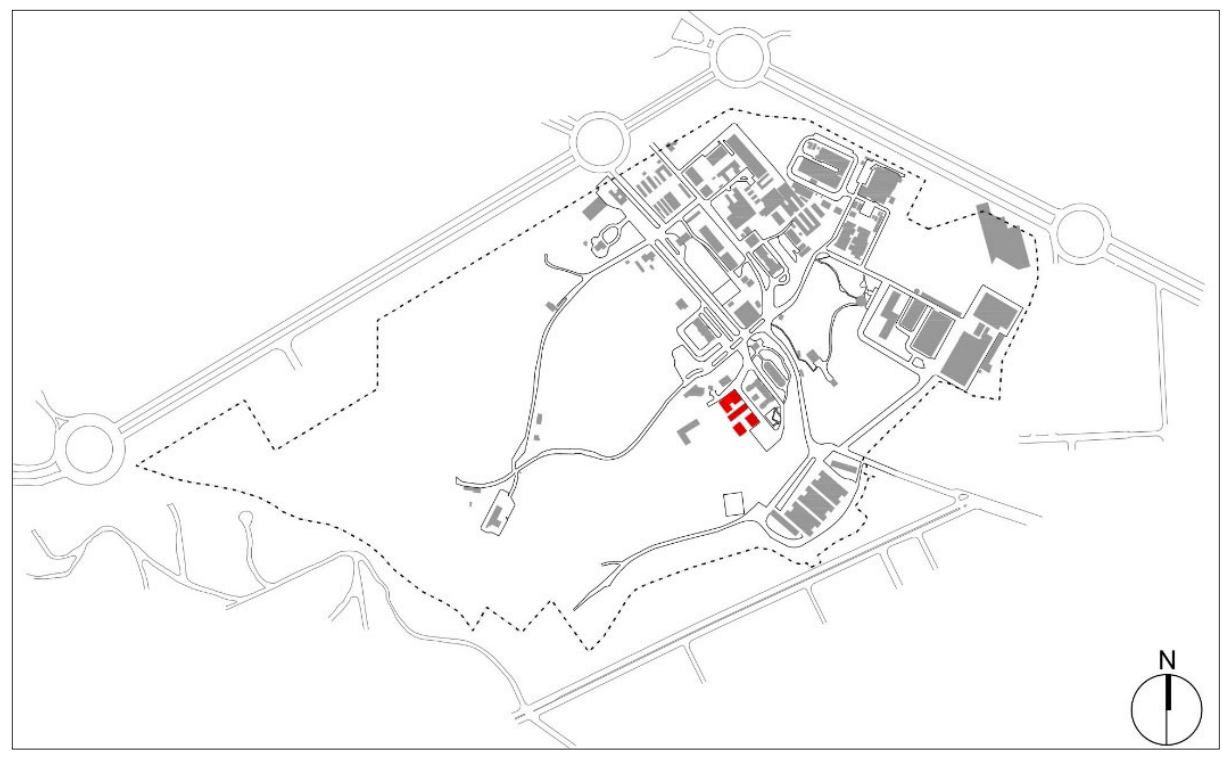

Figura 43 - Localização do conjunto da antiga Cocheira-enfermaria em 2018 (autor)

\section{RESUMO:}

Categoria: edifício

Denominação original: Conjunto cocheira-enfermaria

Denominação atual: Laboratórios diversos

Autoria: Victore Andrigo

Área original: c. $2000 \mathrm{~m}^{2}$

Área atual: $2209 \mathrm{~m}^{2}$

Número de pavimentos original: 1

Número de pavimentos atual: 2

Início-término da construção: 1899-1901 (primeiros blocos), 1917 (último bloco)

Itens arquitetônicos originais:

Estrutura: alvenaria portante

Vedação: alvenaria (tijolo maciço)

Revestimentos paredes externas: argamassa de cimento e cal

Revestimentos paredes internas: argamassa de cimento e cal

Revestimentos pisos internos: cerâmica, cimento queimado

Revestimentos pisos externos: cerâmica

Caixilharia: madeira

Uso original: cocheira-enfermaria, biotério, casa de máquinas

\section{Itens arquitetônicos atuais:}

Estrutura: original + concreto armado

Vedação: original + divisórias leves

Revestimentos paredes externas atual: original + argamassa industrializada monocapa + tinta acrílica

Revestimentos paredes internas atual: original + tinta acrílica

Revestimentos pisos internos atual: originais + cerâmicos, vinílicos e emborrachados

Revestimentos pisos externos: cimento

Uso atual: laboratórios diversos 


\subsubsection{Edifício Principal [Edifício Vital Brazil]}

Este prédio teve sua construção iniciada em 1910 e inauguração em 1914, como o centro de trabalho principal do Instituto, para abrigar laboratórios, administração, museu, biblioteca e áreas de apoio técnico para auxiliar nos trabalhos que até então eram realizados de forma improvisada em construções remanescentes da fazenda recém-adquirida e na Cocheiraenfermaria, situada atrás deste novo edifício. Implantado no alto de uma colina do terreno, com boa visibilidade para quem chegava pela várzea do Rio Pinheiros vindo do centro, o edifício foi concebido com volumetria predominantemente horizontal, com térreo, pavimento superior menor, e embasamento no subsolo, distribuídos em um corpo central, alas laterais e um bloco (chamado de rotunda) posterior.

No primeiro relatório, de 1901, Vital Brazil fez uma listagem das necessidades da equipe, sendo a primeira delas um edifício que reunisse as principais atividades do Instituto (figura 44).

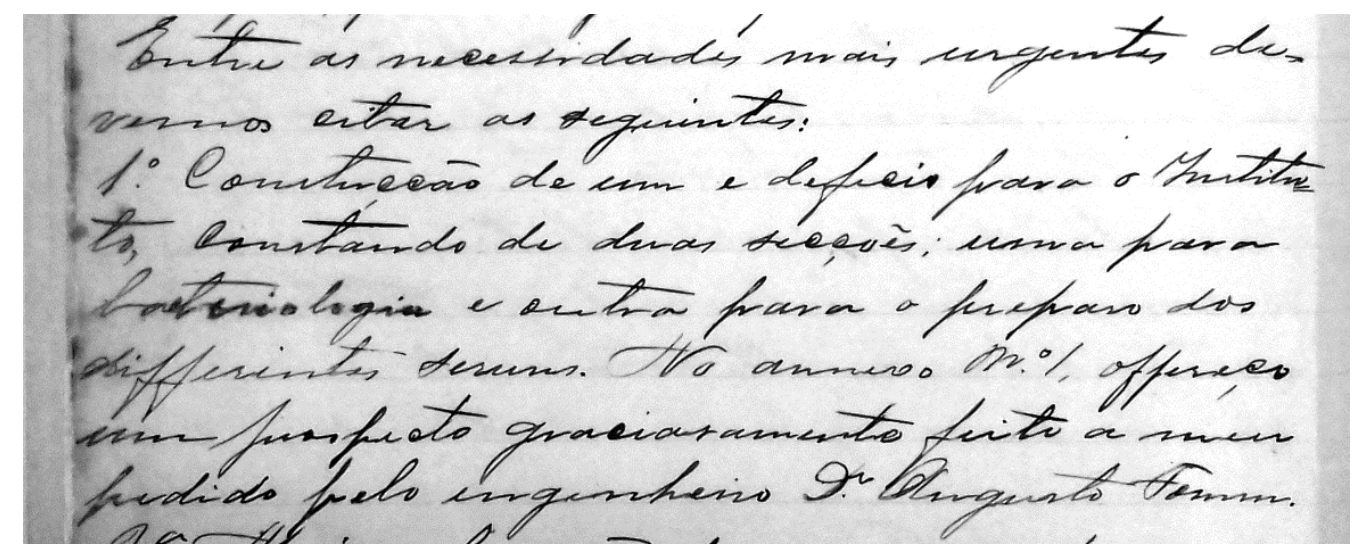

Figura 44 - Trecho do Relatório de 1901, escrito por Vital Brazil para o Serviço Sanitário. Transcrição: "Entre as necessidades mais urgentes devemos citar as seguintes:

$1^{\circ}$. Construcção de um edifício para o Instituto, constando de duas secções: uma para bacteriologia e outra para o preparo dos differentes serums. No annexo $n^{\circ}$. 1, offereço um projecto graciosamente feito a meu pedido pelo engenheiro Dr. Augusto Fomm." (Fonte: RA 1901, p.4)

O estudo inicial para o edifício, que não foi o projeto finalmente executado, indicava a preocupação funcional explicitada no pedido de Vital Brazil ao engenheiro Augusto Fomm, ao setorizar e separar a ala de bacteriologia (à direita) e soroterapia (à esquerda), ou seja, uma ala para estudo da doença e outra para desenvolvimento da cura (figura 45). 


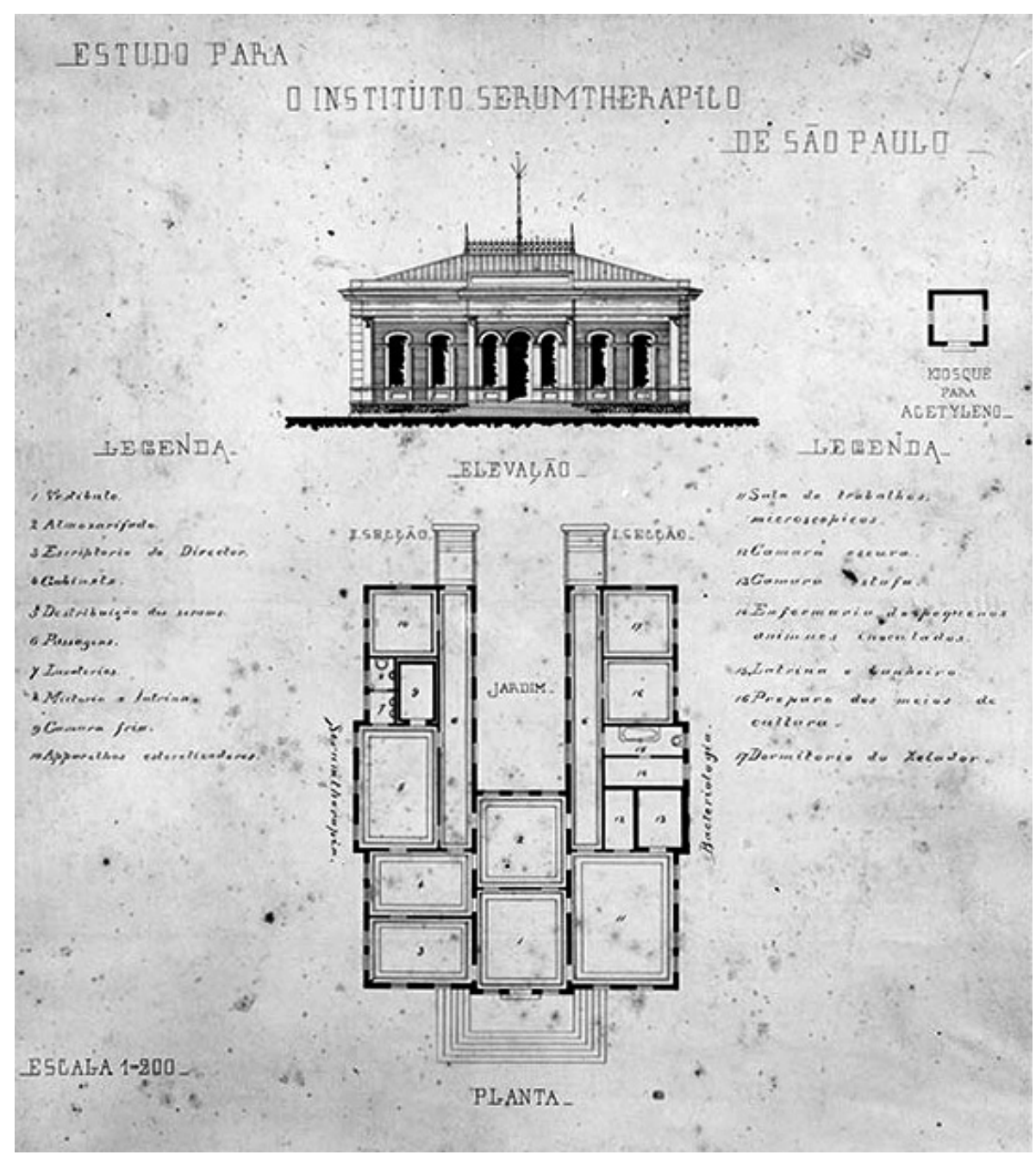

Fig. 45 - Estudo de Augusto Fomm para o edifício principal, 1899, s/escala: vê-se já a opção pela divisão em duas alas (Fonte: IB_ICO_010836)

Como se viu, o engenheiro Augusto Fomm já havia sido responsável pelas primeiras obras, como executor. Esse primeiro estudo do engenheiro para o Edifício Principal era significativamente menor do que o prédio que seria de fato construído a partir de novembro de 1910, pois trazia apenas um pavimento e somava aproximadamente $500 \mathrm{~m}^{2}$, enquanto o edifício construído de fato ficou com cerca de $1100 \mathrm{~m}^{2}$ distribuídos em três pavimentos (térreo, superior e embasamento). Mas esse estudo já trazia preocupações consideradas, na época, mais funcionais e modernas, como a citada setorização de funções, as circulações independentes das salas, a farta ventilação dos ambientes e mesmo o para-raios proeminente, aliando esses aspectos a uma linguagem classicizante (com ornamentos, entablamentos, platibandas e arcos) próprios do período e ligados ao Ecletismo. 
O projeto finalmente executado foi do engenheiro-arquiteto Mauro Álvaro de Souza Camargo, que também dirigiu as obras (figuras 46 a 49), já avançadas em 1912:

\begin{abstract}
Em fins do anno de 1910 foram iniciadas as obras de construcção do novo edifício do Instituto, sob a direcção technica do engenheiro-architecto Dr. Mauro Alvaro, que foi igualmente o autor dos projectos aprovados pelo Governo. Durante os annos de 1911 e 1912 continuaram com regularidade os trabalhos de construç̧ão e installação, achando-se quase que ultimadas as do edifício principal. [...] o edifício comporta além do porão, onde se acham installadas as machinas de gelo, camaras frigorificas, machinas de vácuo e de pressão, deposito de materiaes, etc, dois andares: o primeiro, mais amplo, dividido em duas alas pelo corpo central, destinados aos laboratórios, sala de visita e de demonstração; o segundo ocupando uma área muito menor e correspondendo a porta central do edifício, destinado a secretaria, biblioteca, museu e sala do diretor. As duas alas do andar principal destinam-se uma aos trabalhos de pesquisas, preparo de toxinas, etc., a outra a trabalhos de demonstração e serumtherapia, etc. (RA 1912, pp. 238-239)
\end{abstract}

Não foram encontradas plantas originais do edifício, mas por essa descrição verifica-se que se destinava a várias funções desde o início, abrangendo laboratórios, salas administrativas, biblioteca e áreas técnicas. Inaugurado oficialmente em 4 de abril de 1914 (mas tendo sido concluído e parcialmente ocupado em meados de 1913), passou a ser considerado símbolo do Instituto, e seu projeto foi publicado em 1911 na Revista de Engenharia (figura 50), e apresentado na Exposição Internacional de Higiene em Dresden, no mesmo ano, segundo a mesma revista. A publicação mostra que foi mantido o partido de setorizar duas funções:

No primeiro pavimento distinguem-se duas secções principaes: uma reservada á 'Microbiologia' e a outra á 'Serumtherapia'. Esta occupa a ala esquerda do edifício e a rotunda, ao fundo, onde são preparados e sangrados os animaes para obtenção do serum. (Revista de Engenharia, São Paulo, v.1, n.2, 1911, p.50)

O Edifício Principal também teria repercussão na imprensa não especializada, mostrando seu caráter simbólico, como uma conquista do governo paulista. Na edição de 4 de abril de 1914, dia de sua inauguração, o jornal O Estado de São Paulo ${ }^{82}$ trouxe um histórico completo da instituição, e descrição detalhada dos ambientes do edifício, como é visto no trecho a seguir:

Em Novembro de 1910, sendo presidente o dr. Albuquerque Lins e secretário do Interior o dr. Carlos Guimarães, foi, por ordem deste, iniciada a construcção do novo edifício do Instituto, sob a direcção do engenheiro sanitário dr. Mauro Álvaro. É um prédio moderno, amplo e apropriado, que condiz com a importância do estabelecimento e com o progresso do Estado de S. Paulo. (O Instituto Butantan. $O$ Estado de São Paulo, 04/04/1914, p.3)

\footnotetext{
${ }^{82} \mathrm{O}$ jornal era tido como alinhado ao governo paulista.
} 

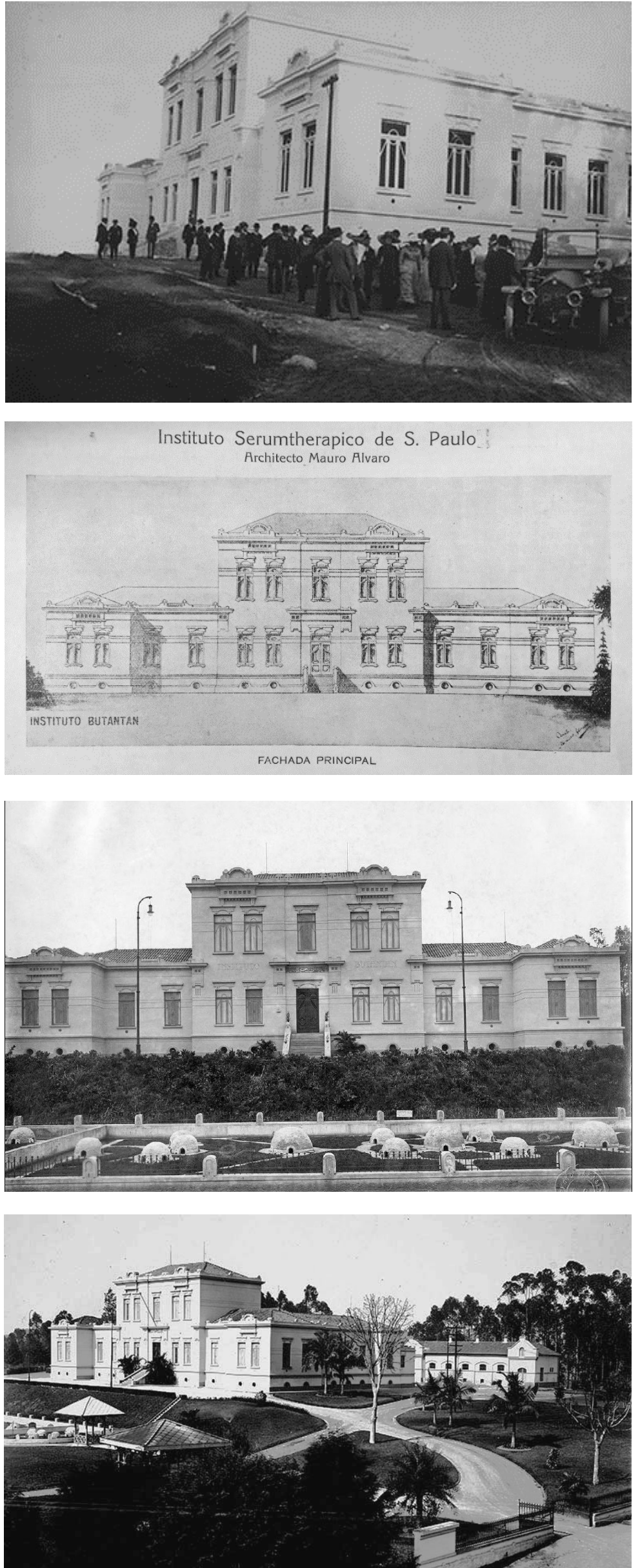

Fig. 46 - Inauguração do Edifício Principal em abril de 1914 (Fonte: Acervo IBu)

Fig. 47 - Desenho da fachada principal: a simplificação de ornamentos já era prevista no projeto de Mauro Álvaro, s/escala (Fonte: Revista de Engenharia, v.1, n.2, p.50, 1911)

Fig. 48 - Fachada principal em 1920: vê-se também o jardim frontal e o serpentário de espécies venenosas (Fonte: Acervo Instituto Moreira Salles)

Fig. 49 - Edifício Principal na década de 1920: vê-se ao fundo a Cocheiraenfermaria, e à frente o serpentário e o quiosque usado como mostruário de extração de veneno (Fonte: IB_ICO_008926) 


\section{Instituto Serumtherapico de S. Paulo \\ Architecto Mauro filvaro}
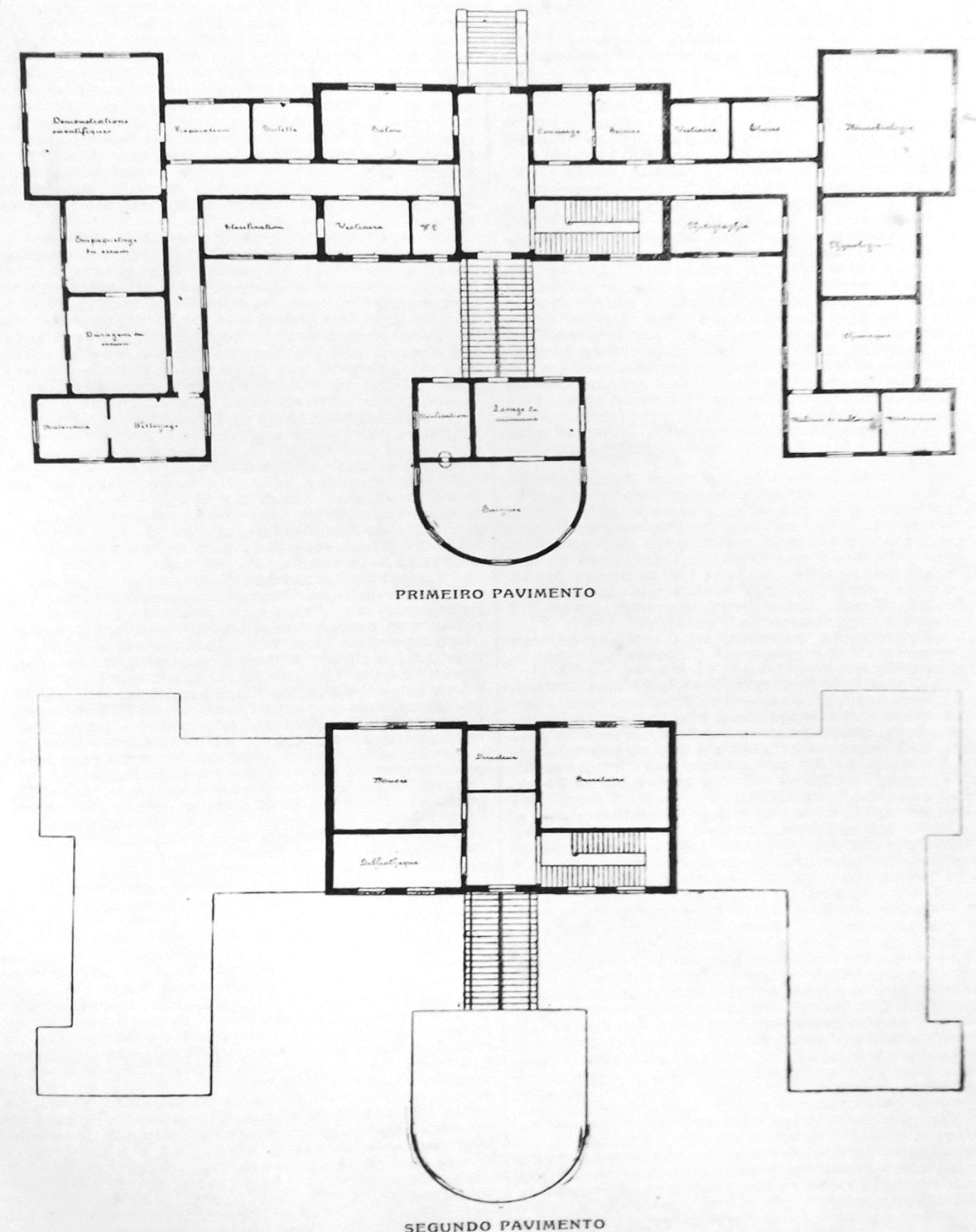

Fig. 50 - Plantas publicadas antes da conclusão do edifício e apresentadas na Feira Internacional de Higiene de Dresden. O térreo é aqui chamado de "PRIMEIRO PAVIMENTO". S/escala (Fonte: Revista de Engenharia, v.1, n.2, p.51, 1911) 


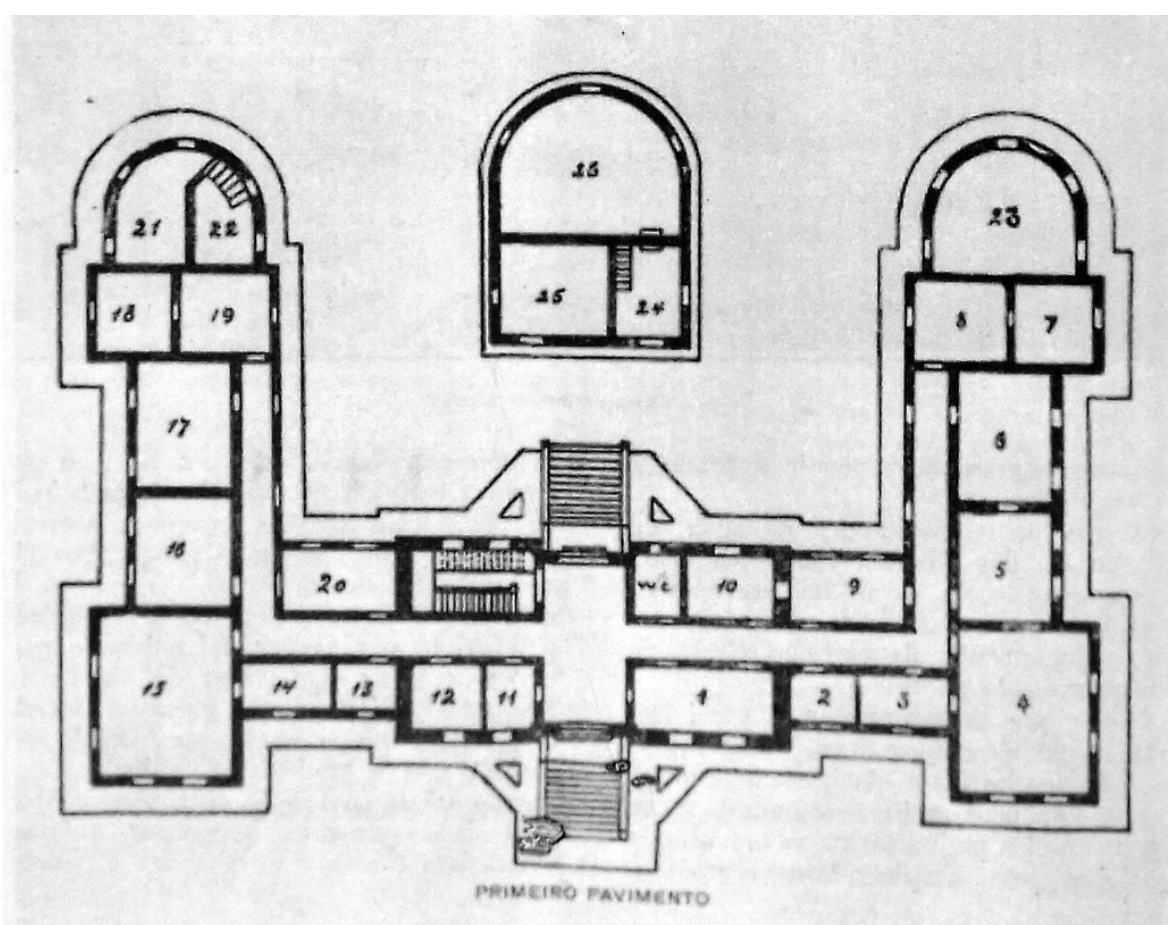

Figura 51 - Essas plantas mostram o início da ocupação da sala semicircular à esquerda com mezanino, em 1914, s/escala. (Revista Médica de São Paulo, ano XVII, n.9, 1914, p.138)

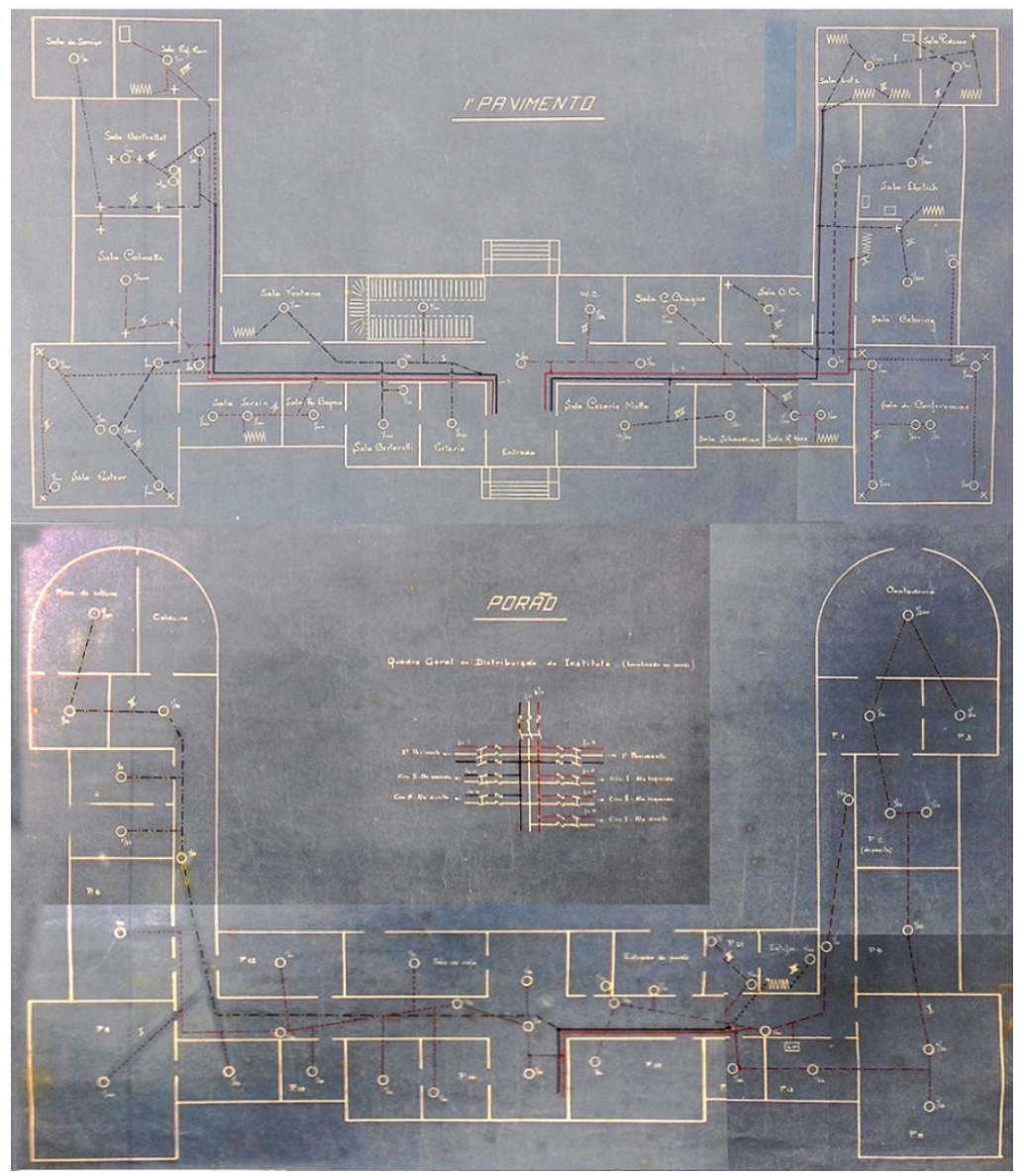

Fig. 52 - Plantas de instalações elétricas, 1928, s/escala: os desenhos revelam aberturas entre algumas salas do térreo (aqui chamado de "1. PAVIMENTO"), conforme relatado por Vital Brazil (Fonte: Acervo IBu) 
Apesar de ter suas obras terminadas em meados de 1913, a solene inauguração, quase um ano depois, mostrava a preocupação em criar e divulgar uma identidade do Instituto, valendose também de seu espaço construído. Em seu discurso de inauguração, L.M. Homem de Mello, funcionário representando a Diretoria Geral do Serviço Sanitário, dizia:

“Testemunharam a construcção d'esse edifício, que obedeceu a todos os reclamos da necessidade e mesmo conveniência, e a perfeita dotação dos seus múltiplos laboratórios, o patriótico esforço do Governo do Estado, em proporcionar todos os recursos para a custosa, si bem que generosamente compensadora instalação dos institutos scientificos creados para servir ao inestimável desígnio de convergir as luzes da Sciencia para a resolução dos muitos e graves problemas de que dependem a saúde publica.

São, portanto, as installações d'este Instituto um monumento de benemerência para as esclarecidas administrações que tem perlustrado o Governo d'este Estado progressista que notavelmente se salienta no seio da Federação Brasileira pela sua civilisação [...].” (RA 1915, p.2)

Esse trecho do discurso chama a atenção por utilizar a imagem do novo edifício como símbolo do progresso de São Paulo (dentro de um clima competitivo entre os Estados, constante desde a descentralização gerada pela federalização da Primeira República). Além disso, a noção de modernidade e utilidade do edifício está presente, aliada à estética, aqui representada pela palavra “conveniência”, que na época se referia à adequação da forma ao propósito do edifício ${ }^{83}$.

O térreo abrigava os laboratórios e seus apoios. No pavimento superior, menor que o térreo, ficavam administração, biblioteca e museu, e no porão, depósitos e máquinas. Vê-se, pela descrição publicada (O Instituto Butantan. O Estado de São Paulo, 04 abr. 1914, p.3), que as extremidades semicirculares das alas eram originalmente utilizadas apenas no nível do porão, e foram depois ocupadas por mezaninos (figuras 51 e 52). O levantamento no local mostra que esses ambientes possuíam pé-direito duplo ${ }^{84}$, para abrigar máquinas (geradores e fornecedores de gases). Sobre isso, o relatório de 1917 descreve um dos primeiro problemas do edifício, relacionado ao motor localizado no subsolo:

Tendo sido defeituosamente montado na parte posterior do grande edifício, determinava uma trepidação constante que era notada em qualquer dos compartimentos do edifício, principalmente nos cômodos do andar superior. [...] Achavam-se as cousas neste pé, quando fomos procurados pelo Dr. B. Airosa engenheiro mecânico electricista que por ordem do Dr. Secretario do Interior vinha

\footnotetext{
${ }^{83} \mathrm{O}$ princípio de conveniência remonta ao tratado De Re Aedificatoria, 1452, no qual Leon Battista Alberti prescreve a estética apropriada a cada uso nos edifícios. (ALBERTI, 2012)

${ }^{84}$ Em 2000 esse subsolo foi dividido por estrutura metálica para uso também no nível térreo.
} 
ocupar-se da questão, pois, este membro do Governo tivera noticia do perigo que corria o bello e novo edifício por intermédio do Dr. Mauro Alvaro que fora o seu architecto e constructor. O Dr. B. Ayrosa depois de maduro exame propôs a substituição do motor a gas pobre por um outro de igual força a óleo bruto instalado em pavilhão separado da casa onde funciona os laboratórios. Este plano asceito com enthusiasmo pelo Director do Serviço Sanitario foi aprovado pelo Dr. Secretario do Interior que autorizou a compra do novo motor e a construcção de um abrigo para o mesmo. (RA 2017, np)

A citação deste trecho mostra o trânsito de Mauro Álvaro nas instâncias superiores da administração, e sua preocupação com a integridade do edifício. O abrigo para o novo motor foi construído atrás da Cocheira-enfermaria.

Em 1924, em sua descrição do estado do Instituto em seu retorno, Vital Brazil relatou:

O edifício principal, onde se acham instalados os laboratórios, acha-se em bom estado de conservação, sendo apenas lastimável que tivessem tido a infeliz ideia de abrir uma porta de comunicação entre dois commodos, medida essa completamente inútil e que muito prejudicará a construcção, por ter sido a abertura praticada em uma das paredes principaes que suporta o peso do andar superior. [...] A secretaria que durante o período das administrações interinas andou de Herodes a Pilatos, encontra-se actualmente muito mal colocada em uma dependência do porão. Trataremos de remove-la para lugar mais apropriado. (RA 1924, p.6)

A menção à referida abertura, que de fato não seria aconselhável em um edifício com alvenaria autoportante, mostra a preocupação do diretor com os aspectos construtivos do Instituto, e revela também como conflitos administrativos influenciavam no espaço físico.

A partir de 1954 a biblioteca passou a ocupar toda a ala direita do pavimento térreo do edifício, e essa configuração permaneceu durante as próximas décadas, até atualmente, com laboratórios ocupando a ala esquerda, o pavimento superior e o subsolo ${ }^{85}$.

Em relação à linguagem arquitetônica, a Revista de Engenharia de 1911 enfatizou questões técnicas e usos, não se fazendo menção à ornamentação do edifício. Nesse aspecto, Mauro Álvaro, com sua implantação sobre um dos pontos altos do terreno e voltado para a chegada de quem vinha do centro, segundo REIS FILHO, seguiu a "linha do 'Floreale' ou 'Liberty' italiano, muito próximo de soluções adotadas por Dubugras na mesma época, como a residência para Afonso Geribello, em Ribeirão Preto” (REIS FILHO, 2005, p.45).

\footnotetext{
${ }^{85} \mathrm{O}$ subsolo continua hoje utilizado por laboratórios de pesquisa, mas o reduzido pé-direito, os desníveis originais do prédio, a deficiente ventilação e circulação, assim como a ocorrência de infiltrações, tornam a ocupação inadequada, e que deve ser alterada pelo novo Plano Diretor.
} 
Nessa arquitetura, elementos como pináculos, ornamentos com formas geométricas simplificadas, janelas mais verticais para aproveitamento da iluminação natural, eram características consideradas inovadoras, assim como a alvenaria estrutural em tijolos de barro, da olaria, técnica considerada moderna para a época, como já mencionado. Alguns elementos, sobretudo detalhes de ornamentação, carpintaria e pintura, remetem à linguagem Art Nouveau.

Em São Paulo, o Art Nouveau, apesar da curta duração, foi ligado à sua rápida industrialização e enriquecimento, tendo sido adotado pelos barões do café, que buscavam estar alinhados com as linguagens de modernidade europeias e se afastar do que era considerado um ranço historicista do Império. Os grandes nomes dessa corrente aqui foram Carlos Eckman e Victor Dubugras (já mencionado no item 2.1), ambos estrangeiros, mas que fizeram as obras mais significativas de suas carreiras no Brasil. ${ }^{86}$

Assim como nas obras desses arquitetos, a preocupação com o desenho dos detalhes ornamentais é vista no Edifício Principal do Instituto. É o caso da escadaria de acesso ao pavimento superior, em madeira; dos caixilhos com motivos florais, e das pinturas que puderam ser identificadas em análises estratigráficas. Porém, a maioria desses elementos são bem mais simplificados do que os da Vila Penteado e da Escola Álvares Penteado, talvez pela própria austeridade exigida para o programa, ou mesmo por questões orçamentárias e de prazos. Além disso, a volumetria do edifício, com alas laterais avançando até a parte posterior, lembra ainda os palácios ecléticos do século XIX.

Quanto a sua preservação, percebe-se que, ao longo do tempo, foram mantidos os usos originais, de laboratórios, biblioteca e administração, mudando apenas a respectiva localização no edifício. Não houve mudanças significativas em sua volumetria, como acréscimos e remoções de área. No entanto, com a evolução das técnicas laboratoriais, diversas adaptações tiveram que ser feitas para abrigar equipamentos, instalações elétricas, hidráulicas e mecânicas específicas e ambientes de pesquisa, resultando em dutos, aparelhos de ar condicionado,

\footnotetext{
${ }^{86}$ Do sueco Carlos Eckman, cabe destacar a mansão da família Penteado (que hoje abriga o curso de pós-graduação da FAU-USP), construída em 1902, com elementos do Floreal e com aquela preocupação de unidade em seus detalhes. Segundo COUTO in MARTINS(2012), ela pode ter sido inspirada no castelo Sterházy, do arquiteto vienense Carl Maria Georg Joseph Urban, de 1899, apresentando semelhanças com a vertente da Secessão vienense. A Escola de Comércio Álvares Penteado, no Largo São Francisco, é outro exemplo de Art Nouveau desse arquiteto.
} 
canaletas e divisórias necessários a essas atividades, bem como aberturas (conforme a queixa de Vital Brazil de 1924). Até 2015 o pavimento superior foi ocupado por laboratórios, mas hoje se encontra interditado devido a problemas de infiltração ainda não resolvidos. Os porões, que originalmente eram ocupados por máquinas e geradores, hoje são utilizados para laboratórios de farmacologia, com instalação inadequada, segundo os próprios pesquisadores. As características originais mais preservadas estão na ala da biblioteca, na qual revestimentos, ladrilhos e assoalhos do piso, portas e janelas, forros e alguns móveis são originais. Também é possível ver o trecho da estrutura em madeira do pavimento superior (figura 53).

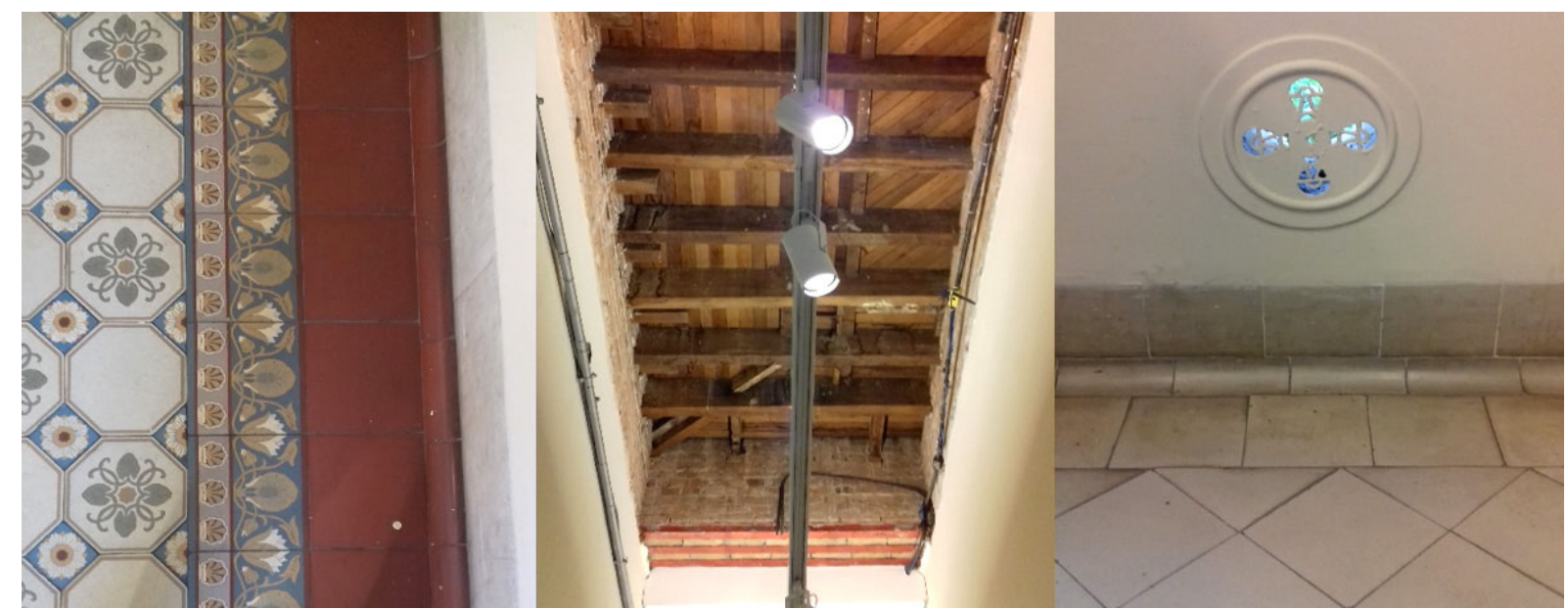

Fig. 53 - Alguns elementos preservados do edifício: ladrilhos e cerâmica com rodapés arredondados, estrutura do piso superior, rótula de ventilação. A estrutura do pavimento superior não era originalmente aparente (Fonte: autor, 2017)

O saguão de entrada mantém pisos em ladrilho hidráulico originais, com rodapés cerâmicos arredondados, para facilitar a limpeza. A escadaria em madeira também é preservada (apesar da interdição do andar superior), e pode-se ver na parede do saguão trecho de levantamento estratigráfico, demonstrando a existência de pinturas ornamentais originais, que hoje estão cobertas por tinta acrílica. Em relação aos revestimentos internos nos laboratórios, foram mantidos pisos e argamassas do pavimento superior. Mas os porões e algumas salas limpas (ver nota 17) receberam revestimentos específicos para os novos usos, como pisos cerâmicos, vinílicos ou emborrachados.

Relatórios da época da construção listam a compra de itens como cimento, areia e cal, o que pode indicar a utilização tradicional da argamassa de cal hidratada. Nos revestimentos externos, algumas séries de fotos mostram mudanças de coloração ao longo dos anos (figura 
55). Há cerca de 3 anos foram feitos reparos em fissuras das fachadas utilizando-se massa única industrializada ${ }^{87}$. Hoje, a pintura externa branca parece prejudicar a visualização de relevos e causar ofuscamento, dependendo da luz do dia.

Uma mudança significativa identificada na iconografia foi a substituição de trechos da cobertura em madeira por laje, em 1985, com vigas se apoiando diretamente em cintas de concreto, eliminando-se forros e telhas originais, e dando a impressão de que tais vigas se apoiam sobre as janelas. Além da localização insólita do apoio da viga (diante das paredes de alvenaria ao redor), esta parece superdimensionada para a carga de uma cobertura (figura 54).

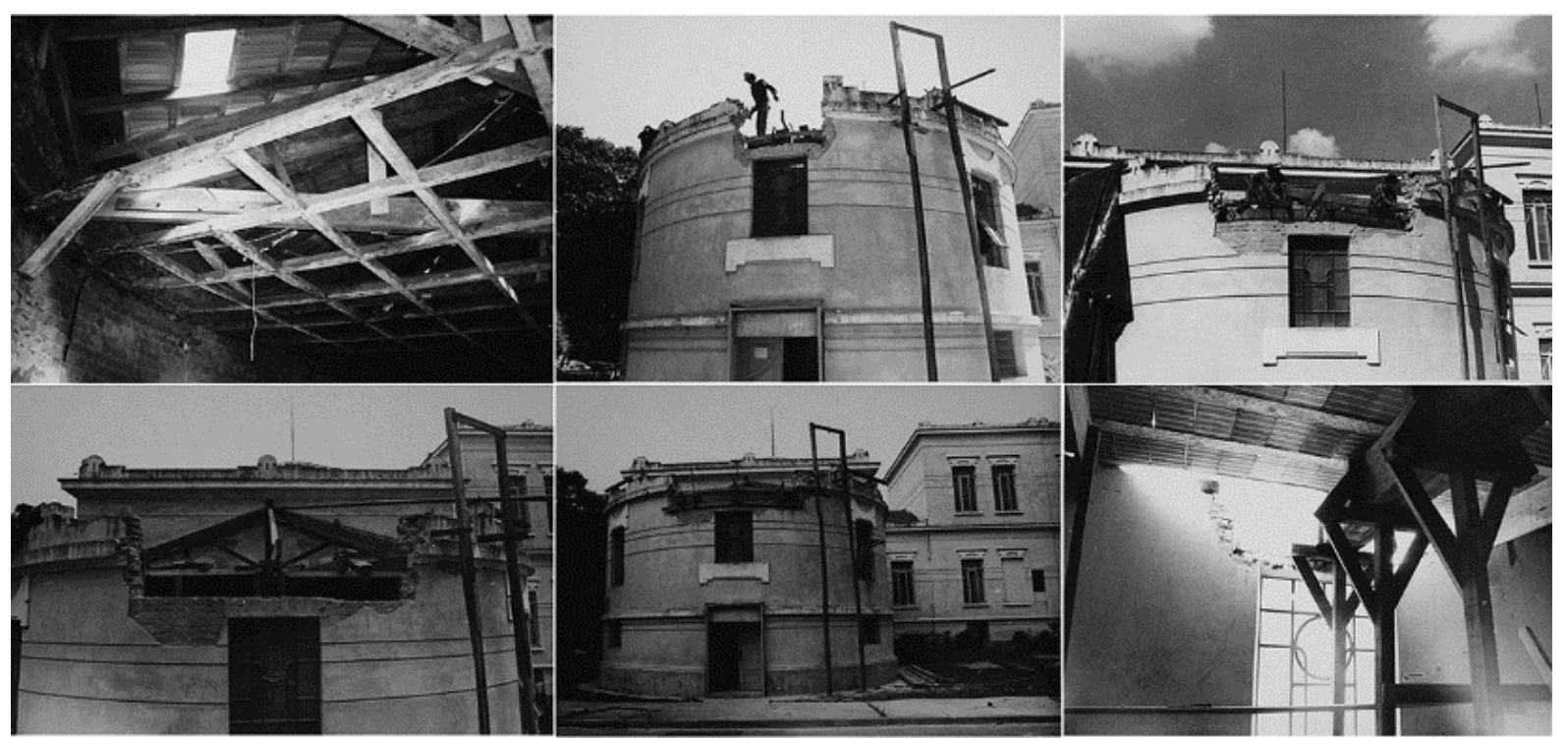

Fig. 54 - Reforma nas coberturas da alas posteriores em 1985: foram executadas lajes com vigas apoiadas em cintas de concreto sobre as janelas (Fonte: Acervo Ibu)

Tem havido nos últimos 10 anos algumas iniciativas em dois sentidos: manutenção dos elementos do edifício original remanescentes, e intervenções alterando-os de forma criteriosa. No primeiro caso, a volumetria externa, os caixilhos, revestimentos cerâmicos internos, assoalhos, parquetes e alguns mobiliários têm sido bem preservados, principalmente na ala da biblioteca, enquanto nos laboratórios (especialmente do subsolo) há uma descaracterização generalizada, devido às necessidades de uso. Já no segundo caso, de alterações seguindo critérios

\footnotetext{
${ }^{87}$ Dá-se o nome de "massa única”, “emboço único" ou "emboço paulista” ao revestimento que, aplicado sobre chapisco, desempenha ao mesmo tempo a função de emboço e reboco, ou seja, substitui as duas camadas mais externas comumente aplicadas em alvenarias, e hoje é produzida industrialmente, bastando acrescentar-lhe água. No entanto, o aspecto final dessa massa é mais "grosseiro", uma vez que utiliza areia média, enquanto o reboco tradicional utiliza a fina. Com isso, podem haver diferenças não só na textura, como na coloração, absorção de umidade e dilatação, criando contrastes entre as áreas originais e as "restauradas".
} 
conservativos, a identificação de procedimentos como o levantamento estratigráfico no saguão de entrada (figura 58), a exibição do forro sobre a circulação da biblioteca, e alguns projetos de restauro, mostram a preocupação mais sistematizada em relação à preservação.

Quanto a esses projetos, foi identificado estudo de 2011 que propunha o uso para fins expositivos de todo edifício, mas não teve prosseguimento. O novo Plano Diretor traz projeto específico de restauro desse edifício (aprofundado no item 3.2), propondo a retirada de usos laboratoriais, e a ocupação com usos administrativos e culturais, listando as principais intervenções arquitetônicas. Tal projeto, já em desenvolvimento em nível executivo, encontrase em fase de aprovação nos órgãos de proteção do patrimônio, segundo equipe da DEA.

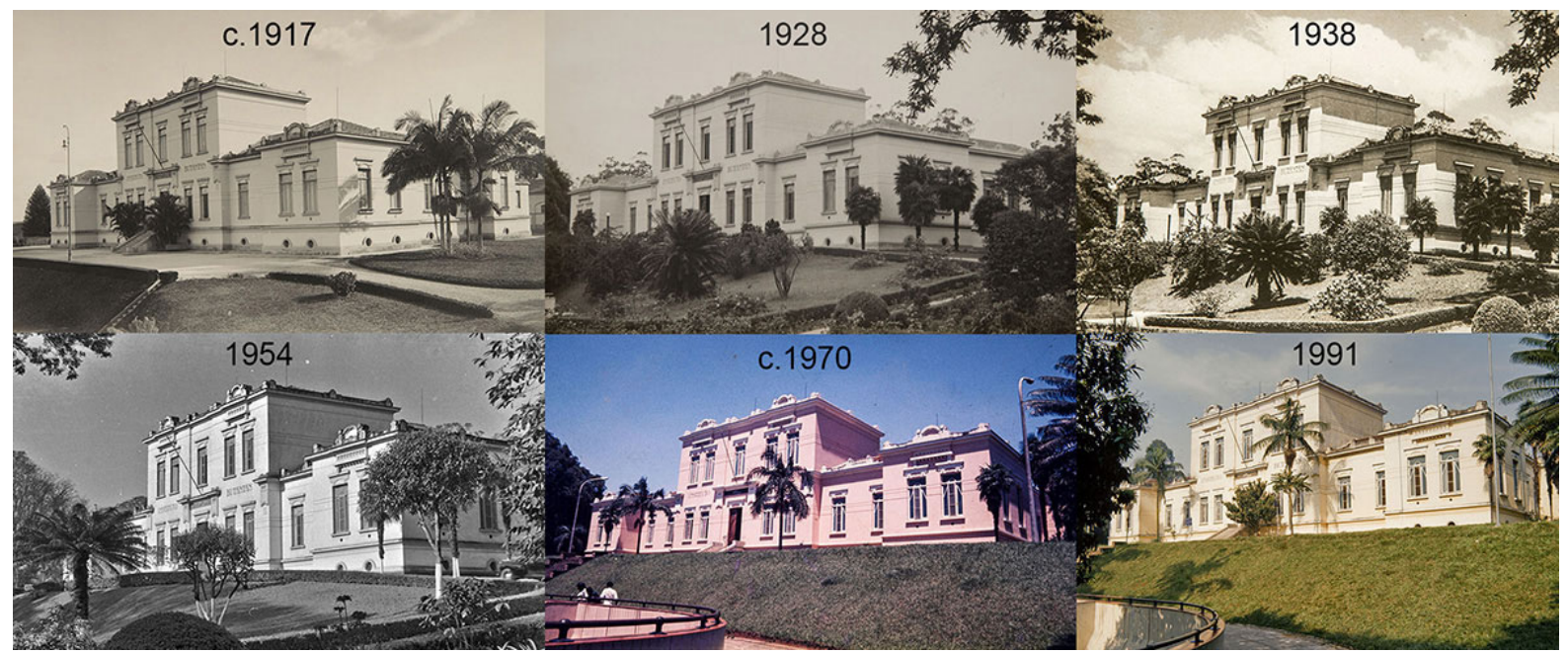

Fig. 55 - Vista frontal do Edifício Principal em diferentes épocas: os principais elementos arquitetônicos não sofreram alterações significativas (exceto a pintura). Percebe-se a grande variação paisagística do entorno (Fonte: Acervo IBu).

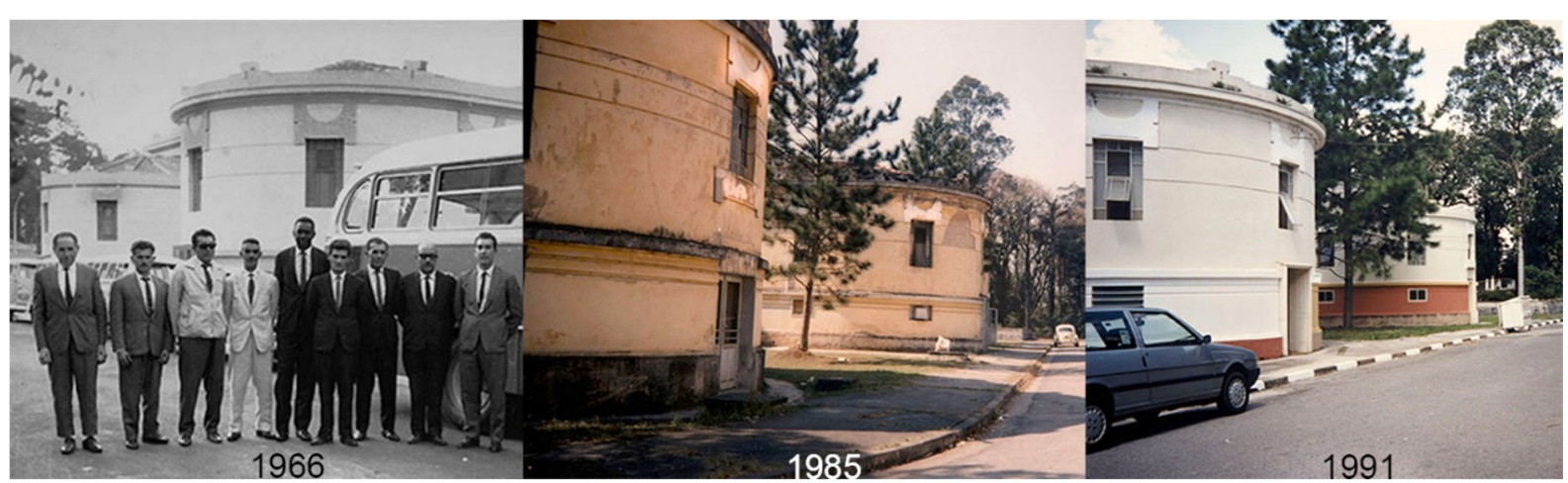

Fig. 56 - Vista da parte posterior em diferentes épocas: as variadas tonalidades e cores da pintura costumavam ser escolhidas pelas equipes de manutenção do momento. Hoje, as alterações precisam ser aprovadas pela Comissão Permanente de Acervo e pela equipe do novo Plano Diretor (Fonte: Acervo IBu). 

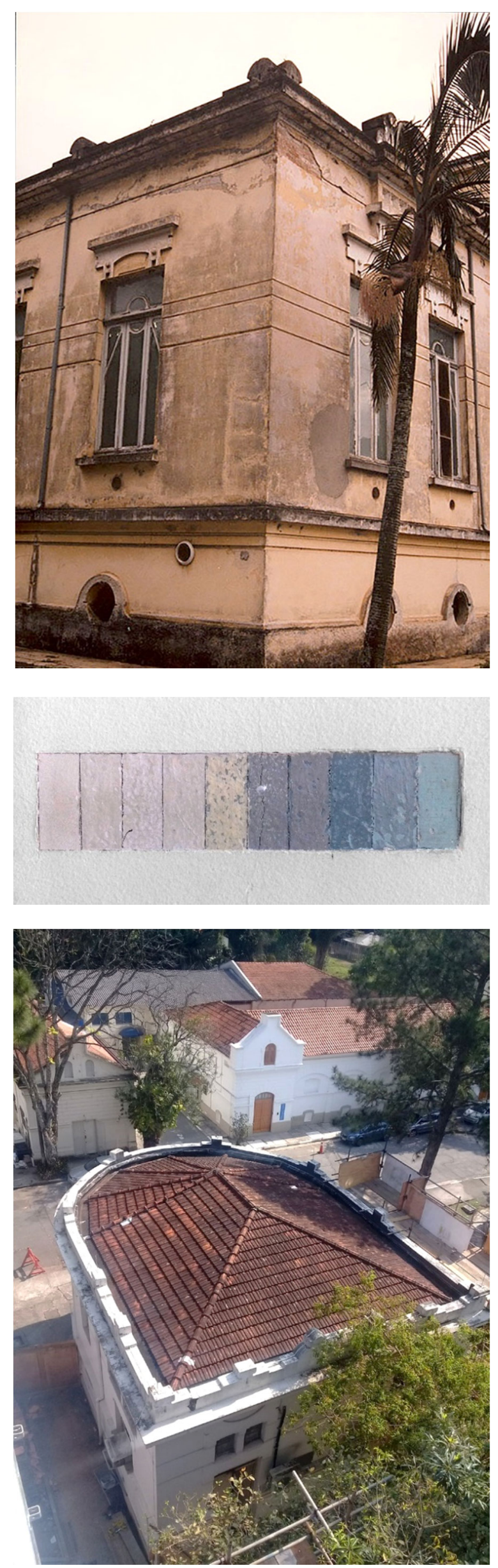

Fig. 57 - Detalhe da fachada em 1985: as principais ações conservativas e restaurativas nas fachadas se referem a destacamentos de argamassa, deterioração da pintura das paredes e caixilhos, sujidades provocadas por umidade ascendente e atmosférica. Não há uma diferenciação entre a pátina natural da idade e as patologias descritas nessas ações (Fonte: IB_ICO_009086).

Fig. 58 - Levantamento estratigráfico do saguão de entrada: nota-se a diferença entre as tonalidades azuladas e acizentadas mais antigas e os brancos e amarelados recentes. (Fonte: autor, 2017)

Fig. 59 - Cobertura da rotunda, que hoje abriga laboratórios. Em segundo plano, o conjunto da antiga Cocheira-enfermaria (Fonte: autor, 2018) 


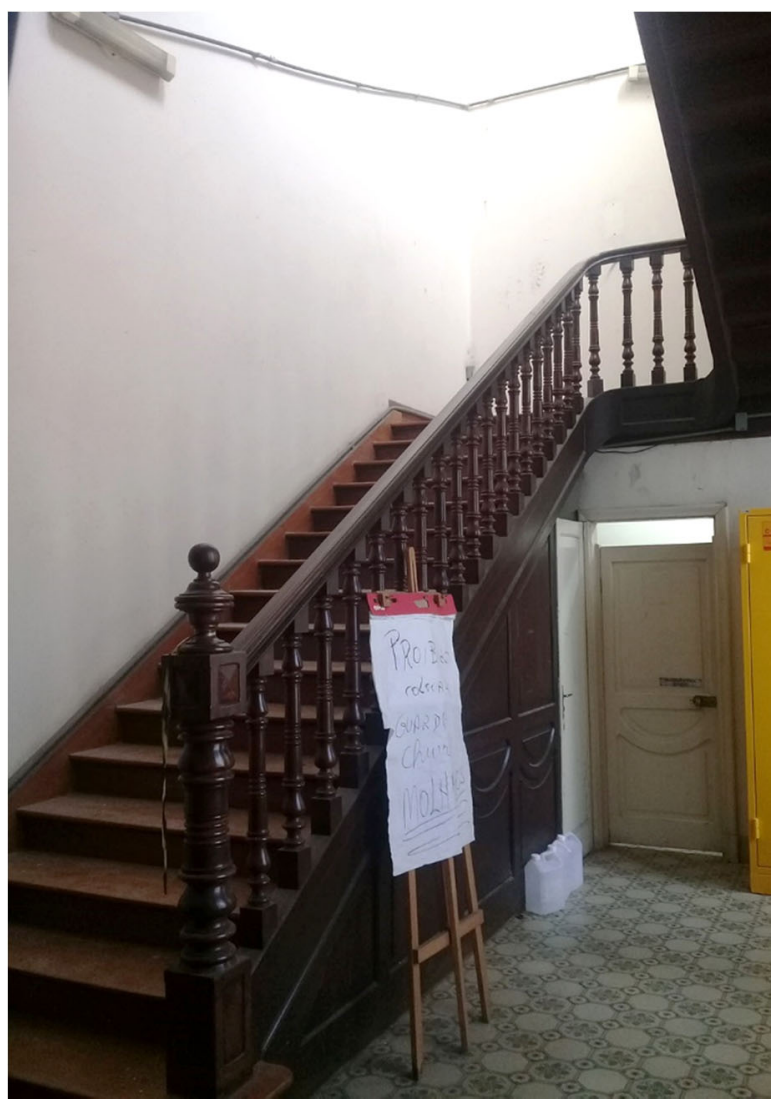

Fig. 60 - Escadaria original em madeira: hoje o andar superior está interditado devido a infiltrações, que devem ser objeto de reforma (Fonte: autor, 2018)
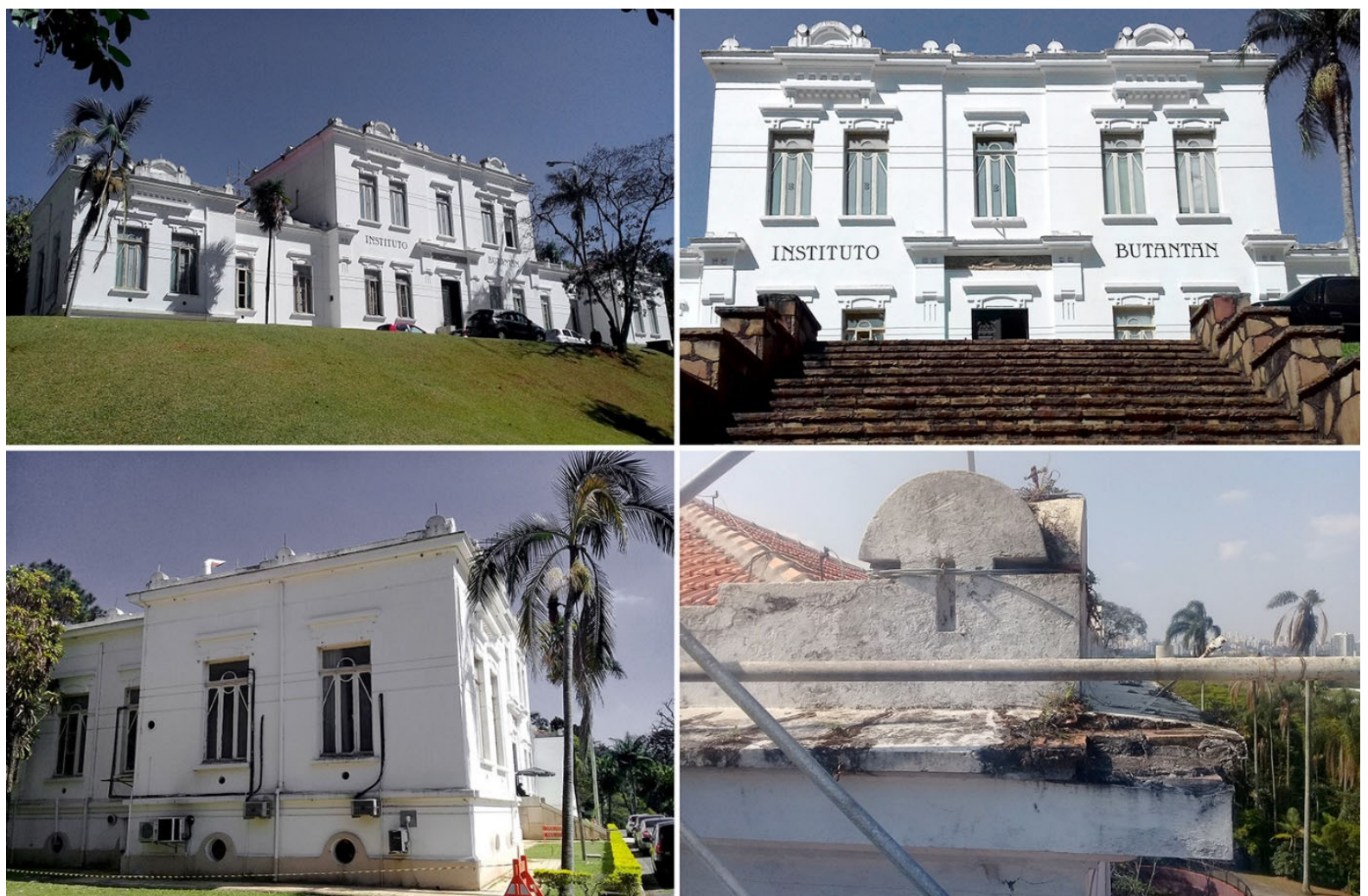

Fig. 61- Edifício Principal hoje: renovação de pintura, cobertura e caixilhos visam à manutenção dos aspectos técnicos e estéticos do prédio, mas ainda há interferências de instalações que devem ser solucionadas, segundo o novo Plano Diretor, com a mudança de uso (Fonte: autor, 2018) 

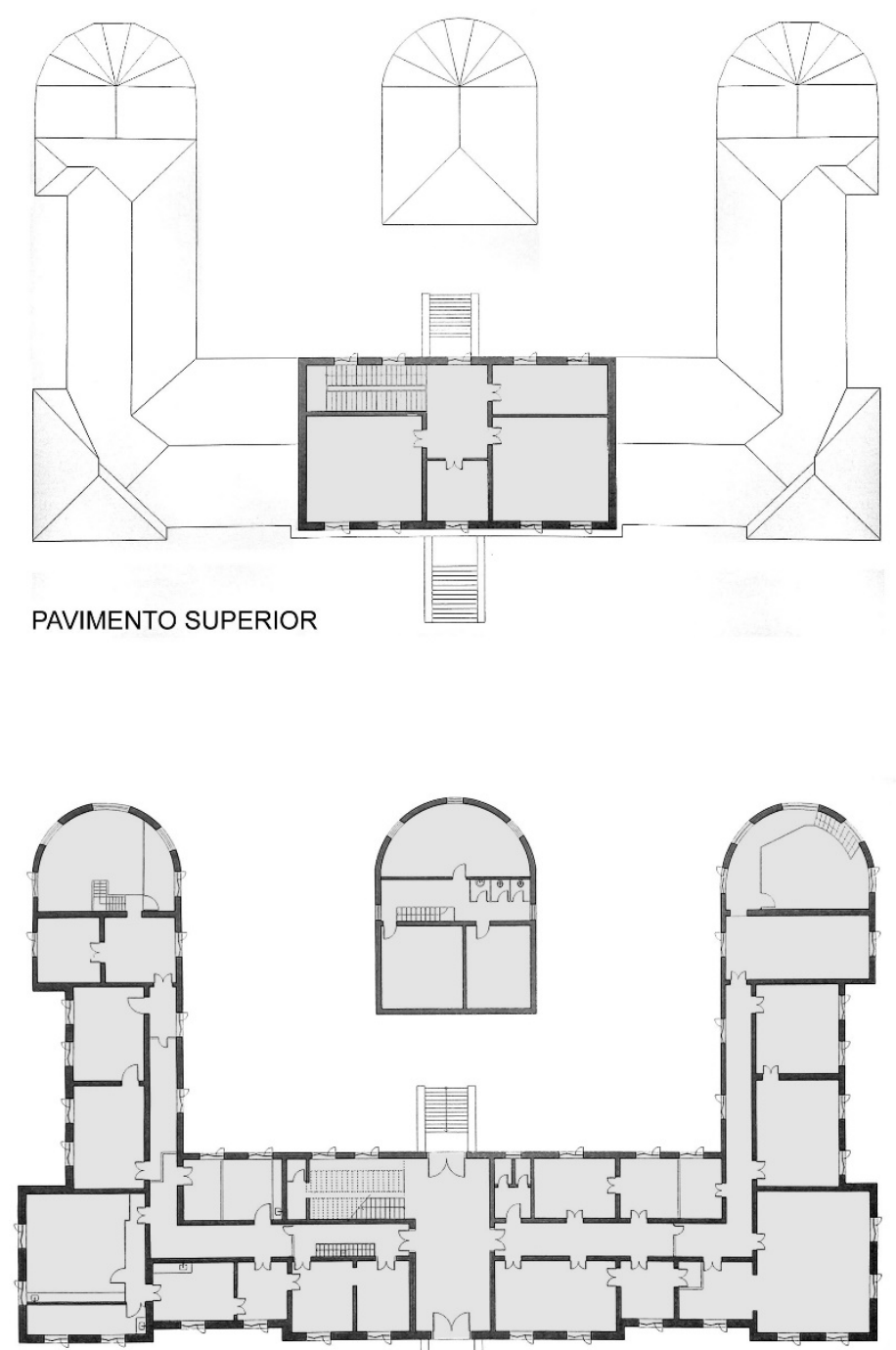

PAVIMENTO TÉRREO

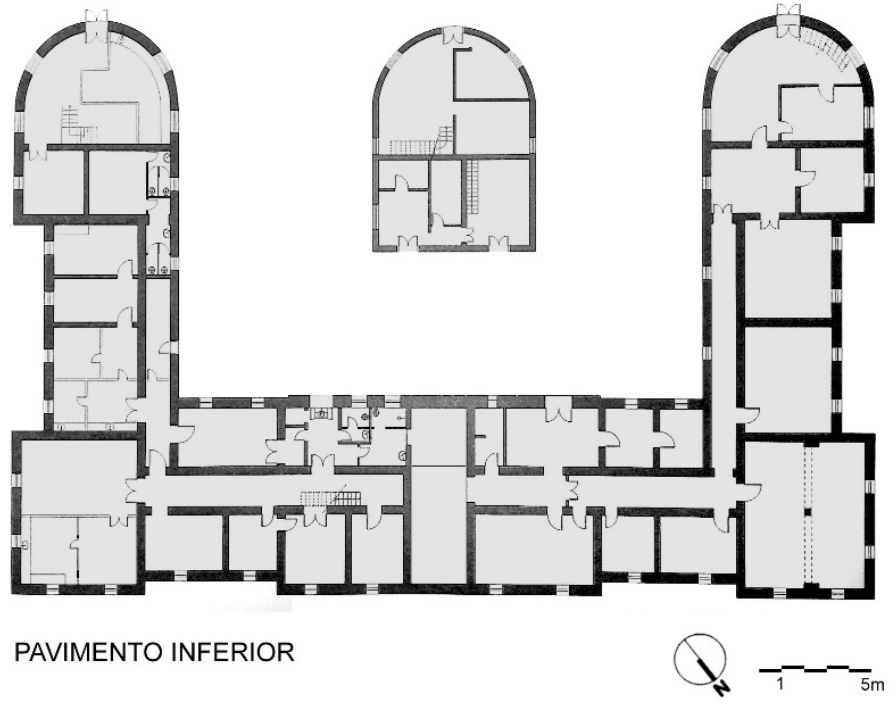

Fig. 62 - Plantas do edifício atualmente (Fonte: IBu, 2016, alterada) 


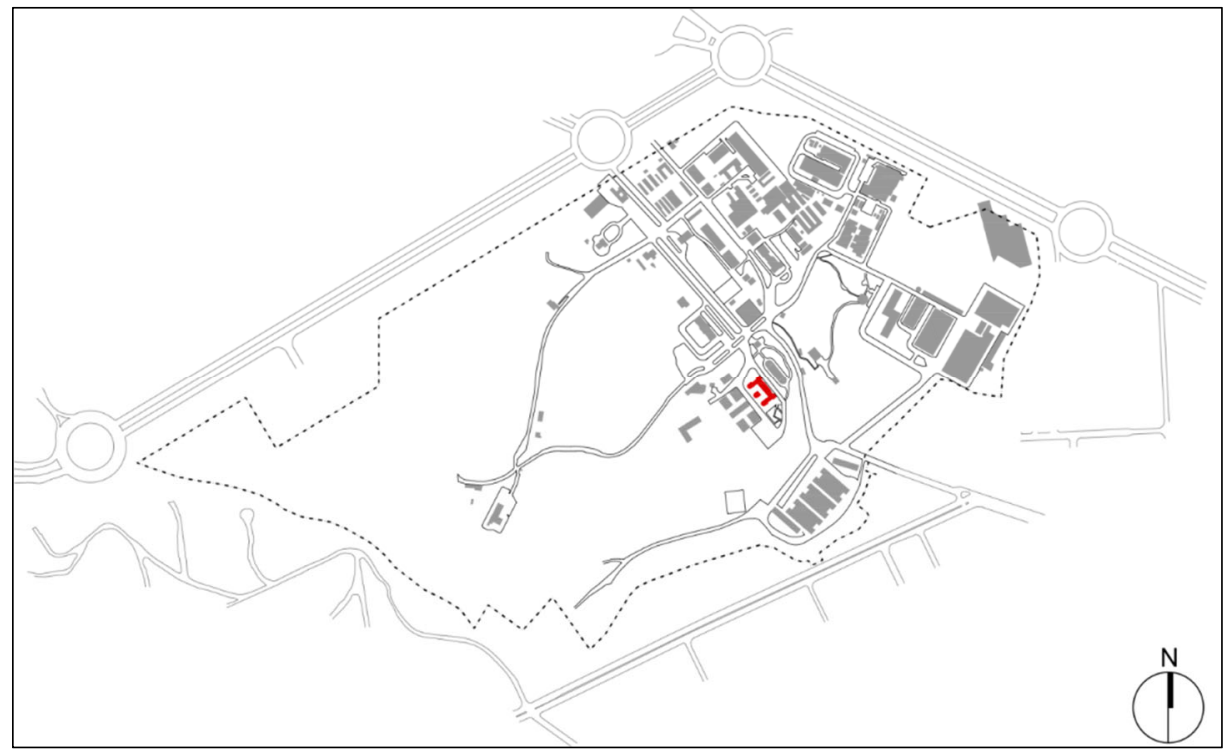

Figura 63 - Localização do Edifício Principal (atual Edifício Vital Brazil) em 2018 (autor)

\section{RESUMO:}

Categoria: edifício

Denominação original: Edifício Principal

Denominação atual: Edifício Vital Brazil

Autoria: Mauro Álvaro de Souza Camargo

Área original: c. $2500 \mathrm{~m}^{2}$

Área atual: $2500 \mathrm{~m}^{2}$

Número de pavimentos original: 1

Número de pavimentos atual: 2

Início-término da construção: 1910-1914

Itens arquitetônicos originais:

Estrutura: Alvenaria portante

Vedação: Alvenaria (tijolo maciço)

Revestimentos paredes externas: argamassa de cimento e cal

Revestimentos paredes internas: argamassa de cimento e cal

Revestimentos pisos internos: cerâmica, cimento queimado

Revestimentos pisos externos: cerâmica

Caixilharia: madeira

Uso original: laboratórios, biblioteca, museu, casa de máquinas

\section{Itens arquitetônicos atuais:}

Estrutura: original + concreto armado

Vedação: original + divisórias leves

Revestimentos paredes externas atual: original + massa única industrializada + tinta acrílica

Revestimentos paredes internas atual: original + tinta acrílica

Revestimentos pisos internos atual: originais + cerâmicos, vinílicos e emborrachados

Revestimentos pisos externos: cimento alisado

Uso atual: laboratórios, biblioteca, núcleo de documentação 


\subsubsection{Serpentários}

Desde sua fundação, o Instituto Butantan se tornou mais conhecido pelo seu trabalho de pesquisa e produção de soros antiofídicos. Nesse sentido, os serpentários têm sempre grande apelo visual ao público que visita o campus, além de sua função na criação de cobras para pesquisa científica. Desde o início dos trabalhos do Instituto, segundo os relatórios e notícias, já havia serpentários improvisados. Vital Brazil e sua equipe costumavam coletar espécies encontradas e recebidas, e o diretor criou um sistema de recebimento de cobras em troca de soro, principalmente de agricultores ${ }^{88}$, e isso necessitava a existência de recintos específicos para manter as espécies. Já existia um serpentário modesto nos primeiros anos, mas foram construídos outros mais sofisticados (de acordo com requisitos científicos da época) juntamente com o Edifício Principal, um deles destinado às espécies não venenosas (figuras 64 a 67) e outro às venenosas (figura 68), que, segundo ANDRADE, PINTO e OLIVEIRA, foram os primeiros do Brasil para fins científicos ${ }^{89}$. O relatório de 1912 descreve suas características:

Em frente ao grande edifício foi construído um grande serpentário, destinado a guardar o grande número de cobras que do Interior são enviadas ao Instituto. É circumdado d'água, que corre em um canal, cuja parede exterior apresenta um ressalto, que constitue um obstaculo sufficiente a sahida das cobras. N'essa installação estão as cobras em completa liberdade. No seu interior veem-se pequenos abrigos em forma de cupins, onde as serpentes se escondem e se protegem da acção do frio, do sol e da chuva. O serpentário está dividido em trez compartimentos: dois destinados a cobras venenosas e um a mussurana e outras cobras não venenosas. (RA1912, p.6)

Dois anos depois, a Revista Médica descrevia mais detalhadamente a utilização e as características construtivas dos dois serpentários, já concluídos,

As cobras são utilizadas no Instituto para dois fins dinstinctos: um o de fornecer veneno que serve para immunisação dos animaes produtores dos séruns antitóxicos; o outro o de fornecer material para observações de biologia com relação ao modo de vida de taes animaes na natureza.

Tem por este motivo o Instituto duas instalações; destinada uma, ás serpentes venenosas, a outra ás serpentes não venenosas.

\footnotetext{
${ }^{88}$ Segundo os relatórios, esse sistema perdurou até 1986, quando foi abolida a entrega de soros em virtude da crise financeira do Instituto.

${ }^{89}$ Anteriormente havia no Brasil serpentários para criar animais de exposição ou estimação, sem “estrutura e funcionamento razoavelmente complexos e diferenciados, pessoal altamente qualificado e programas permanentes de vigilância, revisão e aperfeiçoamento do sistema" (ANDRADE; PINTO; OLIVEIRA, 2002, p.183).
} 
A primeira é o serpentário, colocado em frente ao Instituto.

Consta de uma área de cerca de 500 metros quadrados, cercada por um canal de um metro de largura, tendo na parede externa um muro de 1,50 m. de altura, de faces lisas na parte interna, e na parede externa apenas de 50 centimetros.

A parede externa do canal, bem como o muro que a continúa, são a prumo e de faces lisas, de modo a impossibilitar a subida das cobras e dos outros habitantes do serpentário; a parede interna tem um inclinação para dentro, de modo a facilitar a sahida dos animaes, que porventura caiam no canal ou que nelle venham banhar-se.

$\mathrm{Na}$ área, dividida em canteiros plantados de grama, encontram-se pequenos abrigos em forma de cupins, onde as serpentes podem se esconder e se protegem da acção do frio, do sol e da chuva. O serpentário está dividido em três compartimentos: dois destinados a cobras venenosas e um á musurana.

No canal encontram-se batrachios e peixes.

A outra instalação, verdadeira estação biológica, onde se encontram gramados e arvores diversas, é constituída por uma área de 400 metros, cercada como a primeira, por um canal que, cheio d'agua, oferece um excelente meio liquido para as espécies que vivem n'agua ou que gotam de banhar-se, impedindo ao mesmo tempo a fuga das mesmas, por não oferecer o indispensável ponto de apoio para que possam galgar a parte superior do muro, que se encontra na parede externa do canal. (Revista Médica de S.Paulo, no. 9, 1914, p.151-152)
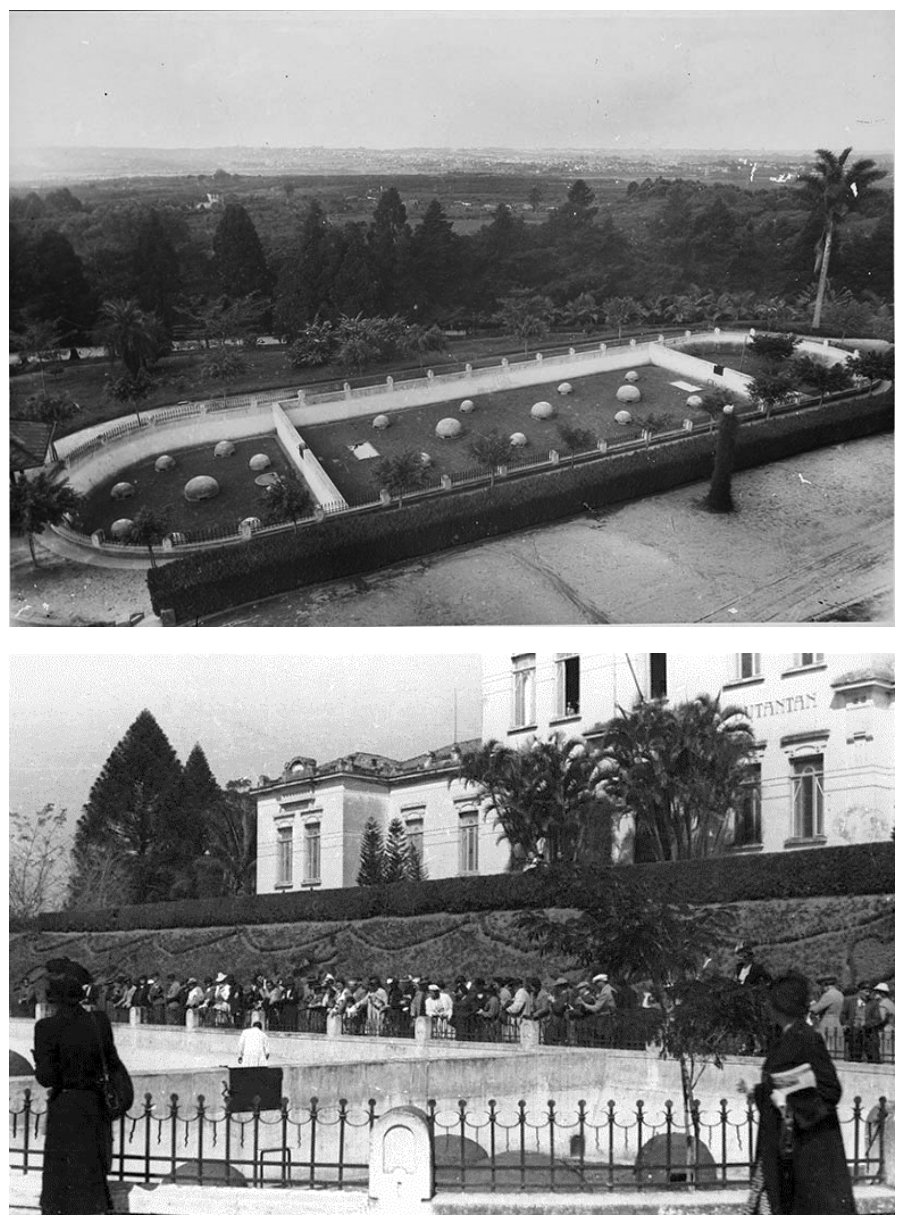

Fig. 64 - Serpentário de espécies venenosas em 1919, vista a partir do Edifício Principal: o ambiente das espécies já era em nível rebaixado, e a planta com extremidades semicirculares, mas os gradis eram diferentes dos atuais (Fonte: IB_ICO_008946)

Fig. 65 - Apresentações de extração de veneno no serpentário: vê-se o Edifício Principal ao fundo. Ainda não havia a escadaria de ligação entre os dois, e os gradis em ferro eram mais baixos e ornamentados, remetendo às formas sinuosas das serpentes e possivelmente à linguagem Art Nouveau de outros projetos de Mauro Álvaro no Instituto (Fonte: IB_ICO_010110) 

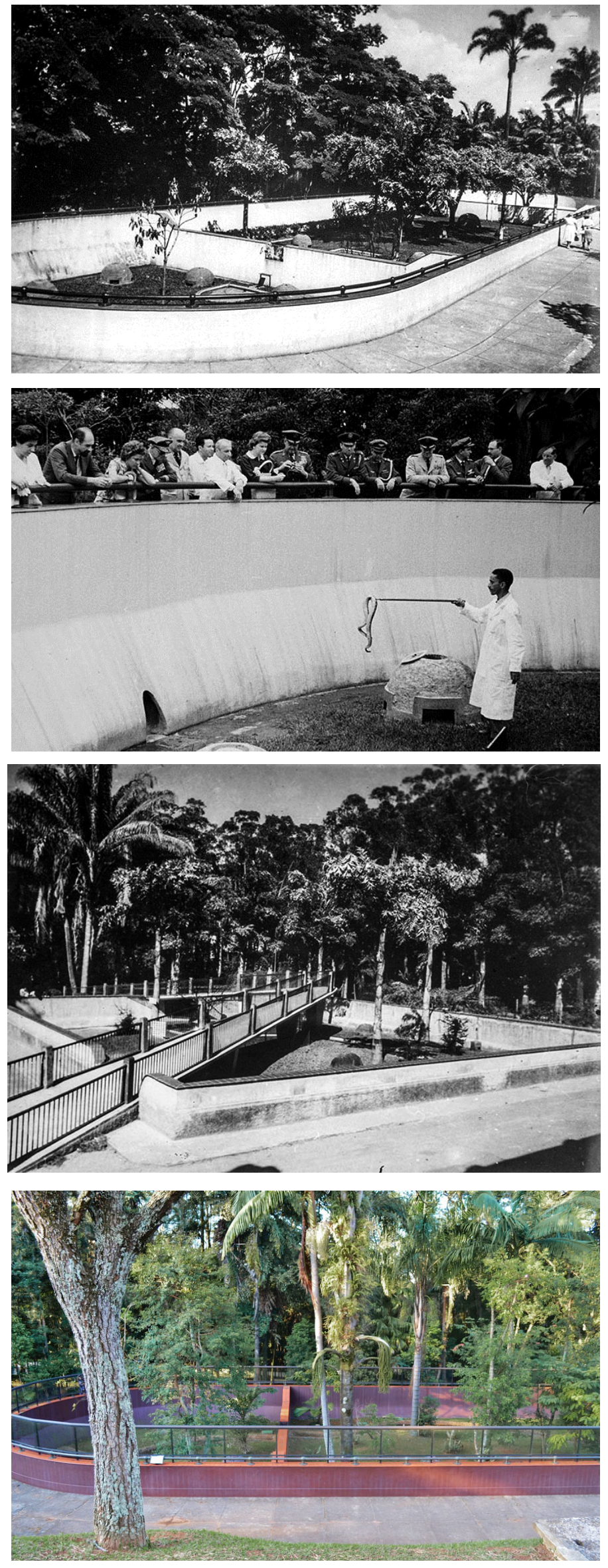

Fig. 66 - Serpentário de venenosas na década de 1950: os gradis ornamentados originais foram substituídos por um guarda-corpo mais alto e mais simples, e alterações técnicas e paisagísticas foram feitas internamente (Fonte: IB_ICO_000421)

Fig. 67- Demonstração para membros do governo militar com espécies peçonhentas, década de 1970 (Fonte: IB_ICO_010067)

Fig. 68 - Serpentário de espécies não venenosas, década de 1940: a ponte e o curso d'água deixam esse serpentário mais cenográfico que o de espécies venenosas (Fonte: IB_ICO_000422)

Fig. 69 - Serpentário de espécies venenosas hoje: elementos cerâmicos e guarda-corpos de vidro instalados em 2000 diferem bastante dos elementos originais, visando à segurança (Fonte: autor) 
As fotos da época mostram que os serpentários já eram recintos em nível rebaixado em relação ao terreno à sua volta, conforme a descrição acima. Mesmo seguindo alguns critérios alegadamente científicos para abrigar as serpentes, na década de 1920 o serpentário recebeu críticas de pesquisadores devido à elevada mortalidade das espécies, causando prejuízos à instituição. Em 1929, a diretoria planeja

[...] reformar o biotério annexo ao Laboratório Central e o cobril das especies venenosas, o qual está a exigir uma modificação radical, para servir realmente à finalidade de sua criação, isto é, à conservação de ophidios. Feita essa modificação, deixarão as serpentes de ser incommodadas repetidamente pelos empregados que acompanham as visitas, ficando, ao mesmo tempo, protegidas contra a irradiação solar e as intemperies. (RA 1929, p.12)

Em sua gestão, o diretor Afrânio do Amaral substituiu as superfícies de cimento, responsáveis pela mortalidade das espécies em climas muito quentes ou muito frios, e diminuiu a quantidade de água nos fossos, nos quais muitas serpentes se afogavam tentando se resguardar do calor excessivo (BENCHIMOL; TEIXEIRA, 1993, p.169).

Pode-se dizer que, sendo o Instituto vinculado principalmente ao ofidismo na memória geral dos visitantes, esses serpentários podem ser considerados seu maior símbolo físico no imaginário popular, inclusive com histórias insólitas como a de 1951:

No Instituto Butantã, ontem, por volta das 15 horas, Nejmour de Oliveira Lima de 20 anos, solteiro, bancário, morador à rua Eugenio Medeiros, 638, por ter brigado com a noiva, resolveu suicidar-se, atirando-se num serpentário, sendo mordido por diversas cobras. Nejmour foi removido para o Hospital Vital Brasil e dali para o Hospital das Clínicas, onde deu entrada em estado desesperador. Sobre o fato foi aberto inquérito. (Tentou suicidar-se. O Estado de São Paulo, 10/07/1951, p.8)

Quanto à sua conservação, reformas foram executadas em 1935, 1943 e 1970, considerando as necessidade de pesquisa e também as apresentações de extração de veneno para o público em geral, ressaltando o caráter turístico do Instituto.

Em relação ao serpentário para espécies não venenosas, encontraram-se poucas informações sobre sua construção, mas foram identificadas plantas da década de 1950, sendo que em 1953 o diretor relatou uma reforma desse espaço em tom de reclamação:

Ultimou-se igualmente a reforma do serpentário das não venenosas, embora se houvesse nela aplicado verba excessiva para as finalidades em vista, que são mínimas, sendo certo que não obedeceu aos melhores padrões de ordem técnica o projeto da construção de passadiço elevado, pelo meio dêsse serpentário, para o público em geral. (RA 1953, np) 
Observa-se que, apesar da queixa, o serpentário de não venenosas possui um projeto paisagístico mais elaborado que o principal, incluindo cursos d'água, espécies vegetais e passarelas que criam caminhos interessantes aos visitantes, talvez uma maneira de compensar a ausência de apresentações ostentosas da extração de veneno, criando um espaço mais cênico.

A conformação original desses serpentários se manteve estável até as crises dos anos de 1980 e 1990 por que passou o setor cultural e de pesquisa do Instituto, quando esses espaços passaram a sofrer principalmente por falta de manutenção, como se vê na notícia de 1999:

Há dois meses, a deterioração e o abandono dos prédios históricos do Instituto Butantã chegaram ao seu ápice. Com o rompimento do fundo do serpentário, as cobras entraram pela tubulação do esgoto e só foram recapturadas em plena Avenida Vital Brasil [...]. (Direção quer recuperar prédios deteriorados. O Estado de São Paulo, 01/08/1999, p.A10)

Devido ao incidente e com a proximidade das comemorações do centenário do Instituto, buscaram-se parcerias na iniciativa privada para recuperar os serpentários, através das quais se conseguiu a reforma que deu o aspecto atual do serpentário de venenosas:

A obra foi gerenciada pela construtora RA Pini e teve a participação de projetistas importantes, como Helena Saia, que conduziu a pesquisa histórica, e Benedito Abbud, que fez o trabalho de paisagismo. Tudo de forma gratuita. Diversas empresas, entre as quais a Santa Marina, Alcoa e Tintas Coral, também forneceram os materiais necessários para o trabalho, como o vidro e os canos de alumínio para o alambrado, as pedras decorativas e dos novos quiosques, as tintas etc.

O serpentário é uma área de $600 \mathrm{~m}^{2}$, escavada a cerca de $3 \mathrm{~m}$ abaixo do nível do solo e subdividido em três fossos, onde se distribuem cerca de 100 serpentes. Todas ficam ao ar livre ou protegidas por quiosques ou iglus - alguns dos antigos foram mantidos, para oferecer uma perspectiva histórica. A restauração não chegou a englobar a parte estrutural. O cimento da superfície foi arrancado, a terra foi trocada - há ali, agora, camadas diferentes e superpostas de terra - e equipamentos de drenagem foram instalados. Dois dos fossos passaram a reproduzir a paisagem da Mata Atlântica. Um terceiro passou a imitar o cenário do semiárido nordestino, a caatinga. [...]

As paredes de concreto da instalação são inclinadas para dentro, a fim de evitar que as cobras as escalem. Os fossos também são afastados da área de visita, e protegidos por um alambrado envidraçado de meio metro de altura, que impede a ocorrência de acidentes, mesmo com um visitante mais afoito. (Revista Construção São Paulo, nº. 2721, 03/04/2000, p.25) 


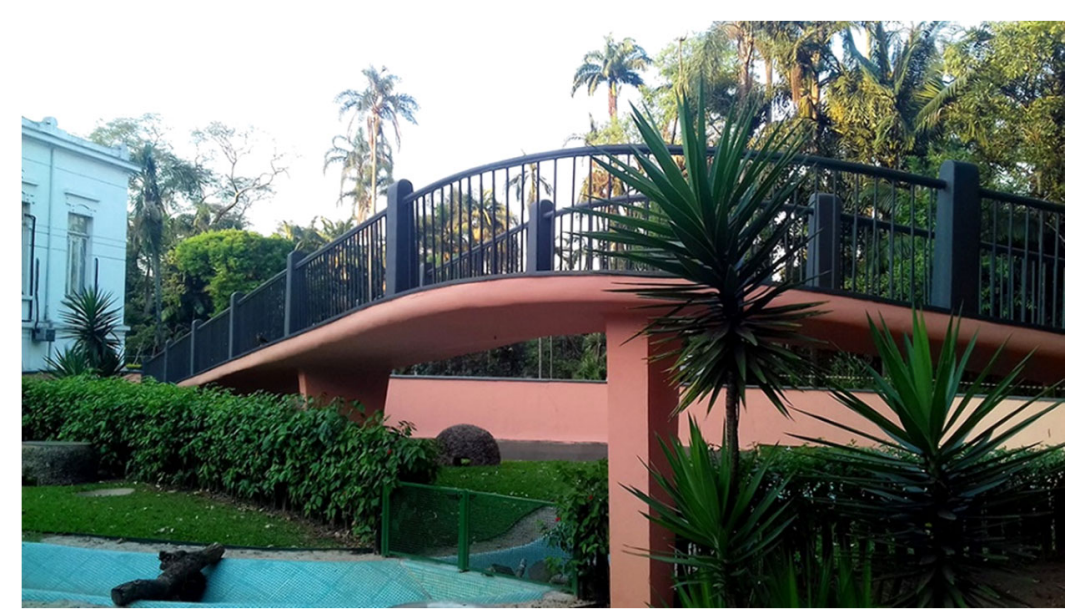

Fig. 70 - Serpentário de espécies não venenosas em 2018: mantém-se o caráter original (mas não se pode confirmar se as cores sempre foram essas). Em segundo plano, o Edifício Principal (Fonte: autor)

A manutenção dos iglus foi uma exigência do Condephaat na época. Hoje o serpentário principal (de venenosas) mantém as alterações realizadas em 2000 (figura 69), e recebe visitas para observação das serpentes. Mas a prática de extração de venenos foi abolida nos últimos anos, graças a novas posturas éticas da comunidade científica no trato com animais (ver nota 67). Em relação aos aspectos arquitetônicos, o serpentário principal perdeu algumas características originais, que incluíam gradis em linguagem Art Nouveau e revestimentos. Mas, pelas descrições das reformas, as alterações se deram para melhoria das condições de segurança e de sobrevivência dos ofídios.

O serpentário lateral (de não venenosas) está atualmente sendo reutilizado, depois de muitos anos vazio, como jardim e biotério de algumas espécies como tartarugas, portanto sem os mesmos fins científicos originais, mas com atrativos paisagísticos (figura 70). O Plano Diretor de 2016 propõe o restauro dos serpentários substituindo revestimentos e renovando pinturas. No caso do serpentário em frente ao Edifício Principal, está prevista a recuperação da escada que liga ambos, substituindo o mosaico português atual por granito levigado. Ao seu lado, aproveitando o talude gramado, deve ser construída uma arquibancada em madeira para observação do serpentário.

Nota-se hoje, também, que a massa arbórea ao redor e dentro dos serpentários cria relações paisagísticas que não existiam originalmente (até porque o plantio dessas espécies era recente), trazendo novos atrativos espaciais no percurso e observação dos visitantes. 


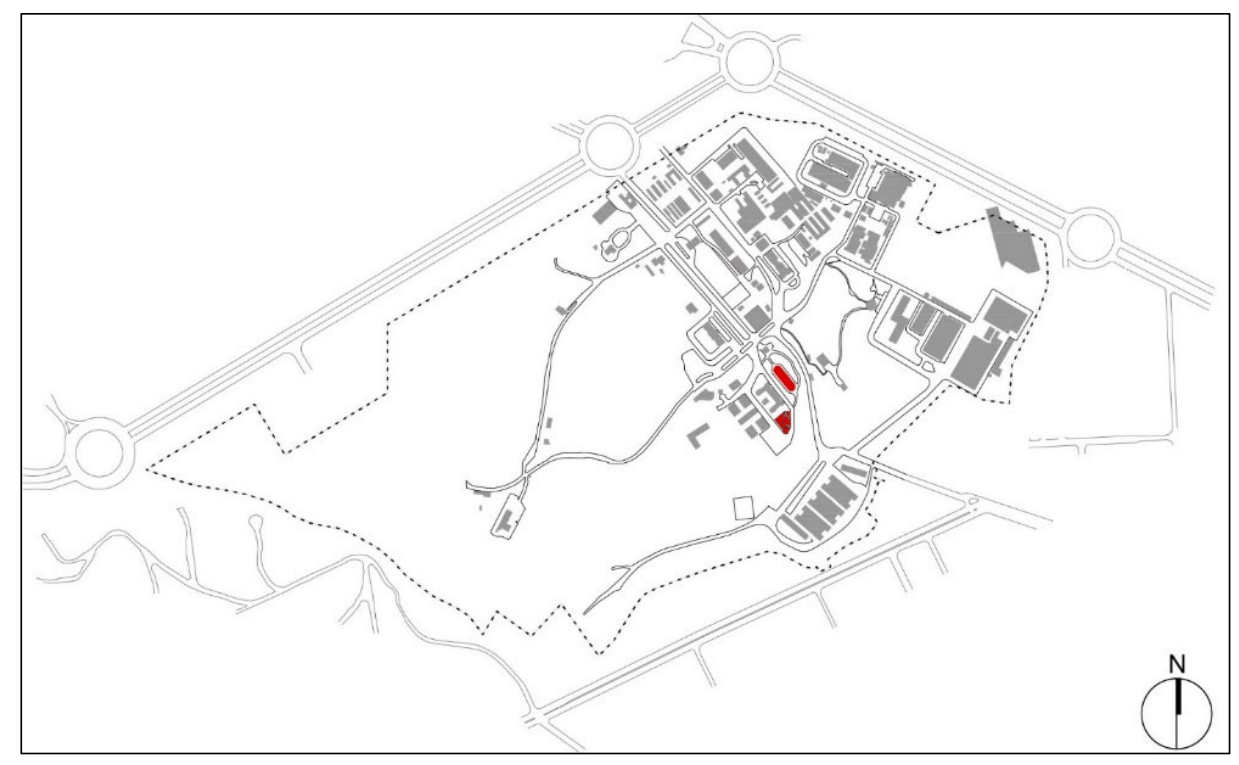

Figura 71 - Localização dos serpentários em 2018 (autor)

\section{RESUMO}

Categoria: edificações abertas

Denominação original: Serpentários

Denominação atual: Serpentários

Autoria: Mauro Álvaro de Souza Camargo

Área original: $440 \mathrm{~m}^{2}$

Área atual: $440 \mathrm{~m}^{2}$

Número de pavimentos original: 1

Número de pavimentos atual: 1

Início-término da construção: c. 1914

\section{Itens arquitetônicos originais:}

Estrutura: alvenaria portante e concreto armado

Vedação: alvenaria (tijolo maciço)

Revestimentos paredes externas: argamassa de cimento e cal, cerâmica

Revestimentos paredes internas: argamassa de cimento e cal

Revestimentos pisos internos: cimento desempenado e terra

Revestimentos pisos externos: cimento desempenado

Caixilharia: aço

Uso original: serpentário

Itens arquitetônicos atuais:

Estrutura: original

Vedação: original + guarda-corpos de aço e vidro

Revestimentos paredes externas atual: original + massa única industrializada + tinta epóxi

Revestimentos paredes internas atual: original + tinta epóxi

Revestimentos pisos internos atual: originais + cimento desempenado

Revestimentos pisos externos: cimento desempenado

Uso atual: serpentários 


\subsubsection{Biotério Central}

Os biotérios são espaços fundamentais nas pesquisas biomédicas, que exigem testes em animais de diversas espécies e portes. O Instituto Butantan teve vários biotérios, que foram modificados devido às constantes inovações dos tipos de pesquisas com animais, à multiplicidade dessas pesquisas e à rapidez com que esse tipo de construção se degrada. Ainda assim, há exemplares no Instituto que trazem valor patrimonial como registros da história da ciência e da sua arquitetura, do início do século XX. A função dos biotérios é abrigar animais para pesquisa, mas esses espaços podem ser de tipos diferentes conforme a espécie estudada, os objetivos do experimento, o tempo de permanência e os recursos disponíveis, podendo ir desde pequenas gaiolas até grandes recintos (como nos zoológicos). No caso do Instituto, há biotérios para coelhos, cães, macacos, ratos, e animais maiores. O que há de comum entre eles é a exigência de segurança dos animais e dos pesquisadores, materiais resistentes e facilmente higienizáveis, o que, do ponto de vista construtivo, resulta em uso de revestimentos monolíticos (sem juntas), resistentes a agentes químicos de limpeza e ao tráfego de equipamentos sobre rodas, sem frestas que possam proliferar insetos, e muitas vezes com controle de luminosidade e ruído ${ }^{90}$. Essas exigências e as técnicas de construção de biotérios evoluíram na história, e os exemplares presentes no Instituto aqui estudados, que representam um registro dessa evolução, são especificamente aqueles do conjunto do Biotério Central, listado no processo de tombamento do Condephaat.

Esse conjunto, localizado entre o Paiol (atual Centro de Difusão) e a Casa Sede da Fazenda (atual Casa Vital Brazil), na divisa com a CUASO, é composto por alas de celas para abrigar diversos animais de pequeno porte (figura 72). As primeiras celas teriam sido construídas em 1901, provavelmente pela própria equipe de infraestrutura do Instituto. Após isso, foi construído um biotério geral (figura 73), segundo o relatório de 1928:

À secção agrícola começou a directoria a dar novos elementos para o seu desenvolvimento e completa eficiencia, sem embargo dos recursos insuficientes com que conta o Instituto. Nella foi organizada definitivamente a secção de obras, tendose iniciado a construcção de um bioterio geral, para creação, em larga escala, de

\footnotetext{
${ }^{90}$ Para mais detalhes sobre requisitos e tipos de biotérios, ver ANDRADE, PINTO E OLIVEIRA (2002).
} 
coelhos, cobaias, pombos e outros pequenos animaes cujo preço prohibitivo no mercado tem consideravelmente onerado as verbas do Instituto. (RA 1928, p.8)

Em sua história, esse conjunto passou por diversas modificações e adaptações. Em 1931 foram construídas novas alas (figura 74), com celas apoiadas em apoios de concreto mais arejados para evitar proliferação de roedores, como ocorria com as celas de 1901, apoiadas sobre compartimentos de alvenaria. Em 1940 o relatório mostra uma planta do novo biotério de cobaias. No relatório de 1954, o diretor Afrânio do Amaral afirma:

No Biotério Geral, foram demolidas as instalações construídas no comêço do século e nos primórdios da vida do estabelecimento, para criação de cobaias. Achavam-se elas em péssimo estado de conservação e inteiramente minadas de galerias de ratos que ali mantinham uma situação de constante contágio com animais de criação. Achando-se igualmente mal conservadas as coelheiras, de que algumas haviam sido, em anos sucessivos e durante a minha ausência da directoria, destelhadas e desmontadas para aproveitamento de materiais, tratei de mandar fazer substancial reforma e modernização em todas elas. (RA, 1954, n.p.)

Foram então, em 1954, reformadas algumas celas, construídas novas, e demolidas as mais antigas. A figura 75 mostra o resultado dessa grande intervenção. Posteriormente, no final década de 1970, houve outra grande reforma onde diversas dessas celas foram demolidas para a construção de um novo biotério com técnicas construtivas mais atuais (concreto armado). Foi por ocasião dessa demolição que se encontraram supostos resquícios do primeiro laboratório do Instituto, dando ensejo à construção do Museu Histórico.

Dessa forma, o conjunto do Biotério Central que se vê hoje traz algumas partes dos anos de 1920, outras de 1954 e outras de 1980, salvo outras pequenas reformas ocorridas e não identificadas, formando um extenso conjunto em que coexistem partes de diversas épocas e técnicas construtivas. Hoje esse conjunto ainda é utilizado como biotério, com diversas adaptações, e sem acesso ao público. São basicamente alas de celas construídas em tijolo maciço, com caixilharia em madeira ou metal, e telhas em fibrocimento e de barro, conforme a idade e a finalidade dos biotérios específicos. 

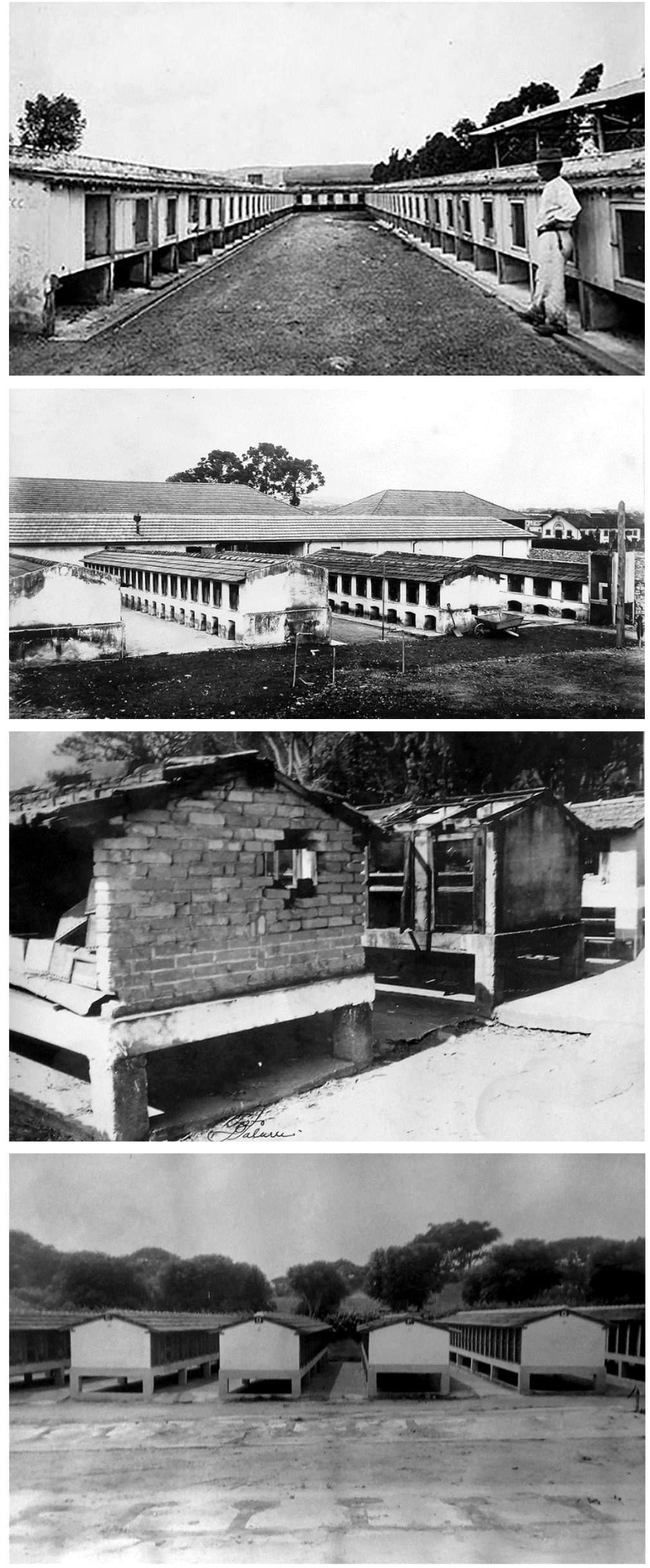

Fig. 72 - Biotério central em 1919: veem-se as celas denominadas coelheiras, que foram demolidas, em sua maioria, em 1954 (Fonte: IB_ICO_010256)

Fig. 73 - Biotério central em 1928: o conjunto inicial era formado por um corpo central com alas de celas, construídas em 1901. A maioria foi demolida em 1954 devido à infestação de roedores. Ao fundo, é possível ver as coberturas do Paiol e oficinas (item 2.3.10) e a cocheira "Cara de Cavalo” (item 2.3.9). (Fonte: RA 1928, p.18)

Fig. 74 - Biotério central em 1954 antes da reforma: veem-se as alas construídas em 1931, sobre bases de concreto, mas já deterioradas. (Fonte: RA 1954, p.35)

Fig. 75 - Biotério central em 1954 após reforma: veem-se as alas de 1931 reformadas. Em primeiro plano estão os vestígios das celas de 1901 demolidas nessa reforma (Fonte: RA 1954, p.36) 


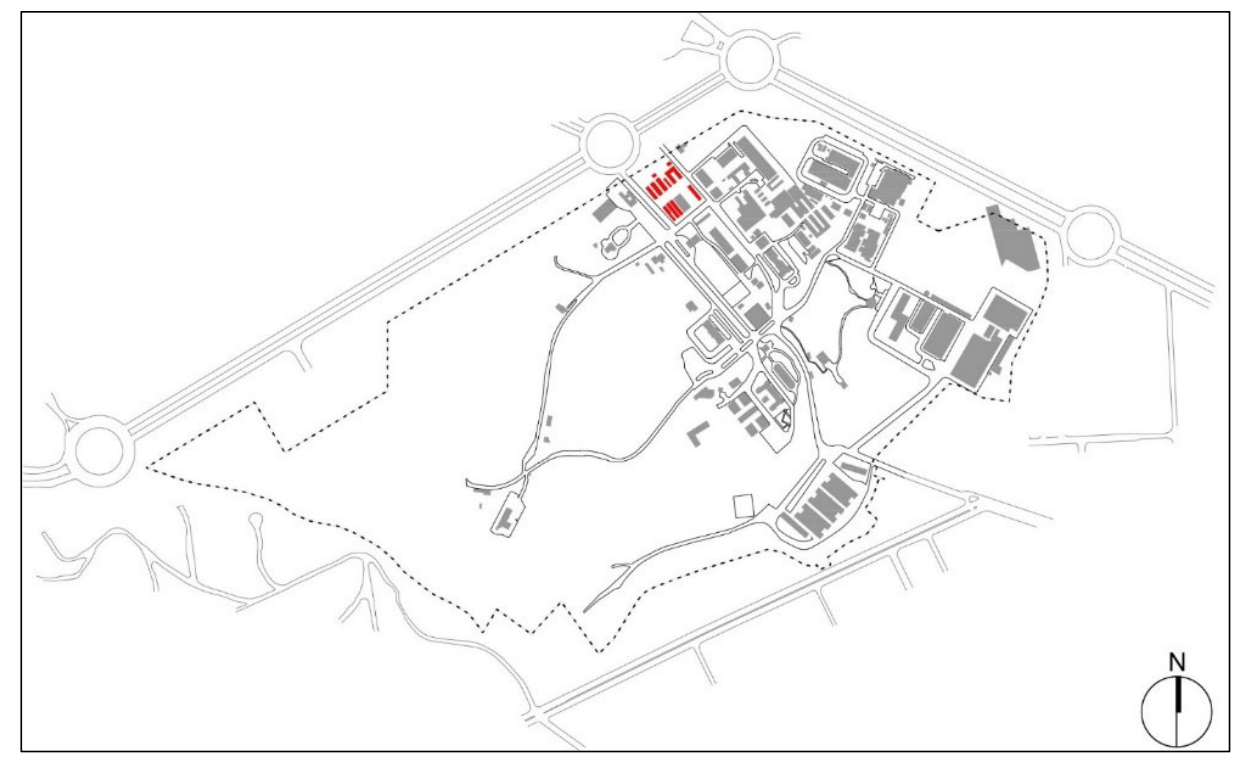

Figura 76 - Localização do Biotério central em 2018 (autor)

\section{RESUMO}

Categoria: conjunto de edifícações

Denominação original: Biotério Central

Denominação atual: Biotério Central

Autoria: desconhecida

Área original: c. $2500 \mathrm{~m}^{2}$

Área atual: $4100 \mathrm{~m}^{2}$

Número de pavimentos original: 1

Número de pavimentos atual: 1

Início-término da construção: 1901-1980

\section{Itens arquitetônicos originais:}

Estrutura: alvenaria portante e concreto armado

Vedação: alvenaria (tijolo maciço)

Revestimentos paredes externas: argamassa de cimento e cal

Revestimentos paredes internas: argamassa de cimento e cal, cerâmica

Revestimentos pisos internos: cerâmica, cimento queimado

Revestimentos pisos externos: cimento desempenado

Caixilharia: aço

Uso original: biotério

\section{Itens arquitetônicos atuais:}

Estrutura: original + concreto armado

Vedação: original + alvenaria (tijolo maciço)

Revestimentos paredes externas atual: original + massa única industrializada + tinta acrílica

Revestimentos paredes internas atual: original + tinta acrílica + tinta epóxi + cerâmica

Revestimentos pisos internos atual: originais + cerâmicos

Revestimentos pisos externos: cimento desempenado

Uso atual: biotério 


\subsubsection{Cocheira Central [Museu Biológico]}

O edifício hoje ocupado pelo Museu Biológico do Instituto Butantan foi originalmente uma cocheira construída em meados da década de 1910, destinada à imunização de cavalos para pesquisa e produção de vacinas e soros ${ }^{91}$. Diferentemente da Cocheira-enfermaria (item 2.3.3), aqui houve uma preocupação maior em seguir, em todo edifício, uma arquitetura considerada moderna na época, tanto do ponto de vista técnico como estético.

Desde as primeiros anos, o Instituto solicitou ao Serviço Sanitário verbas para construção de novas cocheiras, já que até aquele momento as existentes eram reaproveitadas da fazenda, sem elementos necessários para o trabalho científico, como superfícies facilmente higienizáveis e controles de luminosidade e ventilação. No relatório anual de 1912 foi mencionada a construção em andamento da cocheira para 50 animais. No relatório de 1915 foi enfatizada a necessidade de terminar a cocheira já em construção. Já a partir 1917 havia registros fotográficos mostrando a obra concluída. Nos seus primeiros anos, o edifício era circundado por terrenos não arborizados e vias ainda sem pavimentação, que receberiam posteriormente paralelepípedo (figura 77). Não foram encontradas menções à autoria, mas pela linguagem com elementos Art Nouveau, e pelo período de construção, é pertinente a hipótese de que seja do engenheiro-arquiteto Mauro Álvaro.

A primeira característica que se nota no edifício estudado é que, diferentemente da Cocheira-enfermaria, de planta pavilhonar, esta Cocheira Central possuía planta quadrada com pátio interno descoberto. Um mezanino criou um volume vertical marcando sua entrada. A construção original foi em tijolos de barro cozido, aproveitando a disponibilidade da olaria presente no terreno. As paredes do perímetro são espessas (até $50 \mathrm{~cm}$ ). Essa espessura visava dar resistência contra possíveis impactos com os animais, devendo ser paredes construídas com pedra ou tijolos. Esses tijolos receberam argamassa de cimento e cal e, de acordo com acervo fotográfico, foram pintadas com diferentes tonalidades nas empenas e nos relevos.

\footnotetext{
${ }^{91} \mathrm{O}$ edifício também é chamado em alguns relatórios de Cocheira de Imunização e Cocheira $\mathrm{n}^{\circ} .1$.
} 


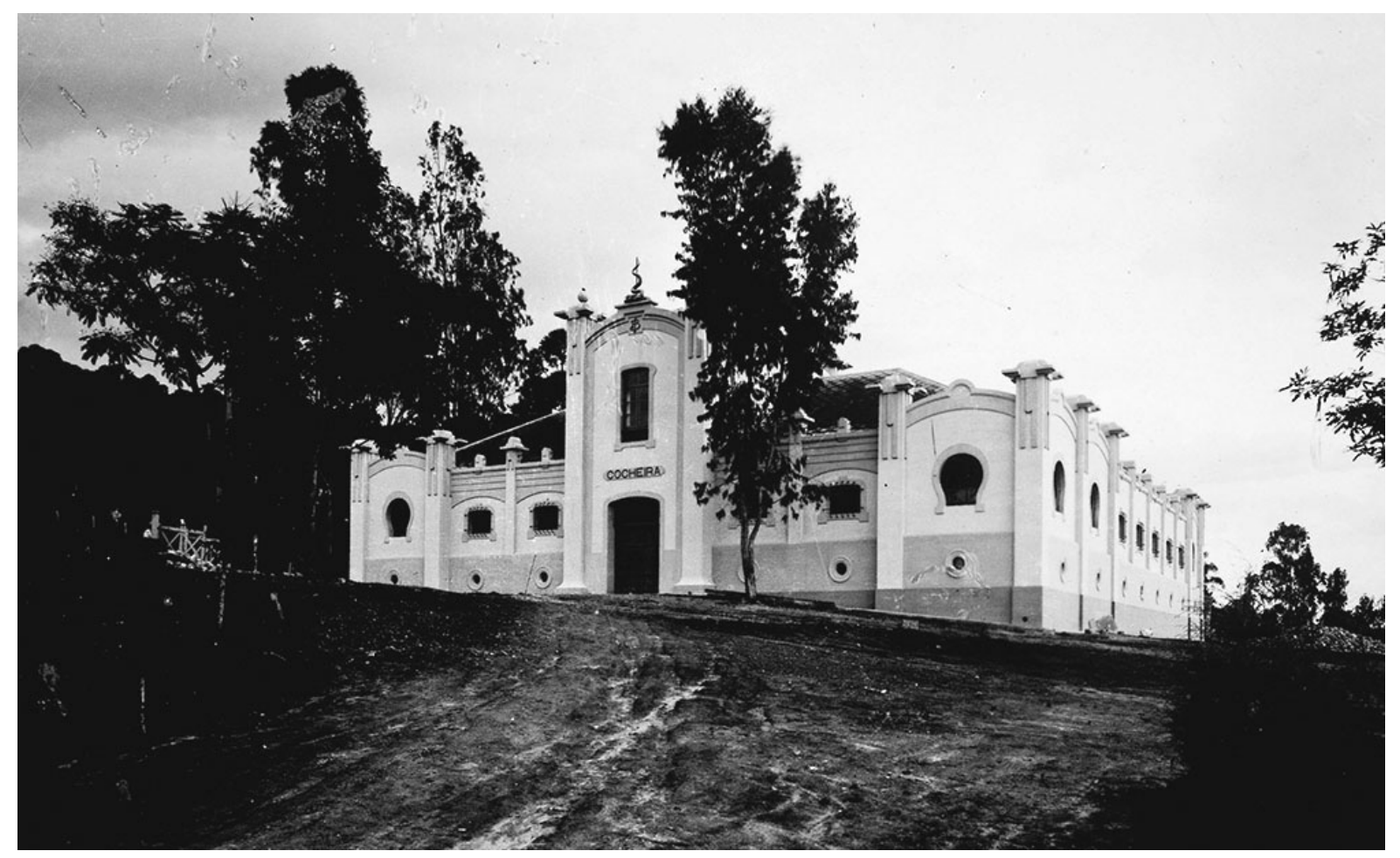

Fig. 77 - Cocheira Central em 1919: os acessos ainda não eram pavimentados. A volumetria, as aberturas e os elementos ornamentais são os mesmos de hoje. (Fonte: IB_ICO_008849)

A cobertura era originalmente em telhas de ardósia com estrutura em madeira. As portas eram duas, uma frontal e uma posterior em madeira maciça. As janelas eram de dois tipos: aquelas localizadas nos recintos dos animais eram mais altas e fechadas apenas com gradis. As do pavimento superior eram em folhas de abrir em madeira com vidro encaixilhado. O único registro do piso é o relato de obras posteriores citando antigas peças originais ${ }^{92}$.

Em relação à linguagem arquitetônica, como se viu, o edifício foge da estrito padrão utilitário das construções rurais, trazendo ornamentação em linguagem Art Nouveau, que ganhava espaço naquele momento principalmente pelas mãos de Dubugras, e foi adotada por Mauro Álvaro no Edifício Principal e provavelmente neste. A volumetria predominantemente horizontal é marcada por um torreão vertical na entrada que, sem elementos neoclássicos, remete a alguns edifícios como o colégio Santa Inês em São Paulo. Quanto à ornamentação e padrões das aberturas, nota-se que as janelas são curvas em forma de ferradura, e há uma escultura metálica representando uma cobra no topo do torreão, características que remetem à

\footnotetext{
${ }^{92}$ O filme "Combatendo o ofidismo", produzido pela Rossi Filmes, do acervo da Cinemateca Brasileira, mostra imagens do pátio central desse edifício sendo utilizado para a inoculação em cavalos, nas quais se podem ver as estruturas aparentes de madeira e os revestimentos do piso.
} 
função do edifício, recurso característico da chamada Architecture Parlante ${ }^{93}$ (figura 78). Essa simbologia também está presente em outros edifícios do campus, como a Escola de Veterinária (item 2.3.8), a Cocheira-biotério (2.3.9) e, em detalhes mais sutis, o Edifício Principal (2.3.4).
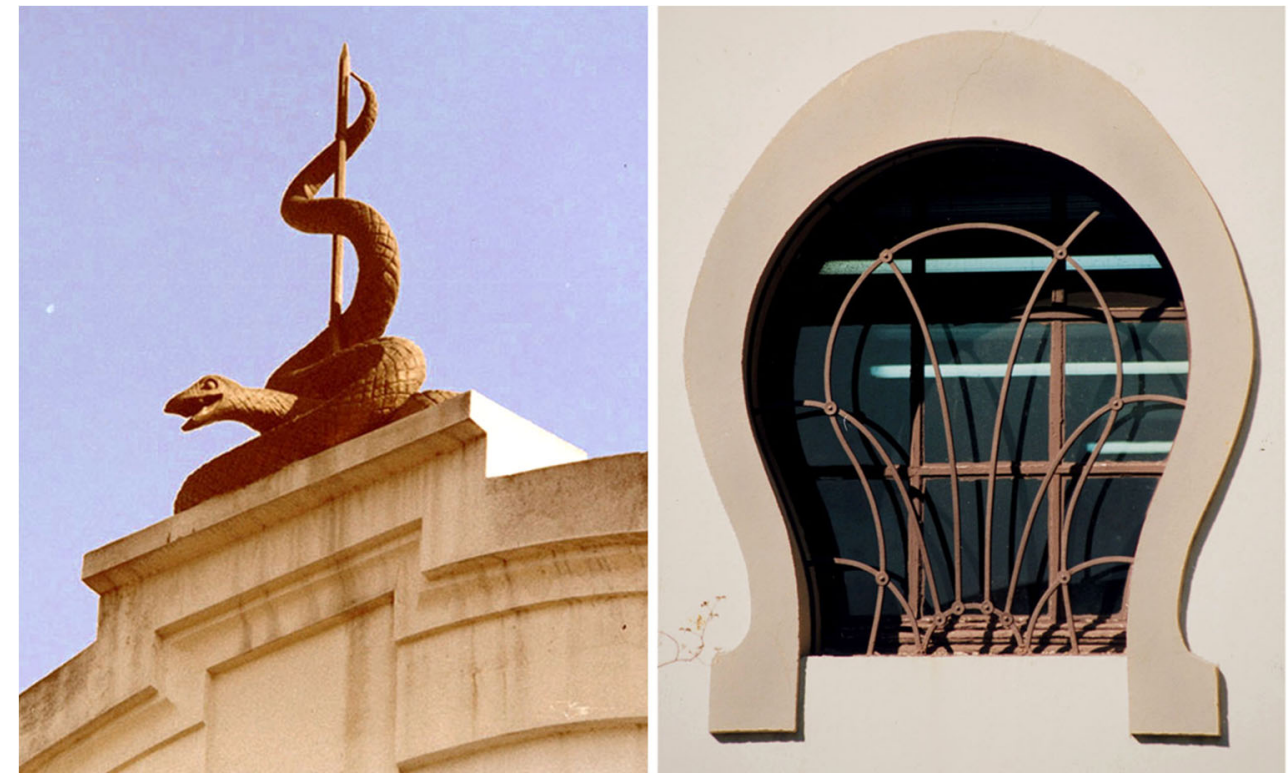

Fig. 78 - Detalhes da Cocheira: a escultura de serpente e a janela em forma de ferradura remetem às atividades desempenhadas no Instituto (Fonte: IB_ICO_009144 e IB_ICO_009066)

Chamam atenção os pináculos na platibanda de todo perímetro, com desenho geometrizado, característicos do Art Nouveau e semelhantes aos vistos na Estação de Mairinque e no projeto para o novo Viaduto do Chá (não executado) de Dubugras, em uma provável homenagem de Mauro ao seu mestre. Mas aqui esses elementos parecem carecer da proporção e dos espaçamentos daquelas obras, resultando em um volume mais "achatado" (figura 79).

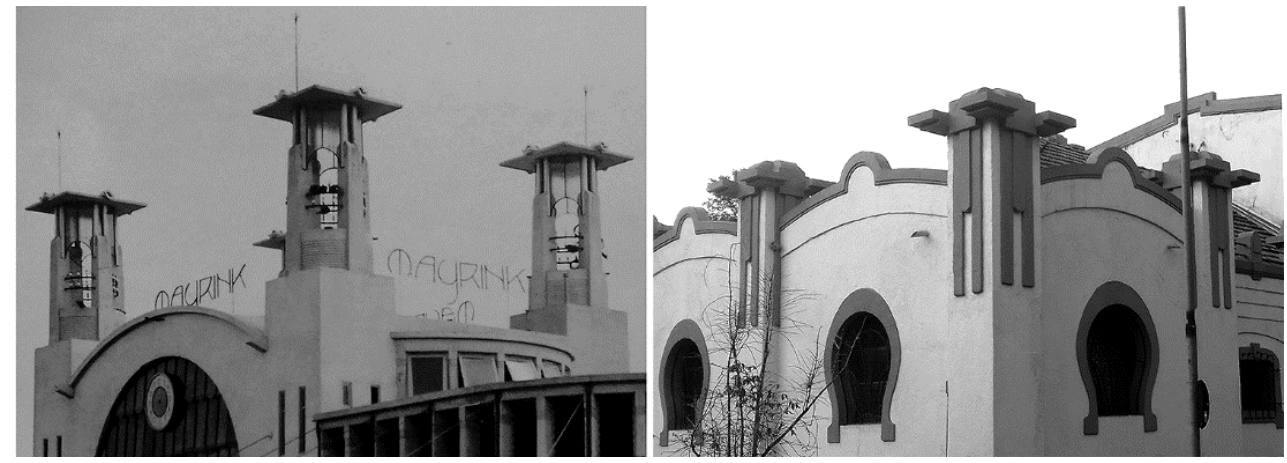

Fig. 79 - Detalhe da Estação Mairinque e da Cocheira: semelhanças nos pináculos podem ser uma referência à obra de Dubugras (Fontes: acervo de Nestor Goulart Reis Filho e autor)

\footnotetext{
${ }^{93}$ A linguagem chamada Architecture Parlante foi vinculada principalmente a arquitetos franceses do final do século XVIII (mas não somente), como Claude Nicolas Ledoux e Étienne-Louis Boullé, e se caracterizava por reproduzir, em suas formas e detalhes, elementos que remetiam à função do edifício
} 
Diversas modificações foram feitas no edifício, sendo que as primeiras ocorreram já nos primeiros anos, devido a vícios de construção ou inadequação ao programa. O relatório de 1919 informa que a Cocheira havia sido escurecida no ano anterior, para evitar moscas. Em 1922, foram feitas solicitações de:

[...] reforma completa do telhado, que no tempo das chuvas deixa penetrar agua nas baias, alagando-as, e substituição da madeira, já completamente apodrecida, das divisões do box, sendo isto elemento favoravel a infecções nos cascos dos animaes immunizados. O pateo interno ainda está descoberto e quando chove ou venta se torna difficil proceder-se às injeções e ao tratamento dos cavallos. (RA1922, p. 28)

O pátio citado pode ser visto na figura 80, e permaneceria descoberto até os anos de 1960.

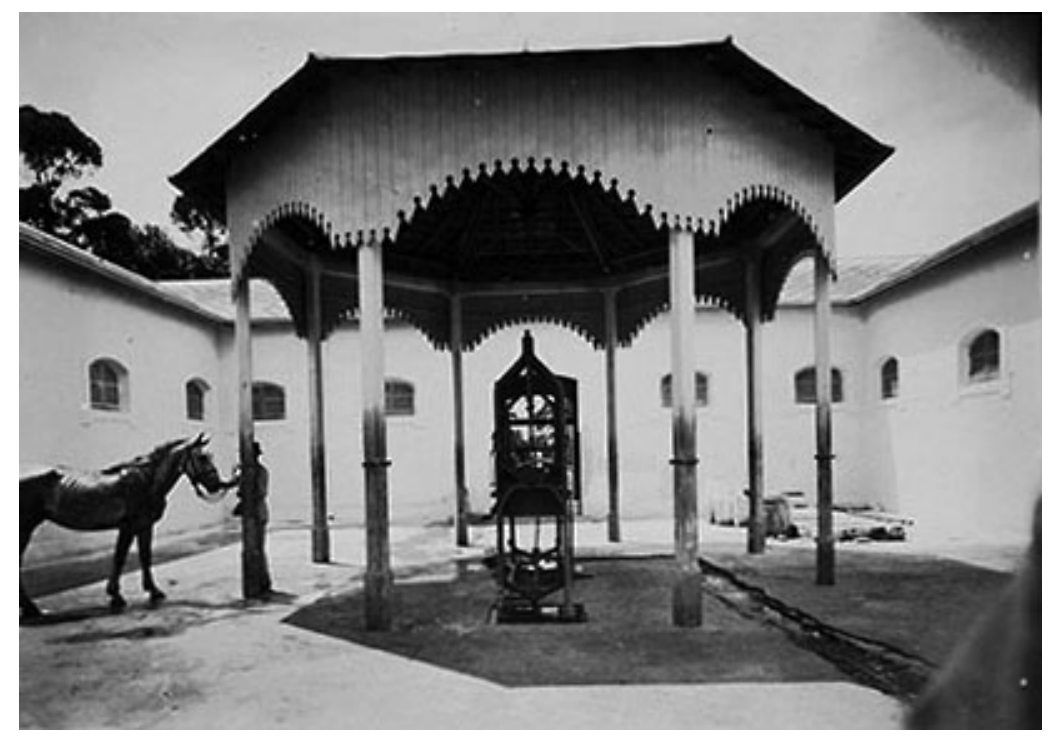

Fig. 80 - Pátio interno da Cocheira Central na década de 1920: usado para imunização de cavalos, esse espaço daria lugar ao auditório a partir da reforma de 1966 (Fonte: IB_ICO_010256)

A partir da década de 1930 passaram a ser feitas pinturas que não preservaram as tonalidades originais. Em 1942, o relatório traz a intenção de mudar o uso do edifício, convertendo-o em biblioteca, sala de conferências e administração. Isso se dá graças à diminuição das atividades com animais de grande porte no campus, devido à aquisição da Fazenda São Joaquim para esse fim. Em 1943 mencionou-se pela primeira vez nos relatórios a proposta de adaptar a Cocheira ao uso museográfico:

[...] onde funcionará um amplo museu educativo sôbre questões de ofidismo, de biologia em geral, de profilaxia e epidemiologia das molétias infecciosas. (RA 1943, p.10)

O plano de retirar o museu, instalado insatisfatoriamente no térreo da Casa do Diretor (item 2.3.13) já vinha de alguns anos, sendo que em 1953 o diretor Afrânio do Amaral relatou: 
A reforma do pesado edifício da antiga Cocheira foi projetada por mim já em 1938, a fim de dar sede condigna, em ponto central dos nosso terrenos, à Biblioteca, ao Museu com os respectivos mostruários e à Sala de conferências, numa unidade que, ao lado dos serpentários, é muito procurada pelos turistas e pelo público sequioso de informações técnicas. Essa reforma, embora iniciada, acha-se parada no momento. A Diretoria de Obras Públicas da Secretaria da Viação determinou, em 1952, fôsse atacada a obra pelo arrancamento dos velhos e preciosos ladrilhos que constituiam o piso da referida unidade. Infelizmente, alegando falta de verba, aquela Diretoria suspendeu, há vários meses, os trabalhos em andamento. (RA 1953, p.25).

Depreende-se, do trecho, que a obra de conversão já havia sido iniciada, encontrando-se interrompida, como ficaria por vários anos. Pelos relatórios, o planejamento dessa reforma foi feito inicialmente pela Diretoria de Obras Públicas. Mas durante esse hiato, em 1965, decidiuse fazer um projeto para instalar na Cocheira, já desativada, o Museu Biológico. Foi então solicitado o projeto à arquiteta Lina Bo Bardi, que desenvolveu estudos aproveitando o perímetro coberto e mantendo um jardim no pátio central, portanto respeitando características construtivas e espaciais do edifício. O projeto não teve prosseguimento, conforme a própria arquiteta afirmou posteriormente:

Alguns cientistas do Instituto Butantã queriam fazer um museu popular para apresentar o trabalho da instituição, especialmente aqueles ligados às aranhas, aos insetos pequenos e também às cobras. Aí me chamaram e eu comecei a fazer o estudo. Mas não havia dinheiro, como de costume. Teríamos conseguido fazer o museu num dos pavilhões 'art nouveau', lá no jardim do Instituto, muito bonito. Mas o governador, parece-me Jânio Quadros, instalou ali uma cavalaria militar. Aí o museu foi esquecido. Depois eles fizeram uma coisa decente, mas não era do porte das nossas ilusões. (FERRAZ, 1993, p.174)

Na verdade, Jânio foi governador de 1955 a 1959, enquanto em 1965 (data dos estudos) era Ademar de Barros, o que pode denotar um lapso de memória da arquiteta, ou que o início dos contatos foi anterior ao da apresentação. De qualquer forma, nas tratativas entre Lina e a diretoria é descrito o estado de conservação sofrível do edifício naquele momento (figura 81).

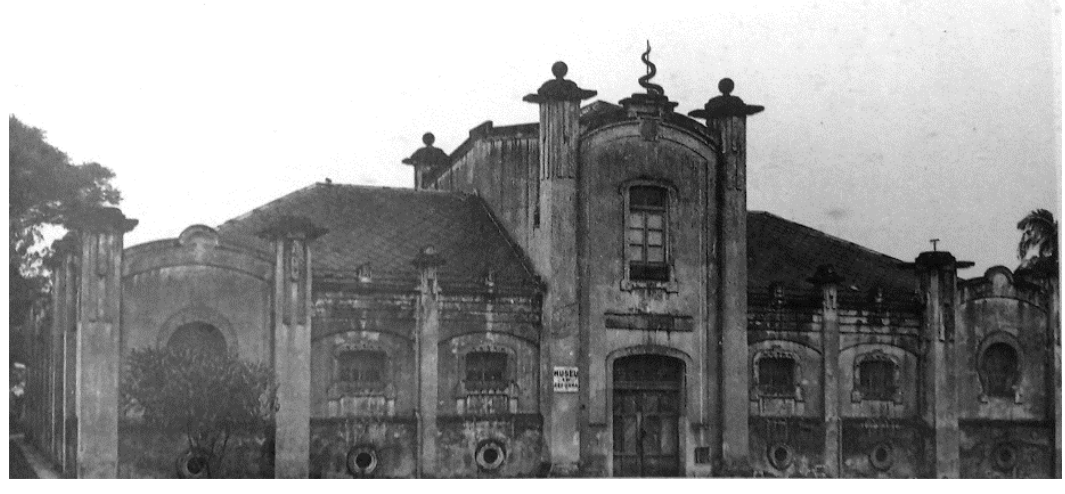

Fig. 81 - Cocheira em 1965: pouco antes da reforma, o edifício era utilizado para abrigar cavalaria militar, e apresentava sinais de pátina, sujeira e umidade em seus revestimentos externos (Fonte: FERRAZ, 1993, p.175) 


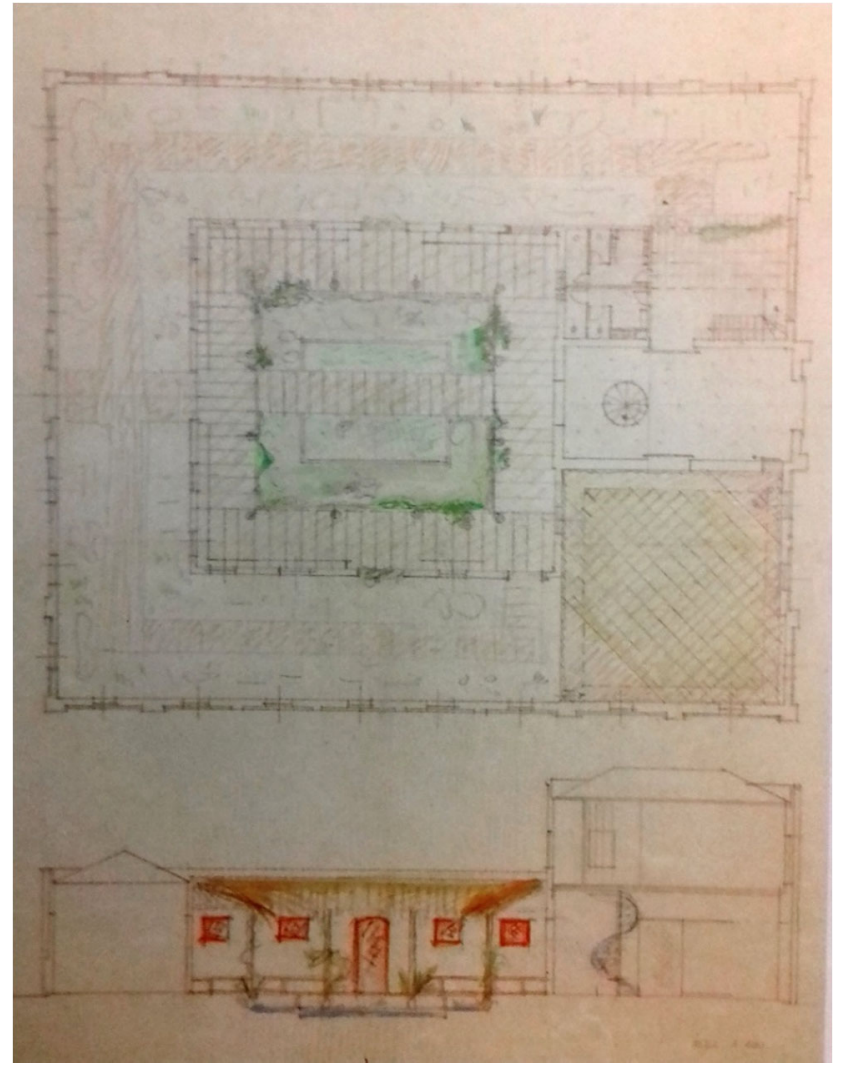

Fig. 82 - Estudo de Lina Bo Bardi em 1965: a proposta mantinha o pátio interno com jardim expositivo, com deques de circulação. Um pequeno anfiteatro era proposto à esquerda da entrada. (Fonte: FERRAZ, 1993, p.176)

O projeto da arquiteta não teve prosseguimento e optou-se por transferir a tarefa à equipe do FCCUASO, liderada pelo arquiteto Osmar Mammini. Assim, em 1966 foi concluída a pretendida reforma convertendo a cocheira em Museu Biológico, com anfiteatro. Segundo depoimento recente do arquiteto para essa pesquisa:

\footnotetext{
Porque o Butantan estava na época (isso foi em 1966) preparando um simpósio internacional sobre venenos de animais e eles queriam reformar a antiga cocheira do Instituto, [...] onde ficavam os cavalos e no meio era o pátio aberto onde eles sangravam o cavalo depois de injetar veneno de cobra pra fazer o soro. Reformei rapidamente isso daqui. Inclusive os azulejos que tinham aqui (eram importados da Alemanha, Art Nouveau) eu doei pra FAU, que era ainda lá na Rua Maranhão. [...] E aí eu fiz no pátio interno uma viga central, um telhado, cobri, fiz um auditório com quatro cabines de tradução simultânea. (Depoimento de Osmar Mammini, 2017)
}

Como se vê, na reforma capitaneada por Osmar Mammini realizaram-se importantes mudanças internas. A maior foi a execução da cobertura do pátio central para abrigar o auditório do Instituto, deixando o perímetro externo para exposição de ciências biológicas. A estrutura interna do auditório foi executada em concreto armado e vedos em alvenaria. Em princípio, as telhas originais de ardósia foram mantidas. Porém, a nova cobertura em duas águas e os pontos de contato entre a estrutura nova e a original criaram pontos de infiltração, 
mencionados já no relatório de 1970, em que o diretor técnico Lauro Travassos solicitava a substituição do telhado. Em 1972, todo telhado no perímetro foi revisto, substituindo-se as telhas de ardósia por telhas cerâmicas, enquanto as originais do torreão foram mantidas, gerando um contraste entre ambas (figura 83). Internamente, foi instalado forro em lambril.

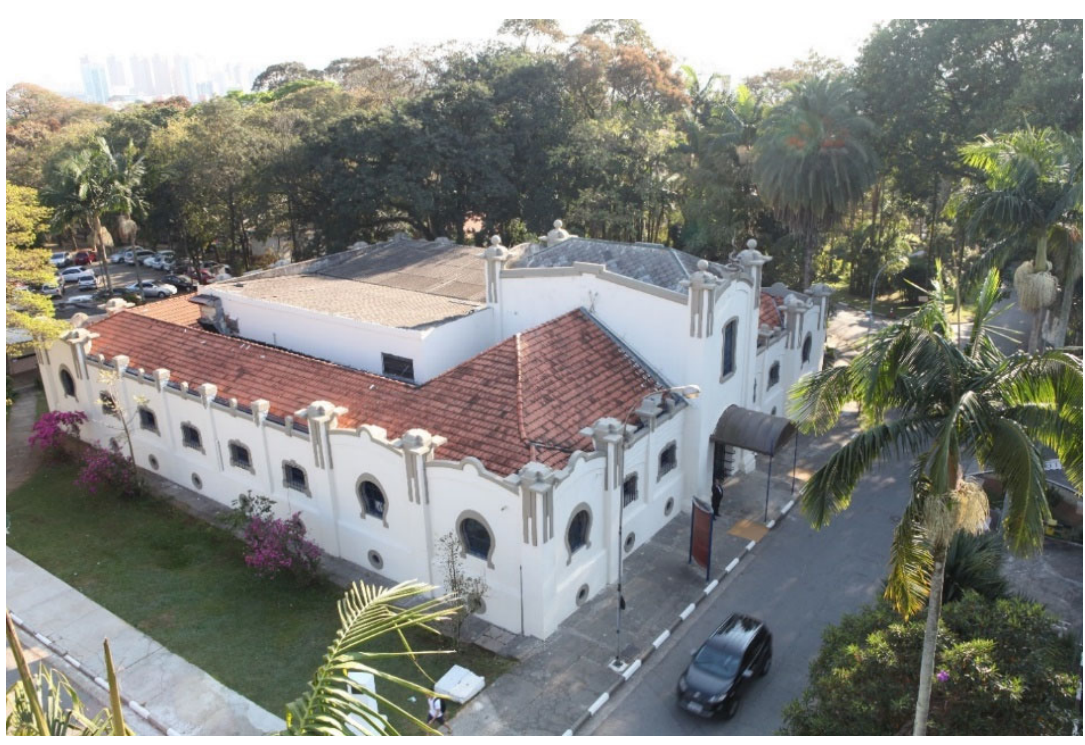

Fig. 83 - Vista aérea do Museu Biológico em 2017: as reformas da equipe do FCCUASO no final da década de 1960 deixaram o edifício com três tipos de cobertura: uma original, em telhas de ardósia, no torreão central; uma modificada, com telhas cerâmicas, em todo anel pré-existente; e uma nova, em telhas de fibrocimento com calha central, ocupando o antigo pátio de imunização. (Fonte: Acervo IBu)

As cores utilizadas na reforma de 1966 inverteram as tonalidades claro-escuro que vinham sendo mantidas, mas se parecem mais com as fotos antigas encontradas da época de construção. Ao longo dos anos 1980 até atualmente, foram feitas diversas pinturas, principalmente com tinta acrílica, com cores variando do branco ao bege.

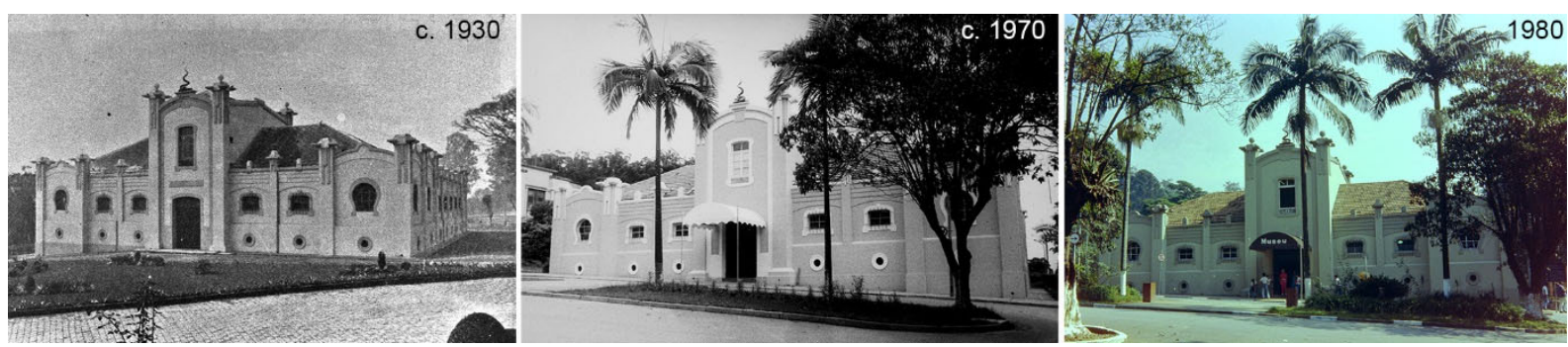

Fig. 84 - Fachada da Cocheira em três épocas: o paisagismo do entorno variou bastante, assim como em outros edifícios do Instituto. Vê-se também as mudanças nas pinturas e na cobertura (Fonte: Acervo IBu).

Quanto ao piso, na parte expositiva foi aplicado material vinílico em 1966. Na década de 1980 foi substituído por placas de borracha (Plurigoma) e nos anos 2000 por piso linóleo. No auditório ainda permanece contrapiso com carpete. Conforme depoimento citado, segundo 
Mammini havia revestimento original do piso (aparentemente em pedra), doado para a FAUUSP após a reforma, que não foi localizado nesta pesquisa, mas pode ser visto na figura 85.

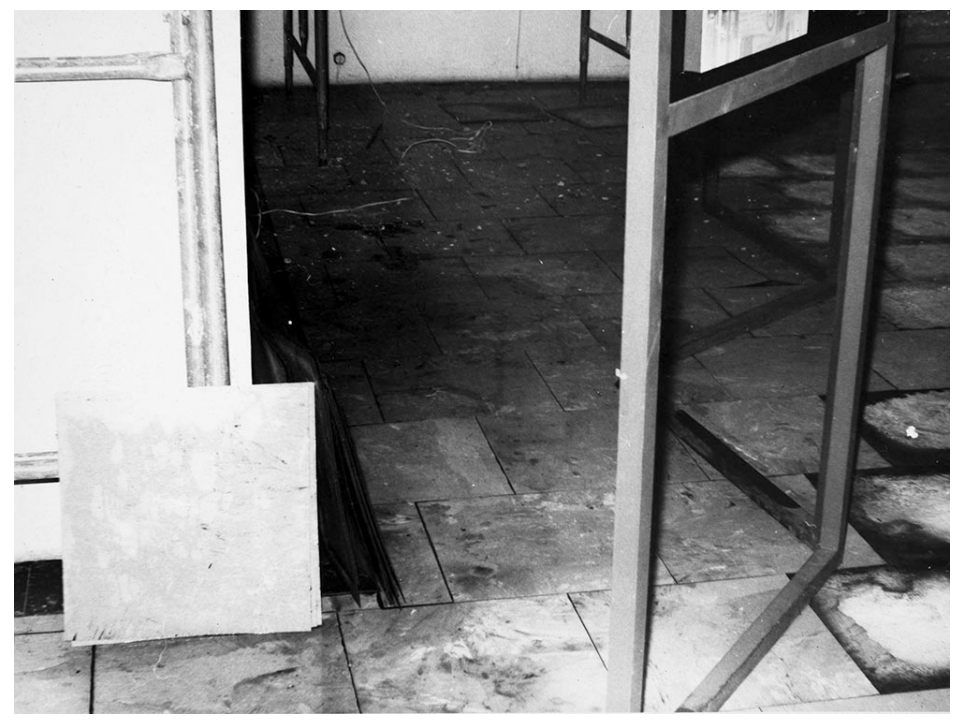

Fig. 85 - Piso original da Cocheira. Segundo Omar Mammini, essas peças em pedra natural (não especificada) foram doadas à FAU-USP na obra de 1966 (Fonte: IB_ICO_009311)

Para as janelas, nessa reforma foram criadas esquadrias sob medida com vidro e caixilho de aço com pintura esmalte. As portas e janelas em madeira foram recuperadas. Os painéis internos, forros e equipamentos expositivos acabaram por encobrir totalmente os elementos construtivos do edifício original internamente.
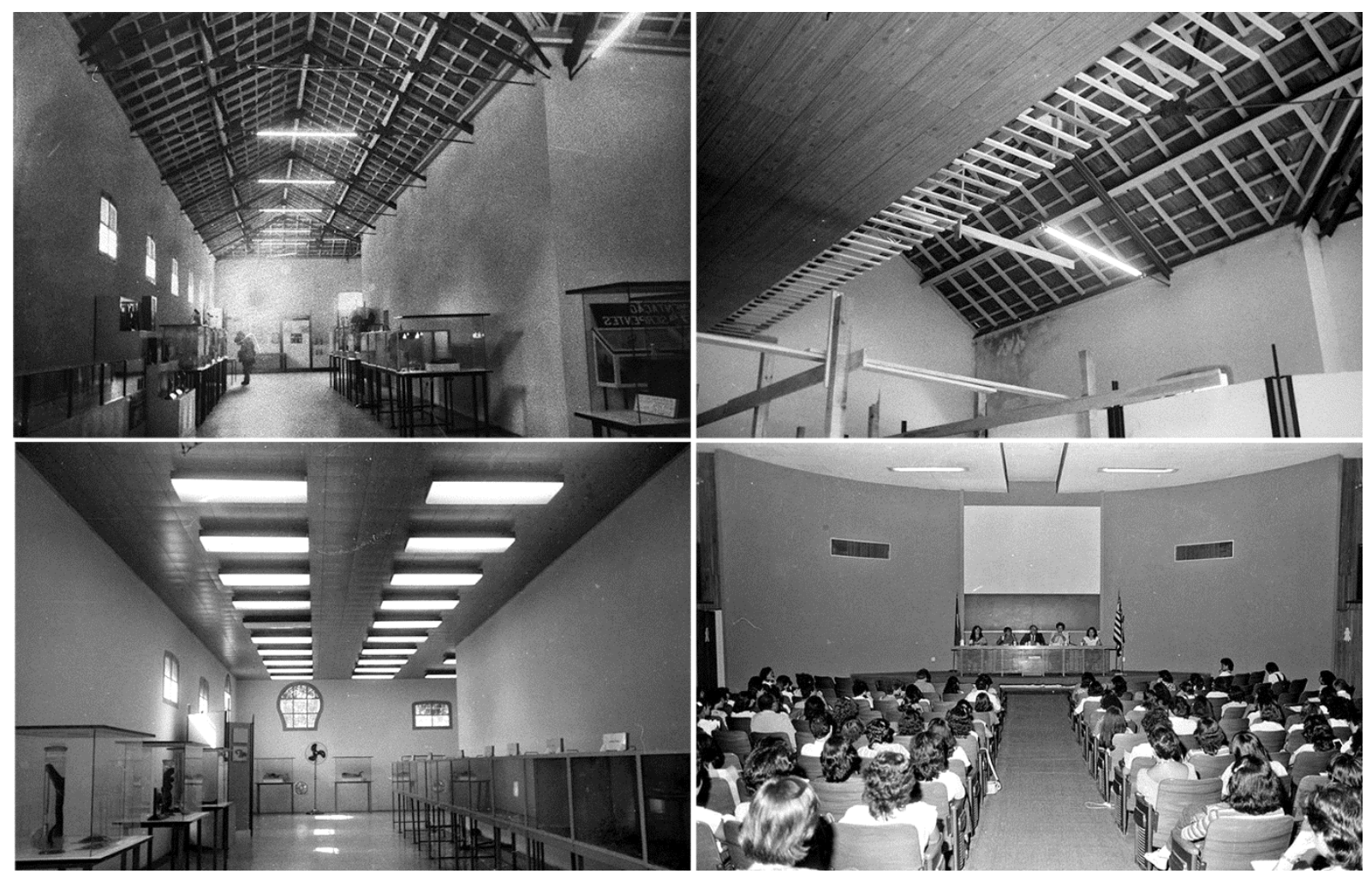

Fig. 86 - Interior da Cocheira em 1966: pode-se ver a solução dada ao forro e o auditório implantado no antigo pátio (Fonte: IB_ICO_003389, IB_ICO_008861, IB_ICO_008859, IB_ICO_001695) 


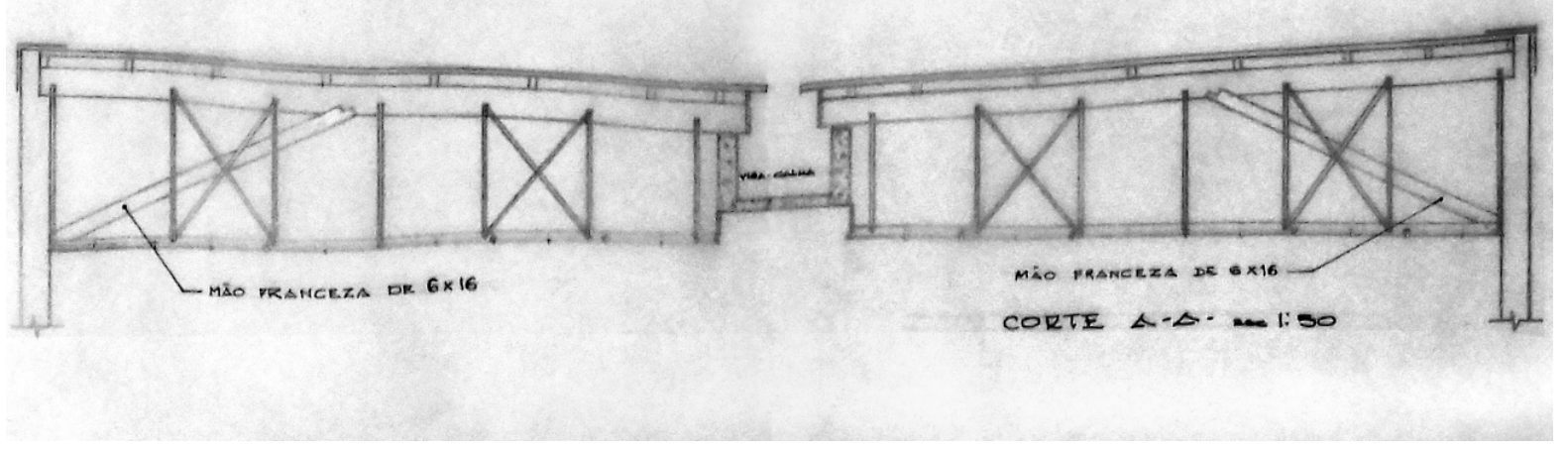

Fig. 87 - Desenho original do corte da nova cobertura, projetada por Osmar Mammini em 1965. A drenagem através de viga central traria problemas de infiltração até recentemente (Fonte: Acervo IBu)

Hoje (2019), em relação a outros edifícios do campus, que vêm sendo construídos desde o final do século XIX, a Cocheira Central se encontra preservada, como Museu Biológico, em suas principais características externas (volumetria e acabamentos), sem grandes interferências de construções próximas, instalações, acréscimos e demolições. Porém, a parte interna já sofreu várias modificações. O Museu Biológico está a cargo do Departamento de Difusão do Instituto Butantan e quaisquer modificações são submetidas às necessidades da diretoria do museu e da Divisão de Arquitetura e Engenharia. O Plano Diretor de 2016 propõe manter os mesmos usos no edifício, mas com adaptações para melhoria nas funções como museu e auditório. Também há no plano ações definidas como restauro, entre elas a recuperação do aspecto original do telhado, que acaba de ser executada (dezembro de 2018). Embora tenha recuperado a leitura original do edifício e eliminado a variedade estética da cobertura, essa reforma retirou as telhas originais que restavam sobre o torreão. Tal questão, assim como outras relativas à preservação e restauro atuais desse edifício serão assuntos aprofundados no item 3.2.2.

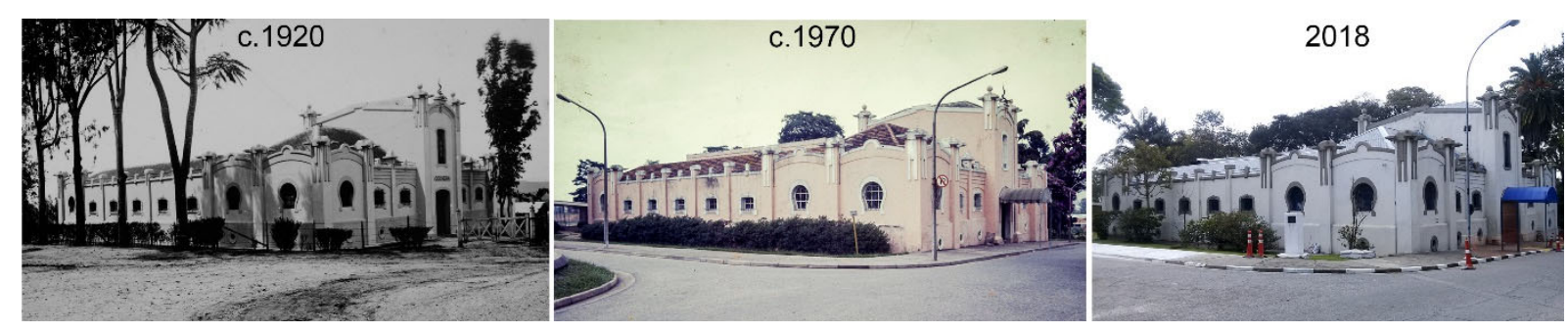

Fig. 88 - Vista lateral da Cocheira Central em três épocas: as mudanças mais significativas estão nas tonalidades da pintura e na cobertura, bem como no acréscimo de toldos de diferentes acabamentos (Fonte: Acervo IBu e autor) 


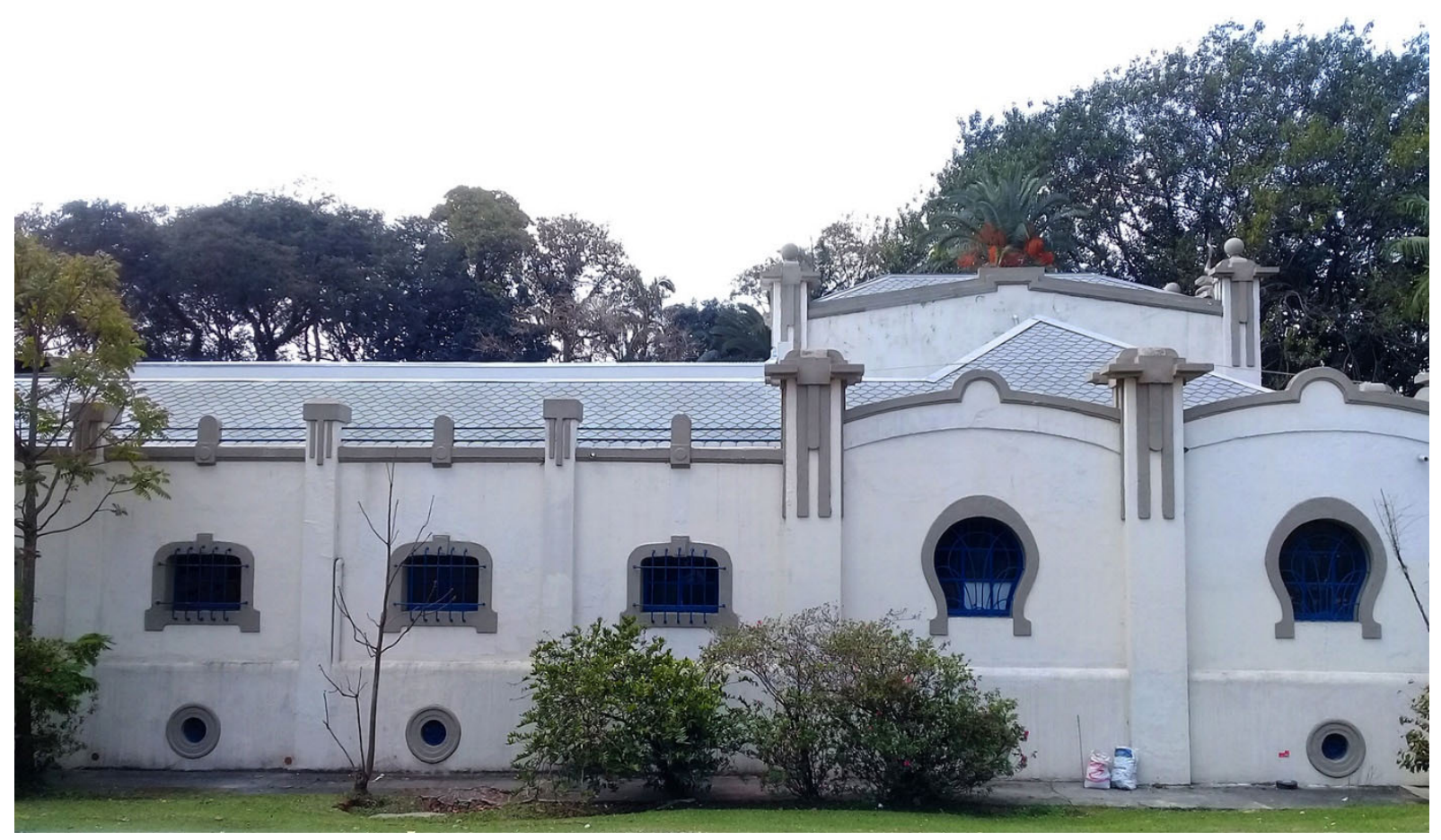

Fig. 89 - Em 2018 foi executado novo telhado em ardósia no intuito de recuperar o aspecto original da cobertura do edifício. Na reforma, o telhado original do torreão também foi substituído pelas novas placas (Fonte: autor, 2018).

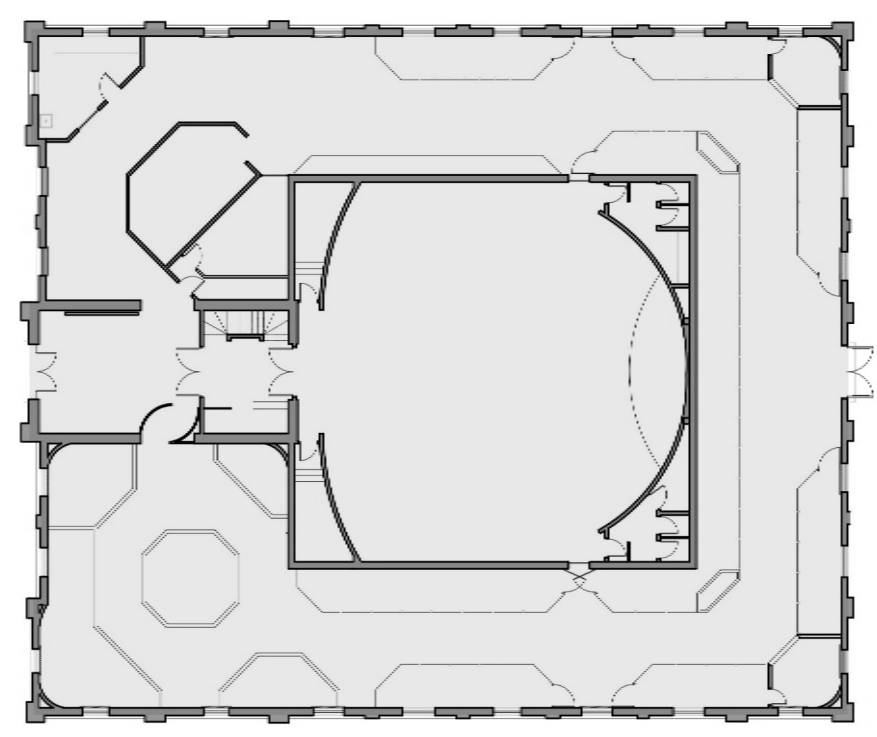

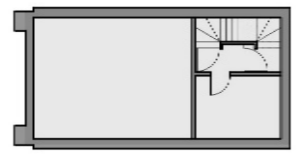

PAVIMENTO INTERMEDIIARIO

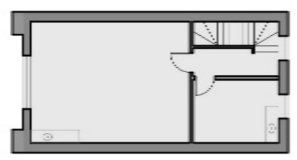

PAVIMENTO SUPERIOR

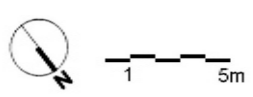

PAVIMENTO TÉRREO

Fig. 90 - Plantas do atual Museu Biológico: vê-se o auditório no centro, onde existia o antigo pátio de imunização (Fonte: IBu, 2016, alterada) 


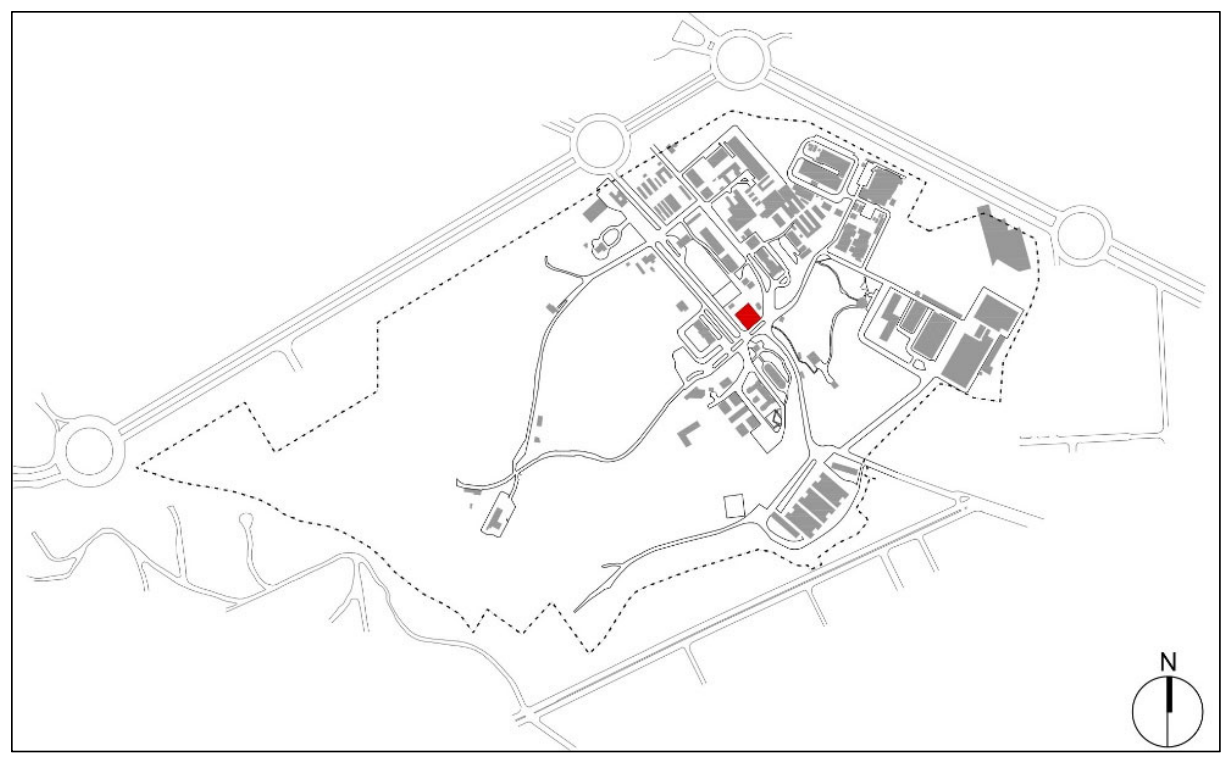

Fig. 91 - Localização da Cocheira Central (atual Museu Biológico) em 2018 (autor)

\section{RESUMO}

Categoria: edifício

Denominação original: Cocheira central

Denominação atual: Museu Biológico

Autoria (atribuída): Mauro Álvaro de Souza Camargo

Área original: c. $1060 \mathrm{~m}^{2}$

Área atual: $1060 \mathrm{~m}^{2}$

Número de pavimentos original: 3

Número de pavimentos atual: 3

Início-término da construção: c.1912-1917

Itens arquitetônicos originais:

Estrutura: alvenaria portante

Vedação: alvenaria (tijolo maciço)

Revestimentos paredes externas: argamassa de cimento e cal

Revestimentos paredes internas: argamassa de cimento e cal

Revestimentos pisos internos: cerâmica, cimento queimado

Revestimentos pisos externos: cimento desempenado

Caixilharia: madeira e aço

Uso original: cocheira

\section{Itens arquitetônicos atuais:}

Estrutura: original + concreto armado

Vedação: original + divisórias leves

Revestimentos paredes externas atual: original + massa única industrializada + tinta acrílica

Revestimentos paredes internas atual: original + tinta acrílica

Revestimentos pisos internos atual: originais + cerâmicos, vinílicos e emborrachados

Revestimentos pisos externos: cimento desempenado

Uso atual: museu 


\subsubsection{Escola de Veterinária [Pavilhão Lemos Monteiro]}

Em 1917, foi criada no Instituto uma Escola de Veterinária (como parte do Instituto de Veterinária ${ }^{94}$ ), para auxiliar no tratamento dos animais utilizados no desenvolvimento de pesquisas e produção de fármacos. A lei no. 1.597, de 31 de dezembro de 1917, estabelecia sua criação dentro do Instituto Butantan, determinando:

Artigo $7 .^{\circ}$ - Serão construidos em terrenos do Instituto do Butantan, para o Instituto de Veterinaria:

a) enfermarias para cincoenta animaes isolados e destinados a equideos, bovideos, suinos e ovinos;

b) um bioterio;

c) uma sala para necropsias;

d) um pavilhão para investigações bacteriologicas e clinicas;

e) um aviario;

f) dois silos.

Segundo noticiário ${ }^{95}$ e fotografias da época, no início de 1920 o edifício já estava finalizado (figuras 92 a 95). Projetado pelo Departamento de Obras Públicas, foi construído sob direção do engenheiro Francisco Godoy M. Costa, da mesma turma de Mauro Álvaro na Politécnica.

A criação desse Instituto parece ter sido recebida a contragosto no Butantan, pois desde o início havia queixas de Vital Brazil sobre a presença de animais doentes em um ambiente de produção de soros e vacinas, deixando a entender que a criação desse Instituto de Veterinária teria sido imposta pelo Serviço Sanitário. Como se sabe, em 1919 Vital deixou a direção, indo para Niterói, em saída conturbada. Já em 1921 o novo diretor, Afrânio do Amaral, sugeriu ao Serviço Sanitário que o Instituto de Veterinária deixasse o campus para que se aproveitasse melhor o edifício. Consta que durante parte de 1920 o prédio também foi utilizado como residência do diretor (RA1925, p.9). Posteriormente, Vital, já tendo reassumido o cargo, deixou claro que a Veterinária não mais ocupava o local:

\footnotetext{
${ }^{94} \mathrm{O}$ Instituto de Veterinária seria a instituição formada por diversos setores listados na lei 1.597/1917, enquanto o hoje chamado Pavilhão Lemos Monteiro foi construído especificamente para a escola.

95 “[...] foi criado nesta capital, em terrenos pertencentes ao Instituto Serumtherapico do Butantan, o Instituto de Veterinária. Esse estabelecimento, que hoje se encontra com as suas principaes installações já concluídas, tinha por objectivo o preparo de vaccinas e sôros necessarios a nossa futurosa industria pastoril - productos esses que, apesar de serem indispensaveis, eram em maioria adquiridos fora do Estado." (Instituto de Veterinária. O Estado de São Paulo 26/04/1920)
} 
"O edifício onde funcionava o Instituto de Veterinaria estava completamente desaproveitado. Caprichosamente construído, dispondo de magníficos laboratórios, está destinado, talvez, em um futuro bem próximo, a ser convenientemente aproveitado no desenvolvimento dos trabalhos technicos do estabelecimento. Actualmente, porem, sobrando o numero de salas no edifício principal, achava-se este em completa disponibilidade, pelo que foi provisoriamente aproveitado para residência do diretor, sala de despacho da directoria e de um laboratório de pesquisas, onde trabalha o diretor." (RA1924, p.7)
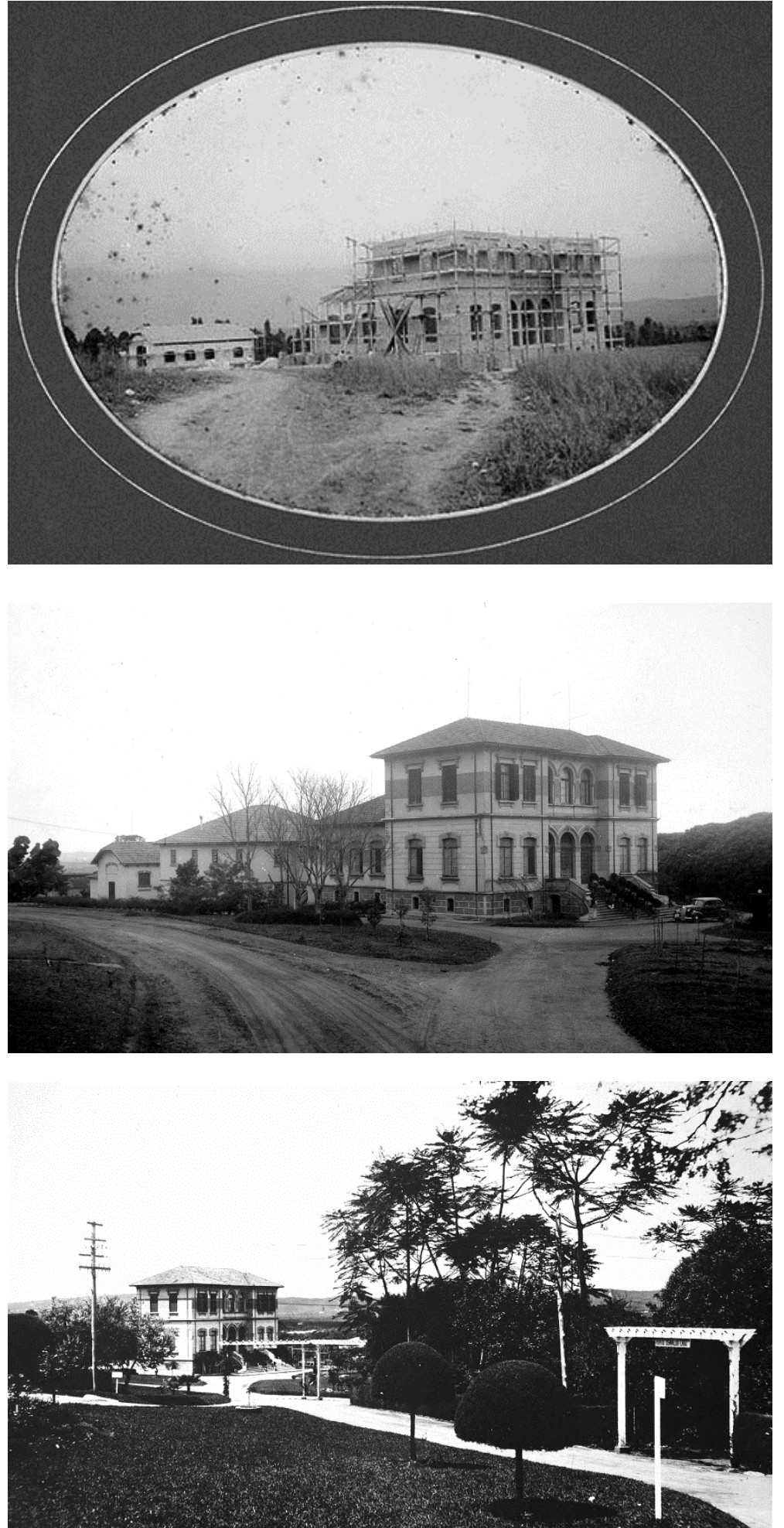

Fig. 92 - Edifício da Escola de Veterinária em construção, 1919: vê-se a alvenaria portante da parte frontal sendo costruída (Fonte: IB_ICO_011496)

Fig. 93 - Escola de Veterinária na década de 1920: a função original rapidamente foi substituída por usos de outros laboratórios. Vê-se o conjunto concluído com os blocos posteriores, e as vias ainda não pavimentadas (Fonte: IB_ICO_008913).

Fig. 94 - Escola de Veterinária na década de 1930: o paisagismo do entorno passa a ser mais elaborado, vendo-se à direita da imagem a entrada do Horto Oswaldo Cruz, criado em 1918 (Fonte: IB_ICO_008911). 


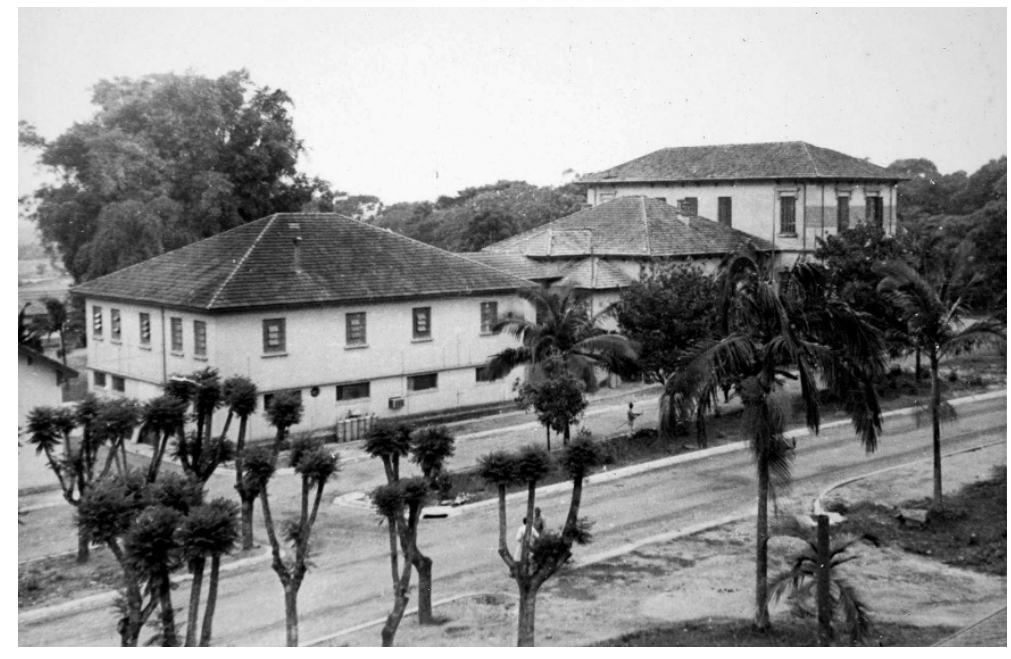

Fig. 95 - Vista da parte posterior, em 1960: em primeiro plano, o bloco de pesquisa, considerado moderno na época, no qual se contaminou o médico Lemos Monteiro, que hoje dá nome ao conjunto (Fonte: IB_ICO_008907).

Com cerca de $1720 \mathrm{~m}^{2}$, o prédio da escola, depois denominado Pavilhão Lemos Monteiro ${ }^{96}$, de 2 pavimentos e um embasamento, seguiu linhas do Ecletismo em viés neorrenascentista, lembrando, por suas proporções e acabamentos, as vilas florentinas, que têm outro exemplo em São Paulo na casa projetada por Felisberto Ranzini ${ }^{97}$. Esse tipo de construção costumava seguir elementos do renascimento, como os arcos plenos, a diferenciação de acabamento entre os andares, combinados com certas características próprias de casas de campo, como os telhados sem platibanda, janelas em madeira e variações cromáticas que amenizavam um pouco o caráter grave do neoclassicismo academicista do século XIX. A entrada da Vila Crespi D’Adda, em Bergamo, na Itália, construída em 1898 (patrimônio pela UNESCO) traz certas semelhanças com essa solução (figuras 96 e 97). Também chamam atenção os elementos que remetem ao uso do edifício (outro exemplo da Architecture Parlante). Esculturas representando animais e instrumentos de laboratório (figura 98) parecem compor com os outros edifícios já citados (Principal e Cocheira Central) uma espécie de narrativa arquitetônico-científica. Apesar de seu caráter bucólico (por remeter às vilas italianas), o edifício não deixa de marcar a paisagem com certa monumentalidade, reforçada pelo paisagismo do entorno, por sua escadaria frontal e, finalmente, pela relação compositiva que acaba estabelecendo com os edifícios anteriores. Essa relação paisagística e urbanística, de

\footnotetext{
${ }^{96}$ Em 1935 o prédio foi batizado de Pavilhão Lemos Monteiro em homenagem ao cientista José Lemos Monteiro, que morreu, assim como seu assistente Edison de Sousa Dias, infectado por tifo. Ambos se contaminaram fazendo experimentos com o carrapato disseminador da doença, fato que causou grande comoção na época.

${ }^{97}$ Sobre a obra de Ranzini, ver SALVATORE (2015).
} 
blocos não contíguos, mas que dialogam por ter certa proximidade, formando uma composição e insinuando um percurso, fica evidente nas fotos do período, principalmente a partir da construção desse edifício.
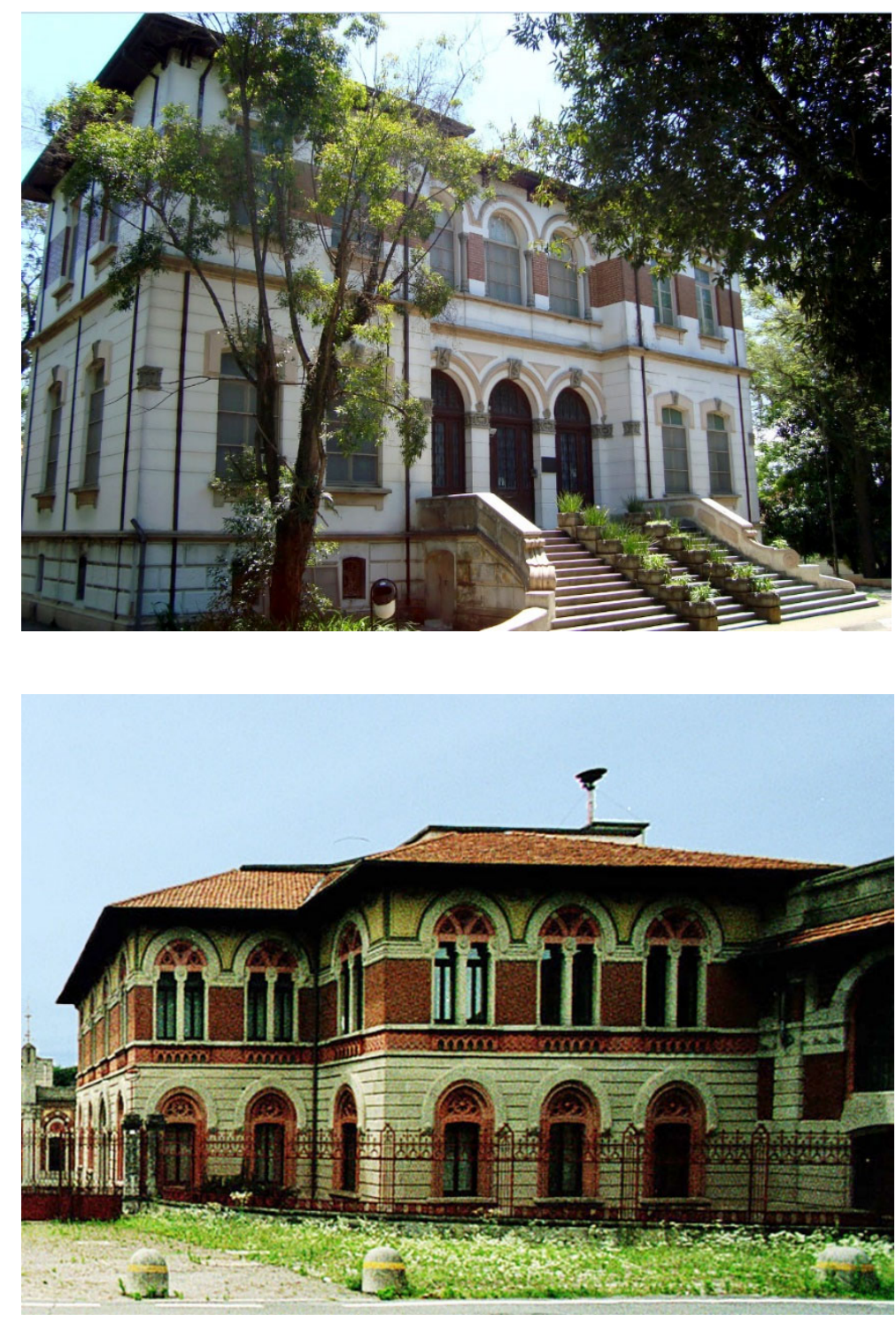

Fig. 96 - Fachada do Pavilhão Lemos Monteiro em 2018 (Fonte: autor).
Fig. 97 - Parte da Vila Crespi D’Adda: exemplo de Ecletismo neorrenascentista (Fonte: http://www.villaggiocrespi.it, 20/09/2018).
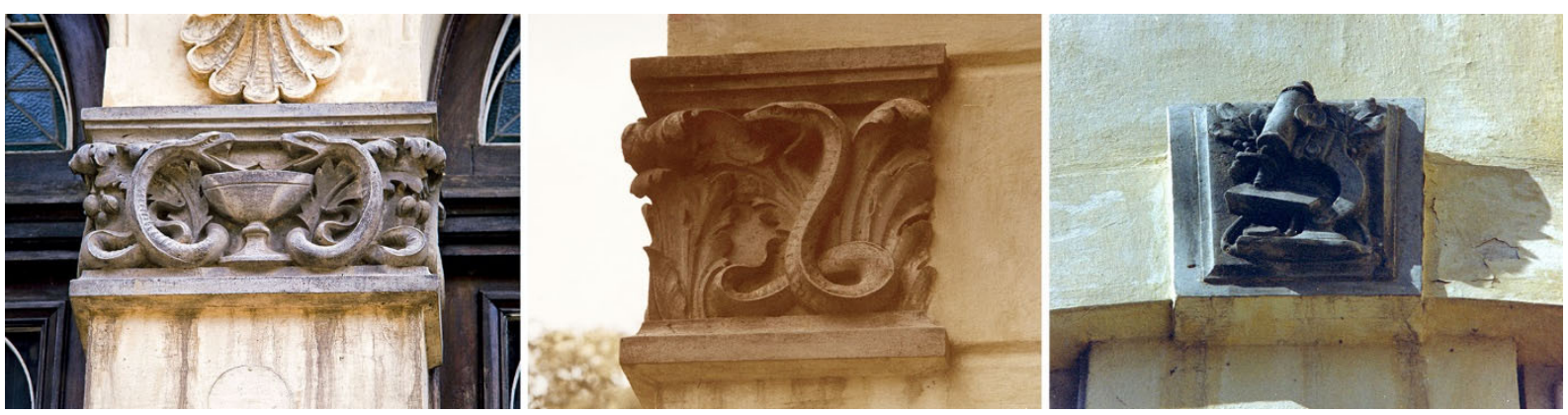

Fig. 98 - Detalhes do Pavilhão Lemos Monteiro, remetendo à pesquisa biomédica, características da chamada Architecture Parlante (Fontes: IB_ICO_005473, IB_ICO_009145 e IB_ICO_003232) 

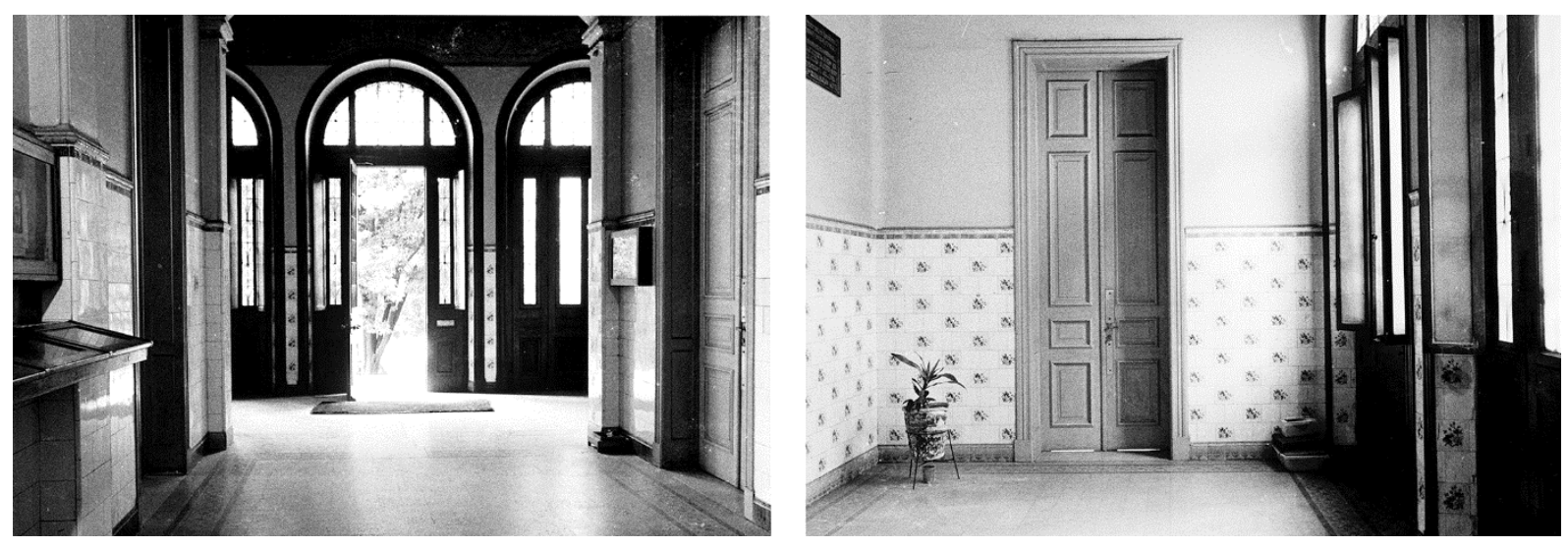

Fig. 99 - Interiores do Pavilhão Lemos Monteiro: apesar das ornamentações características do Ecletismo, os revestimentos cerâmicos também tinham a função de facilitar a higiene nos ambientes laboratoriais (Fontes: IB_ICO_008915 e IB_ICO_008916)

Também são vistas nas paredes exteriores aplicações em massa raspada, também chamada "pedra fingida" (CUNHA, 2017), e uso de granitos na escadaria de entrada, técnicas bastante usadas em edifícios ecléticos e incomuns nas primeiras obras desse campus (figura 100).

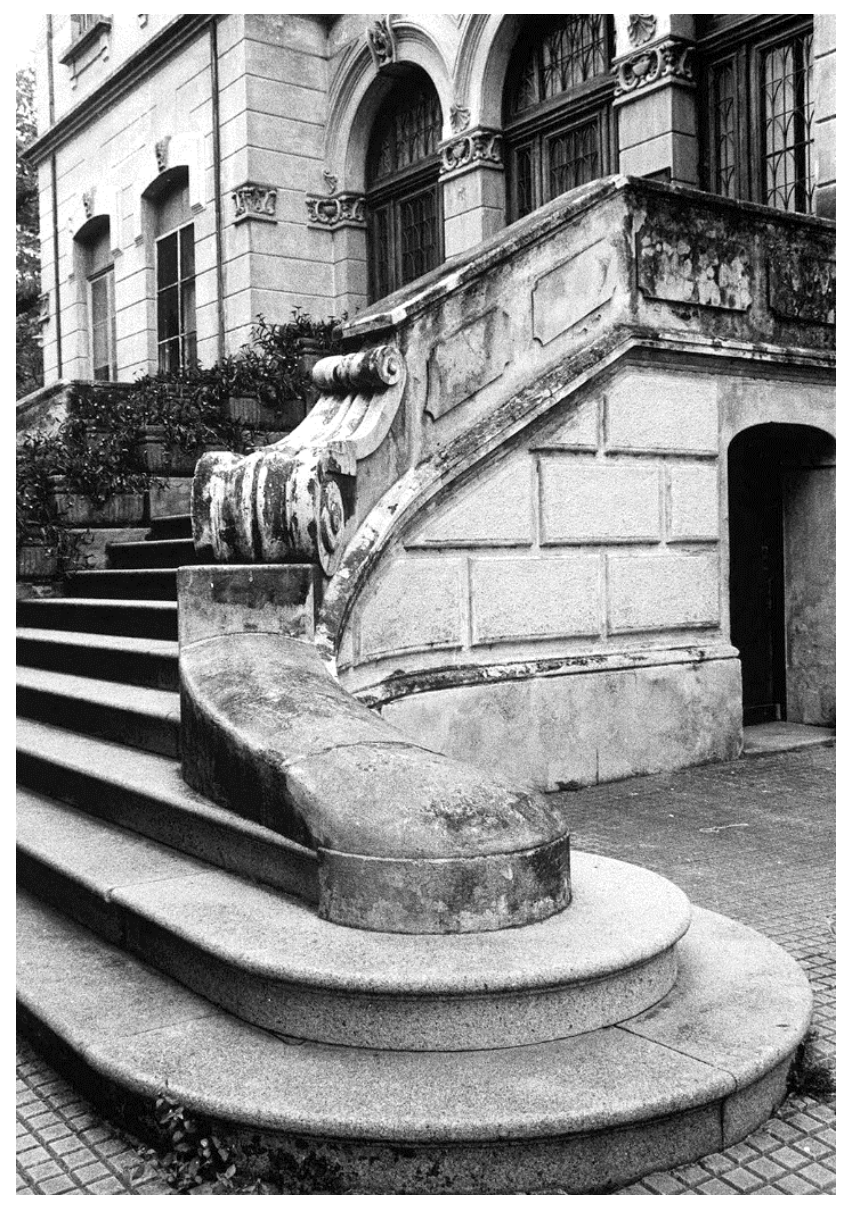

Fig. 100 - Escadaria de entrada na década de 1980: veemse os revestimentos em granito (provavelmente do tipo Mauá) nos degraus e a chamada "pedra fingida" nas paredes, hoje pintadas (Fontes: IB_ICO_008917). 
O prédio recebeu acréscimos na sua parte posterior nas década de 1920 e 1930, sendo que primeiramente se tentou reproduzir alguns ornamentos do primeiro edifício buscando uma continuidade. Mas no bloco construído atrás do principal não há ornamentos, criando-se contraste entre o primeiro volume neorrenascentista e este, já chamado de "moderno" na época:

É um pavilhão construído de pouco e que destoa dos outros do Instituto Butantan pela sua pintura mais recente e construcção mais moderna. [...] Salas de estufa, gabinetes de esterilização, de lavagem, sala onde, em gaiolas, se agitam beneméritas cobaias. (No pavilhão em que trabalhava o Dr. Lemos e o seu assistente. Correio Paulistano, 8 nov. 1935, p.12)

Pode-se dizer que esses acréscimos não tiveram grande preocupação em dar unidade ao conjunto. Em todo caso, hoje a parte frontal continua preservada em sua volumetria, ornamentação e aberturas. No entanto, tem passado por pinturas que prejudicam sua integração na paisagem, problema que se reproduz em outros monumentos, principalmente ao se tentar dar aspecto "novíssimo e branquíssimo" que, nos dias mais ensolarados, ressaltam exageradamente as grandes superfícies, ofuscando a legibilidade de relevos, frisos e texturas ${ }^{98}$.

Em relação ao bloco frontal, neorrenascentista, é interessante retomar uma questão que, para além de ser meramente estética, de certo modo imprimiu nas formas arquitetônicas um conflito que acontecia no campo administrativo, mas que pode ser percebido nos documentos construídos: como foi dito, a administração de Vital Brazil não recebeu bem a imposição de implantar dentro do Instituto um outro instituto com atividades alheias e até prejudiciais às suas, já em certo conflito com o chefe do Serviço Sanitário, Arthur Neiva ${ }^{99}$. E enquanto aqueles primeiros edifícios, sob a administração de Vital, foram concebidos por Mauro nas linguagens arquitetônicas consideradas as mais avançadas da época (a arte nova anti-historicista do novo século XX), aqui, o Departamento de Obras Públicas optou pelo Ecletismo do século XIX, típico dos edifícios públicos de então. Até hoje esse contraste é notado, graças àquela "composição espontânea" mencionada, e, esteticamente, ainda se tem a impressão de que o Pavilhão Lemos Monteiro é anterior à Cocheira Central e ao Edifício Principal.

\footnotetext{
${ }^{98}$ Esse "achatamento" dos relevos com a cor branca tem sido bastante utilizado ultimamente e é por vezes intencional, como ocorre no Conservatório Musical de São Paulo.

${ }^{99}$ Esse conflito atingiu o auge na já mencionada questão da Casa Armbrust, que teria precipitado a saída de Vital em 1919 (ACOSTA, 2015).
} 
Em relação às alterações executadas ao longo do tempo, as atividades laboratoriais geraram os conhecidos problemas de profusão de divisórias para compartimentação de ambientes, fechamento de janelas, aberturas em alvenarias para instalações elétricas, hidráulicas e mecânicas, e adaptação de revestimentos. O novo Plano Diretor propõe que o edifício passe a abrigar um auditório e programas de cursos. Desse modo, as alterações na edificação atual seriam relativamente grandes, principalmente em termos de planta, sobretudo no bloco posterior, que passaria a abrigar o auditório, necessitando a demolição de todas as paredes internas. No bloco principal, é proposta a demolição de divisórias leves e paredes que serviram, bem como instalações diversas (tubulações de ar condicionado, elétrica e hidráulica) executadas para adaptar os laboratórios. Em relação aos revestimentos:

De maneira geral, os padrões cromáticos originais do edifício que forem descritos no relatório de análise estratigráfica cromática, deverão ser revelados mediante remoção das camadas pictóricas mais externas. A remoção deverá utilizar-se de métodos e ferramentas que não comprometam as pinturas murais e frisos comprovadamente existentes nos ambientes internos do edifício. As pinturas murais e frisos revelados nas prospecções serão, por sua vez, analisados pela Coordenação de Arquitetura para determinar a sua permanência e restauro. (IBu, 2016, v.3, Memorial descritivo de especificação de materiais, Pavilhão Lemos Monteiro, p.8)

Diversos revestimentos existentes seriam preservados e recuperados, como argamassas, azulejos, ladrilhos hidráulicos, cerâmicas, granitos e mármores, enquanto nas áreas novas (auditórios, salas, rampas), seriam aplicados granilite, mármore ou ladrilho hidráulico. Há uma combinação de materiais com aspecto original e novos, conforme diz o memorial:

As novas rampas de acesso terão piso revestido por granito em placas assentado com argamassa traço 1:3. O granito deverá ser do mesmo tipo e com o mesmo acabamento do utilizado no revestimento das escadas exteriores de acesso ao edifício principal. [...] Os forros de estuque existentes no hall central da escada do pavimento térreo e superior deverão ser restaurados. As reconstituições que porventura sejam necessárias de trechos perdidos, bem como o tratamento de trincas e fissuras, devem ser realizadas após uma análise do traço da argamassa e a granulometria dos agregados. A pintura deverá ser com tinta a base de cal na cor determinada a partir do resultado da investigação estratigráfica cromática das esquadrias do edifício [...]

Deverão ser restauradas:

- Soleiras de mármore branco;

- Soleiras em madeira;

- Assoalhos e forros em madeira;

- Ladrilhos hidráulicos;

- Estuque ornamentado;

- Granito levigado existentes nas áreas externas.[...]

(Ibid, pp.15-26) 
Pelo novo Plano Diretor, o Pavilhão Lemos Monteiro sofreria alterações de maior vulto, se comparadas às da Casa Sede da Fazenda (item 2.3.2) e do Edifício Principal (item 2.3.4).
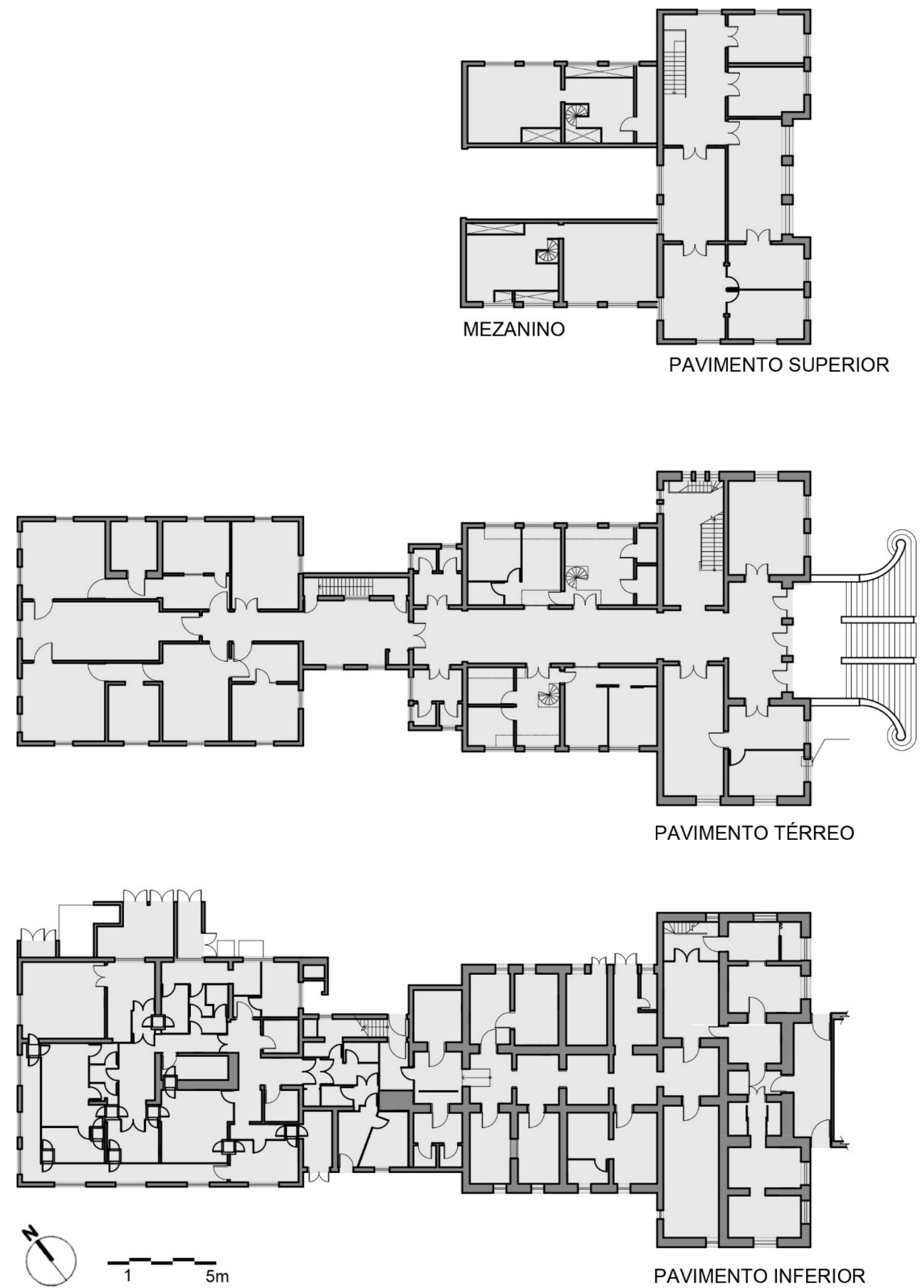

Fig. 101 - Plantas do Pavilhão Lemos Monteiro em 2016 (IBu, 2016, alterada) 


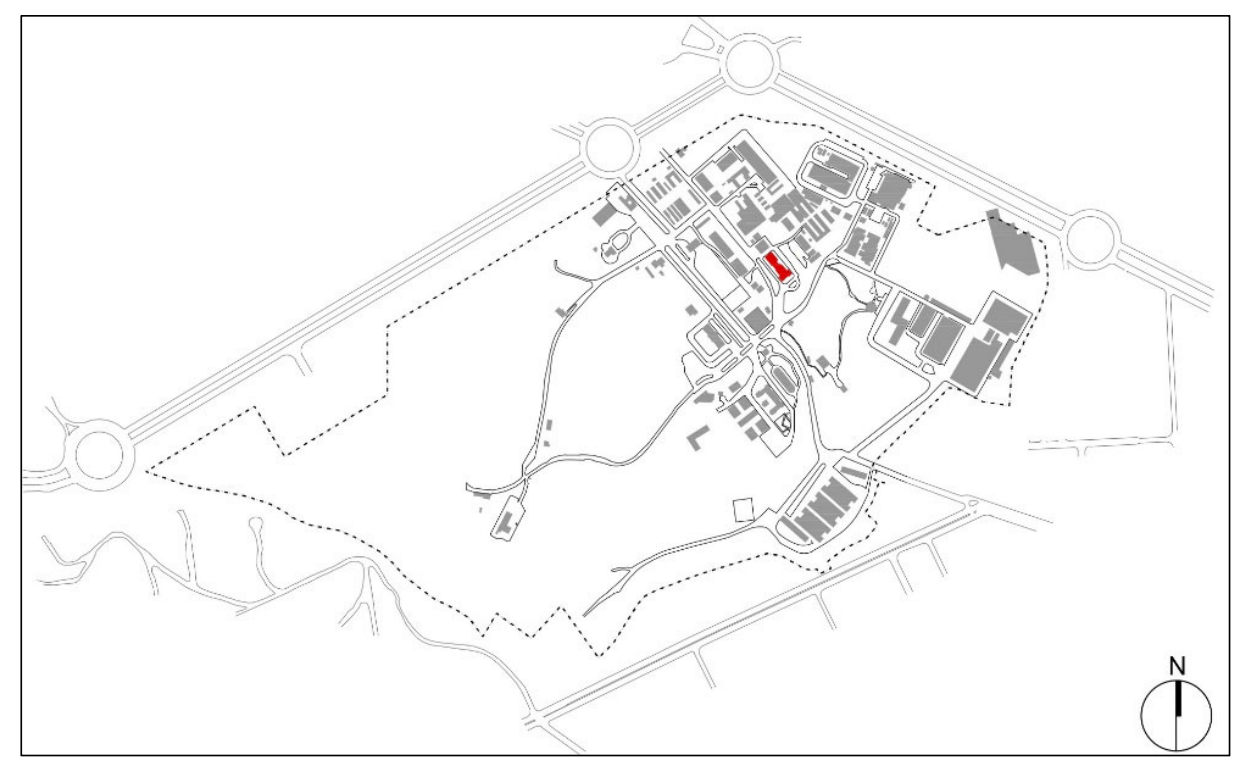

Fig. 102 - Localização da Cocheira Central (atual Museu Biológico) em 2018 (autor)

\section{$\underline{\text { RESUMO }}$}

Categoria: edifício

Denominação original: Escola de Veterinária

Denominação atual: Pavilhão Lemos Monteiro

Autoria: Departamento de Obras Públicas do Estado

Área original: $c .1500 \mathrm{~m}^{2}$

Área atual: $1720 \mathrm{~m}^{2}$

Número de pavimentos original: 1

Número de pavimentos atual: 1

Início-término da construção: c.1917-1919

\section{Itens arquitetônicos originais:}

Estrutura: alvenaria portante

Vedação: alvenaria (tijolo maciço)

Revestimentos paredes externas: argamassa de cimento e cal

Revestimentos paredes internas: argamassa de cimento e cal

Revestimentos pisos internos: cerâmica, mármore

Revestimentos pisos externos: cimento desempenado e granito

Caixilharia: madeira

Uso original: escola

\section{Itens arquitetônicos atuais:}

Estrutura: original + concreto armado

Vedação: original + divisórias leves

Revestimentos paredes externas atual: original + massa única industrializada + tinta acrílica

Revestimentos paredes internas atual: original + tinta acrílica

Revestimentos pisos internos atual: originais + cerâmicos, vinílicos e emborrachados

Revestimentos pisos externos: originais + cimento desempenado

Uso atual: laboratórios 


\subsubsection{Cocheira-biotério ["Cara de Cavalo"]}

Como se sabe, a implantação da Escola de Veterinária não foi bem recebida por Vital Brazil, e logo depois começaram suas queixas em relação à convivência de animais doentes com outros utilizados para pesquisa e imunização, que deveriam estar sãos. Em 1919 ele solicitou a separação completa das atividades, criticando a existência de uma "cocheira improvisada" (nas palavras de Brazil) para a Veterinária atrás da Cocheira Central do Instituto (RA 1919). Pela posição do edifício hoje denominado "Cara de Cavalo", é possível que se trate da mencionada cocheira improvisada para uso da Escola de Veterinária. Essa denominação popular se deve aos ornamentos em alto-relevo nas fachadas representando animais (assim como em outros edifícios já apresentados).

Há também uma cocheira gêmea a essa, da mesma época (início da década de 1920), com implantação simétrica em relação à antiga Escola de Veterinária, o que dá um interesse adicional a esse conjunto, uma vez que ambos ainda coexistem, ao mesmo tempo em que traz algumas dificuldades de identificação, pela semelhança. O levantamento dessa pesquisa se refere à primeira delas. Nos desenhos encontrados no acervo, que parecem ser esboços para essa nova cocheira, na época nomeada de $n^{\circ} .2$ (a Cocheira Central seria a $n^{\circ} .1$ ), não se conseguiu identificar a autoria e data. Mas pela sua relação com a Escola de Veterinária, e pelo comentário de Vital, acredita-se que seja do início de 1919 ou do início da década de 1920, ao mesmo tempo em que parece imprudente atribuí-la a Mauro Álvaro, já que a Escola de Veterinária foi projetada pelo Departamento de Obras Públicas, sem grande apoio do Instituto, ao qual Mauro era mais ligado pelos projetos anteriores. Mesmo sem esses dados precisos, é possível afirmar que esse é um dos remanescentes importantes do núcleo de fundação, tanto por suas características estéticas e funcionais, quanto pelo seu estado de conservação, que mantém diversos elementos originais, sobretudo externos.

Em forma pavilhonar, a cocheira trazia elementos funcionais voltados ao seu uso: grandes portas de entrada nas extremidades longitudinais, janelas altas com folhas de abrir em madeira, lanternins de ventilação e saliências nas vergas e contravergas para afastar águas pluviais. Os revestimentos originais combinavam argamassa de cimento e cal nas paredes externas, com 
azulejos nas internas e piso interno cerâmico. Apesar das características de edifício utilitário, não foram dispensados elementos ornamentais, que o aproximam de cavalariças semelhantes às inglesas. Nelas, as fachadas combinavam emassamento com materiais aparentes (geralmente cerâmicas nas saliências) e eram utilizados alguns detalhes em serralheria ornamentados com volutas, como os suportes dos beirais. O telhado do tipo lanternim promovia ventilação e iluminação aos animais.

O edifício passou por uma primeira reforma de vulto em 1942 deixando de ser cocheira e tornando-se biotério de animais menores, o que implicou a troca de caixilhos e instalação de subdivisões internas. Em 1966, o pavilhão foi novamente reformado para abrigar laboratórios de pesquisa com venenos. Após diversas adaptações, sobretudo internas, a Fundação Butantan permitiu a atuação da iniciativa privada no custeio de obras, e na década de 1990 o edifício foi reformado com recursos das empresas Roche, Giba Geigy e Sandoz, para implantação de biotério de artrópodes, aracnídeos e escorpiões. Segundo os relatórios do período, tais reformas já consideravam os aspectos históricos a serem preservados. Hoje o "Cara de Cavalo" é ocupado por setores de pesquisa em entomologia, parasitologia e artrópodes, necessitando de ambientes mais subdivididos e instalações hidráulicas, elétricas e mecânicas mais complexas, o que implica por vezes na interferência de equipamentos, dutos e aberturas em suas fachadas. Aberturas originais como as do lanternim e das janelas foram obstruídas para o trabalho laboratorial.

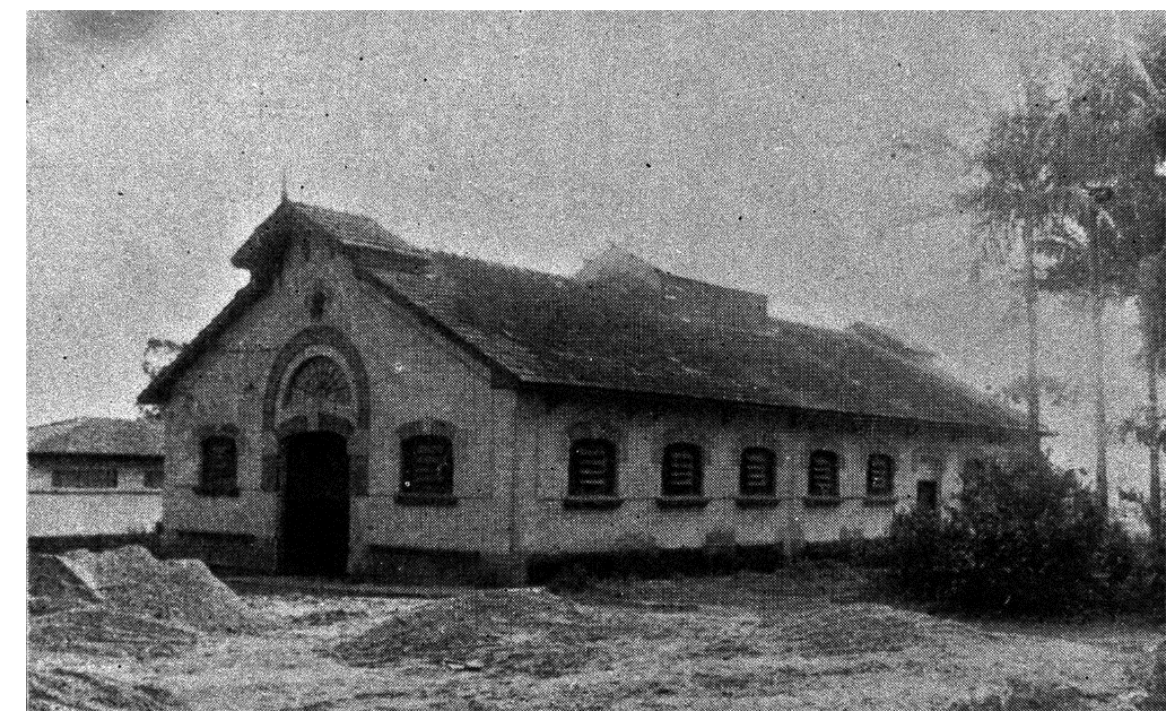

Fig. 103 - Cocheira-biotério na década de 1940: ao fundo vê-se parte da antiga Escola de Veterinária (Fonte: IB_ICO_003387) 

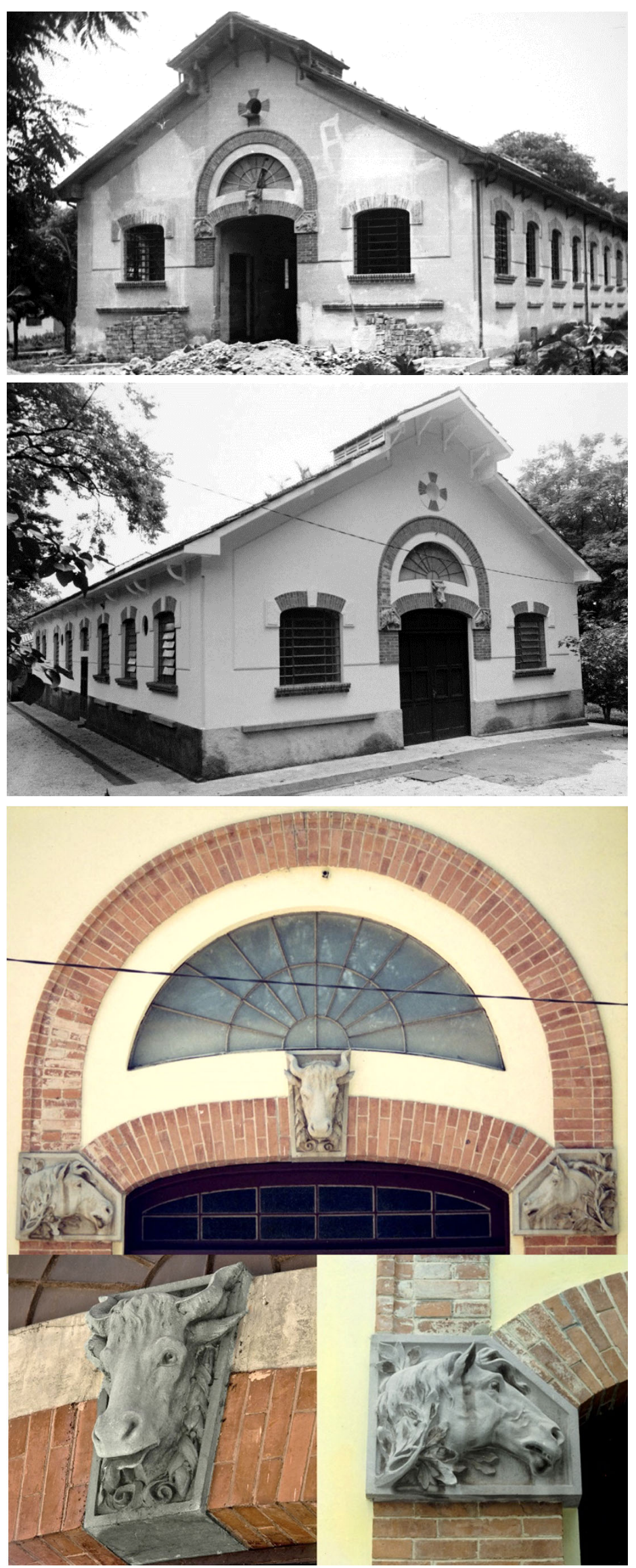

Fig. 104 - Cocheira-biotério durante a reforma de 1942: as contravergas das janelas antigas (mais baixas) foram deixadas após a conversão da cocheira em biotério (Fonte: IB_ICO_009338).

Fig. 105 - Cocheira-biotério em 1990: já utilizada apenas com usos laboratoriais, o edifício conservou grande parte de suas características externas. Contudo, veem-se algumas alterações de pintura e simplificações nos relevos das contravergas da base (Fonte: IB_ICO_009149).

Fig. 106 - Arco sobre a entrada principal hoje: assim como nas outras cocheiras, adotaram-se ornamentos e peças simbólicas, afastando-se das construções apenas utilitárias que foram adaptadas da fazenda (Fonte: IB_ICO_009071, IB_ICO_005474 e IB_ICO_009257). 


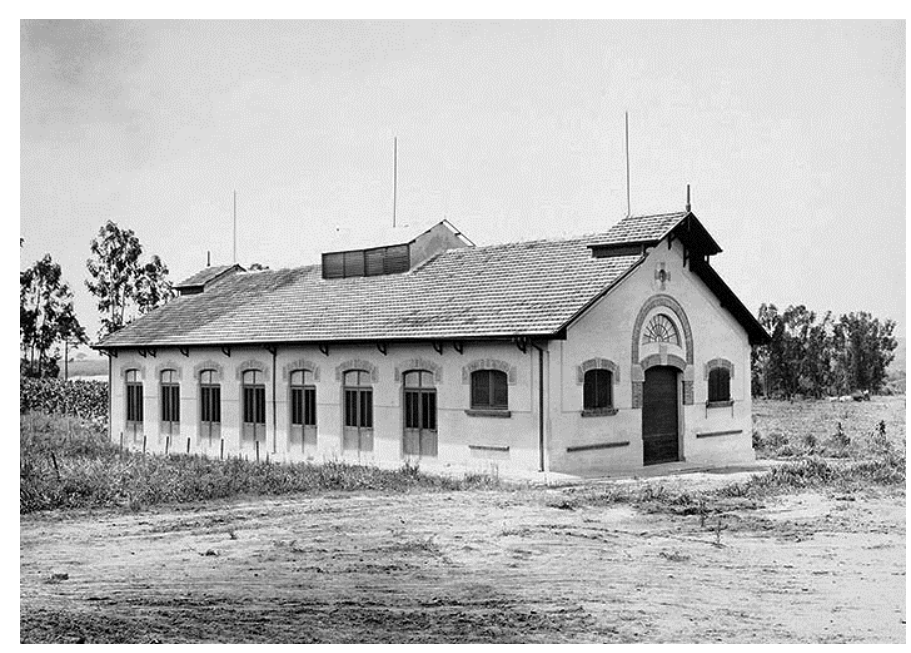

Fig. 107 - Cocheira "gêmea": construída em posição espelhada em relação à Escola de Veterinária, essa cocheira idêntica à anterior mostra como seriam as janelas originais. Mas aqui não foram executados os relevos de animais (Fonte: IB_ICO_010443).

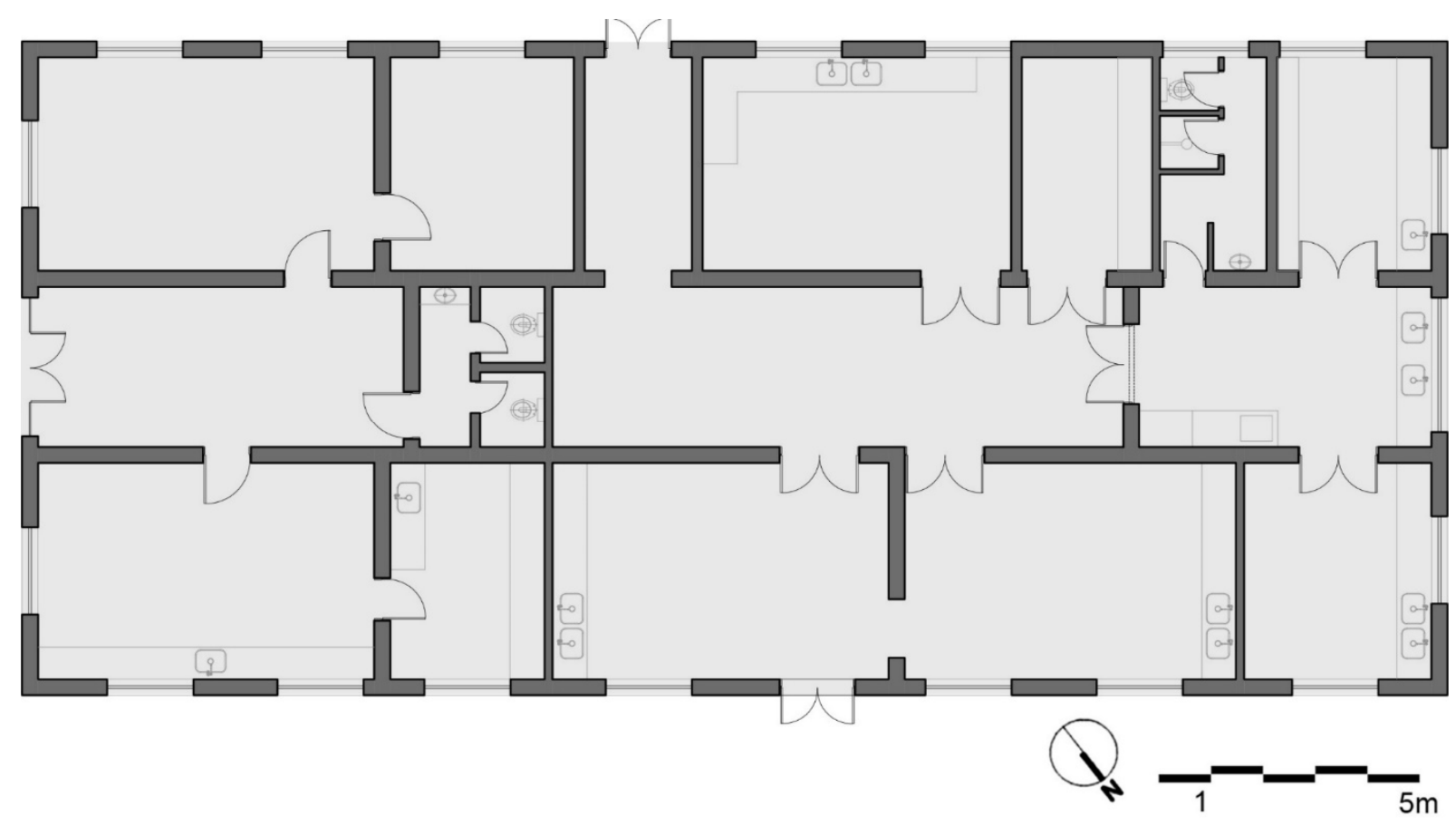

Fig. 108 - Planta da Cocheira-Biotério (conhecida como "Cara de Cavalo”) em 2016. (Fonte: IBu, 2016, alterada) 


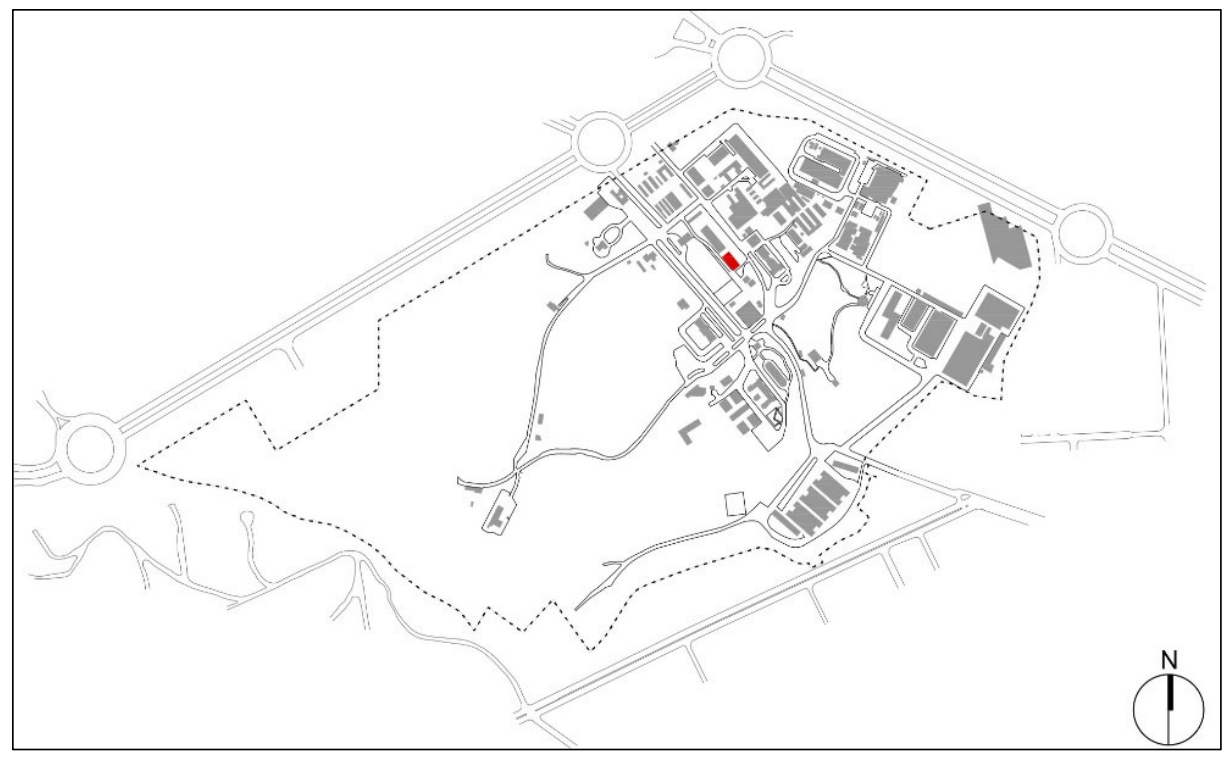

Fig. 109 - Localização da Cocheira-Biotério em 2018 (autor)

\section{RESUMO}

Categoria: edifício

Denominação original: Cocheira-biotério

Denominação atual: "Cara de cavalo"

Autoria: Departamento de Obras Públicas do Estado

Área original: $330 \mathrm{~m}^{2}$

Área atual: $330 \mathrm{~m}^{2}$

Número de pavimentos original: 1

Número de pavimentos atual: 1

Início-término da construção: c.1919-1920

Itens arquitetônicos originais:

Estrutura: alvenaria portante

Vedação: alvenaria (tijolo maciço)

Revestimentos paredes externas: argamassa de cimento e cal

Revestimentos paredes internas: argamassa de cimento e cal

Revestimentos pisos internos: cerâmica

Revestimentos pisos externos: cimento desempenado

Caixilharia: madeira, aço

Uso original: cocheira

\section{Itens arquitetônicos atuais:}

Estrutura: original + concreto armado

Vedação: original + divisórias leves

Revestimentos paredes externas atual: original + massa única industrializada + tinta acrílica

Revestimentos paredes internas atual: original + tinta acrílica

Revestimentos pisos internos atual: originais + cerâmicos

Revestimentos pisos externos: original + cimento desempenado

Uso atual: laboratórios 


\subsubsection{Paiol e Oficinas [Centro de Difusão Científica]}

Em 1922 foi anunciada no Diário Oficial do Estado de São Paulo, pela Diretoria de Obras Públicas:

Concorrência para as obras de construção de um paiol para milho, medindo $21 \times 10$ metros, construído sobre pilares de alvenaria com paredes de taboas espaçadas entre si para ventilação, no Instituto Sôrotherapico de Butantan. (DOE, 4/4/1922, p.2455)

Essa descrição corresponde às características do paiol visto nas fotografias de Rudolph Fischer ${ }^{100}$ do final década de 1920 (figura 110). Já na figura 111, da mesma época, pode-se ver um conjunto formado pelo paiol em madeira e pelo edifício em alvenaria, onde se veem algumas carroças, sendo portanto uma cocheira de apoio. Dessa forma, é provável que sua construção tenha se dado em meados da década de 1920.

O objetivo da construção do paiol seria concentrar os alimentos dos animais, que estariam até então mal acondicionados em telheiros da antiga fazenda. Sendo assim, esta construção seguiu os preceitos utilizados em paióis, elevada do terreno, evitando assim umidade ascendente e acesso de roedores e pragas, e construída com tábuas de madeira com espaçamento entre si, permitindo a ventilação cruzada, que evitava a formação de mofo. Desse modo, essa edificação expressava suas características funcionais, sem preocupação em seguir linguagens estéticas, como no caso de outros edifícios do Instituto.

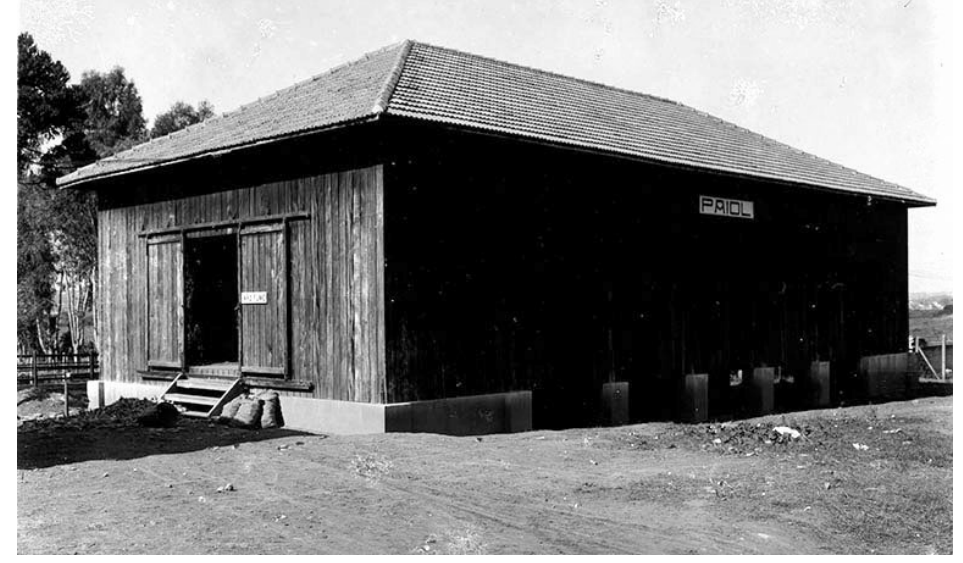

Fig. 110 - Paiol na década de 1920: o edifício utilitário se diferencia dos demais do campus principalmente pelo uso predominante da madeira em vez de alvenaria (Fonte: IB_ICO_010008)

\footnotetext{
${ }^{100}$ O biólogo alemão Carl Rudolph Fischer (1886-1955) veio para Manguinhos em 1912 como ilustrador científico, mesma função exercida no Instituto Butantan a partir de 1915, período no qual registrou diversas fotografias dessas instituições (e de outros temas) formando um acervo relevante do início do século XX.
} 

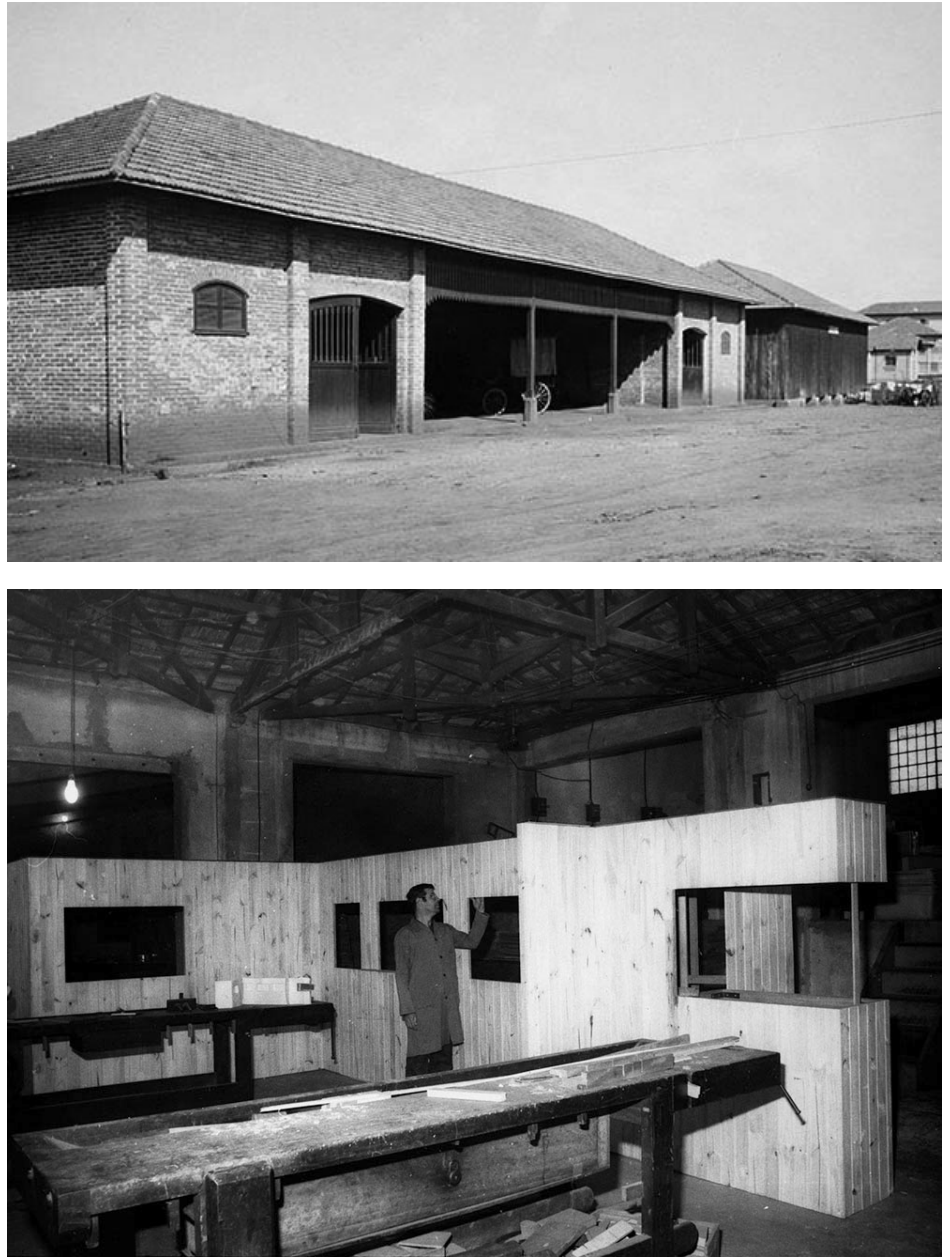

Fig. 111 - Conjunto das Oficinas e Paiol na década de 1920: o bloco de oficinas, em primeiro plano, trazia alguns desenhos ornamentais básicos, sobretudo nos arranjos das madeiras do recinto de serviços, curiosamente assemelhado a uma varanda de casa bandeirista (Fonte: IB_ICO_010437)

Fig. 112- Interior da oficina, no nível inferior, 1966: vê-se o serviço de fabricação dos painéis expositivos para o novo Museu Biológico, que seria instalado na Cocheira Central nesse ano (Fonte: IB_ICO_010437).

Em relação ao bloco de alvenaria, este abrigou diversas funções ao longo do tempo: depósito, oficinas de ferreiro e seleiro, manutenção de veículos e máquinas, marcenaria e serralheria (figura 112). Apesar do aspecto funcional, esse bloco trazia algumas ornamentações simples na forma de corte dos madeiramentos, como é possível ver no acabamento serrilhado dos painéis em madeira sobre o vão da entrada das carroças.

O conjunto permaneceu abrigando diversos serviços de manutenção até ficar desocupado, devido à terceirização dessas atividades no final da década de 1990. Em 2004 o Instituto firmou um convênio com a Fundação Armando Álvares Penteado (FAAP) para que, com projeto de restauração elaborado com ajuda dos alunos do curso de arquitetura dessa instituição, o conjunto de $700 \mathrm{~m}^{2}$ fosse convertido em Centro de Difusão Científica, com áreas de exposição, livraria, café e auditório, no intuito de atrair visitantes de vários perfis. Segundo o diretor da época, Otávio Mercadante: 
"Nós temos uma preocupação com a preservação e a recuperação dos prédios mais antigos" (Parceria com alunos da Faap vai revitalizar galpões abandonados. O Estado de São Paulo. 09/04/2004, p.ZO-8)

De acordo com a mesma notícia:

O diretor do Butantã explica que procurou a FAAP por causa da tradição local em restauração. 'Temos preferência por projetos desse tipo", comenta o diretor da Faculdade de Artes Plásticas da FAAP, que engloba o curso de arquitetura, Sílvio Passarelli. Experiências semelhantes já foram executadas ou estão em andamento, como a criação de um centro cultural numa fábrica abandonada na cidade de Leme, no interior paulista.

Para desenvolver o projeto de recuperação, professores irão orientar os estudantes de arquitetura [...].

Preservação - Apesar de o conjunto não possuir um valor arquitetônico específico, Passarelli garante que a edificação não será descaracterizada, e, caso isso ocorra, será mínima. [...]

O futuro centro deverá fazer parte do roteiro cultural e turístico denominado Butantã Cultura Viva, criado pela subprefeitura da região. Nesse circuito também estarão a Casa do Bandeirante e a Casa do Sertanista, entre outros patrimônios locais. (Ibid)

Com o projeto de restauro e adaptação finalizado em 2007, o Instituto passou a procurar viabilizar a execução da obra e se aliou à então recente Organização de Desenvolvimento Cultural e Preservação (AMA BRASIL) ${ }^{101}$ que, com financiamento do BNDES, realizou a reforma, concluída em 2009. A reforma consistiu em aproveitar as estruturas existentes, mantendo os materiais aparentes originais e criando uma cobertura de estrutura metálica e telhas translúcidas entre o paiol em madeira e bloco de alvenaria das oficinas, explicitando o contraste entre os elementos novos e os antigos.

\footnotetext{
${ }^{101}$ AMA BRASIL (Organização de Desenvolvimento Cultural e Preservação Ambiental) é uma OSCIP (Organização da Sociedade Civil de Interesse Público) voltada a ações de preservação do patrimônio cultural que, entre outras atividades, gerencia obras de restauro, como nesse caso estudado. Essa organização de economia privada foi responsável pelo restauro de monumentos como o Relógio da Estação em Paranapiacaba, o Museu Pélé, o Teatro Guarany e a Casa do Trem Bélico, em Santos. Foi criada em 2004 (ano de início do projeto de restauro do Paiol de oficinas), sendo um de seus sócios-fundadores Otávio Mercadante, diretor do Instituto Butantan na época.
} 


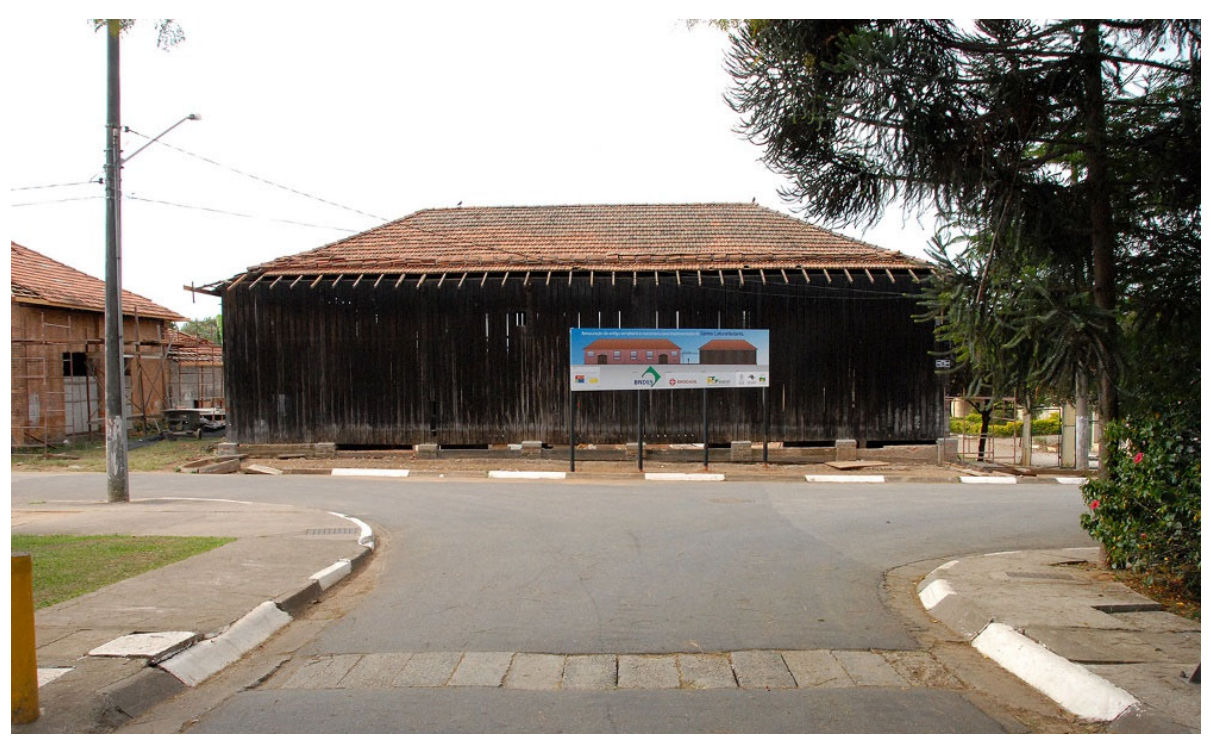

Fig. 113 - Paiol e Oficinas em obras de restauro, 2009: entre o paiol, em madeira, e o bloco de oficinas em alvenaria foi instalado acesso com cobertura em estrutura de aço. (Fonte: autor)
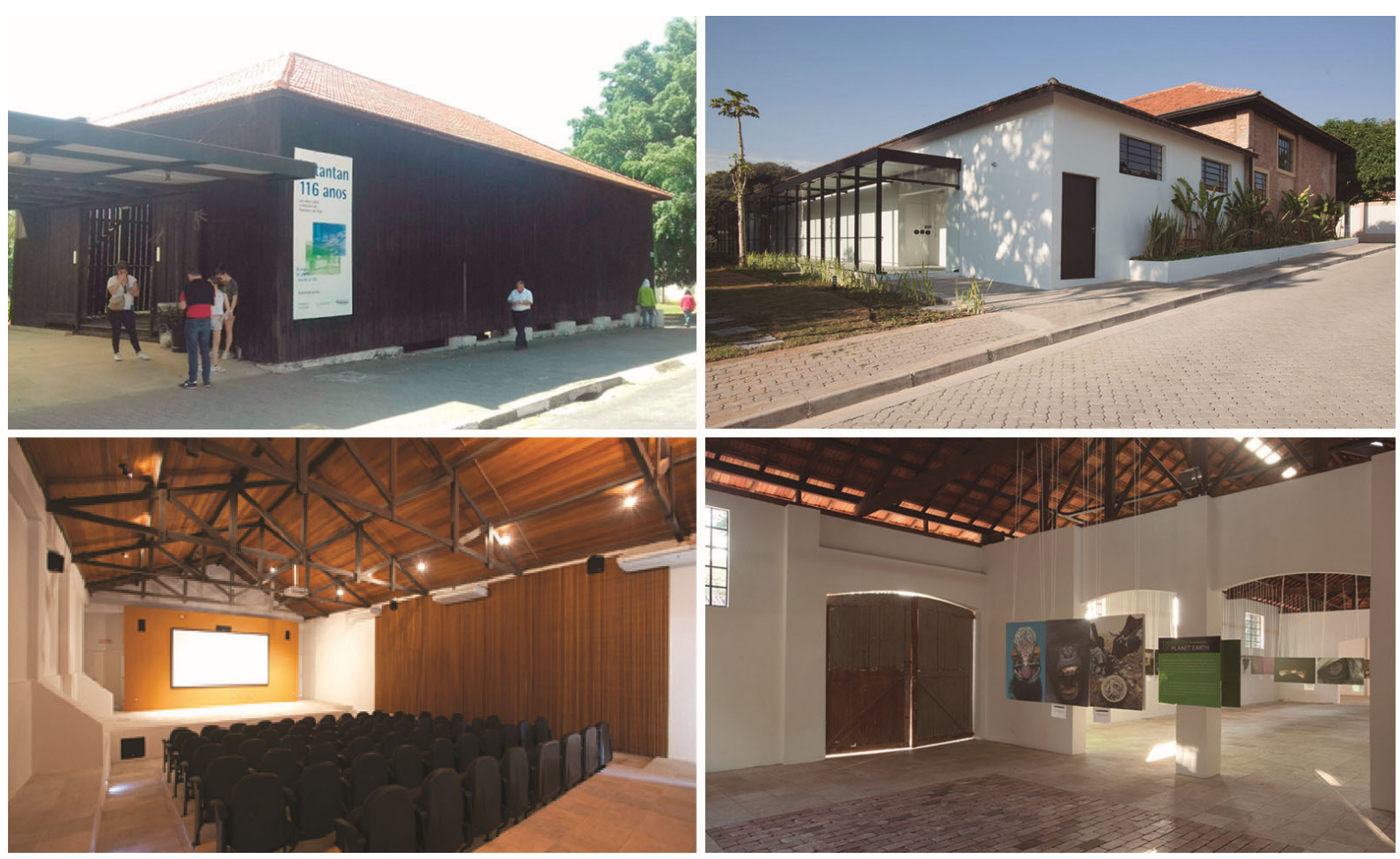

Fig. 114 - Paiol e Oficinas após restauro de 2009: procurou-se diferenciar os elementos novos dos originais, convertendo o conjunto ao uso expositivo e de eventos (Fonte: http:// amabrasil.org.br, 05/12/2018 e autor) 


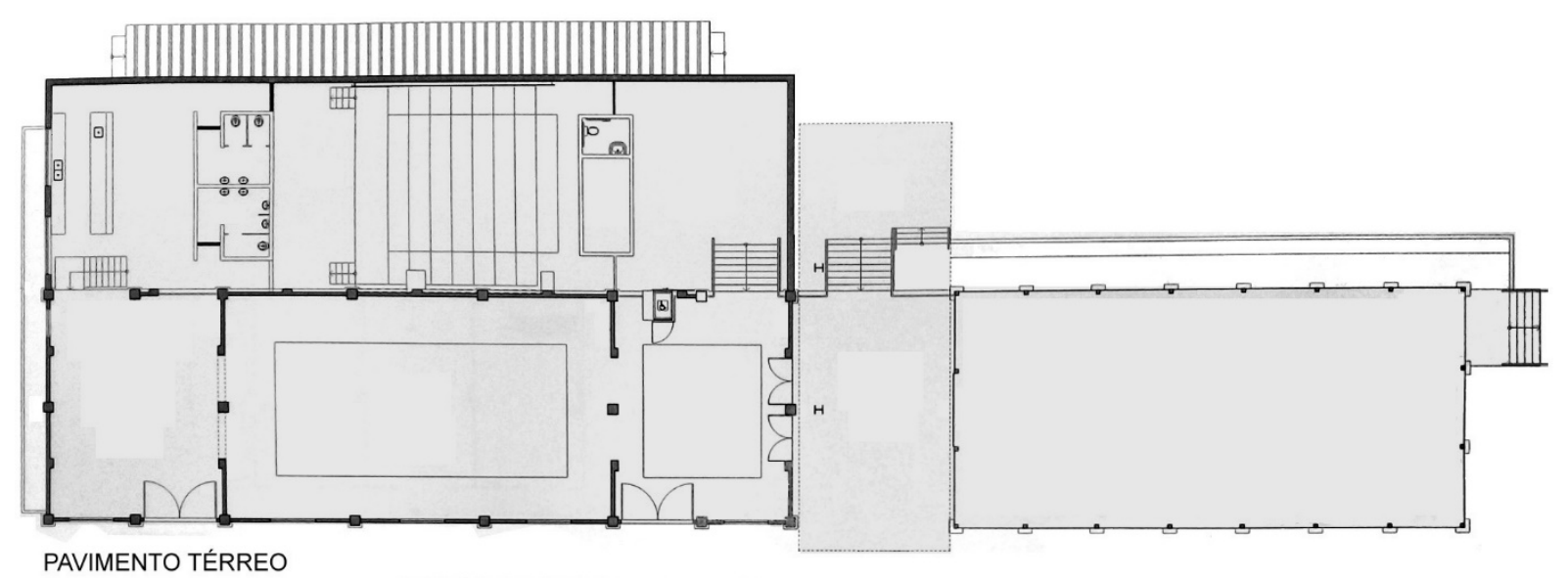

PAVIMENTO TÉRREO

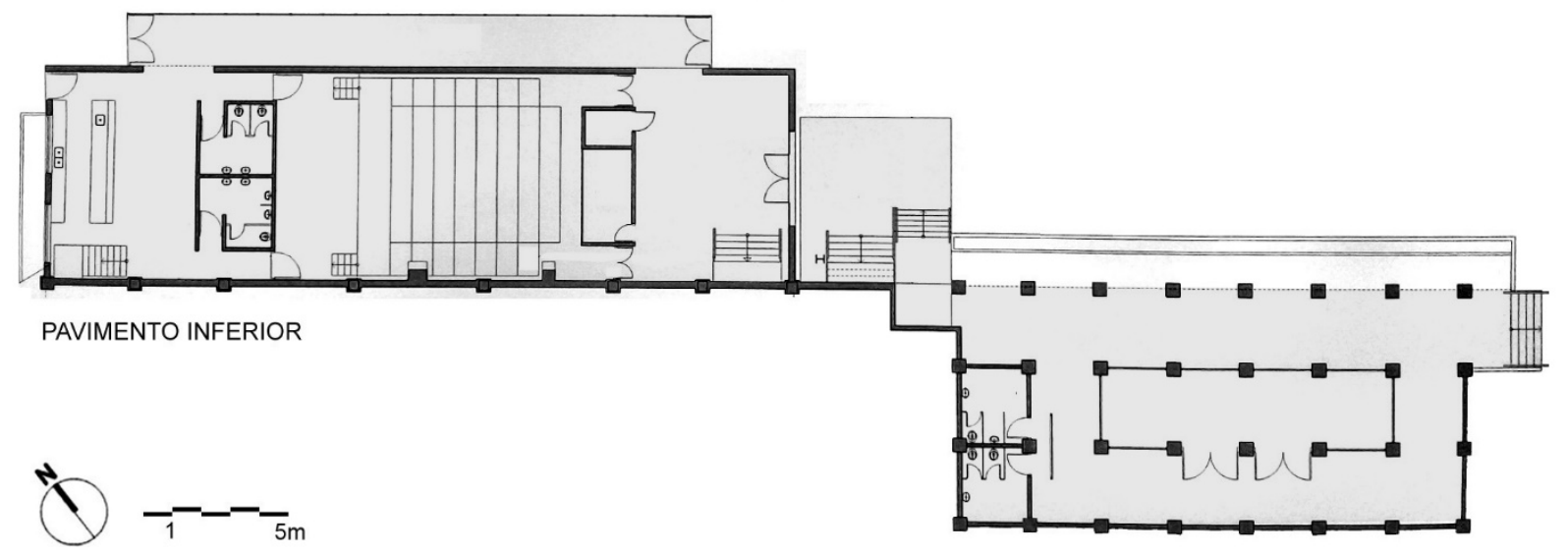

Fig. 115 - Plantas do conjunto em 2016: o paiol (à direita) é ligado às antigas oficinas por um acolhimento coberto, formando diversas salas de exposição articuladas, além do auditório e café (Fonte: IBu, 2016, alterada)

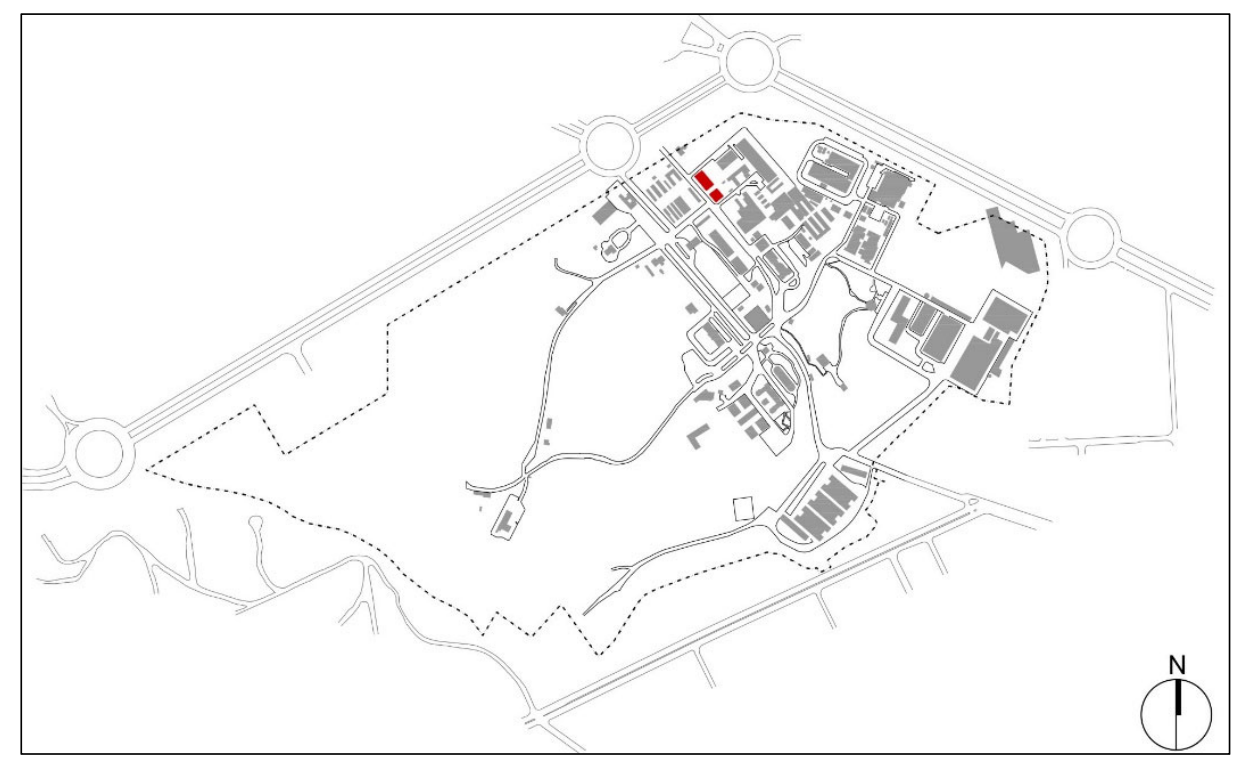

Fig. 116 - Localização do Paiol e Oficinas (atual Centro de Difusão Científica) em 2018 (autor) 


\section{$\underline{\text { RESUMO }}$}

Categoria: conjunto de edificações

Denominação original: Paiol e Oficinas

Denominação atual: Centro de Difusão Científica

Autoria: desconhecida

Área original: c. $520 \mathrm{~m}^{2}$

Área atual: c. $700 \mathrm{~m}^{2}$

Número de pavimentos original: 2

Número de pavimentos atual: 2

Início-término da construção: c. 1922-1925

Itens arquitetônicos originais:

Estrutura: alvenaria portante e madeira

Vedação: alvenaria (tijolo maciço) e madeira

Revestimentos paredes externas: argamassa de cimento e cal e madeira

Revestimentos paredes internas: argamassa de cimento e cal e madeira

Revestimentos pisos internos: cerâmica, cimento queimado e madeira

Revestimentos pisos externos: cimento desempenado

Caixilharia: madeira e aço

Uso original: armazenamento e serviços de manutenção

Itens arquitetônicos atuais:

Estrutura: original + concreto armado

Vedação: original + divisórias leves

Revestimentos paredes externas atual: original + verniz

Revestimentos paredes internas atual: original + tinta acrílica + verniz

Revestimentos pisos internos atual: originais + cerâmicos + granito

Revestimentos pisos externos: cimento desempenado

Uso atual: exposições e eventos

\subsubsection{Mostruário de Cobras [Bilheteria]}

Em fotos do final da década de 1910, com o Edifício Principal e o serpentário concluídos, é possível ver o quiosque que seria então usado para as apresentações de extração de veneno. Foram construídos três quiosques desse tipo, sendo o segundo para recepção de cobras (que eram trocadas por doses de soro) e o terceiro usado como abrigo para espera de ônibus. Os quiosques se tornaram comuns no final do século XIX principalmente na Inglaterra e na França, geralmente construídos em aço. Segundo o West Pier Trust, responsável pelo restauro do quiosque de West Pier ${ }^{102}$, em Brighton na Inglaterra:

\footnotetext{
${ }^{102} \mathrm{O}$ West Pier foi um dos primeiros quiosques construídos totalmente em aço, em 1866, e hoje está restaurado.
} 
Os quiosques foram as primeiras edificações especificamente projetadas para serem construídas em ferro fundido ornamental. Não havia nada parecido até então. Críticos da época tinham dificuldade para descrevê-los. 'Ornamental houses' era o melhor termo que conseguiam para tais construções, antes de ficarem conhecidas como 'kiosks' - uma nova palavra exótica nos anos de 1860, de origem persa, que significa palácio ou pavilhão. (http://www.westpier.co.uk, 02/11/2018, tradução nossa)

A própria nomenclatura revelava a onda orientalizante da época, que chegou ao Brasil, e podia ser vista principalmente no Rio de Janeiro (FEIJÃO, 2011). Há como exemplo a Casa de Chá de Manguinhos, que apesar das dimensões e utilização diversas, possuía o mesmo princípio de construção leve, em madeira, para atividades temporárias ${ }^{103}$. No caso dos quiosques do Instituto Butantan, o material utilizado também foi a madeira, através de encaixes e fixações metálicas. Não se pode afirmar ao certo o quanto e quais outros quiosques influenciaram na construção destes, mas certamente os cientistas e construtores envolvidos tinham contato com exemplares já existentes e com a circulação de métodos construtivos da época.

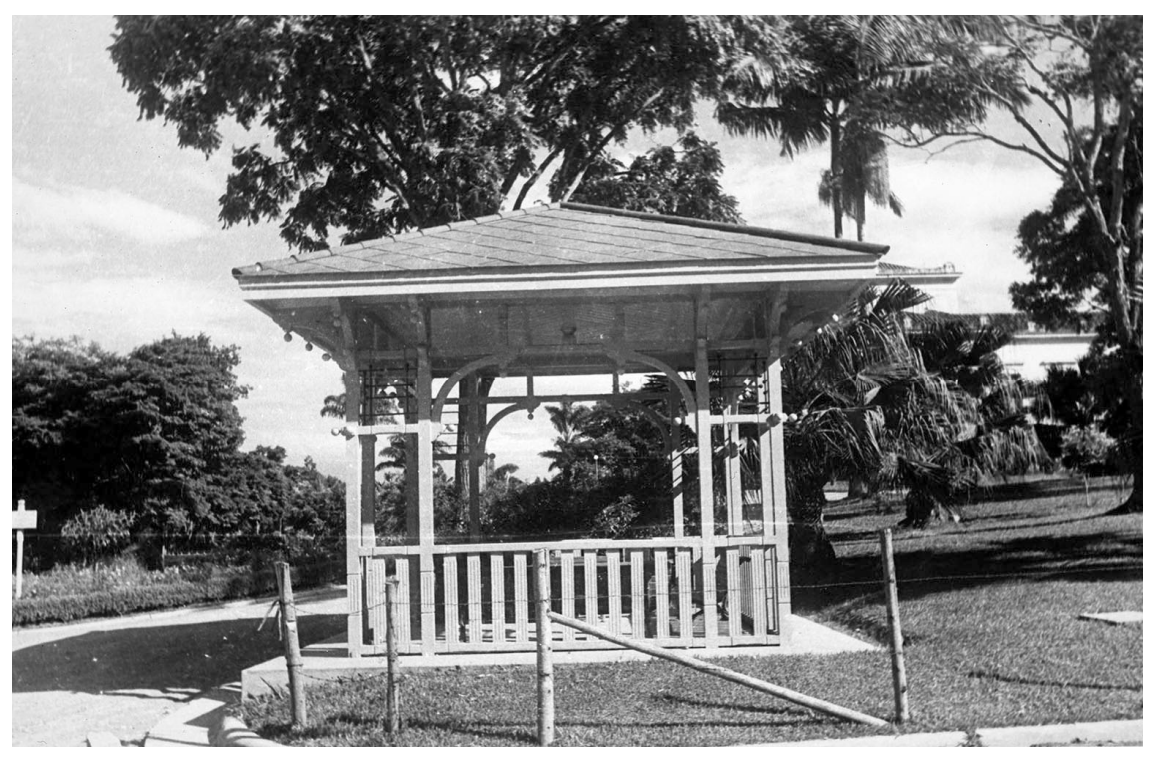

Fig. 117 - Quiosque mostruário de cobras na década de 1920: a estrutura vazada dava um aspecto bucólico à pequena edificação (Fonte: IB_ICO_009335)

O quiosque remanescente no campus, que seria igual aos outros dois, foi construído em planta quadrada, com telhado em ardósia em quatro águas e estrutura de madeira (figura 117). Não havia vedos externos, sendo que a estrutura, vazada, desenvolvia-se formando balanços

\footnotetext{
${ }^{103} \mathrm{O}$ espaço servia de refeitório e ponto de encontro dos cientistas até o início da década de 1950. Atualmente restaurado, retomou sua função original de salão de refeições (http://www.coc.fiocruz.br, 15/10/2018).
} 
curvos em seu topo, lembrando beirais orientais. Embora não tenha estrutura de ferro, as formas alongadas e a predominância formal dos elemento estruturais remetem às construções inglesas pré-fabricadas em ferro do final do século XIX.

A estrutura passou por muitas transformações, sendo principalmente introduzidos vedos em madeira e esquadrias com vidro para fechar o recinto. Pinturas diversas em tinta esmalte e a óleo foram aplicadas, com mudanças de tom (originalmente, pelas fotos, verifica-se que ela tinha cor clara em sua madeira). No início da década de 1990 foi feita, segundo os relatórios, "reforma e restauração" do quiosque, com recursos da Camargo Corrêa e JHS Engenharia (RA 1991-1994, p.5). O relatório de 1991 descreve as doações das empresas:

O projeto foi apresentado a Sebastião Camargo (Construtora Camargo/Corrêa) que efetuou doação de U\$ 10.000, importância que se destinou à aquisição de material (madeira e vidro) necessário à recuperação do quiosque. Os recursos necessários à execução dos serviços, mão de obra, estão sendo doados por J.H.S. Auriemo. As doações foram efetuadas em nome da Fund. Butantan. (RA 1992, p. 473)

Pode-se dizer que as modificações por que passou o antigo Mostruário de Cobras alteraram sobremaneira seu aspecto, que, do ponto de vista de cores, acabamentos, volumetria e aberturas, está bastante longe do original, devido às necessidades de segurança e abrigo próprias de uma bilheteria (uso que, pela trivialidade, poderia ser localizado em outro espaço, sem se desfigurar esse elemento original). Mas o quiosque ainda tem preservadas suas proporções e estrutura de suporte, e pode ter sua legibilidade e relações originais restauradas (transparência e volumetria), caso haja interesse.
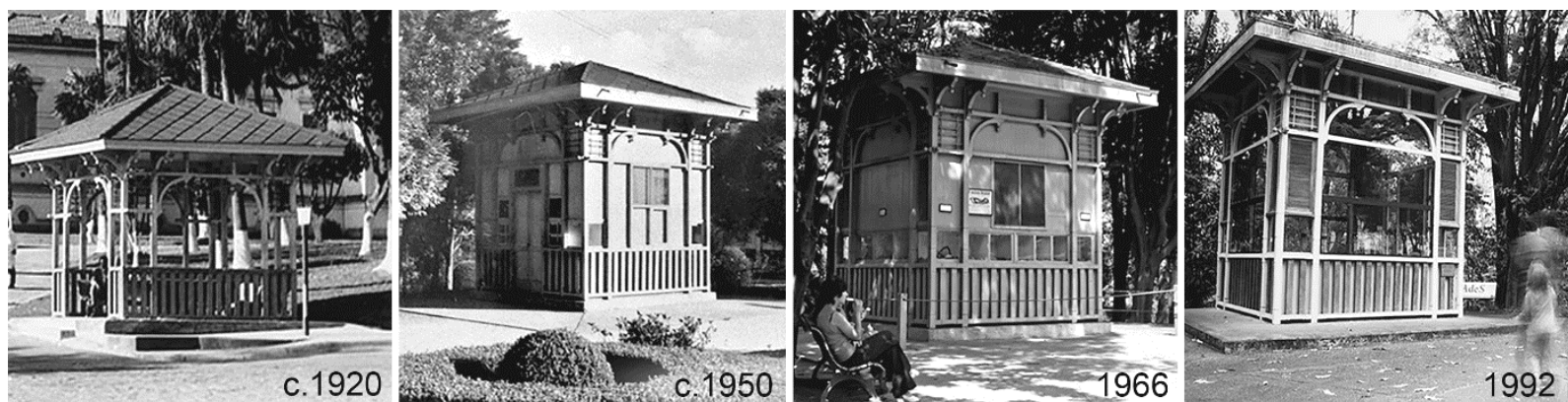

Fig. 118 - Quiosque do antigo Mostruário de Cobras em diferentes fases: inicialmente aberto, o quiosque foi alterado, mas na reforma de 1992 aparentemente se procurou recuperar o aspecto de suas aberturas com uso de vidros. (Fonte: Acervo do IBu) 


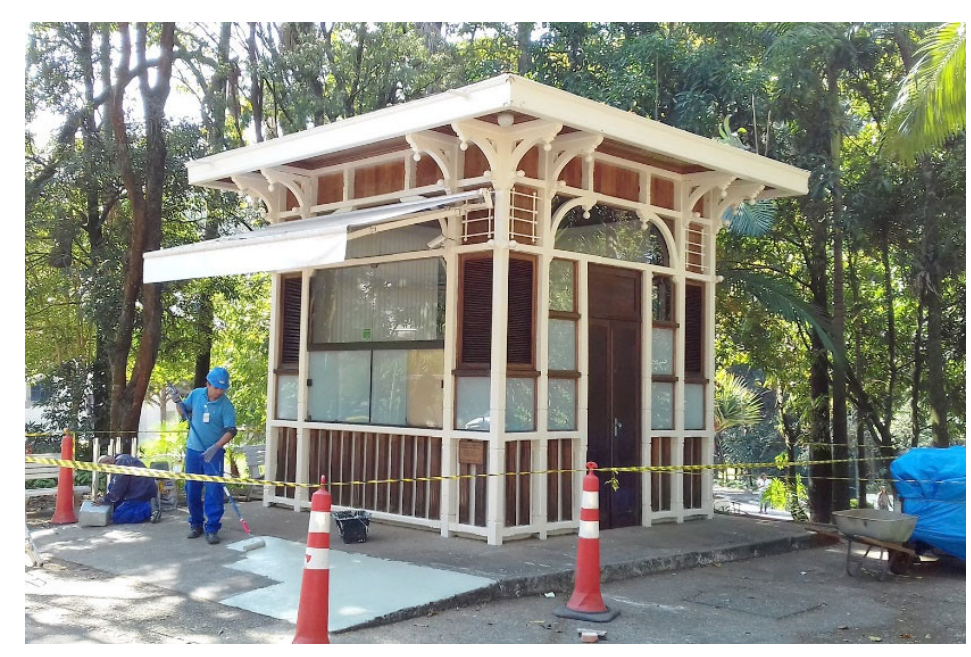

Fig. 119 - Quiosque em 2018: utilizado como bilheteria, ele recebeu diversos acréscimos que mudaram as relações de aberturas e cores. Sua volumetria e simetria também sofreram interferência com o avanço do novo toldo (Fontes: autor)

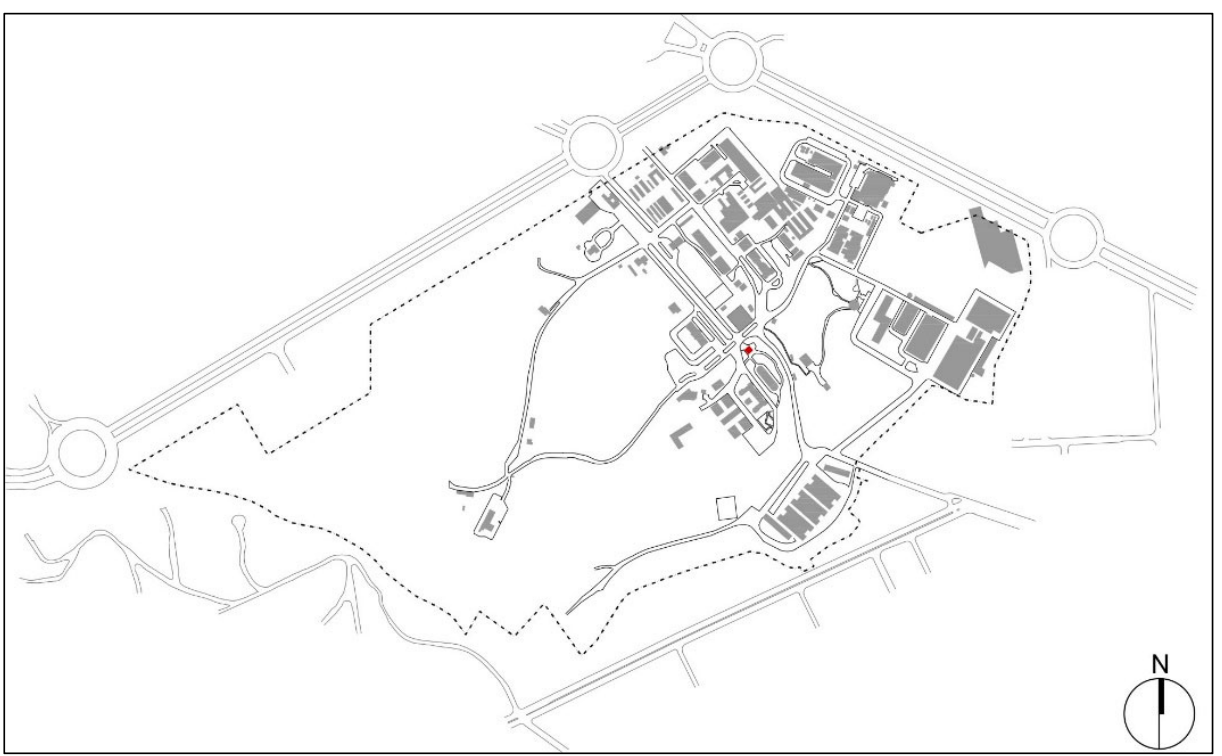

Fig. 120 - Localização do Mostruário de cobras (atual bilheteria) em 2018 (autor)

\section{$\underline{\text { RESUMO }}$}

Categoria: edifício

Denominação original: Mostruário de cobras

Denominação atual: Bilheteria

Autoria: desconhecida

Área original: $14 \mathrm{~m}^{2}$

Área atual: $15 \mathrm{~m}^{2}$

Número de pavimentos original: 1

Número de pavimentos atual: 1

Início-término da construção: c.1914

\section{Itens arquitetônicos originais:}

Estrutura: madeira

Vedação: madeira

Revestimentos paredes externas: verniz e tinta a óleo 
Revestimentos paredes internas: verniz e tinta a óleo

Revestimentos pisos internos: cerâmica

Revestimentos pisos externos: cerâmica

Caixilharia: madeira

Uso original: demonstrações de extração de veneno

Itens arquitetônicos atuais:

Estrutura: original

Vedação: original + divisórias leves

Revestimentos paredes externas atual: original + madeira + tinta esmalte

Revestimentos paredes internas atual: original + tinta esmalte

Revestimentos pisos internos atual: originais + vinílicos

Revestimentos pisos externos: original + cimento desempenado

Uso atual: bilheteria

\subsubsection{Casa do Administrador [Creche]}

No final da década de 1920 foi construída a casa para moradia do administrador do Instituto e sua família, que hoje abriga a creche para filhos de funcionários. Não há muito mais informações históricas sobre ela, mas cabe pontuar que há nessa construção elementos arquitetônicos que viriam a reaparecer na Casa do Diretor em 1931(item 2.3.13) e em outras construções no campus que foram posteriormente demolidas ou bastante desfiguradas.

Trata-se de uma casa de um pavimento e embasamento com porão (para ventilação do piso térreo), que seguia uma linguagem inovadora para a época, pois trazia elementos nacionalistas que seriam vinculados ao nascente neocolonial, que procurava, principalmente após a crise do pós-Primeira Guerra, reinterpretar elementos da arquitetura colonial, ao mesmo tempo em que se afastava do academicismo, adotando soluções volumétricas mais livres, assimétricas, materiais sem revestimento, como o tijolo aparente, e desenho de detalhes que lembravam as propostas advindas do Arts and Crafts inglês (figura 121).

Essa é uma leitura dos aspectos arquitetônicos pois, como foi dito, não há muitos registros iconográficos e documentais de sua criação, apenas a menção à construção da casa no relatório de 1931. Mas pela solução adotada, o período de sua construção, e as semelhanças de alguns elementos com a citada Casa da Diretoria, pode-se aventar a hipótese de que tenha autoria do engenheiro-arquiteto Mauro Álvaro, assim como aquela. 
Hoje, a casa se encontra bastante preservada em sua volumetria e elementos essenciais, como aberturas e vedos. As pinturas procuraram respeitar a dinâmica de materiais aparentes e revestidos (figura 122).

O novo Plano Diretor propõe intervenções conservativas minimamente necessárias, sem alteração significativa das características do edifício, entre elas a revisão de madeiramento danificado da cobertura, remoção de divisórias de laminado melamínico, recuperação de janelas e portas originais e descupinização.
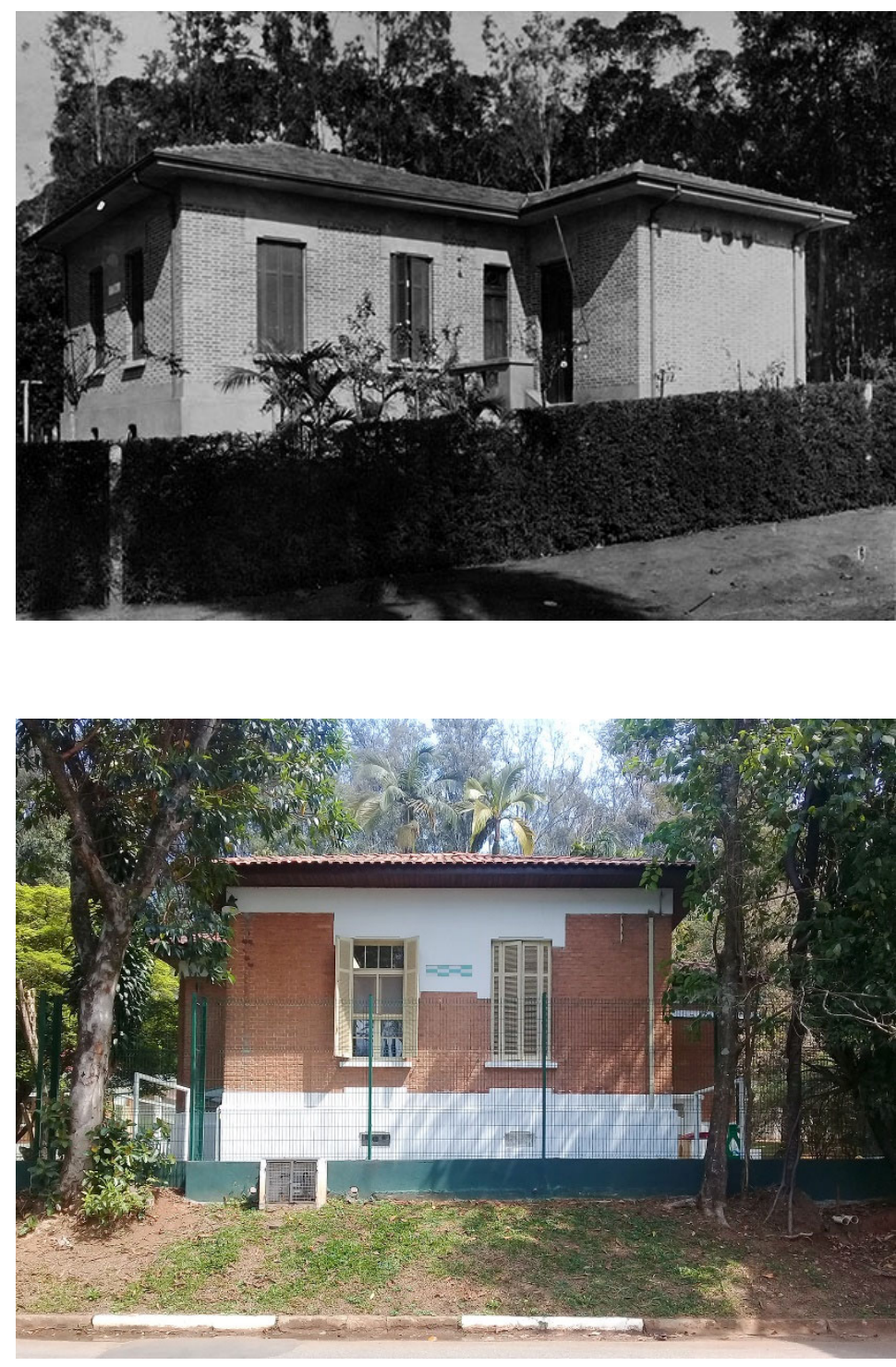

Fig. 121 - Casa do administrador, década de 1940: a pequena construção trazia elementos novos como a assimetria e o uso de alvenaria aparente, características também utilizadas pela linguagem neocolonial e, posteriormente, o brutalismo (Fonte: IB_ICO_010438)

Fig. 122 - Creche, 2018: a mudança de função não implicou em alterações significativas na construção, indicando que o novo uso pode ser adaptado sem prejudicar as características principais do patrimônio (Fontes: autor) 

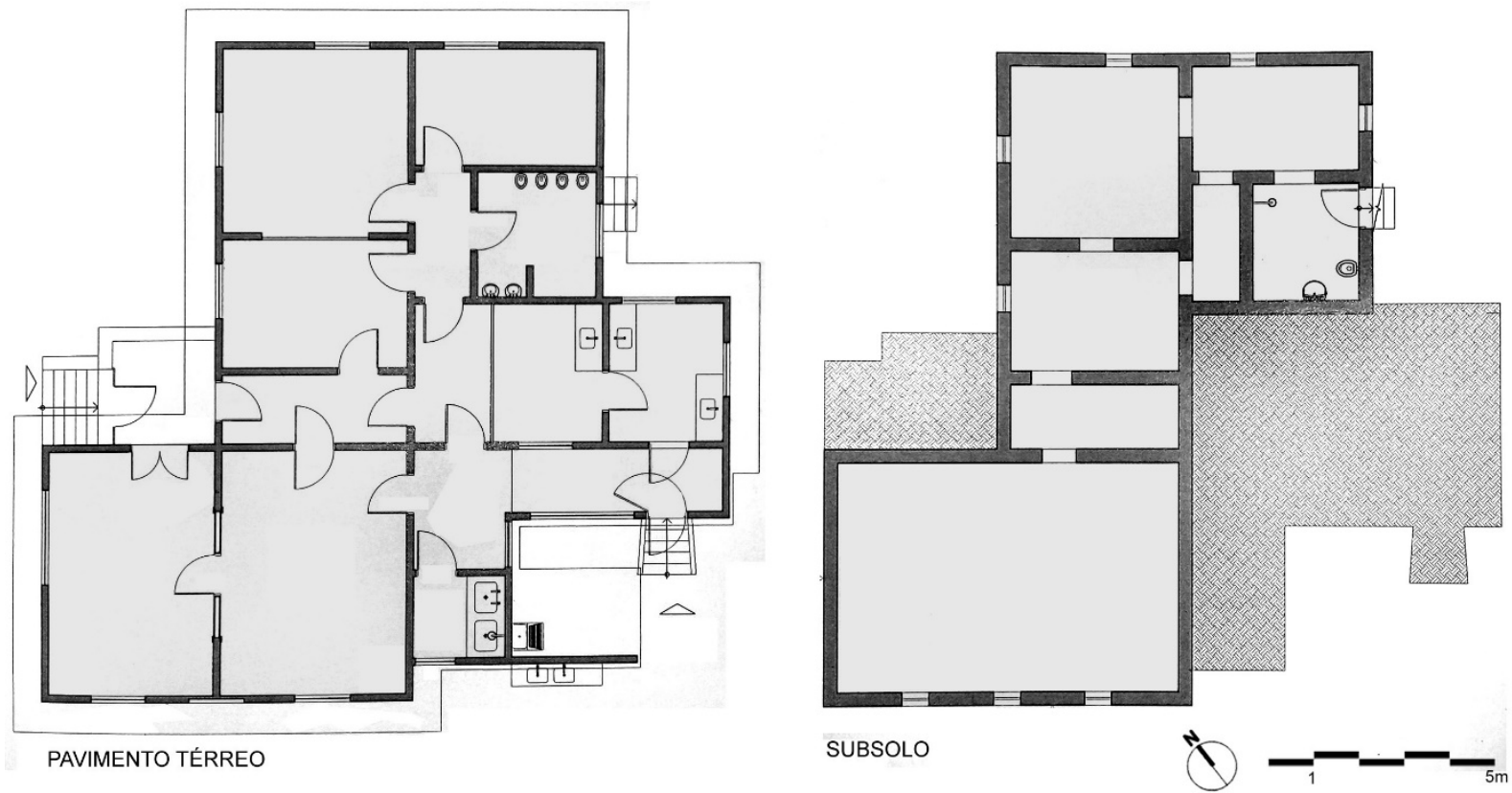

Fig. 123 - Planta da Casa do Administrador atualmente, utilizada como creche (Fonte: IBu, 2016, alterada)

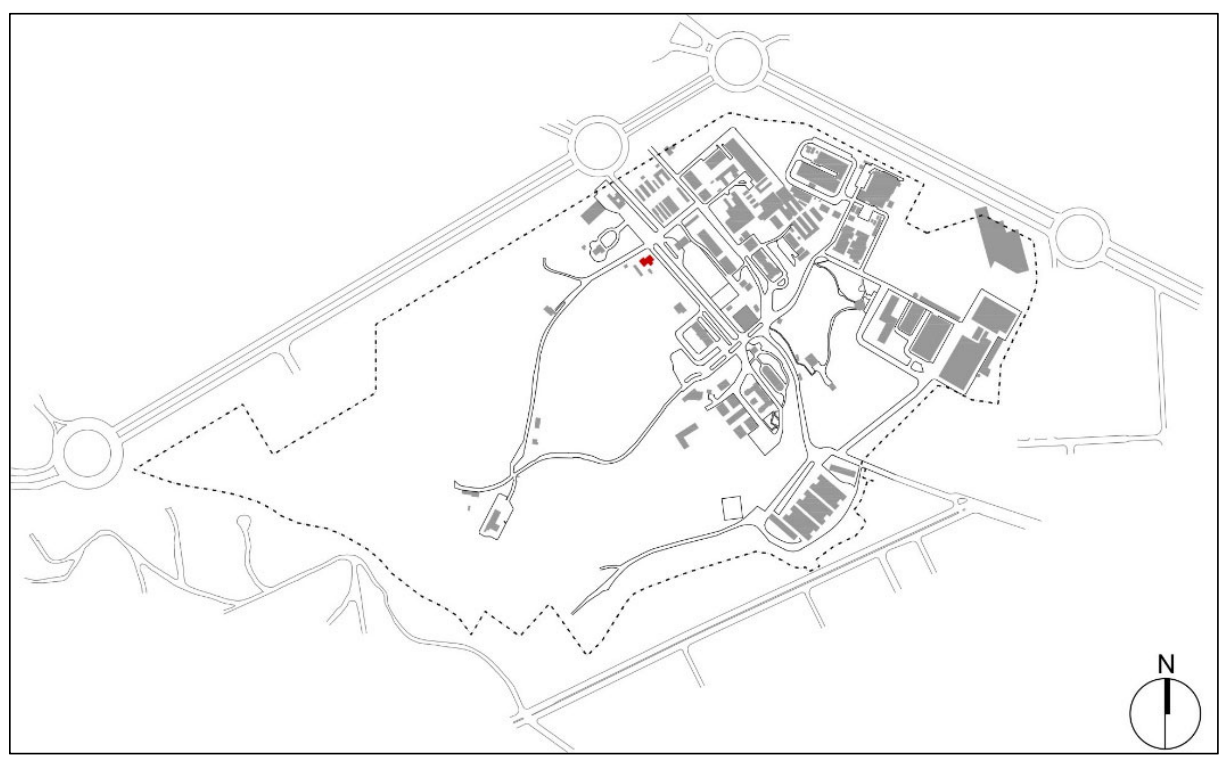

Fig. 124 - Localização da Casa do administrador (atual Creche) em 2018 (autor)

\section{RESUMO}

Categoria: edifício

Denominação original: Casa do administrador

Denominação atual: Creche

Autoria (atribuída): Mauro Álvaro de Souza Camargo

Área original: $270 \mathrm{~m}^{2}$

Área atual: $270 \mathrm{~m}^{2}$

Número de pavimentos original: 2

Número de pavimentos atual: 2

Início-término da construção: c. 1920 


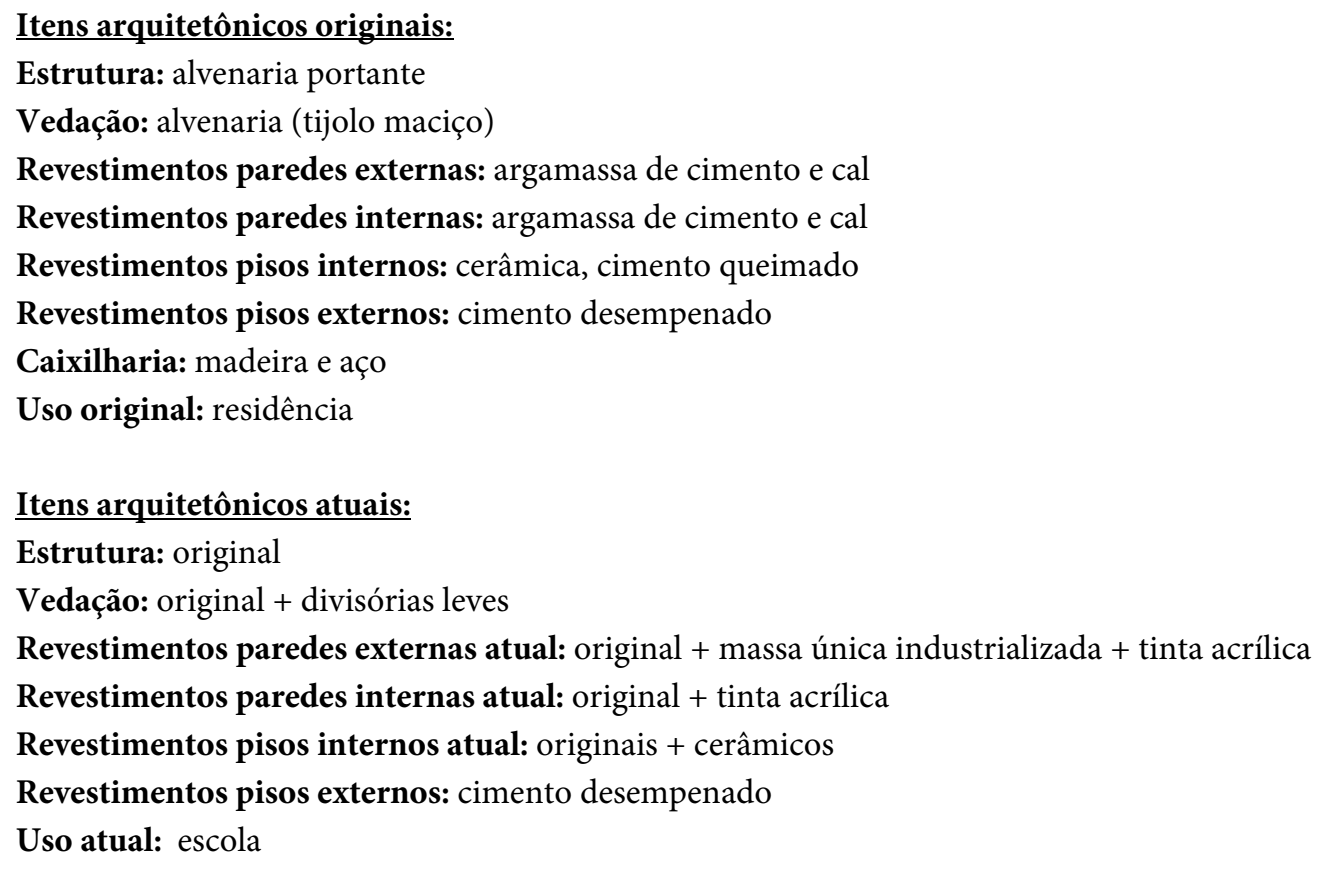

\subsubsection{Casa do Diretor [Diretoria]}

Em 1930, o Instituto, utilizando verba proveniente da venda de sua própria produção de fármacos, iniciou diversas construções e reformas, entre as quais estavam residências voltadas a funcionários e administradores. O relatório desse ano trazia em sua listagem:

Início da construcção da residencia do director, afim de serem installadas, no antigo predio, as escolas reunidas de Butantan. (RA 1930, np)

O antigo prédio mencionado era a Casa Sede da Fazenda (item 2.3.2), que até então servia de residência do diretor do Instituto.

Na Casa do Diretor, concluída em 1931, fica clara a preocupação em destacar essa residência das demais feitas para funcionários, provavelmente pela hierarquia, razão pela qual ela possuía a maior área entre as demais, era isolada (assim como a do administrador), e não em renque, situava-se em um dos promontórios do terreno, com vista privilegiada e possuía piscina. Seu projeto foi assinado por Mauro Álvaro de Souza Camargo, tendo seguido nesse caso uma linguagem mais moderna em relação ao que fizera cerca de duas décadas antes no Edifício Principal e na Cocheira Central. O projeto de 1931 mostra essas soluções. 
Nesse momento o Art Nouveau de São Paulo, com poucos exemplares, já estava em uma fase tardia, e arquitetos considerados mestres do período, como Dubugras, seguiam em um desenvolvimento das ideias do Neocolonial, principalmente nos projetos de residências. TOLEDO (1985), em seu estudo sobre Dubugras, destaca sua "magistral utilização do tijolo aparente" em diversas casas. Assim, havia uma sobreposição de influências e já era difícil definir uma linguagem predominante, mas notava-se uma depuração nas obras, que eram agora caracterizadas por uma liberdade maior na volumetria e planta, afastando-se da simetria e das proporções das linguagens classicizantes e buscando maior variação de dimensões, acabamentos, orientação e aberturas para cada tipo de ambiente, explorando esteticamente essa maior liberdade de soluções técnicas. Os ornamentos ainda não haviam sido totalmente abolidos, mas estavam cada vez mais simplificados e racionalizados, restringindo-se a saliências, beirais e embasamentos, com funções de proteção contra respingos de chuva e umidade.

O uso de materiais aparentes, especialmente o tijolo maciço e as pedras, era mais uma das características desse período (que conceitualmente seriam seminais para a arquitetura paulista denominada "brutalista" no futuro) e podiam ser vistas em obras de casas no período. Essas características também remontam ao movimento inglês Arts and Crafts, que privilegiava o uso de materiais naturais à vista (pedra, tijolo, madeira), plantas e volumetrias mais livres.

Esses traços podem ser vistos na Casa do Diretor, em que não há preocupação em definir simetrias e proporções acadêmicas, mas em adequar sua expressão à suas funções, levando a uma movimentação variada em sua volumetria (figura 125 e 126).

Assim como nos pináculos da Cocheira Central, é possível inferir novamente uma citação a Dubugras na solução de caixilharia dos vidros na fachada posterior que, sobrepostos em ângulos para ventilação, assemelham-se àqueles da fachada na estação de Mairinque.

Em 1945 a casa foi reformada para abrigar o Hospital Vital Brazil: 


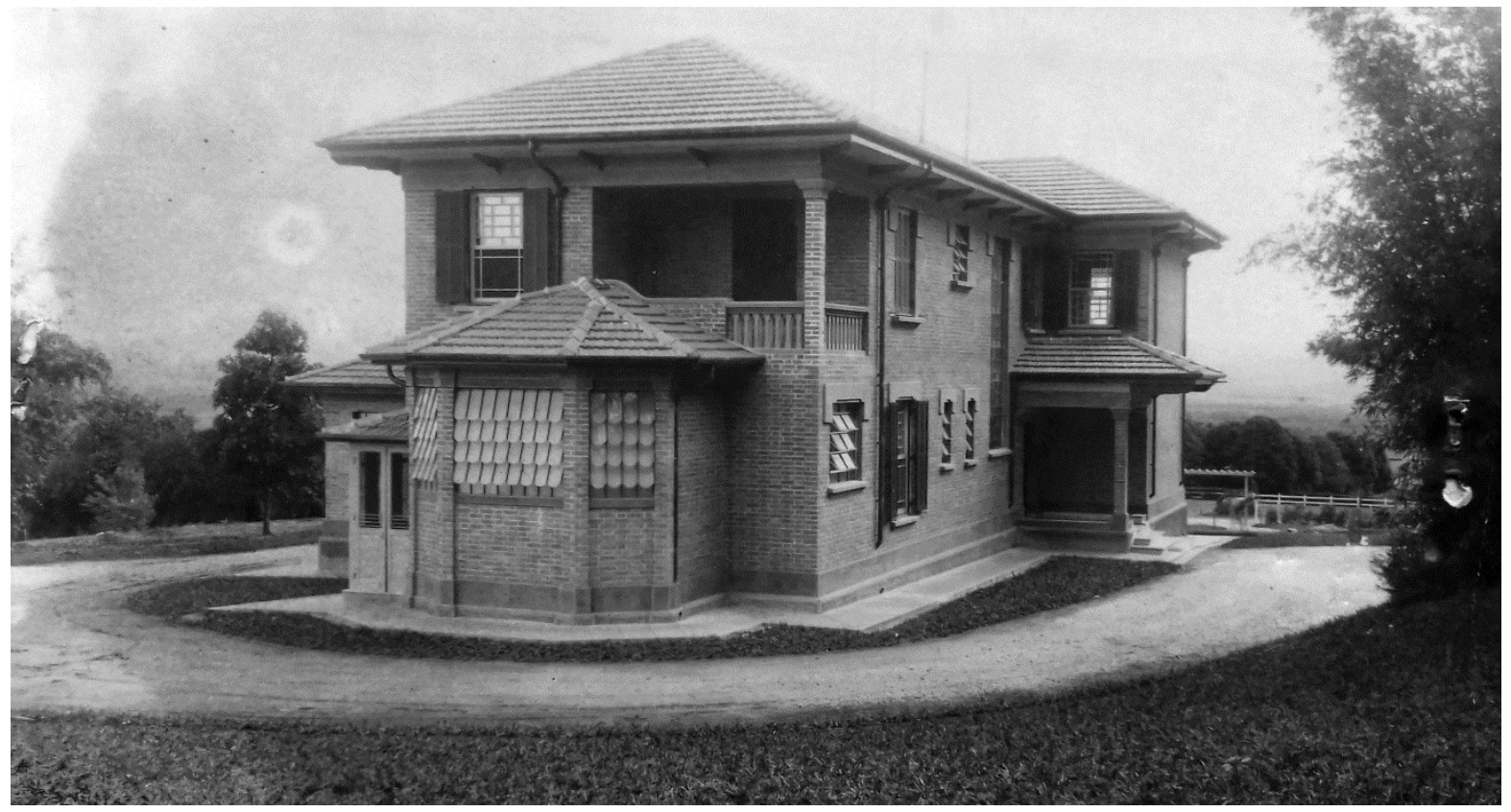

Fig. 125 - Casa do diretor em 1931: aqui Mauro Álvaro substitui os elementos do Art Nouveau utilizados anteriormente por recursos novos, como a assimetria, maior variedade volumétrica, alvenaria aparente, desenhos inovadores em janelas e portas. Esses recursos estéticos e técnicos variados faziam parte de um contexto de experimentação que já vinha aparecendo em obras de arquitetos vinculados ao Neocolonial, como Victor Dubugras. (Fonte: RA 1931, p.33)

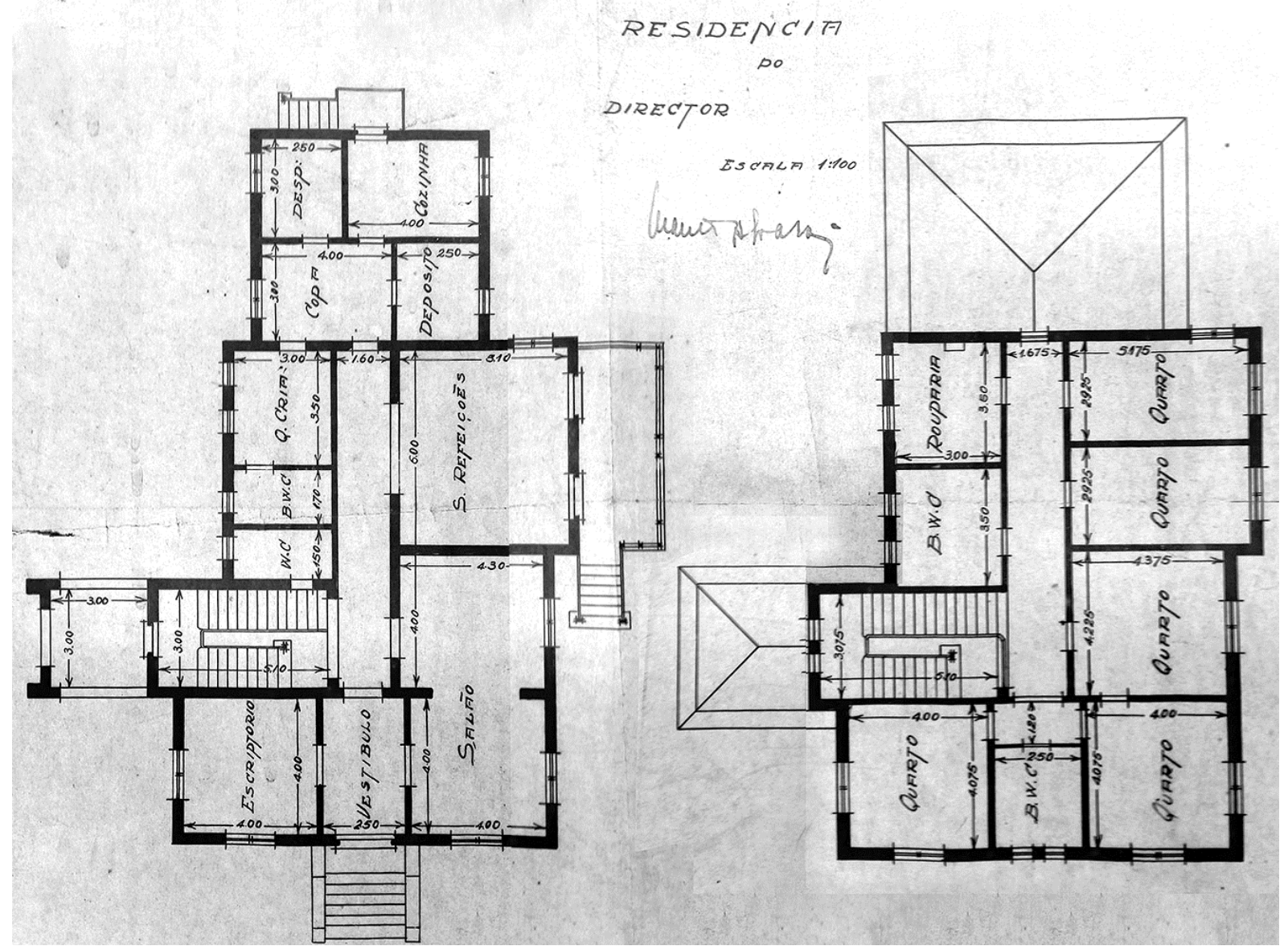

Fig. 126 - Planta assinada por Mauro Álvaro, 1930: vê-se que diversos elementos construídos foram diversos da planta original, indicando modificações em obra (Fonte: Acervo IBu) 
Na reforma que converteu a casa em hospital, os compartimentos internos foram bastante preservados, assim como as principais características estéticas externas (há também um anexo menor utilizado como área técnica).

Externamente não houve grandes alterações. Acredita-se que a piscina em frente à casa tenha sido coberta nesse período.

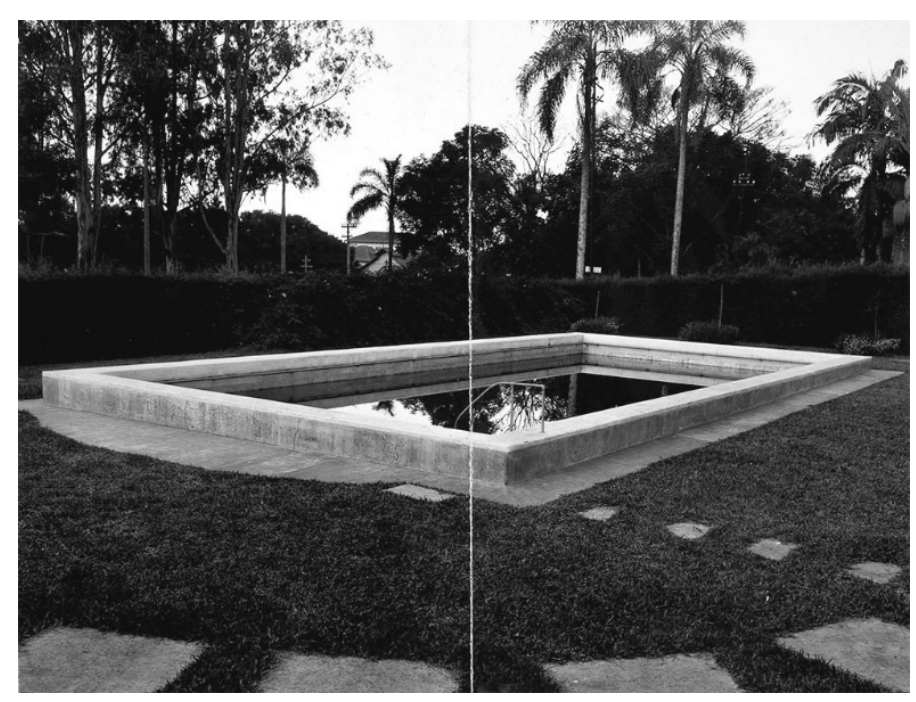

Fig. 127 - Piscina da Casa do Diretor, década de 1930: a piscina foi coberta provavelmente quando o edifício foi convertido em hospital (Fontes: IB_ICO_008775)

Em 1954 o hospital foi transferido para seu novo local (item 2.3.17), e instalou-se provisoriamente no térreo desta casa o museu com acervo de Biologia, que se encontrava também improvisadamente instalado em parte do Pavilhão Lemos Monteiro. O estudo feito para essa instalação previu basicamente a colocação de divisórias, expositores e mobiliários diversos para os itens do museu.

Com a construção do Museu Histórico em 1980, o edifício passou a ser utilizado para funções administrativas do Instituto e da Fundação Butantan, e suas principais características tem sido mantidas. Há planos da Divisão Cultural de fazer prospecções para identificar antiga piscina (figura 127). O Plano Diretor de 2016 propõe que a antiga Casa do Diretor mantenha sua função atual de administração. Segundo o texto, as principais interferências serão:

\footnotetext{
- Criação de uma rampa metálica, externa, para dar acesso aos portadores de necessidades especiais ao prédio, com inclinação e dimensões segundo NBR 9050;

- Criação de uma escada em concreto, externa, para dar acesso ao subsolo do anexo; - Inserção de um elevador interno à edificação, em estrutura de alvenaria de concreto celular, criado para tornar acessível, aos cadeirantes e pessoas com problemas de mobilidade, o pavimento superior da edificação;
} 
- Criação de novos sanitários que atendam aos funcionários e aos diretores. Todas as paredes inseridas [...] serão de dry-wall.

- Inserção de novas portas de madeira na casa principal e portas e esquadrias metálicas no anexo, necessárias ao novo layout previsto.

- Eliminação dos pisos tipo vinílico do pavimento térreo, acrescidos possivelmente quando esse pavimento abrigou o hospital Vital Brasil, escondendo e de certa forma protegendo do uso, os pisos originais em ladrilho hidráulico, granilite, cerâmica São Caetano e tijoleira, neste projeto sendo resgatados.

- Eliminação do piso e revestimento cerâmico dos banheiros, dos dois pavimentos, inserindo novos pisos em ladrilho hidráulico, quando não for possível recuperar os pisos originais recobertos.

- Inserção de piso em ladrilho hidráulico e novo acabamento nas paredes do térreo do prédio anexo, para abrigar o estar de funcionários. (IBu, v.3, Memorial de Projeto Casa do Diretor, 2016, pp. 2-3)

Quanto aos acabamentos, propõe-se manter os materiais aparentes e recuperar as pinturas com tinta látex, esmalte ou verniz, conforme os elementos construtivos, e retirar pisos vinílicos e outros acréscimos posteriores à época em que a edificação foi usada como hospital, na década de 1940. O projeto chega ao nível de especificação de mobiliário, mas recuperando a legibilidade do edifício sem alterações de grande impacto.
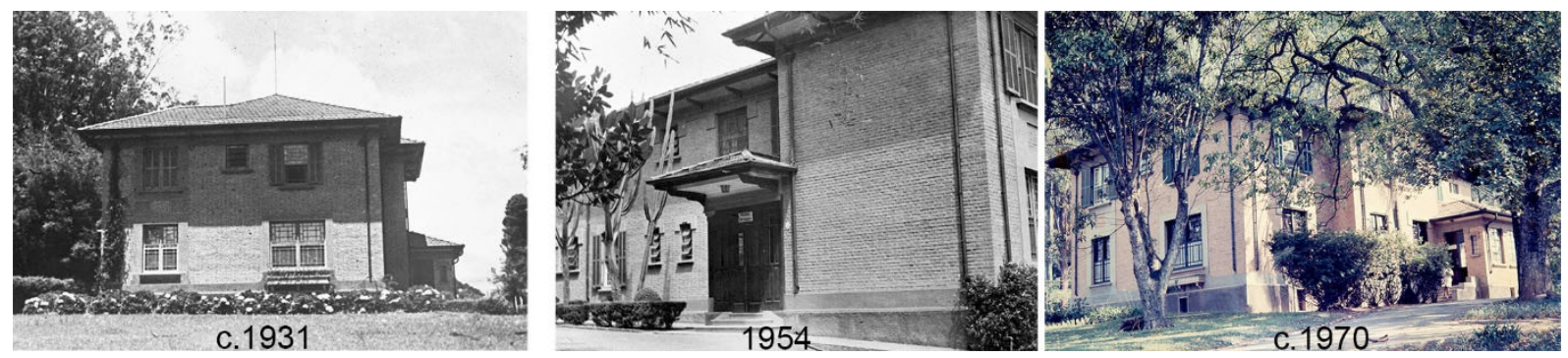

Fig. 128 - Casa do Diretor em diferentes épocas: as principais características externas foram mantidas, havendo mudança no paisagismo do entorno (Fontes: Acervo IBu)

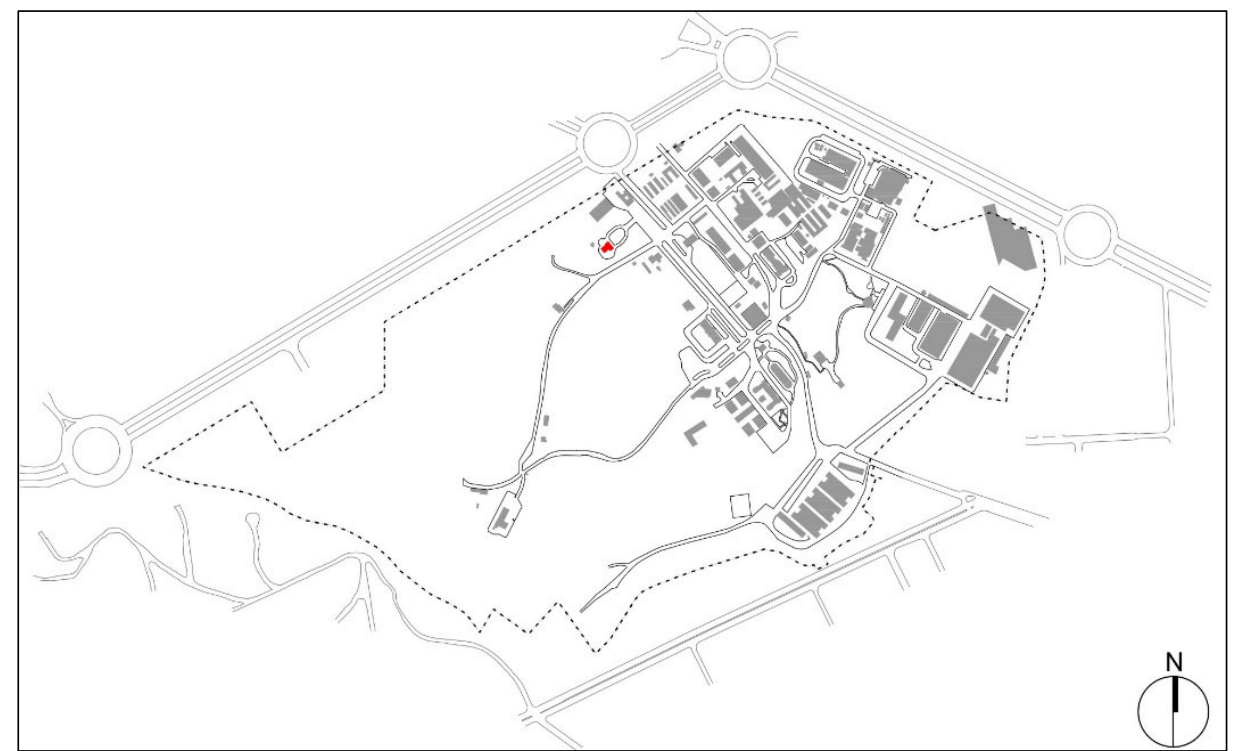

Fig. 129 - Localização da Casa do diretor (atual Diretoria) em 2018 (autor) 


\section{$\underline{\text { RESUMO }}$}

Categoria: edifício

Denominação original: Casa do diretor

Denominação atual: Diretoria

Autoria: Mauro Álvaro de Souza Camargo

Área original: $430 \mathrm{~m}^{2}$

Área atual: $430 \mathrm{~m}^{2}$

Número de pavimentos original: 2

Número de pavimentos atual: 2

Início-término da construção: 1931

Itens arquitetônicos originais:

Estrutura: alvenaria portante

Vedação: alvenaria (tijolo maciço)

Revestimentos paredes externas: argamassa de cimento e cal, tijolo aparente

Revestimentos paredes internas: argamassa de cimento e cal

Revestimentos pisos internos: cerâmica, cimento queimado

Revestimentos pisos externos: granito, cerâmica, cimento desempenado

Caixilharia: madeira e aço

Uso original: residência

Itens arquitetônicos atuais:

Estrutura: original + concreto armado

Vedação: original + divisórias leves

Revestimentos paredes externas atual: original + tinta látex

Revestimentos paredes internas atual: original + tinta látex

Revestimentos pisos internos atual: originais + cerâmicos

Revestimentos pisos externos: cimento desempenado

Uso atual: administração

\subsubsection{4. "Prédio Novo"}

Em 1940 foi feita a primeira menção a esse novo edifício de laboratórios em construção:

Para centralizar, no futuro, os laboratórios de bacteriologia, acha-se em adiantado estado de construção novo e moderno edifício, projeto e execução da conceituada firma construtora desta Capital, Francisco Azevedo \& F. Palma Travassos, cuja pedra fundamental foi lançada a 4 de janeiro do corrente ano, por s. excia. o senhor Interventor Federal. (RA 1940, p.4)

O interventor citado era Ademar de Barros, que, segundo o relatório, mesmo antes de assumir o governo do Estado ${ }^{104}$, estava bastante interessado em saber quais melhorias eram

${ }^{104}$ Ademar de Barros foi interventor, governando o Estado de São Paulo de 27 de abril de 1938 a 4 de junho de 1941, nomeado por Getúlio Vargas no regime do Estado Novo. Ademar retornou ao governo em 1947 e 1963. 
necessárias no campus. Apesar da previsão de término para 1941, a construção durou mais tempo (figura 130) e teve várias interrupções. A revista Acrópole publicou em 1939 os desenhos do edifício, sem reportagem, em um anúncio da firma construtora (figura 131). Em 1942, foi relatada a paralisação das obras (provavelmente em virtude de dificuldades financeiras e de importação de materiais com a Segunda Guerra), e foram descritos alguns detalhes técnicos:

\begin{abstract}
As obras do grande edifício de laboratórios, iniciado em 1938 pela Diretoria anterior, estiveram praticamente paralizadas durante longo tempo, à espera de créditos para pagamento dos serviços já executados e da necessária autorização para o seu prosseguimento. Tendo passado todos os serviços de obras para o controle direto da Secretaria da Viação e Obras Públicas, tomou ela a deliberação de sustar o prosseguimento das obras até a satisfação do débito. Somente em meiados deste ano foi concedida autorização para prosseguimento dos trabalhos, agora em fase final, apenas faltando terminar o acabamento do pavimento térreo e adaptar a aparelhagem de vácuo e pressão e completar as ligações de vapor, gaz, água e eletricidade. Acredita esta Diretoria seja possível inaugurar o novo prédio em março de 1944. (RA1942, np)
\end{abstract}

As obras seguiram até 1945, quando o edifício foi oficialmente inaugurado. Porém, há relatos de que já vinha sendo utilizado pelo menos a partir de $1943^{105}$, sendo que as imagens de 1940 já mostravam as obras em estágio avançado. Em 1943 foi construído na parte posterior um anexo para abrigar centrais de vácuo e ar condicionado.

A empresa de Francisco Azevedo e Francisco Palma Travassos, ambos engenheiros politécnicos, foi fundada em 1922, e já tinha experiência com grandes obras públicas e privadas de infraestrutura, como estrada de ferro e barragens, mas também atuava em escalas menores, realizando projetos de arquitetura e obras. É o caso do edifício Hipólito Pujol ${ }^{106}$ (figura 132), de 1937-1938, que trazia ornamentos vestigiais do neolassicismo (frisos, cimalhas) somados a aspectos do Art Déco (o jogo de volumes, a simplificação geométrica de aberturas, e o avanço do corpo central), que também seriam explorados com mais evidência no projeto do Instituto Butantan. É possível notar algumas semelhanças na volumetria geral entre ambos, sendo que no Prédio Novo aqueles elementos ornamentais ecléticos são abolidos.

\footnotetext{
${ }^{105}$ Em entrevista concedida por Maria Brazil (neta de Vital Brazil), que trabalhou no Instituto como assistente de pesquisa em biomedicina, suas atividades em 1943 já eram neste edifício.

${ }^{106}$ O edifício Hipólito Pujol integrava o antigo conjunto da Escola Politécnica no bairro do Bom Retiro e funcionou como Laboratório de Ensaio de Materiais, Gabinete de Resistência e como a primeira sede do Instituto de Pesquisas Tecnológicas (IPT). Hoje integra o conjunto ocupado pela FATEC, tombado em 2003 pelo Condephaat.
} 
A vertente do Art Déco, que foi bastante disseminada em São Paulo a partir da década de 1930, especialmente em edifícios de instituições públicas, era novidade no Instituto Butantan e se limitou a esse exemplar. Em termos de possíveis influências, sabe-se que desde 1928 era construído um dos mais significativos exemplares nessa linguagem na cidade: o edifício do Instituto Biológico, na Vila Mariana, do arquiteto Mário Whately, que pode ter influenciado diversas obras a seguirem o Art Déco, geralmente com o mesmo partido de um bloco único predominantemente horizontal, com um corpo central saliente pontuando a entrada, ladeado por janelas verticais mais ornamentadas com caixilhos metálicos e vitrais. Um exemplo dessa semelhança entre edifícios públicos é o atual Museu de Zoologia no bairro do Ipiranga, de Christiano Stockler das Neves (figura 133), arquiteto mais conhecido por suas obras na linha do Ecletismo (SILVA, 2006). Concebido para abrigar o Departamento de Zoologia da Secretaria de Cultura, teve seu projeto iniciado em 1939 e construção concluída em 1942, portanto praticamente contemporâneo ao prédio aqui estudado.

A volumetria na obra do edifício de Azevedo e Travassos já segue o conceito de monobloco, evitando o espalhamento do programa em alas, como acontecia no Edifício Principal. O partido aqui concentra a circulação vertical no corpo central e no final dos corredores, e dispõe as salas ao longo desses corredores nos pavimentos. Diferentemente do Edifício Principal, aqui as janelas são predominantemente horizontais, o que é possível graças à estrutura independente de concreto armado.

Os relevos na fachada, desenhos de caixilhos metálicos, combinação de elementos geométricos básicos (retas, retângulos e círculos), são bastante característicos do Art Déco. Além da geometrização, as janelas de grandes dimensões horizontais e a ampla empena curva com blocos de vidro nas laterais são características também comuns na arquitetura moderna.

Em termos de linguagem arquitetônica, este edifício pode ser considerado o marco do final da fase ligada às expressões do início do século XX no campus, sendo a única construção de vulto a adotar o Art Déco, e possivelmente esse seja um dos motivos pelos quais o apelido "Prédio Novo" tenha sido adotado, pelo contraste que surgia em relação aos primeiros edifícios do núcleo histórico. Esse contraste ainda é percebido quando se percorre o conjunto, já que o prédio mantem as principais características externas, ainda que tenha sofrido alterações. 
Reparos em caixilhos e azulejos precisaram ser feitos já na década de 1950. Na década de 1990 foi feita uma grande reforma interna com recursos da Fundação Butantan, adequando-o para atividades modernas de pesquisa. Ainda assim, chama atenção atualmente a interferência de sistemas e equipamentos (gases, ar condicionado, eletricidade e hidráulica) nas fachadas, além de películas arroxeadas em alguns vidros para controle da insolação, e adaptações em caixilhos alterando sua unidade. A maior parte dessas alterações se deve a novas necessidades e protocolos dos laboratórios que não se coadunam facilmente com o edifício da década de 1940 . Hoje o prédio abriga os laboratórios de pesquisa em genética, bacteriologia, imunoquímica, imunogenética, fisiopatologia, virologia e departamento de divisão científica. O Plano Diretor de 2016 prevê a mudança de uso, para abrigar a Biblioteca e o Núcleo de Documentação, hoje localizados no térreo e subsolo do Edifício Principal (item 2.3.4). O Memorial de Restauro apresentado no Plano prevê a requalificação dos espaços para convertê-los ao uso citado, conservando elementos e materiais. Segundo o Plano:

As principais interferências arquitetônicas são:

- Criação de novos sanitários que atendam ao público, aos funcionários e aos diretores. Todas as paredes inseridas para atender a este novo layout serão de alvenaria de concreto celular e todos os revestimentos e divisórias em mármore e em granito. Estas escolhas foram motivadas pela reversibilidade do material e, no caso dos revestimentos e das divisórias, pela continuidade no uso de materiais nobres nos ambientes acessíveis ao público, como no saguão e escadarias.

- Inserção de novas portas de madeira em alguns ambiente e portas metálicas nos sanitários destinados aos funcionários e ao público, necessárias ao novo layout.

- Eliminação dos pisos: vinílico, epóxi, cerâmica branca, carpete e laminado de madeira. Que foram acrescidos no decorrer do tempo e muitas vezes apenas encobriram o piso original, permitindo recuperar os pisos originais recobertos.

- Eliminação do piso e revestimento cerâmico dos banheiros, de todos os pavimentos, inserindo novos pisos e revestimentos em granito e em mármore.

- Inserção de piso em ladrilho hidráulico, ardósia, taco de madeira e cerâmica em alguns ambientes, buscando respeitar a linguagem dos acabamentos originais do prédio.

- Inserção de divisórias em vidro e caixilho de ferro nas salas de estudo para pesquisadores, proporcionando transparência e luminosidade em todas as salas, bem como permitindo que haja continuidade ao partido original do prédio que tem as divisórias em ferro e vidro como elemento principal. (IBu, 2016, p.26) 

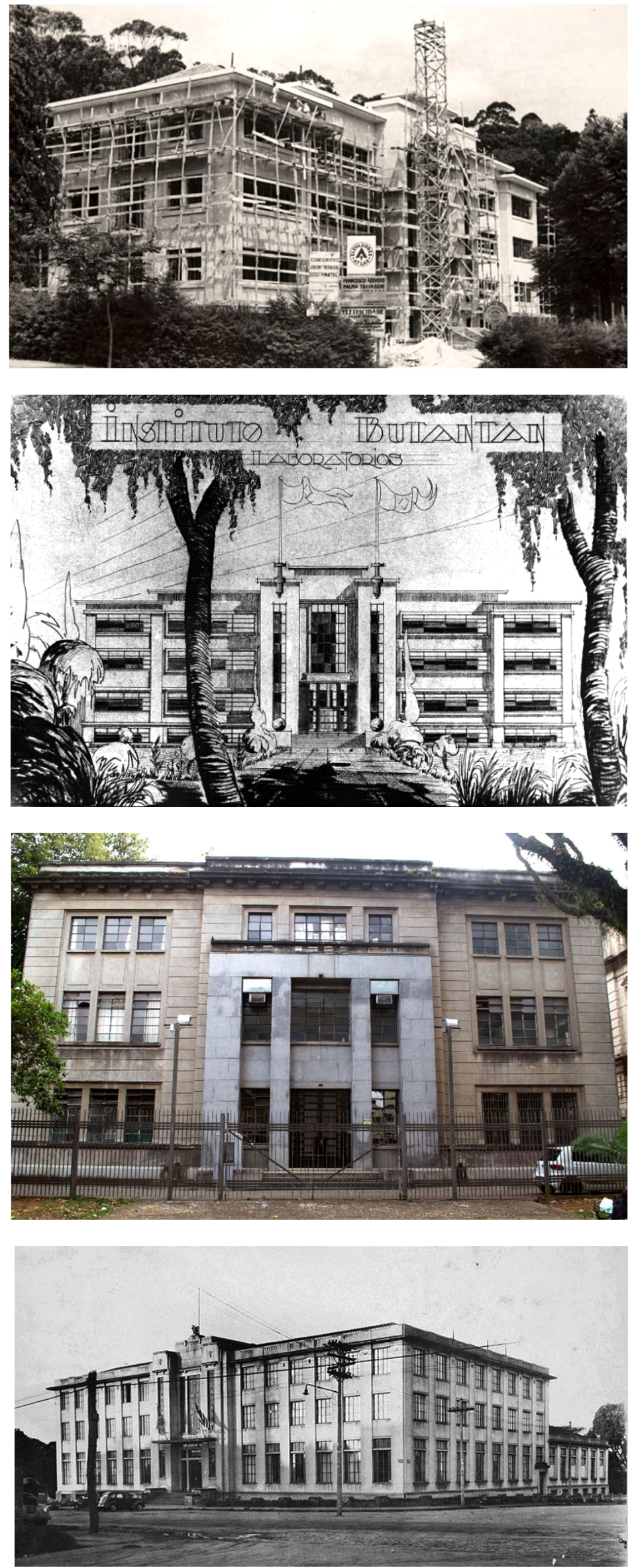

Fig. 130 - "Prédio Novo" em construção, 1940 (Fonte: IB_ICO_009334)

Fig. 131 - Desenho da fachada do "Prédio Novo" (Fonte: Acrópole, 1939, p.61)

Fig. 132 - Edifício Hipólito Pujol (2018): dos mesmos projetistas, já trazia características utilizadas no "Prédio novo" (Fonte: autor)

Fig. 133 - Museu da Agricultura, 1940 (atual Museu de Zoologia): semelhanças com o "Prédio novo" na volumetria e redução de ornamentos (Fonte: IB_ICO_009422) 

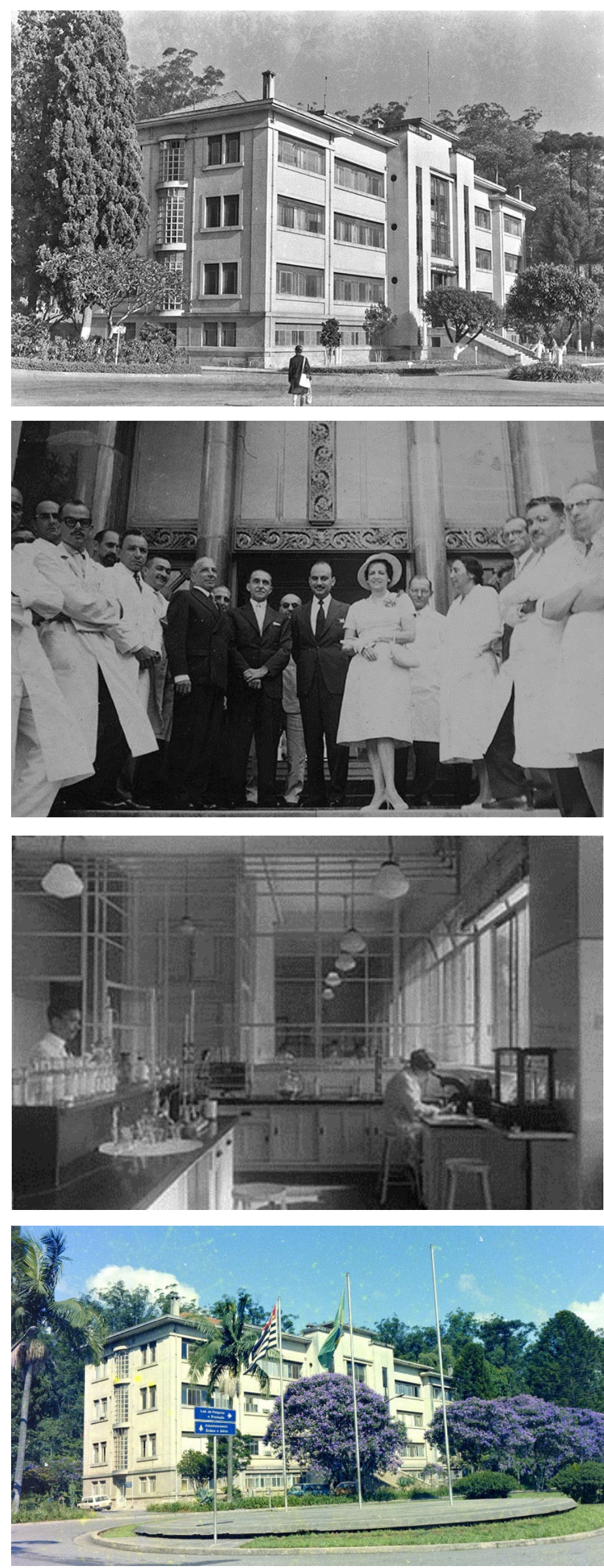

Fig, 134 - "Prédio novo" na década de 1950: a limpeza geométrica do Art Déco simbolizava modernidade (Fonte: IB_ICO_001196)

Fig. 135 - Inauguração do "Prédio Novo": veem-se os ornamentos em serralheria da portaria de entrada (Fonte: IB_ICO_010122)

Fig. 136 - Interior dos laboratórios no "Prédio Novo": uso de divisórias de vidro, mobiliário em alvenaria e instalações aparentes (Fonte: IB_ICO_011557)

Fig. 137 - "Prédio novo" na década de 1980: exemplo da interferência de elementos paisagísticos e mobiliário urbano com os edifícios (Fonte: IB_ICO_003247) 

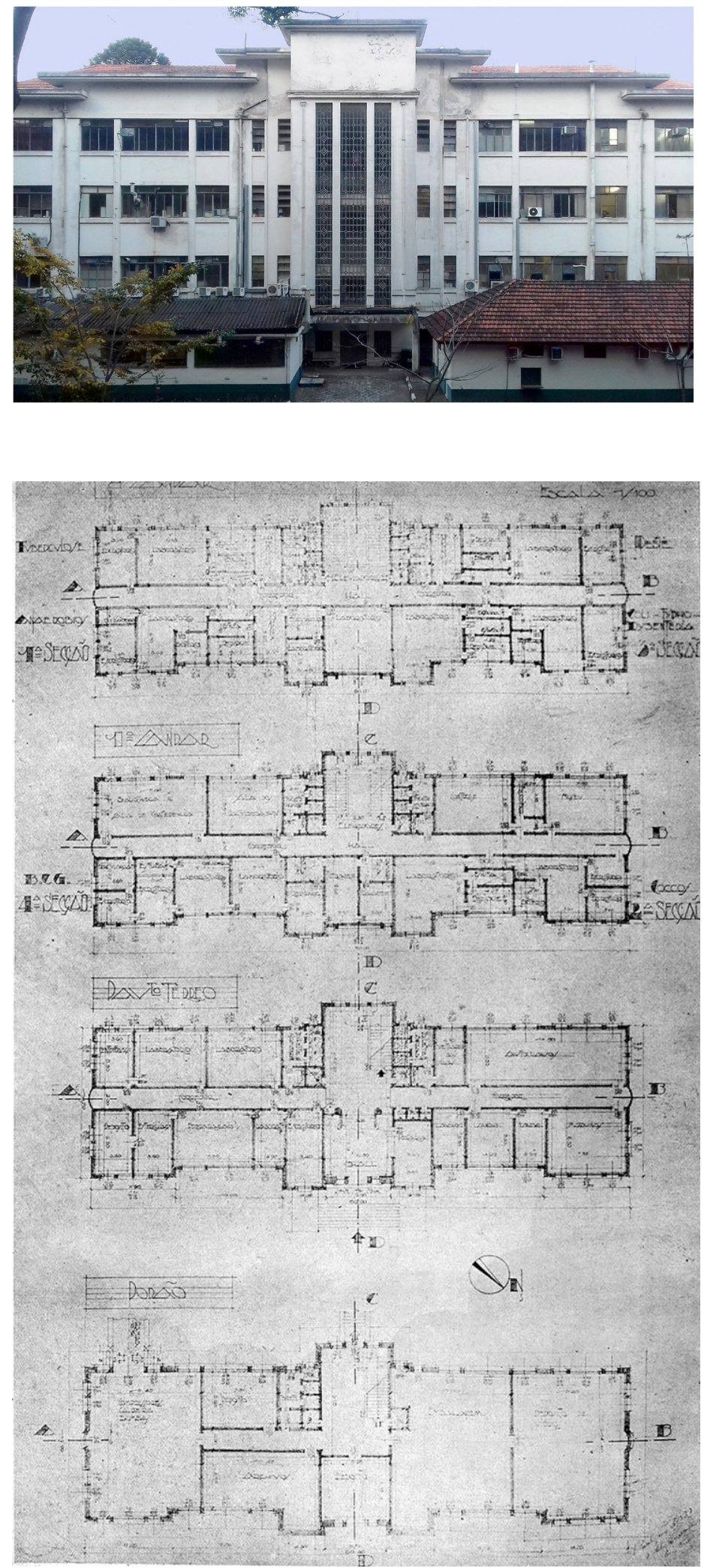

Fig. 138 - Fachada posterior do "Prédio novo" em 2018: vê-se a interferência visual de instalações e anexos (Fonte: autor)

Fig. 139 - Plantas originais de Francisco Azevedo e Francisco Palma Travassos. Sem escala (Fonte: Acrópole, $n^{\circ} .20$, dez. 1939, p.62) 


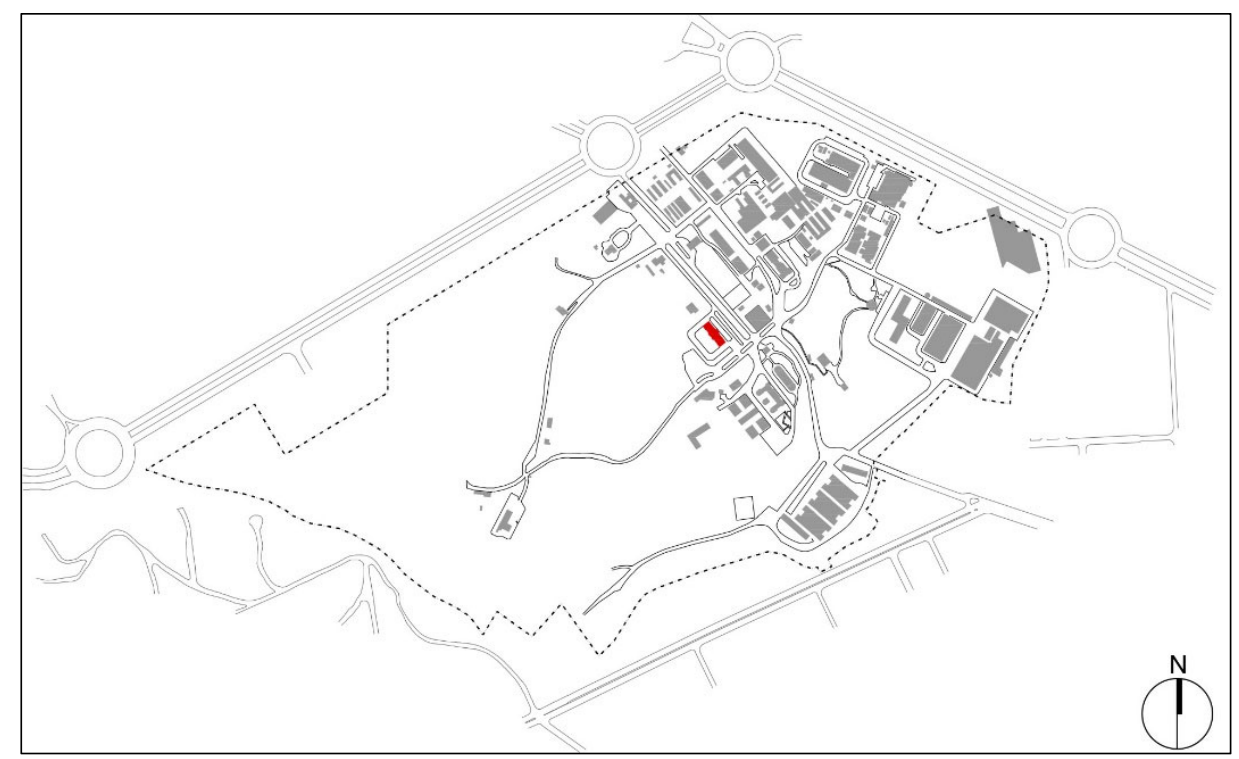

Fig. 140 - Localização do "Prédio Novo" em 2018 (autor)

\section{RESUMO}

Categoria: edifício

Denominação original: "Prédio Novo"

Denominação atual: "Prédio Novo"

Autoria: Francisco Azevedo e Francisco Palma Travassos

Área original: $3040 \mathrm{~m}^{2}$

Área atual: $3040 \mathrm{~m}^{2}$

Número de pavimentos original: 3

Número de pavimentos atual: 3

Início-término da construção: 1940-1945

Itens arquitetônicos originais:

Estrutura: concreto armado

Vedação: alvenaria (tijolo maciço), divisórias leves e vidro

Revestimentos paredes externas: argamassa de cimento e cal

Revestimentos paredes internas: argamassa de cimento e cal

Revestimentos pisos internos: cerâmica, granito

Revestimentos pisos externos: granito, cimento desempenado

Caixilharia: madeira e aço

Uso original: laboratórios

Itens arquitetônicos atuais:

Estrutura: original

Vedação: original + divisórias leves

Revestimentos paredes externas atual: original + tinta acrílica

Revestimentos paredes internas atual: original + tinta acrílica

Revestimentos pisos internos atual: originais + cerâmicos, vinílicos e emborrachados

Revestimentos pisos externos: original + cimento desempenado

Uso atual: laboratórios 


\subsubsection{Pavilhão Vital Brazil}

O relatório anual de 1945 menciona a construção desse prédio, que seria destinado a abrigar o Hospital Vital Brazil. Mas ele acabou sendo ocupado pela Seção de Virologia devido ao surto de Febre Amarela no Estado, que exigiu ação rápida para a produção de vacinas, sendo assim abrigada nesse edifício. O prédio foi inaugurado em 01/03/1948, já com o nome de Pavilhão Vital Brazil. Logo depois, debelado o surto, o edifício passou a abrigar a pesquisa e produção de diversas vacinas. Dessa forma, embora possa ter sido destinado a atividades hospitalares, ele foi logo adaptado para atividades de pesquisa e produção, função pela qual se tornou conhecido, como se vê no relatório de 1968:

[...] temos o Pavilhão mais novo, construído para instalação do Serviço de Febre Amarela e onde agora está instalada a Seção de Virus Vacínico [...]. Ainda no primeiro semestre, a rotulagem de produtos funcionava neste pavilhão.

A crítica aqui se faz pela perda de espaço. A Seção de Virus Vacínico ocupa uma área muito além das necessidades, mas com instalações tecnicamente mal distribuídas. [...] No momento, a Seção de Fisiologia está se transferindo para o andar superior do prédio onde funcionava a rotulagem de produtos. (RA1968, p.4)

O trecho citado indica a existência de um pavimento superior, que não existia segundo as primeiras fotos (figura 141). Originalmente, o edifício era um bloco horizontal, com um pátio central, formando uma planta em "anel", tendo como entrada um saguão em um de seus vértices. Posteriormente teve sua área duplicada com o recurso de espelhamento da mesma planta, formando um grande bloco simétrico, e foi construído o segundo pavimento.

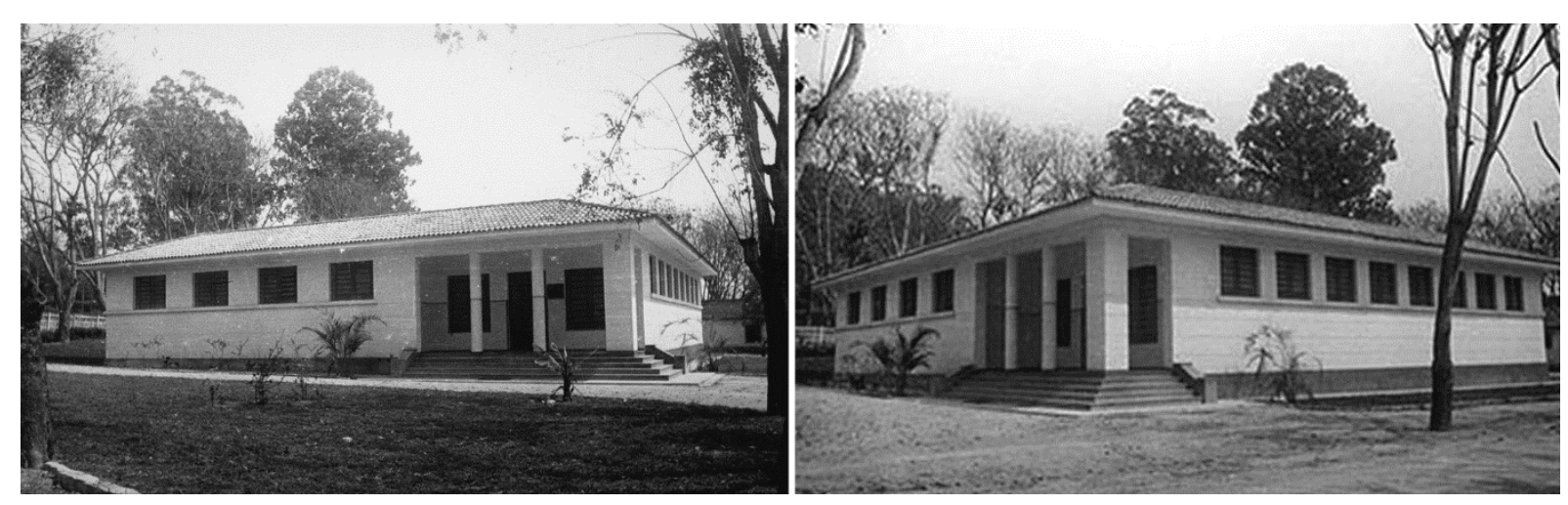

Fig. 141 - Pavilhão Vital Brazil em 1948: os ornamentos se limitavam a frisos horizontais. Essa volumetria seria modificada com acréscimos que duplicariam sua área, inclusive com pavimento superior (Fonte: IB_ICO_009340 e IB_ICO_009106) 


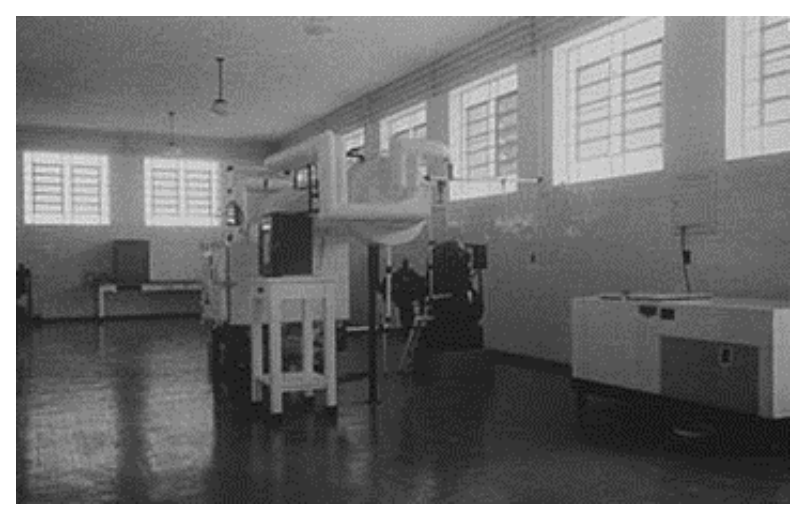

Fig. 142 - Interior do Pavilhão Vital Brazil, década de 1950: o pé-direito com cerca de 4 metros e os peitoris altos permitiam a instalação de grandes equipamentos laboratoriais (Fonte: IB_ICO_011553)

O aspecto mais interessante da construção é que, utilizando alvenaria portante de tijolos maciços, o edifício apresenta vãos de laje e aberturas relativamente grandes, com amplos ambientes de trabalho (figura 142), graças ao uso de cintas de concreto armado, sendo as paredes externas executadas com fiadas duplas de tijolos, o que também garante mais resistência e isolamento térmico e acústico.

Ao longo do tempo o edifício foi ocupado por diversas linhas de pesquisa e produção. Uma grande reforma interna em 2007 deu a configuração atual do Pavilhão Vital Brazil ${ }^{107}$, com seções diferentes coexistindo, em que parte do térreo é ocupada pelo Centro de Toxinologia Aplicada, e outra pela Seção de Raiva. Conforme já mencionado, essa coexistência de diferentes setores no mesmo edifício, sem qualquer relação administrativa e funcional, bem como a profusão de necessidades técnicas diferentes, leva a uma compartimentação excessiva do espaço, que não foi originalmente preparado para essas funções. O resultado é uma planta labiríntica, sem adequadas circulações, rotas de fuga, ventilações e instalações, na qual os pátios internos foram ocupados com blocos de até dois andares. Também tem sido recorrente um problema nas coberturas que, pela presença de árvores de grande porte próximas, têm suas calhas e condutores obstruídos por folhas e galhos, gerando infiltrações e exigindo grande reforma dos telhados em 2011.

O aspecto externo do edifício mantém grande parte de suas características originais (após a ampliação), mas, pela multiplicidade de usos conflitantes, há acréscimos que prejudicam a

\footnotetext{
${ }^{107}$ Participei do projeto e acompanhamento dessa obra em 2007 com a equipe do Departamento de Engenharia e Arquitetura do Instituto Butantan.
} 
unidade arquitetônica (figura 143). Internamente, as alterações se dão principalmente em revestimentos e compartimentações para adaptar o espaço às normas atuais (figura 144).

O Plano Diretor pretende transferir novamente as atividades do Hospital Vital Brazil para esse edifício, retirando, para isso, grande parte dos acréscimos de paredes e divisórias, e reabrindo os pátios centrais para implantação de jardins.
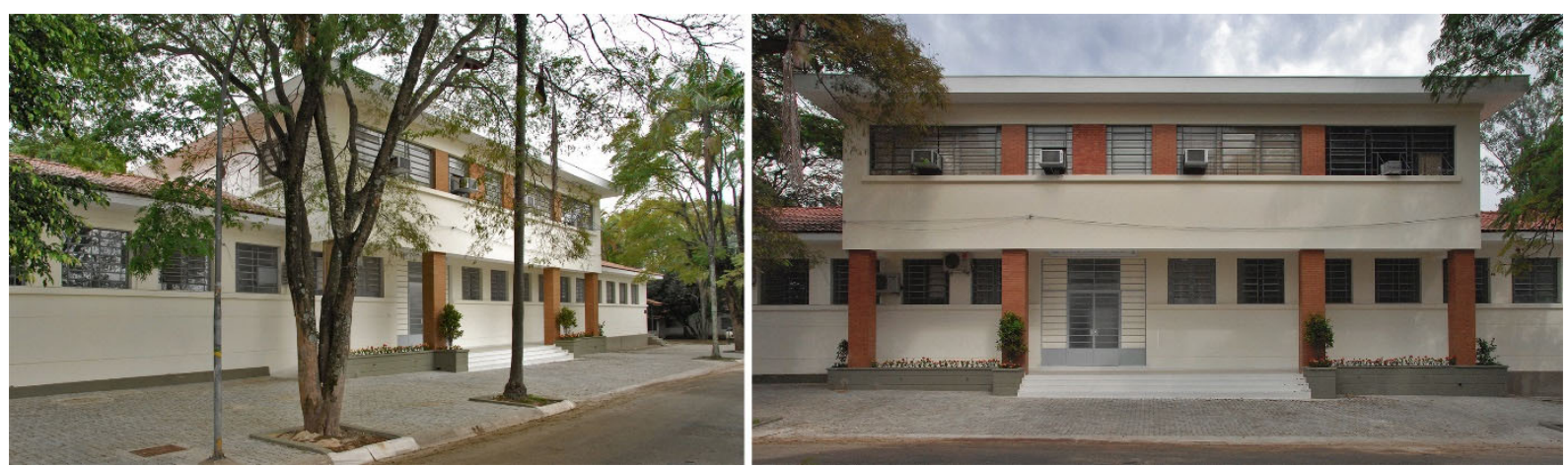

Fig. 143 - Pavilhão Vital Brazil após reforma de 2007: vê-se a interferência de equipamentos na fachada (Fonte: autor)
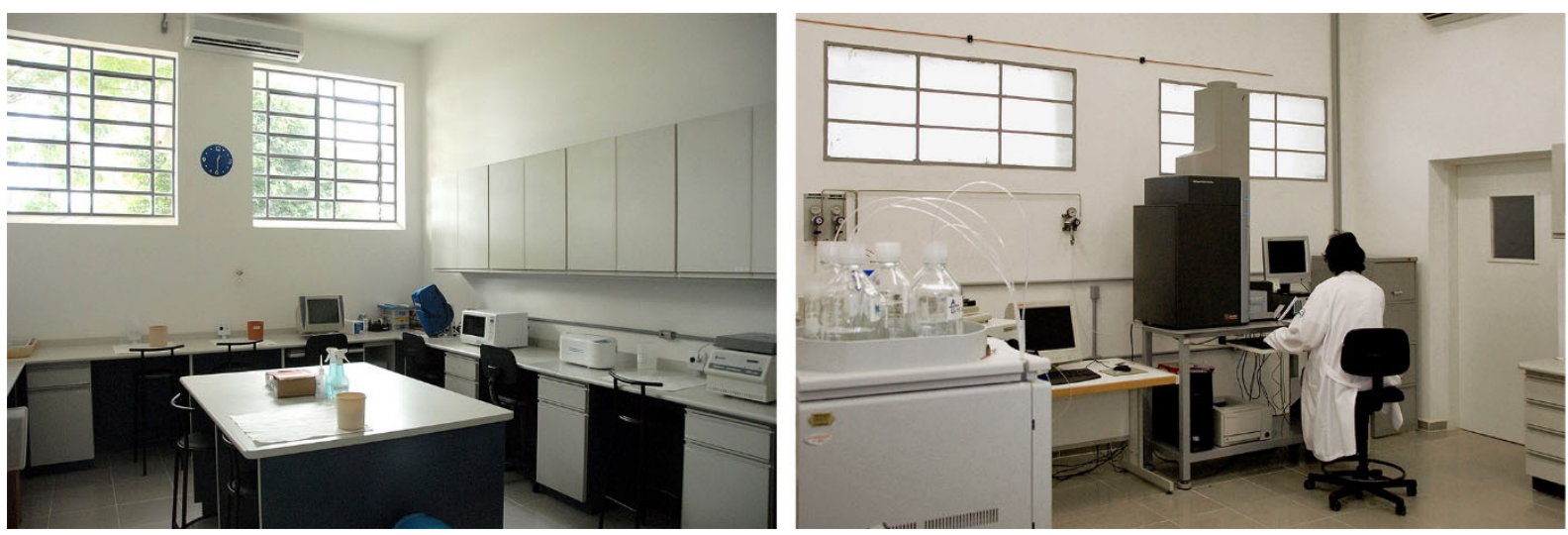

Fig. 144 - Interior do Pavilhão Vital Brazil em 2007: alterações em janelas, portas, mobiliário e revestimentos foram necessárias para adequar os laboratórios às normas de biossegurança (Fonte: autor) 


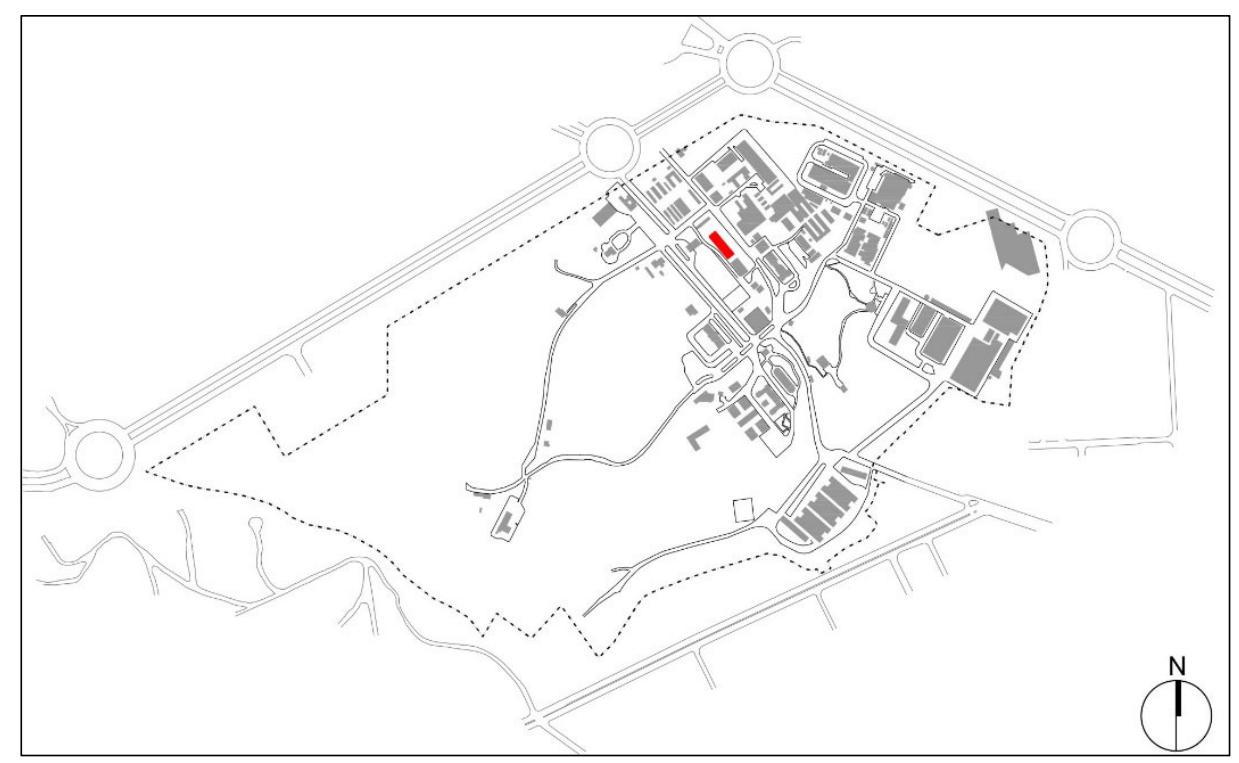

Fig. 145 - Localização do Pavilhão Vital Brazil em 2018 (autor)

\section{$\underline{\text { RESUMO }}$}

Categoria: Edifício

Denominação original: Pavilhão Vital Brazil

Denominação atual: Pavilhão Vital Brazil

Autoria: desconhecida

Área original: c. $500 \mathrm{~m}^{2}$

Área atual: $1500 \mathrm{~m}^{2}$

Número de pavimentos original: 1

Número de pavimentos atual: 2

Início-término da construção: 1945-1948

\section{Itens arquitetônicos originais:}

Estrutura: Alvenaria portante

Vedação: Alvenaria (tijolo maciço)

Revestimentos paredes externas: argamassa de cimento e cal

Revestimentos paredes internas: argamassa de cimento e cal, azulejos

Revestimentos pisos internos: cerâmica

Revestimentos pisos externos: cimento desempenado

Caixilharia: madeira, aço

Uso original: hospital e laboratórios

\section{Itens arquitetônicos atuais:}

Estrutura: original + concreto armado

Vedação: original + alvenaria + divisórias leves

Revestimentos paredes externas atual: original + massa única industrializada + tinta acrílica Revestimentos paredes internas atual: original + tinta acrílica

Revestimentos pisos internos atual: originais + porcelanatos, vinílicos e emborrachados Revestimentos pisos externos: cimento desempenado + blocos intertravados

Uso atual: Laboratórios 


\subsubsection{Recepção de Cobras [Lanchonete]}

No relatório de 1953, o diretor Afrânio do Amaral mencionava:

De acordo com o convênio feito com a Comissão da Cidade Universitária, foi por ela construído, em frente ao Edifício Novo, um pequeno pavilhão, em estilo moderno, para o serviço de extração de venenos de ofídios. (RA 1953, p.25)

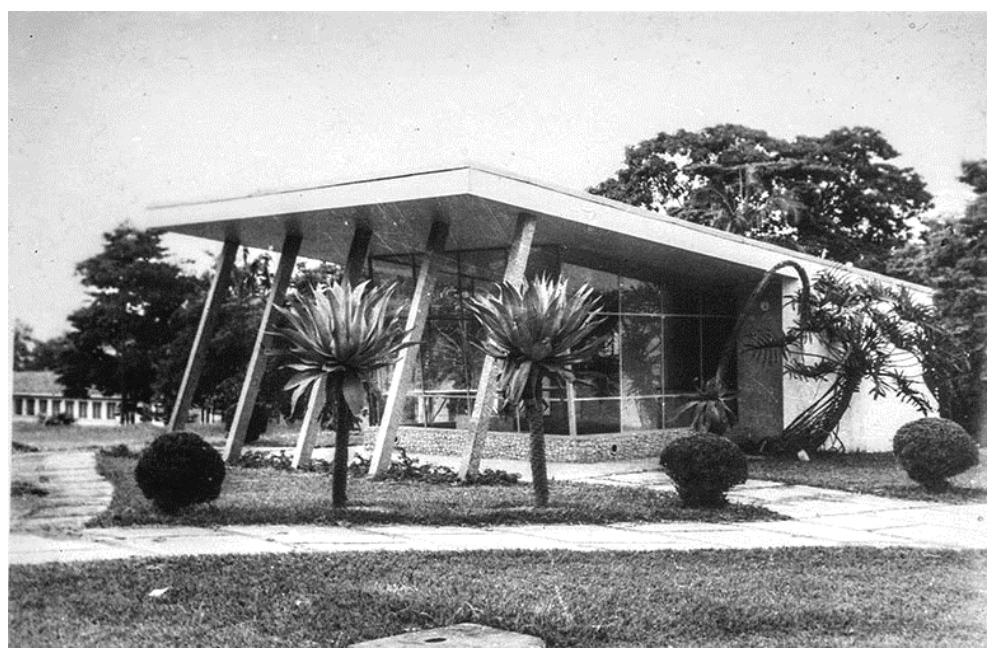

Fig. 146 - Recepção de cobras, década de 1960: a leveza e transparência visual, os planos inclinados e a estrutura delgada são algumas características da chamada Escola Carioca, presentes no projeto de Hélio Duarte (Fonte: IB_ICO_000425)

Esta pequena construção, do arquiteto Hélio Duarte ${ }^{108}$, com projeto de 1951 e construção em 1952, veio trazer uma corrente arquitetônica até então distante do que era feito no campus, com elementos característicos do modernismo, como a estrutura aparente, formas depuradamente geométricas e os grandes panos de vidro, desmaterializando a volumetria (figuras 146, 147). Essa combinação de planos inclinados, pilares esbeltos e revestimentos vincula essa arquitetura muito mais à escola carioca da Arquitetura Moderna. De fato, Hélio Duarte, nascido no Rio de Janeiro em 1906, mesmo após ter atuado em Salvador e em São Paulo, manteve em sua obra uma linguagem mais próxima ao modernismo da ENBA, onde se formou, assim como o colega Abelardo de Souza (seu antigo sócio e que também realizou estudos para

\footnotetext{
${ }^{108}$ Formado em 1930 na Escola Nacional de Belas Artes, no Rio de Janeiro, Hélio Duarte teve uma atuação profissional bastante variada, trabalhando no Rio, em Salvador e em São Paulo, como autônomo, em sociedade com outros arquitetos (Abelardo de Souza e Zenon Lotufo) ou como funcionário em empresas de incorporação, além da atividade de professor (FAU-USP) e arquiteto integrante do FCCUASO, em que concebeu o chamado "corredor de humanas". Seus trabalhos na fase madura (incluindo essa Recepção) são nitidamente vinculados à vertente do modernismo carioca. Para mais detalhes sobre a obra de Hélio Duarte, ver SEGAWA (1988)
} 
o Instituto na década de 1960). Não se sabe se o convite para este projeto partiu do próprio Afrânio ou foi objeto de concurso, mas o fato é que Hélio já era um arquiteto de certo prestígio no meio, sendo um dos autores do edifício do $\mathrm{IAB}^{-S P}{ }^{109}$ e já tendo dirigido a Comissão Executiva do Convênio Escolar da Prefeitura de São Paulo e se tornado professor da FAU-USP. Também cabe pontuar que na época já havia sido construído em Manguinhos, no Rio de Janeiro, o Pavilhão de Cursos (atual Pavilhão Arthur Neiva), que incluía painel de azulejos de Burle Marx, e o Pavilhão Central (atual Pavilhão Carlos Augusto da Silva) dentro dessa linguagem, e nos quais é possível ver (guardadas as peculiaridades) algumas semelhanças com esta recepção, como a quebra da ortogonalidade, combinada à esbeltez da estrutura, dando mais leveza ao conjunto.
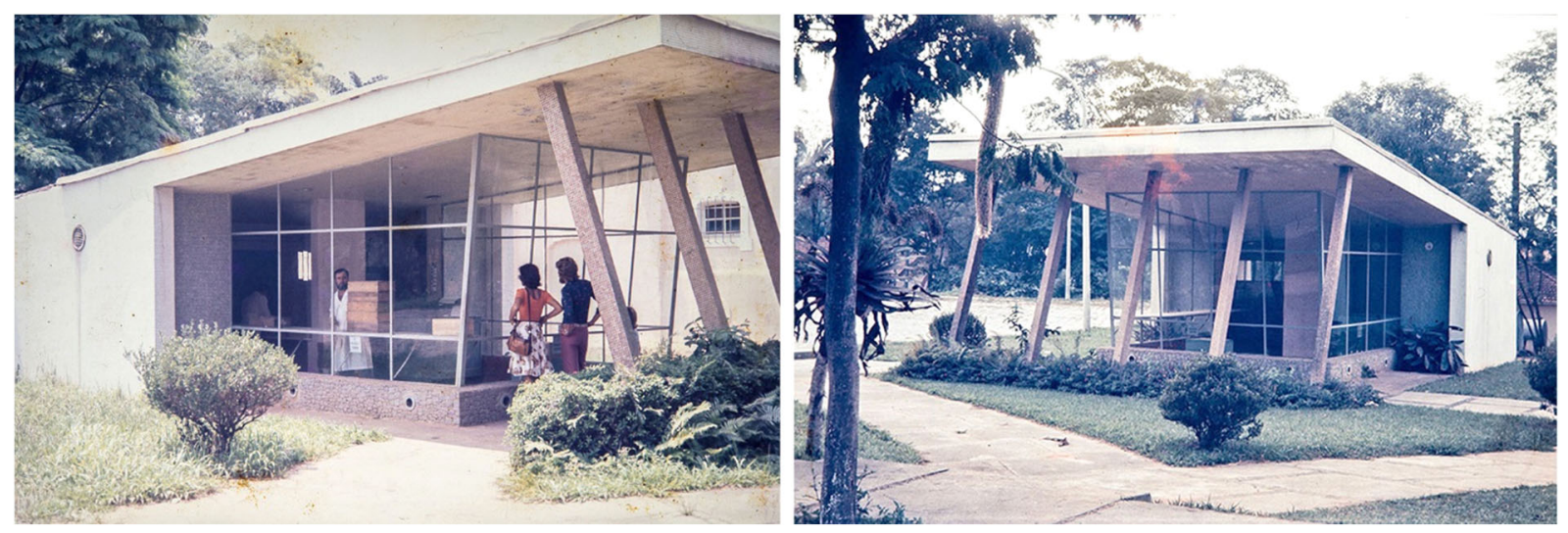

Fig. 147 - Recepção de cobras, c. 1970: o paisagismo dava visibilidade à construção (Fonte: IB_ICO_000209, IB_ICO_000671)

No mesmo texto de 1953 em que o diretor informava a construção dessa recepção, também defendia uma unidade estética do Instituto, que chamava de "colcha de retalhos" em sua arquitetura (conforme já descrito no item 2.1). Afrânio recomendava a linguagem moderna implantada pelo Page na Cidade Universitária e também criticava a construção da passarela do serpentário como algo descabido e desproporcional para a função. Percebe-se certa contradição nas falas do diretor, uma vez que a citada passarela também traz essas características de leveza,

\footnotetext{
${ }^{109}$ Em parceria com Rino Levi, Roberto Cerqueira Cesar, Miguel Forte, Jacob Ruchti, Galiano Ciampaglia, Zenon Lotufo, Abelardo de Souza. O edifício do IAB foi construído entre 1947 e 1950, após concurso público nacional em 1946 com júri composto por Oscar Niemeyer, Firmino Saldanha, Hélio Uchôa, Fernando Saturnino de Britto e Gregori Warchavchik. Na ocasião, foi decidido que as três equipes finalistas realizariam o projeto em conjunto.
} 
depuração formal e quebra da rigidez ortogonal, que a aproximam do projeto de Hélio Duarte. Esses aspectos afastam esse edifício tanto das outras linguagens arquitetônicas já presentes no campus, do início do século, quanto das linguagens que passariam a ser utilizadas na Cidade Universitária (admirada por Afrânio), mais próximas da arquitetura do chamado brutalismo paulista $^{110}$, caracterizado pelas grandes estruturas e vãos em concreto aparente, com composições de formas geométricas básicas, entre outras características ${ }^{111}$, diferentemente da leveza e transparência do modernismo carioca presente nessa edificação. Por fim, ainda que pequena em relação a outros edifícios do entorno, suas dimensões parecem grandes demais para a própria função, que já havia sido desempenhada em um dos quiosques (2.3.11). Não obstante todas essas dissonâncias, a obra de Hélio Duarte, considerada isoladamente, trouxe um aspecto de novidade e contraste interessante à paisagem do Instituto (figura 148), em linguagem que não se repetiu em outros exemplares.

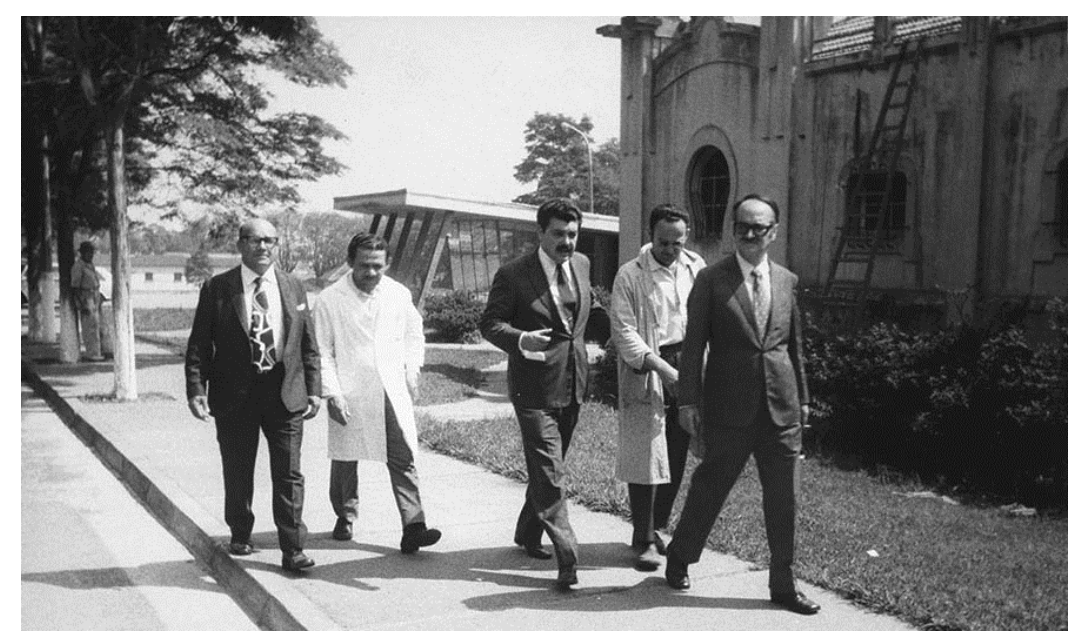

Fig. 148 - Recepção na década de 1960: percebe-se o contraste entre a pequena edificação moderna e outros elementos históricos, como a Cocheira Central, à direita (Fonte: IB_ICO_010116)

Talvez também por esse isolamento estético, e pela flexibilidade de sua planta (basicamente um recinto multifuncional sem grandes especificidades) essa seja uma das edificações mais alteradas em seu aspecto geral, com acréscimos, troca de vedos, pinturas e coberturas muito discrepantes de seu aspecto original, e que pareceram ignorar seu valor

\footnotetext{
${ }^{110} \mathrm{O}$ Brutalismo Paulista não foi a única linguagem seguida no CUASO, mas seu exemplares foram produzidos especialmente durante os anos de 1960, quando foi construída a Faculdade de Arquitetura e Urbanismo, de Vilanova Artigas e Carlos Cascaldi (concluída em 1969), a Faculdade de História e Geografia, de Eduardo Corona (concluída em 1964), e o edifício do Biênio na Escola Politécnica, do próprio Hélio Duarte (concluído em 1962).

${ }^{111}$ Para mais informações sobre Brutalismo Paulista e Modernismo Carioca, ver SEGAWA (2002, pp.143-157)
} 
patrimonial, o que não ocorreu em outros edifícios nesse nível. Desde os anos 1990 o espaço era utilizado como lanchonete, tendo sido acrescentados toldos à sua volta para instalação de acomodações, e a caixilharia substituída por fechamentos retráteis metálicos (figura 149).

O novo Plano Diretor pretende dar à pequena edificação o uso de café, retirando os acréscimos de toldos e fechamentos que prejudicam a leitura de seu valor arquitetônico e propondo o refazimento de caixilhos e revestimentos semelhantes aos originais.

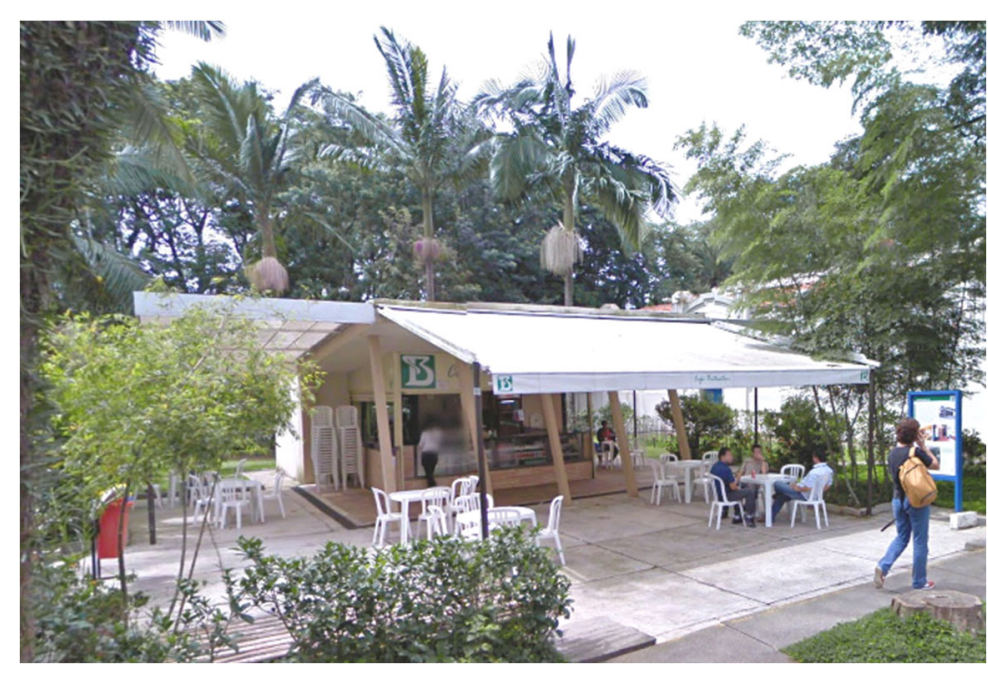

Fig. 149 - Edificação convertida em lanchonete, 2018: com os acréscimos e retiradas de elementos, apenas os pilares dão indício da antiga construção (Fonte: autor)

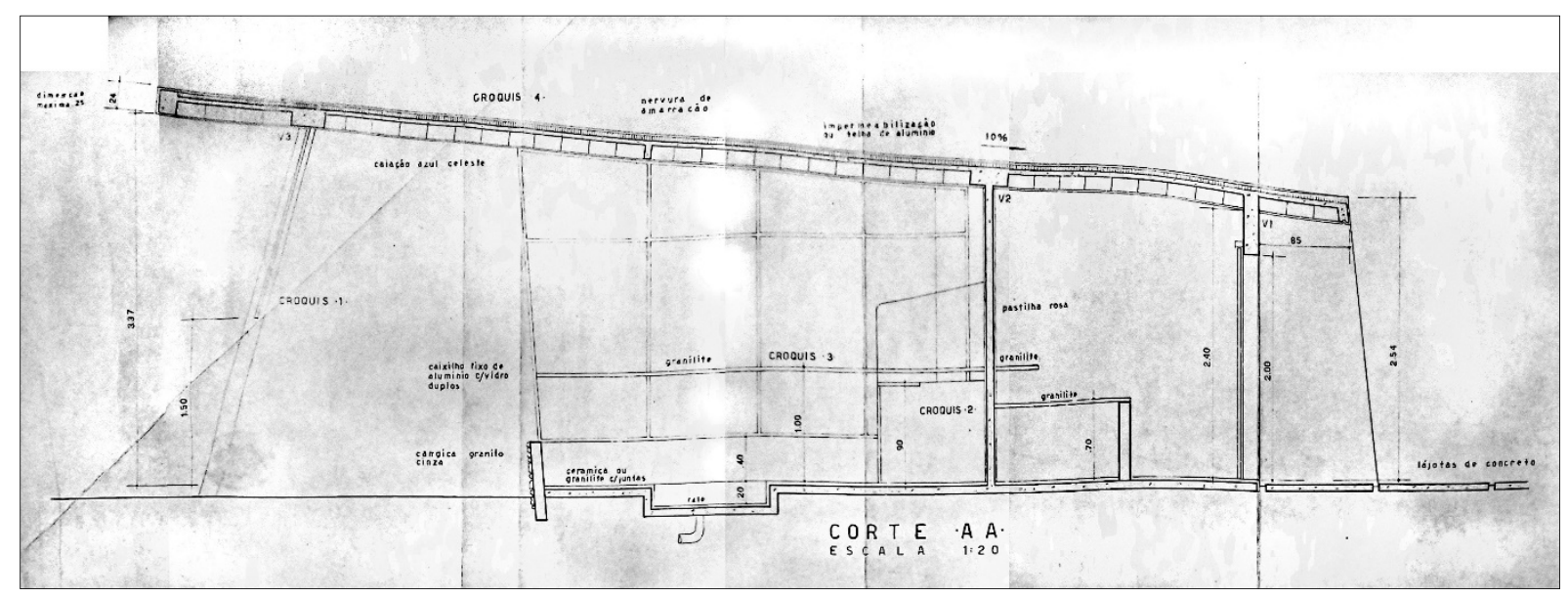

Fig. 150 - Corte original de Hélio Duarte, de 1951: nota-se a variedade nos revestimentos especificados (Fonte: Acervo IBu) 


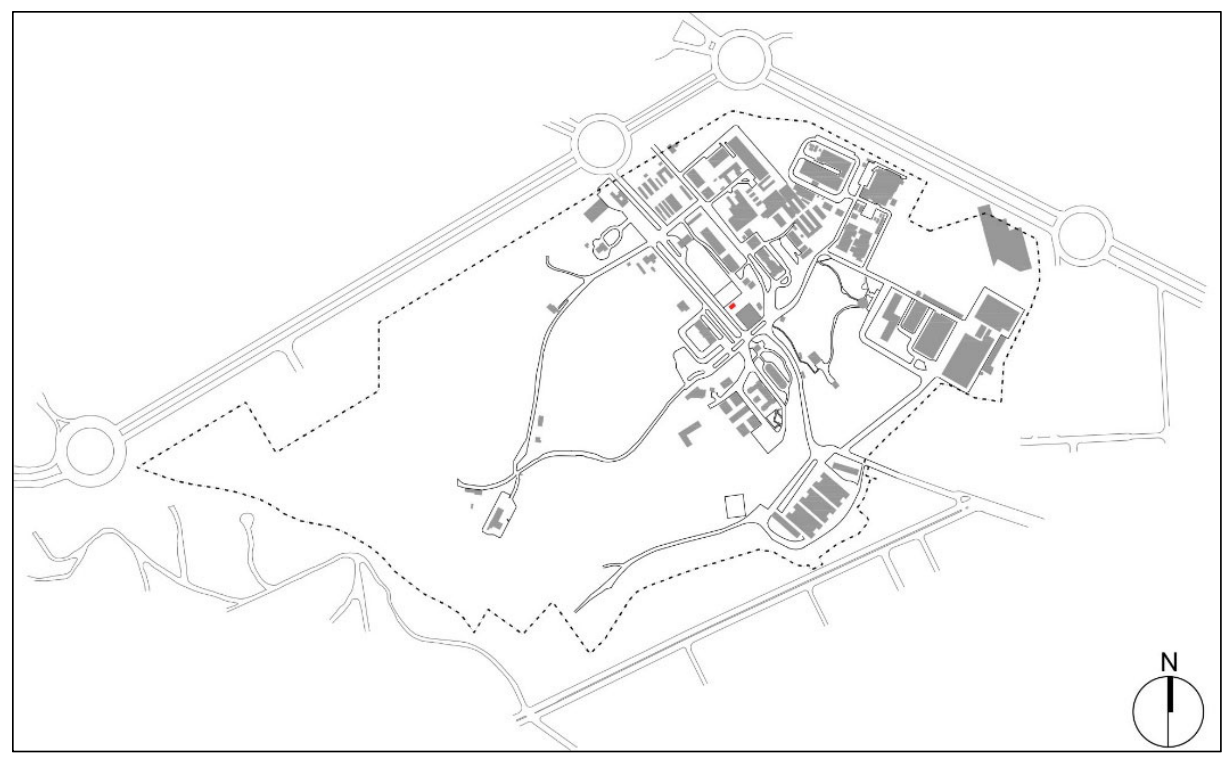

Fig. 151 - Localização da Recepção de cobras (atual lanchonete) em 2018 (autor)

\section{RESUMO}

Categoria: edifício

Denominação original: Recepção de cobras

Denominação atual: Lanchonete

Autoria: Hélio Duarte

Área original: $40 \mathrm{~m}^{2}$

Área atual: $49 \mathrm{~m}^{2}$

Número de pavimentos original: 1

Número de pavimentos atual: 1

Início-término da construção: 1952

Itens arquitetônicos originais:

Estrutura: concreto armado

Vedação: alvenaria e vidro

Revestimentos paredes externas: argamassa de cimento e cal, pastilhas, pedra

Revestimentos paredes internas: argamassa de cimento e cal, pastilhas, granilite

Revestimentos pisos internos: cerâmica

Revestimentos pisos externos: cimento desempenado

Caixilharia: madeira e aço

Uso original: recepção de cobras

Itens arquitetônicos atuais:

Estrutura: original + aço

Vedação: original + alvenaria + divisórias leves

Revestimentos paredes externas atual: original + massa única industrializada + tinta acrílica

Revestimentos paredes internas atual: original + tinta acrílica

Revestimentos pisos internos atual: originais + cerâmicos

Revestimentos pisos externos: cimento desempenado

Uso atual: lanchonete 


\subsubsection{Hospital Vital Brazil}

$\mathrm{O}$ atendimento a vítimas de acidentes com animais peçonhentos ${ }^{112}$ se iniciou na década de 1930 em salas do embasamento do Pavilhão Lemos Monteiro. Na década seguinte, passouse a procurar um edifício maior para abrigar as atividades de atendimento do que se chamaria Hospital Vital Brazil. Escolheu-se para isso a Casa do Diretor (item 2.3.13). Em 1953 foi concluído um novo edifício, destinado especificamente para o hospital, comentado pelo diretor Afrânio do Amaral já antes de sua ocupação:

A nova unidade, construída para servir de sede ao pequeno Hospital Vital Brazil e cujas obras se acham ultimadas desde o meiado do ano, não pôde entrar em funcionamento, por falta de verbas e por insuficiência de pessoal técnico. Edificado em local impróprio; projetado em proporções sobremodo exíguas em face do rápido desenvolvimento que se verifica na cidade e do constante aumento que se nota em nossos índices demográficos; e construído fora de um plano de conjunto, mesmo assim êsse prédio está agora sendo instalado, para aproveitamento pelo menos das verbas que foram nele invertidas [...]. (RA1953, p.6)

Após pedido de recursos para equipar o edifício, ele foi finalmente inaugurado em janeiro de 1954. Nos relatórios é mencionado que o Pavilhão Vital Brazil (2.3.15) foi construído para abrigar tais atividades, mas que logo precisou ser utilizado para produção de vacinas contra a febre amarela em regime de urgência, de forma que os atendimentos foram desalojados (nas palavras do próprio relatório de 1954). Portanto, esse desalojamento emergencial criou a necessidade de se conseguir rapidamente um novo espaço para o hospital:

Inaugurado no dia 8/1/1954, o novo prédio que foi construído para substituir aquele, donde, por necessidade do serviço de Febre Amarela, foram transferidas as instalações clínicas, iniciou auspiciosamente as suas atividades sob a direção do encarregado da Secção de Fisiopatologia (Prof. Gastão Rosenfeld). (RA 1954, p.3)

Talvez essa substituição repentina explique a simplicidade da construção, que se apresentava originalmente quase como um galpão, com alvenaria portante, telhado em fibrocimento com shed de ventilação, aberturas relativamente pequenas e ausência total de ornamentos. É possível que a urgência tenha sido uma das causas da simplicidade e exiguidade

\footnotetext{
${ }^{112}$ Pelas atuais recomendações de bioética, não se usa o termo "ataque" e sim "acidente" com animais, uma vez que estes geralmente só causam ferimentos a humanos em reações de defesa.
} 
dessa construção (conforme comentário de Afrânio do Amaral). Cabe também mencionar que o período de atendimento a vitimados por animais peçonhentos é predominantemente o das estações quentes e chuvosas, sendo quase inexistente no período de inverno ${ }^{113}$, o que também pode ter permitido a interrupção do atendimento durante alguns meses, aproveitando-se esse intervalo para a rápida construção do novo hospital (mais um possível motivo da simplicidade da construção).

Foi encontrada no acervo cartográfico do Instituto uma planta a lápis (figura 152) assinada pelo “engenheiro Dr. Rubens C. Vianna” (figura 153), que menciona o Dr. Gastão, responsável pela fisiologia. Pode-se concluir que se trata do médico Gastão Rosenfeld, primeiro diretor do hospital citado anteriormente, e do engenheiro-arquiteto responsável pelo projeto da torre de 21 andares já comentada (figura 24). Mas o estudo da torre (bastante elaborado) foi apresentado na década seguinte. Já a planta do hospital, a lápis sobre papel vegetal, é bem mais simples e pouco detalhada, podendo-se daí inferir que se tratou de um croqui realizado por Rubens a pedido do diretor Gastão, no contexto da urgência já relatada, provavelmente no início dos contatos do arquiteto com o Instituto.

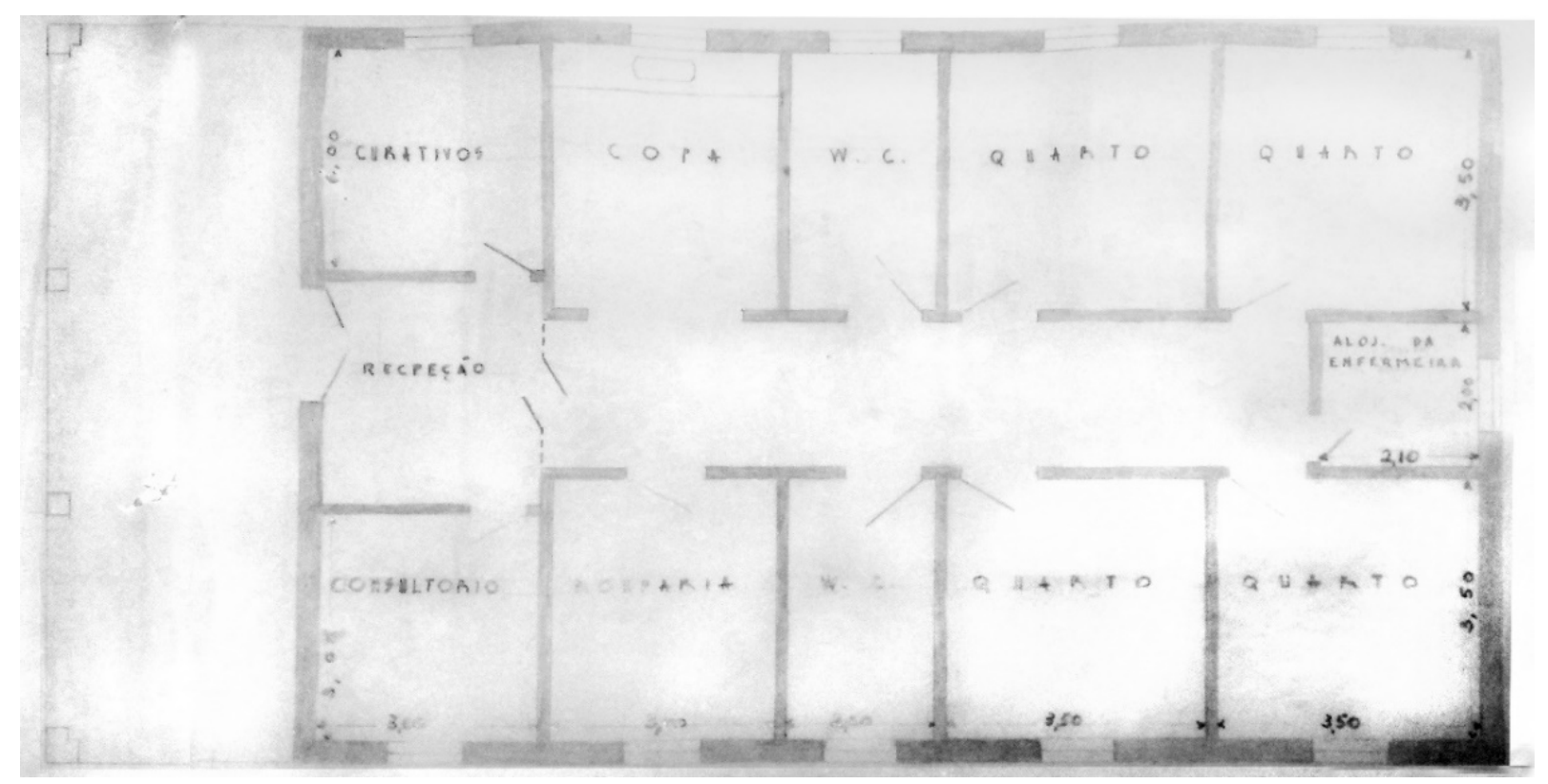

Fig. 152 - Planta mais antiga encontrada do Hospital, c. 1953, assinada pelo engenheiro-arquiteto Rubens C. Vianna: vê-se o alpendre na parte frontal, que foi posteriormente fechado. S/escala. (Fonte: Acervo IBu)

\footnotetext{
${ }^{113}$ Segundo Carlos Medeiros, diretor-clínico do Hospital Vital Brazil, as serpentes são mais ativas e se reproduzem entre setembro e março, período que também coincide com mais atividades rurais.
} 


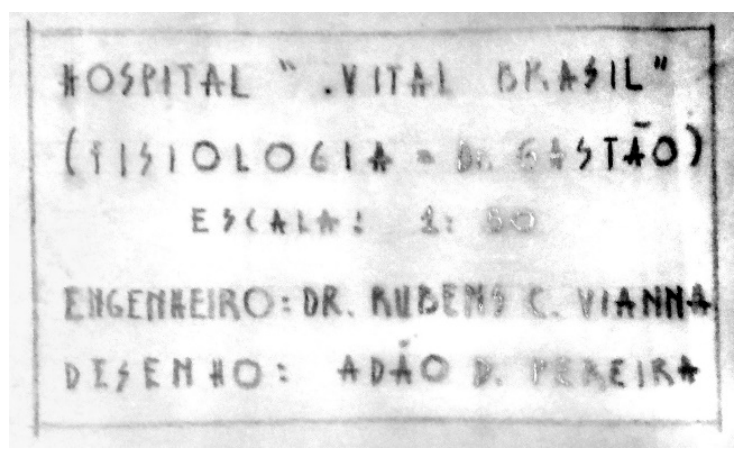

Fig. 153 - Identificação da planta (Fonte: Acrevo IBu)

Já em 1968 a diretoria queixou-se do pequeno edifício:

"Hospital Vital Brazil - Situado atrás do Museu, tendo ao lado campo para pouso de helicóptero. Pavilhão construído especialmente para este serviço, dando péssima impressão como hospital; um corredor de passagem com os quartos e instalações sanitárias lado a lado. Êste prédio está precisando imediatamente de reparos gerais e em especial no telhado, que se encontra em estado precário." (RA 1968, p.4A)

A partir daí, foram feitas alterações na cobertura, com substituição das telhas, e o fechamento do alpendre de entrada (figuras 154, 155).
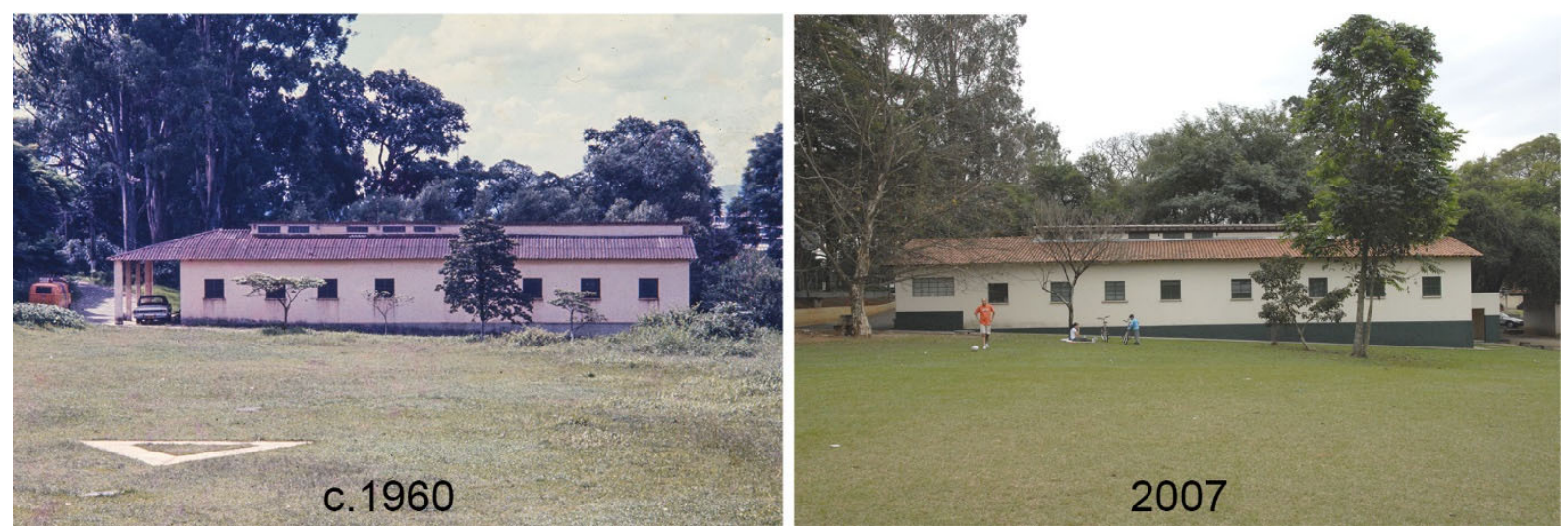

Fig. 154 - Hospital Vital Brazil em dois momentos: visto do campo de pouso de helicópteros, nota-se o alpendre original que foi fechado posteriormente (Fonte: IB_ICO_000195, autor)
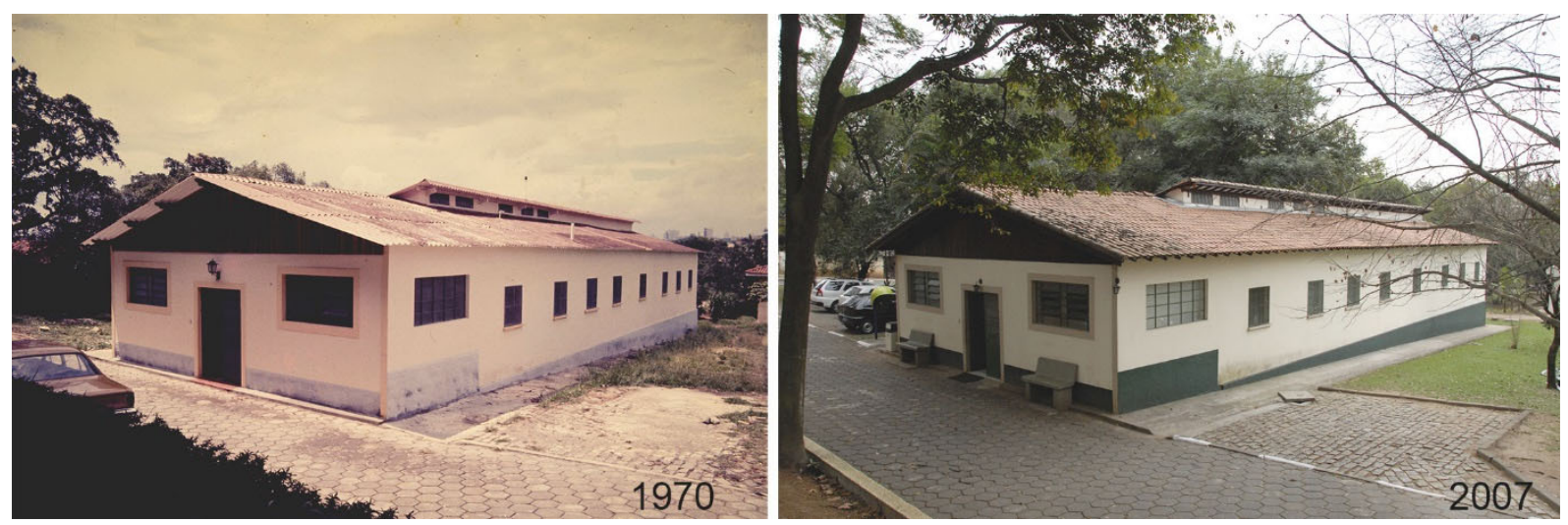

Fig. 155 - Hospital Vital Brazil, vista frontal: nota-se o aspecto utilitário e a ausência de ornamentação do edifício. Houve substituição das telhas em fibrocimento por cerâmicas (Fonte: IB_ICO_000194, autor) 


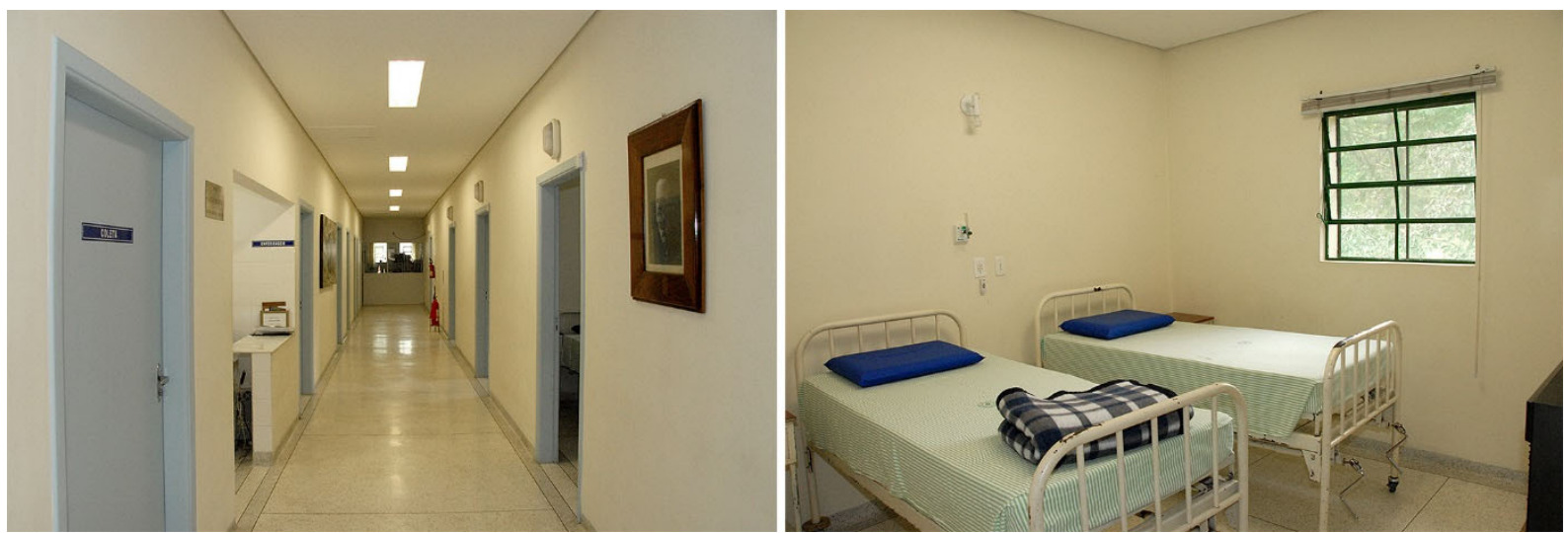

Fig. 156 - Interior do Hospital Vital Brazil: o forro original de lambril foi substituído por gesso acartonado para adequação às normas hospitalares (Fonte: autor)

Em 2005 o edifício, que apresentava problemas em revestimentos, instalações e funcionalidade, passou por nova reforma para atender às normas de saúde, segurança e acessibilidade. ${ }^{114}$ Em consulta do Departamento de Engenharia ao Condephaat, este órgão orientou o Instituto a não realizar alterações externas no edifício (apenas pintura e conserto de peças danificadas de caixilho e telhado), permitindo quaisquer alterações internas necessárias para o funcionamento adequado do hospital (figura 156).

Atualmente mantendo as características da última reforma, o Hospital deve, segundo o novo Plano Diretor, ser convertido em creche, com poucas trocas de revestimentos internos.

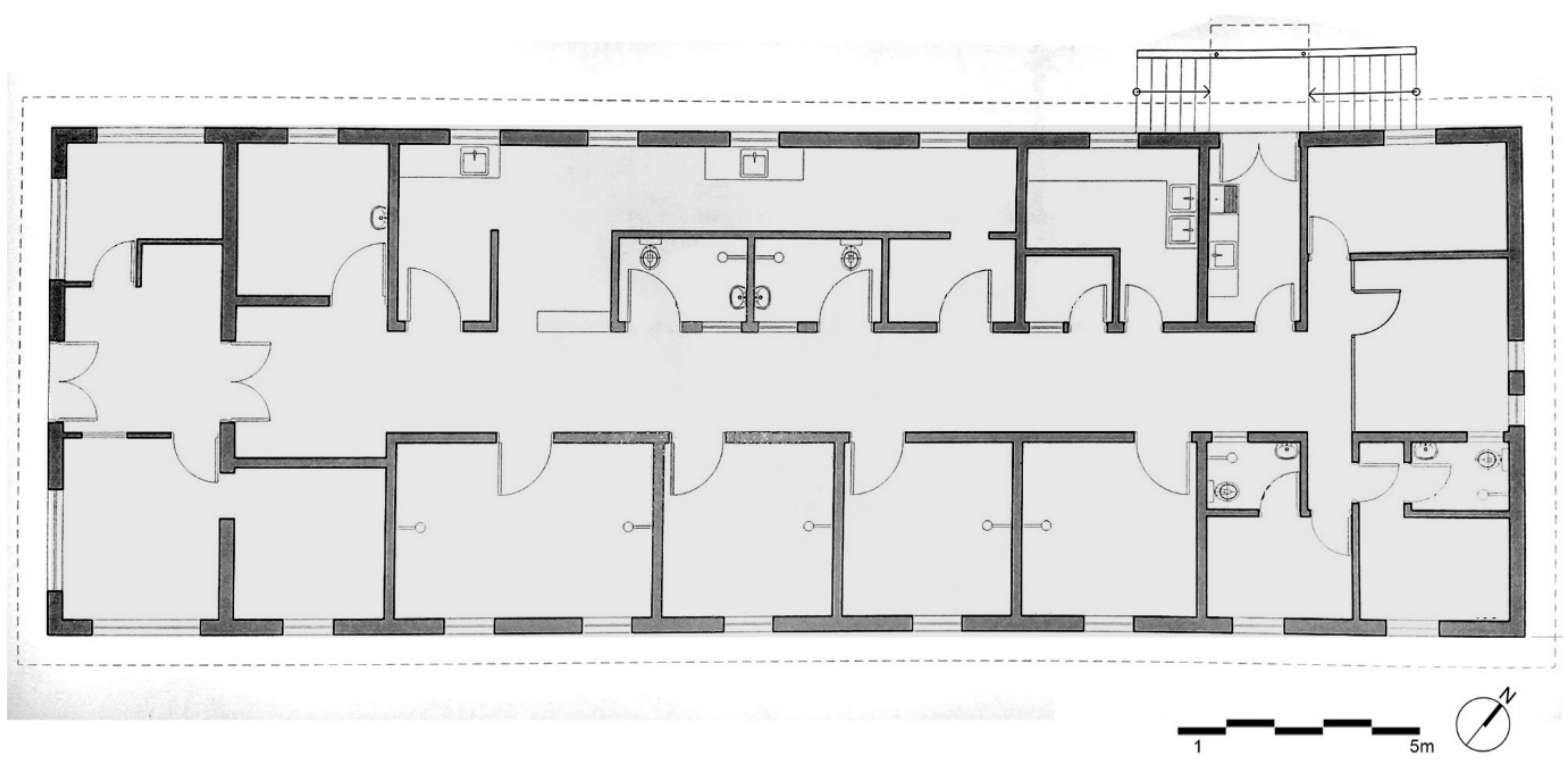

Fig. 157 - Planta do Hospital Vital Brazil atualmente (Fonte: IBu, 2016, alterada)

\footnotetext{
${ }^{114}$ Participei do projeto e acompanhamento dessa obra em 2005 juntamente com o arquiteto Ricardo Romano e a equipe do Departamento de Engenharia do Instituto Butantan.
} 


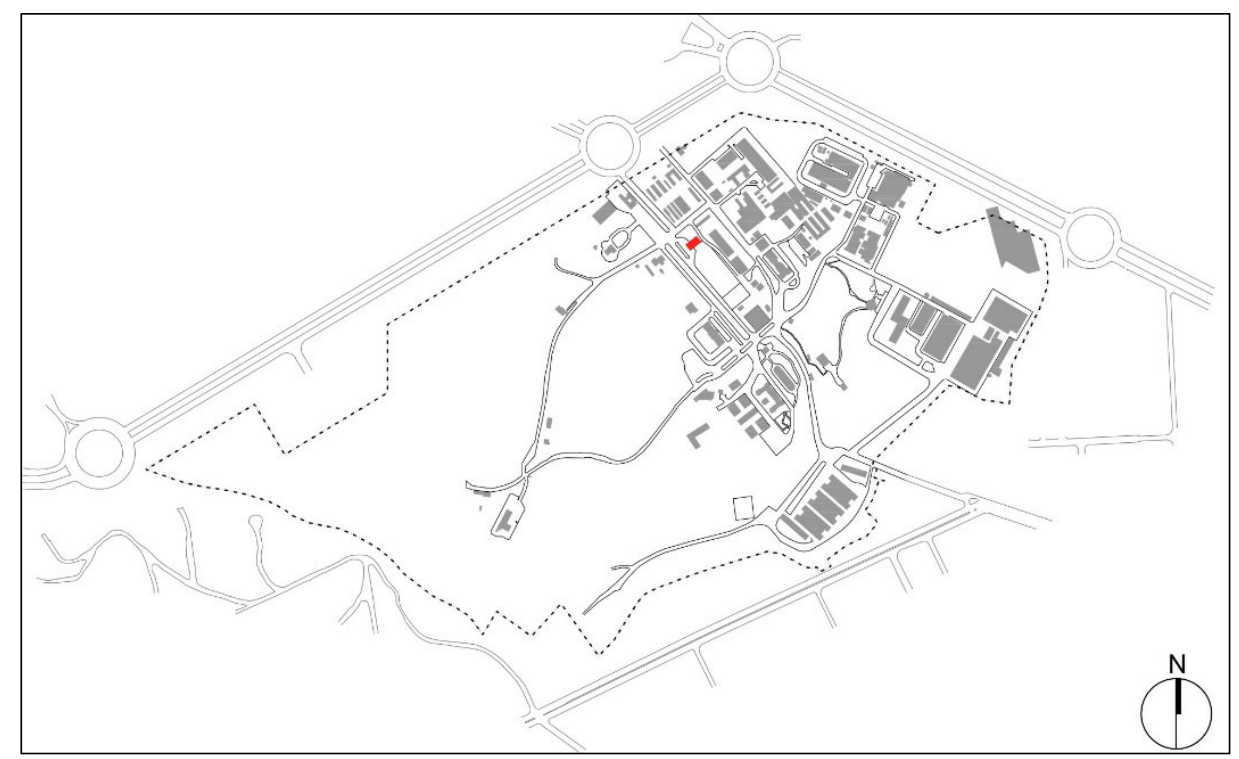

Fig. 158 - Localização do Hospital Vital Brazil em 2018 (autor)

\section{RESUMO}

Categoria: edifício

Denominação original: Hospital Vital Brazil

Denominação atual: Hospital Vital Brazil

Autoria: Rubens Carneiro Vianna

Área original: c. $280 \mathrm{~m}^{2}$

Área atual: c. $280 \mathrm{~m}^{2}$

Número de pavimentos original: 1

Número de pavimentos atual: 1

Início-término da construção: 1953-1954

\section{Itens arquitetônicos originais:}

Estrutura: alvenaria portante

Vedação: alvenaria (tijolo maciço)

Revestimentos paredes externas: argamassa de cimento e cal

Revestimentos paredes internas: argamassa de cimento e cal

Revestimentos pisos internos: cerâmica

Revestimentos pisos externos: cerâmica

Caixilharia: madeira e aço

Uso original: hospital

\section{Itens arquitetônicos atuais:}

Estrutura: original + concreto armado

Vedação: original + divisórias leves + gesso

Revestimentos paredes externas atual: original + massa única industrializada + tinta acrílica

Revestimentos paredes internas atual: original + tinta acrílica

Revestimentos pisos internos atual: originais + cerâmica + granilite

Revestimentos pisos externos: cimento desempenado

Uso atual: hospital 


\subsubsection{Núcleo Residencial [Vila]}

O campus do Instituto Butantan sempre abrigou, além dos usos relacionados ao trabalho científico, diversas residências ou mesmo partes de edifícios utilizadas para moradia. Isso se deve a alguns motivos principais: a distância entre o campus e a área urbana de São Paulo no início do século XX, somada à dificuldade de transporte, fazia com que a opção por morar no próprio Instituto fosse vantajosa para seus funcionários, especialmente diante do entusiasmo da equipe científica com a nascente instituição; além disso, a própria natureza do terreno e das atividades nele desempenhadas (pesquisa e produção científica, plantio, colheita, criação de animais), exigia a permanência de funcionários que as monitorassem em tempo integral; também foi sempre comum a necessidade de alojar visitantes internacionais (autoridades ou pesquisadores) que podiam permanecer por várias semanas ou meses para desenvolver seus trabalhos; por fim, muitos moradores da antiga fazenda permaneceram em casas no campus durante as primeiras décadas do Instituto. Por isso, até pelo menos a década de 1980 a função de moradia, aliada às atividades científicas, era comum no Instituto, havendo projetos e construções feitas especificamente para isso ${ }^{115}$. Dessas construções, um conjunto que pode ser destacado por suas dimensões, pelo contexto histórico em que foi edificado, e por suas características técnico-construtivas, é o Núcleo Residencial executado entre 1963 e 1964.

Formado por 45 casas térreas (figura 159), esse núcleo, também chamado de Vila pelos funcionários, hoje tem seu uso modificado e constitui um conjunto que pode ter relevância como patrimônio cultural ao menos por dois aspectos: pela própria memória do uso residencial no campus, que se relaciona à sua história e à da ciência; e pela representatividade de um tipo de arquitetura ligada aos conjuntos habitacionais, própria do século XX.

Desde as primeiras décadas da instituição, eram solicitadas ao Serviço Sanitário diversas construções de moradias, havendo queixas de que muitos funcionários costumavam se alojar nos próprios laboratórios com suas famílias. Foi em 1925 que apareceu a primeira proposta de um conjunto residencial no local em que hoje se encontra a citada vila:

\footnotetext{
${ }^{115}$ Hoje há alguns edifícios que possuem setores de alojamento, como o hospital ou alguns laboratórios, em que esses espaços são utilizados para plantões de médicos e cientistas, e não para moradia por longos períodos.
} 
[...] é de toda conveniência para os interesses do estabelecimento facilitar a residência dos funcionários dentro de sua própria área de ocupação ou nas suas proximidades. Há na entrada do Instituto um terreno que ficou dividido por uma estrada pública. Esta faixa, que nenhuma utilidade tem para o estabelecimento, poderia ser dividida em lotes e vendida a funcionários, que, de acordo com a lei que regula o assumpto, se habilitariam a construir suas casas. [...] Vamos providenciar no sentido de ser levantada uma planta dos terrenos do Instituto e com esse elemento contamos fazer uma demonstração mais desenvolvida deste plano. (RA1925, pp. 8-9)

Pela citação, cada funcionário seria responsável pela construção de sua casa. Apesar de não ter sido colocada em prática desta forma, essa foi a primeira proposta indicando o terreno junto à entrada do Instituto, na hoje chamada Avenida Vital Brazil. No ano seguinte, o diretor comentou que, como os técnicos do Instituto trabalhavam ali em regime de dedicação integral e afastados do centro urbano, seria conveniente que pudessem morar no campus. Assim, novamente se defendia a construção de casas (embora já houvesse algumas unidades já construídas e outras adaptadas da fazenda para poucos funcionários), desta vez aventando a possibilidade de serem executadas pelo Estado seguindo diferentes tipologias:

O Instituto possue uma quadra de terreno, que por sua localização fora da área ocupada, com livre sahida para a estrada que conduz á cidade e pela proximidade em que se acha dos edifícios principaes, onde estão instalados os diferentes serviços technicos, está em optimas condições de ser ocupada por construcções destinadas a residência dos assistentes e de outros funccionarios de tempo integral. Esta quadra de terreno poderá ser dividida em lotes e vendidos aos funccionarios, com a obrigação de construírem dentro de prazo curto, construcção essa que poderá ser levada a efeito com o auxilio da caixa beneficente. Outra solução igualmente pratica é a do Governo mandar construir as casas de diferentes typos, alugando-as aos funccionarios. (RA1926, np)

De fato foram desenvolvidos projetos para as casas dos funcionários, em geral seguindo tipologias residenciais dos anos 1930 e 1940, criando-se propostas diferentes segundo a hierarquia dos cargos, havendo as casas dos chamados "subalternos" e dos "diretores". Porém, verifica-se pelos relatórios dessas décadas que o conjunto pretendido não foi construído então, sendo executadas apenas algumas unidades. Em 1963, o relatório apresentou os serviços de execução de um novo núcleo residencial (justamente na porção do terreno citada na década de 1920), já sob o convênio com o FCCUASO. Segundo a listagem apresentada, tratava-se de 45 casas. Já em 1965 o relatório traz uma listagem de residências, em um total de 76, com o nome de seus respectivos moradores, sendo que algumas constam como "demolidas". Mas essa listagem traria uma somatória de casas de todo campus (inclusive remanescentes da fazenda) e 
não só desse núcleo. Em seu depoimento, o arquiteto Osmar Mammini afirma que o conjunto já estava concluído e ocupado na sua chegada em 1965. Depreende-se, portanto, que o núcleo tenha sido construído entre 1963 e 1964. O Relatório Geral de Planejamento do Plano de Ação do Governo do Estado, do governador Carvalho Pinto (item 2.1), descreveu em 1963 sua proposta para o que chamou de "Setor VIII-Residencial":

"Nesse primeiro esquema geral, o grupamento residencial, situava-se parcialmente próximo ao setor de produção na área na qual encontrava-se o Club Atlético Butantã, e na área nobre do acesso à Universidade, ficando incrustado entre edifícios de grande porte, formando um contraste inconveniente.

Devidamente autorizados por V.S. demolimos as instalações do Club Atlético Butantã, iniciando os trabalhos de terraplenagem e arruamento do grupo residencial de funcionários subalternos." (Relatório Geral do FCCUASO, 1963, p.2) ${ }^{116}$

O relatório prossegue reafirmando a opção por localizar o conjunto residencial junto à entrada da Avenida Vital Brazil, permitindo que mantivesse interfaces com a cidade, externamente, e com o campus do Instituto, com independência de acessos.

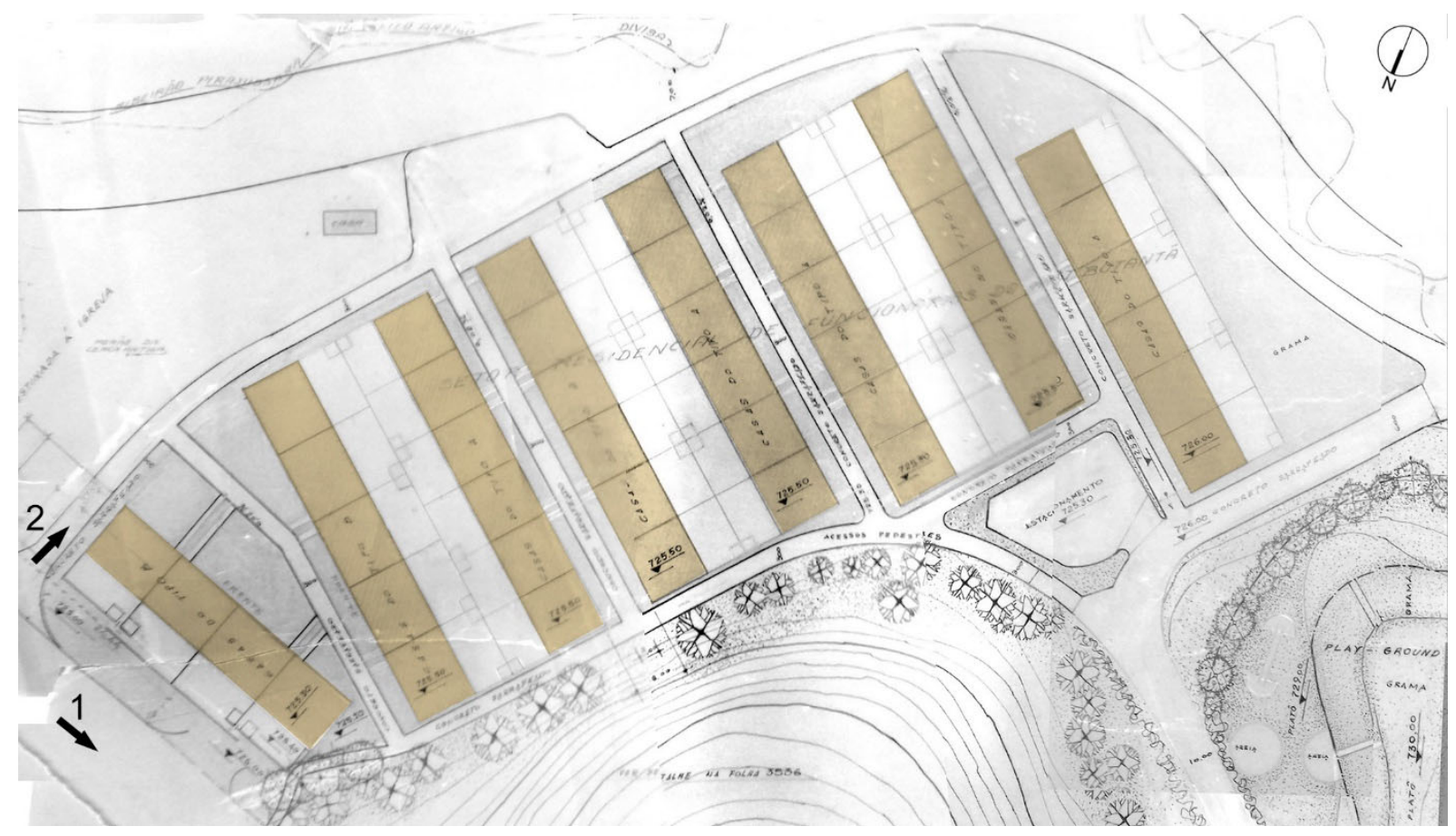

Fig. 159 - Implantação do Núcleo Residencial, desenho de Mário Rosa Soares, 1963: a entrada de veículos do conjunto (2) é independente da entrada do Instituto (1). Os dois renques próximos à entrada possuem quatro e cinco casas, respectivamente, com plantas maiores, que eram destinadas aos médicos. Os demais renques são de seis casas menores, mas todas com 3 dormitórios. Apesar de diversas modificações pontuais (principalmente em vias e canteiros visíveis no estudo), a implantação dos renques permanece a mesma em 2019. S/escala. (Fonte: Acervo IBu)

${ }^{116} \mathrm{O}$ referido clube havia sido fundado em 1922 próximo a essa área. 
Foram identificados no acervo iconográfico do Instituto os estudos e projetos para esse Núcleo Residencial, que teve como autor o arquiteto Mário Rosa Soares, integrante do escritório técnico do FCCUASO, o que faz com que essa seja a maior construção sob o plano de Carvalho Pinto no Instituto Butantan.

O arquiteto Mário Rosa Soares (1926-2004), formado pela Universidade Mackenzie em 1960, teve toda sua carreira vinculada à Universidade de São Paulo, atuando no citado convênio do FCCUASO com o Instituto Butantan ${ }^{117}$. Na Cidade Universitária foi corresponsável pelos projetos dos edifícios da nova Reitoria, da Engenharia Civil, entre outros. Também participou, entre 1967 e 1975, de parcerias entre essa equipe e a de outras universidades, como a Federal de Santa Catarina e a Federal da Paraíba, em que os técnicos faziam um trabalho colaborativo no projeto de tais cidades universitárias, sendo ele responsável pelo pré-plano da Cidade Universitária em João Pessoa. O que se verifica nos outros trabalhos do arquiteto (em conjunto com membros do FCCUASO) é que optou por uma linha com forte influência da Arquitetura Moderna e das diretrizes dos CIAM, especialmente na setorização de funções, separação de fluxos (veículos, pessoas, trabalho, lazer), racionalização das construções, utilização de materiais industrializados inovadores, opção por formas geométricas puras, eliminando ornamentos. Além disso, o uso de materiais aparentes podia ser visto em outras obras do arquiteto para clientes particulares. Essa opção pela chamada "verdade dos materiais" foi associada à corrente brutalista, à qual aderiram muitos arquitetos renomados de São Paulo, diversos deles atuando em projetos para a Cidade Universitária (Artigas, Paulo Mendes da Rocha, Joaquim Guedes). O detalhamento apurado de soluções construtivas que se valiam de produtos industrializados também é uma das características dessas correntes. No entanto, alguns desses recursos já vinham de linguagens do final do século XIX, como no movimento Arts and Crafts, passando pelas obras de Frank Lloyd Wright nos anos 1920 e culminando em nomes com Richard Neutra, nos USA, e Oswaldo Bratke, no Brasil, dos quais se vê certa influência nas casas desse núcleo, guardadas as peculiaridades: variações entre aberturas e paredes cegas, grandes planos de telhados delgados, horizontalidade predominante (figuras 160

\footnotetext{
${ }^{117}$ Mário se graduou com 34 anos, tendo atuado anteriormente na área de ciências contábeis (informações biográficas cedidas por Ana Piza Soares, filha do arquiteto).
} 
a 164). Foi visto que na Casa do Diretor (item 2.3.13), já se utilizavam alguns desses princípios, mas ainda mantendo detalhes ornamentais em pilares, cachorros, corrimãos e beirais.
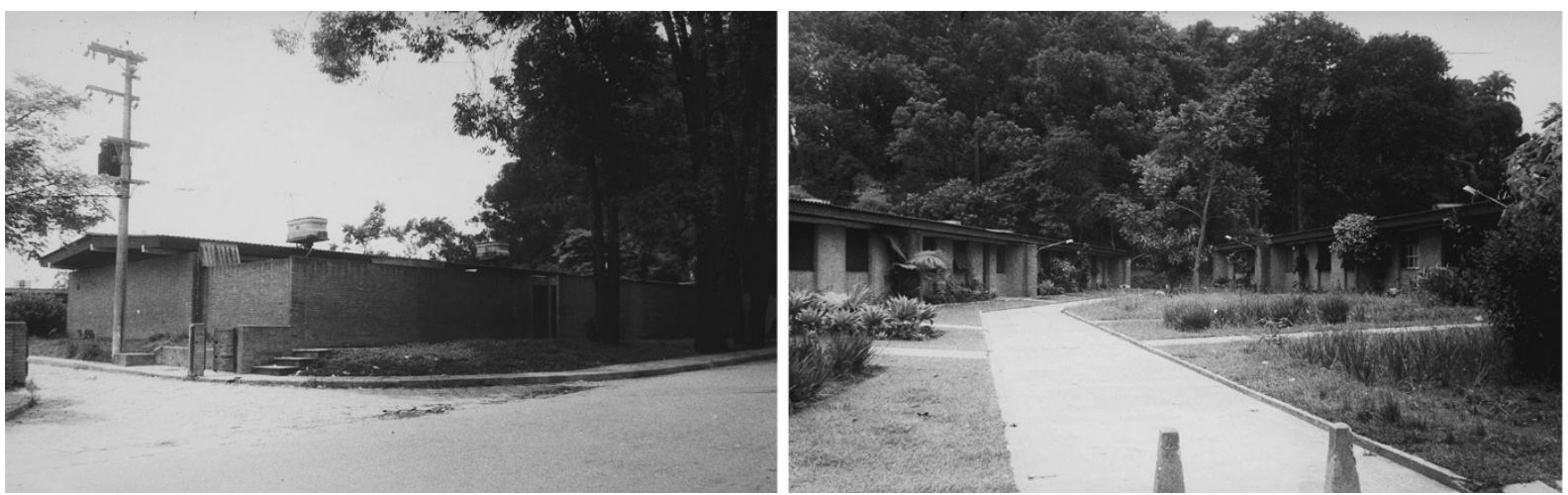

Fig. 160 - Núcleo Residencial em 1970: vê-se o paisagismo e os percursos de pedestres entre as unidades (Fonte: IB_ICO_008772 e IB_ICO_008773)
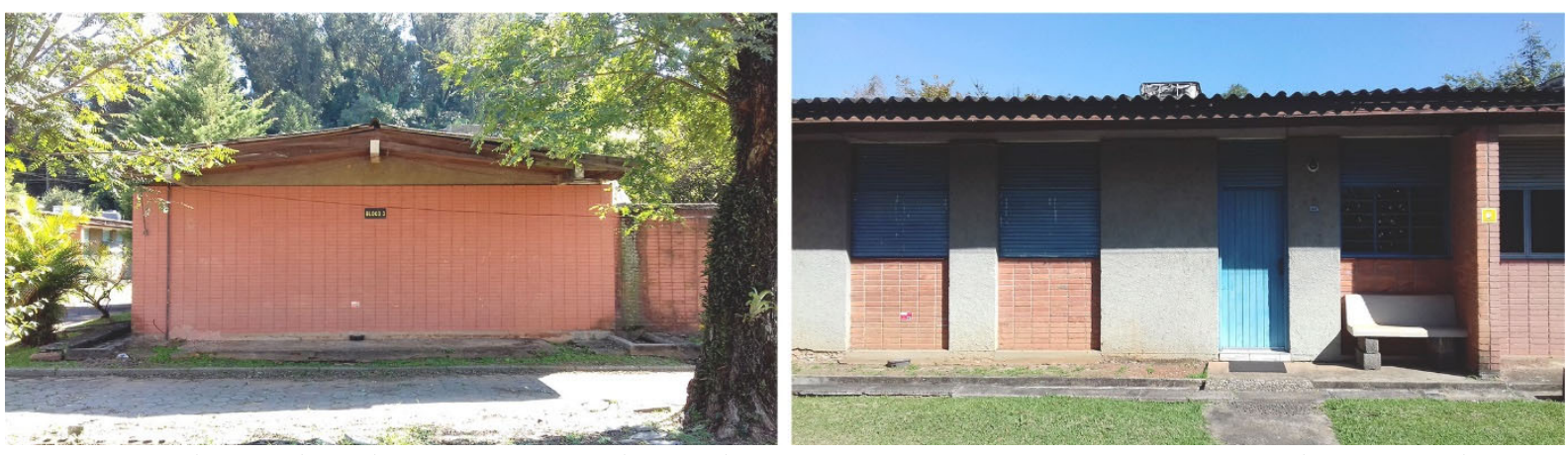

Fig. 161 - Núcleo Residencial em 2018: a racionalização das técnicas e materiais era uma característica dos projetos de Mário Rosa Soares (Fonte: autor)

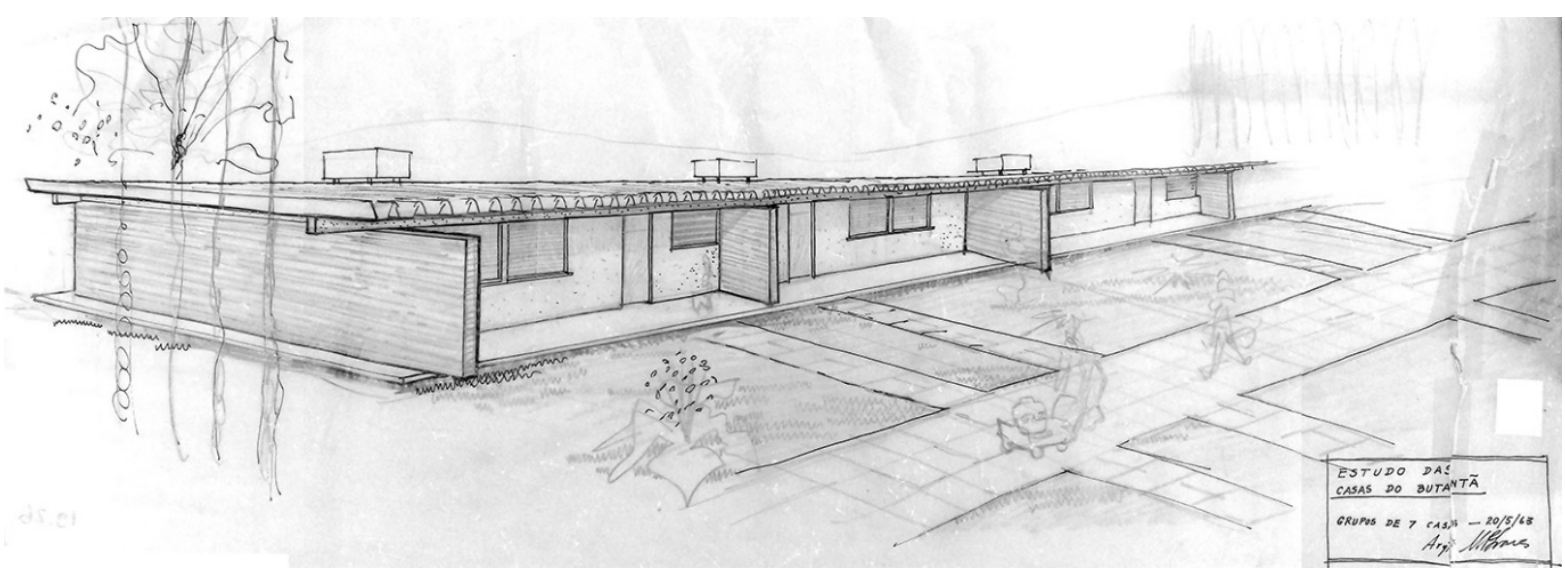

Fig. 162 - Croqui de Mário Rosa para o Núcleo Residencial, 1963. Nota-se a depuração estética aliada à variedade de texturas, recursos que se diferenciam, em parte, daqueles adotados pelo Brutalismo Paulista da época. Os avanços de planos de paredes e coberturas, além de serem um traço expressivo do arquiteto, também promoviam sombreamento, proteção contra chuva e privacidade aos moradores (Fonte: Acervo IBu) 

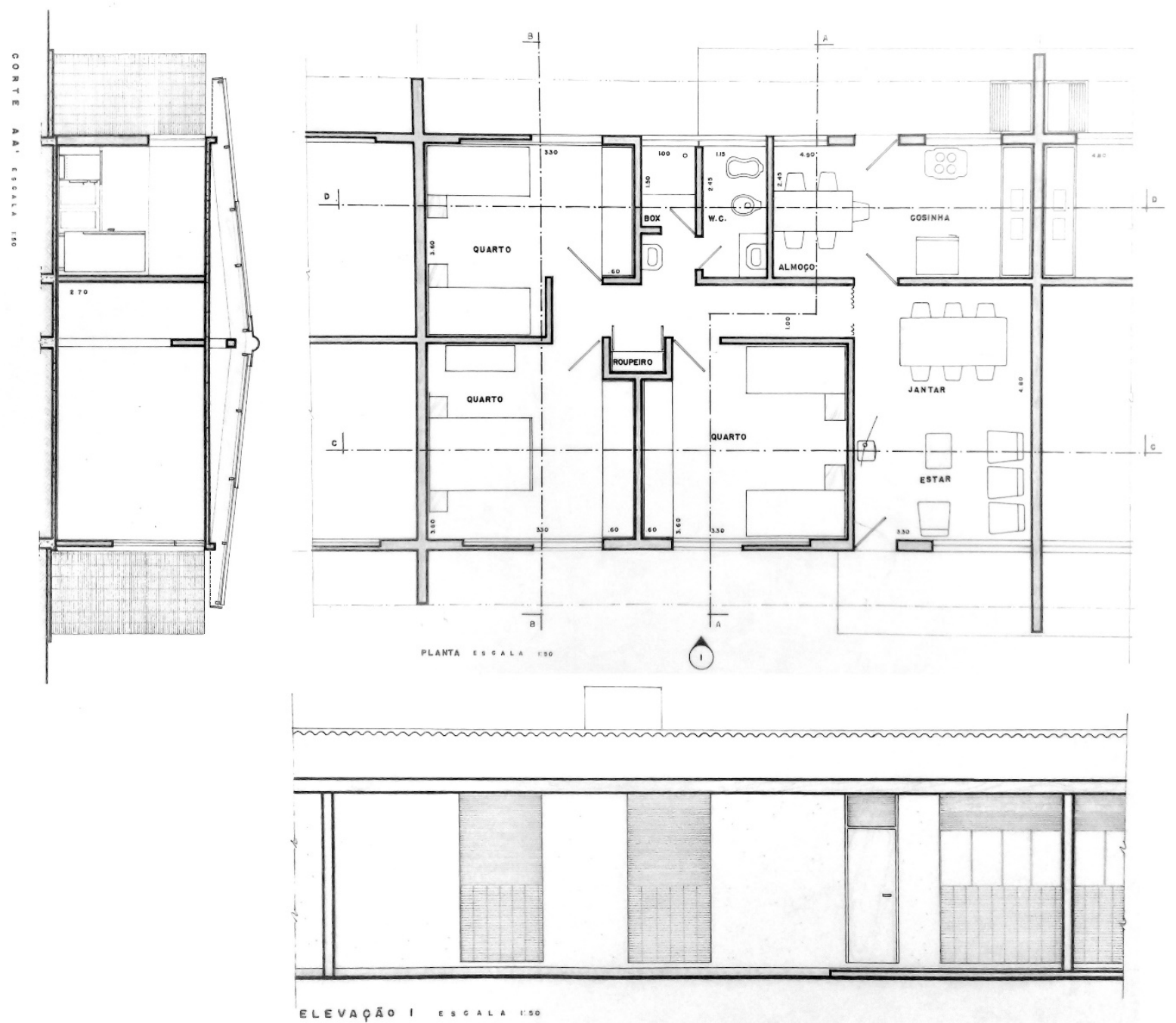

Fig. 163 - Desenhos originais da residência de 3 dormitórios (1963). A planta traz soluções típicas das experimentadas no século XX para a chamada "habitação mínima", como a redução de área de circulação, aproximação e racionalização das "áreas molhadas”, integração de área de jantar e de estar, e ventilação cruzada. Há também um quintal nos fundos de cada unidade, muitos deles com jardins e árvores frutíferas. S/escala. (Fonte: Acervo IBu)
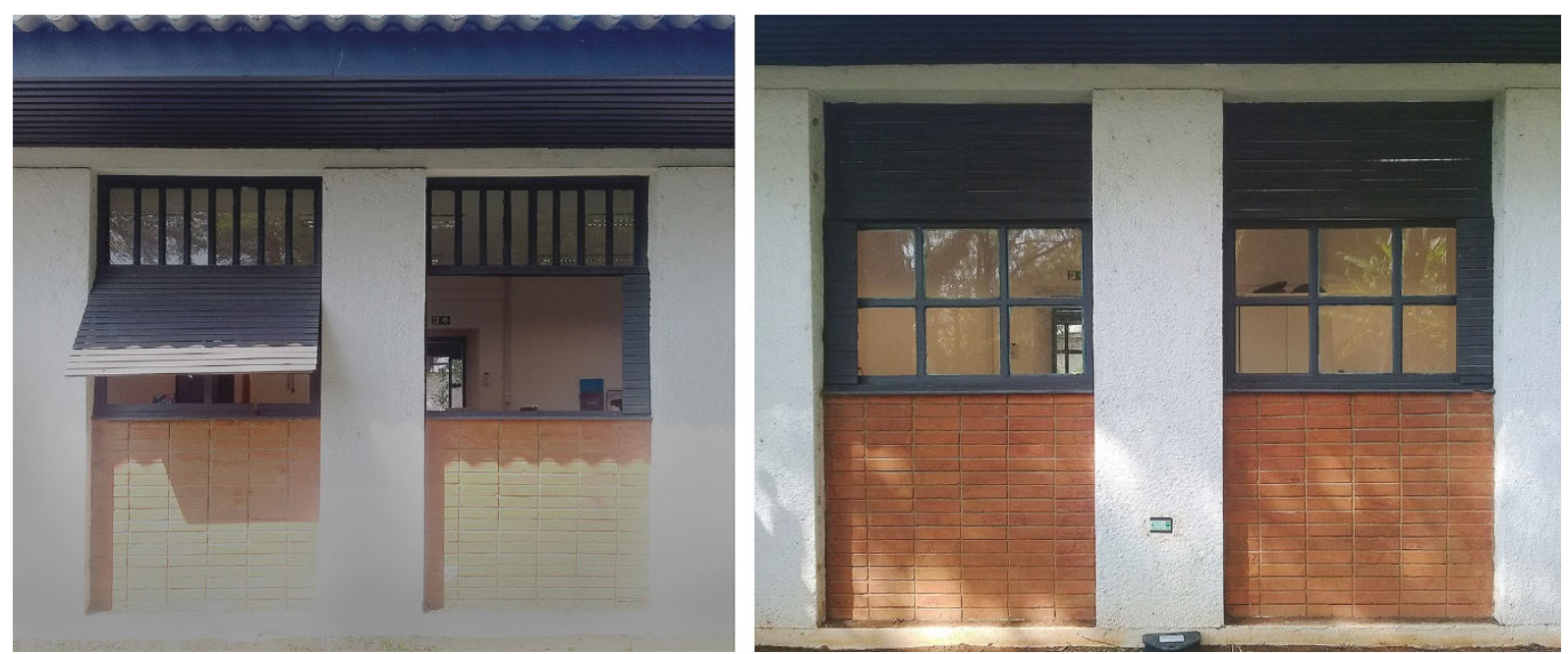

Fig. 164 - Janelas das unidades: houve a preocupação de proporcionar variações nos tipos de aberturas (Fonte: autor, 2019) 
No caso desse Núcleo Residencial, todos esses recursos da Arquitetura Moderna se tornam conscientemente claros, a começar pela própria implantação do conjunto. A distribuição das casas em renque e a hierarquização das vias, faz com que se separem os acessos de veículos (estacionamentos) e de pedestres, além de haver uma segunda via de acesso independente por fora do Instituto, como preconizavam as primeiras propostas dos relatórios. O sistema construtivo utiliza concreto armado, alvenaria, elementos de madeira e aço nos caixilhos, telhas de fibrocimento, entre outros itens acuradamente detalhados em projeto. Nesse sentido, ao adotar tijolos cerâmicos, peças de madeira aparente em beirais, entre outros detalhes, essas casas trazem elementos que as diferenciam das obras em concreto aparente da fase mais radical do Brutalismo Paulista. Essa diversidade de materiais corresponde mais a obras de arquitetos como Oswaldo Bratke, Carlos Milan e Oswaldo Correia Gonçalves, alguns deles também contratados pela FCCUASO, mas que não desenvolveram trabalhos estritamente vinculados ao Brutalismo Paulista, caracterizado pela predominância, entre outras coisas, do concreto aparente e de soluções estruturais mais monumentais ${ }^{118}$.

Além desses aspectos técnicos e estéticos ligados ao Movimento Moderno e à linguagem brutalista, pode-se estabelecer um paralelo entre esse Núcleo e as pesquisas que eram até então realizadas em diversos países na questão da moradia popular (lembrando que se tratava de um núcleo de moradia de "subalternos", segundo os relatórios), um dos programas mais importantes do Movimento Moderno que, segundo Anatole Kopp (1990), teve na habitação popular seu gerador. Paulo Bruna, ao defender o pioneirismo dos Institutos de Aposentadoria e Pensões na introdução da Arquitetura Moderna através da construção de casas populares, faz uma síntese que se aproxima muito de características da Vila aqui estudada:

\footnotetext{
${ }^{118}$ Em seus depoimentos para esse trabalho, Osmar Mammini e Carlos Heck reconheceram que procuraram seguir a linha mais típica dos arquitetos renomados (que admiravam) do Brutalismo Paulista em seus projetos para novos edifícios de produção e biotérios no Instituto, que não foram executados. Esses projetos (publicados na revista Acrópole, $n^{\circ}$. 331, ago. 1966) propunham estruturas em concreto armado com grandes vãos, balanços e circulações, semelhantes aos edifícios de Artigas, Tozzi e Corona para a CUASO, mas aparentemente superdimensionados para a escala e o contexto desse Instituto, assim como outros projetos de arquitetos do Page, já mencionados. Nesse sentido, Mário Rosa parece ter compreendido melhor as necessidades desse entorno em seu Núcleo Residencial, propondo uma implantação mais discreta e integrada à paisagem e à infraestrutura pré-existente.
} 
Para Kopp o movimento moderno não é mais um movimento artístico a se contrapor ao ecletismo dominante, ou ao art-déco, mas sobretudo uma tentativa de participar, ao nível da construção do ambiente, na transformação da sociedade. Segundo Kopp a ideologia do movimento moderno em arquitetura e urbanismo surge dos escombros da Primeira Guerra Mundial, ainda que tenha raízes mais profundas nos movimentos operários do século XIX e nas utopias que, como as de 'Fourier ou de Tchernychesvski, descreviam não só a sociedade ideal do futuro, mas também seu meio ambiente construído'. Assim, será a construção dos grandes conjuntos habitacionais nas décadas de 1920 e 1930 na Holanda, Alemanha, Áustria e Inglaterra que concretamente realizarão pela primeira vez essa arquitetura para as massas proletárias das grandes cidades industriais. Agrupando ao redor de uma série de serviços sociais coletivos centenas e às vezes milhares de habitações 'mínimas', esses conjuntos, pelo seu estudo dos detalhes internos de cada habitação, pelo uso de técnicas industriais de produção, pelo cuidado com a insolação e a ventilação natural e a implantação paisagística, pelo que representaram de inovação em termos de organização e planejamento, acabaram por se tornar os marcos de uma nova concepção do espaço urbano e de uma nova arquitetura. Será pois a habitação operária coletiva o tema central dessa nova arquitetura, do 'Neues Bauen' em forte contraste com a tradição, que colocava o arquiteto como o realizador de obras excepcionais e artisticamente relevantes. Apesar dessas realizações terem sido construídas com técnicas e concepções formais muito diversas, elas guardam entre si um conjunto de traços comuns, de tal forma que se poderia dizer formarem uma nova tipologia arquitetônica. (BRUNA, 2010, p.26)

Essa nova tipologia, embora já presente em alguns exemplares do século XIX, começou a ser desenvolvida sistematicamente na Europa ocidental e, posteriormente, na União Soviética, através de conjuntos habitacionais térreos ou de média altura, com jardins comuns, separação de fluxos de veículos e pessoas, e o estudo minucioso das plantas para construção da "vivenda mínima", atendendo no menor espaço necessário todas as necessidades dos moradores, incorporando para isso princípios tayloristas de otimização dos espaços, redução de circulações e movimentações desnecessárias, e detalhamento cuidadoso da construção. Também eram incorporados conceitos de salubridade como ventilação, iluminação natural e ergonomia. Embora muitas dessas "novas" ideias já estivessem presentes em expressões construtivas anteriores (como as questões de salubridade e detalhamento), o que diferenciava essa arquitetura era a incorporação de dois princípios: a produção em série e a função social. A primeira está ligada, como se viu, aos modelos de produção e gestão surgidos a partir da Revolução Industrial. A função social desses conjuntos veio juntamente com as utopias do Movimento Moderno, entre elas a da valorização da vida comunitária e da não diferenciação das unidades de acordo com classes sociais e ocupações. 
Com efeito, nesse núcleo se desenvolveu uma vida comunitária que criou uma identidade de bairro, ou de vila, na qual conviviam e estabeleciam laços as famílias, formadas por pessoas de várias faixas etárias (incluindo idosos e crianças), o que proporcionava a variedade de usos e de atividades em diversas partes do Instituto, utilizado como área de lazer pelos moradores.

A partir do final dos anos 1990, a vila foi sendo desocupada, pois os funcionários que deixavam o Instituto ou faleciam não eram substituídos, e algumas unidades passaram a ser utilizadas como escritórios, depósitos ou laboratórios. Hoje, das 45 casas, 15 são utilizadas para guarda de documentos ou laboratórios diversos. Houve nos últimos cinco anos acordos entre o Instituto e os últimos moradores para estes que deixassem o núcleo, que deverá, segundo planos recentes, ser demolido para instalação de um estacionamento. Apesar disso, ainda permanece um morador do grupo original que ocupou a Vila (Sr. Siqueira). Em depoimento concedido para este trabalho, ele afirma que construiu memórias e raízes como morador do Instituto Butantan, juntamente com outras famílias, lamentando sua atual destinação. ${ }^{119}$
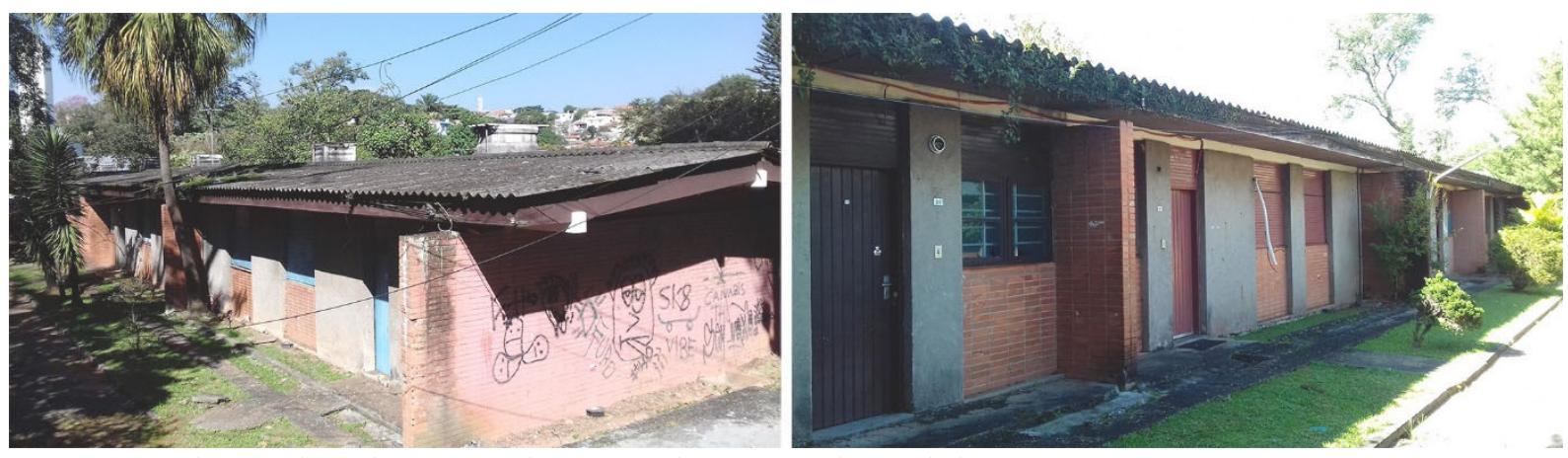

Fig. 165 - Núcleo Residencial em 2018: adaptações e deterioração das unidades (Fonte: autor)
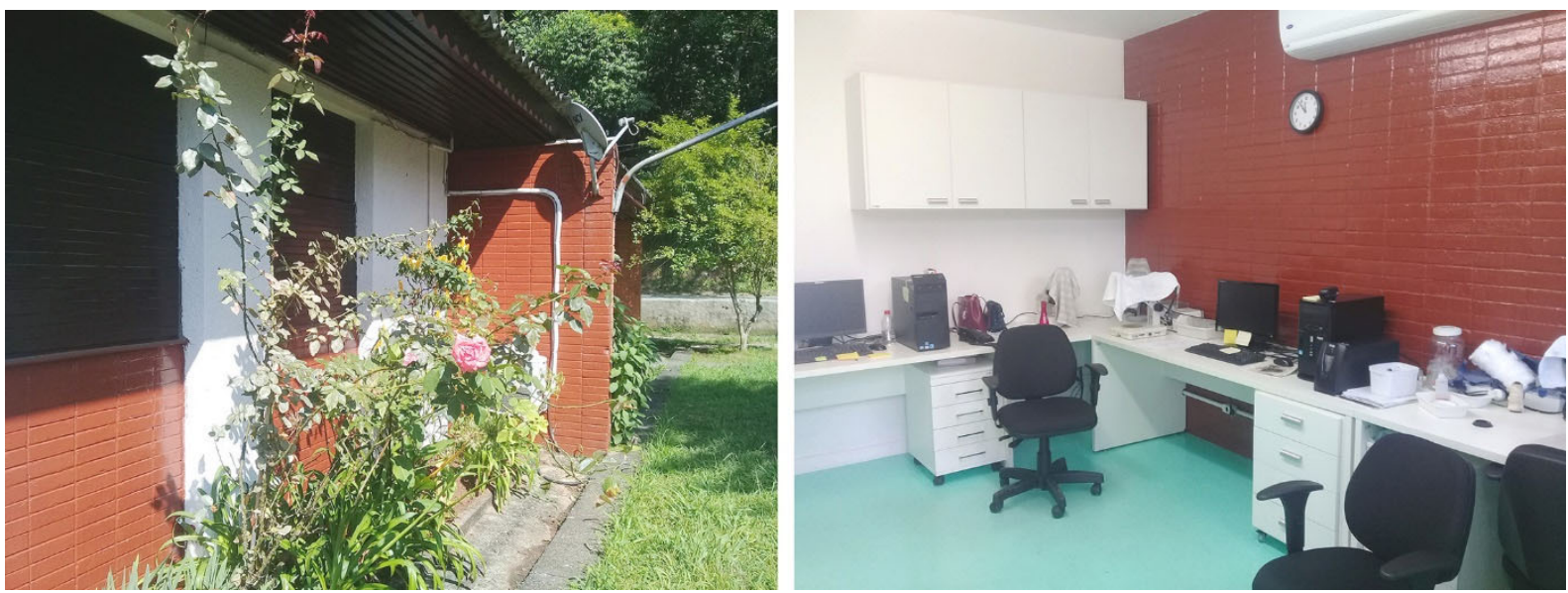

Fig. 166 - Enquanto externamente as unidades ainda apresentam aspecto residencial, internamente muitas tiveram de ser adaptadas em seus revestimentos e instalações para abrigar laboratórios e escritórios (Fonte: autor)

${ }^{119}$ O sr. José Roberto Siqueira deixou a Vila Residencial no mês em que foi finalizada essa pesquisa (fev. 2019). 
Em termos de conservação, desde 1963-64, quando foi construído, o Núcleo passou por modificações, principalmente nas plantas internas, para abrigar escritórios, depósitos e laboratórios. Os próprios moradores alteravam revestimentos e ocupavam os quintais com novas edículas. Também houve alterações em revestimentos externos. No entanto, os aspectos principais que caracterizam sua função residencial, sua filiação a conceitos do racionalismo e seu aspecto urbanístico continuam presentes. Além das alterações, há desgastes próprios do envelhecimento de materiais, mas é possível notar que diversos elementos, como caixilhos, beirais, floreiras, reservatórios, têm apresentado durabilidade satisfatória, o que pode ser resultado do cuidadoso detalhamento verificado nos projetos de Soares e sua equipe, prevendo pingadeiras, soleiras, beirais e outros pormenores (figuras 165 e 166). No Plano Diretor de 2016, foi apresentada proposta de construir um grande edifício centralizando diversos laboratórios do Instituto, próximo à entrada da Avenida Vital Brazil, e para isso esse Núcleo Residencial seria demolido para dar lugar a um grande bolsão de estacionamento, plano que ainda permanece. Há tratativas de membros da atual Divisão de Infraestrutura para tentar preservar ao menos um renque de casas (o que, de qualquer forma, perderia a relação urbanística).

Em dezembro de 2018 (na finalização desse trabalho), procedia-se a demolição de parte dos muros e jardins posteriores do primeiro renque de casas, para alargamento da via de entrada do Instituto na Avenida Vital Brazil (figura 167).
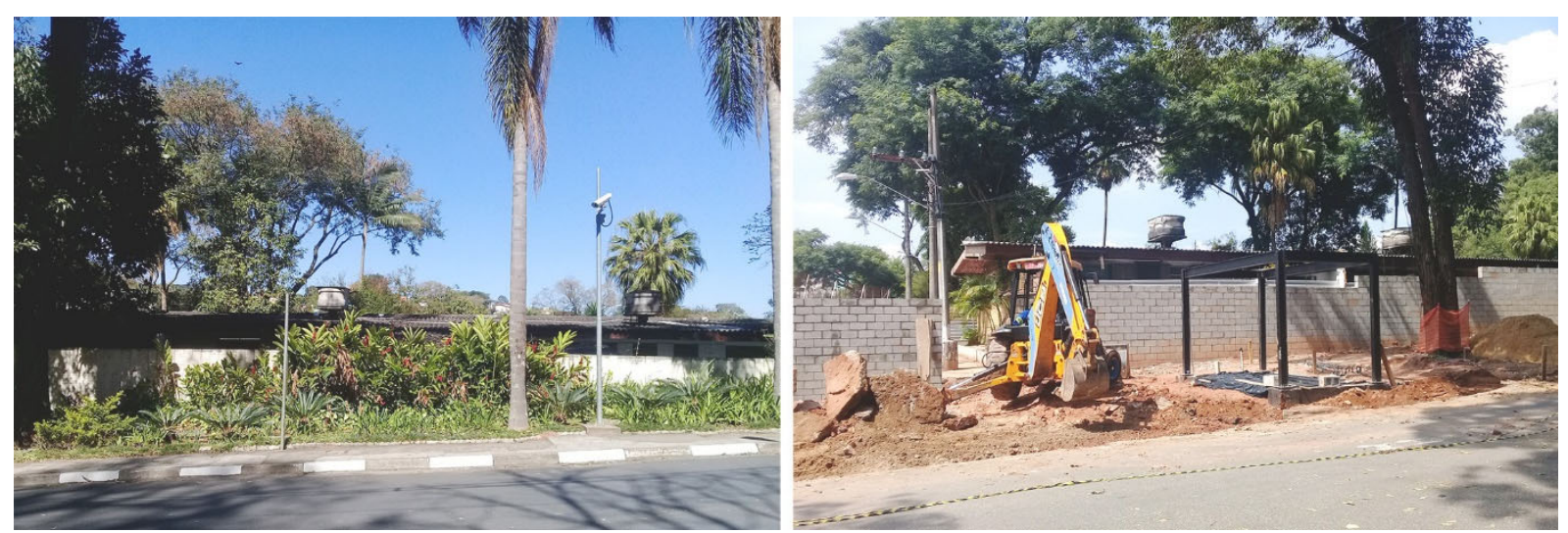

Fig. 167 - Alteração dos jardins e muros da Vila para ampliação da portaria do Instituto, antes e depois (Fonte: autor)

Para demonstrar o valor patrimonial desse núcleo, não cabe aqui o aprofundamento na história da moradia popular, ou, mais recentemente, da Habitação de Interesse Social (HIS), 
que remonta a fins do século XIX e, no Brasil, esteve ligada aos mencionados Institutos de Aposentadoria e Pensões, conforme relatam os trabalhos de BRUNA(2010), BONDUKI(2011) e NASCIMENTO(2016). Também não se pode dizer que, na prática, esse núcleo habitacional era destinado à habitação popular, uma vez que estava reservado para funcionários do Instituto (muitos deles com bons vencimentos), e não para suprir uma demanda social de moradia. Mas cabe pontuar que esse conjunto traz todas as soluções técnico-construtivas, funcionais e estéticas diretamente referenciadas àquelas pesquisas em habitação popular que foram desenvolvidas na Europa, nas décadas de 1920-30, e chegaram ao Brasil na década de 1930, para as quais tem sido reivindicada por estudiosos e órgãos de preservação, maior valorização como patrimônio cultural, por seu protagonismo na história da técnica e da evolução da arquitetura em seu papel social. Também é valorizada como conjunto urbanístico, em contraste com as obras isoladas e excepcionais (que são as mais comuns nesse campus). Flávia Brito do Nascimento afirma, em seu estudo sobre o valor patrimonial da habitação social:

Quer pelo aspecto social, afetivo, simbólico ou histórico, quer pela lógica da arquitetura, até o momento, não houve ações institucionais de fôlego que tenham enxergado nos conjuntos residenciais artefatos de significados memoriais. Os conjuntos residenciais modernos construídos entre 1930 e 1964 no Brasil despertaram apenas interesse ocasional. Apesar de sua importância histórica e de sua representatividade nas cidades brasileiras, é grande a carga negativa construída a seu respeito. Mesmo com os esforço de valorização do moderno, a estigmatização e o preconceito persistem. Ainda se veem os conjuntos produzidos nesse período como inadequados, feios, descartáveis. (NASCIMENTO, 2016, p.20)

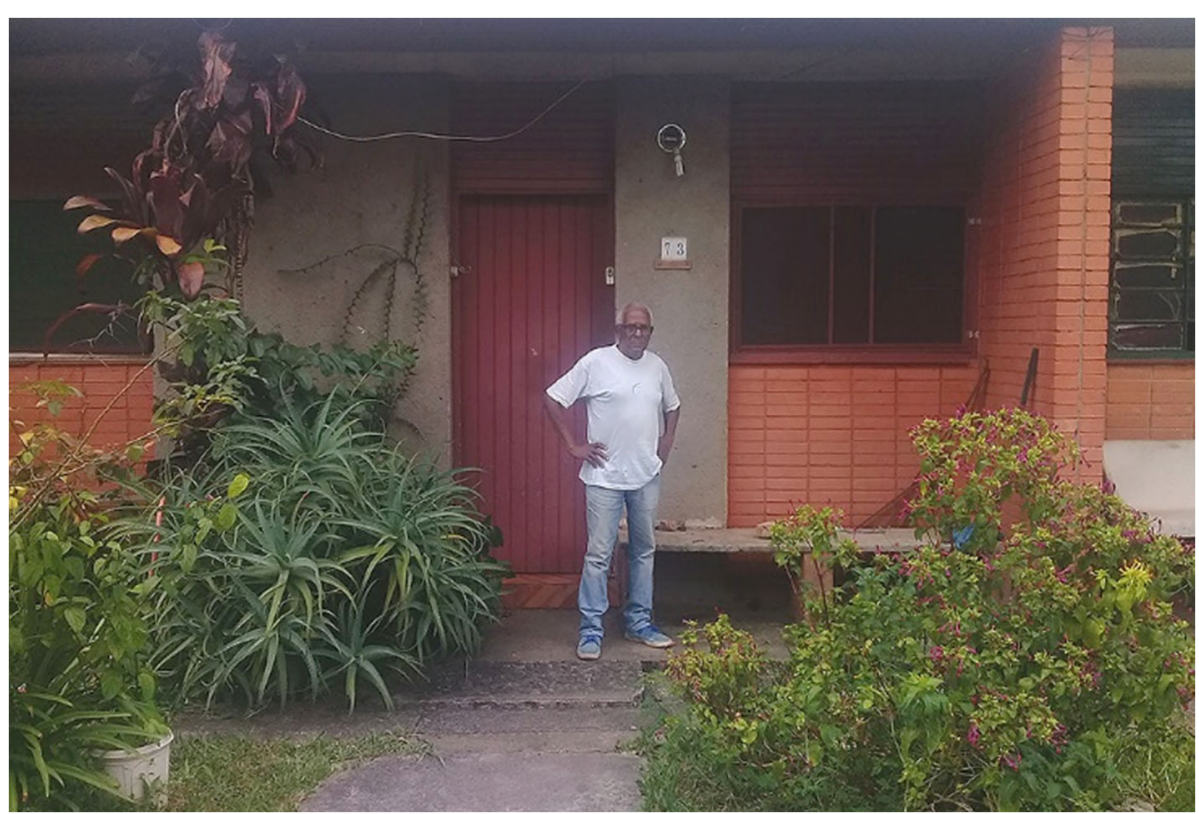

Fig. 168 - Sr. José Siqueira, último morador do Núcleo Residencial em 2019 (Fonte: autor) 


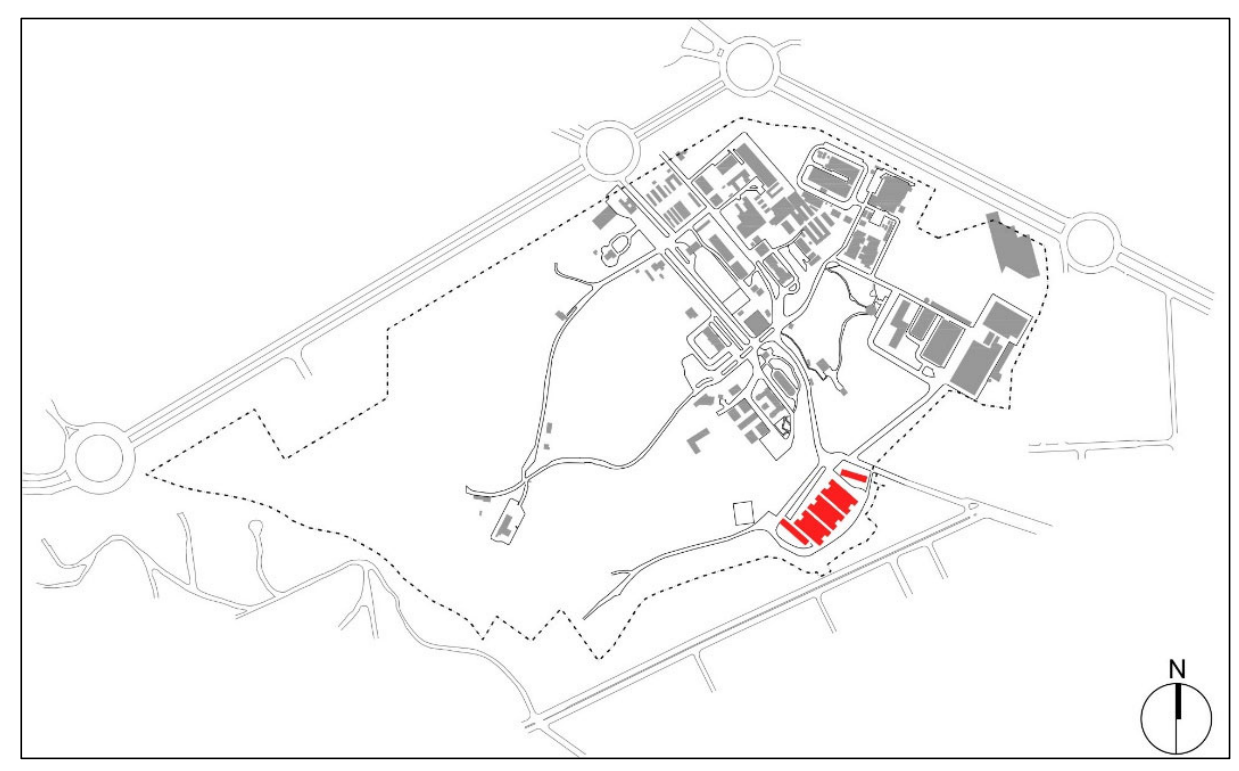

Fig. 169 - Localização do Núcleo Residencial em 2018 (autor)

\section{RESUMO}

Categoria: conjunto de edifícações

Denominação original: Núcleo Residencial

Denominação atual: Vila

Autoria: Mário Rosa Soares

Área original: c. $3100 \mathrm{~m}^{2}$

Área atual: c. $3200 \mathrm{~m}^{2}$

Número de pavimentos original: 1

Número de pavimentos atual: 1

Início-término da construção: 1963-1964

\section{Itens arquitetônicos originais:}

Estrutura: concreto Armado

Vedação: alvenaria (tijolo maciço)

Revestimentos paredes externas: argamassa de cimento e cal, tijolo aparente

Revestimentos paredes internas: argamassa de cimento e cal, azulejos

Revestimentos pisos internos: cerâmica, cimento queimado, tacos de madeira

Revestimentos pisos externos: cimento desempenado

Caixilharia: madeira e aço

Uso original: residências

\section{Itens arquitetônicos atuais:}

Estrutura: original + concreto armado + madeira

Vedação: original + alvenaria + divisórias leves

Revestimentos paredes externas atual: original + massa única + tinta acrílica

Revestimentos paredes internas atual: original + tinta acrílica + azulejos

Revestimentos pisos internos atual: originais + cerâmicos + vinílicos + emborrachados + epóxi

Revestimentos pisos externos: original

Uso atual: original + laboratórios + escritórios + depósitos 


\subsubsection{Museu Histórico}

Conforme já mencionado (itens 2.1 e 2.2), surgiu na década de 1970, com o crescente interesse pela trajetória do Instituto, a intenção de criar um museu voltado a esse tema, não apenas com os aspectos científicos, mas também históricos, sociais, culturais e biográficos (CANTER, 2005). Ao longo do tempo, diversos objetos foram reunidos nesse sentido, e expostos esporadicamente em espaços do próprio Museu Biológico, instalado na antiga Cocheira Central (item 2.3.7).

A ideia de instalar tais exposições em um edifício devidamente projetado foi realizada em 1981 com a construção do Museu Histórico. Este edifício é uma réplica de um estábulo 120 remanescente da Fazenda Butantan, demolido em 1928, no qual Vital Brazil e sua equipe iniciaram os primeiros trabalhos laboratoriais de modo improvisado. O relatório de 1901, conforme transcrito no item 2.1, lista algumas construções da fazenda (sobretudo estábulos e casas) que foram aproveitadas para as primeiras atividades, juntamente com novas construções utilitárias executadas de forma emergencial. Consta nessa primeira lista um "laboratório provisório, aproveitando para tal fim um telheiro já existente”(RA 1901, p.3).

Já em sua Memória Histórica do Instituto Butantan, o próprio Vital Brazil descreve:

Um rancho aberto, ligado ao estábulo, no qual faziam a ordenha, foi rapidamente murado e adaptado aos fins de laboratório. (BRAZIL, 1941, p.12)

Por essa descrição e por fotos da época, fica claro que se tratava originalmente de uma construção rural utilitária, com cobertura (telheiro) remanescente da fazenda, estruturada em madeira e apoiada em pilares de alvenaria. De acordo com a ilustração publicada nas citadas Memórias (figura 170), vê-se um corpo central com um primeiro trecho, apresentando muretas baixas e um prolongamento lateral, e um trecho posterior, com muretas mais altas. Dada a descrição de uso, é possível que essas diferenças estivessem relacionadas à permanência de animais (muretas altas ao fundo), pessoas (rancho na frente) ou estoque de materiais e alimentos (prolongamento do telheiro ao lado). Para os serviços do Instituto, a construção foi

\footnotetext{
${ }^{120}$ Nos relatórios aparecem os termos estábulo, telheiro e racho, indicando que se tratava de uma estrutura de abrigo para atividades diversas de funcionários da fazenda.
} 
inicialmente fechada por paredes laterais. Essas paredes também eram em tijolos de barro cozido, da mencionada olaria, segundo restos encontrados no final da década de 1970. O estábulo já convertido em laboratório pode ser visto na figura 171.

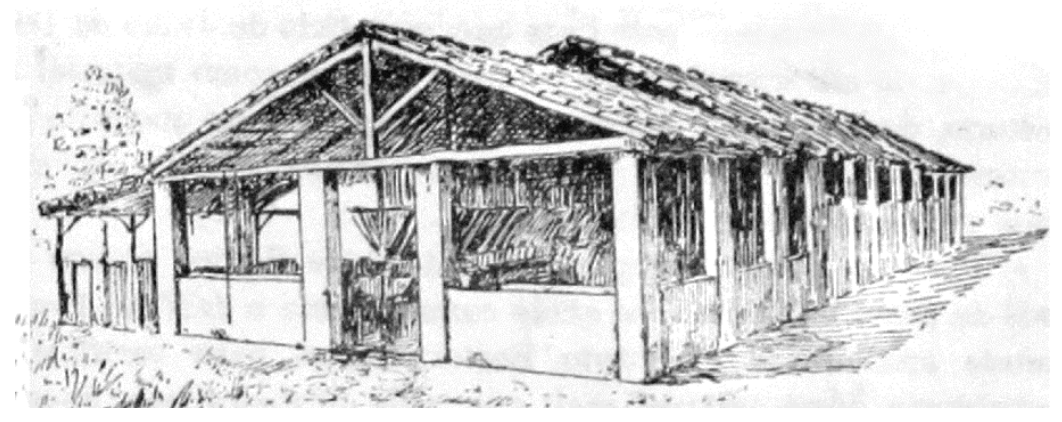

Fig. 170 - Ilustração de como seria o estábulo da fazenda (BRAZIL, 1941, p.25)
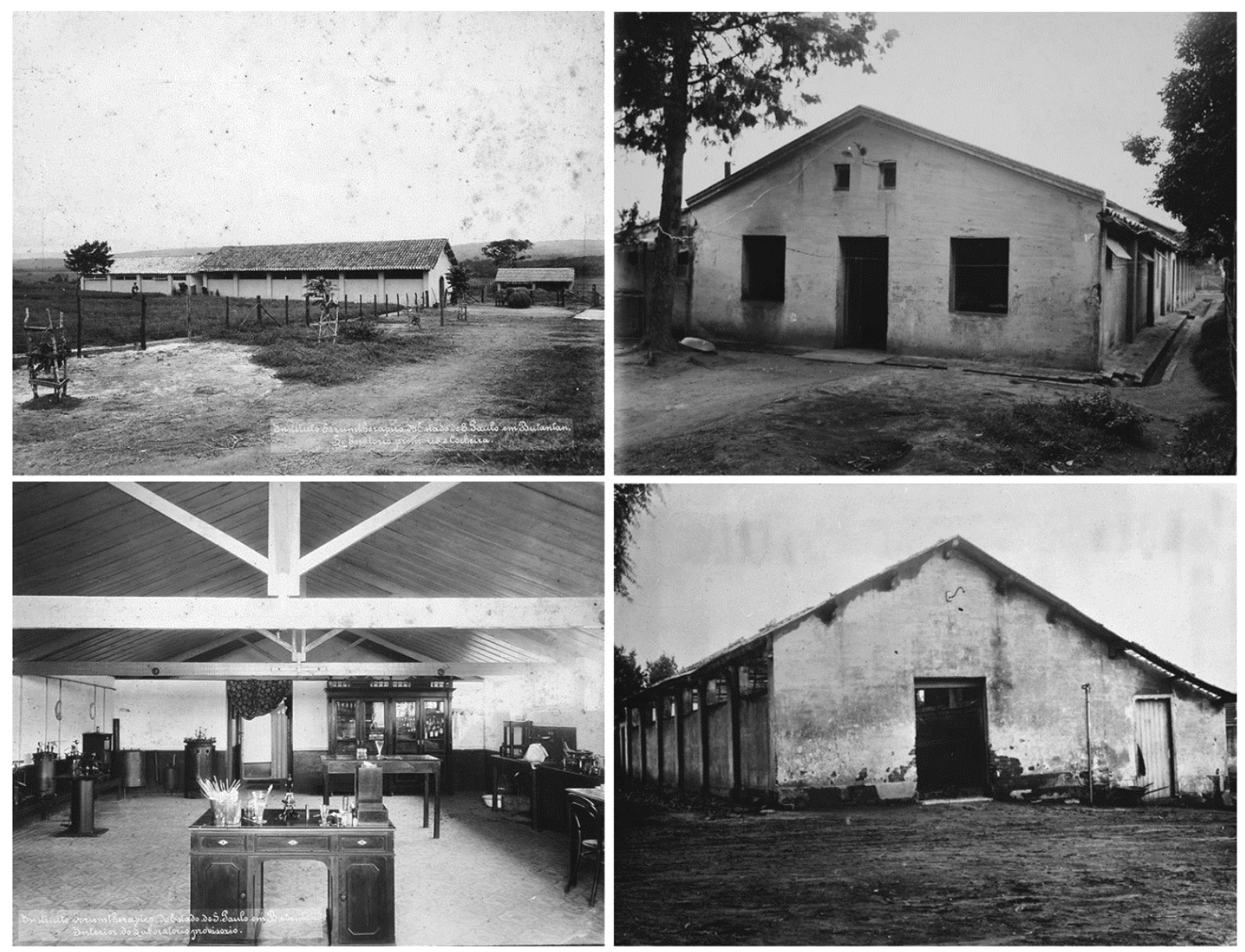

Fig. 171 - Estábulo original na década de 1920: a edificação em que Vital Brazil iniciou seus trabalhos foi demolida em 1928 (Fonte: Acervo IBu) 
Em 1928 o edifício já havia mudado de função, acumulando os usos de cocheira e escola. No relatório desse ano é encontrada a última menção à edificação existente, feita por Afrânio do Amaral, diretor na época:

Por estar ameaçando ruina e não preencher nenhuma das exigencias da lei sanitária vigente mandei derrubar o predio em que funcionava a cocheira velha, em cujo fundo estava installada a antiga escola [...] contra o dispositivo da lei sanitaria vigente (art. 371 e 380). (RA 1928, p.29)

No final dos anos 1970, o Instituto passava por diversas reformas tanto para adaptação de trabalhos de pesquisa, quanto para abrigar novas atividades culturais na esteira das comemorações de seus 80 anos e da tentativa de fortalecimento da identidade da instituição. Assim, em 1978 o então diretor Bruno Soerensen Cardozo criou o Grupo de Trabalho com a finalidade de realizar levantamento de material de caráter histórico da instituição para a futura instalação de um Museu Histórico. Esse grupo produziu um relatório dando, entre outros apontamentos, a seguinte recomendação:

A Comissão julga ser de grande interesse para o Instituto a edificação de uma réplica do primeiro laboratório construído no Instituto Butantan, onde Dr. Vital Brazil realizou seus primeiros trabalhos. A localizaçao do laboratório foi devidamente encontrada, estando anexadas a este, a planta e fotografias indispensáveis para essa realização. (CANTER, 2005, p.67)

A mencionada localização teria sido encontrada durante obras de demolição de coelheiras, em que foram identificados restos do primeiro laboratório:

Quando da remoção de antigas coelheiras, localizou-se o piso, o alicerce e uma das paredes originais do que se acreditava ser o primeiro laboratório em que Vital Brazil iniciara os seus trabalhos na então Fazenda Butantan e que fora demolido em 1928. Entrevistas com antigos funcionários e análise de fotografias possibilitaram, com auxílio de um arquiteto, o dimensionamento correto do que fora aquela edificação. Surgia ali a idéia da criação de um Museu Histórico. (Ibid, pp.65-66)

O arquiteto citado por Canter era Osmar Mammini, que já vinha atuando no convênio entre o FCCUASO e o Instituto Butantan desde 1965.

Em depoimento para este trabalho, o arquiteto, relembra as circunstâncias da construção:

“Aí era o biotério do Instituto. O biotério era uma coisa horrível, ele tinha umas gaiolinhas, uma ao lado da outra com um telhadinho que tomava sol, chuva, tudo, e os animais ficavam lá. E aí eu descobri lá no biotério as fundações desse prédio que foi o primeiro laboratório do Vital Brazil no Instituto [...]. Eu tinha uma fotografia do laboratório, antiga. E na fotografia aparecia um eucalipto ainda novinho, eu disse 'pelo 
eucalipto, essa fundação é do laboratório' [...]. Então eu disse: 'olha, o negócio é refazer'. Então eu procurei fotografias da época, tudo, e restaurei o que foi possível, inclusive colocando os móveis que tinham sido guardados no almoxarifado, abandonados. Tinha escrivaninha de carvalho ainda, importada, que foi do Vital Brazil." (Depoimento de Osmar Mammini, 2017)

Na mesma entrevista, o arquiteto afirma não se lembrar de que foram encontrados pisos e alicerces originais. Mas o Relatório de Atividades 1978/1982 menciona mais detalhadamente:

No local restavam apenas o seu piso original e uma das paredes de barro e, com a remoção da terra, foram encontrados todos os alicerces e esgotos originais. Através de documento fotográfico da época acrescidos de relatos de antigos funcionários que trabalharam nesse laboratório, foi possível restaurar em 10 semanas o referido laboratório com recursos próprios. Após estudo de farto documentário histórico e contratação de duas historiógrafas para procederem o estudo especializado, foi inaugurado o Museu em 11 de junho de 1981, data em que Vital Brazil há 80 anos entregava às autoridades sanitárias as primeiras ampolas de soro antipestoso, produzido naquele laboratório. (RA 1978/1982, p.103)

Em que pese possíveis imprecisões de memória nos depoimentos sobre os elementos encontrados, fica claro que em 1981 se decidiu construir uma réplica do edifício do primeiro laboratório, de forma integral, a partir de elementos remanescentes que se acreditava serem da construção original. Uma vez que esses elementos eram escassos, e não existiam desenhos técnicos originais, essa reconstrução foi baseada em fotografias e relatos de época. Nas palavras do diretor Bruno Soerensen Cardozo, a "restauração" foi feita por funcionários do Instituto em três meses, chegando a uma "reprodução fiel" do laboratório (RA1981, p.7).

O relatório de 1979/1982 mostra o processo de construção do novo museu. Pelas fotografias (172 a 175), verifica-se que foi utilizada alvenaria de tijolos maciços em sua maior parte, mas há trechos em que foram utilizados blocos de concreto. As tesouras em madeira também foram reproduzidas. Quanto ao piso, fotografias da demolição das coelheiras, na qual se encontraram os remanescentes do primeiro laboratório, mostram trechos de peças cerâmicas. Esses trechos, por não ocuparem toda área do atual museu, foram provavelmente complementados com novas peças semelhantes. Já os ladrilhos decorados que existiam na parte interna do laboratório original (figura 171) não foram reproduzidos, optando-se, na parte frontal, por piso em cimento queimado, com desnível em relação ao fundo. O forro em lambril visto na mesma imagem não foi reproduzido. Foram instalados caixilhos com folhas em 
madeira basculantes ou vidros fixos, que não são vistos nas fotografias antigas. Itens de mobiliário, sobretudo laboratoriais, de diversas épocas do Instituto foram expostos no museu, não necessariamente reproduzindo a conformação original.

Relembre-se que durante a concepção do museu o Condephaat, que avançava no processo de tombamento, tomou ciência da demolição de parte do biotério original, e estimulou a construção desta réplica, conforme já citado anteriormente (item 2.2):

Mesmo que tal política de construção não seja adotada por este Condephaat, a solicitação deste diretor deverá ser estudada, pois a solução para tal problemática pode vir a ser facilmente encontrada, realizando-se desta forma nossa contribuição maior, isto é, aliar as reivindicações das comunidades às normas técnicas de restauração. (Condephaat, 1981, pg. 17)

O Museu Histórico foi inaugurado em 11 de junho de 1981 com grande divulgação, sendo apresentado como restauro do estábulo original (figura 176).

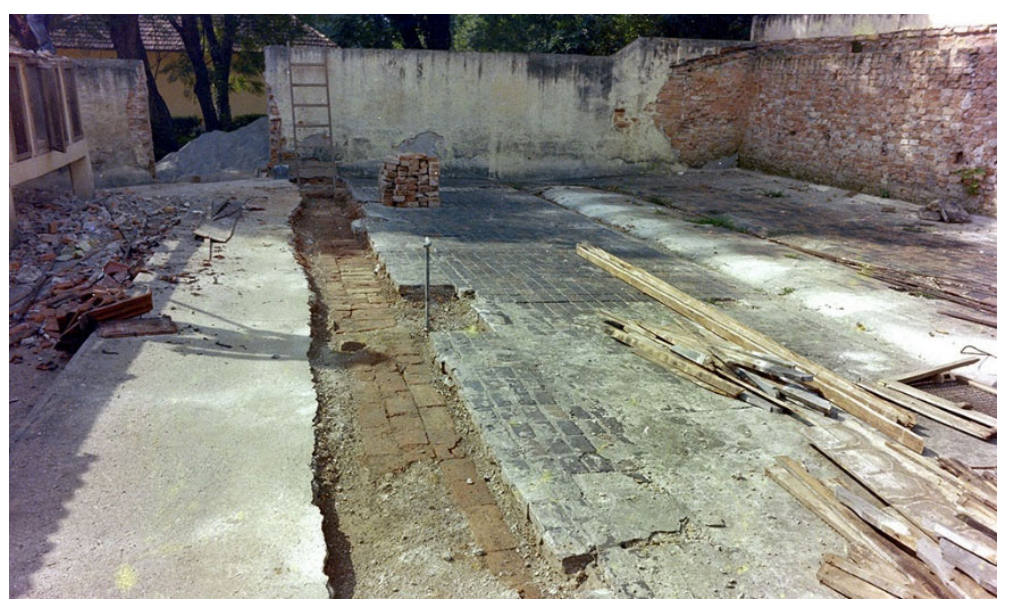

Fig. 172 - Piso original do estábulo identificado durante a demolição de biotérios, c. 1979 (Fonte: IB_ICO_003171)

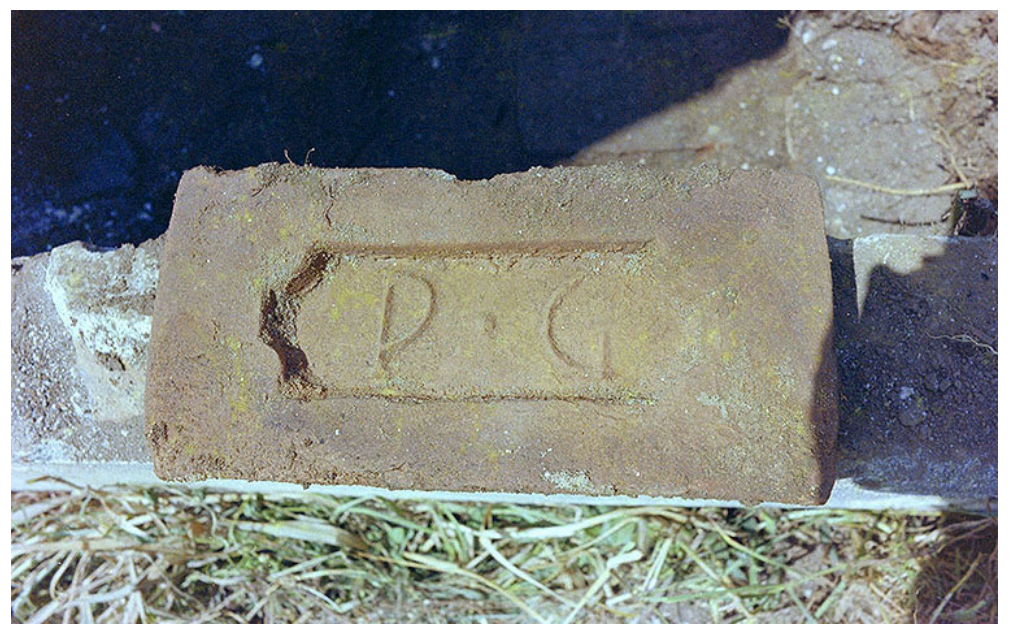

Fig. 173 - Um dos tijolos da demolição: a inscrição PG provavelmente se refere a Paschoal Gravini, dono da antiga olaria já mencionado (Fonte: IB_ICO_003167) 

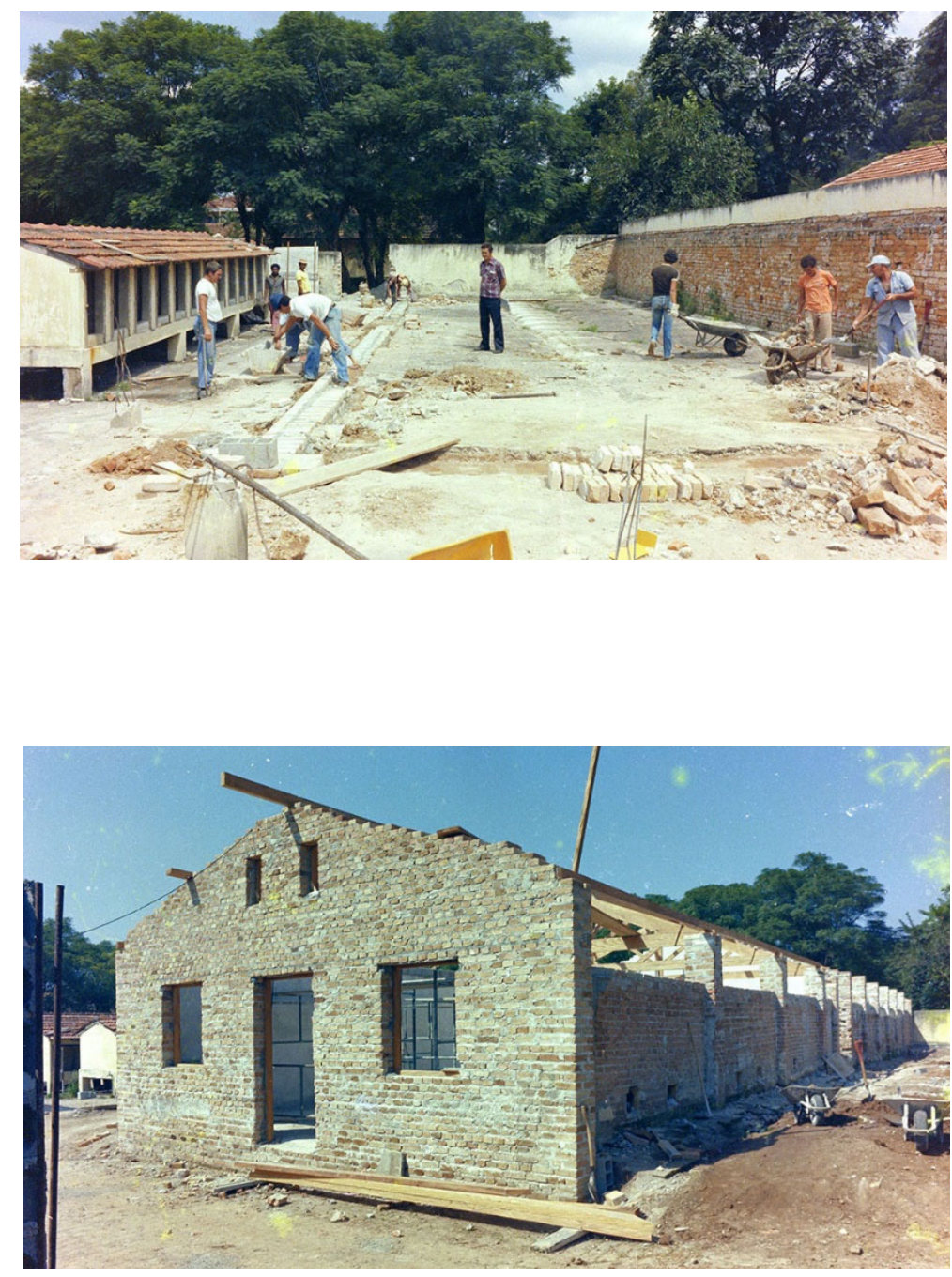

Fig. 174 - Local onde foram encontrados os restos do estábulo e erguida sua réplica, 1980. À esquerda, biotérios do início do século XX em demolição. Ao centro, o arquiteto Osmar Mammini (Fonte: IB_ICO_003197)

Fig. 175 - Início da construção do Museu Histórico, 1980: a réplica do estábulo original combinou tijolos de barro e trechos de bloco de concreto (Fonte: IB_ICO_003177)

Após a inauguração, o prédio foi recebendo pequenas alterações, principalmente em instalações, para se adequar a necessidades expositivas. Em 1991 (dez anos depois da inauguração), foram feitos trabalhos de conservação como pintura e aplicação de verniz em madeiras. Entre as alterações para adaptação a exposições estão aquelas relacionadas a instalações elétricas e luminotécnicas. Externamente, destaca-se a praça Vital Brazil, que recebeu em 2008 mosaicos criados por voluntários liderados pela artista plástica Cláudia Sperb.

O Plano Diretor de 2016 propõe a manutenção da mesma função, com reforma de alguns elementos construtivos para melhoria das atividades museográficas. As questões sobre a réplica do estábulo original serão aprofundadas no item 3.2.3. 

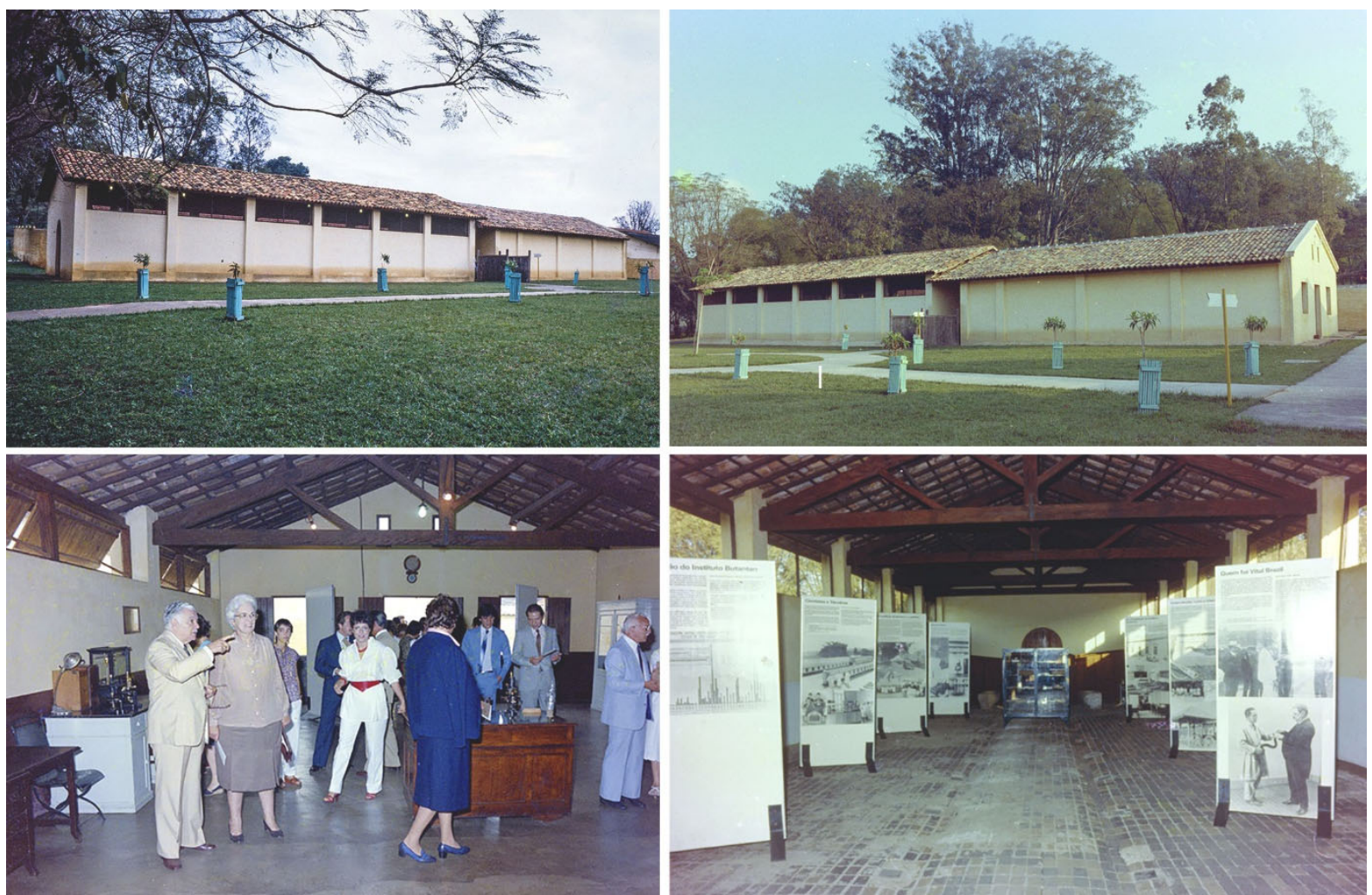

Fig. 176 - Museu Histórico após inauguração, 1981 (Fonte: Acervo IBu)

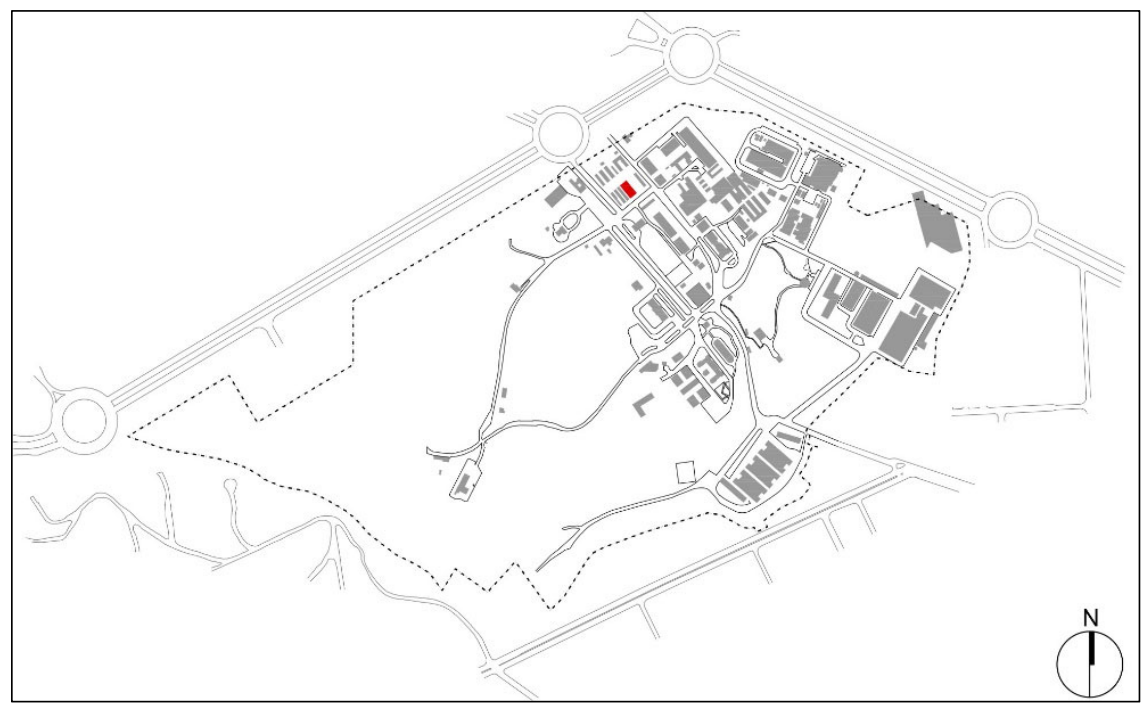

Fig. 177 - Localização do Museu Histórico em 2018 (autor)

\section{RESUMO}

Categoria: edifício

Denominação original: Museu Histórico

Denominação atual: Museu Histórico

Autoria: Osmar Mammini

Área original: c. $430 \mathrm{~m}^{2}$

Área atual: c. $430 \mathrm{~m}^{2}$ 


\author{
Número de pavimentos original: 1 \\ Número de pavimentos atual: 1 \\ Início-término da construção: 1981 \\ Itens arquitetônicos originais: \\ Estrutura: alvenaria portante \\ Vedação: alvenaria (tijolo maciço) \\ Revestimentos paredes externas: argamassa de cimento e cal \\ Revestimentos paredes internas: argamassa de cimento e cal \\ Revestimentos pisos internos: cerâmica, tijolos cozidos, cimento queimado \\ Revestimentos pisos externos: cerâmica, tijolos cozidos e cimento desempenado \\ Caixilharia: madeira \\ Uso original: museu \\ Itens arquitetônicos atuais: \\ Estrutura: original \\ Vedação: original \\ Revestimentos paredes externas atual: original + tinta acrílica \\ Revestimentos paredes internas atual: original + tinta acrílica \\ Revestimentos pisos internos atual: originais \\ Revestimentos pisos externos: originais + cimento desempenado \\ Uso atual: museu
}

\title{
2.3.20. Implantação urbanística e paisagística
}

Um dos aspectos relevantes do Instituto Butantan como patrimônio cultural edificado é o fato de ser um conjunto de edifícios e equipamentos construídos para fins científicos de produção, pesquisa e formação constituindo um espaço com características urbanas: vias, praças, limites, quadras, parques, trilhas, monumentos, zonas de trabalho, residências e lazer. Alguns desses elementos, como as quadras, não o são do ponto de vista cadastral (uma vez que todo o terreno é do poder público e não há lotes e propriedades internas), mas morfológico, já que a implantação de edifícios e desenho urbano das ruas define algumas manchas urbanas, inclusive determinando espaços públicos, semi-públicos e privados.

Além de sua conformação interna, o Instituto é um elemento importante no tecido urbano de São Paulo. Primeiramente, como área verde: desempenhando a função de parque público, ele representa uma importante área verde de lazer da zona oeste. Também se deve considerar que o entorno era de terrenos de várzea, motivo pelo qual o campus trouxe uma 
significativa reconfiguração da topografia, hidrografia e vegetação. Outro aspecto importante em sua localização é seu papel histórico como frente de urbanização na zona oeste, já que a Fazenda Butantan foi escolhida justamente por se encontrar em uma parte de ocupação rarefeita e afastada da mancha urbana de São Paulo em 1899.

Os primeiros mapas e imagens da região junto à várzea do rio Pinheiros mostravam uma ocupação tipicamente rural, onde trilhas não pavimentadas ligavam casas, estábulos, olarias e outros elementos da fazenda. A estrada, passando pelas pontes em madeira sobre o córrego Pirajuçara Mirim e o rio Pinheiros, ligava a fazenda ao centro urbanizado da cidade. A paisagem predominante era de pastos entremeados por áreas inundáveis, ocupados pelas citadas construções de forma esparsa e sem cercamentos, delimitações ou desenho urbano definido, embora houvesse uma lógica intrínseca na disposição dos equipamentos da fazenda voltada à produção leiteira.

As primeiras construções feitas especificamente para o Instituto, entre 1899 e 1914 passaram a ser implantadas relativamente próximas umas das outras, seguindo uma disposição ortogonal que respeitava um eixo partindo da Casa Sede da fazenda até o promontório onde foi construída a Cocheira Enfermaria e, posteriormente, o Edifício Principal. Já no mapa de 1926 (figura 19, item 2.1) é possível identificar esse conjunto que viria a se tornar o núcleo histórico do Instituto. Não foram encontrados nessa pesquisa menções claras a um plano urbanístico, mas sua implantação revela essa preocupação em privilegiar essa porção da fazenda, estabelecendo um eixo (figura 178 a180) e seguindo o mencionado sistema Tollet (item 1.1).

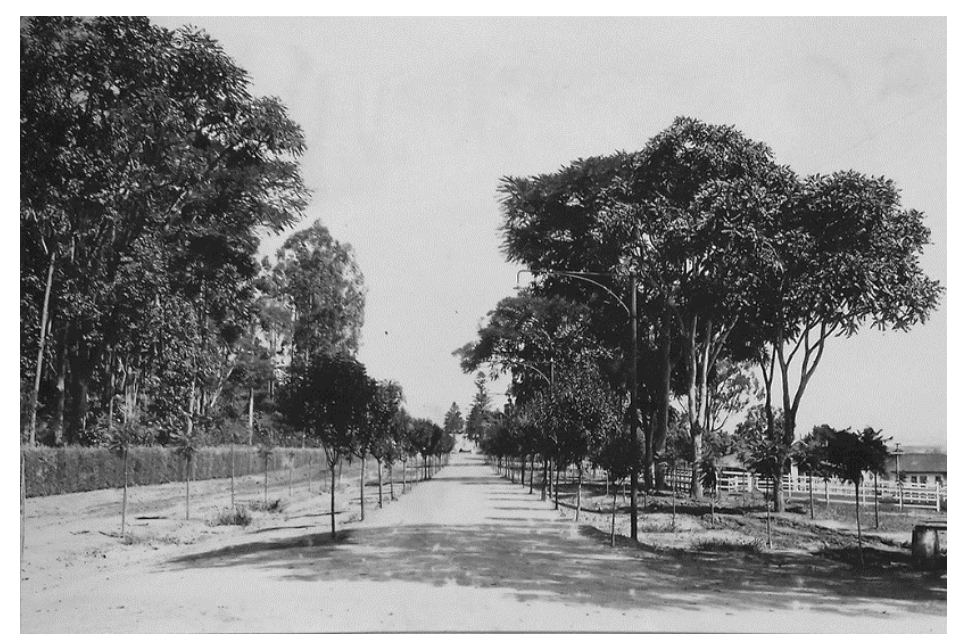

Fig. 178 - Alameda Principal na década de 1920 (Fonte: RA 1929, p.18) 

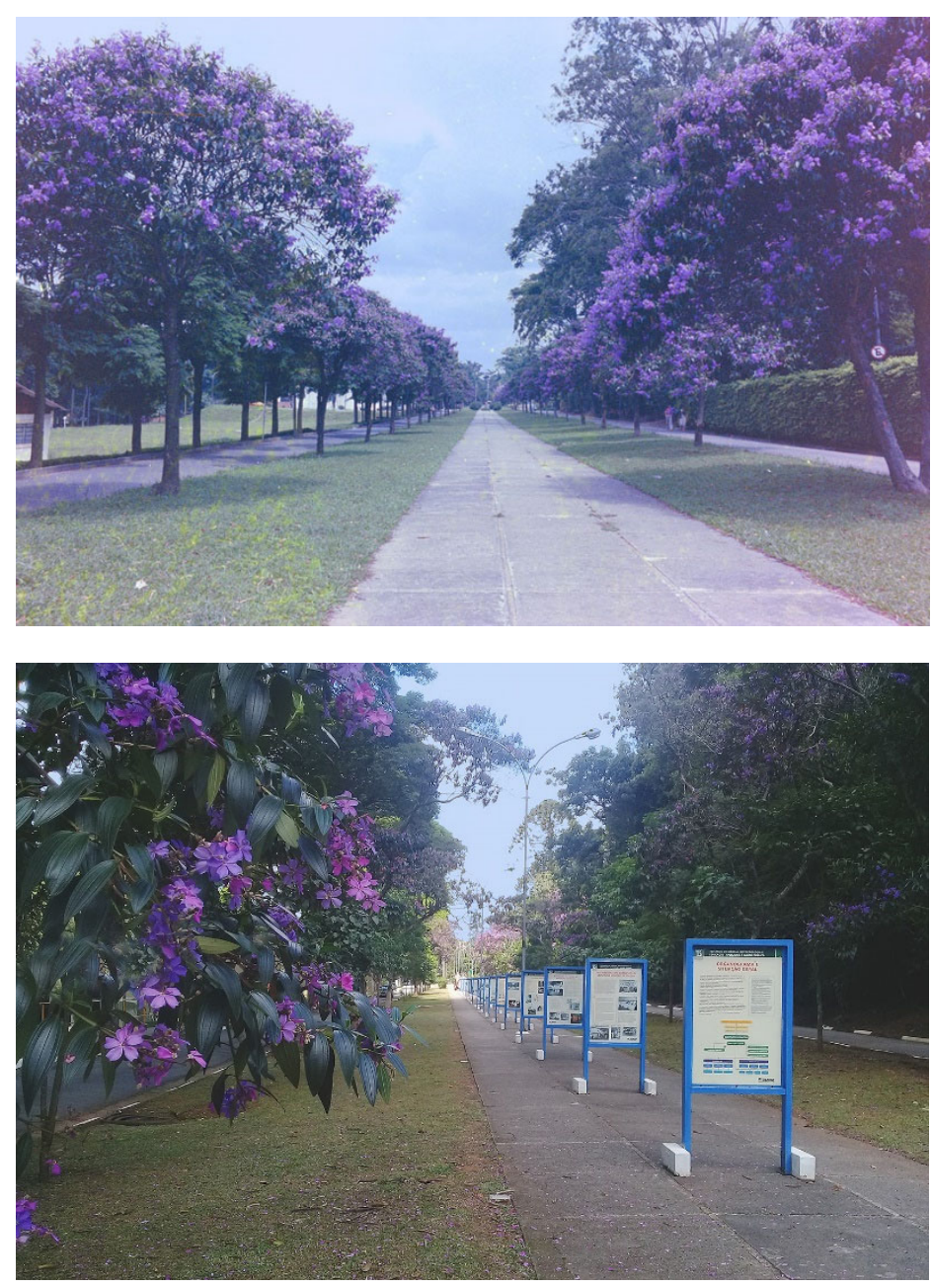

Fig. 179 - Alameda Principal na década de 1980: as espécies arbóreas reforçam o caráter de eixo do núcleo histórico (Fonte: IB_ICO_003351)

Fig. 180 - Alameda Principal em 2019: a via ainda conserva seu aspecto paisagístico, abrigando hoje também o Museu de Rua (Fonte: autor)

Desde a implantação do horto e o plantio da porção oeste, esse núcleo histórico ficaria mais delimitado, e nesse perímetro seriam construídos os edifícios em sua maioria, criando um percurso em que se podem visitar a maioria dos prédios históricos. Na primeira década também foram construídos gradis, portões, calçadas, definindo alguns limites do terreno (mas não totalmente). Os arruamentos desse núcleo também são praticamente os mesmos hoje, e eram inicialmente utilizados por carroças. Na década de 1920, foram feitas obras de drenagem e vias internas começaram a ser asfaltadas, para melhorar a circulação e também diminuir a poeira, que prejudicava os trabalhos científicos (figura 181). Segundo Afrânio do Amaral:

Iniciou-se no ultimo semestre, o revestimento e impermeabilização systematica das estradas internas do Instituto para eliminar-se o problema da poeira e da lama, no qual tinha o Instituto gasto somas apreciaveis sem jamais ter procurado para ele solução definitiva. (RA1928, p.8) 
Essa conformação urbanística permaneceria com poucas alterações até o início dos anos de 1940, quando uma parte da área teve de ser cedida para a retificação do Rio Pinheiros e para instalações da companhia Light Power. Em 1941, como se sabe, o Decreto 12.401 de 16 de dezembro desmembrou cerca de $80 \%$ do Instituto Butantan para a instalação da Cidade Universitária da Universidade de São Paulo ${ }^{121}$.
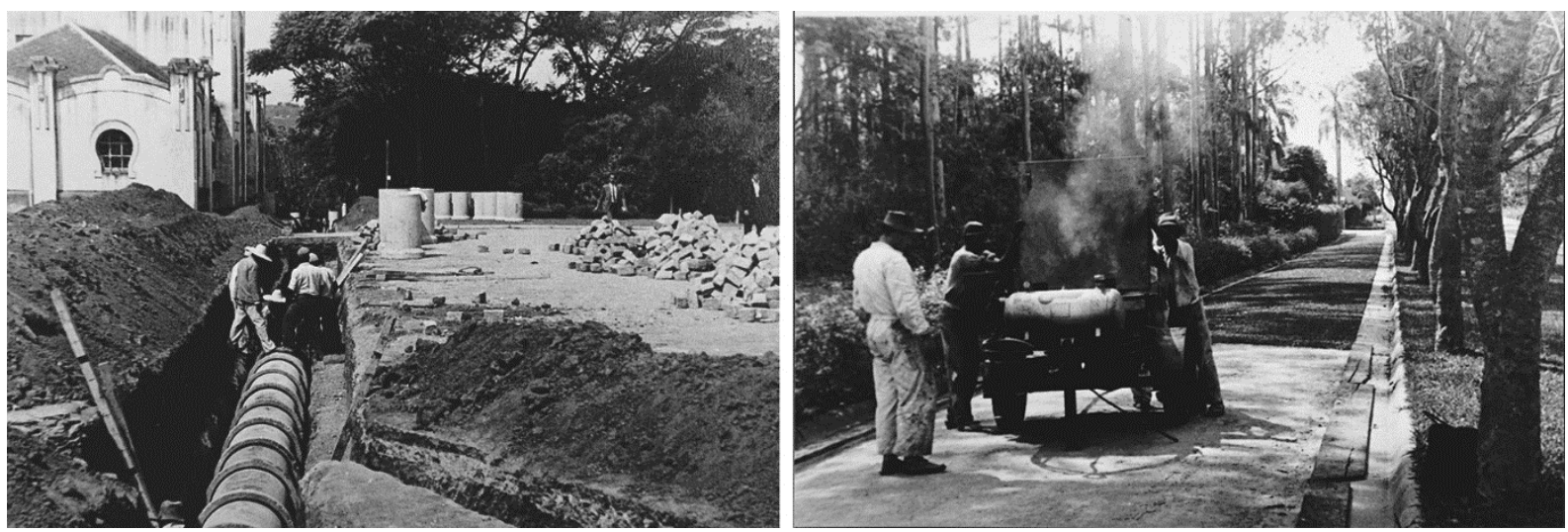

Fig. 181 - Obras de drenagem e asfaltamento: a partir da década de 1920, intensificaram-se os serviços de infraestrutura que, aliados à construção de edifícios e ao plantio de espécies arbóreas, transformaram a paisagem agrícola da fazenda em um conjunto urbanístico-paisagístico semelhante ao atual (Fonte: IB_ICO_009099 e IB_ICO_009100)

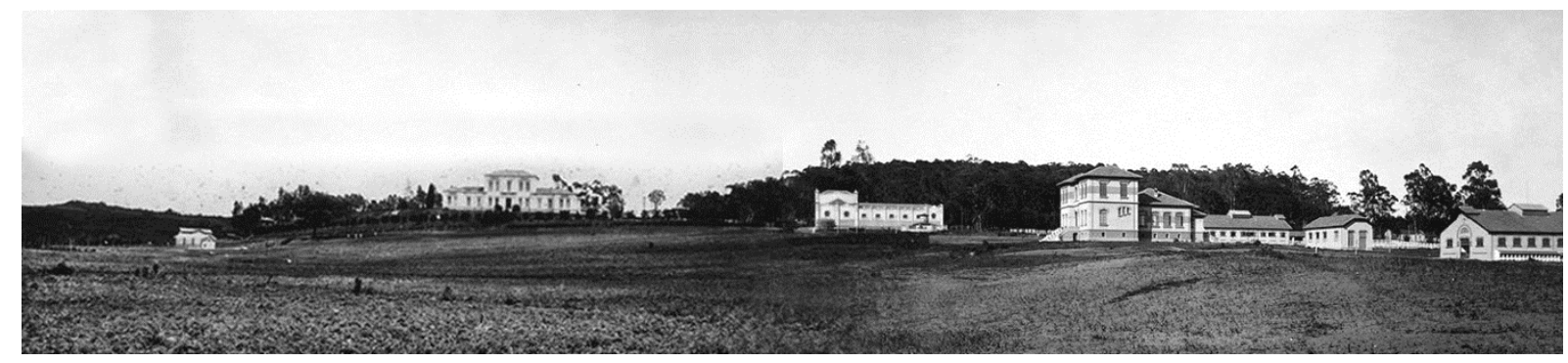

Fig. 182 - Montagem panorâmica do Instituto na década de 1920: a disposição dos edifícios, ditada por necessidades funcionais e pela topografia do terreno, criou com o tempo um "percurso arquitetônico". Da esquerda para a direita: pequena casa do Horto Oswaldo Cruz, Edifício Principal, Cocheira Central, conjunto da Escola de Veterinária e Cocheira-biotério "gêmea". (Fonte: IB_ICO_010864 e IB_ICO_010446)

Esse desmembramento teve, inevitavelmente, impacto no aspecto urbanístico do Instituto. Primeiramente em suas dimensões, mas também em sua dinâmica interna, ao concentrar funções no núcleo original e retirar a criação de animais em grandes áreas do terreno, além da

121 “Artigo 1. - Fica reservada, na Fazenda Butantã, a área ao sul do leito da Adutora de Cotia, com todas as benfeitorias existentes, para o Instituto Butantã, e, a área remanescente, para localização da Cidade Universitária, a que se refere o artigo 47, - parágrafo único do Decreto n. 6.283, de 25/01/1934." (Decreto 12.401, Diário Oficial, $16 / 12 / 1941)$. 
já mencionada preocupação do Instituto com a delimitação e proteção de seu perímetro. $\mathrm{Na}$ década de 1950 passou-se a pensar em planos de conjunto para o campus, que resultariam no trabalho do arquiteto Carlos Cerqueira Lemos, levantando as necessidades do Instituto, e na elaboração do primeiro Plano Diretor, em 1959, pelo arquiteto Rubens Gouveia Carneiro Vianna (ver Anexo A), revisado em 1963 e em 1966 (já com participação de Mammini). Com base nele foram contratados, pelo FCCUASO, projetos de diversos arquitetos para novos edifícios do Instituto (figura 183). Esse primeiro plano integrava (ao menos espacialmente) o Instituto Butantan e a Cidade Universitária, sendo por esta o acesso principal, e não mais pela Avenida Vital Brazil. Nesse projeto, a quase totalidade dos edifícios históricos do Instituto seria substituída por edificações modernas, tornando esse campus uma continuação da CUASO.

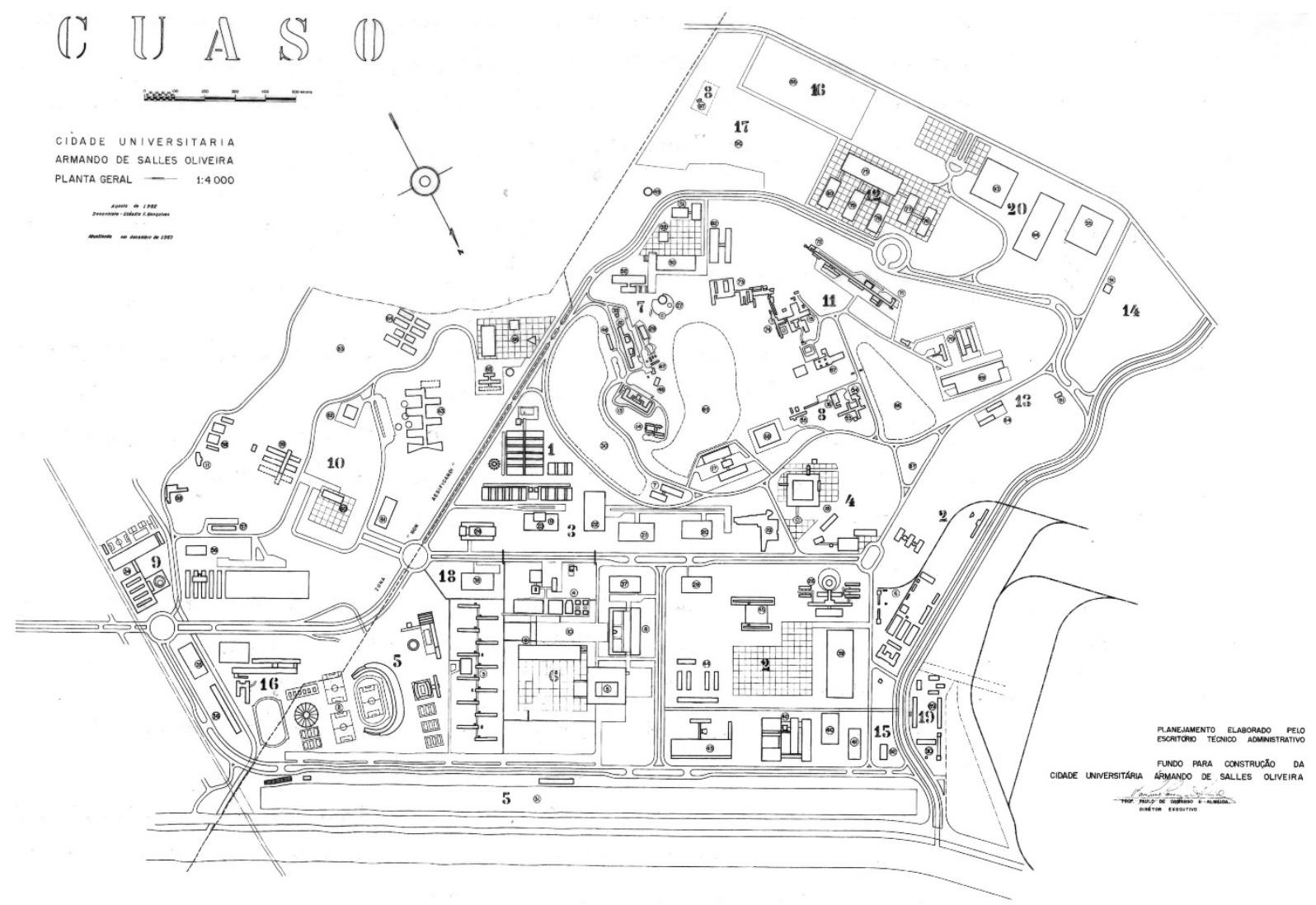

Fig. 183 - Projeto de implantação da CUASO, 1963: a proposta integra o Instituto Butantan (setor 10) à Cidade Universitária, inclusive no partido urbanístico, desconfigurando o núcleo histórico original (Fonte: SEF-USP)

Embora desse plano só tenham sido executados elementos pontuais, ele significou, na prática, um controle maior do perímetro (com muros, portões, guaritas), e a ocupação da maior parte do terreno com equipamentos. 
A preocupação com a coesão do campus pode ser notada no relatório de 1968:

Esta paisagem de conjunto sôbre a situação e instalação das Seções Técnicas do Instituto Butantan teve o propósito de chamar a atenção sôbre a dispersão das mesmas, o que acarreta enormes dificuldades na manutenção do entrosamento e contato dos trabalhos em geral, sendo que a fiscalização é quase impossível. O mesmo acontece com as seções administrativas, com dificuldades de entrosamento entre sí e com os trabalhos relacionados com as seções técnicas. (RA 1968, p.4a)

Durante os anos 1970, como se viu (item 2.1), foram implementadas obras para a consolidação do território, como a execução dos lagos, a arborização, e a melhoria das vias.

A partir dos anos 1980, com o entorno do Instituto já adensado, passou a ser crescente o tráfego de veículos, gerando um uso inadequado do campus como atalho para automóveis que pretendiam transitar entre a Avenida Corifeu de Azevedo Marques e a Avenida Vital Brazil, "cortando" caminho pela Cidade Universitária e pelo Instituto Butantan, subterfúgio interrompido no final da década de 1990 com a proibição de passagem de veículos não autorizados entre a USP e o Instituto. O controle, além de procurar diminuir o congestionamento de veículos nas vias internas, pretendeu reduzir as trepidações que, segundo as equipes de manutenção, danificaram a cobertura do auditório no Museu Histórico.

Quanto ao aspecto paisagístico, sabe-se que a zona oeste de São Paulo no final do século XIX era ainda de aspecto rural, com lavouras e criação de gado, sendo sua vegetação original típica de várzea, junto aos rios Pinheiros e seu afluente, o córrego Pirajuçara Mirim. Após sua fundação, o Instituto manteve durante muitos anos o mesmo aspecto da fazenda, inclusive com as plantações e as casas dos trabalhadores que ali viviam. A vegetação presente era basicamente de pastos e poucas espécies de grande porte, o que se pode constatar em fotos da época. Assim, a área verde hoje de grande relevância no Instituto e nessa região da cidade foi resultado de anos de plantio planejado e executado para fins científicos e para ambiência do campus. Os fins científicos estão relacionados, em primeiro lugar, à alimentação dos animais de pesquisa, implicando basicamente em forrações; em segundo lugar, para pesquisa das próprias espécies vegetais, o que se intensificou com a implantação do horto em 1917/1918. Já a ambiência do Instituto está relacionada à construção de sua identidade, levando à sua conformação de parque, que também tem um papel importante do ponto de vista histórico e estético para o paisagismo. 
Há também a importância da arborização para estabilização do terreno, contribuindo para sua drenagem e evitando o assoreamento característico das várzeas. Todos esses aspectos importantes do caráter paisagístico do Instituto são verificados em seus relatórios e nas publicações acerca de sua história.

No relatório de 1903, foi feita uma listagem dos plantios realizados tanto para o pasto quanto para arborização:

Terrenos arados e gramados: $77.329 \mathrm{~m}^{2}$

Árvores fructiferas: 320

Árvores de ornamentação: 260

Árvores limpas e adubadas: 236

Número total de árvores existentes: 980

Cafeeiros-pés: 175 (RA 1903, np)

Este tipo de listagem se repetiu nos anos seguintes. Em 1907, pode-se ver o plantio de espécies de grande porte, provavelmente para auxiliar na estabilização e drenagem do solo:

Foram replantadas 750 mudas de eucalyptos

Existem em latas 1133 mudas de eucalyptos

Existem em latas 85 mudas de accácias

Existem em latas 43 mudas de ciprestes

Existem em um viveiro 5000 mudas de eucalyptos (RA 1907, n.p.)

Já no relatório de 1911, o administrador Francisco Iglesias (uma espécie de zelador do Instituto) relatava ao diretor Vital Brazil:

Os effeitos do MUCUNA UTILIS já se fizeram sentir. As terras que antes eram extremamente argillosas, terras cuja pobreza era eloquentemente provada pela vegetação que a cobria, hoje apresentam-se mais e mais férteis: as propriedades physicas e chimicas foram melhoradas.

Dividimos, para embellezar o campo e facilitar a cultura, o terreno em rectangulos.[...] No dia 1 de Dezembro começamos a plantar as mudas de madeira de lei, vindas de Piracicaba. Com interrupção de alguns dias, terminamos no dia 12 do mesmo mez. Plantamos 300 mudas de madeira de lei, entre as quaes abundam mais, peroba e guarantã.

Plantamos também 168 pinheiros (Araucaria braziliensis), 115 eucaliptus de várias espécies. (RA 1911, p.212)

Muitas das espécies desse plantio na primeira fase do Instituto permanecem ainda hoje, formando principalmente a mata na porção central do terreno. Outra iniciativa importante, que trouxe mudanças paisagísticas, foi a criação do Horto Oswaldo Cruz em 1917, com inauguração no início de 1918. No Album da Secção de Botanica do Museu Paulista e Suas Dependencias, 
etc., organizado por F.C.Hoehne ${ }^{122}$, são narrados os primeiros anos desse horto, mostrando uma preocupação ecológica na iniciativa:

O extermínio imprudente e desassisado das florestas e o desapparecimento coetaneo de milhares de especies vegetaes e animaes uteis, são males de que se penitenciam todos os povos. [...]

No Brasil não são de hoje os protestos e clamores contra a devastação da natureza - quinhão unico de que nos podemos orgulhar deante dos demais povos, não é, tão pouco, de nossos dias a lembrança da urgente necessidade de hortos e estações biologicas bem como reservas florestaes publicas. [...]

A criação de um departamento publico destinado ao estudo das plantas medicamentosas e toxicas, fez parte dos projectos do altruista e benemerito fundador do Instituto de Manguinhos. Se elle não o realisou, foi porque a morte inclemente o arrebatou quando apenas se havia esboçado o plano para a sua organisação em sua mente fertil e brilhante. A idéa, porém, ficou, deitou raizes, não poude mais ser olvidada.

Annos após o fallecimento do Dr. Oswaldo Cruz, o Dr. Arthur Neiva, - um dos seus mais dilectos e dos muitos discípulos admiradores, - chamado para dirigir o Serviço Sanitário do Estado de S. Paulo, - depois de haver dado provas cabaes do seu valor e alta competencia technica e scientifica no estrangeiro, - aqui tentou dar forma e vida ao plano que o seu mestre insigne lhe confiara na intimidade. Annexo ao Instituto do Butantan e subordinado ao Serviço Sanitario, resolveu fazer o que aquelle não conseguira realizar no mencionado instituto do Rio de Janeiro.[...]

'É este o terreno em que vamos construir o nosso horto' - disse-nos mui amavelmente o Dr. Vital Brasil, impondo-se desde logo pela sua jovial e attrahente maneira de fallar com os seus subalternos. (HOEHNE, 1925, p.36-40)

A publicação prossegue, com seu tom épico, a narração do surgimento do Horto Oswaldo Cruz, apresentando algumas imagens da época (figuras 184, 185). Além do plantio de espécies para estudo sistemático, o horto contou com pequenas construções para atividades laboratoriais e uma estufa. É interessante notar as premissas de implantação descritas pelo autor:

Num terreno já preparado e arado, apresentando aqui e acolá ainda alguns buracos e reclamando muito trabalho no amanho, fôram lançadas as bases para $o$ horto que deveria perpetuar a memoria do grande scientista que da ruina salvou $o$ nosso paiz, em exterminando a febre amarella da Capital Federal.

A primeira cousa que se fez, foi levantar topographicamente toda a area de terreno destinada e reservada para o horto. Em seguida organisamos a planta e delineamos o plano geral. Uma e outra cousa tinham sido executadas dois mezes depois e em começo estavam então as obras da estufa e uma parte do terreno já semeado.

De accordo com os processos e methodos mais modernos da esthética, arranjamos o plano de modo a fazer predominar as linhas curvas. Como modelo para o conjuncto escolhemos o Jardim Botanico de Dahlem, em Berlim, mas, a este, o plano esboçado fica muito a dever na amplitude e na organisação dos grupos e mais

\footnotetext{
${ }^{122}$ Frederico Carlos Hoehne (1882-1959), renomado botânico mineiro, foi convidado por Arthur Neiva em 1917 para criar o Horto Oswaldo Cruz e dirigir a novo departamento de Botânica do Instituto.
} 
modestos são os objectivos visados, porque bem diverso deveria ser a funcção dessa nova dependencia do Butantan daquelle grande e antiquissimo jardim de plantas da Allemanha. Esta teria por fim: cultivar e acclimar plantas medicinaes e toxicas, ao passo que aquelle jardim, tem por escopo apresentar os diversos typos e agrupamentos florestaes do globo inteiro.

Cultivando especies vegetaes medicamentosas e toxicas, poderíamos, porém conseguir um grande parque, que, pelo seu aspecto geral, nada ficaria a dever a um verdadeiro parque ou jardim botanico [...]. (HOEHNE, 1925, p.41)

Essas atividades de pesquisa foram transferidas em 1921 para o bosque do Museu Paulista, quando o diretor Rudoph Krauss verificou sua inviabilidade econômica. Mas a massa arbórea plantada no Instituto já estava estabelecida e assim ainda permanece, criando uma ambiência paisagística interessante na entrada principal do Instituto, na qual a ladeira de paralelepípedos leva até o alto da primeira colina, ladeando o Horto já centenário.
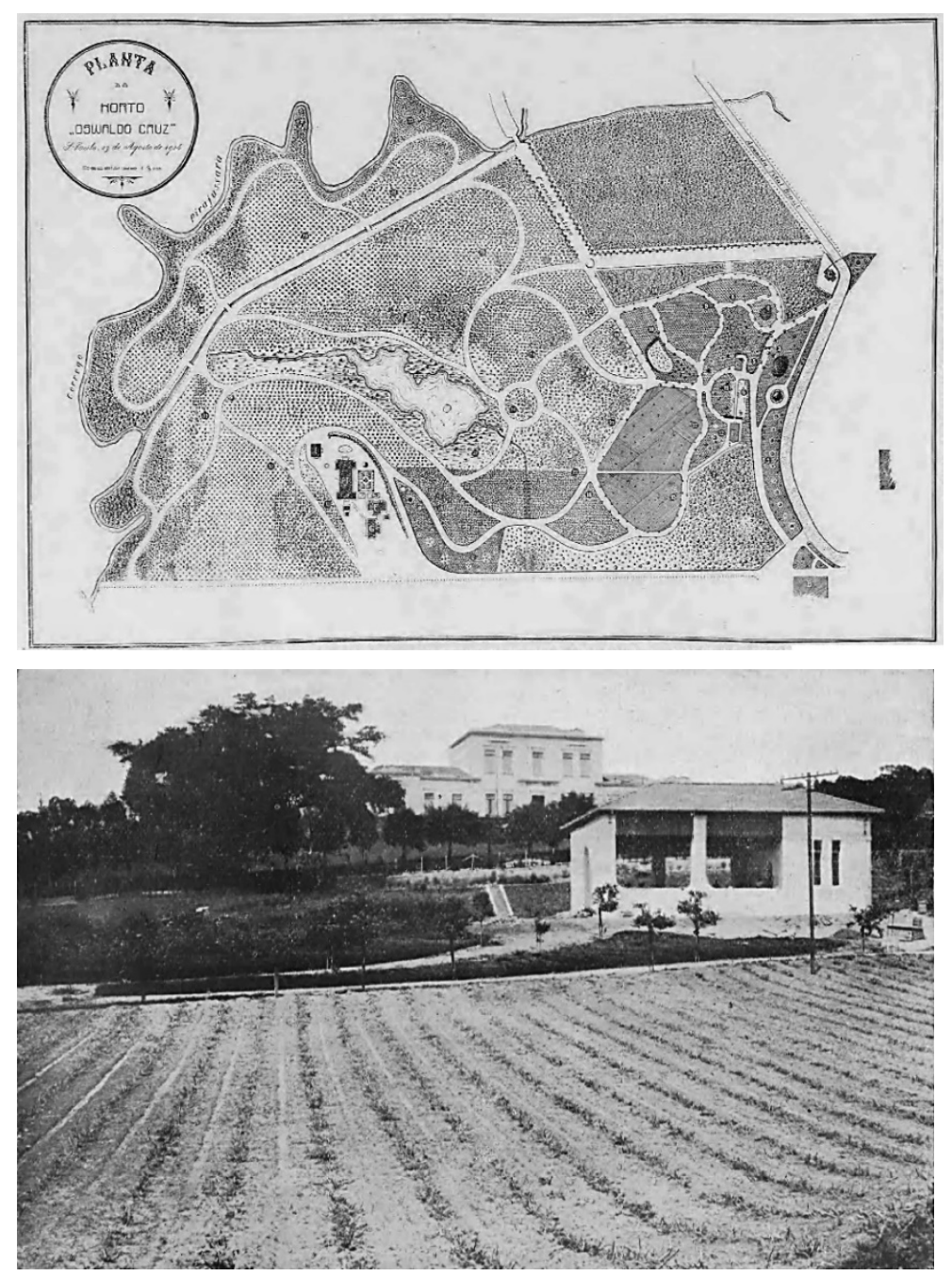

Fig. 184 - Planta do Horto Oswaldo Cruz, 1917: havia uma preocupação não só com os aspectos técnicos, mas também paisagísticos. Sem escala (Fonte: HOEHNE, 1925, p.42)

Fig. 185 - Início da plantação do Horto Oswaldo Cruz: hoje permanece o maciço vegetal em frente ao Edifício Principal, visto ao fundo (Fonte: HOEHNE, 1925, p.64)

Depois de sua fundação, do plantio das primeiras árvores e da implantação do Horto Oswaldo Cruz, o Instituto permaneceria ainda por alguns anos mantendo características de 
fazenda, com vastos pastos e plantações destinadas a alimentar os animais, até que as novas árvores atingissem maiores dimensões. $\mathrm{O}$ traçado de vias e disposição da vegetação remetia ao paisagismo inglês, e permanece em grande parte. Assim como no aspecto urbanístico, a diminuição do terreno em virtude da CUASO traria mudanças no paisagismo, aliada à aquisição da Fazenda São Joaquim. A partir de então, com as massas arbóreas consolidadas, o aspecto de área rural deu lugar ao de parque, e graças aos planos dos anos 1960, foram definidos canteiros, ajardinamento de calçadas, com colorações e portes variados. A composição do Museu de Rua (instalado na alameda central nos anos 1990) acentuou a reta que liga a Casa Sede da Fazenda ao Edifício Principal, reforçando um eixo que remete ao paisagismo francês, de características monumentais, assim como a parte em frente ao Edifício Principal, em que se localiza o Serpentário de espécies venenosas.

Como se sabe, a partir do final dos anos de 1970 e com o tombamento em 1981, a preocupação das diretorias em garantir a integridade do terreno levou-as a buscar ocupá-lo em sua totalidade com elementos paisagísticos (figura 186), conforme se vê nos trechos a seguir:

O Instituto lutava contra o fracionamento da sua área, porque seus terrenos, em grande parte não eram ocupados e, portanto, se encontravam abandonados. [...] Dos seus cinquenta hectares, apenas vinte estavam ocupados. Durante nossa administração foram aproveitados mais vinte hectares onde, em terreno de difícil utilização, foram construídos lagos e praças, com recursos próprios da Instituição, auxiliados pelos funcionários. Nesta área foram plantadas aproximadamente 2.000 árvores com trabalhos de arruamento, gramados extensos e exposição de grandes equipamentos antigos de laboratório ou de suporte às atividades do Instituto. Estes equipamentos se encontram instalados em pequenas praças e cada um possui uma pequena placa de identificação. Nesta mesma área foi preservada toda a flora, assim como todos os vestígios que restavam da infraestrutura do Instituto nas suas primeiras décadas de existência. Foram construídos 3.000 metros de ruas, contando com tratamento paisagístico, associado à área de lazer e de cultura. (RA 1979, p. 152)

No relatórios de 1980 e 1981, também se vê a preocupação em ocupar as áreas o terreno:

Ampliação e melhoria do arruamento interno do Instituto Butantan com a cosntrução de dois pequenos diques para o represamento de água no sentido de se fornecer dois lagos internos, que servirão ao paisagismo visual e ao projeto de soroterápicos. (RA $1980, \mathrm{np})$

O parque do Instituto foi melhorado, consideravelmente, dos 27 alqueires apenas 7 alqueires eram ocupados no presente exercício independentemente do melhoramento do aspecto estético do Instituto foram integrados aproximadamente 10 alqueires recuperados pelo Dr. Fauze Carlos na Administração do Instituto, de terrenos que por apresentarem condições impróprias e não incluídos no plano diretor do Instituto foi 
transformada em belíssima área de lazer através da construção de 4 lagos, plantio de 600 árvores regionais e grande área gramada, sendo preservados os bosques naturais existentes. (RA 1981, np)

Assim, passeios de trilhas foram criados na área ainda pouco ocupada do campus, conformando um bosque de passeio para o público.
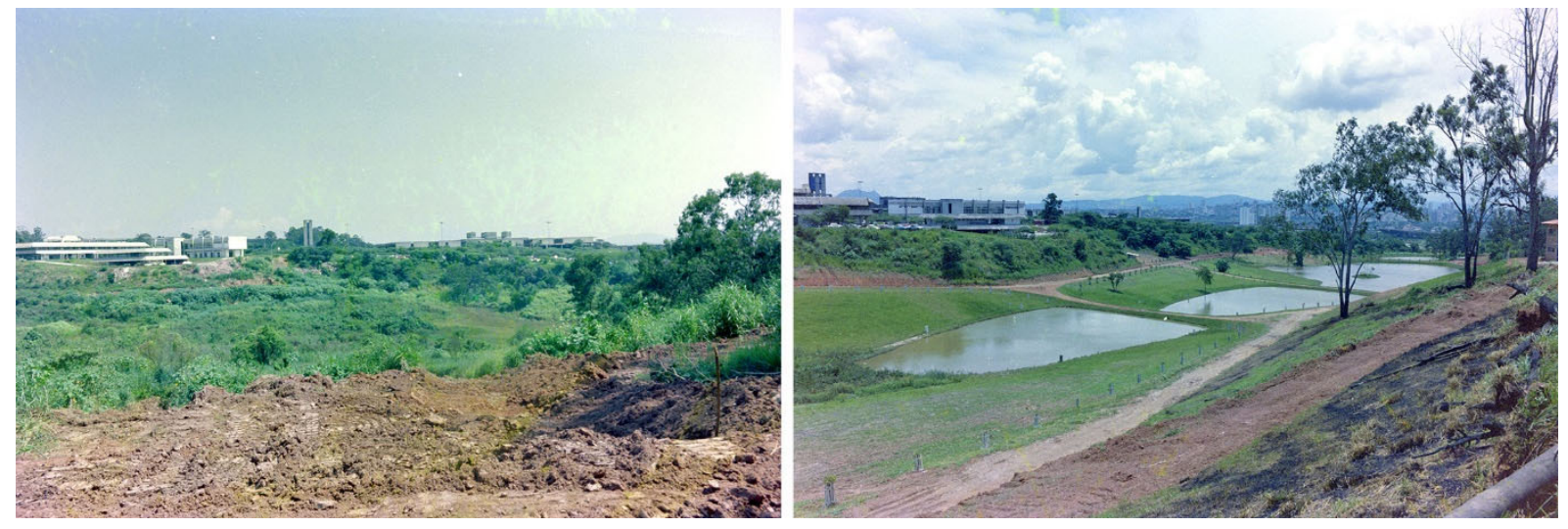

Fig. 186 - Execução dos lagos na porção noroeste do Instituto: o local antes baldio (à esquerda), recebeu tratamento paisagístico como forma de apropriação do território em 1980 (à direita) (Fonte: IB_ICO_003292, IB_ICO_003295)

Na parte mais consolidada/urbanizada, os canteiros e a variedade de forrações, massas arbustivas e árvores de diversos portes formam um conjunto geralmente harmônico com os edifícios históricos, sem prejudicar a legibilidade destes, com destaque para o entorno do Pavilhão Lemos Monteiro e do Edifício Principal, com palmeiras de grande porte, arbustos e forrações, do Museu Histórico, com pau-brasil e outras árvores de grande porte, e da Diretoria, com o bosque e caminhos à inglesa (figura 187, 188). Na área da Vila Residencial também há jardins que amenizam o aspecto de repetição da série tipológica. Já na área de produção, a arborização e jardinagem limita-se a canteiros com menos protagonismo.

Tem sido feito nos últimos anos o trabalho de identificação dessas espécies, com fixação de placas para informação do público. A manutenção é feita por empresas terceirizadas de paisagismo. O novo Plano Diretor propõe manter a vegetação no entorno dos edifícios do núcleo histórico, com maiores alterações na porção oeste, em que seriam instalados equipamentos de lazer e trilhas pavimentadas, proposta criticada por alguns membros do Instituto, que consideram o aumento do acesso de visitantes nociva para os trabalhos científicos, que exigem, em diversos casos, segurança e sigilo. 

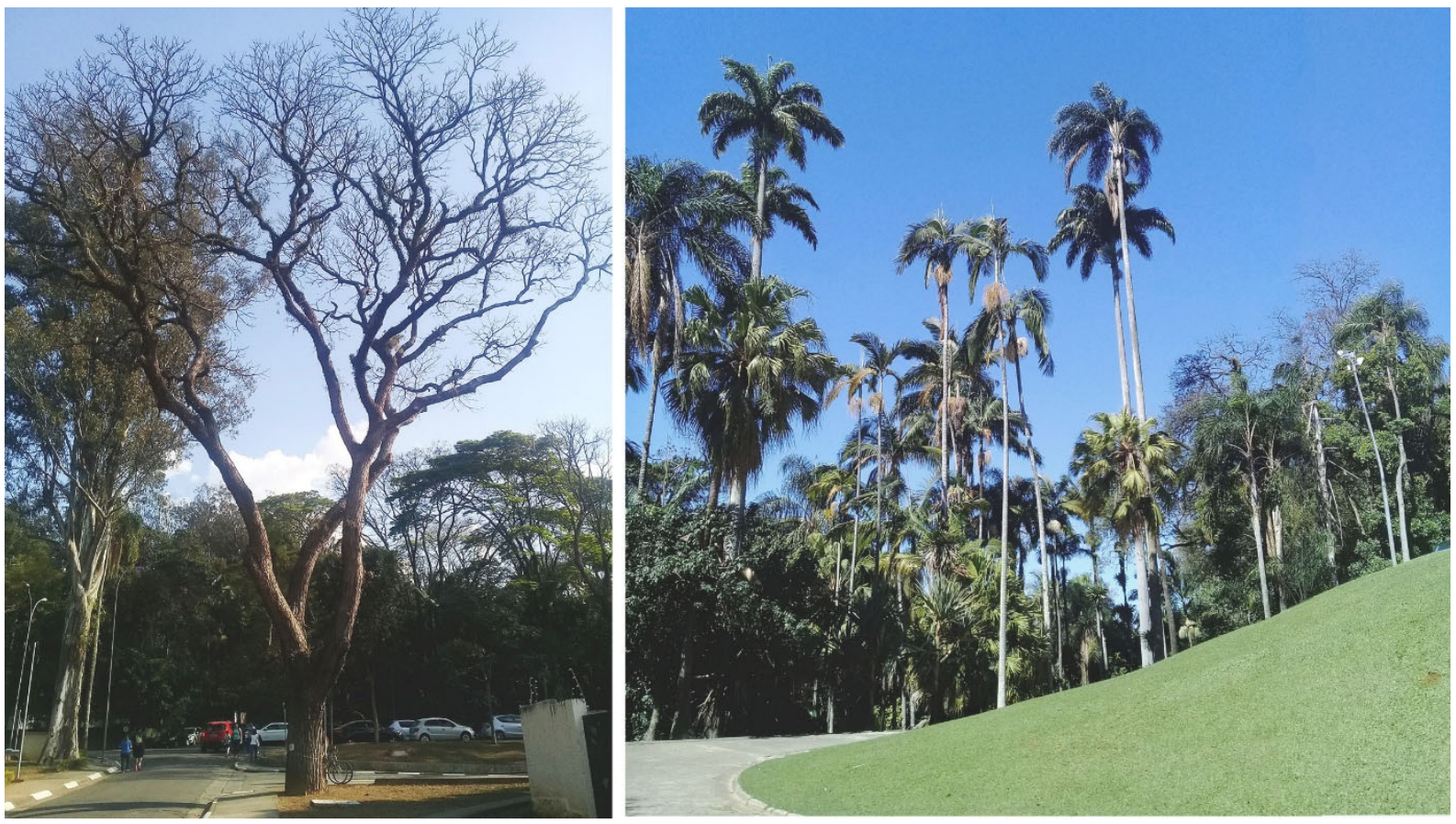

Fig. 187 - Árvores de grande porte: a maioria das espécies foram plantadas no início das atividades do Instituto, sendo algumas centenárias, formando um espaço com qualidades paisagísticas a preservar (Fonte: autor)
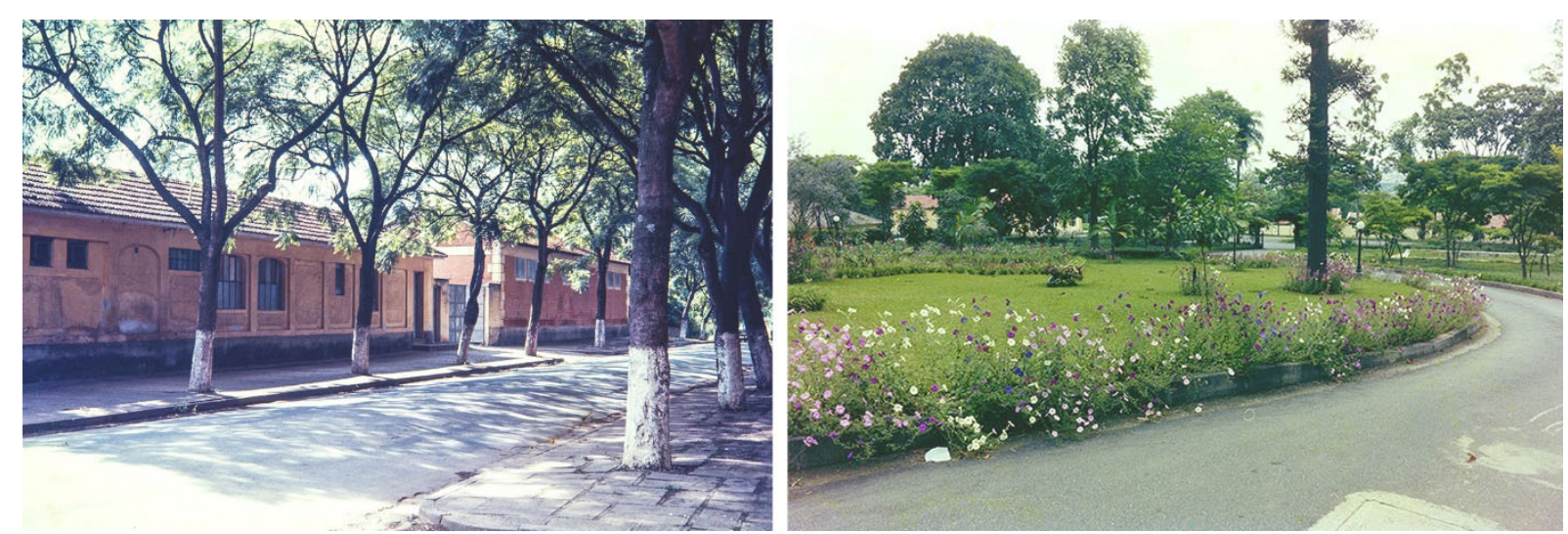

Fig. 188 - Elementos paisagísticos, década de 1980. As ruas com plantio regular de árvores e os canteiros de arbustos e forrações mostram a variedade de espécies do campus (Fonte: IB_ICO_000190, IB_ICO_001637) 


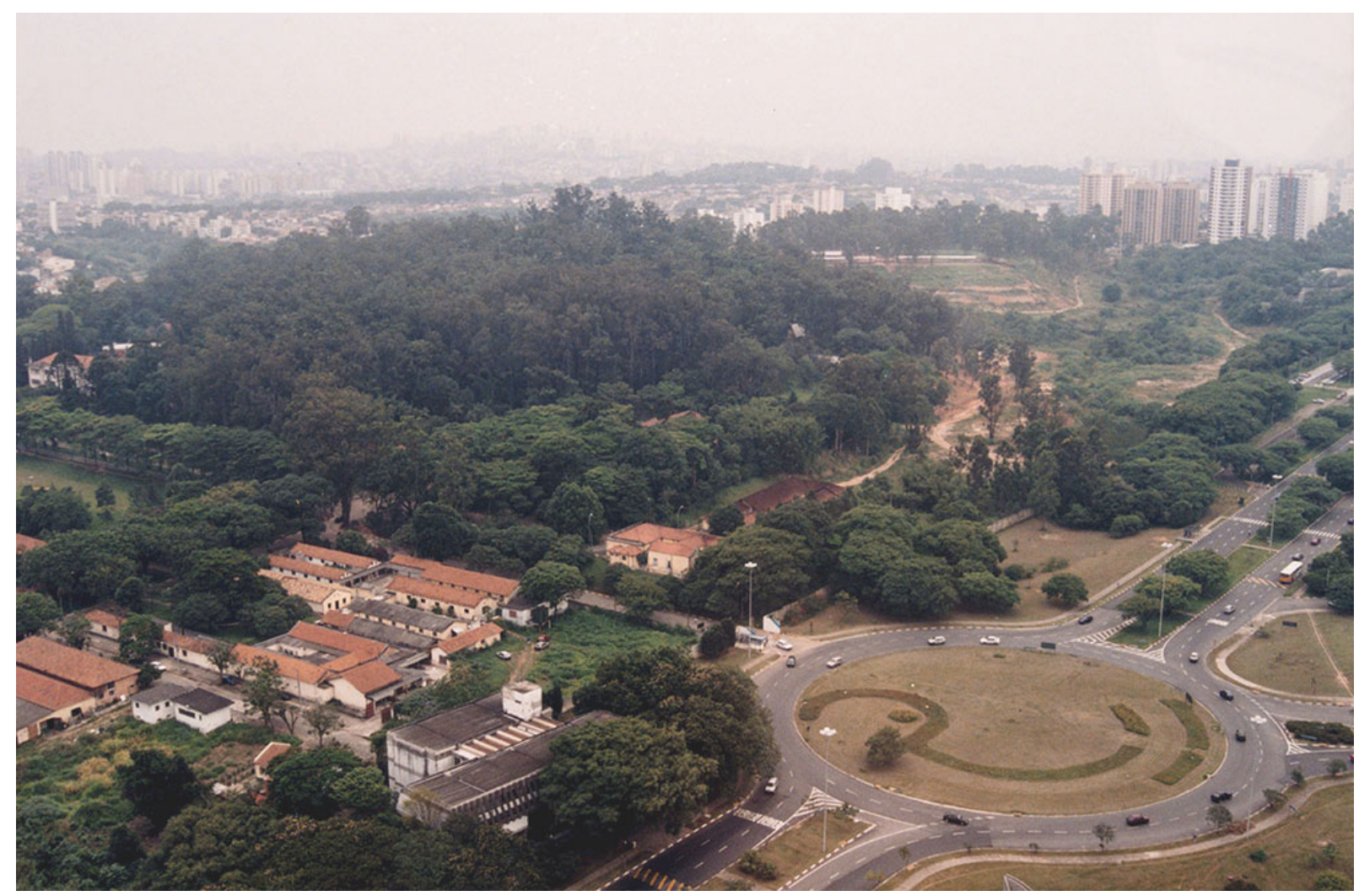

Fig. 189 - Vista aérea (c.1980): há um contraste entre a escala e a densidade urbanística da Cidade Universitária (à direita) e o Instituto Butantan. O portão de acesso ao Instituto, pela rotatória da CUASO, foi por muitos anos utilizado como "atalho" por veículos da zona oeste. Vê-se ao fundo o início das terraplenagens para construção dos lagos, em uma tentativa de proteção do território (Fonte: IB_ICO_009207)

\subsubsection{Outros elementos possíveis}

O resultado selecionado é certamente um recorte que poder ser ampliado, tanto pelas próprias dimensões e número de construções do Instituto, quanto por diversos critérios de seleção possíveis. Entre os elementos que também poderiam ser estudados de forma mais aprofundada futuramente, podem se destacar, por exemplo, construções que foram demolidas ao longo da história, como o Instituto Vacinogênico e a Lavanderia, que também dão uma dimensão dos critérios utilizados para preservação ou renovação do campus. Outra frente possível de listagem é dos projetos não construídos, que vão desde as residências concebidas na década de 1920 até os grandes planos da década de 1960, sob direção do FCCUASO, o estudo de Lina Bo Bardi para o Museu Biológico. Tais elementos não realizados indicam escolhas em determinado momento histórico, e, especialmente no caso do Page, foram fundamentais para manter íntegro o núcleo original do campus. Há também outros elementos dos primeiros anos 
do Instituto, como as pequenas construções do Horto Oswaldo Cruz (vivário e casa), que sofreram muitas alterações, a ponto de serem totalmente descaracterizadas. Por fim, há os elementos mais recentes, que também podem ser reconhecidos como patrimônio cultural, como é o caso do Museu de Microbiologia, do arquiteto Márcio Kogan, adaptando a estrutura do antigo restaurante da década de 1960, ou os diversos edifícios novos do setor de produção, que, pela sua complexidade, dariam margem a diversas análises possíveis. Entre os elementos técnicos que podem ser considerados incluem-se os grandes reservatórios do Instituto, que utilizaram tecnologia avançada de concreto armado.

Para o âmbito dessa pesquisa, como foi dito, a seleção de elementos apresentada teve por objetivo final analisar como estes têm sido conservados ou alterados até o momento atual, considerando premissas de preservação do patrimônio recomendadas pela legislação, pela literatura de preservação, e por cartas patrimoniais.

\subsection{Proposta de periodização}

Concluindo esse capítulo de levantamento do patrimônio do Instituto Butantan, com base no histórico apresentado (item 2.1) e nas descrições dos elementos de interesse (item 2.3), foi possível elaborar uma proposta de periodização da trajetória do Instituto Butantan com foco no seu patrimônio arquitetônico, que pode se somar a outras periodizações já existentes da instituição, baseadas em outros focos.

Nesse sentido, FONSECA(1954) e BRAZIL(1941) trazem memórias do Instituto se concentrando em uma narrativa de tom biográfico (sobre seus cientistas e colaboradores) ou episódico (descrevendo momentos chave como a fundação, as produções de fármacos mais importantes e a construção de edifícios marcantes para seus autores). Por ocasião da inauguração do Museu Histórico, Jandira Oliveira traz em sua cronologia uma abordagem que procura relatar essa história de forma mais contextualizada, trabalho que vem a ser o

[...] primeiro passo para a elaboração da história do Instituto Butantan, seu papel no desenvolvimento das ciências no Brasil e sua inserção na história de São Paulo. (OLIVEIRA, 1981, p.11) 
TEIXEIRA (2006) destaca o papel das diferentes administrações, influenciando a produção científica do Instituto, com destaque para a diferença entre a gestão de Vital Brazil (1901-1919, e 1924-1927) e de Afrânio do Amaral (1927-1938) ${ }^{123}$.

O trabalho de IBANEZ, WEN e FERNANDES (2005) propõe uma periodização considerando principalmente o caráter institucional, público e científico do Instituto, conforme as características clássicas da burocracia weberiana e o esprit de corps da intituição, aliado às fases da ciência nos períodos considerados. Essa proposta procura identificar os aspectos

relativos ao contexto, mudanças estruturais e legislativas, situação sanitária, instituições científicas, empresas, entre outras afins; relativos ao projeto institucional, estratégias institucionais e principais dirigentes; influência e relação com situações do contexto; eventos significativos relativos das áreas de pesquisa, produção e difusão. (IBAÑEZ, WEN, FERNANDES, 2005, p.112)

Os autores resumem essas fases em uma linha do tempo (figura 190). Nota-se que essa periodização estabelece fases vinculadas tanto aos nomes dos diretores do Instituto quanto às principais características de atuação científica e administrativa de então. Segundo eles, o referencial teórico para essa periodização foi o institucionalismo e o neo-institucionalismo.

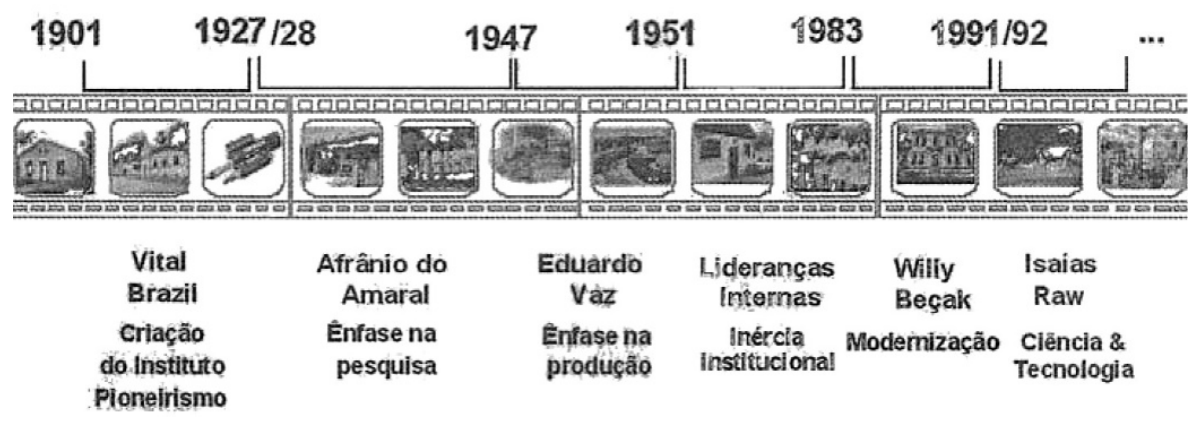

Fig. 190 - Proposta de periodização de IBAÑEZ, WEN e FERNANDES (2005, p.122)

No âmbito do presente trabalho, cujo enfoque é o patrimônio cultural edificado, propõese uma periodização histórico-arquitetônica que combine dados das periodizações consultadas com determinadas fases de ocupação física e da preservação do patrimônio cultural identificadas através da iconografia, fontes primárias e levantamentos in loco. Desse modo, as

\footnotetext{
${ }^{123}$ A primeira gestão de Vital Brazil teve um intervalo de maio de 1904 a maio de 1905, quando o médico foi realizar especialização na Europa, ficando em seu lugar o médico Dorival de Camargo Penteado.
} 
fases resultantes aqui podem não coincidir diretamente com aquelas, uma vez que trazem enfoques diversos. Mas as periodizações dialogam entre si nos aspectos contextuais. A seguir, listam-se as fases propostas do ponto de vista histórico-arquitetônico e preservacionista. São descritos de forma resumida os principais fatos ocorridos, no intuito de contextualizar e justificar a delimitação de cada fase:

\subsubsection{Primeiras ocupações (1899-1910)}

Em seus primeiros anos, como se sabe, as construções do Instituto eram predominantemente remanescentes da Fazenda Butantan, de caráter rural / utilitário. Apenas a Casa Sede da Fazenda, desses remanescentes, trazia uma preocupação estética evidenciada na aplicação de ornamentação neoclássica simplificada. Foi iniciada a ocupação com novas construções pelo conjunto de Cocheira-enfermaria, de 1901. Segundo os relatórios, também foram construídos outros equipamentos voltados a sistemas de abastecimento de gás e água. Apesar dessas novas construções, a paisagem da fazenda se mantinha no Instituto, com grandes áreas de plantio, caminhos de terra, sem delimitações claras de cercamentos, área frequentemente inundada pela bacia dos rios Pirajuçara Mirim e Pinheiros, e ainda sem as massas arbóreas que seriam consolidadas a partir da década de 1910. Essa primeira fase evidencia, em seu espaço construído, o chamado "mito de origem", com a narrativa heroica de adaptação dos cientistas ao meio inóspito para produção dos soros e vacinas. Assim, a transição do cenário bucólico avançou nos últimos anos dessa primeira década, nos quais a paisagem de várzea e pasto foi dando lugar à imagem institucional do núcleo histórico que permanece.

\subsubsection{Construções institucionais (1910-1941)}

A partir de 1910 acelerou-se a ocupação com novos edifícios para atender às necessidades da instituição, sendo construídos laboratórios, cocheiras, residências e diversos equipamentos específicos, com participação de arquitetos e construtores da época, sendo Mauro Álvaro de Souza Camargo o de participação mais proeminente, como responsável pelo Edifício Principal, 
a Casa da Diretoria, os Serpentários, e provavelmente a Cocheira Central e a Casa do Administrador. Também atuaram a equipe do DOP e outros escritórios contratados. A ocupação passou a ter uma organização urbanística, com vias internas, asfaltamentos, calçamentos, iluminação e paisagismo que passaram a dar a conformação de campus ao Instituto, afastando-o gradativamente do aspecto rural (pelo menos no núcleo inicial). A arquitetura, que seguia as linguagens consideradas mais modernas na época, além de atender às necessidades técnicas do trabalho científico, passou a ser utilizada como símbolo de progresso do Instituto e do Estado. Além dos aspectos estéticos, as técnicas construtivas também procuravam seguir os avanços do período, sobretudo nos detalhes destinados a melhorar as atividades científicas.

\subsubsection{Reconfiguração territorial (1941-1961)}

A maior mudança nessa fase foi a reconfiguração do terreno do ponto de vista urbanístico, já que em 1941 o Instituto cedeu 80\% de sua área para a implantação da Cidade Universitária, que passou a ser efetivamente ocupada no final dos anos 1950. Além dessa alteração, com a Segunda Guerra Mundial, Butantan e Manguinhos assumiram um papel estratégico e emergencial para atender às necessidades internas e externas de imunobiológicos. Assim, os investimentos se concentraram em equipamentos e plantas fabris já existentes, havendo um declínio na quantidade de novos edifícios e de reformas, em comparação com outros períodos do Instituto, por isso relativo. Ainda assim, alguns elementos importantes surgiram nessa fase, como a Recepção de Cobras, projeto do arquiteto Hélio Duarte, um dos poucos exemplares da arquitetura modernista, de influência carioca, no campus.

\subsubsection{Convênio com a Cidade Universitária (1961-1981)}

Com o início do convênio entre o FCCUASO e o Instituto Butantan, no âmbito do Page e depois Pladi, resultando no Plano Diretor desenvolvido entre 1959 e 1966, o espaço físico passou a ser pensado em conjunto, recebendo novas obras e reformas de edifícios existentes, 
mudando o eixo das principais construções para o setor de produção, e delimitando mais claramente um núcleo histórico com os elementos da primeira metade do século XX. As novas obras efetivamente realizadas nessa fase foram de responsabilidade da equipe permanente do FCCUASO, que atuava concomitantemente na Cidade Universitária e no Instituto Butantan. Do ponto de vista de linguagem arquitetônica, os novos edifícios propostos por essa equipe de jovens arquitetos, principalmente Osmar Mammini, Carlos Heck e Mário Rosa Soares, também seguiram características do chamado Brutalismo Paulista, mas procurando adaptá-lo às preexistências do campus, a essa altura já historicizado. Em relação aos edifícios históricos, foram realizadas reformas para adaptá-los às atividades de então, mas agora já com a preocupação de manter suas características originais, ainda que não tenha havido inicialmente clareza conceitual. Mas devido às sucessivas perdas de área sofridas pelo Instituto, intensificouse nessa época a consciência de defesa de seu território, levando a ações de efetiva ocupação urbanística e paisagística das áreas até então ociosas, e também a levantamentos do patrimônio cultural edificado que culminariam no tombamento do Instituto em 1981.

\subsubsection{Preservação e expansão (1981-2010)}

Tomando-se como referência o ano de tombamento do Instituto pelo Condephaat, podese afirmar que a questão da preservação e restauro dos bens culturais edificados do campus passou a fazer parte ativa da gestão do Instituto, influenciando em sua ocupação física, o que implicou na manutenção de um núcleo histórico aliado à ampliação de novas áreas de produção. Os novos edifícios construídos nessa fase tiveram caráter eminentemente industrial, optando por soluções pré-fabricadas e já comuns no mercado da construção, na qual características como a flexibilidade, a modulação, a reprodutibilidade dos elementos, o uso de fechamentos leves, se sobrepõem à chamada "arquitetura assinada" (com algumas exceções, como a reforma do Paiol e Oficinas).

A partir da criação da Fundação Butantan, em 1989, para auxiliar na administração, ficou cada vez mais evidente a opção pelo crescimento do setor de produção com novas vias, edifícios e sistemas de água, gás, eletricidade e segurança. Já no núcleo histórico original, os edifícios 
continuaram abrigando atividades administrativas, culturais, de pesquisa e ensino, mas com dificuldades de adaptação de atividades laboratoriais e com discrepâncias na destinação de recursos, em um cenário que, do ponto de vista espacial, gerou descompassos, na primeira década de 2000, entre edifícios bem mantidos e outros em mal estado de conservação. A falta de uma visão de conjunto teve como marco negativo o incêndio do edifício de Coleção de Serpentes em 2010. O acontecimento, de repercussão mundial, levou à mobilização para se pensar um plano integrado de gestão do espaço físico.

\subsubsection{Gestão integrada (2010 - atualmente)}

Passou-se a pensar em um plano de conjunto para o campus, e aumentou a conscientização sobre seu patrimônio edificado. Já em 2010 se iniciaram as primeiras Caminhadas Históricas, apresentando em seu roteiro a arquitetura desse Instituto. Em 2011 foi contratado um grupo de arquitetos para desenvolver um Plano Diretor, que envolveu a participação de todos os setores no intuito de desenvolver projetos com uma visão de conjunto do campus, levando em conta diversos aspectos de uso desse espaço, incluindo o restauro dos edifícios históricos. Essa iniciativa, por si só, representou uma mudança de mentalidade das diretorias e da comunidade do campus, iniciando uma fase em que o espaço físico é tratado de forma integrada.

Concluída sua fase conceitual em 2016, e ainda sob implantação, pode-se dizer que o novo Plano Diretor já leva a resultados no espaço físico, como as reformas que têm sido implementadas nos edifícios do núcleo histórico, muitas delas apoiadas em critérios adequados. Também há casos em que as intervenções são incompatíveis com algumas recomendações da área de Restauro, como se verá no capítulo seguinte. 
3 - Preservação do patrimônio edificado 
Para estabelecer levantamento e análise de iniciativas de preservação e restauro no campus do Instituto Butantan, considerou-se necessário trabalhar primeiramente na contextualização histórica dessas iniciativas, ou seja, pesquisar como a consciência de que essa instituição possuía um patrimônio cultural edificado foi se formando em sua trajetória até ser objetivamente sistematizada através de políticas de preservação dos órgãos de defesa do patrimônio e desse próprio Instituto. Após essa contextualização histórica, são elencados alguns elementos mais representativos das diferentes abordagens e resultados das ações sobre esse patrimônio, sejam elas adequadas ou não a determinadas premissas, apresentadas no item 3.2.

Para a narrativa histórica das ações de preservação, opta-se aqui por um recorte intermediário, ou seja, consideram-se tanto as iniciativas conscientemente baseadas na área de conhecimento do Restauro, com seus critérios, recomendações e normativas legais, quanto aquelas iniciativas mais espontâneas, tomadas mesmo sem plena consciência das teorias e práticas de preservação do patrimônio, mas que acabaram de alguma forma contribuindo para sua conservação ou depreciação dentro do Instituto. O primeiro caso está mais relacionado às ações recentes, como o tombamento realizado pelos órgãos de defesa do patrimônio, os projetos de restauro e as atividades de pesquisa e educação envolvendo esse patrimônio, já com a participação de profissionais cientes das discussões nesse campo. O segundo caso se deu pela própria dinâmica no desenvolvimento desse espaço, onde a comunidade que o ocupa fez opções de construção ou demolição/alteração baseadas em valores de memória ou por necessidades urgentes, que acarretaram a formação de uma imagem patrimonial desse conjunto.

\subsection{Histórico de preservação}

Em um sentido amplo, pode-se considerar que as primeiras iniciativas de preservação do patrimônio edificado no Instituto surgiram em sua própria criação, ao se utilizarem estruturas existentes da fazenda, adaptando-as às atividades científicas, como é o caso do primeiro laboratório improvisado em um estábulo, depois reproduzido em 1980 (item 2.3.19). Nesse início também foram mantidas diversas casas de moradores e trabalhadores da fazenda, sendo a principal a Casa Sede (item 2.3.2) que teve suas características estéticas e construtivas razoavelmente preservadas. Pode-se dizer que as ações de preservação desses primeiros anos 
foram ocasionadas pela urgência e a necessidade material de ter rapidamente um lugar de combate à epidemia que se espalhava pelo Estado. Mas a decisão de manter essas estruturas, mesmo depois de debelado o surto, revelou determinado respeito pela memória do lugar e o início da formação de uma imagem institucional, da qual faz parte o "mito de origem" discutido no item 2.1.

Em uma descrição das condições físicas do Instituto em 1921, o diretor Afrânio do Amaral chamava atenção para o estado de conservação dos edifícios e da necessidade de limpeza e reforma geral (RA 1921, p.32). Embora se tratasse de manutenção, essas ações tinham implicação direta na integridade material das edificações e podiam ser enquadradas como ações de conservação preventiva.

Os primeiros 50 anos do Instituto foram marcados, no campo de conservação dos edifícios, por essas duas vertentes: a adaptação de algumas construções remanescentes da fazenda, e a conservação preventiva dos edifícios novos. Não havia preocupação em seguir recomendações de teorias do Restauro ${ }^{124}$ de arquitetura. Tampouco houve incidência de legislações protetivas sobre o campus nesse primeiro período ${ }^{125}$. Mas desde sua fundação houve a consciência de preservação da memória material do Instituto principalmente através de seu acervo científico: mobiliário, instrumentação laboratorial, espécies animais e documentos escritos foram desde o início protegidos e sistematizados com a preocupação de apresentá-los ao público interessado. Assim, a ideia de museu do Instituto aparecia já em seus primeiros anos com sua importante coleção de serpentes:

O pequeno museu do Instituto possue, além de um numero mui limitado de peças anatômicas, muitos exemplares de cobras nacionais e estrangeiras, conservadas em

\footnotetext{
${ }^{124} \mathrm{Na}$ época já eram publicados na Europa os trabalhos de teóricos como Boito, Riegl, Giovannoni, além dos mais antigos (Viollet-le-Duc, Ruskin). Mas ainda tinham circulação muito restrita no Brasil. As primeiras ações normativas para preservação do patrimônio se dariam na década de 1920, com projetos de lei para impedir a evasão de obras de arte e com o surgimento das primeiras Inspetorias Estaduais de Monumentos Nacionais e, finalmente, com os planos para criação do SPHAN em 1937 (PINHEIRO, 2006). Mas toda essa movimentação passou ao largo das ações no Instituto, seja pelo fato de ser um espaço ainda relativamente novo na primeira metade do século XX, seja porque as primeiras iniciativas de preservação do patrimônio no Brasil privilegiaram os elementos do período barroco/colonial, em detrimento de obras do final do século XIX e início do XX.

125 A origem do Serviço do Patrimônio Histórico e Artístico Nacional (SPHAN), primeira instituição governamental nacional voltada para a proteção do patrimônio cultural do País (Lei 378/1937), e do Decreto-Lei 25/1937, regulamentando o tombamento, deram-se quando o Instituto Butantan era relativamente recente e não se enquadrava nos modelos de patrimônio "belo e antigo", conforme já mencionado.
} 
álcool a maior parte, algumas em liquido de Kaiserling. Acham-se representadas na sua collecção 119 especies, das quaes 66 existentes no Brasil. [...] O Instituto permutou material durante o anno com os museos de Stutgart, Berlin, e Paris [...] (RA1912, p.237)

Nesse caso, a ideia de museu estava ligada à formação de um acervo para pesquisa científica, seja de espécies animais ou vegetais, sem relação direta à pesquisa histórica e social. Mas foi importante na formação de uma consciência da imagem do Instituto como um lugar de memória e educação, que mais tarde influenciaria nas iniciativas de preservação do patrimônio material e imaterial, como se pode ver no relatório de 1920:

Com o intuito de despertar no publico o amor, o interesse e o gosto pela Scientia amabilis e enthusiasmar os novos elementos que se preparam para continuar o estudo da nossa flora, instalamos uma exposição permanente de varias espécies consideradas medicamentosas e toxicas, que é facultada aos visitantes do Instituto. Esta dependência tem merecido, desde a sua inauguração, não poucos aplausos do publico." (RA1920, p.79)

Assim, também se pode considerar o Serpentário, o Horto, a biblioteca, as publicações memorialistas e biográficas, e mesmo as placas comemorativas, como formadores dessa consciência de instituição que não fosse apenas uma fábrica de soros e vacinas (o que já seria importante), mas também um lugar de memória da ciência. Portanto, essa primeira metade do século XX foi fundamental para as futuras ações conservativas do Instituto.

Como foi dito no item 2.1, outro período importante nessa conscientização foi aquele a partir da década de 1940, com o desmembramento do terreno da Cidade Universitária, quando a comunidade do Instituto Butantan passou a reforçar o sentido de unidade e identidade para defender esse território, o que passou pela valorização de sua memória. Com a proximidade do cinquentenário, em 1951, surgiram as primeiras ideias de reformar edifícios e reunir acervos para apresentar a história do Instituto.

Ainda nas ações periódicas de manutenção, uma notícia sobre a Casa Sede (item 2.3.2) representa bem como essa preocupação com aspectos técnicos dos edifícios colaborou para que passassem a ser preservados também do ponto de vista histórico e estético:

Encontra-se em péssimo estado o prédio onde está instalada a Secção de Ofiologia do Instituto Butantã. Trata-se de um casarão construído no início do século, composto de nove salas e que foi, por muito tempo, residência do cientista Vital Brasil. A secção compõe-se de um laboratório, (onde estão guardados, em vidros apropriados, $18 \mathrm{mil}$ 
espécimes de ofídios), escritório e pequena biblioteca. Há 10 anos é dirigida pelo dr. Alphonsus Richard Hoge. Há quatro anos foi elaborado um plano para edificação de um prédio, dotado de todos os requisitos tecnicos, para sede da Secção, e foi aprovada verba, à qual se acrescentou outra, de 20 milhões de cruzeiros, para obras de reaparelhamento, mas nada foi feito até agora e as paredes do velho casarão estão cedendo à ação do tempo e da umidade.

Três compartimentos foram ocupados inteiramente pelas coleções ofiológicas, dispostas em prateleiras improvisadas. O local carece de luz e ar. Além de impróprio para alojar uma das maiores coleções de ofidios do mundo, está sujeito a um incendio pois ali existem 20 toneladas de alcool, usado para conservar os animais em vasilhames gastos, velhos, alguns cujas tampas estão rachadas, o que permite evaporação do álcool.

O estado precario do predio que abriga a Secção de Ofiologia tem sido comentado, inclusive no Exterior. Um cientista alemão, o dr. Robert Martens observava, na revista "Natur und Volk" que o prédio onde está instalada a Secção de Ofiologia do Butantã é "velho e insignificante, indigno de possuir a mais valiosa coleção de ofídios do Brasil".

De todas as partes do Brasil são enviadas à Secção de Ofiologia exemplares para estudo. Têm sido, assim, descobertas espécies novas, como a serpente 'Xenoboa Cropanii', descrita pelo prof. Alphonsus Richard Hoge, em Miracatu, no Interior de São Paulo, de que só se conhece até agora um exemplar. (O unico exemplar conhecido. O Estado de São Paulo, 26/10/1957, p.1)

As propostas resultantes do convênio entre o Instituto Butantan e o FCCUASO (1961) incluíam planos urbanísticos que previam a demolição de grande parte dos edifícios do núcleo histórico. Esses planos não foram executados, e optou-se por reformar diversos daqueles prédios e construir novos em áreas ainda desocupadas do terreno. Não se encontraram, nessa pesquisa, evidências de que tenha havido uma resistência explícita da diretoria do Instituto contra os projetos "arrasa quarteirão" do FCCUASO, mas se nota um recuo nas ações seguintes, inclusive nos relatórios, como no de 1965, que menciona "zonas antigas que serão conservadas pelo valor histórico" (RA1965, p.12). A partir de então as indicações de que o Instituto buscava preservar seu território, e, em consequência, seu patrimônio edificado, culminaria nas tratativas para o tombamento do seu campus pelo Condephaat em 1981, como se viu no item 2.2.

Concomitantemente, cresciam no Instituto os trabalhos relacionados à memória da instituição, incluindo o desenvolvimento de pesquisas e publicações historiográficas, levantamentos, sistematização de acervos e contratação de profissionais da área cultural.

Além do processo de tombamento, motivou a contratação de historiadores a fundação do Museu Histórico em 1981 (item 2.3.19). A questão controversa (quanto à questão da réplica) 
será tratada adiante. Mas em termos de contribuição para a valorização da memória e do patrimônio cultural edificado do Instituto, o Museu Histórico foi um balizador, responsável por diversas exposições e pesquisas em seu campo, abordando história da ciência, cronologias, biografias, contextualizações etc ${ }^{126}$. Também passaram a ser ministrados com frequência cursos de museologia/museografia, conservação, organização de documentos e historiografia. Outra iniciativa importante desses pesquisadores pode ser vista nos Informativos (pequenos jornais internos dos Instituto) que trouxeram, entre outros assuntos, notas sobre seu patrimônio ${ }^{127}$.

Além dessas atividades, o Instituto passou a desenvolver contatos externos relacionados à preservação de seu patrimônio, como se vê no relatório de 1984:

"A chefia da Seção de Museu sensibilizou o Condephaat no sentido de fornecer recursos para a recuperação global do prédio do Museu. Uma primeira vistoria foi feita e aguarda-se a autorização dos serviços necessários.

Num plano mais amplo, envolvendo não apenas o Museu, mas também o Horto e demais instalações do Instituto Butantan tombadas pelo patrimônio histórico, contatou-se a Fundação Roberto Marinho. Foram realizadas várias reuniões com seus representantes em São Paulo, que encaminhou nossa solicitação à Sede no Rio de Janeiro; a Fundação já se manifestou favorável à assinatura de convênio ou acordo prevendo a concessão de auxílio ao Instituto Butantan."

Foi possível consultar o projeto citado, encaminhado em 5/8/1991 à Fundação Roberto Marinho. Nele, o Instituto, em nome do diretor da Divisão de Extensão Cultural, Henrique Canter, apresentava propostas a fim de obter recursos para a execução de reformas:

As mesmas foram separadas em dois grupos, um envolvendo o aspecto de restauração - recuperação de edificações e ambientes, outro de natureza editorial - áudio visual; Restauração - recuperação:

- Prédio da Biblioteca

- Prédio da Herpetologia

- Prédio Animais Inoculados / Biotério

- Quiosque e Serpentário

- Horto Oswaldo Cruz

- Sinalização Editorial - áudio visual:

- Museu manuseável itinerante

\footnotetext{
${ }^{126}$ Os relatórios a partir de 1981 trazem listagens desses trabalhos de pesquisadores do Museu Histórico e posteriormente do Núcleo de Documentação, entre os quais cabe citar Jandira Lopes de Oliveira, Henrique Moisés Canter, Paula C. Lapolla Gomes dos Reis, Suzana Gouveia Fernandes, Adriana Mortara, entre outros.

${ }^{127}$ Essas notas foram publicadas na sessão "Histórias do Instituto Butantan", entre as quais podemos citar: LIMA, Solange F. de, Lançamento da Pedra Fundamental do Prédio Novo, Informativo do IBu, no. 17/08/1986, p.2; CORRÊA, Dora Shellard. Ladrilhos, Informativo do IBu, no. 26/06/1988, p.2; Idem. A primeira construção do Instituto Soroterápico do Estado de São Paulo. Informativo do IBu, no . 32, set. 1989, p.2.
} 
- Nova edição da "Cartilha de Ofidismo - Cobral"

- Produção de Folheto e vídeo institucional (Plano apresentado a Fundaçao Roberto Marinho pelo Instituto Butantan em 1991, Acervo IBu)

Em seguida, o plano trazia um histórico e um conjunto de projetos de recuperação de cada edifício/elemento citado. O trecho sobre o Edifício Principal (item 2.3.4), deixa claras as intenções restaurativas do plano:

Edificado em estilo 'art nouveau', projeto do arquiteto e engenheiro sanitário Mauro Álvaro, o referido prédio encerra inúmeras preciosidades em termos de adornos arquitetônicos, arabescos, janelas, vidros, fechaduras, ladrilhos hidráulicos, elevador de documentos, etc, que a mercê de anos de utilização e até desvirtuamento de finalidades, foi se deteriorando e descaracterizando. Sob este último aspecto, canos de PVC, aparelhos de ar condicionado, 'spots' para iluminação, anexos e edícolas foram acrescentados modificando a construção original. [...]

Solicita-se para o mesmo restauração geral, compreendendo:

- pintura

- revisão de instalações elétricas e hidráulicas

- telhado

- construção de sanitários

- reposição de vidros, portas, adornos, etc.

(Plano apresentado a Fundação Roberto Marinho pelo Instituto Butantan em 1991, NDoc)

O plano prosseguia fazendo a descrição, contextualização histórica e proposta de restauro para cada um dos edifícios citados, com assinatura de Yuko Yamamoto Inoue, identificado como arquiteto do Instituto Butantan. Pelos documentos encontrados, das reformas/restaurações propostas, apenas a do quiosque foi financiada pela Fundação Roberto Marinho. Ainda que se possam questionar algumas soluções, como refazimentos completos de elementos (coberturas, pisos), pode-se considerar este como sendo o primeiro documento do Instituto a propor um plano seguindo explicitamente premissas recomendadas por teorias e normativas da área do Restauro. Não se sabe se Inoue tinha conhecimento aprofundado de tais bases, pois o plano não entra em pormenores como mapas de danos e projeto executivo, o que não era seu escopo, mas é nítida a abordagem crítica em relação aos edifícios, analisando elementos originais e interferências, objetivando uma reforma não apenas para atender aspectos técnicos, mas também culturais, ao mencionar a descaracterização e a autenticidade do edifício. Também difere do assim chamado restauro do Museu Histórico, que foi na verdade uma réplica, segundo as teorias e normas pertinentes na área. Nesse sentido, esse documento de 1991 pode ser considerado outro marco importante no histórico de preservação do patrimônio 
edificado do Instituto. Pouco depois, o setor cultural mencionaria claramente entre seus objetivos o de "recuperar o patrimônio histórico" (RA1991-1994, p. 34).

Já no campo da educação patrimonial, em 1989 foi criado o Projeto Serpente, cujo objetivo era:

[...] a reurbanização e musealização do Instituto Butantan, com a criação de espaços para visitação, através da reutilização de áreas, integração de pontos de visitação, orientação do ingresso e da visitação ao Instituto, ampliação da área do MIB e fornecimento de informações institucionais. (RA1989, p. 1197)

Isso significava apresentar aos visitantes não apenas elementos isolados, mas o conjunto, em um percurso concebido sob o ponto de vista turístico. Não foi possível verificar se o projeto foi colocado em prática, mas sua menção é importante como ação de educação patrimonial, que teria em 2004 um marco institucional relevante com a criação do Laboratório de História da Ciência, para o desenvolvimento de pesquisas e publicações também no campo patrimonial.

Apesar de tais atividades de reconhecimento, a situação de degradação material dos edifícios históricos permanecia e passou a chamar a atenção dos frequentadores no final da década de 1990. Conforme já mencionado (item 2.1), passaram a ser constantes as reportagens sobre esses edifícios. A notícia reproduzida a seguir mostra que a conservação do patrimônio tornava-se uma nova preocupação para o grande público e para a diretoria:

Para eliminar a profunda dicotomia entre o patrimônio histórico, deixado em segundo plano nos últimos anos, e a área técnica, que busca ampliar a produção de vacinas e soros, o Instituto Butantã procura parcerias com a iniciativa privada. De acordo com o professor Walter Colli, já foi aprovado um projeto de financiamento pela Fundação de Amparo à Pesquisa (Fapesp), além do apoio da R. A. Pini Construtores Associados.

A velha Casa da Fazenda, construída no ano de 1850 e tombada pelo Patrimônio Histórico, contará com um programa de recuperação financiado pela Fapesp, cujo projeto arquitetônico está em fase de elaboração.

Coleção - O edifício é uma das maiores preocupações de Colli, pois guarda a maior coleção de cobras do mundo, com dezenas de milhares de espécimes preservadas em vidros. Essa preocupação é compartilhada por cientistas do mundo inteiro, já que essa coleção é objeto de pesquisa de especialistas de vários países.

Já está sendo recuperado também o serpentário, graças à R. A. Pini Construtores Associados, que fez o projeto para transformar o grande recinto elíptico em uma área de exposições. 'Numa ponta teremos a reconstituição de um trecho da mata atlântica, com jararacas, típicas da área', diz o diretor, no centro de um recinto que reproduz o clima árido, com cactus e plantas do deserto, onde ficarão as cascavéis.

O terceiro recinto, o que mais agrada a Colli, será recoberto de terra de várias cores que, por absorverem o calor do Sol de forma diferenciada, darão condições 
preferidas pelas demais espécies de cobras, que se distribuirão de acordo com o seu hábitat.

Esse projeto está esbarrando, contudo, em um entrave. As obras estão paralisadas porque o projeto prevê a destruição dos antiquados “iglus”, onde as cobras se escondem, que são protegidos pelo Conselho de Defesa do Patrimônio Histórico, Artístico, Arqueológico e Turístico do Estado de São Paulo (Condephaat).

Para o grande público, porém, o maior atestado da decadência do Butantã é a situação do Museu Biológico. O edifício, feito inteiramente em madeira, está completamente tomado pelos cupins. Um trabalho de descupinização do prédio poria em risco as cobras, aranhas, sapos e escorpiões espalhados pelos terrários.

Outro ponto com problemas é o anfiteatro existente no centro do museu. A viga central do anfiteatro, submetida à trepidação constante provocada pela passagem dos veículos, quebrou, obrigando o instituto a fechar uma passagem para a Universidade de São Paulo (USP). 'O projeto de recuperação do anfiteatro está pronto e foi liberada a verba para uma nova viga, mas não há dinheiro ainda para substituir o madeiramento por alvenaria ou alumínio.'

Também faltam recursos para pintar o prédio da biblioteca e consertar o telhado do Hospital Vital Brazil - um barracão com meia dúzia de leitos onde são salvas, a cada dia, as vidas de duas ou três pessoas picadas por cobras. (Direção quer recuperar prédios deteriorados. O Estado de São Paulo, 01 ago. 1999, p.A10)

Nota-se que o texto aborda a dicotomia entre os trabalhos científicos e a preservação do patrimônio, que deveria ser enfrentada. Também é interessante ver como, ao dizer que "o maior atestado da decadência do Butantã é a situação do Museu Biológico”, o texto identifica, "metonimicamente", o espaço construído com a própria Instituição, o que não era necessariamente verdadeiro (pois o Instituto já estava se recuperando da crise financeira), mas mostrava um aspecto da construção de memória a partir do patrimônio edificado.

No início da década de 2000, as obras realizadas no Instituto eram em geral iniciadas e administradas por cada setor de forma bastante independente, ou seja, sem uma centralização atuante do Setor de Engenharia. Isso se devia em grande parte à sobreposição de administrações e fontes de recursos (o Instituto e a Fundação Butantan, bem como os recursos externos da Fapesp, Finep, Merck, diversas empresas privadas da indústria farmacêutica e órgãos internacionais). Devido às constantes alterações de plantas, revestimentos e instalações internas necessárias para os trabalhos científicos, a fiscalização quanto à preservação do núcleo histórico tinha de ceder às urgências desses trabalhos. Nesse momento, havia também uma deficiência que sempre fora tema de queixas de diretores e funcionários: os sistemas elétricos e hidráulicos, de abastecimento e proteção. No final da década de 2000, não havia um sistema integrado de hidrantes e combate a incêndio, e cada edifício possuía seu sistema, não havendo um projeto 
unificado $^{128}$. A sabida disparidade de recursos de cada setor resultava na coexistência de espaços bem equipados em suas instalações (geralmente os de produção ou com verbas de indústrias farmacêuticas) e outros com instalações deficientes, obsoletas ou mesmo inexistentes (geralmente ligados à cultura e acervos). O resultado trágico desse desequilíbrio foi o já relatado incêndio de 15 de maio de 2010 no prédio que abrigava o acervo de serpentes (figura 191), que causou a perda do maior acervo ofídico do mundo, material colecionado desde a fundação do Instituto. Nele, o edifício que abrigava os animais não possuía sistema adequado de combate a incêndio, além disso, as espécies eram armazenadas em recipientes com álcool e a instalação elétrica era obsoleta, conforme amplamente divulgado pelo noticiário da época. É interessante notar que essas inadequações não eram recentes, e já havia alertas antigos:

Toda a coleção de serpentes está alojada em um pavilhão ao lado deste [Casa Sede], que também está condenado. Seu teto, com rachaduras, põe em risco esta coleção de valor científico incalculável; estando conservada em frascos com álcool, qualquer desmoronamento, podendo ocasionar incêndio, destruirá precioso material de estudo. (RA1968, np)

O pavilhão mencionado era o edifício da coleção de serpentes que, apesar de não ser uma construção relevante como patrimônio arquitetônico, encontrava-se ao lado da Casa Sede (item 2.3.2), a mais antiga do Instituto, o que poderia ter trazido perdas ainda maiores. Após esse acidente de repercussão internacional ${ }^{129}$, foram tomadas medidas para atualizar os sistemas elétricos e hidráulicos do campus. Em 2012 foi iniciado projeto de rede de hidrantes percorrendo toda a área histórica (o setor de produção já estava guarnecido), que está em processo de implantação e ampliação.

\footnotetext{
${ }^{128}$ Segundo a Instrução Técnica N.11 do Corpo de Bombeiros do Estado de São Paulo, vigente na época, os edifícios com menos de $750 \mathrm{~m}^{2}$ não necessitavam Auto de Vistoria da corporação.

${ }^{129}$ Sao Paulo fire destroys one of the largest collections of dead snakes. The Guardian, 16/05/2010.
} 


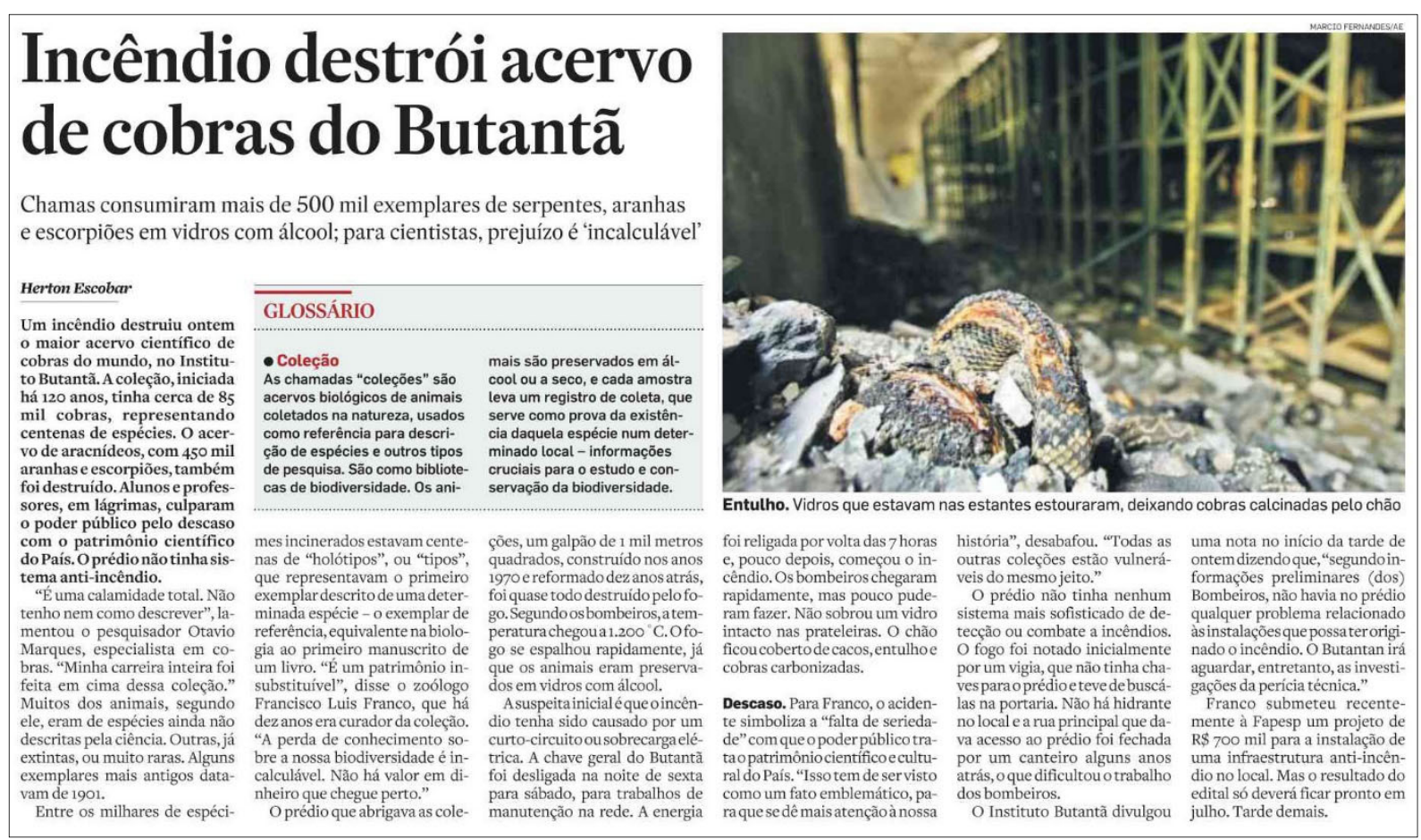

Fig. 191 - Notícia sobre o incêndio no edifício da coleção de serpentes: o fato gerou grande repercussão na época e ainda é mencionado quando ocorrem novos incidentes semelhantes, como o do Museu da Língua Portuguesa, em 2015, e do Museu Nacional, em 2018. (Fonte: O Estado de São Paulo, 16/05/2010)

No mesmo ano do incêndio relatado, foi criada a Caminhada Histórica ${ }^{130}$ (organizada pelo MHIB), que foi um marco importante do ponto de vista de conscientização da comunidade do Instituto sobre seu patrimônio edificado e de educação patrimonial. Motivada, entre outras coisas, pela necessidade de expandir o espaço de atividades do Museu Histórico, essa atividade consiste em um roteiro guiado pelo campus, abordando as características arquitetônicas e históricas de seus principais edifícios e espaços, para visitantes e interessados em geral. Essa pode ser considerada a primeira atividade de educação patrimonial voltada especificamente ao patrimônio arquitetônico do Instituto ${ }^{131}$. Nesse mesmo ano foi criado o Núcleo de Documentação, para liderar a gestão, preservação e divulgação dos acervos textuais, iconográficos, fotográficos, cartográficos e audiovisuais do Instituto, que se encontravam dispersos ou pouco acessíveis até então.

\footnotetext{
${ }^{130}$ Criada em 2010 pela equipe do Museu Histórico, liderada pela historiadora Suzana Gouveia Fernandes, a Caminhada Histórica é hoje realizada sob direção dos historiadores Adriana Mortara e Osvaldo Sant'Anna, e acontece durante as Jornadas do Patrimônio (evento organizado pela Prefeitura de São Paulo) e em outras datas selecionadas pelo Instituto.

${ }^{131}$ Sobre o mencionado Projeto Serpente, de 1989, embora tenha sido uma primeira iniciativa importante como educação patrimonial, não se encontraram registros confirmando se incluía efetivamente a arquitetura no roteiro.
} 
Desse modo, a área cultural e educativa passou a ser formada por:

- Museu Biológico;

- Museu Histórico;

- Museu de Microbiologia;

- Museu de Saúde Pública Emílio Ribas (fora do campus);

- Biblioteca;

- Núcleo de Documentação;

- Núcleo de Difusão do Conhecimento;

- Núcleo de Produções Técnicas e de Comunicação;

- Laboratório Especial de História da Ciência.

As ações mais recentes relacionadas à preservação se dão em duas frentes: as ações diretas sobre os elementos edificados (restauros, ações preventivas e planos de conservação) e as ações de educação patrimonial, ligadas à divulgação e à pesquisa desses elementos.

Quanto à primeira frente, o Plano Diretor de 2016 é a ação recente de maior impacto, pois traz no seu escopo a seção de Conservação e Restauro, com projetos de restauro para os edifícios do núcleo histórico, além de projetos de novos edifícios. Tais propostas adotam como premissas, segundo o texto do plano, recuperar "a qualidade espacial, estética ou documental dos bens" (IBu, 2016, p.100). Segundo a equipe do Departamento de Infraestrutura, hoje estão em processo de detalhamento os projetos de restauro do Edifício Principal (Edifício Vital Brazil) e da Cocheira Central (Museu Biológico), já aprovados pelo Condephaat. Qualquer alteração em edifícios no campus hoje precisa ser previamente informada ao Departamento de Infraestrutura e aprovada por ele, segundo as diretrizes de preservação.

Em novembro de 2017, foi criada uma Comissão Permanente de Acervos no intuito de estabelecer debates, estudos e diretrizes para regular os usos e alterações de elementos com valor de patrimônio cultural, formada por responsáveis por cada tipo de acervo: bibliográfico, arquivístico, museológico, zoológico e arquitetônico. ${ }^{132}$ Segundo depoimentos de funcionários,

\footnotetext{
${ }^{132}$ A Comissão Permanente de Acervos foi instituída pela portaria IB-28 em 02/11/2017, no intuito de "estabelecer diretrizes institucionais com vistas à preservação, armazenamento, segurança, tempo de guarda, empréstimo,
} 
a criação desse grupo foi motivada por algumas intervenções pontuais em edifícios históricos realizadas sem critério e sem consulta às equipes responsáveis por manutenção e reformas. Essa comissão visa complementar as ações do Plano Diretor no aspecto de valorização e preservação dos monumentos e acervos históricos do Instituto.

No plano da educação patrimonial, a partir de 2017 foram organizadas pelo Laboratório de História da Ciência do Instituto as primeiras publicações tratando especificamente de arquitetura sob diversos aspectos, incluindo o histórico e patrimonial: em 2017 foi editado um Guia de Arquitetura do Butantan (MONTEIRO, 2017), e em 2019 o periódico Cadernos de História da Ciência, organizado pelo mesmo laboratório, deve dedicar um número ao tema da arquitetura pela primeira vez.

Todas essas ações com direta influência na preservação do patrimônio cultural edificado do Instituto servem de contexto para abordar os elementos isoladamente, elencados nos estudos de caso a seguir.

\subsection{Estudos de caso por linhas de preservação}

Com base nos levantamentos do histórico de intervenções e do estado atual, serão analisados a seguir alguns elementos elencados sob o ponto de vista das teorias de restauro. $\mathrm{O}$ objetivo foi analisar como é preservado o patrimônio cultural edificado do Instituto hoje, tomando alguns elementos significativos que representem linhas diferentes de preservação (seja com resultados positivos ou negativos), uma vez que seu estado de conservação e os tipos de intervenções sofridos são diversos.

Os critérios para essa listagem e análise se apoiam aqui em dois textos de base: Teoria da Restauração, de Cesare Brandi (2004) ${ }^{133}$, diretor do Instituto Central de Restauro italiano, publicado pela primeira vez em 1963, e a Carta de Veneza (CURY, 2004), como ficou conhecida a Carta Internacional para Conservação e Restauração de Monumentos e Sítios, resultante do

\footnotetext{
acesso e difusão das diversas tipologias de acervo que se encontram sob a responsabilidade da instituição" (DOE, 17/11/2017, p.117). Entre as diversas tipologias está a arquitetônica.

${ }^{133}$ Apesar de ser considerado um marco da preservação e restauro, a teoria de Brandi é tributária de alguns teóricos anteriores como Giulio Carlo Argan, Roberto Pane e Renato Bonelli, que já traziam alguns de seus conceitos.
} 
segundo Congresso Internacional dos Arquitetos e Técnicos dos Monumentos Históricos, em $1964^{134}$. O texto de Brandi é considerado marco fundamental do chamado Restauro Crítico ${ }^{135}$, que preconiza o restauro como ato cultural fundamentado na história e na estética, e também pode ser considerado como a maior influência teórica da Carta de Veneza. Esta, por sua vez, tornou-se o texto-base mais importante na orientação a diversas legislações e normativas de órgãos de preservação e educação patrimonial. Assim, esses textos fornecem um arcabouço teórico para avaliar a política de conservação dos elementos estudados. Existem outras linhas teóricas possíveis, mas a opção por esses textos se baseia em juízos teóricos e no fato de tais bases serem corroboradas pela maioria dos autores da área de restauro, e também pelos órgãos de preservação responsáveis pelo tombamento do Instituto Butantan (Condephaat e Conpresp).

A escolha dos estudos de caso foi feita principalmente por contraste, ou seja, procurandose elencar para análise alguns elementos com graus de conservação e intervenção bastante diferentes, podendo-se, assim, cobrir uma amplitude significativa de diversos tipos de atitudes em relação aos bens culturais aqui estudados. Como exemplos diversos, podem-se citar o "Edifício Novo", que tem sido mantido, em grande parte, fiel a sua conformação e uso original; o atual Museu Biológico, que teve seu uso original (cocheira) bastante modificado; o atual Museu Histórico, construído em 1980, que vem a ser uma réplica de um estábulo original, demolido em 1928, e a olaria da antiga fazenda, hoje em ruína. Outros elementos analisados são a implantação urbanística e paisagística, além do novo Plano Diretor.

Em que pese o possível aspecto subjetivo nessa listagem (como de toda listagem de patrimônio), a intenção não será fazer uma avaliação pessoal da qualidade das intervenções de preservação, que são diversas, e sim procurar verificar em que nível elas atendem às recomendações dos textos de base citados, uma vez que os elementos são tombados por órgãos

\footnotetext{
${ }^{134}$ A Carta de Veneza é o documento base do ICOMOS (Conselho Internacional de Monumentos e Sítios), fundado em 1965 e ligado à ONU através da UNESCO, do qual o Brasil é signatário.

${ }^{135} \mathrm{O}$ restauro crítico "parte da afirmação de que toda intervenção constitui um caso em si, não possível de classificar em categorias (como aquelas meticulosamente precisadas pelos teóricos do chamado restauro 'científico': completamento, liberação, inovação, recomposição etc.), nem responde a regras prefixadas ou a dogmas de qualquer tipo, mas deve ser reinventado com originalidade, de vez em vez, caso a caso, em seus critérios e métodos. Será a própria obra, indagada atentamente com sensibilidade histórico-crítica e com competência técnica, a sugerir ao restaurador a via mais correta a ser empreendida". (CARBONARA, 1997, p.285)
} 
que corroboram tais recomendações. Nesse ponto, é importante ressaltar que os processos de tombamento do Instituto Butantan são vagos quanto a quais edifícios, arruamentos, elementos paisagísticos e mesmo escultóricos são protegidos, e quais os níveis dessa proteção (volumétrico, parcial ou integral) limitando-se a considerar todo o campus como objeto de tombamento, o que dificulta, na prática, a própria fiscalização dessa preservação.

Considerando as premissas aqui apresentadas, os elementos elencados para análise de sua preservação ou influência na preservação do patrimônio, sob a luz dos texto-base são:

- Edifício principal (atual Edifício Vital Brazil)

- Cocheira Central (atual Museu Biológico)

- Museu Histórico

- Remanescentes da fazenda (atualmente ruínas)

- Implantação urbanística e paisagística

- Plano Diretor

Como se vê, não foram elencados apenas monumentos individuais, mas também elementos urbanísticos e paisagísticos, além do Plano Diretor, que seria um elemento normativo. Outras obras podem ser citadas para aprofundar as ideias discutidas. Admite-se primeiramente que os elementos construídos selecionados possuem relevância histórica, social e artística, para constituírem um patrimônio cultural edificado. A dimensão histórica é clara, uma vez que tais obras estão relacionadas à trajetória desse Instituto, à história da ciência e do início da República. A importância social, relacionada ao valor atribuído pela comunidade que o utiliza, envolve aspectos de memória, vivência e identidade dessa comunidade em relação à instituição. Por fim, a dimensão artística é constituída pelo valor que o público, os estudiosos, pesquisadores e produtores da área cultural, em especial de arquitetura, reconhecem nesses elementos, por suas características estéticas, técnicas e construtivas que os singularizam como documentos de determinadas linguagens da arquitetura ou como obras notáveis per se. A combinação dessas dimensões não é simples, mas é indispensável, pois o caráter interdisciplinar é reconhecidamente basilar na área de Preservação e Restauro, tanto nos tipos de valor atribuído 
aos elementos, quanto nos profissionais envolvidos nessa valorização e identificação ${ }^{136}$. Portanto, a dimensões histórica, social e artística, com valores atribuídos por vários atores, foram fundamentais nessa seleção.

Além de alguns princípios e recomendações, presentes na teoria de Brandi e na Carta de Veneza, que podem ser relacionados diretamente aos estudos de casos específicos, há princípios gerais que se aplicam a todas as ações de restauro, e que podem ser reunidos preambularmente. De início, a definição de restauração de Brandi, bastante conhecida no meio, tem um aspecto muitas vezes negligenciado que é a defesa do trabalho multidisciplinar, ao se referir aos aspectos estéticos, materiais e históricos coexistindo no objeto de restauro:

A restauração constitui o momento metodológico do reconhecimento da obra de arte, na sua consistência física e na sua dúplice polaridade estética e histórica, com vistas à sua transmissão para o futuro. (BRANDI, 2004, p.30)

A partir daí, o autor defende seus corolários:

Restaura-se somente a matéria da obra de arte. [...] A restauração deve visar ao restabelecimento da unidade potencial da obra de arte, desde que isso seja possível sem cometer um falso artístico ou um falso histórico, e sem cancelar nenhum traço da passagem da obra de arte no tempo. (Idid., pp. 31-33)

Depreende-se, portanto, que o restauro deve partir de alguma preexistência, que é material, não abstrata ou simbólica. Assim, segundo o italiano, restauram-se entes reais (pinturas, esculturas, monumentos etc. $)^{137}$. Além disso, o objetivo dessa ação não é restituir o estado original da obra (que, em muitos casos, é impossível delimitar), mas sim recuperar sua unidade potencial, relacionada à legibilidade e a transmissão do que ele chama de artisticidade.

\footnotetext{
136 "Pela própria definição de Brandi, a metodologia da restauração conduz ao trabalho multidisciplinar (consistência física e dúplice polaridade estética e histórica), mesmo que a parte operacional seja executada por uma única pessoa." (KUHL, 2006, p.23)

${ }^{137}$ Para Salvador Muñoz Viñas, a "eficácia do objeto como símbolo é um dos objetivos da Restauração, que a diferencia de outras atividades similares [...]. O material que compõe o objeto [...] só é importante como suporte dessa capacidade simbólica. O primeiro axioma brandiano ('restaura-se somente a matéria da obra de arte') não só não é um axioma, como também é errôneo uma vez que o significado também é matéria de restauração; hoje se reconhece que o objetivo final da restauração não é conservar o material por si mesmo, mas antes manter e ajustar os valores contidos no patrimônio.” (VIÑAS, 2010, p. 176, tradução nossa). Porém nota-se, contrariamente ao que Viñas afirma, que Brandi considera claramente a dimensão simbólica do objeto ao afirmar que "o restauro é ato crítico, dirigido ao reconhecimento da obra de arte (sem o que a restauração não é o que deve ser); voltado à reconstituição do texto autêntico da obra; atento ao 'juízo de valor' necessário para superar, frente ao problema específico das adições, a dialética das duas instâncias, a histórica e a estética.” (BRANDI, 2004, pp. 11-12). Portanto, o autor italiano limita à matéria do objeto apenas os procedimentos de restauro e não o valor do objeto restaurado.
} 
A unidade potencial e a artisticidade são, sim, abstratas, mas intermediadas pela matéria (a tela, a tinta, o ornamento, a pedra, o metal etc.) que, além de transmitir tais valores de arte, possuem um valor em si que é o histórico ${ }^{138}$.

Coloca-se, por isso, em primeiro lugar, a inalienabilidade do monumento como exterior do sítio histórico em que foi realizado. Em segundo lugar, deve-se examinar a problemática que nasce da alteração de um sítio histórico no que concerne às modificações ou ao desaparecimento, parcial ou total, de um monumento que dele fazia parte.

Do primeiro reconhecimento da inalienabilidade do monumento como exterior derivam, entretanto, alguns corolários:

a absoluta ilegitimidade da decomposição e recomposição de um monumento em lugar diverso daquele onde foi realizado, dado que tal ilegitimidade deriva ainda mais da instância estética do que da existência histórica porque, com a alteração dos dados espaciais de um monumento, chega-se a invalidá-lo como obra de arte;

a degradação do monumento, decomposto e reconstruído em outro lugar, a falso de si mesmo obtido com os seus próprios materiais, pelo qual se torna ainda menos do que uma múmia em relação à pessoa que foi quando viva;

a legitimidade da decomposição e recomposição ligada apenas à salvaguarda do monumento, quando não for possível assegurar a sua salvação de outro modo, mas sempre e somente em relação ao sítio histórico onde foi realizado. (BRANDI, 2004, pp.133-134)

De acordo com o autor, dever-se-á:

[...] procurar reconduzir os dados espaciais do sítio ao estado o mais próximo possível daqueles originais; mas o monumento não deverá ser removido, mesmo se a alteração dos dados espaciais for insanável. A consciência de autenticidade que induz o monumento não removido deverá sempre ser anteposta à consciência hedonística do próprio monumento. [...] é necessário distinguir de pronto se os elementos desaparecidos, com cuja supressão se veio a alterar a espacialidade do ambiente originário, sejam em si monumentos ou não. Se não constituem monumentos em si, poderá até ser admitida uma reconstituição, pois, mesmo que sejam falsos, não sendo obras de arte, reconstituem, no entanto, os dados espaciais; mas exatamente porque não são obras de arte, não degradam a qualidade artística do ambiente em que se inserem só como limites espaciais genericamente qualificados. [...]

Se, ao contrário, os elementos desaparecidos tiverem sido em si obras de arte, está absolutamente fora de questão que se possam reconstituir como cópias. $\mathrm{O}$ ambiente deverá ser reconstituído com base nos dados espaciais e não daqueles formais do monumento que desapareceu." (Ibid., p.136)

\section{Os princípios}

[...] abarcam toda a problemática da restauração monumental, pois se relacionam com a especial estrutura espacial da arquitetura. Para todo o resto, a problemática referente é comum àquela das obras de arte; da distinção entre aspecto e estrutura à conservação

${ }^{138}$ A coexistência de diversos valores também foi abordada por Alois Riegl ao desenvolver sua teoria sobre como os diversos valores (valor histórico, valor de antiguidade, valor volível, advindo do conceito de "volição de arte" (kunstwollen), valor utilitário, valor de novidade) podem se combinar nos agentes da preservação (RIEGL, 2014). 
da pátina e das fases históricas pelas quais passou o monumento. (BRANDI, 2004, p.137)

\section{A Carta de Restauração de 1972, reproduzida por Brandi em sua Teoria da Restauração ${ }^{139}$,} traz as seguintes normativas:

A consciência de que as obras de arte - entendidas na acepção mais vasta que vai do ambiente urbano aos monumentos arquitetônicos e àqueles da pintura e da escultura, e do remanescente paleolítico às expressões figurativas das culturas populares - devam ser tuteladas de modo orgânico e paritário, leva necessariamente à elaboração de normas técnico-jurídicas que sancionem os limites dentro dos quais deve ser entendida a conservação, seja como salvaguarda e prevenção, seja como intervenção de restauro propriamente dita." (Ibid., p.226)

Segundo a carta, proíbem-se:

1. complementos em estilo ou analógicos, mesmo se com formas simplificadas, ainda se existirem documentos gráficos ou plásticos que possam indicar qual era o estado ou devia ser o aspecto da obra acabada;

2. remoções ou demolições que apaguem a passagem da obra através do tempo, a menos que se trate de alterações limitadas, deturpadoras ou incongruentes em relação aos valores históricos da obra, ou de completamentos em estilo que falsifiquem a obra;

3. remoção, reconstrução ou recolocação em lugares diversos dos originários; a menos que isso seja determinado por superiores razões de conservação;

4. alteração das condições acessórias ou ambientais em que chegou até os nossos tempos a obra de arte, o conjunto monumental ou ambiental, o complexo decorativo, o jardim, o parque etc.;

5. alteração ou remoção das pátinas. (Ibid., p.230)

Admitem-se:

1. Acréscimos de partes acessórias com função estática e reintegrações de pequenas partes historicamente confirmadas, executadas, segundo o caso, seja determinando de modo claro o perímetro das integrações, seja dotando material diferenciado, embora harmônico, claramente distinguível a olho nu, em particular nos pontos de ligação com que as partes antigas, ademais com siglas e datas sempre que possível;

2. limpezas que, para as pinturas e esculturas policromadas, não devem nunca atingir a película da cor, respeitando a pátina e eventuais vernizes antigos; para todas as outras categorias de obras, não se deverá chegar à superfície nua da matéria de que são feitas as próprias obras;

3. anastiloses documentadas de modo seguro, recomposições de obras que se fragmentaram, sistematização de obras lacunosas, reconstituindo os interstícios de pouco vulto com técnica claramente distinguível a olho nu, ou com zonas neutras realizadas em nível diverso das partes originárias, ou ainda deixando à vista o suporte

${ }^{139}$ A Carta de Restauração, divulgada em 1972 pelo Ministério da Instrução Pública italiano para orientar as ações de todos os institutos de restauro é reproduzida na Teoria da Restauração a partir da edição de 1977, por seguir os princípios dessa teoria "quase por completo", nas palavras do próprio autor (BRANDI, op.cit., p.20, 225) 
originário e, de todo modo, jamais integrando ex novo zonas figuradas e inserindo elementos determinantes para a figuratividade da obra;

4. modificações e novas inserções com finalidade estática e de conservação na estrutura interna ou no substrato ou suporte, desde que, depois de completada a operação, não haja alteração, nem cromática nem da matéria, tal como se observa na superfície;

5. nova ambientação ou sistematização da obra quando não mais existirem ou tiverem sido destruídas a ambientação ou a sistematização tradicional, ou quando as condições de conservação exigirem a remoção. (BRANDI, 2004, pp. 231-232)

Ainda sobre as intervenções:

Art. $8^{\circ}$. Toda intervenção na obra, ou mesmo na área a ela contígua, para os efeitos do disposto no art. $4^{\circ}$, deve ser executada de modo tal, e com tais técnicas e materiais, que possa ficar assegurado que, no futuro, não tornará impossível uma nova eventual intervenção de salvaguarda ou de restauração. Além disso, toda intervenção deve ser previamente estudada e justificada por escrito (último parágrafo do art. $5^{\circ}$.) e de seu decorrer deverá ser elaborado um diário, que será seguido por um relatório final, com a documentação fotográfica de antes, durante e depois da intervenção. Serão ainda documentadas todas as pesquisas e análises eventualmente realizadas com o subsídio da física, da química, da microbiologia e de outras ciências. (Ibid., p.232)

Essas transcrições se referem a princípios básicos comuns da teoria de Brandi e da Carta de Veneza. A seguir, as análises dos elementos individuais do Instituto suscitarão outros princípios dos textos-base.

\subsubsection{Edifício Principal [Edifício Vital Brazil] - análise}

Como se viu na descrição do Edifício Principal (item 2.3.4), houve diversas alterações na edificação desde sua conclusão, mas que se concentraram em sua parte interna, e foram ligadas a modificações em compartimentação, vedos, aberturas e instalações para que este fosse adaptado às diferentes funções que desempenhou. Na parte externa, além das alterações próprias do tempo, como a pátina e algumas patologias causadas por umidade, o edifício sofreu intervenções principalmente em pinturas e interferências de instalações, que, no entanto, não alteraram significativamente seu aspecto volumétrico e estético.

Sobre as alterações internas, é importante lembrar que o edifício já foi inaugurado em 1914 com uma multiplicidade de usos díspares, de modo que não ficou configurado um único aspecto utilitário fortemente definido e expresso em sua arquitetura, como foi o caso das cocheiras, serpentários e biotérios. Assim, por se prestar a diversos usos, o edifício foi sendo 
adaptado ao longo dos anos para receber laboratórios, escritórios administrativos, espaços expositivos e, atualmente, Biblioteca e Núcleo de Documentação (além de laboratórios que permanecem no térreo e subsolo). No entanto, essa multiplicidade de usos acabou causando diversidade de tratamentos em pisos, pinturas, aberturas, passagem de instalações, que tiveram como principal consequência do ponto de vista patrimonial a perda de unidade compositiva interna do edifício. Externamente, é sobretudo na parte posterior que se verificam as interferências que comprometem a coesão na sua legibilidade, pois é onde se localizam as alas laterais e a rotunda, formando um conjunto que, somado ao paisagismo, é arquitetonicamente indivisível. Brandi trata dessa questão em suas proposições sobre a unidade do objeto:

Temos duas proposições definidas para estabelecer os termos da restauração, isto é, regular uma práxis.

Atinamos que a obra de arte goza, com efeito, de uma singularíssima unidade pela qual não pode ser considerada composta de partes; em segundo lugar, que essa unidade não pode ser equiparada à unidade orgânico-funcional da realidade existencial.

[...] a obra de arte, não constando de partes, ainda que fisicamente fracionada, deverá continuar a substituir potencialmente como um todo em cada um de seus fragmentos e essa potencialidade será exigível em uma proposição conexa de forma direta aos traços formais remanescentes, em cada fragmento, da desagregação da matéria. (BRANDI, 2004, p.46)

A original Cocheira-enfermaria, que hoje abriga laboratórios de pesquisa, também apresenta perda de unidade. É notável que ambos os edifícios citados estejam voltados para a mesma via, que pode ser considerada, portanto, a mais histórica do Instituto, já que possui o primeiro edifício (Cocheira-enfermaria) e o mais simbólico (o Edifício Principal), o que, somado ao paisagismo do serpentário ao final dela, poderia constituir um conjunto histórico melhor explorado. Sobre a Cocheira-enfermaria, hoje cada edifício é tratado esteticamente de forma diferente, ao contrário do proposto pelo autor citado:

[...] a 'forma' de toda obra de arte singular é indivisível, e em casos em que, na sua matéria, a obra de arte estiver dividida, será necessário buscar desenvolver a unidade potencial originária que cada um dos fragmentos contém, proporcionalmente à permanência formal ainda remanescente neles. (Ibid., p.46)

Voltando ao Edifício Principal, além das alterações em compartimentação que foram feitas com acréscimos e supressões de divisórias e paredes, também foram realizadas alterações estruturais, principalmente nas escadas dos porões, que eram originalmente utilizados para 
maquinaria, e na construção de lajes de cobertura nas alas posteriores. Estas, realizadas nos anos 1980, foram motivadas por infiltrações do telhado que levaram a diretoria a optar pela construção de laje no lugar do forro. Para isso, foi preciso construir vigas, cujo posicionamento interfere na legibilidade do espaço original. A questão da estrutura é tratada por Brandi em termos gerais, como "suporte" em contraste com a "camada pictórica" ou "imagem":

A matéria de que resulta a imagem “[...] é insubstituível só quando colaborar diretamente para a figuratividade da imagem como aspecto e não para aquilo que é estrutura. Disso deriva, mas sempre em harmonia com a instância histórica, a maior liberdade de ação no que se refere aos suportes, às estruturas portantes e assim por diante. (BRANDI, 2004, p.48)

Embora não seja simples transpor esse conceito para a arquitetura, Brandi deixa claro que o suporte ou estrutura da obra de arte é a sustentação invisível que possibilita a existência da imagem. O autor não se refere a uma estrutura abstrata, conceitual ou metafórica, mas material, nomeando-a objetivamente (a estrutura portante). Nesse sentido, a alteração estrutural do monumento, que não seja claramente amparada por razões técnicas e funcionais, interfere inadequadamente na unidade da obra.

Nas alterações mencionadas, até o início da década de 2010, compreende-se que ainda não havia uma sistematização das ações sob um plano de preservação e restauro conscientemente elaborado. A partir do novo Plano Diretor, entende-se que as propostas para o edifício seguem premissas teóricas e normativas relacionadas à área. O Plano faz uma proposta de restauro, em nível de projeto executivo, que para ser realizado contou com levantamentos dimensionais, fotográficos, estratigráficos e históricos realizados previamente. Isso vai ao encontro do que é recomendado pela Teoria da Restauração e pela Carta de Veneza.

Como se viu no item 2.3.4, do ponto de vista funcional, o Plano propõe utilização do edifício para uso administrativo. Para isso, o Memorial Descritivo do Plano explicita suas premissas de restauro:

$\mathrm{O}$ partido do projeto segue o princípio da mínima intervenção, respeito às características originais, reversibilidade e contemporaneidade na linguagem dos materiais e formas, de modo que a leitura do antigo seja sempre mantida, em contraste com as novas intervenções. (IBu, 2016, Memorial Executivo de Restauro, Edifício Principal, p.34) 
As premissas estão de acordo com as proposições de Brandi, quando esclarece seus princípios práticos:

A integração deverá ser sempre e facilmente reconhecível; mas sem que por isso se venha a infringir a própria unidade que se visa a reconstruir. Desse modo, a integração deverá ser invisível à distância de que a obra de arte deve ser observada, mas reconhecível de imediato, e sem necessidade de instrumentos especiais, quando se chega a uma visão mais aproximada. Nesse sentido, são contraditos muitos axiomas da restauração chamada arqueológica, porque se assere não apenas a necessidade de atingir a unidade cromático-luminosa dos fragmentos com as integrações, mas, quando a distinção entre pedaços acrescentados e fragmentos puder ser assegurada com um especial e duradouro lavor, tampouco se exclui o uso de uma mesma matéria e da pátina artificial, sempre que se tratar de restauração e não de refazimento. (BRANDI, 2004, pp.47-48)

Em seguida, o Memorial Descritivo do Edifício Principal lista as intervenções a serem feitas de acordo com o projeto executivo. Estas são algumas delas:

- Rebaixamento de $50 \mathrm{~cm}$ do piso do porão em toda a ala direita, nivelando-o com o piso da ala esquerda - que havia sido rebaixado na década de 40 - a fim de se ampliar o pé-direito deste trecho do porão para $2,50 \mathrm{~m}$;

- Criação de duas rampas externas, com inclinação de $8 \%$, também como a função de atender a acessibilidade universal aos dois acessos externos da edificação;

- Inserção de um elevador interno a edificação, em estrutura metálica criado para tornar acessível, aos cadeirantes e pessoas com problemas de mobilidade, os três pavimentos da edificação: porão, pavimento térreo e superior;

- Eliminação do piso do pavimento térreo da rotunda lateral esquerda, afim de se criar um pé-direito duplo. Será construída uma escada, acompanhando o arco da planta, em estrutura metálica, ligando o pavimento térreo ao piso do porão.

- Eliminação dos pisos do pavimento térreo das rotundas lateral direita e central, com reconstrução de novas lajes de piso, a fim de eliminar os desníveis entre elas. $\mathrm{Na}$ rotunda lateral direita e central, para as novas lajes de piso será executada uma nova estrutura independente metálica com laje de concreto pré-moldada e piso em madeira, e escada metálica para acesso do pavimento térreo ao piso do porão;

Criação de novos sanitários e copas que atendam aos usos administrativo e cultural em todos os andares. Todas as paredes inseridas para atender a este novo layout serão de dry-wall. Esta escolha foi motivada pela leveza do material, a fim de se sobrecarregar o menos possível a estrutura de tijolos auto-portante existente, como também pela limpeza de sua construção e seu caráter reversível. (IBu, 2016, Memorial Executivo de Restauro, Edifício Principal, p.35-36)

Em relação aos revestimentos, o projeto preconiza, entre outras coisas, que:

- Deverão ser removidos os revestimentos das paredes externas (pinturas e argamassas das fachadas) conforme indicações do Projeto Arquitetônico de Restauro, para posterior recomposição dos revestimentos à sua condição original.

- As paredes internas, quando indicado no Projeto de Arquitetura, deverão também ser submetidas ao procedimento de retirada dos revestimentos para posterior recomposição de revestimentos similares aos originais. 
- [...] Os pisos de ladrilho hidráulico no pavimento térreo deverão ser restaurados. Áreas fissuradas e trincadas deverão ser tratadas de modo a reestabelecer a integridade das peças. As peças faltantes ou que não puderem ser restauradas deverão ser substituídas por peças idênticas, obedecendo-se sempre os padrões de cor, textura e paginação originais. (IBu, 2016, Memorial Executivo de Restauro, Edifício Principal, p.7)

De acordo com as intervenções expostas, há alguns itens novos que interferem consideravelmente na unidade do edifício, pois alteram sua estrutura, sua compartimentação e seu aspecto externo. Estes itens são principalmente aqueles relacionados às exigências e recomendações para permitir acessibilidade do edifício ${ }^{140}$, e são necessários para que pessoas com deficiência possam se locomover nos espaços. Embora a integração desses elementos contemporâneos e exógenos à obra seja complexa, o projeto foi coerente ao procurar integrálos sem mimetismo e sem contraste excessivo, como no caso do elevador e das rampas. Sobre a questão de evitar a mimetização de novos elementos, a Teoria da Restauração afirma:

\begin{abstract}
A ação de restauro, ademais, e pela mesma exigência que impõe o respeito da complexa historicidade que compete a obra de arte, não se deverá colocar como secreta e quase fora do tempo, mas deverá ser pontuada como evento histórico tal como o é, pelo fato de ser ato humano e de se inserir no processo de transmissão da obra de arte para o futuro. Na atuação prática, essa exigência histórica deverá traduzirse não apenas na diferença das zonas integradas, já explicitada quando se tratou do restabelecimento da unidade potencial, mas também no respeito pela pátina, que pode ser concebida como o próprio sedimentar-se do tempo sobre a obra, e na conservação das amostras do estado precedente à restauração e ainda das partes não coevas, que representam a própria translação da obra no tempo. (BRANDI, 2004, p.61)
\end{abstract}

Ao mesmo tempo, o plano prevê que no futuro esses novos elementos possam ser substituídos caso existam novas tecnologias mais adequadas, o que também é recomendado pelo teórico italiano ao prescrever que "qualquer intervenção de restauro não torne impossível mas, antes, facilite as eventuais intervenções futuras.” (Ibid., pp.47-48)

A Carta de Veneza também defende a prática de estabelecer contraste adequado entre os acréscimos e as partes originais dos monumentos:

Artigo 12 - Os elementos destinados a substituir as partes faltantes devem integrar-se harmoniosamente ao conjunto, distinguindo-se, todavia, das partes originais a fim de que a restauração não falsifique o documento de arte e de história.

\footnotetext{
${ }^{140}$ Esses itens, obrigatórios para edifícios públicos, estão descritos pela norma técnica ABNT NBR 9050/2004.
} 
Artigo 13 - Os acréscimos só poderão ser tolerados na medida em que respeitarem todas as partes interessantes do edifício, seu esquema tradicional, o equilíbrio de sua composição e suas relações com o meio ambiente" (CURY, 2004, p.94)

Alguns itens do projeto, porém, mostram-se pouco claros quanto à amplitude da intervenção, o que pode gerar contradições em relação às premissas adotadas. Um deles é a retirada de revestimentos de pisos, paredes internas e externas. Dependendo da área a ser retirada, esse procedimento pode, segundo os textos-base citados, alterar a imagem original, que Brandi chama de unidade, e a Carta de Veneza de esquema. Finalmente, a estrutura do edifício também receberia várias interferências, algumas justificadas, como o acréscimo de elementos para acessibilidade; outras controversas, como as aberturas e retiradas para retornar a um suposto estado original, o nivelamento do subsolo para uma suposta correção do edifício, e a retirada ou substituição das lajes térreas das rotundas. Nesse caso, não se trata apenas de estruturas no sentido de suporte físico descrito por Brandi, mas também de elementos que configuram o espaço e podem ser parte importante do histórico da técnica do edifício.

$\mathrm{Na}$ finalização dessa dissertação, estavam em andamento obras de reparos em todas as coberturas, portas e janelas do edifício. Segundo a equipe contratada, foi necessário substituir telhas danificadas. Mas na ausência de telhas com as mesmas dimensões, alterações estruturais deveriam ser feitas para adequar os suportes (ripas e terças) às bitolas comerciais atuais, questão que ainda não havia sido decidida ao término dessa pesquisa.

\subsubsection{Cocheira Central [Museu Biológico] - análise}

Enquanto o Edifício Principal manteve o aspecto geral de sua tipologia e de suas funções (que, como se mostrou, eram múltiplas desde o início), pode-se afirmar que a Cocheira Central foi o elemento que sofreu a maior alteração de função e tipologia entre os listados aqui. Até a década de 1960, as alterações verificadas pela iconografia e pelos relatórios eram sempre relacionadas a procedimentos e melhorias no trato com os animais, portanto ligadas ao uso original (como o escurecimento já relatado, ou os reparos na cobertura). Com a transferência de animais para a Fazenda São Joaquim, o edifício passou a abrigar cavalaria militar (FERRAZ, 
1993), uso que também era próximo ao precedente. Ocorreram as alterações típicas do envelhecimento do edifício, que chegou aos anos de 1960 com deterioração das pinturas, infiltrações, destacamento de argamassas e oxidação de metais.

Foi em 1966 que o edifício sofreu a maior intervenção, na qual se mudou seu uso para convertê-lo de cocheira de imunização para Museu Biológico. Essa reforma, na qual o pátio interno foi coberto, dando lugar a um auditório, afetou diretamente sua planta, seus fluxos, o esquema de cheios e vazios, a estrutura e o aspecto interno. Como se sabe, na época o conjunto ainda não havia sido tombado ${ }^{141}$.

Os dois textos-base aqui adotados, e a maioria dos teóricos do restauro, defendem que é desejável dar uma utilização aos edifícios históricos, como forma de mantê-los "vivos" e servindo à sociedade, o que leva naturalmente à sua preservação. Ao mesmo tempo, esses usos não devem desvirtuar a tipologia, estrutura e aspectos principais de tais monumentos. Isso não significa manter o mesmo uso original (o que nem sempre é possível), mas elencar, entre as novas funções possíveis, aquelas que possam melhor se adaptar ao espaço, ressaltando seus valores e deles se beneficiando, ao invés de sobrepujá-los ou escondê-los. CHOAY reconhece esse equilíbrio difícil entre a necessidade de dar um uso ao monumento e a sua conservação como patrimônio cultural:

A reutilização, que consiste em reintegrar um edifício desativado a um uso normal, subtraí-lo a um destino de museu, é certamente a forma mais paradoxal, audaciosa e difícil da valorização do patrimônio. Como o mostraram repetidas vezes, sucessivamente, Riegl e Giovannoni, o monumento é assim poupado aos riscos do desuso para ser exposto ao desgaste e usurpações do uso: dar-lhe uma nova destinação é uma operação difícil e complexa, que não deve se basear apenas em uma homologia com sua destinação original. Ela deve, antes de mais nada, levar em conta o estado material do edifício, o que requer uma avaliação do fluxo dos usuários potenciais. (CHOAY, 2001, p.219)

Sobre isso, a Carta de Veneza preconiza:

Artigo $5^{\circ}$. - A conservação dos monumentos é sempre favorecida por sua destinação a uma função útil à sociedade; tal destinação é portanto, desejável, mas não pode nem deve alterar a disposição ou a decoração dos edifícios. É somente dentro destes limites que se deve conceber e se pode autorizar as modificações exigidas pela evolução dos usos e costumes.

\footnotetext{
${ }^{141}$ Ainda não existia o Condephaat, fundado em 1968, nem o Conpresp, fundado em 1985. Também não houve manifestação do Iphan na época, embora já se esboçasse sua valorização a monumentos com linguagens da virada do século XIX para o XX.
} 
Artigo $6^{\circ}$. - A conservação de um monumento implica a preservação de um esquema em sua escala. Enquanto subsistir, o esquema tradicional será conservado, e toda construção nova, toda destruição e toda modificação que poderiam alterar as relações de volumes e de cores serão proibidas.” (CURY, 2004, pp. 92-93)

Portanto, as possibilidades de mudança de uso devem estar circunscritas em um universo de opções que não altere o chamado "esquema"142 do monumento. Brandi é mais explícito ao tratar da preservação das funções, sempre que possível:

Os elementos edilícios que fazem parte do conjunto devem ser conservados não apenas em seus aspectos formais, que qualificam sua expressão arquitetônica ou ambiental, mas também em suas características tipológicas, como expressão de funções que caracterizaram, ao longo do tempo, o uso desses próprios elementos. (BRANDI, 2004, p.258)

Note-se que o autor também não preconiza a preservação do uso original do edifício, o que seria um engessamento arbitrário e, ademais, impossível de ser mantido, sobretudo em uma instituição de saúde, como é o caso do espaço aqui estudado. Mais uma vez, defende-se a preservação das características tipológicas que expressam sua função original, termo que remete ao "esquema tradicional" mencionado naquela Carta. Assim, nesse edifício, o uso original da Cocheira, caracterizado por uma tipologia, volumetria e esquema com um vazio central circundado por alas semiabertas, era um aspecto marcante que remetia a sua história e à da ciência, cuja preservação seria desejável.

Esse tipo de edifício com pátio central, comum na fase do Ecletismo, e necessário para a função descrita, é frequentemente objeto de restaurações com resultados diversos. Como exemplo, pode-se citar o caso da Pinacoteca do Estado de São Paulo (de Ramos de Azevedo e Domiziano Rossi), com projeto de restauro do arquiteto Paulo Mendes da Rocha, que teve seus vazios internos preservados em sua tipologia e em sua volumetria, mesmo com as alterações e acréscimos contemporâneos, com resultado reconhecidamente bem sucedido. Já para o Museu Nacional de Belas Artes, no Rio de Janeiro (projeto original de Adolpho Morales de los Rios), o mesmo arquiteto propôs uma torre contemporânea no vazio central, solução que, segundo os

\footnotetext{
${ }^{142}$ Os textos da Carta em francês e inglês utilizam, respectivamente, os termos "cadre" e "setting", que passam a ideia de arranjo e volumetria dos monumentos.
} 
princípios aqui considerados, deturparia a legibilidade tipológica do edifício, bem como seu aspecto na paisagem, o que gerou críticas ao projeto, que não foi executado (figura 192).

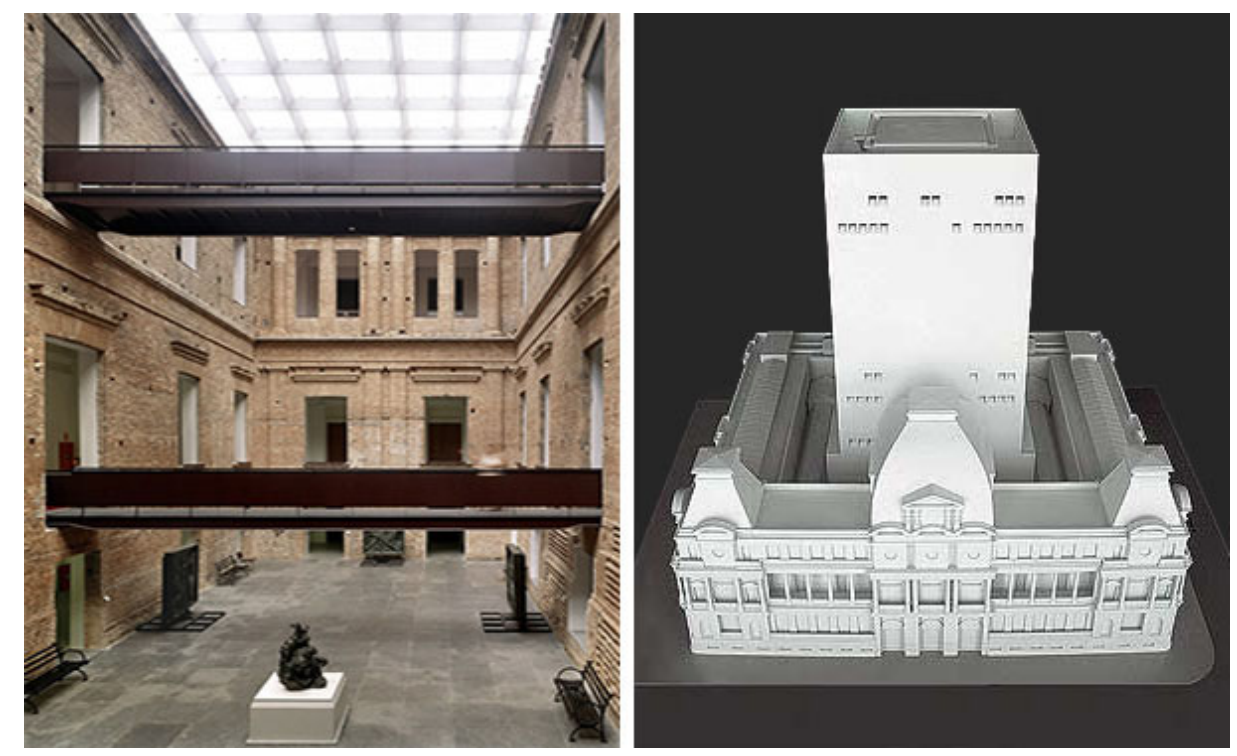

Fig. 192 - Pinacoteca do Estado e maquete do Museu de Belas Artes, ambos projetos de restauro de Paulo Mendes da Rocha: exemplos contrastantes de intervenção em pátios (Fonte: Nelson Kon e METRO Arquitetos Associados)

No caso da Cocheira, provavelmente teria sido possível instalar ali o museu, mantendo características fundamentais de sua tipologia, como propunha Lina Bo Bardi em 1965, optando por manter o vazio central, transformando-o em jardim e procurando integrar as intervenções ao existente de forma não mimética.

A reforma realizada em 1966 não levou em conta muitos desses princípios. Cabe pontuar que a Carta de Veneza e a Teoria da Restauração ainda tinham menos de 3 anos, e não possuíam adesão nos meios técnicos e acadêmicos da área de preservação ${ }^{143}$. Além disso, o espírito renovador (e quase refundador) da equipe do FCCUASO atuando nesse Instituto não tinha na preservação sua tônica, pelo menos nos moldes daqueles princípios. O resultado foi a alteração significativa da unidade e tipologia da Cocheira na parte interna, com o fechamento do pátio central, sem soluções de contraste entre os novos elementos e os originais. Já no lado externo, o aspecto geral da volumetria, aberturas e revestimentos foi relativamente mantido. Mas sabese que em 1972 foram substituídas as telhas de ardósia, originais, por telhado cerâmico, que

\footnotetext{
${ }^{143}$ Ainda há ações práticas e recomendações dos órgãos de preservação e nos meios acadêmicos que divergem de tais bases, especialmente da Carta de Veneza, mesmo nos que corroboram tais princípios.
} 
perdurou até recentemente. Mammini afirma (em depoimento para estes trabalho) que optou por manter as telhas de ardósia na época para preservar o aspecto histórico do edifício, e enviou as peças cerâmicas (segundo ele em linguagem Art Nouveau importadas da Alemanha) para a FAU-USP (na Vila Penteado). Isso deixa claro que havia a vontade de preservar características históricas e estéticas do edifício, embora não houvesse uma sólida base teórica para tal. Em contato com a FAU-USP, não foram identificadas a peças de piso mencionadas.

Após essa reforma, nos mais de cinquenta anos seguintes, o edifício se firmou como sede do Museu Biológico, tornando-se centro de exposições e de conferências do Instituto. As novas reformas que sofreu foram adaptativas para melhoria desses usos. Já os revestimentos externos passaram por diversas alterações. A iconografia mostra a diversidade de escolha de tonalidades, sendo o aspecto atual, com tonalidade levemente amarelada, presente desde a década de 1990.

O novo Plano Diretor, em fase de implantação, tem projeto de alterações nesse edifício, coordenado como projeto de restauro. Entre os documentos do projeto executivo, está um Memorial de Restauro, assinado por Carlos Faggin e Maria Luiza Dutra. Esse memorial, iniciando-se com um resumo histórico do edifício, chega a um documento chamado Partido de Restauro, no qual define suas premissas:

O Projeto de Restauro em questão procura se aproximar ao máximo da proteção integral do bem tombado em seu estado original. Ao mesmo tempo, busca incorporar as condicionantes de seu uso atual. O restauro integral não é totalmente possível, pois o interior do edifício encontra-se bastante alterado. [...] A intervenção que introduziu o auditório não é de todo desprovida de interesse. Do ponto de vista histórico, significa um importante momento de colaboração entre o Instituto Butantan e a Cidade Universitária Armando Sales de Oliveira. Mesmo do ponto de vista arquitetônico, apresenta engenhosas soluções de acústica e de visibilidade, como as curvas de algumas paredes e a dupla curvatura do piso da plateia. No entanto, do ponto de vista estrutural a intervenção foi bastante agressiva. (IBu, 2016, v.3, Memorial Executivo de Restauro, Museu Biológico, p. 41)

Desse modo, o Plano afirma que opta por incorporar as alterações realizadas em 1966 como documento histórico a ser preservado. Essa opção encontra algum amparo na Carta de Veneza, quando esta enuncia:

Artigo 11 - As contribuições válidas de todas as épocas para a edificação do monumento devem ser respeitadas, visto que a unidade de estilo não é a finalidade a alcançar no curso de uma restauração, a exibição de uma etapa subjacente só se justifica em circunstâncias excepcionais e quando o que se elimina é de pouco interesse e o material que é revelado é de grande valor histórico, arqueológico, ou 
estético, e seu estado de conservação é considerado satisfatório. O julgamento do valor dos elementos em causa e a decisão quanto ao que pode ser eliminado não podem depender somente do autor do projeto. (CURY, 2004, pp. 93-94)

Assim, esse artigo ressalta que, na obra de restauro, o ato menos recomendável é a retirada ou destruição de partes do monumento, que só devem ser realizadas em casos extremos e muito bem justificados. Ou seja, a decisão de manter o anfiteatro (ainda que tenha sido uma adição prejudicial do ponto de vista preservacionista), parece acertada de acordo a Carta, uma vez que o uso permanecerá o mesmo. Provavelmente, se houvesse uma nova mudança de uso que ensejasse a reabertura do pátio, isso poderia ser proposto. Mas, novamente, o artigo volta à importância de que essas decisões basilares sejam tomadas por conjuntos multidisciplinares de profissionais. Já na sua Teoria, Brandi também trata dessa questão do tratamento de acréscimos:

Do ponto de vista histórico a adição sofrida por uma obra de arte é um novo testemunho do fazer humano e, portanto, da história: nesse sentido a adição não difere da cepa originária e tem os mesmos direitos de ser conservada. A remoção, ao contrário, apesar de também resultar de um ato e por isso inserir-se igualmente na história, na realidade destrói um documento e não documenta a si própria, donde levaria à negação e destruição de uma passagem histórica e à falsificação do dado. Disso deriva que, do ponto de vista histórico, é apenas incondicionalmente legítima a conservação da adição, enquanto a remoção deve sempre ser justificada e, em todo caso, deve ser feita de modo a deixar traços de si mesma e na própria obra.

Disso decorre que a conservação da adição deve ser considerada regular; excepcional, a remoção. Totalmente o contrário daquilo que o empirismo oitocentista aconselhava para as restaurações. (BRANDI, 2004., pp.71-72)

O autor também trata a remoção como ato extremo, em consonância com a propagada frase de Adolphe Napoléon Didron:

"No que tange aos monumentos antigos, é melhor consolidar do que reparar, reparar do que restaurar, restaurar do que refazer, refazer do que embelezar; em nenhum caso se deve acrescentar e, sobretudo, nada suprimir." (BOITO, 2008, p.22)

Mas cabe ressaltar que Brandi sempre trabalha com a noção dialética entre a instância histórica e estética, de modo que, caso haja um elemento (ainda que importante como documento histórico) que interfira negativamente na unidade da obra, pode se justificar sua remoção, sempre decidida multidisciplinarmente, registrada e documentada, pois a "restauração deve privilegiar a instância estética ('que corresponde ao fato basilar da artisticidade pela qual a obra de arte é obra de arte')"(BRANDI, 2004, p.12). No caso da 
Cocheira/Museu, novamente, o Plano Diretor informa que decide manter a volumetria de 1966, uma vez que o uso permaneceu, e essas alterações foram predominantemente internas.

Apesar de tais afirmações, notam-se algumas incongruências no projeto executivo em que

o Plano Diretor lista as intervenções do que chama "reabilitação e reconversão arquitetônica" do auditório e da edificação:

- Reconstituição das ornamentações adulteradas na fachada;

- Revelação de três das aberturas originais voltadas para o antigo pátio central;

- Revelação e restituição da abertura da porta posterior, com instalação de nova porta de segurança;

- Consolidação do revestimento original em argamassa de cal com resina própria para recebimento de pintura mineral, e recobrimento com pintura mineral de silicato de potássio;

- Restituição do entelhamento de ardósia, com consequente substituição de parte do madeiramento da cobertura;

- Restauro das esquadrias e repintura nas cores originais com pintura a base de esmalte;

- Eliminação da escada de acesso e do piso espúrio intermediário no prumo do torreão central;

- Adaptação do antigo laboratório no alto do torreão para a instalação de casa de máquinas para ar condicionado;

- Troca de todos os pisos espúrios por pisos de granilite, com soleiras de granito;

- Consolidação dos revestimentos interiores com paralóide a base de resina e recobrimento com nova pintura a base de óleo;

- Remodelação do espaço do auditório, com eliminação da dupla curvatura do piso e sua substituição por plano inclinado com inclinação de $10 \%$, remoção de parte dos lambris de madeira para revelação das aberturas originais, troca de revestimentos de carpete, troca de revestimentos de forro, instalação de painéis refletores acústicos no teto, redesenho do palco com nova escada de acesso e instalação de plataforma elevatória pra p.n.e., troca de poltronas e instalação de nova iluminação;

- Inserção de duas novas portas acústicas e de segurança para acesso e evacuação do auditório. (IBu, 2016, v.3, Memorial Executivo de Restauro, Museu Biológico, p. 44-45)

O Plano, a partir desse Memorial de Restauro, apresenta o projeto para a obra e um Memorial Descritivo, que detalha:

Deverão ser demolidos: a escada de acesso aos pavimentos superiores, o piso intermediário em sua totalidade e parte do piso superior. [...] Todos os pisos e rodapés deverão ser removidos, retirando-se todos os resíduos até o contrapiso, quando não indicada a demolição do próprio contrapiso.. [...]Deverão ser demolidas as paredes de alvenaria, as divisórias e os embasamentos dos expositores. [...] Serão também removidos vedos de alvenaria em trechos das paredes internas, visando a recomposição de alguns vãos originais que foram fechados. [...]Todos os revestimentos das paredes que delimitam o auditório, na face voltada para a área expositiva do museu, deverão ser removidos até a exposição da alvenaria original. [...]Deverá ser executada toda a terraplanagem necessária, incluindo-se as escavações, 
aterros e reaterros, e a remoção dos pisos existentes, para a execução do novo piso do auditório. (IBu, 2016, v.3, Memorial Executivo de Restauro, Museu Biológico, p. 7)

O que se revela nos trechos citados é uma contradição entre o projeto e aquelas premissas de manter os elementos originais ou os documentais da reforma de 1966, pois o auditório de então é modificado em seus elementos estruturais (paredes, forro e inclusive o contrapiso inclinado) bem como são substituídos todos os revestimentos. Nesse caso de tamanha alteração do anfiteatro, cabe indagar se não seria o caso de recuperar a tipologia do pátio original, já que o Plano prevê novos edifícios com instalações mais adequadas no campus, ou se seria melhor deixar essa intervenção de Mammini e de sua equipe mantida em suas principais características (esquema e materiais). A remoção de todos os revestimentos até a exposição da alvenaria original também traz um novo elemento estético que nunca existiu no edifício, de forma que também não mantém os acréscimos como documento histórico, nem recupera o aspecto original. Trata-se portanto de acréscimo de um elemento estético novo, o que não é um problema em si, desde que não ofusque aspectos autênticos da obra para impor uma estética contemporânea. Sobre isso, Jokilehto declara:

Arquitetos geralmente costumam deixar uma marca de sua criatividade na obra em que trabalham, embora ao lidar com construções históricas o princípio seja optar pela humildade e respeito. Essa abordagem não tem sido necessariamente aceita por consenso, e os recentes debates deixam claros os conflitos a esse respeito. Tomando alguns teóricos italianos como exemplo, Renato Bonelli definiu restauro como "um processo crítico seguido por um ato criativo"; Brandi considerou todas as intervenções no preexistente como "restauração", mas aceitou adições criativas de qualidade; De Angelis d'Ossat não excluiu a "inovação" do contexto histórico - desde que não confundida com "restauração". Marco Dezzi Bardeschi insistiu na total preservação do todos os materiais históricos e de seu aspecto antigo. Paolo Marconi, por outro lado, optou pelo uso de formas e tecnologias tradicionais para completar e reintegrar partes perdidas de construções históricas, apoiado em cuidadoso estudo e compreensão das tradições construtivas, registradas nos próprios edifícios, e perpetuadas por manuais de construção adequados. (JOKILEHTO, 2011, pp.312-313, tradução nossa).

As grandes alterações propostas pelo Plano ainda não foram iniciadas no Museu Biológico, mas no final de 2018 foi executada a troca do telhado de cerâmica, pouco posterior à reforma de Mammini, e instaladas novas telhas de ardósia, no intuito de recuperar o mesmo acabamento original da Cocheira, voltando à tonalidade escura e acinzentada desse material rochoso. Nesse caso, recai-se na questão discutida pela Carta e por Brandi sobre o retorno ao 
estado original, tema bastante discutido nas teorias de restauro. O documento de Veneza aborda o tema ao tratar da originalidade e autenticidade da obra:

Artigo $9^{\circ}$. - A restauração é uma operação que deve ter caráter excepcional. Tem por objetivo conservar e revelar os valores estéticos e históricos do monumento e fundamenta-se no respeito ao material original e aos documentos autênticos. Termina onde começa a hipótese; no plano das reconstituições conjeturais, todo trabalho complementar reconhecido como indispensável por razões estéticas ou técnicas destacar-se-á da composição arquitetônica e deverá ostentar a marca do nosso tempo. A restauração será sempre precedida e acompanhada de um estudo arqueológico e histórico do monumento. (CURY, 2004, p.93)

Brandi explicita qual deve ser o momento ao qual se deve reconduzir a obra:

O único momento legítimo que se oferece para o ato da restauração é o do próprio presente da consciência observadora [...]. A restauração, para representar uma operação legítima, não deverá presumir nem o tempo como reversível, nem a abolição da história. (BRANDI, 2004, p.61)

Assim, o autor deixa claro que não é possível retornar ao passado do edifício e, nesse caso, não caberia devolver-lhe a mesma cobertura. Mas nesse caso, há um fator importante, já mencionado, que mostra a duplicidade do monumento, sob a esfera histórica e artística: a troca das telhas de ardósia por cerâmicas, em 1972, não havia ocorrido em todas as coberturas, mantendo-se no torreão as telhas originais. Isso gerou uma falta de unidade visual-cromática que interferiu negativamente no edifício. Apesar da questão histórica, a recuperação dessa identidade estética cromática se tornaria uma decisão coerente do ponto de vista da Teoria da Restauração, que, como foi visto, defende a prevalência da instância estética sobre a documental sempre que houver esse impasse. Porém, nessa reforma as telhas originais que restavam no torreão também foram substituídas, deixando toda a cobertura com aspecto novo.

Segundo Brandi, a prevalência da instância estética não deve levar ao equívoco de "retorno ao original", e sim de restauro da "unidade potencial". No caso, essa unidade do ponto de vista estético poderia ser alcançada substituindo-se apenas as telhas de barro para devolver a unidade cromática, mas não as telhas originais. Segundo a equipe do DEA, as intervenções serão documentadas e será colocada placa no Edifício identificando sua data. 


\subsubsection{Museu Histórico - análise}

A reprodução de um estábulo do século XIX para abrigar o Museu Histórico traz a réplica como tema central, do ponto de vista da preservação e restauro arquitetônico.

A partir desse tema, há uma primeira questão específica, que diz respeito à classificação da obra realizada em 1980. Quanto a isso, os textos-base aqui utilizados não deixam dúvida de que não se tratou de um restauro. O fato de terem sido encontrados, em demolições e escavações, os vestígios do suposto alicerce e de um trecho de parede, não seriam suficientes para configurar uma restauração, pela própria forma de identificação desses vestígios, com escavações não científicas, baseadas em depoimentos de frequentadores antigos e em fotografias que não mostravam tais elementos. E ainda tenham sido verdadeiramente do antigo estábulo (demolido em 1928), a proporção entre tais vestígios e a quantidade de construção nova realizada é muito díspar. Nesse ponto, volta-se ao princípio de Brandi de que a ação de restauro se dá sobre a matéria, no intuito de recuperar sua unidade potencial, sem cometer um falso artístico ou histórico. Portanto, a ausência de matéria sobre a qual aplicar o restauro configura uma reprodução. Não obstante, o termo restauro foi bastante usado na época da fundação do novo edifício (ver Anexo B). Mas após as mencionadas ações de valorização da arquitetura do campus e de sua história, com as Caminhadas Históricas, as pesquisas e publicações do Laboratório de História da Ciência e as atividades do próprio Museu Histórico, os termos "reprodução", "reconstrução" e "réplica" têm sido mais utilizados ${ }^{144}$.

Definida a classificação da construção realizada, cabe a segunda questão que é sobre a pertinência de se reconstruir um monumento desaparecido, no mesmo local, procedimento também conhecido no meio do restauro pelo termo italiano "Com'era dov'era" (como era, onde era). Em princípio, os textos base são claros ao rejeitar a prática da réplica. A Carta de Veneza aborda esse tema, como também o da acuidade de escavações:

Artigo 15 - Os trabalhos de escavação devem ser executados em conformidade com padrões científicos e com a 'Recomendação Definidora dos Princípios

\footnotetext{
${ }^{144}$ O Guia de Arquitetura descreve que se decidiu "reproduzir a edificação original como testemunho do 'mito de origem' da instituição" (MONTEIRO, 2017)
} 
Internacionais a serem aplicados em Matéria de Escavações Arqueológicas', adotada pela UNESCO em 1956.

Devem ser asseguradas as manutenções das ruínas e as medidas necessárias à conservação e proteção permanente dos elementos arquitetônicos e dos objetos descobertos. Além disso, devem ser tomadas todas as iniciativas para facilitar a compreensão do monumento trazido à luz sem jamais deturpar seu significado.

Todo trabalho de reconstrução deverá, portanto, ser excluído a priori, admitindo-se apenas a anastilose, ou seja, a recomposição de partes existentes, mas desmembradas. Os elementos de integração deverão ser sempre reconhecíveis e reduzir-se ao mínimo necessário para assegurar as condições de conservação do monumento e restabelecer a continuidade de suas formas. (CURY, 2004, pp. 94-95)

Brandi é enfático em suas exposições contra as reconstruções, tratando inclusive da reconstrução a partir de ruínas, como é o caso aqui estudado:

Não basta saber como, mesmo se com a mais vasta e minuciosa documentação, a obra era antes de se tornar ruína. A reconstrução, a repristinação, a cópia não podem nem mesmo ser tratadas como tema de restauração, de que naturalmente exorbitam para entrar tão só no campo da legitimidade ou não da reprodução a cru dos procedimentos da formulação da obra de arte. [...]

O restauro Com'era dov'era é a negação do próprio princípio da restauração, é uma ofensa à história e um ultraje à Estética, colocando o tempo como reversível e a obra de arte como reproduzível à vontade. (BRANDI, 2004, p.67-89)

No entanto, o autor faz algumas ponderações que diferenciam os tipos de reconstrução quanto à intenção de falsificação, baseadas na atribuição do valor de autenticidade que essas réplicas venham a receber:

[...] a falsidade se funda no juízo. Ora, o juízo de falso coloca-se como aquele em que é atribuído a um sujeito particular, um predicado, cujo conteúdo consiste na relação do sujeito ao conceito. [...] Portanto, na base da diferenciação entre cópia, imitação e falsificação não está uma diversidade específica nos modos de produção, mas uma intencionalidade diversa. Podem ocorrer, por isso três casos fundamentais:

Produção de um objeto semelhante a, ou reproduzindo, um outro objeto; ou, ainda, no modo e no estilo de um determinado período histórico ou de determinada personalidade artística, para nenhum outro fim a não ser uma documentação do objeto ou o prazer que dele se quer extrair;

Produção de um objeto como referido acima, mas com o intento específico de levar outros ao engano a respeito da época, da consistência material ou do autor;

Imissão no comércio ou, de qualquer modo, difusão do objeto, mesmo que não tenha sido feito com a intenção de levar ao engano, como uma obra autêntica, de época, ou de matéria, ou de fabricação, ou de autores diversos daqueles que dizem respeito ao objeto em si.

Ao primeiro desses casos corresponde a cópia e a imitação, que ainda que conceitualmente não coincidam, representam dois graus diversos no processo de reprodução de uma obra singular ou de retomada de modos ou de um estilo próprio a uma época ou a um determinado autor. O segundo e o terceiro casos individuam as duas acepções fundamentais do falso. (BRANDI, 2004, pp.114-115) 
Por essa classificação, o primeiro caso descrito seria mais relacionado às linguagens “neos", típicas do Ecletismo, mas que também ocorreram nas correntes posteriores da arquitetura. O Museu Histórico estaria mais ligado ao terceiro caso, já que, aparentemente, não houve a má intenção de levar o público ao engano, mas uma convicção dos próprios envolvidos de que se tratava de um restauro do original. Essas acepções do autor não contradizem sua negação da réplica como um tipo de restauro, mas relativizam de certa forma o grau de falsidade dessa réplica em termos de intenção. Essa relativização também é explícita, principalmente para o caso aqui estudado, quando Brandi menciona os usos possíveis das reconstruções:

Ora, nem na sede histórica, nem na sede estética se pode conseguir legitimar a
substituição com uma cópia, a não ser quando a obra de arte substituída tem mera
função integrativa de elemento, e não vale por si só. A cópia é um falso histórico e um
falso estético e por isso pode ter uma justificação puramente didática e rememorativa,
mas não se pode substituir sem dano histórico e estético ao original. (BRANDI, 2004,
p.88)

Nota-se que o autor admite a cópia com uma função educativa, desde que fique explícito não se tratar da obra autêntica. Além disso, reconhece que as reconstruções podem, em si, documentar as predileções de determinada época:

\begin{abstract}
Por isso, a cópia, a imitação e a falsificação espelharão a faceis cultural do momento em que foram executadas e nesse sentido desfrutarão de uma historicidade que se poderia dizer dúplice pelo fato de terem sido concretizadas em um determinado tempo e pelo fato de portarem consigo, inadvertidamente, o testemunho das predileções, do gosto e da moda daquele tempo. Donde a história da falsificação pertence por direito não apenas à história da crítica da arte, porque o falso poderá espelhar a forma particular de ler uma obra de arte e de inferir o estilo que foi próprio a um dado período histórico. (Ibid., p. 117)
\end{abstract}

Como se vê, as réplicas possuem aspectos mais complexos do que a simples rejeição de sua prática. Ademais, a cópia não é um assunto novo e, dependendo da cultura em que se insere, é considerada legítima, como no caso das culturas orientais, nas quais os edifícios sagrados são reconstruídos continuamente. Já na tradição ocidental, a materialidade é tida como elemento fundamental, e não apenas um vetor de um valor abstrato, seja religioso, seja intelectual (como o projeto). Essa posição, que valoriza tanto o significado abstrato, quanto a matéria em si, ainda que predominante, não é consensual. JOKILEHTO (2011) menciona o historiador Giovan Pietro Bellori como um dos preservacionistas neoplatônicos, ainda no século XVII: 
Em 1664, Bellori [...] baseou sua teoria na percepção neoplatônica de 'Ideias das coisas' contida no 'Intelecto Supremo e Eterno' como uma base de criação dos objetos materiais no mundo físico. Enquanto as 'ideias' abstratas e etéreas mantinham sua beleza original, os objetos materiais eram sujeitos a alterações e imperfeições devido à efemeridade dos materiais. (JOKILEHTO, 2011, p.53, tradução nossa)

A partir dessa separação entre "ideia" e "matéria", alguns autores defendem que a autenticidade pode ser reservada ao projeto, ou seja, à concepção abstrata do monumento, sendo a matéria um mero vetor da ideia, o que justificaria a reprodução do objeto material, preservando a mesma "ideia da coisa"145. Um desses autores é Muñoz Viñas, que afirma:

[...] a ideia de que os objetos podem existir em um estado falso não é correta. Todos os estados pelos quais passa um objeto desde sua criação são testemunhos confiáveis e verdadeiros de sua história. Considerar que um deles é mais verdadeiro, mais autêntico que outros, não está objetivamente justificado. [...] Em outras palavras, não há objetos intrinsicamente falsos, e sim objetos mal identificados (VIÑAS, 2010, pp.92-94, tradução nossa)

Essa noção coloca ênfase nos aspectos abstratos e subjetivos do restauro. Ainda que sejam posturas válidas em determinados contextos, a abstração e o subjetivismo totais não são dimensões adequadas para estabelecer normativas e trabalhos multidisciplinares, como é exigido em qualquer ação sobre objetos públicos. Assim, a flexibilidade de Viñas vai de encontro ao defendido pelos textos-base aqui adotados, que usam dados objetivos (tanto quanto possível) para avaliar a autenticidade dos monumentos, na instância histórica e artística.

Para além da questão histórica-artística, tem crescido recentemente a feitura de réplicas de monumentos relacionadas ao turismo, marketing e comércio, nos quais Las Vegas é o maior exemplo, com suas réplicas de cidades históricas europeias. Novas cidades da China também têm reproduzido monumentos emblemáticos (BOSKER, 2013). Mas essas práticas são ligadas, como se disse, à propaganda e ao turismo ${ }^{146}$.

\footnotetext{
${ }^{145}$ Walter Benjamin discute, em seu célebre texto sobre a reprodutibilidade, a eficácia das reproduções na arte contemporânea, defendendo que estas têm muitas vezes alcance maior que a obra original. Mas tais reflexões cabem, segundo o próprio autor, muito mais ao campo do audiovisual e das artes gráficas (BENJAMIN, 1994).

${ }^{146}$ As Normas de Quito, de 1967, resultantes de encontro promovido pela Organização dos Estados Americanos (OEA), deram ênfase ao contexto socioeconômico dos monumentos, estimulando seu uso para ganhos econômicos, por meio do turismo e atração de público. Essas recomendações, embora beneficiem a utilização dos monumentos, trazem, para alguns críticos, o inconveniente de poderem transformá-los em espaços cenográficos e que não respeitem aspectos de autenticidade e envelhecimento intrínseco a eles, fortalecendo um ideal de não conspurcação pelo tempo, de perfeição e de integridade física que não corresponde à realidade.
} 
Existem dimensões mais sofisticadas das réplicas que estão relacionadas diretamente ao restauro e à memória social, tema que é estudado em profundidade por Ascensión Hernández Martínez na obra La clonación arquitectónica (2007). A autora lista algumas reproduções de edifícios assinados por arquitetos célebres (como o Pavilhão da Alemanha em Barcelona, de Mies Van der Rohe, e Pavilhão L'Esprit Nouveau de Le Corbusier em Bolonha), que hoje são desavisadamente tidas como originais por alguns, mas afirma que as cópias podem ser aceitas quando relacionadas a eventos traumáticos, como guerras, catástrofes naturais e acidentes ${ }^{147}$, ação corroborada por cartas patrimoniais (Carta de Burra, 1979, Carta de Cracóvia, 2000) mas que devem ser realizadas criteriosamente, como defende JOKILEHTO (2011):

Se a reconstrução de monumentos não for cuidadosamente controlada, em vez de conservar a historicidade de um sítio antigo de acordo com os desígnios da Carta de Veneza, os resultados correm o risco de se tornarem kitsch. Outro problema da extensa reconstrução em sítios arqueológicos é que [...] ela pode se sobressair demais em um entorno de ruínas; em vez de facilitar a interpretação do sítio, a nova construção pode perturbar a relação entre um monumento isolado e seu contexto histórico. (JOKILEHTO, 2011, pp.308-309, tradução nossa)

No caso do Museu Histórico aqui estudado, não houve evento traumático que causasse seu desaparecimento. Mas ele se coaduna com as intenções didáticas e rememorativas admitidas nos textos citados e, hoje, perto de completar 40 anos, também acumula memórias da comunidade do Instituto, não do estábulo original, mas da história do estabelecimento do próprio MHIB, que se insere no contexto de revalorização do patrimônio do Instituto que ganhou força a partir da década de 1960, conforme já descrito. Novamente, de acordo com os textos e cartas patrimoniais citados, esse valor documental justifica a preservação do Museu a partir de agora, mas não como restauro do antigo estábulo. Acrescente-se que essa reconstrução

\footnotetext{
${ }^{147}$ A reconstrução com'era dov'era de diversos edifícios em Dresden, Praga e outras cidades europeias após a Segunda Guerra, e do Campanário de Veneza em 1912, são exemplos de reconstruções após eventos traumáticos. A Carta de Cracóvia, de 2000, preconiza:

"[...]A reconstrução total de um edifício, que tenha sido destruído por um conflito armado ou por uma catástrofe natural, só é aceitável se existirem motivos sociais ou culturais excepcionais, que estejam relacionados com a própria identidade da comunidade local."

(http://www.patrimoniocultural.gov.pt/media/uploads/cc/cartadecracovia2000.pdf, acessado em 30/11/2018)

No Brasil, o incêndio e colapso do edifício Wilton Paes de Almeida, em São Paulo, juntamente com o desmoronamento parcial da Igreja Luterana ao lado, tem motivado discussões entre a comunidade e os próprios profissionais de restauro sobre a pertinência de reconstruir ou completar tais edifícios com seus aspectos originais (assunto debatido em encontro promovido pelo DPH-PMSP na XIII Semana do Patrimônio, de 14 a 16/08/2018).
} 
não é idêntica àquela, o que se pode notar pela comparação das imagens, pois foi baseada em relatos sujeitos a imprecisões. Assim, não cabe nesse trabalho analisar a pertinência, acuidade ou semelhança entre detalhes construtivos daquele estábulo e desse museu (o que, além de não ser o foco dessa pesquisa, seria impossível), razão pela qual se optou por discutir a questão teórica da reprodução arquitetônica e os casos em que pode ser aceita.

\subsubsection{Remanescentes da fazenda [ruínas] - análise}

Sabe-se hoje que muitas estruturas modestas da fazenda, diferentemente da Casa Sede, permaneceram por muitos anos e algumas permanecem até hoje. Porém, essas estruturas foram modificadas a ponto de se tornarem irreconhecíveis. Outras se encontram cercadas pela mata da porção oeste do campus, de acesso difícil ou proibido por questões de segurança biológica. Por isso, nessa pesquisa, não foi possível identificar e fotografar tais estruturas, sendo as informações sobre elas baseadas nos depoimentos de funcionários. Ainda assim, considera-se importante mencioná-las como base de discussão do problema das ruínas, muitas vezes negligenciadas pelas ações de preservação e restauro, seja na forma de abandono irrestrito, seja na forma de renovações desfigurantes.

A questão das ruínas como patrimônio já foi tratada por diversos teóricos do restauro como Ruskin, Riegl, Brandi, entre outros, por se tratar de um tipo de patrimônio material que termina por ganhar novos significados diante de sua aparente e real degradação. Percebe-se que a identificação e o tratamento das ruínas se transformaram ao longo da história, e os remanescentes da Antiguidade, que se degradavam durante séculos e serviam de modelo de estudo para artistas do Renascimento e do Neoclassicismo eram ruínas de outra natureza em relação aos restos de guerras e catástrofes do século XX. Ou seja, a própria classificação das ruínas possui subdivisões. Além disso, o uso e a forma de conservação que se faz delas também suscita diferentes abordagens. Em seu artigo A problemática da ruína, RODRIGUES se aprofunda no assunto e levanta de que forma diversos teóricos e cartas patrimoniais trataram do tema: 
$\mathrm{Na}$ rede de valorações e atribuições de significado que envolve o conceito de patrimônio cultural, verifica-se que teóricos como Quincy, Riegl, Giovannoni, Pane e Brandi abordam elementos ou integram a problemática da identificação da ruína cuja complexidade implica a confluência dos seguintes aspectos: grau descaracterização da construção, condição de uso e idade das edificações, distanciamento temporal e causas do processo de arruinamento. A partir da constatação dessa intrincada caracterização é que podem ser apresentadas as asserções sobre a preservação da ruína. (RODRIGUES, 2017, p.17)

A autora prossegue exemplificando como cada época tratou de suas ruínas, mencionando o Coliseu e o Arco de Tito (emblemáticos da questão em eu período), e chegando à atualidade, em que autores como Pane e Bonelli defendem a intervenção crítica e criativa, mas de forma respeitosa para com os restos históricos. Brandi, no texto base aqui mencionado, defende:

Ruína será, pois, tudo aquilo que é testemunho da história humana, mas com um aspecto bastante diverso e quase irreconhecível em relação àquele de que se revestia antes[...] Por isso, a restauração, quando voltada para a ruína, só pode ser a consolidação e conservação do status quo, ou a ruína não era uma ruína, mas uma obra que ainda continha uma vitalidade implícita para promover uma reintegração da unidade potencial originária. (BRANDI, 2004, pp. 65-66)

Isso vai de encontro ao que foi realizado em algumas casas na chamada "Fazendinha" (parte oeste do campus), reformadas para servirem de depósitos e áreas de instalações, as quais foram totalmente renovadas, com troca de coberturas, revestimentos e caixilhos, restando vagamente sua volumetria. Já a olaria, conforme fotos da década de 1980 (item 2.3.1), passou a ser obstaculizada pela vegetação circundante e, aparentemente, por movimentação de terra para obras próximas, o que prejudicou a sua legibilidade, mesmo como ruína, assunto tratado no artigo 15 da Carta de Veneza:

Devem ser asseguradas as manutenções das ruínas e as medidas necessárias à conservação e proteção permanente dos elementos arquitetônicos e dos objetos descobertos. Além disso, devem ser tomadas todas as iniciativas para facilitar a compreensão do monumento trazido à luz sem jamais deturpar seu significado. (CURY, 2004, p.94)

O próprio Brandi orientou o projeto de restauro das ruínas da Villa Del Casale, em que estruturas de consolidação e cobertura protegem os mosaicos do piso, permitindo que os visitantes possam observá-los, sem contato direto. No Brasil, sítios como o Engenho São Jorge dos Erasmos, em Santos, São Miguel das Missões no Rio Grande do Sul (com intervenção de Lúcio Costa) e o recém escavado Cais do Valongo, na zona portuária do Rio de Janeiro, são exemplos da valorização desse tipo de remanescente pelos órgãos de proteção do patrimônio, 
geralmente optando pela mínima intervenção e a adição de estruturas contemporâneas anexas para visitantes, iniciativas que poderiam ser estudadas pelo Instituto, já que suas estruturas originárias da Fazenda Butantan certamente possuem um papel relevante como testemunho do mencionado "mito de origem" da instituição (basta lembrar que a antiga olaria forneceu o material para a construção de praticamente todos os primeiros edifícios do núcleo histórico do Instituto), além de constituírem registros de técnicas e formas de cultura de determinada época.

Sabe-se que em Manguinhos há planos de exploração e estudo de ruínas encontradas naquele campus, que incluem restos dos fornos de incineração do final do século XIX. O novo Plano Diretor não trata dessas ruínas, mas sabe-se que o Instituto já incluiu em sua programação educativa da Jornada do Patrimônio, promovida pela PMSP, a atividade de escavação arqueológica, iniciativa que pode indicar o interesse por esse tipo de prospecção.

\subsubsection{Implantação urbanística e paisagística - análise}

Como foi exposto no item 2.3.20, o valor patrimonial cultural do Instituto Butantan não está só em seus monumentos isolados, mas também no seu conjunto como campus de pesquisa, produção e educação na área de saúde, além de ser um equipamento público, funcionando como parque, na zona oeste de São Paulo, aliado à Cidade Universitária da USP, mas com estruturas e escalas diferentes.

Porém, há duas abordagens possíveis quanto ao tratamento desses conjuntos. A primeira, considera-os sob o ponto de vista de entorno dos monumentos. Nesse caso, o foco está nas unidades isoladas, ou seja, nos edifícios, sendo que as áreas envoltórias compõem o contexto estético e histórico do qual tais elementos emergem. A segunda abordagem considera o espaço urbanístico e paisagístico, conjuntamente com as edificações, como um monumento em si. No caso do Instituto Butantan, o processo de tombamento do Condephaat, que protege todo o conjunto do campus, parece dar mais ênfase à primeira abordagem, mencionando os edifícios e seu espaço circundante, referindo-se esporadicamente ao conjunto como um todo. 
Ao tratar da proteção de sítios urbanos, os aspectos valorizados e conservados, bem como as escalas de atuação, devem ser diversos daqueles considerados nos monumentos isolados. RUFINONI, em seu trabalho sobre preservação e restauro urbano, defende que:

[...] devemos atentar para as especificidades de escala, composição e dinâmica evolutiva dos sítios urbanos que inevitavelmente requerem, como temos tratado, a aproximação interdisciplinar, teórica e prática, entre projeto arquitetônico, restauro e urbanismo. Dessa forma, em diferentes escalas de projeto, o processo de transformação e "inovação" deve ser objeto de atenta avaliação e acurada definição projetual; deve ser tratado, portanto, como um problema de restauro que convoca a participação e contribuição de outras disciplinas. (RUFINONI, 2013, p. 313)

Os dois textos-base aqui adotados conciliam as duas abordagens em suas proposições de conservação dos conjuntos urbanísticos e paisagísticos. A Carta de Veneza utiliza os termos "sítios urbanos" ou "sítios monumentais":

Artigo $1^{\circ}$. - A noção de monumento histórico compreende a criação arquitetônica isolada, bem como o sítio urbano ou rural que dá testemunho de uma civilização particular [...].

Artigo 14 - Os sítios monumentais devem ser objeto de cuidados especiais que visem a salvaguardar sua integridade e assegurar seu saneamento, sua manutenção e valorização. Os trabalhos de conservação e restauração que neles se efetuarem devem inspirar-se nos princípios enunciados nos artigos precedentes." (CURY, 2004, pp. $92-$ 94)

Em Teoria da Restauração, Brandi apresenta primeiramente o reconhecimento do valor desses espaços como entorno e contexto da arquitetura:

[...] na arquitetura a espacialidade própria do monumento é coexistente ao espaço ambiente em que o monumento foi construído. Se então, em uma obra de arquitetura como interior, a salvaguarda da dimensão exterior-interior é assegurada só pela conservação do interior, em uma obra de arquitetura como exterior, a dimensão interior-exterior exige a conservação do espaço ambiente em que o monumento foi construído. (BRANDI, 2004, p.132)

Em seguida, o autor acrescenta o valor da dimensão urbana e paisagística em si, equiparando-o ao valor do edifício como elemento unitário:

[...] não apenas a arquitetura, mas também a estrutura urbana possui, por si mesma, significado e valor.[...] No que respeita aos elementos singulares através dos quais se efetua a salvaguarda do organismo em seu conjunto, devem ser levados em consideração tanto os elementos edilícios quanto os outros elementos que constituem os espaços exteriores (ruas, praças etc.) e outras estruturas significativas (muralhas, portas, fortalezas etc.) assim como eventuais elementos naturais que acompanham o 
conjunto, caracterizando-o de modo mais ou menos acentuado (perfis naturais, cursos d'água, singularidades geomorfológicas etc.). (BRANDI, 2004, pp.256-258).

Sobre a preservação e restauro dos tecidos urbanos e paisagísticos, além dos textos-base aqui adotados, outras cartas patrimoniais tratam do tema, com destaque para a Declaração de Amsterdã (1975) e a Carta de Washington (1987) ${ }^{148}$. A primeira defende que:

Os urbanistas devem reconhecer que os espaços não são equivalentes e que convém tratá-los conforme a especificidades que lhes são próprias. O reconhecimento dos valores estéticos e culturais do patrimônio arquitetônico deve conduzir à fixação dos objetivos e das regras particulares de organização dos conjuntos antigos. Não basta sobrepor as regras básicas de planejamento às regras especiais de proteção aos edifícios históricos, sem uma coordenação. (CURY, 2004, pp. 202-203)

A Carta de Washington diz:

Os valores a preservar são o caráter histórico da cidade e o conjunto de elementos materiais e espirituais que expressam sua imagem, em particular:

a. A forma urbana definida pelo traçado e pelo parcelamento;

b. As relações entre os diversos espaços urbanos, espaços construídos, espaços abertos e espaços verdes;

c. A forma e o aspecto das edificações (interior e exterior), tais como são definidos por sua estrutura, volume, estilo, escala, materiais, cor e decoração;

d. As relações da cidade com seu entorno natural ou criado pelo homem;

e. As diversas vocações da cidade, adquiridas ao longo de sua história (Ibid., p.282)

No caso do Instituto Butantan, não se trata de uma cidade histórica, mas nele existem elementos urbanos conforme os mencionados nas cartas citadas, aos quais se podem aplicar essas recomendações. Viu-se que as diretorias do Instituto passaram a atentar mais para a importância da visão de conjunto do espaço edificado a partir da década de 1960, com as obras da Cidade Universitária e a valorização das visitações do campus para turismo e lazer. O desenvolvimento dos planos dessa década e, posteriormente, as tratativas que levaram ao tombamento pelo Condephaat em 1981, incluindo o processo desse órgão, estiveram de acordo, ainda que indiretamente, com os preceitos dos textos-base aqui estudados, pelo menos quanto ao tratamento do núcleo mais antigo do Instituto. Mas foi a partir do novo Plano Diretor que essa visão de conjunto foi sistematizada, incluindo projetos de desenho urbano, sobre os quais

\footnotetext{
${ }^{148}$ A Declaração de Amsterdã resultou do Congresso do Patrimônio Arquitetônico Europeu em 1975. A Carta de Washington (Carta Internacional para a Salvaguarda das Cidades Históricas) foi adotada na Assembleia Geral do ICOMOS em 1987.
} 
se podem levantar algumas questões do ponto de vista preservacionista. Hoje se pode dizer que a implantação urbanística e os aspectos paisagísticos no núcleo histórico original do Instituto estão preservados em sua estrutura espacial e funcional. Não há um marco temporal de definição dessa estrutura, como em geral acontece com as edificações, uma vez que as vias, praças internas, áreas ajardinadas e parques do campus tiveram um processo relativamente longo de configuração, mas pode-se definir a década de 1940 como uma referência, já que os principais equipamentos e um zoneamento de funções já estavam definidos estruturalmente nessa época, bem como o Horto Oswaldo Cruz, a via central e os acessos. Trata-se aqui principalmente do núcleo histórico original, com os primeiros edifícios, que gravitam em torno da alameda principal onde hoje se encontra o Museu de Rua. Já a área de produção e a "Fazendinha" têm dinâmicas diferentes, seja pelas intensas modificações impostas ao núcleo fabril, seja pela área de vegetação inacessível, mais ligada à preservação ambiental. Pelas necessidades funcionais relacionadas a instalações hidráulicas, elétricas e mecânicas, circulação de veículos, drenagem e interferências de instalações com vegetação, diversas alterações pontuais foram realizadas, traduzindo-se em abrigos, casas de máquinas, novos bolsões de estacionamento, retornos, asfaltamentos, postes, calçadas, guaritas e sinalização. Em relação a esses elementos, as recomendações de Brandi sobre as intervenções urbanísticas dão uma base de avaliação:

Os principais tipos de intervenção urbanística são:

a. Reestruturação urbanística. É voltada a verificar e, eventualmente, a corrigir quando necessário, as relações com a estrutura territorial ou urbana com a qual forma unidade. É de particular importância a análise do papel territorial e funcional que o centro histórico desenvolve ao longo do tempo e no presente. Nesse sentido, deve-se dedicar atenção especial à análise e à reestruturação das relações existentes entre centro histórico e desenvolvimentos urbanísticos e edilícios contemporâneos, sobretudo do ponto de vista funcional, com particular referência à compatibilidade de funções diretoras.

b. Reordenação viária. Refere-se à análise e à revisão das conexões viárias e dos fluxos de tráfego que incidem sobre a estrutura, com o fim prevalente de reduzir os aspectos patológicos e de reconduzir o uso do centro histórico a funções compatíveis com as estruturas do passado.

Deve ser considerada a possibilidade de instalação de equipamentos e de serviços públicos estreitamente ligados às exigências de vida do centro.

c. Revisão do mobiliário urbano. Concerne às ruas, às praças e a todos os espaços livres existentes (pátios, espaços interiores, jardins etc.) com o objetivo de obter uma conexão homogênea entre edifícios e espaços externos.

(BRANDI, 2004, p. 260) 
O autor fala de centro histórico se referindo, certamente, ao âmbito total das cidades. No caso do Instituto, seu núcleo mais antigo (até o período de 1940) pode desempenhar esse papel. Como se disse, as alterações sofridas foram pontuais, mas necessitam de regulação para que não haja interferências de maior vulto, como algumas que já aconteceram. Entre elas, podese citar a construção do anexo de administração do Museu de Microbiologia, criando um volume espúrio na paisagem, que veio a ser nomeado informalmente de "feinho" pelos funcionários do Instituto ${ }^{149}$, mostrando sua consciência, mesmo que intuitiva, do valor histórico e estético urbanístico do campus, que deve ser preservado através de práticas como a definição de gabaritos, afastamentos e zoneamento para novas construções. Essa tarefa foi assumida pelo novo Plano Diretor, que, como se sabe, disciplina as novas construções, que devem passar pela análise da equipe da DEA responsável pelo Plano Diretor e pela Comissão Permanente de Acervos formada em novembro de 2017.

Outro um problema permanente que se nota na paisagem do campus, de difícil solução atualmente, é a quantidade de veículos de funcionários e visitantes estacionados nas vias internas, interferindo funcionalmente e visualmente na unidade do conjunto. O novo Plano prevê novos bolsões, e a Divisão de Infraestrutura pretende limitar, futuramente, o tráfego e estacionamento junto aos edifícios e espaços do núcleo histórico.

Sobre as características paisagísticas relacionadas à vegetação, a Carta de Veneza não aborda especificamente o tema, mas pode inferir-se que esteja incluído nas considerações em que usa o termo "sítio". Brandi aborda o tema ao se referir ao exterior como estruturante da unidade dos monumentos:

\footnotetext{
Deve-se precisar, no entanto, que se falou de sítio histórico e não apenas de ambiente monumental, porque do ponto de vista do monumento, também o ambiente natural em que ele se possa encontrar faz as vezes de ambiente monumental; mesmo sendo difícil que se realize a recíproca, que para o ambiente natural possam ser reconhecidas as mesmas exigências de um ambiente monumental. (BRANDI, 2004, p.134)
}

\footnotetext{
${ }^{149}$ Construído entre 2007 e 2010, consta que não houve acordo com o arquiteto Márcio Kogan para que este projetasse o anexo, e a tarefa foi assumida pela equipe de engenharia da época.
} 


\subsubsection{Plano Diretor - análise}

Este elemento, que é na verdade normativo e diretivo, também é abordado pela Carta de Veneza e pela Teoria da Restauração, dando indícios de como deve ser elaborado e aplicado um plano diretor e qual sua finalidade. A Carta trata principalmente do aspecto arquivístico quando fala sobre a documentação das ações preservacionistas, que também pode ser constituída por documentos projetuais:

Artigo 16 - Os trabalhos de conservação, de restauração e de escavação serão sempre acompanhados pela elaboração de uma documentação precisa sob a forma de relatórios analíticos e críticos, ilustrados com desenhos e fotografias. Todas as fases dos trabalhos de desobstrução, consolidação, recomposição e integração, bem como os elementos técnicos e formais identificados ao longo dos trabalhos serão ali consignados. Essa documentação será depositada nos arquivos de um órgão público e posta à disposição dos pesquisadores; recomenda-se sua publicação. (CURY, 2004, p.95)

Como se vê, a Carta se refere ao aspecto documental das ações conservativas, que seria realizado a posteriori. Mas pode ser aplicada ao caso do Plano Diretor aqui estudado, uma vez que este documenta, através de projetos, memoriais descritivos e memoriais de restauro as intervenções que têm sido feitas ou serão realizadas no futuro. Assim, o Plano Diretor atende aos preceitos da Carta de Veneza tanto em relação à documentação das intervenções propostas, quanto aos levantamentos prévios. Sobre esses levantamentos, Brandi manifesta:

A elaboração do projeto para a restauração de uma obra arquitetônica deverá ser precedida de um atento estudo do monumento, feito a partir de diversos pontos de vista (que examinem a sua posição no contexto territorial ou no tecido urbano, os aspectos tipológicos, os traços marcantes e qualidades formais, os sistemas e características estruturais etc.) em relação à obra originária, assim como os eventuais acréscimos ou modificações. Serão parte integrante desse estudo as pesquisas bibliográficas, iconográficas e arquivísticas etc, para obter todos os possíveis dados históricos. O projeto será baseado em um completo levantamento gráfico e fotográfico, a ser interpretado também sob o aspecto metrológico, dos traçados reguladores e dos sistemas de proporção, e compreenderá um acurado e específico estudo para verificar as condições de estabilidade.

A execução das obras pertinentes à restauração dos monumentos, que são, em geral, operações delicadíssimas e sempre de grande responsabilidade e, se possível, conduzida por administração direta, em vez de contabilizada 'por quantidades' ou 'por empreitada'. (BRANDI, 2004, pp. 242-243) 
Em seguida, o autor prossegue detalhando os tipos de intervenções possíveis nos monumentos:

\begin{abstract}
Os principais tipos de intervenção edilícia são:
1. Saneamento estático e higiênico dos edifícios, que tende à manutenção de sua estrutura e a um uso equilibrado da mesma; essa intervenção deve ser realizada em função das técnicas, das modalidades e das diretrizes a que se referem as instruções para conduzir restaurações arquitetônicas. Nesse tipo de intervenção é de particular importância o respeito das qualidades tipológicas, construtivas e funcionais do organismo, evitando-se as transformações que alterem suas características.

2. Renovação funcional dos organismos internos, a ser permitida somente nos casos em que for indispensável aos fins de manutenção em uso do edifício. Nesse tipo de intervenção é de importância fundamental o respeito das qualidades tipológicas e construtivas dos edifícios, proibindo-se todas intervenções que alterem suas características, assim como os esvaziamentos da estrutura edilícia ou a introdução de funções que deformem excessivamente o equilíbrio tipológico-construtivo do organismo. (BRANDI, 2004, p. 261)
\end{abstract}

Finalmente, Brandi menciona os planos como formas de ação operativa para implementar aquelas intervenções:

\footnotetext{
Os instrumentos operativos dos tipos de intervenção edilícia são: -planos diretores gerais, que reestruturem as relações entre centro histórico e território e entre o centro histórico e a cidade em seu conjunto; -planos pormenorizados relativos à reestruturação do centro histórico em seus elementos mais significativos; -planos de execução setorial, referentes a um quarteirão ou a um conjunto de elementos organicamente reagrupáveis. (BRANDI, 2004, p.261)
}

Mas essa gradação de tipos de plano traz à luz uma questão conceitual sobre a natureza de um plano diretor como instrumento orientador/planificador, diferentemente de instrumento interventor/projetual. O Plano de 2016, assim como o de 1966, filia-se ao segundo caso, sendo propositivo, pois apresenta uma série de projetos, muitos em nível executivo, para edifícios e para a implantação urbanística e paisagística, definindo as obras que devem ser feitas, e não as regras que devem ser observadas em obras futuras. Os planos diretores, como o próprio nome diz, estabelecem diretrizes que delimitam as possibilidades de atuação dos agentes em determinado espaço, definindo parâmetros dentro dos quais existe certo grau de possibilidades de ação. Como exemplos, podem-se mencionar os índices mínimos e máximos de área construída, gabaritos de altura de edifícios, porcentagens de área permeável e outros indicadores quantitativos. Também pode haver regulações qualitativas, especialmente no caso da preservação do patrimônio. Os zoneamentos de atividades, estabelecendo quais usos são 
permitidos ou vedados em determinado local, são exemplos de regulações qualitativas. Portanto, um plano diretor é um instrumento definidor de premissas a partir das quais se desenvolve o espaço físico. Esse tipo de plano é comumente elaborado para ordenamento de municípios ${ }^{150}$, mas também se aplica a estruturas espaciais menores ${ }^{151}$. Ocorre que, nessas estruturas menores, é comum que esse plano de premissas e diretrizes se transforme em um compêndio de projetos que estabelecem as transformações e inovações a serem postas em prática (construções, reformas, demolições). Para alguns autores (BUENO; CYMBALISTA, 2007), esse trabalho não deveria ser classificado como "plano diretor". Termos como "plano piloto" (bastante usado em experiências do Movimento Moderno, como Brasília), "plano de obras" ou "caderno de encargos" seriam mais adequados. Mais do que uma discussão semântica, trata-se de como esse plano será posto em prática e influenciará o futuro do espaço planificado. No caso de um plano diretor nos termos apresentados, as intervenções no espaço serão iniciativas dos ocupantes, dentro dos parâmetros estabelecidos, tendo tal plano um tempo de duração indefinido, uma vez que permanece como suporte conceitual às intervenções, que podem ocorrer a qualquer tempo. No caso do plano piloto/de obras, o próprio planejador institui as intervenções, que possuem um tempo de duração, após o qual o plano se conclui e perde o efeito. No campo da administração, essas duas concepções também são diferenciadas como "trabalho regular" e "projeto", sendo o primeiro contínuo, e o segundo com princípio, meio e fim.

No caso do Plano Diretor aqui estudado, verifica-se essa diferença na prática quando se fala de fiscalização das obras realizadas no campus. Como o plano é formado por um conjunto de projetos executivos, as intervenções esporádicas ocorridas no campus não puderam recorrer a um corpo de diretrizes e regras a seguir. Isso ensejou a criação da Comissão Permanente de Acervos (um ano após a finalização desse Plano Diretor), cuja atribuição é analisar caso a caso as propostas de intervenções que forem demandadas pelos departamentos do campus (reformas

\footnotetext{
${ }^{150}$ A lei 10.257 de 10 de julho de 2001 (conhecida como Estatuto da Cidade), exige a elaboração de Plano Diretor para cidades com mais de 20.000 habitantes.

151 Também têm sido cada vez mais implementados os "planos de conservação", envolvendo áreas históricas, que envolvem levantamentos e programas de manutenção e conservação preventiva (KERR, 2013).
} 
e construções necessitadas pelos pesquisadores). Essa comissão sem dúvida é um avanço no campo da preservação, mas revela essa ambiguidade conceitual do Plano de 2016.

Do ponto de vista normativo, também houve queixas de alguns setores do Instituto em relação à falta de diálogo entre os elaboradores do plano e a comunidade do campus. Porém, segundo depoimento dos coordenadores (Alessandro Ventura e Carlos Faggin), e mesmo de alguns funcionários do campus, houve consultas e apresentações ao longo da elaboração do trabalho. O que se verifica é que o formato desse diálogo talvez não tenha atendido a todas as expectativas de determinados setores, o que é comum em uma instituição tão complexa. Ainda assim, em comparação com os períodos precedentes, tem-se hoje a preocupação de pensar o campus em conjunto e considerar a preservação do patrimônio edificado como uma variável importante ao lado das necessidades dinâmicas do Instituto.

Como foi visto, há no plano o objetivo de aglutinar funções semelhantes em zonas específicas, evitando a pulverização e a ineficiência desses usos (figura 193). Em relação à preservação do patrimônio arquitetônico, esse zoneamento implica na retirada de funções laboratoriais dos edifícios do núcleo histórico, proposta que tem sido implantada gradativamente, já que a equipe do setor de Infraestrutura, responsável pelos projetos e fiscalização de alterações, é bastante reduzida. Ainda assim, hoje estão em fase de aprovação nos órgãos responsáveis os projetos de restauro, desenvolvidos pela Divisão de Infraestrutura, convertendo o Edifício Principal, o Pavilhão Lemos Monteiro, a Casa Vital Brazil e a Recepção de Cobras para usos culturais ou administrativos. 

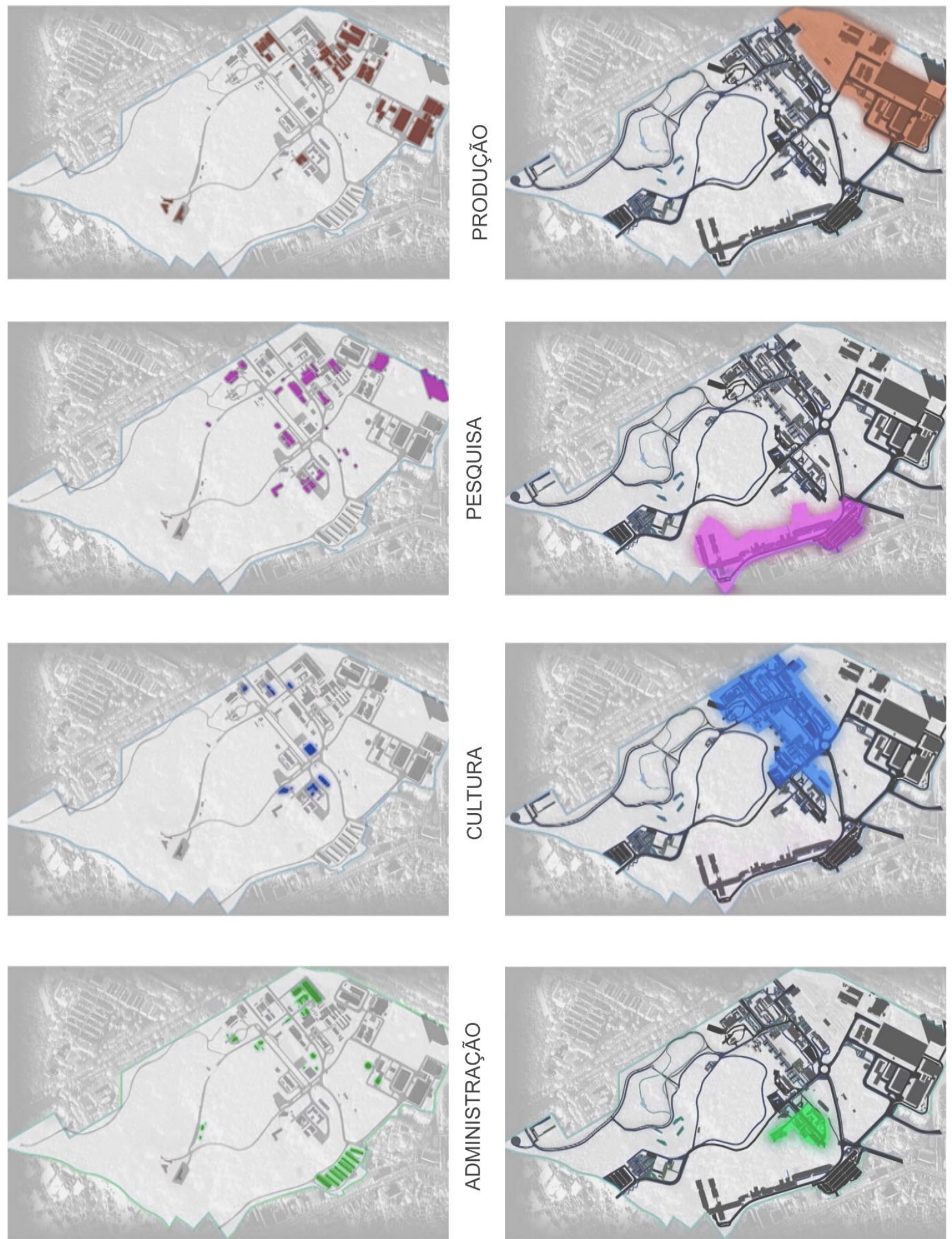

Fig. 193 - Localização atual de usos no campus (à esquerda) e localização proposta pelo Plano Diretor (à direita), s/escala: o objetivo é aproximar as funções correlatas, evitando a dispersão destas. O projeto também propõe alterações no sistema viário e maior ocupação das áreas subutilizadas com trilhas e equipamentos de lazer ${ }^{152}$ (Fonte: DEA-IBu)

${ }^{152}$ Conforme já relatado, esse plano está em revisão e provavelmente deve passar por diversas mudanças, sendo que apenas alguns pontos (reformas e regulações) tem sido implantados gradativamente pela Divisão de Infraestrutura, razão pela qual se optou por não detalhá-lo minuciosamente nessa dissertação, cujo foco foi a preservação do patrimônio arquitetônico de fato existente. 
Considerações finais 
Constatou-se, por meio das pesquisas e análises, que a valorização e a preservação do patrimônio cultural edificado no Instituto Butantan foram construídas paulatinamente ao longo de sua história, tendo alguns marcos que as impulsionaram, como as mencionadas controvérsias territoriais e administrativas, por um lado, e o contexto de reconhecimento crescente do patrimônio da saúde, por outro.

A arquitetura dos institutos de saúde tem sido objeto de crescente valorização tanto pelos órgãos de proteção do patrimônio cultural quanto pelas próprias instituições envolvidas, além da atenção dada pela sociedade em geral. Essa valorização pode ser notada pelo crescente número de processos de patrimonialização, pesquisas relacionadas a esse assunto, publicações, projetos de preservação e restauro e mesmo discussões promovidas em diversas esferas, como nos grupos de moradores de bairro, ex-funcionários e estudiosos do patrimônio da saúde. Essas mudanças são vistas no Instituto Butantan, que especialmente a partir de 2010 tem dado atenção contínua e sistematizada à preservação e divulgação de seu patrimônio arquitetônico.

Essa conscientização nasceu, em grande parte, da atuação de profissionais da área que têm trabalhado pelo reconhecimento da arquitetura da saúde nos últimos 30 anos, entre os quais se podem destacar especialmente as equipes da Casa de Oswaldo Cruz, em Manguinhos, que desde de 1985 desenvolve trabalhos relevantes nesse campo, e as equipes da Divisão Cultural do Instituto Butantan, que através dos seus museus, Núcleo de Documentação, Biblioteca, e Laboratório de História da Ciência participam dessa movimentação. O campus aqui estudado vinha passando por vários anos de ingerências sobre seu território desde 1941, o que provocou as tratativas que culminaram em seu tombamento. Já no início dos anos 2000, as deficiências e disparidades que causaram o incêndio em sua coleção de serpentes levaram a uma conscientização maior da necessidade de preservação de seu patrimônio cultural edificado, culminando com a elaboração do Plano Diretor.

Esse histórico indica como um objeto se torna patrimônio cultural quando seus usuários, sua comunidade e seus apreciadores reconhecem seu valor de patrimônio, e esse reconhecimento pode acontecer por etapas cumulativas de momentos bem identificáveis no tempo. Esse valor pode permanecer latente e difuso por grande períodos, e tornar-se explícito em determinados instantes relativamente definidos, quando há um fato ou conjunto de fatos 
que motivem sua manifestação inequívoca, fatos que muitas vezes podem ser traumáticos, como no caso dos incêndios do Museu da Língua Portuguesa, no Museu Nacional, e o mencionado nesse instituto. Esses momentos-chave, relativamente definidos no tempo, de conscientização do valor patrimonial, são abordados por Brandi quando o autor define a própria restauração como o "momento metodológico do reconhecimento da obra de arte", propondo pela primeira vez uma definição temporal e, portanto, empírica e crítica desse campo de conhecimento, e não apenas idealista. Mas nesse Instituto, embora se tenha mencionado a intenção meramente prática por trás da iniciativa de tombamento, essa ação não seria possível sem a conscientização patrimonial de vários envolvidos, assim como no caso do incêndio.

Assim, não se podem justificar deficiências nas políticas de preservação com as crises econômicas, pois muitas diretrizes (cartas patrimoniais e legislações) surgiram para estabelecer critérios de preservação em meio a crises como guerras, catástrofes naturais e situações excepcionais. Desse modo, as crises não são motivo para o enfraquecimento das políticas de preservação, mas em geral são as ocasiões que as provocam, sendo a falta de recursos um argumento falacioso, se usado isoladamente, ainda mais se considerados os custos muito maiores necessários para reparos de danos causados pela falta de conservação, que podem ser irreparáveis em alguns casos. Mais do que isso, a crise é, não raro, o momento em que o valor patrimonial emerge ao se verificar sua degradação.

Além da importância do conjunto estudado, por documentar a história da ciência e algumas linguagens arquitetônicas, tem-se o valor do campus como tecido urbanístico e paisagístico, que sempre foi reconhecido nas teorias de restauro e tem sido crescentemente considerado pelos órgãos de preservação do patrimônio, haja vista os tombamentos de conjuntos urbanísticos, dos quais o desse instituto faz parte. Em relação à valorização e preservação desse campus como conjunto e não apenas como somatória de monumentos isolados, o atual Plano Diretor do Instituto desempenha papel fundamental nos futuros encaminhamentos. Torna-se necessário, para isso, atentar para a necessidade de abordagem multidisciplinar em relação ao seu patrimônio cultural (preconizada nos textos-base aqui adotados), e promover a participação da comunidade do Instituto nas definições mais importantes, sem o que essas decisões se configuram impositivas e unilaterais. Portanto, assim 
como as forças que atuam para destruir o patrimônio são múltiplas, também devem ser múltiplas aquelas para preservá-lo.

Nesse sentido, transpareceram ao longo da pesquisa as diversas ingerências na preservação ou destruição do patrimônio arquitetônico, destruição em grande parte das vezes evitável e sem justificativas técnicas claras. Essas ingerências surgem em grande parte da condição pública desse Instituto, e da riqueza que ele produz (tanto econômica, quanto científica e cultural), gerando relações institucionais e pessoais por vezes controversas. No entanto, essa própria condição pública é que permite a fiscalização e a transparência através das quais podem ser identificadas tais relações inadequadas. Por outro lado, a atuação das administrações também se mostrou fundamental nas decisões acertadas de estabelecer políticas de preservação do patrimônio, mostrando a importância da gestão adequada, em contraste com decisões meramente pessoais. A gestão do patrimônio arquitetônico no Instituto Butantan tem melhorado na presente década e, como em qualquer instituição desse porte, necessita estar permanentemente atenta à captação e distribuição correta e equilibrada de recursos para seus diferentes setores. Nesse sentido, os exemplos de Manguinhos, com a Casa de Oswaldo Cruz, são um bom ponto de comparação para reproduzir ações bem sucedidas, ou corrigir aquelas inadequadas, estabelecendo trocas de experiências que podem enriquecer a ambas (considerando também que a Fiocruz é uma instituição federal, com diferenças essenciais de recursos e atribuições), e a outras instituições semelhantes.

Por fim, ressalte-se novamente que a preservação da arquitetura da saúde faz parte da valorização da própria história da ciência, da qual participa indissociavelmente, haja vista as iniciativas nacionais e internacionais de reconhecimento e proteção desse patrimônio (Docomomo, Rede Latino-americana de História e Patrimônio Cultural da Saúde, Biblioteca Vitual da Saúde). Assim como no campo das Ciências Biológicas, o campo da Preservação e Restauro avança muitas vezes combinando o encantamento das descobertas (seja de uma espécie, seja de um monumento que não se reconhecia) com a pesquisa rigorosa e continuada, com possíveis desvios que fazem parte desse processo, mas não devem ser repetidos. Nesse sentido, hoje infelizmente se repetem surtos de doenças que já haviam sido consideradas extintas, e espaços são adaptados, construídos ou demolidos às pressas para a premente tarefa 
de debelá-las. Que nessa relativa repetição de fatos, e nas urgências que traz, também se repitam os acertos e se corrijam os erros daquela pequena equipe que chegou à Fazenda Butantan em 1899, preservando-se os testemunhos dessa história.

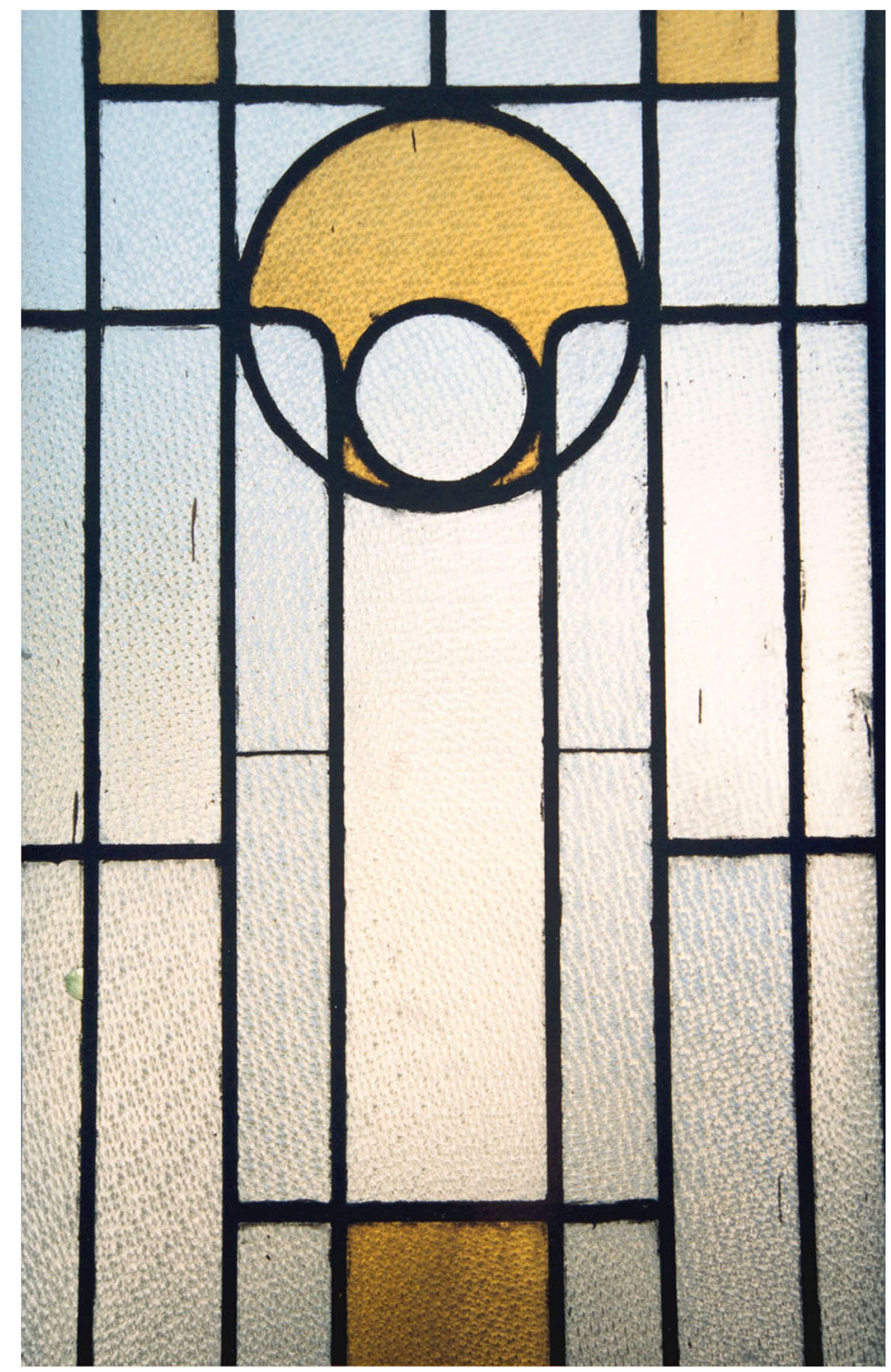

Fig. 194 - Detalhe de janela do Edifício Principal (Fonte: IB_ICO_009078) 
Referências bibliográficas 
ACOSTA, Sabrina. Vital Brazil e o caso da Casa Armbrust, as relações entre a ciência, os cientistas e a gestão em saúde pública. Cadernos de História da Ciência. São Paulo, v.10, n.1, pp.56-76, 2015.

ALBERTI, Leon Battista. Da arte de construir. São Paulo: Hedra, 2012.

ALMEIDA, Adriana Mortara et al. Correspondências administrativas do Instituto Butantan: ofícios e cartas expedidos de 1900 a 1905. Cadernos de História da Ciência. São Paulo, v.10, n.1, pp.93-114, 2015

ALMEIDA, Adriana Mortara. A relação do público com o Museu do Instituto Butantan: análise da exposição 'na natureza não existem vilões'. São Paulo: Dissertação de mestrado, Escola de Comunicações e Artes da Universidade de São Paulo, 1995.

ANDRADE, Antenor; PINTO, Sérgio Correia; OLIVEIRA, Rosilene Santos de (org.). Animais de Laboratório: criação e experimentação. Rio de Janeiro: Fiocruz, 2002.

ARTIGAS, João Batista Vilanova. Sobre Escolas. Acrópole, São Paulo, n.377, ano 32, 1970.

ASSUMPÇÃO, Maurício Torres. A história do Brasil nas ruas de Paris. São Paulo: Casa da Palavra - Leya, 2014.

AZEVEDO, Fernando de. As ciências no Brasil. Rio de Janeiro: UFRJ, 1994.

BARRACLOUGH, Geoffrey. Introdução à história contemporânea. São Paulo: Círculo do livro, 1964.

BENCHIMOL, Jaime L. (coord.). Manguinhos do sonho à vida: A ciência na Belle Époque. Rio de Janeiro: Fiocruz-COC, 1990.

BENCHIMOL, Jaime L; TEIXEIRA, Luiz Antonio. Cobras e lagartos e outros bichos: uma história comparada dos Institutos Oswaldo Cruz e Butantan. Rio de Janeiro: UFRJ, 1993.

BENJAMIN, Walter. A obra de arte na era de sua reprodutibilidade técnica. In BENJAMIN, Walter. Obras escolhidas: magia e técnica, arte e política. São Paulo: Brasiliense, 1994.

BERTUCCI, Liane Maria. Influenza, a medicina enferma: ciência e práticas de cura na época da gripe espanhola em São Paulo. Campinas: Editora Unicamp, 2004.

BITENCOURT, Fábio (Org.). A arquitetura do Instituto Vital Brazil: um patrimônio modernista de saúde: 90 anos de história. Rio de Janeiro: Rio Books, 2009.

BOITO, Camilo. Os restauradores. Cotia: Ateliê Editorial, 2008.

BONDUKI, Nabil. Origens da habitação social no Brasil: arquitetura moderna, lei do inquilinato e difusão da casa própria. São Paulo: Estação Liberdade, 2011.

BOSKER, Bianca. Original copies: architectural mimicry in contemporary China. Honolulu: Hawaii Press, 2013. 
BRANDI, Cesare. Teoria da restauração. Cotia: Ateliê, 2004.

BRAZIL, Oswaldo Vital. Vital Brazil e o Instituto Butantan. Campinas: Unicamp, 1996.

BRAZIL, Vital. Memória histórica do Instituto de Butantan. São Paulo: Elvino Pocai, 1941.

BRUNA, Paulo Júlio Valentino. Os primeiros arquitetos modernos: habitação social no Brasil 1930-1950. São Paulo: Edusp, 2010.

BUFFA, Ester; PINTO, Gelson de Almeida. O território da universidade brasileira: o modelo de câmpus. Revista Brasileira de Educação. Rio de Janeiro, v.21, n.67, pp. 809-831, dez. 2016 .

BURKE, Peter (org.). A escrita da história: novas perspectivas. São Paulo: Unesp, 2011.

BUZZAR, Miguel Antonio; CAMARGO, Mônica Junqueira de; CORDIDO, Maria Tereza Regina Leme de Barros. Os significados da mudança de paradigma arquitetônico advindo com o Plano de Ação de Governo de Estado/SP (Page) na gestão Carvalho Pinto (1959-1963). 11 ${ }^{\circ}$. Seminário Docomomo - O campo ampliado do Movimento Moderno, Recife, 2016.

BUZZAR, Miguel Antonio; CORDIDO, Maria Tereza Regina Leme de Barros; SIMONI, Lucia Noemia. A arquitetura moderna produzida a partir do Plano de Ação do governo Carvalho Pinto-Page-(1959/1963). Revista Arq.urb-Universidade São Judas Tadeu, São Paulo, n.14, pp. 157-170, 2015.

CAMARGO, Mauro Álvaro de Souza Camargo. Hospitaes. São Paulo: Escolas Profissionais Salesianas, 1930.

CAMARGO, Mauro Álvaro de Souza. Projectos de grupos, escolas reunidas e ruraes. São Paulo: Serviço Sanitário, 1920.

CAMARGO, Mônica Junqueira de. Inventário dos bens culturais relativos ao Plano de Ação do Governo Carvalho Pinto (1959-1963). Revista CPC. São Paulo, n.21, pp.164-203, 2016.

CANTER, Henrique Moisés. Museu Histórico: origem e memória. Cadernos de História da Ciência. São Paulo, v.1, n.1, pp.63-81, 2005.

CARBONARA, Giovanni. Avvicinaento al restauro. Napoli: Liguori, 1997.

CASTRO SANTOS, Luiz Antonio de. Power, ideology and public health 1889-1930. Cambridge: Harvard University, 1987.

CHOAY, Françoise. A alegoria do patrimônio. São Paulo: Estação Liberdade, 2001.

CONDEPHAAT. Processo de Tombamento 21306/80: Instituto Butantan. São Paulo: Condephaat, 1981.

COSTA, Renato da Gama-Rosa (org.). Caminhos da Arquitetura em Manguinhos. Rio de Janeiro: Fiocruz-COC; FAPERJ, 2003. 
COUTO, Edgard Tadeu Dias do. Vila Penteado: A Inspiração de Uma Ideia. In: MARTINS, Maria Lucia Refinetti Rodrigues (org.). Vila Penteado 1902-2012: Pós-Graduação 40 Anos. São Paulo: FAUUSP, 2012.

CRIPPA, Maria Atonietta. Storie e storiografia dell'architettura dell'ottocento. Milão: Jaca Book, 1994.

CUNHA, Fernanda Craveiro. Pedra fingida: protagonista invisível do centro de São Paulo. São Paulo: GAPS, 2017.

CURY, Isabelle (org.). Cartas patrimoniais. Rio de Janeiro: Iphan, 2004.

CYTRYNOWICZ, Monica Musatti; CYTRYNOWICZ, Roney; STÜCKER, Ananda. Do Larazerto dos Variolosos ao Instituto de Infectologia Emilio Ribas: 130 anos de história da saúde púbica no Brasil. São Paulo: Narrativa Um, 2010.

DANTES, Maria Amélia M. Espaços da ciência no Brasil: 1800-1930. Rio de Janeiro: Editora Fiocruz, 2001.

DIAS, Carlos Eduardo Sampaio Burgos. As relações Brasil-França na criação do Instituto Butantan. Cadernos de História da Ciência, São Paulo, v. 6, n. 1, pp107-127, jul. 2010 .

DVOŘÁK, Max. Catecismo da preservação de monumentos. Cotia: Ateliê Editorial, 2015.

EMPLASA. Memória urbana: a grande São Paulo até 1940 (v. 1, 2 e 3). São Paulo: Arquivo do Estado, Imprensa Oficial, 2001.

FABRIS, Annateresa (org.). Ecletismo na Arquitetura Brasileira. São Paulo: Nobel, 1987.

FABRIS, Annateresa. Arquitetura eclética no Brasil: o cenário da modernização. Revista Anais do Museu Paulista, São Paulo, n.1, p.131, pp.131-143, 1993.

FEIJÃO, Rosane. Moda e modernidade na belle époque carioca. São Paulo: Estação da Letras e Cores, 2011.

FERRAZ, Marcelo Carvalho (org.). Lina Bo Bardi. São Paulo: Instituto Lina Bo e P. M. Bardi, 1993.

FICHER, Sylvia. Os arquitetos da Poli: ensino e profissão em São Paulo. São Paulo: Edusp, 2005.

FIOCRUZ. Plano de ocupação da área de preservação do campus Fiocruz Manguinhos. Rio de Janeiro: Fiocruz-COC, 2011.

FONSECA, Flávio da. Instituto Butantã: sua origem, desenvolvimento e contribuição ao progresso de São Paulo. Capítulo in INSTITUTO HISTÓRICO E GEOGRÁFICO DE SÃO PAULO. São Paulo em quatro séculos. São Paulo: Instituto Histórico e Geográfico, 1954.

FREYRE, Gilberto. Ordem e Progresso. Rio de Janeiro: Record, 2000. 
GÓES, Ronald de. Manual prático de arquitetura para clínicas e laboratórios. São Paulo: Blucher, 2010.

GUALTIERI, R.C. O Instituto Butantan e a saúde pública (São Paulo: 1901-1927). São Paulo: Dissertação de mestrado, Faculdade de Educação da Universidade de São Paulo, 1994.

HOEHNE, F.C. Album da seç̧ão de botanica do Museu Paulista e suas dependencias, etc. São Paulo: Imprensa Methodista Editora, 1925.

HUGO, Victor. Notre-Dame de Paris - 1482. São Paulo: Estação Liberdade, 2011.

IBAÑEZ, Nelson; SANT'ANNA, Osvaldo Augusto. Instituto Butantan: a pesquisa e o desenvolvimento tecnológico da Saúde em São Paulo. In NATALINI, Gilberto (org). 450 anos de história da medicina paulista. São Paulo: Imprensa Oficial, 2004.

IBAÑEZ, Nelson; WEN, Fan Hui; FERNANDES, Suzana C. G. Instituto Butantan: história institucional. Desenho metodológico para uma periodização preliminar. Cadernos de História da Ciência. São Paulo, v. 1, n. 1, pp.115-144, 2005.

INSTITUTO BUTANTÃ. Plano Diretor do Instituto Butantã. São Paulo: IBu, 2016.

INSTITUTO BUTANTAN. 100 anos de Instituto Butantan. São Paulo: IBu, 2001.

JOKILEHTO, Jukka. A history of architectural conservation. Oxford: Butterworth-Heinemann, 2011.

JUNIOR, Jefferson de Lara Sanches. O desenvolvimento da política científica e tecnológica na Primeira República (1889-1930): uma análise a partir dos institutos de pesquisa paulistas e federais. Cadernos de História da Ciência. São Paulo, v. 8, n. 1, pp.107-124, jun. 2012.

KAMIDE, Edna Hiroe Miguita (coord.). Patrimônio cultural paulista: Condephaat, bens tombados, 1968-1998. São Paulo: Imprensa Oficial do Estado, 1998.

KERR, James Semple. Conservation Plan 2013. A guide to the preparation of conservation plans for places of European cultural significance. Australia ICOMOS. Disponível em http://australia.icomos.org/wp-content/uploads/The-Conservation-Plan-7th-Edition.pdf.

KOPP, Anatole. Quando o moderno não era um estilo e sim uma causa. São Paulo SP, Nobel, 1990.

KÜHL, Beatriz Mugayar (org.). Gustavo Giovannoni. Textos escolhidos. Cotia: Ateliê Editorial, 2013.

História e ética na conservação e na restauração de monumentos históricos. Revista CPC, n.1, p.16-40, 1 abr. 2006.

LANNA, Ana Lúcia Duarte (org.). Cidades universitárias: patrimônio urbanístico e arquitetônico da USP. São Paulo: CPC-USP, Edusp, 2005. 
LATOUR, Bruno; WOOLGAR Steve. Laboratory Life: The Social Construction of Scientific Facts. Los Angeles: Sage, 1986.

LEMOS, Carlos A. C. Alvenaria burguesa: breve história da arquitetura residencial de tijolos em São Paulo a partir do ciclo econômico liderado pelo café. São Paulo: Nobel, 1985.

LOPES, Maria Margaret. O Brasil descobre a pesquisa científica: os museus e as ciências naturais no século XIX. São Paulo: Hucitec, 2009.

MARTÍNEZ, Ascención Hernández. La clonación arquitectónica. Madrid: Siruela, 2007.

MELLO, Débora Luz de. Análise de processos de reorganização de institutos públicos de pesquisa do Estado de São Paulo. Campinas: Tese de Doutorado, UNICAMP, 2000.

MIURA, Priscila Miyuki. Quadrilátero da Saúde: espaço de ensino, pesquisa e saúde pública em São Paulo. São Paulo: Dissertação de Mestrado, FAU-USP, 2012.

MONTEIRO, Flávia A.; RIBEIRO, Nelson P. O patrimônio cultural da saúde: reconhecimento, preservação e mapeamento dos bens tombados no Brasil. Revista Forum Patrimônio, Belo Horizonte, v.6, n.1, jan/jul. 2013.

MONTEIRO, Paulo Henrique Nico (org.). Guia de arquitetura do Butantan. São Paulo: Instituto Butantan; Centro de Desenvolvimento Cultural, 2017.

MOTOYAMA, Shozo (org.). Prelúdio para uma história: ciência e tecnologia no Brasil. São Paulo: EDUSP, 2004.

MOTT, Maria Lucia; SANGLARD, Gisele (org.). História da saúde em São Paulo: instituições e patrimônio arquitetônico (1898-1958). Barueri: Fiocruz/Manole, 2011.

MOTTA, Flávio L. São Paulo e o Art Nouveau. Habitat, São Paulo, n.10, pp.3-18, 1953.

NASCIMENTO, Flávia Brito do. Blocos de memórias: habitação social, arquitetura moderna e patrimônio cultural. São Paulo: Edusp/Fapesp, 2016.

. Patrimônio Cultural e escrita da história: a hipótese do documento na prática do Iphan nos anos 1980. Anais do Museu Paulista, São Paulo, v. 24, n. 3, p. 121-147, dez. 2016.

OLIVEIRA, Benedito Tadeu de (coord.); COSTA, Renado da Gama-Rosa; PESSOA, Alexandre José de Souza. Um lugar para a ciência: a formação do Campus de Manguinhos. Rio de Janeiro: Fiocruz, 2003.

OLIVEIRA, Jandira L.; Cronologia do Instituto Butantan: 1888-1981 in Memórias do Instituto Butantan, v.44/45, p.11-79, 1981.

PACCE, MÁRUA ROSENY. A propósito da Casa do Bandeirante. Revista do Arquivo Municipal, São Paulo, ano 43, n. 193, pp.3-50, 1980 
PAIVA, Luiz Miller de. História científica do Intituto Butantan. São Paulo: Departamento do Serviço Público, Serviço de Documentação, 1946.

PINHEIRO, Marcos J.A. et al. Metodologia e tecnologia na área de manutenção e conservação de bens edificados: o caso do Núcleo Arquitetônico Histórico de Manguinhos. Rio de Janeiro: Casa Oswaldo Cruz, 2009.

PINHEIRO, Maria Lucia Bressan. Neocolonial, modernismo e preservação do patrimônio no debate cultural dos anos 1920 no Brasil. São Paulo: EDUSP, 2012.

Origens da noção de preservação do patrimônio cultural no Brasil. Rev. Risco, São Carlos, no. 3, pp.4-15, 2006.

PORTO, Angela et al. História da saúde no Rio de Janeiro: instituições e patrimônio arquitetônico (1808-1958). Rio de Janeiro: Fiocruz, 2011.

REIS FILHO, Nestor Goulart. Victor Dubugras: precursor da arquitetura moderna na América Latina. São Paulo: EDUSP, 2005.

RIEGL, Alois. O culto moderno dos monumentos: a sua essência e a sua origem. São Paulo: Perspectiva, 2014.

RODRIGUES, Angela Rosch. A problemática da ruína: das teorias da preservação patrimonial do século XIX ao restauro crítico. Revista CPC, n. 24, pp.9-34, dez. 2017

RODRIGUES, Marly. Imagens do passado: a instituição do patrimônio em São Paulo: 1969-1987. São Paulo: UNESP / Imprensa Oficial / CONDEPHAAT / FAPESP, 2000.

ROULEAU, Bernard. Villages et Faubourgs de L'ancien Paris. Histoire d'un espace urbain. Paris: Éd. Seuil, 1985.

RUSKIN, John. A lâmpada da memória. Cotia: Ateliê Editorial, 2015.

SALDAÑA, Juan José; PRIEGO, Natalia. Entrenando a los cazadores de microbios de la república: la domesticación de la microbioología en México. Revista QUIPU, Cidade do México, n. 2, v. 13, Maio-Agosto 2000.

SALVATORE, Waldir. Ecletismo paulista italiano e nosso: Felisberto Ranzini e o "estilo florentino”. São Paulo: Cultura Acadêmica, 2015.

SCHWARCZ, Lilia Moritz; STARLING, Heloisa Murgel. Brasil: uma biografia. São Paulo: Companhia das Letras, 2015.

SEGAWA, Hugo. Arquiteturas no Brasil 1900-1990. São Paulo: Edusp, 2002.

Moderno, peregrino, educador - Documento Hélio Duarte. Arquitetura e Urbanismo, São Paulo, n. 80, pp.59-64, out.-nov., 1998. 
SERRES, Juliane Conceição Primon. Preservação do patrimônio cultural da saúde no Brasil: uma questão emergente. Rev. História, Ciências, Saúde - Manguinhos, Rio de Janeiro, v.22, n.4, p.1411-1426, out.-dez. 2015.

SEVCENKO, Nicolau. A Revolta da Vacina. São Paulo: Cosac Naify, 2010.

SIGAUD, J.F.X. Du climat e des maladies du Brésil ou statistique médicale de cet empire. Paris: Chez Fortin, Masson et Cle, libraries, 1844.

SILVA, Maurício Candido. Christiano Stockler das Neves e o Museu de Zoologia da Universidade de São Paulo. São Paulo: Dissertação de mestrado, FAU-USP, 2006.

TEIXEIRA, Luiz Antonio. A trajetória do Instituto Butantan: pesquisa e produção de imunobiológicos para a saúde pública. Rev. Brasileira de Inovação, Campinas, n.15, pp.165-174, jan-jun 2016.

. Pesquisa biomédica e produção de imunobiológicos em São Paulo: um duelo entre o público e o privado. Cadernos de História da Ciência, São Paulo, v. 2, n. 1, pp.105-123, 2006.

TELAROLLI JUNIOR, Rodolpho. Poder e saúde: as epidemias e a formação dos serviços de saúde em São Paulo. São Paulo: UNESP, 1996.

TOLEDO, Benedito Lima de. São Paulo, três cidades em um século. São Paulo:Cosac Naify, 2004. . Victor Dubugras e as atitudes de inovação em seu tempo. São Paulo: Tese de Livre Docência, FAU-USP, 1985.

TOLEDO, Roberto Pompeu de. A capital da vertigem: uma história de São Paulo de 1900 a 1954. Rio de Janeiro: Objetiva, 2015.

TURNER, Paul V. Campus: An American tradition. Cambridge: MIT Press, 1984.

VAZ, Eduardo. Fundamentos da história do Instituto Butantan: Seu Desenvolvimento. São Paulo: ERGT, 1949.

VIDEIRA, Antonio Augusto Passos. Rio científico: inovação e memória. Rio de Janeiro: EDUERJ, 2010.

VIOLLET-LE-DUC, Eugène Emmanuel. Restauração. Cotia: Ateliê Editorial, 2000.

WAISMAN, Marina. O interior da História. São Paulo: Perspectiva, 2013.

WATKIN, David. Morality and Architecture. Oxford: Clarendon, 1977.

XAVIER, Priscila de Almeida. Representação cinematográfica e história institucional: uma análise de filmes sobre o Instituto Butantan (1928 - 1953). São Paulo: Dissertação de mestrado, ECA-USP, 2010. 


\section{Fontes primárias:}

- Relatórios anuais do Instituto Butantan, anos 1901 a 2016 (NDoc - IBu).

- Desenhos técnicos do acervo cartográfico, anos 1901 a 1980 (NDoc - IBu).

- Informes do Instituto Butantan, n.1-ano 1983 a n.185-ano 2012.

- Acervo de fotografias, anos 1901 a 2017 (NDoc - IBu).

- Acervo de material expositivo e documental (MHIB - IBu).

- Acervo documental do Instituto Lina Bo Bardi.

- Acervo de desenhos do CPOS-SP.

- Acervo de desenhos da Biblioteca FAU-USP.

- Acervo da SEF-USP.

- Departamento de arquivo e documentação - Fiocruz, COC.

- Arquivo Geral da Cidade do Rio de Janeiro.

- Hemeroteca Digital da Biblioteca Nacional.

\section{Depoimentos:}

- Adriana Mortara - historiadora, diretora do Museu Histórico do IBu.

- Alessando Ventura - arquiteto, coordenador do Plano Diretor de 2016.

- Ana Piza Soares - filha do arquiteto Mário Rosa Soares, do FCCUASO e IBu de 1960 a 1994.

- Carlos Faggin - arquiteto, coordenador de restauro do Plano Diretor de 2016.

- Carlos Heck - arquiteto do FCCUASO de 1965 a 1967.

- Caroline Tonacci Costa - arquiteta do DEA-Núcleo de Arquitetura e Urbanismo - IBu.

- Cristiano Azevedo Marques - pesquisador do Laboratório de História da Ciência - IBu.

- Daniel Moreira - arquiteto, do DPH da COC - Manguinhos.

- José Roberto Siqueira - morador do Núcleo Residencial e funcionário do IBu.

- Maria Brazil - neta de Vital Brazil e médica, trabalhou no Instituto de 1944 a 1953.

- Osmar Mammini - arquiteto, trabalhou no FFCUASO e IBu de 1965 a 1981.

- Osvaldo Sant'Anna Jr. - historiador do MHIB - IBu.

- Paulo Henrique Monteiro - coordenador do Centro de Ensino - IBu.

- Rogério Bertani - aracnólogo do Laboratório de Ecologia e Evolução - IBu.

- Sérgio de Simone - arquiteto do Laboratório de História da Ciência - IBu.

- Suzana Gouveia Fernandes - historiadora, diretora do Núcleo de Documentação - IBu.

- Tadeu Foa - arquiteto do DEA-Núcleo de Arquitetura e Urbanismo - IBu.

\section{Periódicos}

- Diário Oficial do Estado de São Paulo, São Paulo.

- Jornal Correio Paulistano, São Paulo.

- Jornal da Tarde, São Paulo.

- Jornal Folha de São Paulo, São Paulo.

- Jornal O Estado de São Paulo, São Paulo.

- Pós - Revista do Programa de Pós-Graduação FAUUSP, São Paulo. 
- Revista Acrópole, São Paulo.

- Revista Arquitetura e Urbanismo, Editora PINI, São Paulo.

- Revista Adusp, Associação dos Docentes da USP, São Paulo.

- Revista Cadernos de História da Ciência, Instituto Butantan.

- Revista Arquitetura e Construção, Editora Abril, São Paulo.

- Revista de Engenharia, São Paulo.

- Revista do Patrimônio Histórico e Artístico Nacional, Iphan, Brasília.

- Revista História, Ciências, Saúde, Casa Oswaldo Cruz - Fiocruz, Rio de Janeiro.

- Revista Médica de São Paulo, São Paulo.

- Revista dos Constructores, Rio de Janeiro.

Principais sítios da Internet (acessados entre março/2017 e fevereiro/2019)

- Biblioteca Virtual em Saúde: http://brasil.bvs.br

- Biblioteca Virtual Oswaldo Cruz: http://www.dichistoriasaude.coc.fiocruz.br

- Casa de Oswaldo Cruz: http://www.coc.fiocruz.br

- Condephaat: http://condephaat.sp.gov.br

- Conpresp: http://www.prefeitura.sp.gov.br/cidade/secretarias/cultura/conpresp/

- Dicionário Histórico-Biográfico das Ciências da Saúde no Brasil (1832-1930): http://www.dichistoriasaude.coc.fiocruz.br

- Fiocruz: http://portal.fiocruz.br

- Instituto Butantan: http://www.butantan.gov.br

- Instituto Pasteur: http://www.pasteur.fr

- Iphan: http://www.iphan.gov.br

- Prefeitura de São Paulo: http://www.capital.sp.gov.br

- Secretaria de Saúde do Estado de São Paulo: http://www.saúde.sp.gov.br 
Anexos 


\section{ANEXO A - Relatório Anual do Instituto Butantan, 1961, pp. 1 a 10}

O Instituto Butantan vem, desde alguns anos, sentindo a necessidade de organizar-se de modo tal que suas construções deixem de ser meros apêndices de prédios maiores, construídos com economia e sem obediência a preceitos estéticos e urbanísticos.

Para fazê-lo de acôrdo com preceitos arquitetônicos e integral aproveitamento da área de que dispõe, sentiu o Instituto que era indispensável pensar quanto antes em um Plano Diretor das construções a serem daí em diante levadas a efeito.

Com êsse intuito, conseguiu a Diretoria do Instituto que fosse colocado à disposição do mesmo o Arquiteto Carlos Alberto Cerqueira Lemos que, articulando-se com o Dr. Aristides Vallejo-Freire, assistente do Instituto Butantan, fêz um levantamento topográfico e uma avaliação das necessidades da entidade. Vários estudos foram realizados e plantas foram apresentadas desde 1953.

Em 1958, com a Diretoria do Dr. Luiz Augusto Ribeiro do Valle, tomou impulso a idéia do Plano Diretor, tendo em 1959 na vigência da atual Diretoria, passado para o Arquiteto Rubens Gouveia Carneiro Vianna, os trabalhos de projetos do referido plano.

Nesta ocasião, baseado no Plano Diretor, o Arquiteto Rubens Gouveia Carneiro Vianna começou a planejar os edifícios que a atual Diretoria julgava necessários. Esta última orientação estava ligada à determinação governamental de realizar, dentro do Plano de Ação do Govêrno, uma série de obras que redundariam na transformação total do Instituto Butantan, ao mesmo tempo que se aproveitariam os edifícios com valor técnico ou histórico indiscutível.

Mediante dados colhidos de vários especialistas do Instituto Butantan foi idealizado um Plano Piloto para sua remodelação e urbanização, o qual deveria ser pôsto em concurso público.

Tal concurso incluiria o seguinte programa:

a) plano geral de zoneamento e de regulamentação do uso de tôda a área do Instituto na escala 1:1.000. Deveriam ser previstas zonas destinadas aos setores relativos às seguintes atividades: Administração, Oficinas, Biotério, Produção Industrial, Pesquisa, Biblioteca-Auditório, Turismo e Residencial. A zona reservada ao Turismo deveria incluir o atual serpentário e a antiga cavalariça, de reputado valor arquitetônico, que deveria ser futuramente reformada e adaptada para Museu de caráter específico e elucidativo, sôbre assuntos ligados ao Butantan.

b) traçado das ruas, avenidas e outros logradouros públicos que deveriam atender às necessidades funcionais do Instituto, preservando sempre que possível os aspectos paisagísticos que oferecem a topografia e a flora locais.

c) no Plano Geral, deveria constar a locação dos seguintes edifícios:

1 - Biotério, com área aproximada de $3.500 \mathrm{~m}^{2}$.

2 - Produção, com área aproximada de $19.000 \mathrm{~m}^{2}$, divididos em 4 blocos:

$1^{\circ}$. Serviços Gerais - $10.000 \mathrm{~m}^{2}$

$2^{\circ}$. Laboratório de Bacteriologia e Imunoterapia $4.000 \mathrm{~m}^{2}$

$3^{\circ}$. Laboratório de Virusterapia $-3.000 \mathrm{~m}^{2}$

$4^{\circ}$. Laboratório de Quimioterapia - $2.000 \mathrm{~m}^{2}$

3 - Hospital Vital Brazil, com área aproximada de $2.000 \mathrm{~m}^{2}$

4 - Pesquisa, com área aproximada de $6.000 \mathrm{~m}^{2}$

5 - Biblioteca para 200.000 volumes e conjunto “Auditório-Sala de Projeção"

6 - Restaurante-bar

7 - Gazómetro, para abastecimento dos edifícios de Pesquisa e Produção

8 - Pôsto de abastecimento, lavagem e oficina mecânica de veículos

9 - Tipografia e Oficinas de Carpintaria, Serralheria, Eletricidade, Hidráulica, Pintura, Vidraria e de Obras destinadas à conservação do patrimônio do Instituto, com área de aproximadamente $1.200 \mathrm{~m}^{2}$.

Previu-se ainda a construção de cem residências com acesso independente para via pública.

Dentro dêste plano, o Arquiteto Rubens Carneiro Vianna, em contacto direto com a atual Diretoria do Dr. Flávio da Fonseca, que designou como Assistente Técnico o Consultor junto ao setor de planejamento o Dr. Reynaldo Schmindt Furlanetto, projetou um Biotério para criação de animais dentro dos mais atualizados moldes 
científicos e arquitetônicos. Nesta ocasião, sentindo que adviriam dificuldades de entrega à Diretoria de Obras Públicas da Secretaria da Viação dos ante-projetos que fossem preparados no Instituto Butantan, pois já o DOP estava superlotado com projetos de obras que não conseguia levar adiante, expôs à Diretoria do Instituto, por várias vezes à Secretaria de Saúde, os seus temores, mesmo porque o ante-projeto de Biotério de pequenos animais entrege ao DOP levara longo tempo transitando até ser transformado em planta.

Foi então que surgiu a determinação do Senhor Governador de entregar as obras do Instituto Butantan aos cuidados da Comissão do Fundo para Construção da Cidade Universitária, cuja forma de trabalho permitiria rápidos contactos e conhecimento dos problemas urbanísticos do Instituto, pois já se achavam iniciadas as obras da Cidade Universitária nos terrenos cedidos pelo Instituto Butantan.

Receiosa de que o entrosamento no Plano para Construção da Cidade Universitária viesse redundar em cessão, pelo Instituto Butantan, de área ainda maior à Cidade Universitária, a atual Diretoria do Instituto fêz ênfase, em reuniões e representações, na necessidade de não mais ser o Instituto espoliado em sua propriedade, já tornada pequena pela mutilação até então sofrida.

Havia também o perigo do Instituto Butantan ser diluido durante a organização da Cidade Universitária, instituição complementar que é da Universidade de São Paulo, vindo a perder as suas características fundamentais e únicas no país, de incluir um conjunto de técnicos interessados em pesquisas de fisiopatologia humana, na ciência aplicada na produção de medicamentos que atendem e previnem a saúde pública, na divulgação de conhecimentos através de cursos e estágios ministrados a interessados de todo o mundo, no pioneirismo de estudos diversos sôbre a fauna e a flora do país, na atualização de conhecimentos da ciência nos diferentes ramos de seu interêsse.

O Instituto Butantan, como entidade "sui generis", não poderia correr o perigo de perder suas características e finalidades.

Foi por isso aventada a idéia de estabelecer um convênio em que ficasse taxativamente estabelecido que haveria apenas um compromisso de entrosamento paisagístico e urbanistico, sem qualquer interpenetração, respeitada a autonomia das duas entidades. Eis o teor integral dêsse instrumento:

\section{"CONVÊNIO}

Em 7 de Julho de 1961, no salão da Diretoria do Instituto Butantan, com a presença dos Senhores: Secretário da Saúde Pública e da Assistência Social, Dr. Fauze Carlos; Magnífico Reitor da Universidade de São Paulo, Prof. Antonio Barros de Ulhôa Cintra; Presidente do Fundo para Construção da Cidade Universitária, Prof. Paulo de Camargo e Almeida; Diretor substituto do Instituto Butantan, Prof. Flavio Oliveira Ribeiro da Fonseca; Arquiteto Rubens Gouveia Carneiro Vianna, Assistentes do Instituto Butantan e autoridades da Secretaria da Saúde, foi assinado um convênio entre a Universidade de São Paulo e a Secretaria da Saúde.

“TÊRMO DE CONVÊNIO QUE ENTRE SI FAZEM A UNIVERSIDADE DE SÃO PAULO E A SECRETARIA DA SAÚDE, REFERENTE ÀS OBRAS URBANÍSTICAS E ARQUITETÔNICAS DO INSTITUTO BUTANTAN, QUE SERÃO PROJETADAS E EXECUTADAS PELO FUNDO PARA CONSTRUÇÃO DA CIDADE UNIVERSITÁRIA “ARMANDO DE SALLES OLIVEIRA” - (Proc. 11088/61).

Aos sete dias do mês de Julho do ano de 1961, no Instituto Butantan, presentes o Senhor Secretário da Saúde Pública e Assistência Social, Dr. Fauze Carlos - devidamente autorizado pelo Senhor Governador, conforme respeitável despacho exarado no Expediente No. GE-6139, de 1961, e a Universidade de São Paulo, representada pelo Magnífico Reitor, Prof. Dr. Antonio Barros de Ulhôa Cintra, deliberaram assinar o presente convênio mediante as seguintes cláusulas: I - A organização do Plano Diretor das edificações do Instituto Butantan, que será feito pelo Fundo para Construção da Cidade Universitária, integrar-se-á no Plano Geral da Cidade Universitária. II - As obras urbanísticas e arquitetônicas do Instituto Butantan serão projetadas e executadas pelo Fundo para Construção da Cidade Universitária, obedecidas as prescrições técnicas determinadas pelas respectivas entidades. III - As despesas com a execução das obras urbanísticas e arquitetônicas do Instituto Butantan, referidas neste convênio, correrão a conta dos recursos atribuidos pela Lei No. 5444, de 17 de Novembro de 1959 (P a G) ao Setor "C" - Saúde Pública e Assistência Social, cuja aplicação ficará a cargo do Fundo para Construção da Cidade Universitária. O registro da aplicação dêsses recursos deverá ser feito descriminadamente, em contta especial, distinta das que se destinam ao registro das operações próprias do Fundo para Construção da Cidade Universitária “Armando de Salles Oliveira”. IV - O Instituto Butantan compromete-se, no prazo máximo de 15 (quinze) dias, apresentar o programa geral de suas necessidades. V - Dentro de 30 (trinta) dias, a partir da entrega feita pelo 
Instituto Butantan de seu programa, compromete-se o Fundo para Construção da Cidade Universitária a apresentar o anteprojeto da integração no Plano Piloto do Instituto Butantan no plano geral da Cidade Universitária. VI - Uma vez aprovado o plano geral fica estabelecido que não será permitida a inclusão de órgãos estranhos ao desenvolvimento do ensino e da pesquisa a que se destinam a Universidade e o Instituto Butantan, dentro do referido plano e dos limites territoriais estabelecidos, ficando cada uma das partes contratantes obrigadas a respeitar a autonomia e o patrimônio da outra, apesar de não haver separação territorial entre elas, mantida, porém, a unidade quanto aos aspectos urbanísticos e arquitetônicos. E por estarem acordes, lavrou-se êste convênio que vai assinado pelas partes e as testemunhas abaixo, Senhores Paulo de Camargo e Almeida, Diretor-Executivo do Fundo para Construção da Cidade Universitária “A.S.O.”, e o Senhor Flávio da Fonseca, Diretor do Instituto Butantan. São Paulo, 7 de Julho de 1961”.

Já nesta ocasião, o Instituto Butantan, após sucessivas e exaustivas reuniões com seus técnicos superiores, havia entregue ao Presidente do Fundo para Construção da Cidade Universitária os dados técnicos e as necessidades de áreas de cada setor a ser estudado. Após sucessivas discussões e exaustivas colheitas de dados, foi apresentada uma conceituação geral baseada no plano diretor.

Embora tivessem sido abandonados os estudos anteriores ao convênio, muito se aproveitou da experiência adquirida com o levantamento sôbre as necessidades do Instituto.

Foi então realizado pelos técnicos do F.C.C.U. um estudo, dividido em diversos setores, numa visão prévia do futuro funcionamento do Instituto em bases ideais. Serviu nesta ocasião de contacto entre o Instituto Butantan e o F.C.C.U. o engenheiro Dr. Savério Orlandi.

Os setores apresentados pela Diretoria do Instituto e estudados quanto à sua função e consequentes áreas necessárias são os seguintes:

1) Setor Administrativo - inclui Diretoria Geral e Diretoria Administrativa, Arquivo, Relações Públicas, Fundo de Pesquisas e demais setores que constituem a Administração.

2) Setor Turismo - inclui anfiteatro, cinema, serpentário, museu histórico e museu turístico.

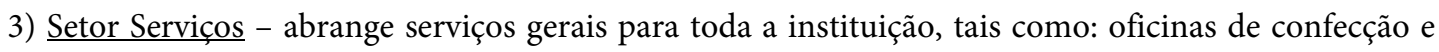
oficinas de manutenção, eletricidade, hidráulica, transportes, etc.

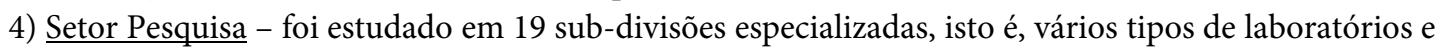
anexos de cada ramo científico estudado pelo Instituto.

5) Setor pesquisa - necessidades complementares - inclui entre outras necessidades o Hospital Vital Brazil, Biotérios Geral e de observação, Cursos e Coleção de Ofídios.

6) Setor Biotério - estudo visando criação, manutenção e observação de animais de laboratório, além de terrários para animais peçonhentos.

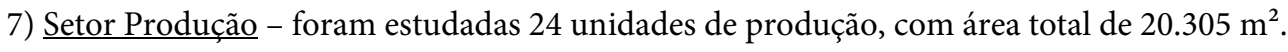

8) Setor Residencial - estudo para construção de 100 residências para funcionários de diferentes níveis.

Em poder dos arquitetos do Fundo para Construção da Cidade Universitária êstes dados tranformaramse em ante-projetos, plantas precisas e detalhadas e finalmente numa maquete que constitui parte de um conjunto apresentado ao público de São Paulo a 28 de Dezembro de 1961 no saguão da Faculdade de Direito de São Paulo.

A atual diretoria acompanhou com zêlo necessário todo o desenvolvimento do anteprojeto, através de um contato contínuo com o grupo de arquitetos do F.C.C.U.. Todos os estudo foram sempre submetidos à sua interessada aprovação.

Todas as alterações paisagísticas que sofrerá o Instituto foram submetidas à apreciação da Diretoria, que concordou com o demonstrado pela equipe do F.C.C.U..

Foi, portanto, com grande satisfação que, a 28 de Dezembro de 1961, assistiu a atual Diretoria, com a presença de seus técnicos superiores, a abertura da exposição de plantas, perspectivas, e maquetes do conjunto da Cidade Universitária e dos prédios referentes ao Instituto Butantan, pelo Governador do Estado, Prof. Carlos Alberto de Carvalho Pinto e estando presentes o Secretário da Saúde Pública e da Assitência Social, Dr. Fauze Carlos, Magnífico Reitor da Universidade de São Paulo, Prof. Antonio Barros de Ulhôa Cintra, Presidente do Fundo para Construção da Cidade Universitária, Prof. Paulo de Camargo e Almeida e autoridades da Secretaria da Saúde do Estado e do Gabinete do Governador.

O conjunto de prédios do Instituto Butantan apresentado constitui-se de um prédio de 22 andares para o Setor de Pesquisas, o conjunto Biblioteca-Auditório e o Instituto de Virus com área de [ilegível] $\mathrm{m}^{2}$. 
Convém assinalar-se a grande importância que representa êsse convênio para o Instituto Butantan.

Tendo sido o seu primeiro prédio de laboratórios construido em 1914 e sòmente em 1945 concluida outra construção de vulto - prédio com $3.500 \mathrm{~m}^{2}$ - sente-se esta Diretoria empolgada com um planejamento com base tanto na técnica científica quanto na arquitetônica e urbanística, com tamanha área de construção.

Ficando as verbas destinadas à atualização das construções do Instituto Butantan manipuladas por um grupo de técnicos de alto nível, que é constituido o grupo de engenheiros e arquitetos do F.C.C.U., é de se esperar um resultado sob todos os aspectos ótimo da sua atuação.

Além dos projetos, as construções terão assistência técnica permanente dada por um grupo interessado em que o conjunto da Cidade Universitária mantenha uma linha harmônica, paisagística e urbanística.

Baseado nos têrmos do convênio ficará o Butantan enquadrado no plano geral de urbanização, com tôdas as vantagens das proximidades de outros centros técnicos e culturais, e com todo o embelezamento da zona estudada, sem no entretanto perder suas características, finalidades e independência, a fim de poder continuar sempre e cada vez mais a ser um marco representativo de São Paulo, tanto no Brasil como no Exterior. (RA 1961, pp. 1 a 10)

\section{ANEXO B - Texto do folheto distribuído na inauguração do Museu Histórico do Instituto Butantan, em 11 de junho de 1981}

\section{APRESENTAÇÃO}

Ao completar o Instituto Butantan, em 1981, 80 anos de existência, dentro dos eventos programados para comemorar esta data, a inauguração do MUSEU HISTÓRICO é um dos pontos altos.

A Diretoria do Instituto Butantan e a Comissão do Museu Histórico decidiram instalar o Museu no primeiro laboratório onde Vital Brazil iniciou rotineiramente seus trabalhos no Instituto Butantan, em 1901. Inicialmente localizou-se o prédio, descobrindo-se seu piso, alicerce e uma das paredes originais e, por análise de fotografias e entrevistas com servidores da época, obteve-se a correta disposição do prédio e aspectos de seu interior. Com a colaboração do arquiteto, foi dimensionado corretamente. Contratou-se especialistas em história e museologia para assessorar a Comissão na instalação e planificação atual e futura do Museu.

A Comissão contou, na estruturação do Museu, com a colaboração inestimável de servidores do Instituto Butantan, que nela se motivaram até emocionalmente.

Ao entregar o Museu Histórico do Instituto Butantan ao público, a Diretoria e a Comissão do Museu desejam mostrar, sobretudo aos jovens, que neste prédio simples, adaptado de um telheiro e de uma cocheira, Vital Brazil produziu o soro e a vacina anti-pestosa, pesquisou e produziu soros anti-peçonhentos, com isso salvando vidas e elevando o nome da ciência brasileira.

Neste local iniciou o Instituto Butantan o seu caminho de aplicação da ciência em prol da saúde pública, há 80 anos.

$[\ldots]$

\section{EQUIPE TÉCNICA}

Obras de restauração: arq. Osmar Mammini

Projeto do Museu e textos: mus. e hist. Marlene Suano, Jandira Lopes de Oliveira, Elisabeth Braz

Comunicação Visual: arq. Julio Abe Wakahara

(Folheto de inauguração do MHIB, IBu, 1981, acervo do MHIB) 